FACULDADE DE FILOSOFIA, LETRAS E CIÊNCIAS HUMANAS DEPARTAMENTO DE HISTÓRIA PROGRAMA DE PÓS-GRADUAÇÃO EM HISTÓRIA ECONÔMICA

\title{
Nos fios de uma trama esquecida: a indústria têxtil paulista nas décadas pós-Depressão (1929-1950)
}

Felipe Pereira Loureiro

Dissertação apresentada ao Programa de Pós-Graduação em História Econômica da Faculdade de Filosofia, Letras e Ciências Humanas da Universidade de São Paulo para a obtenção do título de Mestre em História.

Orientação: Wilson do Nascimento Barbosa 
Agradecimentos.

Abreviaturas.

Resumo.

Introdução. .05

Fundamentação teórica 09

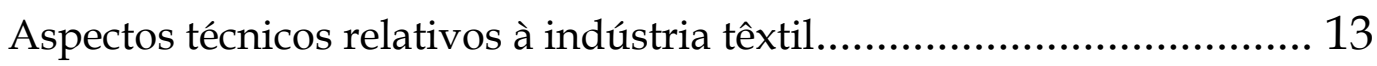

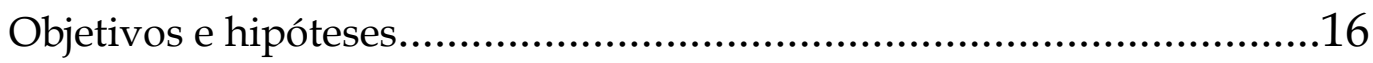

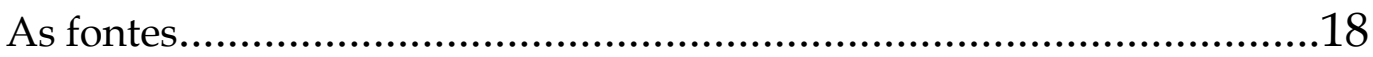

Capítulo 1 - A radiografia da indústria têxtil paulista (1928).............21

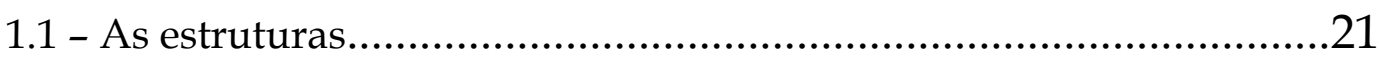

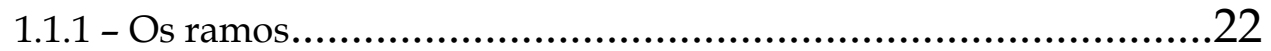

1.1.2 - A localização das fábricas.....................................................27

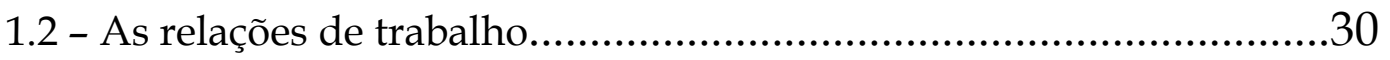

1.3 - A situação econômica do final da década de 1920............................38

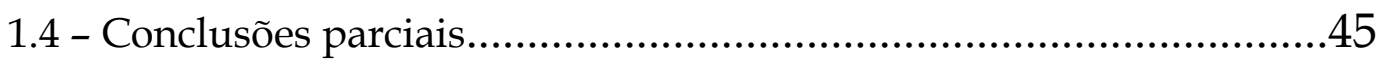

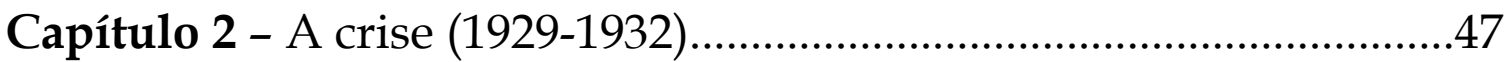

2.1 - A grande depressão e a economia doméstica....................................47

2.2 - A grande depressão e a indústria têxtil paulista...............................50

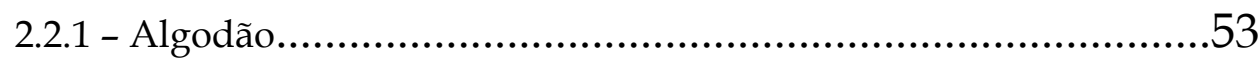

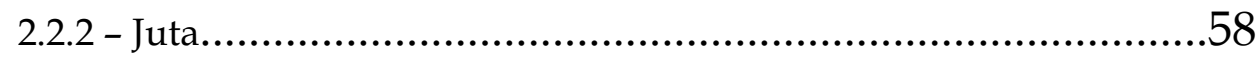

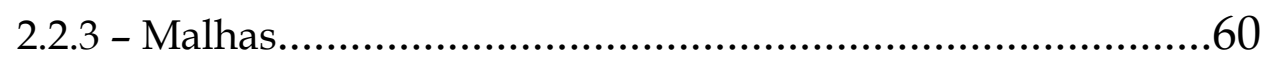

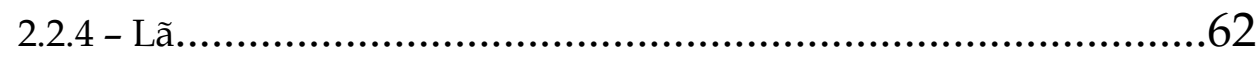

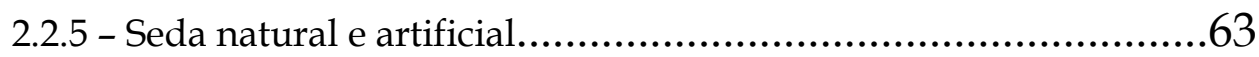

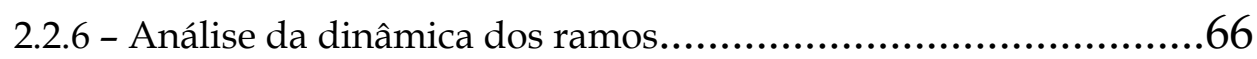

2.3 - A grande depressão e os operários têxteis.....................................79

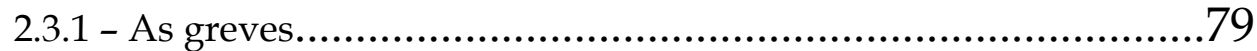

2.3.2 - As leis trabalhistas pós-1930 e a burguesia têxtil........................82

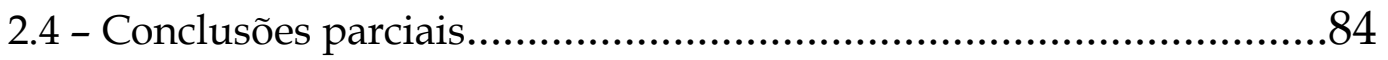


3.1 - A recuperação da economia brasileira.............................................85

3.2 - A recuperação da indústria têxtil paulista........................................89

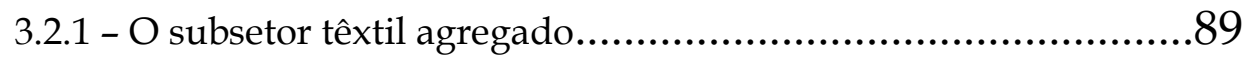

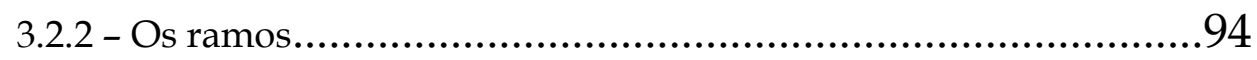

3.2.3 - Análise da evolução têxtil paulista no período 1932-1939..........111

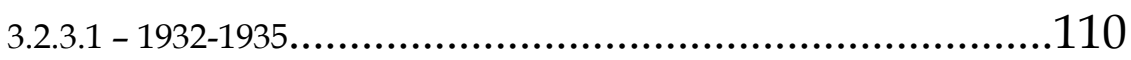

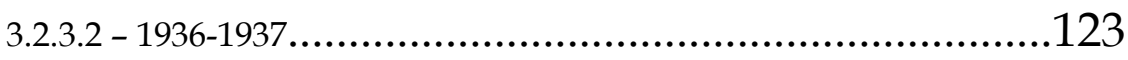

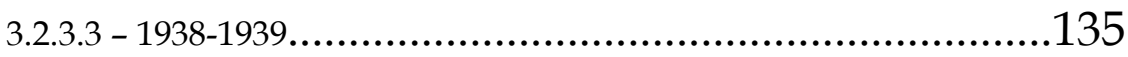

3.3 - As relações de trabalho no período 1932-1939.............................139

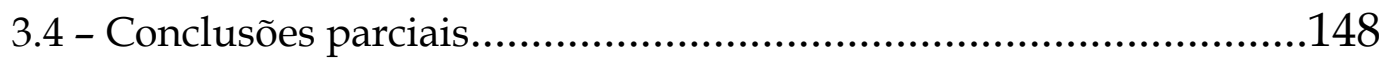

Capítulo 4 - A indústria têxtil paulista e a guerra (1939-1945).........150

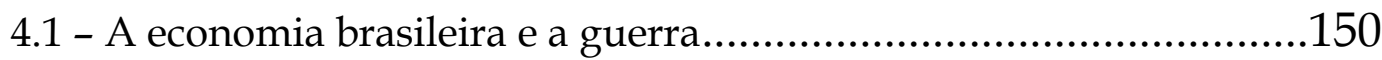

4.2 - A indústria têxtil paulista e a guerra............................................155

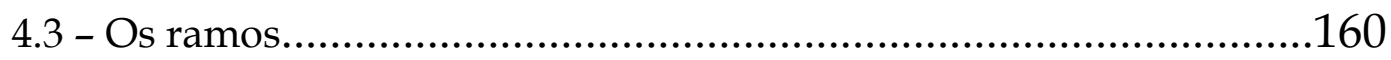

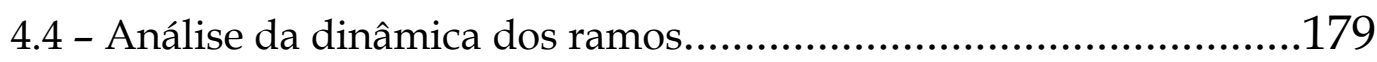

4.5 - O intervencionismo estatal no subsetor têxtil durante a guerra......186

4.6 - As relações de trabalho nas fábricas têxteis durante a guerra.........194

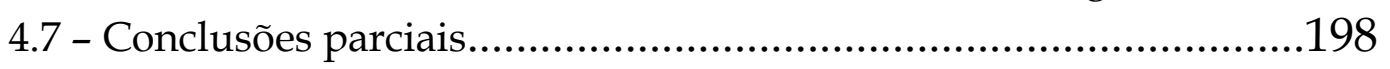

Capítulo 5 - A indústria têxtil paulista no pós-guerra (1946-50)......200

5.1 - A economia brasileira no pós-guerra...........................................200

5.2 - A indústria têxtil paulista no pós-guerra.......................................203

5.3 - Análise da dinâmica do subsetor têxtil e dos seus ramos...............212

5.3.1 - O período 1946-1947.........................................................218

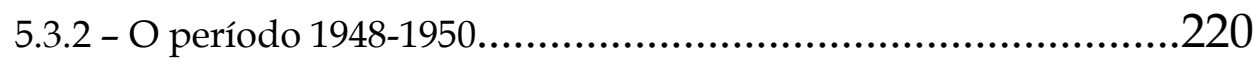

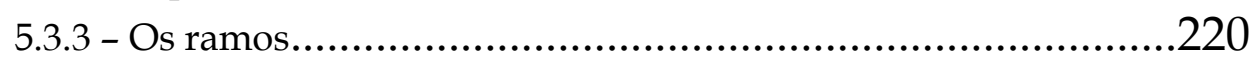

5.4 - As relações de trabalho nas fábricas têxteis no pós-guerra............222

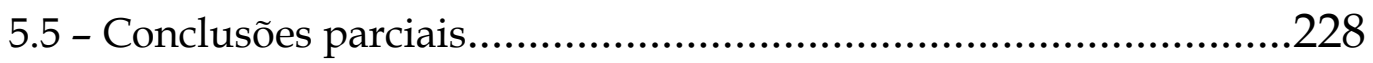

Capítulo 6 - Radiografia da indústria têxtil paulista (1950).............230

6.1 - A participação das indústrias têxteis paulistas nos setores fabris

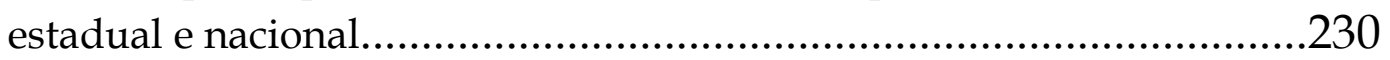

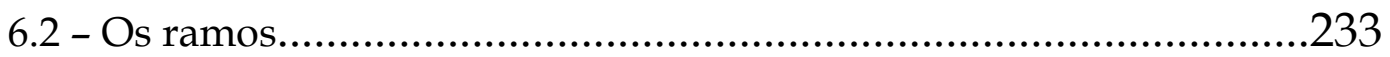

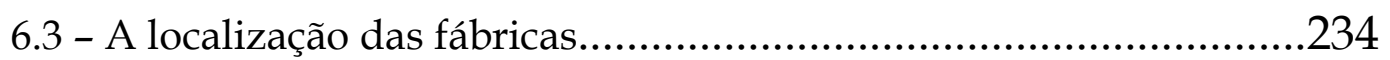


6.4 - As relações de trabalho.

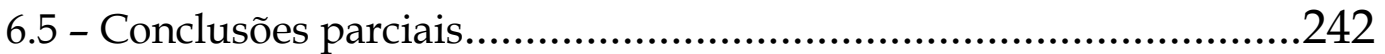

Conclusão .243

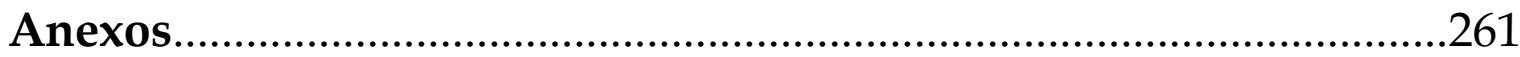

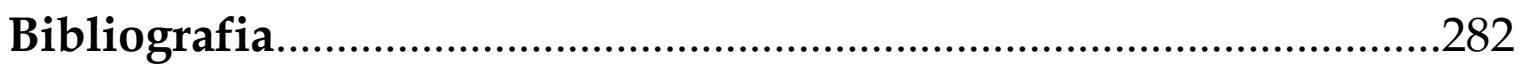




\section{$\underline{\text { Sumário de Tabelas e Gráficos }}$}

Tabela 1.1 - Participação da indústria têxtil paulista perante as indústrias totais do Estado (1928) .p.21

Tabela 1.2 - Estabelecimentos, capital aplicado e número de operários na indústria têxtil de São Paulo e na indústria têxtil brasileira (1920)...... .p.22

Tabela 1.3 - Participação relativa dos ramos da indústria têxtil paulista (1928) - \%. p.23

Tabela 1.4 - Participação relativa (\%) de pequenos, médios e grandes estabelecimentos nos ramos da Indústria Têxtil Paulista (1928). .$p .24$

Tabela 1.5 - Composição orgânica do capital e índices de concentração e produtividade nos ramos da Indústria Têxtil Paulista (1928). .p.25

Tabela 1.6 - Localização das Indústrias Têxteis Paulistas - Capital e Interior (1928) - \%. p.28

Tabela 1.7 - Localização das Indústrias Têxteis por tamanho - Capital / Interior (1928) - \%. p.29

Tabela 1.8 - Número de operários da Indústria Têxtil Paulista discriminado por sexo e idade (1919). .p.31

Tabela 1.9 - Participação em porcentagem dos operários discriminados por sexo e idade em alguns ofícios da indústria têxtil - Brasil (1920).

Tabela 1.10 - Média dos salários da indústria têxtil paulista (1919) - Mil-réis p.32

Tabela 1.11 - Produção da indústria têxtil paulista discriminada por ramo - 1920 / 1925-1928. p.39

Tabela 1.12 - Dados variados: Importação de bens de capital doméstica, preço café e taxa de câmbio milréis/libra (1918-1930). p.41

Tabela 1.13 - Importação de tecidos diversos - Porto de Santos (1927 e 1928)....... p.42

Tabela 2.1 - Índices do número de estabelecimentos, capital, operários, força motriz e valor de produção Indústrias gerais e têxteis - estado de São Paulo (1928-1933, 1928=100).......................51

Tabela 2.2 - Composição orgânica do capital e índices de concentração e produtividade nos setores da indústria têxtil paulista (1932)...... p.52

Tabela 2.3 - Número de paralisações na indústria têxtil paulista (1929-1932) p.53

Tabela 2.4 - Indústria têxtil paulista - Índices de crescimento por ramo (1928-1933)..... p.54

Tabela 2.5 - Produção dos ramos têxteis paulistas (1928-1933) - metros. p. 56

Tabela 2.6 - Participação relativa dos ramos têxteis perante total do total subsetorial em termos de capital, estabelecimentos, operários, força motriz (H.P.) e valor de produção (contos - D) - estado de São Paulo $(1928 / 1933)$ p.58

Tabela 2.7 - Importação de tecidos no porto de Santos em metros e contos deflacionados (1927-1933). .p. 67

Tabela 2.8 - Importação de bens de capital - Indústria têxtil (1927-1933). p. 69 
Tabela 2.9 - Relação da quantidade de produção anual (1.000 metros) e número de teares - Indústria têxtil do algodão e da juta - estado de São Paulo (1925-1932)......

Tabela 2.10 - Relação da quantidade de produção anual e número de teares - Indústria têxtil da seda (artificial e natural) e da lã - estado de São Paulo (1928 e 1932). p. 73

Tabela 3.1 - Dados econômicos domésticos I - PNB, Índices setoriais de produção e balança comercial Brasil (1932-1939). p.86

Tabela 3.2 - Dados econômicos II - taxa de câmbio e papel-moeda emitido / circulação (1931-1939). p.88

Tabela 3.3 - Índices do número de estabelecimentos, capital, relação capital-fábrica, operários, relação capital-operários, força motriz, valor de produção e relação capital-valor de produção das indústrias gerais e têxteis paulistas $(1928,1932-37,1928=100)$. p.90

Tabela 3.4 - Consumo de energia, número de operários e valor da produção das indústrias gerais e têxteis paulistas (1938 e 1939) p.91

Tabela 3.5 - Taxas geométricas de crescimento - Indústrias gerais e têxteis paulistas (1932-37, 1932-35 e 1935-37), em \% .$p .92$

Tabela 3.6 - Índices de concentração, índices de produtividade e composição orgânica do capital Indústrias gerais e têxteis (1928, 1932-1937), 1928=1. p.93

Tabela 3.7 - Participação relativa dos pequenos, médios e grandes estabelecimentos em termos de capital e operários - indústria têxtil paulista $(1932,1935$ e 1937), em \%. .p.94

Tabela 3.8 - Índices variados dos ramos da indústria têxtil paulista (1928, 1932-1937). p.96

Tabela 3.9 - Taxas de crescimento geométrico dos ramos da indústria têxtil paulista (1932-1937) p.97

Tabela 3.10 - Índices de concentração, produtividade e composição orgânica do capital dos ramos da indústria têxtil paulista $(1933,1935$ e 1937). p.97

Tabela 3.11 - Participação relativa das pequenas, médias e grandes empresas em termos de capital e operários - Ramos da indústria têxtil paulista (1932, 1935 e 1937), em \%.

Tabela 3.12 - Participação relativa dos ramos da indústria têxtil paulista no subsetor têxtil agregado do Estado de São Paulo (1932, 1935 e 1937), em \%. p.99

Tabela 3.13 - Consumo de energia (Kw/h), número de operários e produção (Cr\$ 1.000 - D) dos ramos da indústria têxtil paulista (1938-1939). p.101

Tabela 3.14 - Localização das indústrias têxteis paulistas - Capital (C) e Interior (I) - 1932, 1935 e 1937. p.109

Tabela 3.15 - Produção têxtil paulista discriminada por ramos (1932-1937), em metros..... p.112

Tabela 3.16 - Importação de tecidos - Porto de Santos (1932-1937), em quilos p.112

Tabela 3.17 - Relação peso / preço de tecidos importados pelo porto de Santos (1928, 1932-1937)

Tabela 3.18 - Comércio de cabotagem - São Paulo / Brasil (toneladas - 1.000 Cr\$). p.115

Tabela 3.19 - Exportação têxtil paulista por cabotagem - 1928-1931 e 1933-1935 p.115 
Tabela 3.20 - Exportação têxtil paulista por cabotagem discriminada por setores - 1933-1939......

Tabela 3.21 - Relação produção têxtil paulista (1925, 1928 e 1932-1937) / número de teares (1932)

Tabela 3.22 - Importação de bens de capital para a indústria têxtil paulista pelo porto de Santos (1928, 1932-1939)

Tabela 3.23 - Comércio têxtil de cabotagem - Brasil (1933-1939).

Tabela 3.24 - Importação de máquinas têxteis - Brasil (1928, 1933-1939), quilos.

Tabela 3.25 - Participação relativa da indústria têxtil nas unidades da Federação (1920-1940), em $\%$.

Tabela 3.26 - Distribuição relativa das máquinas da indústria têxtil paulista, segundo a idade (1939), em $\%$. .139

Tabela 4.1 - Dados macroeconômicos - PNB, Índice setorial do produto, balança comercial e índices de preços e de quantum das exportações e importações (1939-1945). p.151

Tabela 4.1b - Exportação por classes de produtos - Brasil (1940 / 1944), em \%..... p.152

Tabela 4.2 - Meios de pagamento - Brasil (1938-1945), milhões de Cr\$. .153

Tabela 4.3 - Importação de carvão, coque, petróleo bruto e querosene - Brasil (1939-1945). .154

Tabela 4.4 - Número de estabelecimentos, capital, operários, energia elétrica consumida e valor da produção das indústrias gerais do estado de São Paulo (1939, 1943 e 1944). p.155

Tabela 4.5 - Número de estabelecimentos, capital, operários, energia elétrica consumida e valor da produção das indústrias têxteis do estado de São Paulo (1939, 1943 e 1944). p.155

Tabela 4.5b - Participação relativa do subsetor têxtil paulista - indústrias gerais do Estado de São Paulo $(1939,1943$ e 1944)...... p.156

Tabela 4.6 - Distribuição das máquinas têxteis paulistas segundo a idade (1944) - \%..... p.157

Tabela 4.7 - Importação de bens de capital para a indústria têxtil paulista (1938-1944)-quilos. .157

Tabela 4.8 - Número de estabelecimentos, capital, operários, energia elétrica consumida e valor da produção da indústria de bens de capital de fiação e de tecelagem do estado de São Paulo (1939, 1943 e 1944).

p.158

Tabela 4.9 - Tempo médio de trabalho nas seções de fiação e tecelagem de algodão - Brasil e São Paulo (1945) - em horas p.160

Tabela 4.10 - Índices de concentração e de produtividade nas indústrias gerais e têxteis do estado de São Paulo (1939, 1943 e 1944)

Tabela 4.11 - Estabelecimentos, capital, operários, energia elétrica consumida e valor de produção dos ramos da indústria têxtil paulista $(1939,1943$ e 1944). .p.161

Tabela 4.12 - Capital, máquinas, lucros brutos e dividendos das empresas têxteis algodoeiras do estado de São Paulo correspondentes aos grupos II, III e IV - em Cr\$ 1.000 deflacionados (1939-1945). p.162

Tabela 4.13 - Capital, máquinas, lucros brutos e dividendos das indústrias de juta do estado do São Paulo correspondentes ao Grupo V - em Cr\$ 1.000 deflacionados (1939-1945)..

Tabela 4.14 - Produção local e importação de juta - Brasil (1938-1945), em toneladas. .p. 169 
Tabela 4.15 - Capital, máquinas, lucros brutos e dividendos das fábricas de lã do estado de São Paulo pertencentes ao grupo VII (1939-1945) - Cr\$ 1.000 deflacionados

Tabela 4.16 - Capital, máquinas, lucros brutos e dividendos das fábricas de seda natural e artificial do Estado de São Paulo pertencentes ao grupo VI (1939-1945) - Cr\$ 1.000 deflacionados. p. 175

Tabela 4.17 - Importação têxtil paulista - Porto de Santos (1937, 1940 - 1944), em quilos e Cr\$ 1.000 deflacionados.

Tabela 4.18 - Importação de fios paulista - Porto de Santos (1937, 1940 - 1944), em quilos e Cr\$ 1.000 deflacionados.

Tabela 4.19 - Exportações têxteis paulistas de cabotagem - Porto de Santos (1939, 1941-1944), em quilos.

Tabela 4.20 - Exportação têxtil paulista (1937, 1940-1945), em quilos e Cr\$ 1.000

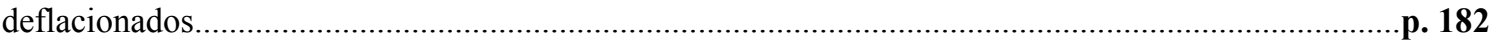

Tabela 4.21 - Exportação de tecidos algodoeiros locais discriminada por continente de destino (1940-1945), em metros. p. 183

Tabela 4.22 - Índices ponderados do custo de vida da classe operária na cidade de São Paulo (1939-1945), $1939=100$.

Tabela 4.23 - Resumo dos custos relativos dos setores da indústria têxtil paulista (1939, 1943 e 1944).

Tabela 4.24 - Salário per capita dos operários da indústria têxtil paulista (1939, 1943 e 1944) p.197

Tabela 5.1 - Dados econômicos variados - Brasil (1945-1950).

Tabela 5.2 - Importações domésticas discriminadas por classe de produtos - Brasil - Cr\$ 1.000 deflacionados.

Tabela 5.3 - Dados das indústrias gerais e têxteis do estado de São Paulo (1939, 1944 e 1950). p.204

Tabela 5.4 - Dados dos setores têxteis paulistas (1944 e 1950) p.205

Tabela 5.5 - Dados do setor algodoeiro paulista referente aos grupos VIII e IX (1945-1948) .p.207

Tabela 5.6 - Dados do setor de juta paulista referente aos grupos X e XI* (1945-1948), em Cr\$ 1.000 deflacionados. p.208

Tabela 5.7 - Dados do ramo lanífero paulista referente ao grupo XII* (1945-1948), em Cr\$ 1.000 deflacionados. p.209

Tabela 5.8 - Dados do ramo das sedas paulista referente ao gupo XIII* (1945-1948), em Cr\$ 1.000 deflacionados. p.210

Tabela 5.9 - Exportações têxteis - Porto de Santos e São Paulo via aérea (1945-1946 e 1948-1950). .p.215

Tabela 5.10 - Exportações domésticas discriminadas por classes de produtos (1945 e 1950), em $\%$.

Tabela 5.11 - Importações têxteis - Brasil (1945-1950) - Cr\$ 1.000 deflacionados. p.219

Tabela 5.12 - Importação de bens de capital têxteis - Porto de Santos e São Paulo via aérea (1945-1946; 1948-1950) ..p.220

Tabela 5.13 - Índices ponderados do custo de vida da classe operária na cidade de São Paulo, 1945 - 1950 $(1939=100)$ 
Tabela 5.14 - Salários totais e per capita dos operários têxteis paulistas (1940, 1944 e 1950).....

Tabela 5.15 - Acidentes sofridos por operários na indústria têxtil paulista (1945-1949)

Tabela 6.1 - Participação relativa das indústrias têxteis paulistas no agregado fabril estadual (1928 e 1950), em $\%$.

Tabela 6.2 - Participação das indústrias têxteis paulistas no agregado têxtil nacional (1928 e 1950).

Tabela 6.3 - Participação das indústrias têxteis paulistas no agregado fabril nacional (1928 e 1950).

Tabela 6.4 - Participação relativa dos ramos têxteis paulistas na indústria têxtil estadual (1928 e 1950), em $\%$.

p.234

Tabela 6.5 - Índices de produtividade, de concentração e composição orgânica do capital da indústria têxtil paulista discriminada por ramo (1928 e 1950) p.236

Tabela 6.6 - Estabelecimentos e números de operários dos ramos da indústria têxtil paulista na cidade de São Paulo e interior (1928 e 1950). p.237

Tabela 6.7 - Indicadores econômicos das indústrias gerais paulistas discriminados por região: Capital, Grande São Paulo (GSP) e Interior do estado (1950), em \%.

p.239

Tabela 6.8 - Número de trabalhadores das indústrias gerais e têxteis paulistas discriminados por sexo (1950). p.240

Tabela 1A- Índice de preços - Brasil (1928-1950), 1919=100 p.253

Tabela 1 - Indústria geral paulista (1928-1937) p.254

Tabela 2 - Indústria têxtil paulista (1928-1939) p.254

Tabela 3 - Indústria têxtil algodoeira paulista (1928-1939) p.254

Tabela 4 - Indústria têxtil da juta paulista (1928-1939). p.255

Tabela 5 - Indústria têxtil de malhas paulista (1928-1939) p. 256

Tabela 6 - Indústria têxtil lanífera (1928-1939). p. 256

Tabela 7 - Indústria têxtil de seda (natural e artificial), 1928-1939. p.257

Tabela 8 - Indústria têxtil paulista geral e discriminada por ramo (1943) p.258

Tabela $8 \mathbf{b}$ - Indústria têxtil paulista e discrminada por ramo (1950) p.259

Tabela 9 - Indústria têxtil paulista discrminada por tamanho e ramo (1928) .260

Tabela 9b - Indústria têxtil paulista discriminada por tamanho e ramo (1932) p.261

Tabela 9c - Indústria têxtil paulista discriminada por tamanho e ramo (1935) . 262

Tabela 9d - Indústria têxtil paulista discriminada por tamanho e ramo (1937) p.263

Tabela 10 - Indústria têxtil paulista discriminada por localização (capital e interior) e por ramo (1928). .p.264

Tabela 10b - Indústria têxtil paulista discriminada por localização (capital e interior) e por ramo (1932). .p.265 
Tabela 10c - Indústria têxtil paulista discriminada por localização (capital e interior) e por ramo (1935).

Tabela 10d - Indústria têxtil paulista discriminada por localização (capital e interior) e por ramo (1937). p. 267

Tabela 11 - Comércio de cabotagem - Brasil e São Paulo, toneladas e Cr\$1.000 (1929-1947). p.268

Tabela 11b - Crescimentos percentuais do comércio de cabotagem - Brasil e São Paulo (1929-1947)..p.269

Tabela 11c - Participação relativa comércio de cabotagem São Paulo - Brasil (1929-1947). p.270

Tabela 12 - Indústria têxtil discriminada por unidade da Federação (1929-1940) p.271

Tabela 12b - Indústria têxtil discriminada por unidade da Federação (1920-1940), \% p.272

Tabela 13 - Indústria têxtil discriminada por unidade da Federação (1920-1950). p. 273

Tabela 13b - Indústria têxtil discriminada por unidade da Federação (1929-1950), \% p.274

Tabela 14 - Empresas têxteis paulistas sob estatuto jurídico de sociedade anônima (S.A.) fundadas durante a Segunda Guerra (1939-1945). p.275

Tabela 14b - Empresas têxteis paulistas sob estatuto jurídico de sociedade anônima (S.A.) fundadas no pósguerra (1939-1945). p.276

Gráfico 2.1 - Evolução do produto nacional bruto (1928-1933).... p.51

Gráfico 3.1 - Valor das máquinas do Grupo I das indústrias algodoeiras do estado de São Paulo (1934-1939) p.102

Gráfico 4.1 - Reserva de ouro domésticas (1938, 1943 e 1945), quilos. p.153

Gráfico 5.1 - Casulos de bicho-de-seda produzidos no Estado de São Paulo (1945-1950), em toneladas 


\section{Agradecimentos}

Este trabalho foi fruto do auxílio e do apoio de muitas pessoas. Agradecê-las é o mínimo que posso fazer. Em razão do espaço exíguo, porém, sou obrigado a selecionar apenas aquelas que participaram ativamente do processo de pesquisa.

Agradeço, em primeiro lugar, ao meu orientador Wilson do Nascimento Barbosa, que, com suas palavras firmes, guiou-me nos caminhos tortuosos da pesquisa acadêmica.

Agradeço, em segundo lugar, aos seguintes professores da Faculdade de Filosofia, Letras e Ciências Humanas da Universidade de São Paulo, que me auxiliaram muito ao longo da pesquisa: Armen Mamigonian, Benedito Heloiz do Nascimento, Lincoln Secco e Raquel Glezer.

Além destes, agradeço a enorme atenção prestada ao meu trabalho pelos professores da Faculdade de Economia e Administração da Universidade de São Paulo, principalmente aos professores Flávio Saes e Nelson Nozoe. Ao primeiro, em especial, sou muito grato em razão das suas preciosas indicações documentais e da sua atenção para com meus inúmeros e-mails, repletos de dúvidas e textos para sugestões.

Recebi também auxílio de docentes dos Institutos de Economia e Filosofia e Ciências Humanas da Universidade Estadual de Campinas, em especial Maria Alice Rosa Ribeiro, Wilson Cano e Wilson Suzigan. Além disso, devo ao professor Almir Pita (Universidade Federal do Rio de Janeiro) as preciosas indicações de pesquisa no Centro de Indústrias de Fiação e Tecelagem de Algodão. Sou também imensamente grato ao professor Renato Perim Colistete (Universidade Estadual Paulista - Araraquara), que acompanhou todo processo de pesquisa, desde seu nascimento, dando-me inúmeras sugestões e indicações bibliográficas. A todos professores citados, meu muito obrigado.

Além dos docentes, fui muito bem recebido em todos os arquivos e bibliotecas que pesquisei. Cito, a seguir, apenas algumas pessoas cujas prestezas devem ser lembradas. Agradeço aos funcionários Atílio, Eliane, Henrique, Lúcia e Sidney do Arquivo do Diário Oficial do Estado de São Paulo (Imprensa Oficial); aos atendentes do Arquivo do Estado de São Paulo, principalmente ao Caio; aos membros do Arquivo Roberto Simonsen no Instituto de Filosofia e Ciências Humanas da Universidade de Campinas, em especial à Fabiana e à Sandra; às atendentes Jussara, Sandra e Isabel da Fundação SEADE (Sistema Estadual de Análise de Dados); à Raquel a ao Geraldo, do Centro de Indústrias de Fiação e Tecelagem de Algodão no Rio de Janeiro; às funcionárias e funcionários da Biblioteca 
Nacional e da biblioteca da Faculdade de Filosofia, Letras e Ciências Humanas; e ao Haroldo e à Geni, da ABIT (Associação Brasileira da Indústria Têxtil).

Agradeço aos membros do Núcleo de Economia Política e História Econômica (NEPHE) da Universidade de São Paulo, especialmente aos pesquisadores Luiz Eduardo Simões de Souza, Vitor Eduardo Schincariol e ao professor Marcos Cordeiro Pires. Nossas profícuas discussões semanais, além de seus apontamentos pertinentes em meus escritos, foram fundamentais para a realização deste trabalho.

Agradeço também aos colegas do Departamento de História - USP que, direta ou indiretamente, ajudaram-me na concretização desta pesquisa, especialmente Marisa Midouri e minha irmã - não de sangue, mas de alma - Maíra Torrecillas. Do Instituto de Filosofia e Ciências Humanas da UNICAMP, gostaria de agradecer, principalmente, ao Marcelo, responsável pela indicação dos documentos referentes ao DET (Departamento Estadual do Trabalho).

Agradeço também aos colegas do Curso e Colégio Etapa, que, ao longo desses três anos, substituíram-me em aulas sempre que preciso. Sou especialmente grato ao prof. Rogério Forastieri da Silva, em razão de nossas conversas e discussões acerca do tema. Muito obrigado pela compreensão de vocês.

Sou imensamente grato também aos meus amigos André, Caio, Cristiano, Diego, Eduardo, Fabiano, Gustavo e Rafael Passos, que sempre me apoiaram em quaisquer situações. Gostaria de fazer uma menção especial ao Hans, o qual, além de amigo, ajudoume muito em toda parte de econometria e estatística do trabalho.

Agradeço profundamente aos membros de minha família materna e paterna. Faço menção especial ao meu tio José Carlos e minha tia Jeanete, que, tratando-me como um filho, muito me apoiaram na carreira universitária. A segunda, infelizmente, não se encontra mais entre nós, deixando profunda saudade. Muito obrigado a todos.

Agradeço à minha namorada, Claudia, que, além do apoio, paciência, carinho e compreensão para comigo, reviu todo o texto final da dissertação. Se não houver erros de português nesse trabalho, ela é a responsável. Não tenho palavras para expressar o profundo agradecimento por tudo que fez por mim. Muito obrigado.

Agradeço, por último, à minha querida e amada mãe. Não tenho receio algum em dizer que se hoje sou um pesquisador da área de História Econômica, devo quase tudo ao esforço que ela sempre realizou por mim. Pessoa corajosa; em 1992, perdeu o marido e tinha um filho de onze anos para cuidar. Nunca fraquejou. Fez de tudo para que eu pudesse me dedicar apenas aos estudos, seja no Ensino Fundamental e Médio, seja no 
Superior. Durante o mestrado, apesar de pouco compreendê-lo, esteve sempre ao meu lado, rezou todos os dias aos seus santos e a seu Deus, foi compreensiva para com a minha falta de tempo ao longo desses três anos. Impossível agradecer por tudo o que a senhora fez por mim. O pouco que posso fazer é dedicar este trabalho, com todo meu carinho e amor, para a senhora. Muito obrigado! 


\section{Abreviaturas}

ADOESP - Arquivo do Diário Oficial do Estado de São Paulo

CDEN - Comissão de Defesa da Economia Nacional

CIB - Centro Industrial do Brasil

CIESP - Centro das Indústrias do Estado de São Paulo

CETex - Comissão Executiva Têxtil

CFCE - Conselho Federal de Comércio Exterior

CFECT - Comissão Fiscalizadora e Executiva do Convênio Têxtil

CFP - Comissão Federal de Preços

CIFTSP - Centro das Indústrias de Fiação e Tecelagem de São Paulo

CIFTA - Centro de Indústrias de Fiação e Tecelagem de Algodão

CME - Coordenação da Mobilização Econômica

CNE - Conselho Nacional de Estatística

DET - Departamento Estadual do Trabalho

DEE - Departamento Estadual de Estatística

DOPS - Departamento de Ordem Política e Social

EIESP - Estatísticas Industriais do Estado de São Paulo

FCSM - French Colonial Supply Mission

FIESP - Federação das Indústrias do Estado de São Paulo

SIFTESP - Sindicato das Indústrias de Fiação e Tecelagem do Estado de São Paulo

SIFTERJ - Sindicato de Fiação e Tecelagem do Estado do Rio de Janeiro

SOFTESP - Sindicato dos Operários de Fiação e Tecelagem de São Paulo

UOFTESP - União dos Operários em Fábricas de Tecidos de São Paulo

UNRRA - United Relief and Rehabilitation Administration 


\title{
Resumo
}

Estudar a indústria têxtil paulista, um dos mais importantes setores fabris no final dos anos (19)20, é, de uma certa maneira, compreender uma parte fundamental daquilo que abrange o complexo industrial brasileiro. $\mathrm{O}$ objeto desse estudo, nesse sentido, é a evolução econômica da indústria têxtil do estado de São Paulo durante as duas décadas pós-Depressão (1929-1950). Seu desempenho produtivo, as mudanças das suas estruturas subsetoriais e espaciais e suas relações de trabalho são alguns dos aspectos que este trabalho pretende examinar.

\section{Palavras-Chave}

Indústria, Indústria Têxtil, Estado de São Paulo, décadas pós-Depressão, relações de trabalho

\begin{abstract}
To study São Paulo's textile industry, one of the most important ones in the late 1920s., is, in a certain way, to comprehend a fundamental part of what the brazilian industrial complex comprises. The object of this study, thus, is the economic evolution of São Paulo state's textile industry during the two post-depression decades (1929-1950). Its production performance, the changings of its sub-sectorial and spacial structures and its labour relations are some of the aspects that this work seeks to examine.
\end{abstract}

\section{Keywords}

Industry, Textile Industry, São Paulo's State, post-Depression decades, labour relations. 
"Se um capitalista, individualmente, barateia camisas, elevando a força produtiva do trabalho, não tem ele necessariamente em mira reduzir em determinada porcentagem o valor da força de trabalho e, conseqüentemente, o tempo de trabalho necessário, mas na medida em que, por fim, contribui para esse resultado, concorre para elevar a taxa geral da mais-valia"

(Karl Marx. O Capital, p. 364) 


\section{Introdução}

$\mathrm{O}$ alvorecer do sistema manufatureiro doméstico, ocorrido entre meados e final do século XIX, identificou-se umbilicalmente com o nascimento do subsetor têxtil. Surgidas no interior de uma estrutura econômica periférica, de caráter primário-exportador e dependente da compra de bens manufaturados de países centrais, as primeiras fábricas de tecidos abasteciam mercados que, de alguma forma, não eram contemplados pelas importações. Artigos de vestuário rústicos, destinados à escravaria e aos grupos urbanos e rurais de baixa renda, perfaziam grande parte das vendas dessas empresas. Além disso, (a) a abundância de matéria-prima (algodão); (b) a existência de consideráveis fontes de energia hidráulica; (c) o acúmulo de capitais propiciados pelo crescimento das atividades agrário-exportadoras (em especial, a cafeeira); (d) e o desenvolvimento das indústrias de bens de capital nos países centrais - possibilitando, assim, a aquisição de máquinas pelas regiões periféricas - complementam o quadro explicativo da primazia do subsetor têxtil no processo de industrialização local ${ }^{1}$.

A Província da Bahia abrigou as primeiras grandes unidades produtoras de tecidos, tais como a Fábrica de Todos os Santos, fundada em $1844^{2}$. Na década de (18)60, porém, a cidade do Rio de Janeiro começou a se destacar como principal pólo fabril, muito em razão do florescimento da cafeicultura no Vale do Paraíba. O predomínio das empresas têxteis na capital federal era visível. Algumas destas se tornaram, no início dos Novecentos, as maiores fábricas do País. Foram os casos das companhias Brazil Industrial (1870) e América Fabril (1878)³.

No final do século XIX, entretanto, devido à crescente penetração dos cafezais em áreas paulistas, modificou-se o pólo dinâmico da economia doméstica. Nos anos (19)10, fomentado pelo processo substitutivo de importações - que se acelerou no contexto da

\footnotetext{
${ }^{1}$ Para maiores informações, ver: Stanley Stein. Origens e evolução da indústria têxtil no Brasil (1850-1950). Ed. Campus, Rio de Janeiro, 1979.

${ }^{2}$ Nícia Vilela Luz. As tentativas de industrialização no Brasil. In: Sérgio Buarque de Holanda e Pedro Moacyr de Campos. História Geral da Civilização Brasileira. Tomo II - O Brasil Monárquico. $5^{\circ}$ Edição. Ed. Bertrand Brasil, Rio de Janeiro, 1995, p. 35-36.

${ }^{3}$ Stanley Stein, op. cit., p. 41-42. Para maiores informações sobre a evolução particular da Companhia América Fabril - a maior fábrica têxtil do país até os anos (19)20 -, ver: Elisabeth Von der Weid e Ana Maria Rodrigues Bastos. O fio da meada. Estratégia de expansão de uma indústria têxtil. Companhia América Fabril (1878-1930). Fundação Casa Rui Barbosa / Confederação Nacional da Indústria, Rio de Janeiro, 1986.
} 
Primeira Guerra ${ }^{4}$-, o estado de São Paulo já se destacava como a unidade federativa mais industrializada do País. Dos setores fabris paulistas, a preponderância de tecidos era evidente. Em 1928, as empresas têxteis concentravam mais da metade do montante de capital investido e do número de operários do total fabril estadual ${ }^{5}$.

Percebe-se, assim, que a indústria de tecidos paulista era o setor fabril essencial do maior estado manufatureiro no final dos anos (19)20. Analisar sua evolução é, portanto, bastante representativo para se compreender a dinâmica das próprias fábricas locais agregadas. Não há dúvida de que foi por esse motivo que tantos estudiosos se dedicaram ao tema ${ }^{6}$.

Verifica-se, porém, que a maioria dos trabalhos sobre a indústria têxtil paulista centrou suas atenções no período que transcorre da constituição desse parque fabril (final do século XIX) até a crise de 1929. Com a exceção de um artigo escrito por José Mendonça de Barros e Douglas Graham - o qual, segundo os próprios autores, tinha a pretensão apenas de "introduzir" o tema ${ }^{7}$-, não há trabalhos empíricos que tratem, especificamente, da evolução dessas fábricas a partir da Depressão (1929-1932) .

Esta lacuna historiográfica, no entanto, pode ser esclarecida. Até o final dos anos (19)20, percebe-se que o desenvolvimento da indústria doméstica resumiu-se, em grande parte, à instalação de fábricas produtoras de bens de consumo não-duráveis (tecidos, alimentos, sapatos, chapéus, fumo, moagem de cereais, etc. $)^{9}$. Foi apenas na década de (19)20 que se verificou uma pequena diversificação industrial interna, em razão do

\footnotetext{
${ }^{4}$ Para maiores informações sobre o papel da Primeira Guerra Mundial no processo de industrialização doméstico, ver, principalmente: Wilson Suzigan. Indústria brasileira. Origens e desenvolvimento. Ed. Huitec / Ed. da Unicamp, São Paulo, 2000.

${ }^{5}$ Para maiores informações sobre a concentração industrial paulista e sobre as razões do crescente domínio fabril de São Paulo perante a Capital Federal, ver: Wilson Cano. Raízes da concentração industrial em São Paulo. $4^{\circ}$ Edição. Ed. da Unicamp, Campinas, 1998 e Paul Singer. Desenvolvimento econômico e evolução urbana. Análise da evolução econômica de São Paulo, Blumenau, Porto Alegre, Belo Horizonte e Recife. Companhia Editora Nacional, São Paulo, 1968..

${ }^{6}$ Destacam-se, nesse sentido: Maria Izilda de Matos. Trama e poder. Um estudo sobre as indústrias de sacaria para o café (São Paulo / 1889-1934). SESI-DN, Brasília, 1994; Fábio Ricci. Origens e aspectos do desenvolvimento das indústrias têxteis no Vale do Paraíba Paulista na República Velha. Tese de doutoramento, FFLCH / USP, 2002; Maria Alice Rosa Ribeiro. Condições de Trabalho na Indústria Têxtil Paulista (1870-1930). Editora da Unicamp/Huitec, São Paulo, 1998; e Flávio Rabelo Versiani e Maria Teresa R. Versiani. A industrialização brasileira antes de 1930: uma contribuição. In: Flávio Rabelo Versiani e José Mendonça de Barros (Org.). Formação Econômica do Brasil. A experiência da industrialização. Edição Saraiva, São Paulo, 197, pgs. 121-142.

${ }^{7}$ José Roberto Mendonça de Barros e Douglas H. Graham. A recuperação econômica e a desconcentração de mercado da indústria têxtil paulista durante a Grande Depressão: 1928-1937. In: Revista Planejamento Econômico, Rio de Janeiro, n. 11 (1), abril.1981, pp. 79-105.

${ }^{8}$ Encontram-se, apenas, estudos de caráter genérico, os quais analisam superficialmente a evolução da indústria têxtil doméstica no período aqui focado. Exemplo desses tipos de trabalho é a boa síntese de Stanley Stein. Origens e evolução da indústria têxtil no Brasil (1850-1950). Ed. Campus, Rio de Janeiro, 1979.

${ }^{9}$ Setores fabris designados também por estudiosos como leves ou tradicionais.
} 
crescimento de setores fabris produtores de bens intermediários e bens de capital ${ }^{10}$. A partir de 1929, essa tendência foi acentuada. Observou-se, desde então, crescimento mais significativo destes em detrimento dos chamados leves. Entre 1919 e 1939, por exemplo, o índice de elevação do produto real das empresas fabris de bens intermediários (340\%) e de bens de capital e de consumo duráveis (1392\%) foi muito superior ao das indústrias de bens de consumo não-duráveis $(222 \%)^{11}$. Iniciava-se, dessa forma, um processo substitutivo de importações que englobava não apenas produtos de baixo valor agregado, mas também bens fundamentais para a manutenção da industrialização local (siderurgia, metalurgia, química, produção de máquinas, dentre outros). Por esse motivo, os estudos realizados sobre a indústria brasileira após 1930 centraram-se, quase exclusivamente, na análise desses setores pesados ${ }^{12}$. No máximo, considerações de caráter genérico foram feitas sobre os ditos leves - estes, entre os quais se inclui o têxtil, foram, em grande parte, marginalizados pelos estudiosos.

Apesar de o crescimento das fábricas de tecidos ter sido menor do que o das indústrias pesadas pós-1929, o subsetor têxtil continuaria a ser um dos mais representativos do estado de São Paulo, bem como do País, até meados dos Novecentos. Em 1949, tais empresas concentravam $19,6 \%$ do valor de transformação industrial paulista, perdendo, apenas, para o subsetor de bens alimentícios $(20,5 \%)^{13}$. Afora esse aspecto, deve-se lembrar também que “(...) taxas de crescimento relativo podem ser enganadoras quando a base da qual se parte é muito estreita"14. Em outras palavras, não se pode comparar os altos incrementos ocorridos nesse período nas fábricas produtora de bens pesados com os menores verificados nas ditas tradicionais. Isso acontece porque aquelas praticamente não existiam antes de 1929. Assim, qualquer elevação quantitativa nas mesmas, por mínima que seja, geraria valores consideráveis quando observadas em taxas de crescimento relativo. No caso dos subsetores leves, diferentemente, mesmo que

\footnotetext{
${ }^{10}$ Setores designados também por estudiosos como pesados ou modernos.

${ }^{11}$ Wilson Cano. Desequilíbrios regionais e concentração industrial no Brasil (1930-1970/1970-1995). Ed. da Unicamp, Campinas, 1998, p. 380.

${ }^{12}$ Ver, por exemplo: Wilson Suzigan. Indústria brasileira. Origens e desenvolvimento. Ed. Hucitec / Ed. da Unicamp, São Paulo, 2000; Wilson Cano. Desequilibrios regionais e concentração industrial no Brasil (1930-1970/1970-1995), op. cit; Barjas Negri. Concentração e desconcentração industrial em São Paulo (1889-1990). Editora da Unicamp, Campinas, 1996; Sônia Draibe. Rumos e metamorfoses. Estado e industrialização no Brasil: 1930-1960. Paz e Terra, Rio de Janeiro, 1985; João Manuel Cardoso de Mello. O capitalismo tardio. Contribuição à revisão crítica da formação e desenvolvimento da economia brasileira. Ed. Brasiliense, São Paulo, 1994; Liana Maria Aureliano. No limiar da industrialização. Editora Brasiliense, São Paulo, 1981; Werner Baer. A industrialização e o desenvolvimento econômico no Brasil. Fundação Getúlio Vargas, Rio de Janeiro, 1966.

${ }^{13}$ Barjas Negri, op. cit., p. 104.

${ }^{14}$ Paul Singer. Interpretação do Brasil: uma experiência histórica de desenvolvimento. In: FAUSTO, Boris (org). História Geral da Civilização Brasileira. Tomo III. Volume 4. Ed. Difel, São Paulo, 1994.
} 
ocorressem acréscimos de vulto em suas variáveis econômicas, eles não se mostrariam tão abundantes, se vistos por variação percentual.

Portanto, seja em razão da importância relativa do subsetor têxtil paulista diante das indústrias agregadas locais, seja devido à lacuna de estudos empíricos sobre o tema, justifica-se a necessidade de um trabalho sistemático sobre as fábricas de tecidos do estado de São Paulo no período posterior ao da Grande Depressão. O corte temporal deste estudo contempla as décadas de 1930 e 1940. A partir de 1950, as indústrias pesadas tomam definitivamente a dianteira do processo de industrialização doméstico, ganhando um espaço maior perante as leves - daí o porquê de a análise se centrar até o final dos anos (19)40. Além disso, lembra-se que serão analisados apenas os cincos ramos têxteis mais significativos no que condiz ao número de estabelecimentos, capital aplicado, força motriz, operários e valor de produção, a saber: algodão, juta, malha, lã e seda (natural e artificial).

Tendo já definido o objeto de estudo, ainda se fazem necessárias breves considerações sobre (a) a fundamentação teórico-metodológica que embasou o trabalho; (b) os aspectos técnicos relativos à indústria têxtil; (c) os objetivos e hipóteses da dissertação; e, por último, (d) as fontes consultadas.

\section{Fundamentação teórica}

Compreende-se industrialização como um "processo histórico-social por meio do qual a indústria fabril se torna o setor predominante da economia de um país (grifo

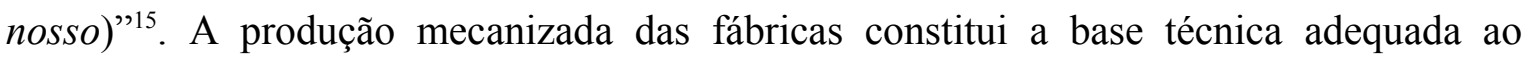
capital; ou, em outras palavras, a formação do modo de produção capitalista só se completa com o surgimento da indústria moderna, a qual faz nascer forças produtivas adequadas às relações sociais de produção existentes no capitalismo.

A produção manufatureira ${ }^{16}$, anterior à da grande indústria, não era ainda a forma produtiva eminentemente capitalista. Isso se deve a dois motivos : (a) o entrave à extração

\footnotetext{
${ }^{15}$ Paulo Sandroni. Dicionário de Economia. Abril Cultural, São Paulo, 1985, p. 206.

${ }^{16}$ Manufatura é a “(...) forma característica do processo de produção capitalista durante o período (...) que (...) vai de meados do século XVI ao último terço do século XVIII” e que se caracterizou pela concentração “(...) numa oficina, sob comando do mesmo capitalista, (de) trabalhadores de ofícios diversos e independentes, por cujas mãos tem de passar um produto até seu acabamento final” Karl Marx. O Capital. Crítica da Economia Política. Volume 1. Livro 1. $5^{\circ}$ Edição. Ed. Civilização Brasileira, Rio de Janeiro, 1980, p. 386.
} 
de mais-valia ${ }^{17}$; (b) e a inexistência de uma subordinação técnica do trabalhador aos meios de produção.

Com relação ao primeiro aspecto, lembra-se que a manufatura, por utilizar ferramentas, possui pequena capacidade de incrementar a produtividade do trabalho. Assim, o acréscimo de mais-valia nesse sistema de produção se dá apenas pela extensão da jornada, isto é, mediante extração da mais-valia absoluta ${ }^{18}$. Esta, por essência, é limitada, pois não pode ultrapassar 24 horas diárias. Reduz-se, com isso, as possibilidades do capitalista em elevar sua apropriação do trabalho excedente.

Já no que se refere ao segundo motivo, sabe-se que o modo de produção capitalista se constitui, efetivamente, pela separação dos trabalhadores dos seus respectivos meios de produção. A separação física se deu, essencialmente, mediante a violência extraeconômica. O processo dos cercamentos ingleses, ocorrido ao longo da Época Moderna, exemplifica tal coerção. Em razão deles, inúmeros pequenos produtores rurais foram expulsos de suas terras. Criaram-se, dessa maneira, condições históricas para a transformação massiva da força de trabalho em mercadoria ${ }^{19}$.

A expropriação física dos meios de produção dos trabalhadores não gera, por si só, uma separação técnica entre esses elementos. Em outras palavras, o fato de o artesão não possuir mais fisicamente o tear não significa que o mesmo tenha esquecido tudo o que aprendera para manuseá-lo. A utilização de uma ferramenta pressupõe conhecimentos especializados mínimos. Como o trabalhador domina a técnica de seu manuseio, ele ainda controla, por conseqüência, o ritmo de produção, regulando o próprio processo do trabalho $^{20}$. A manufatura, por utilizar ferramentas, enquadra-se nessa situação.

\footnotetext{
${ }^{17}$ Dá-se a designação de mais-valia ao trabalho excedente do proletário apropriado pelo capitalista. Como o valor das mercadorias corresponde ao tempo de trabalho socialmente necessário para produzi-las, vê-se que as horas de trabalho que o proletário trabalha a mais para o capitalista - isto é, além das horas necessárias para reproduzir socialmente a mercadoria força de trabalho - constituem uma mais-valia, ou seja, um valor excedente apropriado pelo capital. Para maiores informações, ver: Karl Marx. O Capital, op. cit., especialmente Capítulo VII - A taxa de mais-valia, p. 237-259.

${ }^{18}$ Supõe-se uma jornada de $\boldsymbol{a}$ horas. O tempo de trabalho socialmente necessário para a subsistência e reprodução do proletário é de $\boldsymbol{b}$ horas. A mais-valia, portanto, dá-se por $\boldsymbol{a}-\boldsymbol{b}=\boldsymbol{c}$. Há duas maneiras de se expandir a mais-valia: (a) absolutamente, isto é, aumenta-se $\boldsymbol{a}$, mantendo-se inalterado $\boldsymbol{b}$; ou relativamente, diminui-se $\boldsymbol{b}$, mantendo-se inalterado $\boldsymbol{a}$. Segundo as palavras do próprio Marx, "chamo de mais-valia absoluta a produzida pelo prolongamento do dia de trabalho, e de mais-valia relativa a decorrente da contração do tempo de trabalho necessário e da correspondente alteração na relação quantitativa entre ambas as partes componentes da jornada de trabalho (a saber: trabalho necessário, isto é, aquele que é socialmente necessário para a subsistência e reprodução do trabalhador; e trabalho excedente, ou seja, a mais-valia em si)". Karl Marx, O Capital, op. cit., p. 363.

${ }^{19}$ Ver: Karl Marx. O Capital. Livro I. Volume II, op. cit., especialmente Capítulo XXIV - A chamada acumulação primitiva, p. $828-882$.

${ }^{20}$ Carlos Alonso Barbosa de Oliveira. Processo de industrialização. Do capitalismo originário ao atrasado. Ed. Unesp, São Paulo, 2003, p. 42-43.
} 
Pode-se, agora, compreender melhor o porquê de a indústria moderna constituir a base técnica adequada ao modo de produção capitalista. Ela destrava os limites impostos para a extração da mais-valia e separa tecnicamente os trabalhadores dos meios de produção.

Do ponto de vista conceitual, "indústria moderna" é a unidade de produção que funciona com o emprego de maquinaria ${ }^{21}$. Esta, por sua vez, pode ser caracterizada como “(...) um mecanismo que, ao lhe ser transmitido o movimento apropriado, realiza com suas ferramentas as mesmas operações que antes eram realizadas pelo trabalhador com ferramentas semelhantes. Provenha a força motriz do homem ou de outra máquina, a coisa não muda em sua essência. Quando a ferramenta propriamente dita se transfere do homem para um mecanismo, a máquina toma o lugar das simples ferramentas (grifo nosso)" $)^{\prime 22}$.

A máquina possui suas próprias ferramentas, manuseando-as sem depender do conhecimento técnico do trabalhador. Este, no máximo, utiliza sua força para movimentála, atuando como um elemento subjacente - e não mais como necessário. Abrem-se, assim, possibilidades para o uso de forças motrizes mais possantes e livres das irregularidades e imperfeições dos movimentos humanos, tais como a energia térmica ${ }^{23}$. O trabalhador torna-se subordinado à máquina, apenas vigiando e corrigindo seu funcionamento. Ele não dita mais o ritmo no processo produtivo. A separação técnica entre o proletário e os meios de produção permite ao capital um domínio completo do trabalho ${ }^{24}$.

Além desse aspecto, a maquinaria, ao elevar a produtividade do trabalho ${ }^{25}$, torna-se instrumento de extração de mais-valia relativa - isto é, ao diminuir o tempo de trabalho socialmente necessário para reproduzir a mercadoria força de trabalho, aumenta-se o trabalho excedente (mais-valia) e reduz-se o trabalho necessário nos processos produtivos.

\footnotetext{
${ }^{21}$ Karl Marx. O Capital. Livro I. Volume I, op. cit., p. 432. Sabe-se, porém, que, de um ponto de vista mais amplo, que indústria é “(...) o conjunto de atividades produtivas que se caracterizam pela transformação de matérias-primas, manualmente ou com auxílio de máquinas e ferramentas, no sentido de fabricar mercadorias". Paulo Sandroni. Dicionário de Economia, op. cit., p. 206.

${ }^{22}$ Karl Marx. O Capital, op. cit., p. 426-427.

${ }^{23}$ Idem, op. cit., p. 429.

24 "Ainda que seja característica comum a toda produção capitalista a submissão do trabalhador às próprias condições de trabalho como capital, essa inversão somente adquire uma expressão tecnicamente tangível com o advento das máquinas". Luiz Gonzaga de Mello Belluzo. Valor e capitalismo. Ed. Brasiliense, São Paulo, 1980, p. 96.

25 "Entendemos aqui por elevação da produtividade do trabalho em geral uma modificação no processo de trabalho por meio do qual se encurta o tempo de trabalho socialmente necessário para produção de uma mercadoria, conseguindo-se produzir com a mesma quantidade de trabalho, quantidade maior de valor de uso". Karl Marx. O Capital. Livro I. Volume I, op. cit., p. 362.
} 
Esse crescimento da produtividade pode ser identificado pela elevação dos valores assumidos pela composição orgânica do capital ${ }^{26}$.

Lembra-se, no entanto, que "para diminuir o valor da força de trabalho, tem o aumento da produtividade de atingir ramos industriais cujos produtos determinam o valor da força de trabalho, pertencendo ao conjunto dos meios de subsistência costumeiros ou podendo substituir esses meios (grifo nosso) ${ }^{\prime 27}$. Para se compreender a maneira pela qual se aumenta relativamente a extração de mais-valia dos proletários, devese perguntar, portanto, quais produtos "determinam o valor da força de trabalho". Enquadram-se nesse conjunto os diversos subsetores fabris que compõem o grupo produtor de bens de consumo não-duráveis, tais como a indústria de alimentos, de bebidas, de calçados e a têxtil. O barateamento de camisas, por exemplo, contribui para a elevação da taxa geral de mais-valia.

Tem-se consciência, no entanto, de que um processo de industrialização em si requer a autodeterminação do capital, isto é, eliminação de quaisquer barreiras à acumulação de capital, seja na reprodução do capital constante, seja na do variável. Isso significa que a industrialização de uma dada formação social prescinde do desenvolvimento de um subsetor fabril básico, o qual produza bens intermediários e de capital em quantidade necessária para manutenção do processo acumulativo ${ }^{28}$.

Pode-se questionar, nesse sentido, qual é a importância de se estudar a evolução da indústria têxtil paulista num contexto histórico (década de 1930 e 1940) em que o processo de industrialização local ainda era "restringido", isto é, incapaz de efetivar uma autodeterminação plena do capital devido à reduzida dimensão das indústrias pesadas ${ }^{29}$. A importância reside não apenas no fato de as fábricas de tecidos paulistas serem relativamente significativas na indústria e na própria economia domésticas - contribuindo, assim, de maneira fundamental, para o nível de demanda agregada ${ }^{30}$-, mas também em

${ }^{26}$ A composição orgânica do capital pode ser definida “(...) pela relação entre o capital constante e o variável, relação em valor que reflete a composição técnica do capital, ou seja, a relação entre o volume dos meios de produção e o volume de trabalho vivo mobilizado pelo capital". Carlos Alonso Barbosa de Oliveira, op. cit., p. 363.

${ }^{27}$ Karl Marx. O Capital. Livro I. Volume I, op. cit., p. 363.

${ }^{28}$ Maria da Conceição Tavares. Acumulação de capital e industrialização no Brasil. $3^{\circ}$ Edição. Ed. da Unicamp, Campinas, 1998, p. 32.

${ }^{29}$ Sabe-se que a maturação dos setores industriais de base no país ocorreu a partir dos anos (19)50. João Manuel Cardoso de Mello. O capitalismo tardio. Contribuição à revisão crítica da formação e desenvolvimento da economia brasileira. Ed. Brasiliense, São Paulo, 1994. Ver, principalmente, Capítulo II - A industrialização retardatária, p. 88-173.

${ }^{30}$ Lembra-se, porém, que a contribuição dada pela indústria têxtil paulista à demanda agregada doméstica vincula-se, em grande parte, aos seus investimentos em capital variável. Os investimentos em capital constante, como muitas vezes são feitos mediante importações - em razão da própria insuficiência do setor de bens de produção doméstico no contexto estudado -, canalizam-se para o exterior. O efeito multiplicador 
razão de as mesmas, por constituírem um dos subsetores que "determinam o valor da força de trabalho", possibilitarem a elevação da taxa de mais-valia geral na sociedade. Estudálas é, portanto, tentar compreender o próprio amadurecimento do modo de produção capitalista local, na medida em que a mesma contribuía para o acréscimo de extração de mais-valia relativa dos setores econômicos internos.

\section{$\underline{\text { Aspectos técnicos relativos à indústria têxtil }}$}

A indústria têxtil divide-se em $\operatorname{ramos}^{31}$, de acordo com a matéria-prima utilizada no processo produtivo. Estas, por sua vez, são classificadas em dois grupos: fibras naturais (vegetais e animais) e químicas (artificiais e sintéticas) ${ }^{32}$.

Dentre as fibras naturais de origem vegetal, destacam-se o algodão, o linho, a juta e o cânhamo. O primeiro é um fruto de uma espécie de árvore (no caso, o algodoeiro), cuja composição é de, aproximadamente, $2 / 3$ de sementes e $1 / 3$ de fibras ${ }^{33}$. As demais são fibras de caule. O linho provém de uma planta da família das urtigas, sendo uma das mais fortes fibras vegetais. O cânhamo é muito utilizado na produção de cordas. A juta, por último, é produzida por uma planta herbácea. Seus fios confeccionam, principalmente, sacos e tecidos para embalagem em geral ${ }^{34}$.

Dentre as fibras naturais de origem animal, citam-se a lã e a seda. A primeira, resultante do tosqueamento das ovelhas, era a principal matéria-prima têxtil nas zonas temperadas antes do advento da Revolução Industrial inglesa ${ }^{35}$. A segunda, predominante nas regiões orientais do globo, origina-se do casulo tecido pelo bicho da seda quando este,

do investimento, portanto, reduz-se substancialmente. Recorda-se que o multiplicador do investimento "(...) nos indica que, quando se produz um acréscimo no investimento agregado, a renda sobe num montante igual a $\boldsymbol{k}$ vezes o acréscimo do investimento." John Maynard Keynes. Teoria Geral do Emprego, do Juro e da Moeda. Ed. Abril, São Paulo, 1983, p. 88. Para maiores informações sobre o conceito de multiplicador, ver: Raúl Prebisch. Keynes. Uma introdução. Ed. Brasiliense, São Paulo, 1998, Capítulo II - A propensão a consumir e a teoria do multiplicador, p. 49-76.

${ }^{31}$ Do ponto de vista concentual, a economia de uma dado país divide-se em setores (industrial, agrícola e serviços). Estes, por sua vez, subdividem-se em subsetores (no caso do setor fabril: subsetor têxtil, subsetor metalúrgico, subsetor de calçados, subsetor de fósforos, subsetor de bebidas, etc.). Os subsetores estão parcelados em ramos (no caso do subsetor têxtil, em ramo algodoeiro, lanífero, jutífero, malhas, sedas, linho, etc.).

${ }^{32}$ Emil Dove. Economia industrial têxtil. Elementos para su estudio. Volume 1. Gráficas Marina S.A., Barcelona, 1946, p. 40-119.

${ }^{33}$ Idem, op. cit., p. 70.

${ }^{34}$ Maiores informações acerca da história do cânhamo e da juta, ver: Maria Izilda de Matos. Trama e poder. Um estudo sobre as indústrias de sacaria para o café (São Paulo / 1889-1934). SESI-DN, Brasília, 1994, p. 35; e Ministério do Trabalho, Indústria e Comércio. Comissão Executiva Têxtil (CETex). A juta brasileira. Rio de Janeiro, 1948.

${ }^{35}$ Ver, principalmente: Paul Mantoux. A Revolução Industrial no Século XVIII. Editora Unesp / Huitec, São Paulo, s/d. 
em sua fase de larva, prepara-se para se transformar em crisálida. Mata-se a crisálida mediante exposição do casulo em fortes raios solares. Após isso, por meio da utilização de água quente, dá-se o desenrolar dos seus fios ${ }^{36}$.

Já no grupo das fibras químicas, encontram-se as fibras artificiais e as sintéticas. As primeiras, cujo maior exemplo é o rayon (denominado também de seda artificial), tem como base o protoplasma de celulose, obtido seja de restos de algodão, seja de madeiras. Inventado em 1884 pelo conde francês Hillaire Chardonnet, desenvolveu-se muito ao longo da Primeira Guerra Mundial (1914-1918), devido à impossibilidade das nações centrais comprarem matérias-primas dos países periféricos ${ }^{37}$. As sintéticas, por sua vez, são originárias da petroquímica. Desse grupo, destacam-se o nylon, o acrílico, o poliéster, o polopropileno e a elastomérica. Com exceção do nylon (1938), tais fibras foram inventadas num contexto posterior ao do contemplado por este trabalho. Serão, assim, desconsideradas como objeto de análise ${ }^{38}$.

Além do aspecto concernente às diferentes fibras utilizadas pelos ramos têxteis, é importante apresentar também as fases do processo de produção de tecidos ${ }^{39}$, a saber: (a) beneficiamento; (ii) fiação; (iii) tecelagem; e (iv) acabamento ${ }^{40}$.

O beneficiamento caracteriza-se pela fase de preparo da matéria-prima para a fiação. Soltam-se, em primeiro lugar, as felpas de algodão dos seus respectivos enfardamentos, desamassando-as e descomprimindo-as. Utilizam-se, após isso, os abridores e batedores, os quais têm a função de extrair das felpas o maior número de impurezas possíveis, tais como terra, resíduos de caroços e folhas. O algodão sai dos batedores em forma de mantas enroladas, denominadas rolos. É encaminhado para as cardas - cilindros possuidores de agulhas de aço -, que limpam melhor os rolos, coordenam as fibras e desfazem os nós. Resultam, desse processo, fitas de algodão de 2 a

\footnotetext{
${ }^{36}$ Emil Dove, op. cit., p. 44-52.

${ }^{37}$ Emil Dove, op. cit., p. 112-119; Ely Mitie Massuda. Inovação na Indústria Têxtil Brasileira (1983-1989) o caso das fiações na região de Maringá. Tese de Doutorado, FFLCH, USP, 2002, p. 45-46.

${ }^{38}$ Sobre o histórico das fibras sintéticas, encontra-se bom resumo em Luigi Spreafico. A transferência da tecnologia na indústria têxtil e do vestuário, São Paulo, 1970 (mimeo).

39 Serão apresentadas as fases do processo produtivo algodoeiro, a qual é a mais conhecida. As fontes existentes sobre a produção dos demais tecidos ratificam a semelhança entre tais processos. Para informações específicas acerca dos demais ramos, ver: Ministério do Trabalho, Indústria e Comércio. Comissão Executiva Têxtil (CETex). A juta brasileira. Rio de Janeiro, 1948; B. Monteiro. Curso breve de técnica de lanifícios. In: Lanificios - Boletim Mensal, n. 117-118, Lisboa, s/d, pp. 563- 579; e Luigi Spreafico, op. cit.

${ }^{40}$ A descrição a seguir tem como base as seguintes obras: Antônio Francisco Bandeira Jr. A indústria no estado de São Paulo em 1901. Tipografia do Diário Oficial, São Paulo, 1901; Maria Alice Rosa Ribeiro, op. cit; Ely Mitie Massuda, op. cit; e Emil Dove, op. cit.
} 
$3 \mathrm{~cm}$ de largura. Na última fase do beneficiamento, as passadeiras transformam, aproximadamente, seis fitas de cardas em um fio.

Isso feito, inicia-se o processo de fiação propriamente dito. As fitas de algodão das passadeiras são encaminhadas às maçaroqueiras, cuja função é a de estirá-las e torcê-las, reduzindo seus diâmetros e unindo fitilhos separados durante o beneficiamento. Uma torção bem realizada impede que os fios arrebentem no processo de tecelagem. Quanto maior o número de filamentos utilizados para a criação de um fio, mais rude e áspero será o tecido. Os fitilhos das maçarocas, após isso, dirigem-se às fiandeiras, que realizam maiores estiragens e torções, com o intuito de constituir um fio mais fino do que o anterior: este será o fio utilizado na tecelagem.

$\mathrm{O}$ ato de tecer consiste no cruzamento e entrelaçamento dos fios produzidos nas etapas anteriores, os quais, congregados, formam um tecido. Para que a tecelagem se concretize, no entanto, devem-se alocar os fios de maneira distinta: um grupo tecerá no sentido longitudinal e outro estará posicionado perpendicularmente àquele. Chama-se a formação dos primeiros de teia ou urdidura; e, a dos segundos, levado pelas lançadeiras, de tramas. Os fios verticais, assim, iam para as urdideiras em forma de carretéis, enquanto os horizontais se dirigiam às espulas (cilindros de madeira), que alimentam as lançadeiras.

Deve-se atentar para o fato de que, no caso dos fios coloridos, há sensível modificação no processo entre a fiação e a tecelagem. Após as fiandeiras, os fios dirigemse às meadeiras, para serem enrolados em meadas. Posteriormente, ingressam, dependendo de cada caso, nas seções de tinturaria $^{41}$, mercerização $^{42}$ e alvejamento $^{43}$.

A última das fases é a do acabamento. Nesta, dava-se a preparação final do tecido para venda. Ingressavam nas calhandras máquinas formadas por cinco cilindros superpostos, nas quais os tecidos passavam sob forte pressão, devido à utilização do vapor d'água. Visava-se, com isso, comprimi-los para melhor medição e, conseqüentemente, para melhor corte. Tinha-se, por último, o ensacamento.

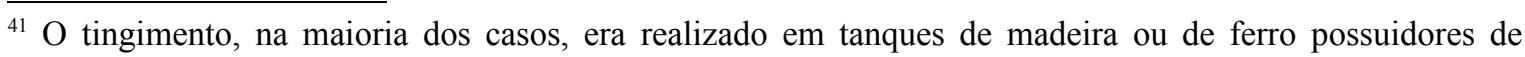
substâncias químicas corantes nas quais os fios eram embebidos.

${ }^{42}$ Operação que consiste em impregnar de soda cáustica os fios e tecidos de algodão. Dava-se, com isso, uma aparência brilhante e sedosa aos mesmos, bem como se aumentava sua resistência e garantia-se maior absorção das cores.

${ }^{43}$ Ato de branquear os fios.
} 
Objetivos e hipóteses

Os principais objetivos desse estudo são:

(i) analisar a dinâmica produtiva do subsetor ao longo do período 1929-1950; isto é, visase observar e compreender a evolução da composição orgânica do capital e os momentos de elevação / decréscimo da produção;

(ii) comparar a situação econômica do subsetor têxtil paulista com a dos demais subsetores fabris domésticos. Quantificar e apreender as mudanças de participação relativa do primeiro perante os segundos;

(iii) nos períodos de crescimento produtivo do subsetor têxtil, constatar as suas formas de realização, a saber: utilização de capacidade ociosa e/ou inversões ampliadoras de tal capacidade;

(iv) examinar a evolução da participação relativa dos ramos têxteis paulistas perante o subsetor agregado ao longo do período. Analisar seus respectivos desempenhos no processo substitutivo de importações, por meio da observação de dados acerca da entrada de tecidos estrangeiros pelo porto de Santos;

(v) quantificar e avaliar a evolução da balança comercial têxtil paulista com relação a outros estados durante o processo de integração do mercado local, aprofundado na Era Vargas (1930-1945);

(vi) quantificar e avaliar a evolução da balança comercial têxtil com relação a outros países ao longo do período;

(vii) verificar a dinâmica da concentração industrial no subsetor têxtil e em seus ramos durante as décadas em estudo;

(viii) observar o impacto - seja negativo, seja positivo - das políticas econômicas públicas no subsetor de tecidos. Examinar, mediante documentação patronal, a relação entre a burguesia têxtil paulista e o Governo; 
(ix) analisar a evolução das condições de trabalho das fábricas têxteis paulistas nesse interregno. Observar possíveis resistências por parte da burguesia de tecidos paulista em aplicar as leis trabalhistas criadas, bem como as alternativas técnicas criadas pela mesma para manter a extração de igual montante de mais-valia dos operários têxteis.

As principais hipóteses do trabalho são:

(a) o período 1929-1950 foi, no geral, momento de crescimento para a indústria têxtil paulista em razão do aprofundamento do processo substitutivo de importações (propiciado pela Grande Depressão e pela Segunda Guerra Mundial) e do fortalecimento do mercado doméstico, muito devido à sua integração, constituída, inicialmente, na Era Vargas;

(b) o processo de integração do mercado local, que permitiu expansão de vendas para a indústria têxtil paulista (especialmente na década de 1930), foi resultado, entre outras razões, de muitas lutas das burguesias regionais do subsetor. Exemplo maior desses conflitos - cujos vitoriosos foram, em geral, os empresários de tecidos do Centro-Sul foram as discussões concernentes à criação e, depois, à manutenção da lei proibitiva de importação de máquinas para as indústrias consideradas em superprodução (1931-1937). Esta lei congelou posições relativas entre as empresas têxteis, favorecendo àquelas que já se encontravam em condições técnicas superiores antes da Grande Depressão, a saber: as paulistas. A conquista do mercado interno por elas processadas - e que se iniciou nesse contexto - deveu-se muito à legislação supracitada;

(c) A evolução do subsetor têxtil paulista nesse período não se processou de maneira homogênea. Houve diferenças entre os desempenhos econômicos dos ramos, que, por sua vez, resultaram em mudanças das participações relativas entre os mesmos;

(d) A indústria têxtil paulista, ao longo dos anos (19)30 e (19)40, passou por processo de desconcentração setorial (maior preponderância de pequenas e médias empresas) e espacial (interiorização das unidades fabris);

(e) as condições de trabalho dos operários têxteis, apesar da melhora ocasionada pela implementação das leis trabalhistas, ainda se mantiveram essencialmente precárias. $\mathrm{O}$ relacionamento entre burguesia e Estado, conflituoso no início dos anos (19)30 em razão 
da negativa patronal em efetivar as ditas leis, tornou-se cada vez mais harmônico ao longo desse período.

\section{$\underline{\text { As fontes }}$}

Para análise da evolução econômica do subsetor têxtil e dos seus ramos, utilizaram-se quatro tipos de fontes: (i) estatísticas e relatórios oficiais confeccionados por órgãos públicos (federal, estadual e municipais); (ii) documentos de associações patronais; (iii) documentos de empresas; e (iv) jornais.

Sobre o primeiro tipo de fonte, destacam-se os Anuários Estatísticos (Brasil - São Paulo), as Estatísticas Industriais (São Paulo); e as Estatísticas do Comércio do Porto de Santos, incluindo as de Cabotagem. Tais documentos permitiram uma análise macroeconômica da indústria têxtil paulista, possibilitando a percepção de tendências gerais das mais importantes variáveis econômicas do subsetor (número de estabelecimentos, montante de capital, operários, força motriz, valores e quantidades produzidas, entre outros). Além disso, no que se refere aos dados da balança comercial do estado, verificou-se a evolução do domínio dos têxteis paulistas em relação aos outros mercados regionais.

O segundo tipo de fonte foi formado pela documentação das associações patronais, sejam as das indústrias agregadas (Centro das Indústrias do Estado de São Paulo, CIESP; Federação das Indústrias do Estado de São Paulo, FIESP; Centro Industrial do Brasil, CIB), sejam as das fábricas têxteis (Centro Industrial de Fiação e Tecelagem de Algodão, CIFTA; Centro dos Industriais de Fiação e Tecelagem de São Paulo, CIFT; Sindicato Patronal das Indústrias Têxteis do Estado de São Paulo, SPITESP). Destas associações, pesquisaram-se quatro tipos de documentação primária: (i) atas de assembléias ordinárias e extraordinárias; (ii) atas de reunião de diretoria; (iii) relatórios de diretoria; e (iv) circulares. Tais fontes possibilitaram vislumbrar os pontos de vista da burguesia industrial - notadamente a têxtil - como grupo, sob os mais variados temas. Permitiram, ainda, a extração de dados econômicos específicos, não-arrolados pelas instituições de estatística governamentais, e a observação do relacionamento burguês com o Estado.

O terceiro tipo de fonte é composto por documentos de algumas empresas têxteis paulistas. Utilizaram-se, aqui, (i) balanços; (ii) atas de assembléias ordinárias e extraordinárias; (iii) relatórios de diretoria; e (iv) cartas. Os três primeiros foram extraídos, majoritariamente, do Diário Oficial do Estado de São Paulo. Lembra-se que 
somente as indústrias organizadas sob a forma de sociedade anônima eram obrigadas a publicar esses documentos no Diário Oficial, para informar seus acionistas acerca da situação financeira e das deliberações em assembléia das empresas. Já as cartas destinavam-se, em sua maioria, às associações patronais. Estas fontes auxiliaram na ratificação das tendências produtivas dos ramos têxteis, extraídas de estatísticas macroeconômicas. Além disso, quando negaram tais tendências, tornaram-se exemplificativas da complexidade e da heterogeneidade das fábricas de tecidos paulistas.

Por último, no que se refere aos jornais (O Estado de São Paulo; Jornal do Comércio - SP e RJ -; Folha da Manhã; Folha da Noite; entre outros), pode-se dizer que sua principal importância residiu na publicação de editoriais, sobre os mais variados temas, redigidos por indivíduos ligados à burguesia industrial têxtil, ou contra a mesma (Sociedade Rural Brasileira, por exemplo).

Além dessas fontes, agregou-se, com relação à temática das relações sociais de produção, os boletins do Departamento Estadual do Trabalho (DET) do estado de São Paulo. Estes possibilitaram a elucidação das condições de emprego no interior das fábricas têxteis paulistas do final dos anos (19)20 e início dos (19)30. Os documentos das associações patronais, por sua vez, permitiram compreender a argumentação burguesa com relação às condições fabris e às leis trabalhistas postas em vigência na Era Vargas (1930-1945). Pesquisaram-se também os arquivos do DOPS (Delegacia de Ordem Política e Social), fonte importante para a compreensão do relacionamento burguesia Estado, em especial no que condizia à contenção dos movimentos operários e às greves. Finalmente, periódicos do operariado (A Plebe; A Terra Livre; etc.), panfletos e circulares dos sindicatos de trabalhadores têxteis (União dos Operários em Fábrica de Tecidos de São Paulo, depois denominado Sindicato dos Operários em Fiação e Tecelagem de São Paulo), publicados em jornais ou apreendidos pelo DOPS, complementaram a perspectiva da evolução das relações de trabalho nas indústrias de tecidos.

O trabalho está organizado em cinco capítulos, divididos mediante critério cronológico. No primeiro deles, faz-se uma radiografia da indústria têxtil paulista antes da Grande Depressão (1929). No segundo, discutem-se as implicações da crise 1929-1932 para o subsetor de tecidos estadual. No terceiro, apresenta-se o processo de recuperação têxtil durante o interregno 1933-1939, considerado crucial para a compreensão da sua dinâmica posterior. No quarto, analisa-se o desempenho das indústrias de tecidos no contexto da Segunda Guerra Mundial (1939-1945). Por último, no quinto, mostra-se a 
evolução das empresas têxteis paulistas no pós-guerra. Realiza-se também um balanço do ramo no final da década de (19)40, objetivando, com isso, apreender as continuidades e modificações ocorridas no mesmo durante as décadas aqui estudadas. 


\section{CAPÍTULO 1 - A radiografia da indústria têxtil paulista (1928)}

Neste capítulo, objetiva-se realizar um panorama da estrutura produtiva, das relações de trabalho e da situação econômica das fábricas de tecidos paulistas antes da crise mundial. Assim, por meio desta referência, será possível perceber melhor os impactos sofridos pelo subsetor têxtil e pelos seus diversos ramos no período da grande depressão (1929-1932) e ao longo dos anos (19)30 e (19)40.

\section{$\underline{1.1-\text { As estruturas }}$}

Em 1928, o estado de São Paulo destacava-se como a unidade federativa mais industrializada do País. Segundo dados do Recenseamento Geral de 1920, São Paulo possuía, em tal ano, mais de 30\% do número de estabelecimentos industriais, concentrava $27 \%$ do capital investido, $29 \%$ dos operários e $31,5 \%$ de todo o valor produzido no setor fabril doméstico ${ }^{44}$.

Dentre as indústrias existentes no estado, a têxtil era a mais importante. Apesar do seu reduzido número de estabelecimentos, os quais não perfaziam nem $4 \%$ do total estadual (Tabela 1.1), este subsetor possuía mais de $30 \%$ da força motriz e do valor produtivo e quase $50 \%$ do capital investido e do número de operários. Apresentava-se, portanto, como "a mais poderosa de todas as indústrias paulistas"

Tabela 1.1 - Participação da indústria têxtil paulista perante as indústrias totais do Estado (1928)

\begin{tabular}{lccc} 
& Têxtil & Geral & Têxtil/Geral (\%) \\
\hline Estabelecimentos & 264 & 6.923 & 3,8 \\
Capital (contos) & 468.955 & 1.101 .823 & 42,6 \\
Operários & 67.810 & 148.376 & 45,7 \\
Força Motriz (h.p.) & 62.259 & 181.076 & 34,4 \\
Valor da Produção (contos) & 829.105 & 2.441 .436 & 34,0 \\
\hline
\end{tabular}

Fonte: Estatística Industrial do Estado de São Paulo, 1928.

Comparando-se o subsetor têxtil de São Paulo com o total das indústrias de tecidos domésticas, chega-se a observações sobre a preponderância do primeiro sobre as suas congêneres nacionais. Quase 30\% dos estabelecimentos têxteis do Brasil estavam localizados no estado de São Paulo (Tabela 1.2), o qual também concentrava aproximadamente $27 \%$ do capital investido e mais de $34 \%$ do número de operários.

44 Brasil. Ministério da Agricultura, da Indústria e do Comércio. Diretoria Geral de Estatística. Recenseamento do Brasil realizado em 1 de setembro de 1920, p. 08.

${ }^{45}$ Correio Paulistano. A Indústria Paulista, 09.05.1930. 
Menciona-se também a questão da relativa rigidez tecnológica existente no subsetor de tecidos, gerador de significativa concentração industrial. Em 1928, apenas $12,5 \%$ das fábricas têxteis paulistas possuíam $69,9 \%$ do capital aplicado e mais de $70 \%$ do número de operários ${ }^{46}$. Essa rigidez tecnológica deve-se, entre outros fatores, à seção de fiação, cuja estrutura fabril tinha de se adequar a grandes escalas de produção, diferentemente das tecelagens ${ }^{47}$. Além disso, altos investimentos energéticos também se faziam necessários para a viabilização de tamanha força produtiva ${ }^{48}$. Requisitava-se, assim, um montante de capital considerável para a realização de uma inversão neste subsetor.

Tabela 1.2 - Estabelecimentos, capital aplicado e número de operários na indústria têxtil de São Paulo e na indústria têxtil brasileira (1920)

\begin{tabular}{lccc} 
& São Paulo & Brasil & Relação São Paulo / Brasil \\
\hline Estabelecimentos & 112 & 391 & 0,29 \\
Capital Aplicado (contos) & 181.192 & 663.332 & 0,27 \\
Operários & 34.825 & 103.945 & 0,34 \\
\hline
\end{tabular}

Fonte: Recenseamento Geral do Brasil, 1920.

\subsection{1 - Os ramos}

Dentre os ramos mais importantes da indústria têxtil paulista, destaca-se o de fiação e tecelagem de algodão. Tendo sido o primeiro a se desenvolver no estado, a partir das décadas de 1860 e $1870^{49}$, possuía, em 1928, mais de $64 \%$ do capital, $60 \%$ do número de operários e $74 \%$ da força motriz existente no subsetor têxtil (Tabela 1.3).

Além da sua preponderância econômica, o ramo algodoeiro caracterizava-se pela alta concentração industrial. Em 1928, apenas 31,7\% das fábricas têxteis de algodão paulistas detinham $78,3 \%$ do capital investido e $82,7 \%$ dos operários empregados no total

\footnotetext{
${ }^{46}$ Ver Anexo - Tabela 9.

47 Entretanto, muitas seções de tecelagem eram construídas nas mesmas dimensões das de fiações, para não deixar estas últimas com capacidade ociosa. Ver: Wilson Cano. Alguns aspectos da concentração industrial. In: Flávio Rebelo Versiani e José Mendonça de Barros (Org.). Formação econômica do Brasil. A experiência da industrialização. Ed. Saraiva, São Paulo, 1977, p. 69-70.

${ }^{48}$ Sabe-se que, conforme o problema energético vai sendo resolvido no estado de São Paulo - por meio da criação de novas redes de distribuição de eletricidade -, bem como o da fiação - por meio do crescimento da produção de fios -, a tendência é que se possibilite o aparecimento de um número maior de pequenos e médios investidores no subsetor. A verificação de tal tendência será feita ao longo deste trabalho. Para maiores informações sobre a questão energética no estado de São Paulo, ver: Catullo Branco. Energia elétrica e capital estrangeiro no Brasil. Ed. Alfa-Ômega, São Paulo, 1975.

49 Para maiores informações sobre os primórdios do desenvolvimento têxtil algodoeiro, ver: Alice P. Canabrava. O desenvolvimento da cultura do algodão na Província de São Paulo (1861-1875). S/e, São Paulo, 1951, especialmente a seção 4.1 - As primeiras fábricas de tecidos; e Stanley Stein. Origens e evolução da indústria têxtil no Brasil (1850-1950). Ed. Campus, Rio de Janeiro, 1979.
} 
das mesmas (Tabela 1.4). As relações capital-fábrica e trabalho-fábrica eram as segundas mais altas entre todos os ramos têxteis (Tabela 1.5). Este fato pode ser explicado pela existência de muitas empresas possuidoras de fiações ${ }^{50}$, inviabilizando, assim, pequenos investimentos. Apenas três empresas de tecidos de algodão do estado - a S.A. Fábrica Votorantim (Sorocaba); as Fábricas Mariângela e Belemzinho, das Indústrias Reunidas Francisco Matarazzo (capital); e o Cotonificio Rodolfo Crespi (capital) - possuíam 20,2\% do capital aplicado no ramo; 31,4\% do número de operários; $33 \%$ dos fusos; e 35\% dos teares $^{51}$. A composição orgânica do capital situava-se em terceiro lugar, enquanto sua produtividade era a mais baixa do subsetor têxtil, demonstrada pelas elevadas relações capital-produto e operário-produto (Tabela 1.5). Por último, lembra-se que a matériaprima, em sua maioria adquirida domesticamente, provinha da região Nordeste e do próprio estado de São Paulo ${ }^{52}$.

Tabela 1.3 - Participação Relativa (\%) - Ramos da Indústria Têxtil Paulista (1928)

\begin{tabular}{lccccc} 
& Algodão & Juta & Lã & Malha & Seda* \\
\hline Estabelecimentos & 31,5 & 2,0 & 5,6 & 42,4 & 18,5 \\
Capital (contos) & 64,5 & 12,6 & 4,0 & 6,7 & 12,1 \\
Operários & 60,6 & 13,0 & 4,6 & 10,9 & 10,9 \\
Força Motriz & 74,6 & 10,8 & 5,2 & 3,8 & 5,5 \\
Produção (contos) & 43,4 & 11,1 & 10,2 & 12,1 & 23,2 \\
\hline
\end{tabular}

Fonte: Anexo - Tabelas 1 à $7 . /$ * Inclui fiação e tecelagem de seda natural e artificial (rayon).

Após o têxtil algodoeiro, ressalta-se o ramo da fiação e tecelagem de juta - segundo lugar em três das variáveis arroladas (capital, operários e força motriz - Tabela 1.3). Mais do que qualquer outro, caracterizava-se por elevada concentração industrial, com preponderância de grandes estabelecimentos (Tabela 1.4). Possuía a maior composição orgânica do capital, bem como as mais elevadas relações capital-fábrica e trabalho-fábrica entre todos os ramos de tecidos do estado (Tabela 1.5). Essa concentração explica-se pela rigidez tecnológica na fabricação dos tecidos de juta, em razão das grandes inversões necessárias na seção de fiação ${ }^{53}$. Das cinco empresas existentes no ramo, três possuíam

\footnotetext{
${ }^{50}$ Segundo Villela e Suzigan, em 1929, o ramo possuía mais de 825 mil fusos instalados. Aníbal Villela e Wilson Suzigan. Política do governo e crescimento da economia brasileira (1889-1945). IPEA.INPES, Rio de Janeiro, 1973, p. 357 e 364.

${ }^{51}$ Estatística Industrial do Estado de São Paulo, 1928, p. 82-85.

${ }^{52}$ Somente em 1928, o porto de Santos recebeu, via cabotagem, mais de 18 mil toneladas de algodão, provenientes, em sua maioria, de estados nordestinos (Paraíba, Pernambuco e Rio Grande do Norte). Já, via mercado externo, o porto recebeu um pouco menos de 4 toneladas. In: Comércio de cabotagem pelo porto de Santos, 1928-1929, p. 11; e Estatística do comércio do porto de Santos, 1927-1928, p. 06.

${ }^{53}$ Para maiores informações sobre as especificidades da produção dos tecidos de juta e da alta rigidez tecnológica existente no ramo, ver: Maria Izilda de Matos. Trama e poder. Um estudo sobre as indústrias de sacaria para o café (São Paulo / 1889-1934). SESI-DN, Brasília, 1994, p. 63-66.
} 
fiações. Nestas, os altos investimentos tornavam-se necessários. A maior das três, a Companhia Nacional de Tecidos de Juta, com sede na cidade de São Paulo, concentrava acima de $75 \%$ do capital nele investido; $59 \%$ do número de operários e de fusos; e $64 \%$ da quantidade de teares e da força motriz. O ramo apresentava, além disso, consideráveis índices de produtividade (Tabela 1.5). Grande parte da produção de fios era realizada internamente, porém a dependência com relação à importação de juta bruta era considerável. Somente em 1928, comprou-se mais de 12 mil toneladas dessa matériaprima do exterior ${ }^{54}$.

Tabela 1.4 - Participação relativa (\%) de pequenos, médios e grandes estabelecimentos nos ramos da Indústria Têxtil Paulista (1928)*

\begin{tabular}{|c|c|c|c|c|c|c|}
\hline & Pequeno & Médio & Grande & Pequeno & Médio & Grande \\
\hline & \multicolumn{3}{|c|}{ Algodão } & \multicolumn{3}{|c|}{ Juta } \\
\hline Fábricas & 26,8 & 41,5 & 31,7 & 0,0 & 40,0 & 60,0 \\
\hline Capital & 3,1 & 18,6 & 78,3 & 0,0 & 3,5 & 96,5 \\
\hline Operários & 2,1 & 15,3 & 82,7 & 0,0 & 4,7 & 95,3 \\
\hline & \multicolumn{3}{|c|}{ Lã } & \multicolumn{3}{|c|}{ Malha } \\
\hline Fábricas & 52,4 & 47,6 & 0,0 & 85,1 & 14,0 & 0,9 \\
\hline Capital & 20,3 & 79,7 & 0,0 & 37,5 & 59,7 & 2,8 \\
\hline \multirow[t]{2}{*}{ Operários } & 14,0 & 86,0 & 0,0 & 34,9 & 46,9 & 18,2 \\
\hline & \multicolumn{3}{|c|}{ Seda Natural e Artificial } & \multicolumn{3}{|c|}{ Têxtil Geral } \\
\hline Fábricas & 65,9 & 26,8 & 7,3 & 59,7 & 27,8 & 12,5 \\
\hline Capital & 19,3 & 26,9 & 53,8 & 7,5 & 22,6 & 69,9 \\
\hline Operários & 21,4 & 29,6 & 49,0 & 7,6 & 21,6 & 70,8 \\
\hline
\end{tabular}

Como terceira força têxtil de São Paulo, em 1928, destacam-se as fábricas de seda natural e artificial; segundo lugar em produção e terceiro em capital, operários e força motriz (Tabela 1.3). Apresentava índices de produtividade medianos (Tabela 1.5). Além disso, diferentemente das empresas de algodão e de juta, sua concentração industrial não era tão elevada. Vê-se (Tabela 1.4) que o número de operários somados dos pequenos e médios estabelecimentos de seda superam $50 \%$ do total do ramo; enquanto os capitais agregados de tais empresas quase atingem os 47\%. A composição orgânica do capital, porém, era grande, demonstrativa de significativa capitalização fixa. (Tabela 1.5).

Essa aparente contradição pode ser explicada pelo fato das tecelagens de seda, com pequena rigidez tecnológica, não terem necessidade de altas inversões de capital ${ }^{55}$. Como o

\footnotetext{
${ }^{54}$ Estatística do comércio do porto de Santos, 1927-1928, p. 12.

${ }^{55}$ Exceção a isso é a Tecelagem de Seda Ítalo-Brasileira, situada na cidade de São Paulo, responsável por mais de $34 \%$ do capital e $22 \%$ dos operários do ramo de sedas (fiações e tecelagens). Esta, apesar de ser $n a$ teoria apenas uma tecelagem, tinha controle acionário sobre uma grande fiação de seda natural em São Paulo, o que a torna completamente atípica perante as demais.
} 
seu número no universo do ramo da seda é grande, contrabalança-se, assim, o efeito concentrador das fiações de seda natural e artificial. Estas, por sua vez, são empresas de porte considerável, muito capitalizadas. No que se refere às primeiras, a S.A. Indústria de Seda Nacional ${ }^{56}$, fundada em 1922, é a única grande fiadora de seda natural no estado antes de 1929. Favorecida por decreto federal ${ }^{57}$, cujo objetivo era o de incentivar a produção de matéria-prima e de fios para a indústria da seda, a empresa obteve isenção de direitos para a importação de maquinarias, bem como subsídios e empréstimos para o início da produção de amoreiras e ovos de bicho-de-seda em São Paulo. Em 1923, instalou uma estação experimental de sericultura na região de Campinas, distribuindo sua produção para diversos locais do estado. Apesar do crescimento da produção de fibras de seda natural $^{58}$, a dependência da importação desta matéria-prima e dos fios era ainda muito grande em 1928. Neste ano, importou-se por São Paulo mais de 32 toneladas de casulos e 230 toneladas de fios para tecelagem ${ }^{59}$. Além disso, quase todos os fios de seda produzidos pela S.A. Indústria de Seda Nacional destinavam-se apenas a uma empresa, a Tecelagem de Seda Ítalo-Brasileira, que possuía grande controle acionário da primeira ${ }^{60}$.

Tabela 1.5 - Composição orgânica do capital e índices de concentração e produtividade nos ramos da Indústria Têxtil Paulista (1928)*.

\begin{tabular}{ccccccc} 
& Algodão & Juta & Lã & Malha & Sedas & Têxtil Geral \\
\hline (1) Capital - Fábrica & 3.787 & 12.140 & 759 & 309 & 1.136 & 1.783 \\
(2) Trabalho - Fábrica & 565 & 1.278 & 110 & 63 & 113 & 257 \\
(3) Capital - Trabalho & 7,2 & 9,5 & 6,9 & 4,9 & 8,3 & 7,3 \\
(4) Capital - Produto & 0,75 & 0,48 & 0,42 & 0,15 & 0,49 & 0,57 \\
(5) Trabalho - Produto & 0,11 & 0,05 & 0,08 & 0,02 & 0,06 & 0,08
\end{tabular}

Fonte: Estatística Industrial do Estado de São Paulo, 1928 /* Os índices de concentração - (1) e (2) - medem o grau de concentração industrial em dado subetor fabril. Os indices de produtividade - (4) e (5) - mensuram a produtividade de determinado subsetor, seja em termos do capital constante, seja em termos do capital variável (trabalho). A composição orgânica do capital - (3) -, por último, apresenta a relação entre capital fixo e variável nos mesmos ${ }^{61}$.

\footnotetext{
${ }^{56}$ Conforme a Estatística Industrial do Estado de São Paulo, havia mais duas outras empresas fiadoras de seda natural no estado em 1928: a Fábrica Fioseda, em Cordeiros; e a Fábrica Andraus, em Bragança. Todavia, não há informações acerca do capital, operários ou valor de produção das mesmas.

${ }^{57}$ Decreto n. 16.154, 15.09.1923. Estatística (...), 1928, p. 84-85.

${ }^{58}$ Em 1923, o Brasil produzia 9 toneladas de casulos. Em 1934, a produção aumentou para mais de 600 toneladas. Mesmo assim, como 10 quilos de casulos são suficientes apenas para produzir 1 quilo de fios, a demanda por matéria-prima estrangeira ainda se manteve alta no ramo de sedas. Maiores informações, ver: Wilson Suzigan. Indústria brasileira. Origens e desenvolvimento. Ed. Huitec / Ed. da Unicamp, São Paulo, 2000, p. 345.

${ }^{59}$ Estatística do Comércio do Porto de Santos, 1927-1928, p. 27.

${ }^{60}$ Em 1930, constava no passivo da S.A. Indústria de Seda Nacional, na seção refere às 'contas correntes', mais de 7 mil e 900 contos pertencentes à Tecelagem de Seda Ítalo-Brasileira, sendo que o capital nominal da primeira se resumia 6 mil contos. Balanço 27.03.1931, S.A. Indústria de Seda Nacional. O jornal Folha da Manhã, em artigo próprio, chama a ligação do Instituto de Sericultura de Campinas (pertencente à Seda Nacional) para com a Ítalo-Brasileira de "dependência absurda". Folha da Manhã, As tarifas sobre fios de seda artificial, 03.04.1931.
} 
Tem-se situação semelhante para o ramo de fiação de seda $\operatorname{artificial}^{62}$. Em 1919, um importador de corantes do Rio de Janeiro, Max Naegeli, obteve a patente do processo de fabricação de rayon $^{63}$. Arrendou-a para os Matarazzo, que, em 1924, fundaram a primeira fábrica de fiação de seda artificial do Brasil, Visco Seda Matarazzo Ltda., localizada em São Caetano. Esta entrou em funcionamento em 1926. No ano de 1929, surgiu em São Bernardo a segunda fábrica de fiação de seda artificial paulista, a Cia Brasileira de Sedas Rhodiaseta, subsidiária de uma empresa francesa, a Societé pour la fabrication de la soie 'Rhodiaseta' ${ }^{94}$ - ela, porém, iniciou sua produção, porém, apenas em $1933^{65}$.

Após o ramo de sedas, encontra-se, em ordem de importância, o de malhas (Tabela 1.3), possuidor de $42,3 \%$ do número de estabelecimentos têxteis paulistas e da maior produtividade por operário (Tabela 1.5). Apesar disso, era responsável por apenas $6,7 \%$ de todo o capital investido no subsetor de tecidos do estado. Verifica-se aqui a principal característica do ramo de malharias: a preponderância absoluta de pequenos e médios estabelecimentos fabris. Os índices de concentração são os mais baixos entre todos os ramos têxteis (Tabela 1.5). Essa descentralização industrial muito se explica em razão da absoluta preponderância de tecelagens no ramo. As maiores malharias são as fornecedoras de fios para as demais. Das 114 existentes no estado, três empresas apenas, a Fiação para Malharia Indiana S.A., a Fiação e Malharia Ypiranga Assad S.A. e as Indústrias Gebara S.A, situadas na cidade de São Paulo e produtoras de fios, eram responsáveis, em 1928 , por $35 \%$ de todo o capital do ramo ${ }^{66}$.

Por último, em quinto lugar, citam-se as fábricas de lã; penúltimo lugar em número de estabelecimentos e força motriz e último em capital aplicado e quantidade de operários (Tabela 1.3). Apesar de não possuir grandes estabelecimentos (Tabela 1.4), vê-se que sua

\footnotetext{
${ }^{61}$ Para maiores informações sobre os índices de produtividade e de concentração, ver: Reinaldo Gonçalves. Vagão descarrilhado. O Brasil e o futuro da economia global. Ed. Record, Rio de Janeiro, 2002, p. 81-82.

${ }^{62}$ A seda artificial (rayon acetato e rayon viscose) foi a primeira das fibras artificiais a ser inventada. Surgida no final do século XIX, possui como matéria-prima a celulose, extraída da pasta de madeira ou do línter do algodão. Nos anos (19)20, a sua produção cresceu rapidamente em todo o mundo. Para maiores informações, ver: Conselho Estadual de Política Industrial, Comercial e Agroindustrial (COINCO). A indústria têxtil brasileira: diagnóstico setorial. Campinas, 1985, p. 06-07.

${ }_{63}$ Warren Dean. A industrialização de São Paulo (1880-1945). $4^{\circ}$ Edição. Ed. Bertrand Brasil, Rio de Janeiro, 1991, p. 134-135.

${ }^{64}$ Ata Geral de Constituição. Cia. Brasileira de Seda "Rhodiaseta", 15.01.1929.

${ }^{65}$ Relatório da Diretoria. Cia Brasileira de Seda "Rhodiaseta", 27.03.1932. Erroneamente, Dean afirma que Matarazzo, em razão da sua patente, manteve o monopólio da produção de rayon até 1934. Warren Dean, op. cit., p. 135 Wilson Suzigan, op. cit., p. 348. Apesar disso, as vendas de seda artificial em fios provenientes da matriz francesa -, e de tecidos de seda artificial já começaram em meados de 1930. Ver: Relatório da Diretoria. Cia. Brasileira de Seda 'Rhodiaseta', 14.03.1930.

${ }^{66}$ Estatística Industrial do Estado de São Paulo, 1928, p. 87-90.
} 
relação capital-fábrica e composição orgânica são maiores que no ramo de malharia. Explica-se o fato pela preponderância no mesmo do número de médios estabelecimentos, os quais, na maioria dos casos, integraram fiações e tecelagens. Assim, em razão das primeiras, inviabilizava-se a existência de pequenas unidades fabris. Estas, como se pode observar, perfazem uma minoria do ramo. Entretanto, mesmo com as fiações existentes, São Paulo importava do exterior uma grande quantidade de fios de lã para tecelagem. Tais compras, em 1928, totalizaram quase 900 toneladas $^{67}$.

\subsection{2 - A localização das fábricas}

As primeiras indústrias têxteis paulistas surgiram em áreas interioranas do estado, entre as décadas de 1860 e 1870 . Produtoras de artigos algodoeiros rústicos, as unidades fabris situavam-se no interior em razão da proximidade dos mercados consumidores rurais, da disponibilidade de matéria-prima e da existência de rios fornecedores de energia hidráulica, com abundância ${ }^{68}$. Entretanto, a partir do final do século XIX, evidencia-se a emergência da cidade de São Paulo como epicentro fabril estadual ${ }^{69}$.

Essa mudança se deveu a muitos fatores. Destacam-se o (i) crescimento do mercado consumidor da cidade; (ii) a expansão da malha ferroviária do estado, permitindo, assim, um fluxo barato e rápido de mercadorias e matérias-primas; (iii) o surgimento de redes de distribuição de energia elétrica; (iv) a formação de um verdadeiro mercado de capitais na mesma, em razão da concentração bancária; dentre outros ${ }^{70}$.

Dessa forma, em 1928, São Paulo era, visivelmente, o núcleo têxtil mais importante do estado (Tabela 1.6). Tomando-se o subsetor de tecidos como um todo, sozinho, ele concentrava quase $64 \%$ dos capitais investidos e $60 \%$ dos operários empregados. Não quer dizer, entretanto, que as áreas interioranas não possuíssem certa importância. Mais de $40 \%$ da mão-de-obra têxtil lá se encontrava. Além disso, no que se refere ao ramo algodoeiro, percebe-se um equilíbrio entre o interior e a capital. Esta era

\footnotetext{
${ }^{67}$ Estatística do comércio do porto de Santos, 1927-1928, p. 13-14.

${ }^{68}$ Alice P. Canabrava, op. cit., p. 275-286.

${ }^{69}$ Para maiores informações sobre essa importante transição espacial da indústria têxtil paulista, ver: Edgard Carone. A evolução industrial de São Paulo. Ed. Senac, São Paulo; Heitor Ferreira Lima. Evolução industrial de São Paulo. Esboço histórico. Editora Livraria Martins, São Paulo, 1954 e Wlademir Pereira. Evolução industrial do Estado de São Paulo. Empresa Gráfica da Revista dos Tribunais S.A., São Paulo, 1969.

${ }^{70}$ Paul Singer. Desenvolvimento econômico e evolução urbana. Análise da evolução econômica de São Paulo, Blumenau, Porto Alegre, Belo Horizonte e Recife. Companhia Editora Nacional, São Paulo, 1968, p.p. 33-39.
} 
mais capitalizada (52,4\% de todos os capitais investidos), porém aquela empregava maior número de operários $(53,3 \%)$. Dois fatores explicam tal equilíbrio: seu pioneirismo nas regiões interioranas, o que facilitou a manutenção de certas unidades produtivas já montadas; e o baixo valor dos seus tecidos grossos, adequado aos mercados consumidores rurais. Cita-se, a título de exemplo, a importância de Sorocaba como centro produtor de tecidos de algodão. A cidade abrigava duas das maiores fábricas têxteis do País: a S.A. Votorantim e a Santa Rosália, as quais, juntas, concentravam mais de 13\% do capital estadual aplicado no ramo. Jundiaí foi outro núcleo urbano do interior que se destacou nessa produção, por meio das S.A. Fábrica Japy e da Argos Industrial S.A.

Tabela 1.6 - Localização das Indústrias Têxteis Paulistas - Capital e Interior (1928) - \%

\begin{tabular}{|c|c|c|c|c|c|c|c|c|c|c|c|c|}
\hline & \multicolumn{2}{|c|}{ Geral } & \multicolumn{2}{|c|}{ Algodão } & \multicolumn{2}{|c|}{ Juta } & \multicolumn{2}{|c|}{ Lã } & \multicolumn{2}{|c|}{ Malha } & \multicolumn{2}{|c|}{ Seda } \\
\hline & $\mathrm{C}$ & I & $\mathrm{C}$ & I & $\mathrm{C}$ & I & $\mathrm{C}$ & I & $\mathrm{C}$ & I & $\mathrm{C}$ & I \\
\hline Fábricas & 74,5 & 25,4 & 50,0 & 50,0 & 80,0 & 20,0 & 85,7 & 14,3 & 86,8 & 13,2 & 82,9 & 17,1 \\
\hline Capital & 63,8 & 36,2 & 52,4 & 47,6 & 98,7 & 1,3 & 61 & 38,9 & 88,5 & 11,5 & 76,4 & 23,5 \\
\hline Operários & 59,6 & 40,4 & 46,7 & 53,3 & 97,1 & 2,9 & 66,7 & 33,3 & 84,3 & 15,6 & 82,7 & 17,3 \\
\hline
\end{tabular}

O ramo lanífero vinha em segundo lugar como o mais equilibrado entre interior e capital, dos cinco. Está bem mais concentrado na cidade de São Paulo do que no caso algodoeiro. Porém, ainda é possível encontrar grandes unidades produtoras de tecidos de lã fora da capital, tais como a Fábrica Kowarick S.A., em São Bernardo. Os ramos de malharia e de seda situavam-se preponderantemente na capital paulista, ultrapassando o montante de $80 \%$ em quase todas as variáveis arroladas. As fábricas de juta, por sua vez, praticamente só existia dentro da cidade de São Paulo. Mais de 97\% dos operários e de 98\% do capital empregado estava ali concentrado em 1928. É provável que, nos casos da lã, da seda e das malharias, o fator mercado de consumo tenha sido preponderante para a localização das fábricas, seja por produzirem bens de maior preço, demandadores de mercados robustos, seja por serem ramos novos, que já nascem sob a égide da cidade de São Paulo como região economicamente mais dinâmica do estado. No que se refere à juta, a necessidade de altas inversões iniciais pode explicar essa proeminência da capital paulista no abrigo deste ramo. É nele que se encontrava o mercado de capitais mais desenvolvido. 
Tabela 1.7 - Localização das Indústrias Têxteis por tamanho - Capital / Interior (1928) - \%*

\begin{tabular}{ccccccc} 
& Número & \% Estabelecimentos & Capital (contos) & \% Capital & Operários & \% Operários \\
\hline Pequenos - C & 135 & 51,33 & 28.528 & 6,08 & 4.051 & 6,30 \\
Pequenos - I & 22 & 8,37 & 6.519 & 1,39 & 852 & 1,32 \\
Médios - C & 46 & 17,49 & 62.711 & 13,37 & 8.517 & 13,24 \\
Médios - I & 27 & 10,27 & 43.369 & 9,25 & 5.360 & 8,33 \\
Grandes - C & 15 & 5,70 & 207.757 & 44,30 & 25.972 & 40,38 \\
Grandes - I & 18 & 6,84 & 120.074 & 25,60 & 19.758 & 30,72 \\
\hline
\end{tabular}

Fonte: Estatística Industrial do Estado de São Paulo, 1928.

* Segue o mesmo critério da Tabela 1.4.

Quanto ao tamanho das empresas e sua respectiva distribuição espacial no estado, pode-se perceber (Tabela 1.7) que os pequenos estabelecimentos preponderam na capital, em quantidade cinco vezes superior às existentes nas áreas interioranas, em quaisquer das variáveis arroladas. Já os estabelecimentos medianos da capital, apesar de serem numericamente superiores aos do interior (17,49\% contra 10,27\%), são, em média, menos capitalizados do que estes $(13,37 \%$ contra 9,25\%). Também possuem uma quantidade menor de operários $(13,24 \%$ contra $8,33 \%)$, já que a proporção da diferença capitalinterior diminui nestas duas últimas variáveis. Por último, os grandes estabelecimentos, apesar de se encontrarem em maior número no interior, são menos capitalizados e possuem maior quantidade de operários do que os da cidade de São Paulo.

Tais dados são bastante exemplificativos da complexidade do mercado consumidor da capital estadual. Este, por contemplar desde bens de luxo até produtos mais populares, possibilitava a proliferação tanto de pequenas, quanto de grandes fábricas têxteis. Além disso, percebe-se o quanto não era desprezível a formação industrial do interior paulista. Dava-se em razão, entre outros fatores, da existência de fábricas medianas, mais capitalizadas do que as suas congêneres da capital ${ }^{71}$.

\section{2 - As relações de trabalho}

De modo geral, três elementos caracterizavam as relações de trabalho nas fábricas têxteis paulistas nos anos (19)20 22 : (i) o emprego de mulheres e menores em grande escala;

\footnotetext{
71 Para maiores informações sobre a evolução do papel das indústrias do interior no processo de industrialização do estado de São Paulo, ver: Barjas Negri. Concentração e desconcentração industrial em São Paulo (1889-1990). Editora da Unicamp, Campinas, 1996.

${ }^{72}$ Infelizmente, os dados disponíveis sobre as relações de trabalho nas fábricas têxteis paulistas datam do término da década de 1910 e alvorecer da de 1920. Entretanto, informações extraídas dos Boletins do Ministério do Trabalho, Indústria e Comércio de 1935 confirmam a manutenção de muitas das características do início dos anos (19)20. Além disso, as demandas do proletariado têxtil também permaneceram muito semelhantes ao longo de todo esse período. Para maiores informações, ver: Boletim do Ministério do Trabalho, Indústria e Comércio, n¹8, 1935, p. 96; no que condiz às reivindicações operárias,
} 
(ii) a precariedade das condições de trabalho; (iii) e a resistência da burguesia têxtil na concessão de benefícios mínimos para o proletariado.

Inicia-se com o primeiro dos elementos citados. O subsetor têxtil, entre todos do estado de São Paulo, era o que mais empregava mulheres e menores em 1919. Possuía, assim, a menor porcentagem de homens adultos como operários. A mão-de-obra feminina participava com mais de $55 \%$ do total, enquanto os menores (meninos e meninas) quase atingiam 38\% (Tabela 1.8). Após o têxtil, o subsetor de vestuário, ligado ao primeiro, era o que mais empregava mulheres e menores, respectivamente $42,8 \%$ e $30,4 \%{ }^{73}$. Os demais subsetores possuíam preponderância leve (químico e farmacêutico) ou grande (transportes e comunicações) de homens adultos ${ }^{74}$.

Nota-se, nas fábricas têxteis, que os trabalhos feminino e infantil eram predominantes nas funções leves, não-demandadoras de grande esforço físico, e naquelas com pequeno saber técnico. Segundo levantamento realizado pelo Recenseamento de 1920 (Tabela 1.9), nos batedores e cardas, seções preparatórias para a fiação, tem-se um absoluto predomínio da mão-de-obra masculina adulta, em razão da necessidade de grande força muscular. Funções muito especializadas, tais como a de engomador, tintureiro, estampador e mecânico ratificam a predominância do homem-adulto, quando o saber técnico tornava-se essencial. Por último, nos trabalhos de comando e controle do proletariado no interior da fábrica, a mão-de-obra masculina adulta também era predominante. Mais $93 \%$ dos contramestres e mestres eram do sexo masculino e tinham acima de 18 anos.

Tabela 1.8 - Número de operários da Indústria Têxtil Paulista discriminado por sexo e idade (1919)

\begin{tabular}{ccc} 
& Quantidade & $\%$ \\
\hline Total & 12.044 & 100 \\
Homens & 5.095 & 42,3 \\
Mulheres & 6.949 & 57,7 \\
Adultos & 7.530 & 62,5 \\
Menores & 4.554 & 37,8 \\
Até 12 anos & 35 & 0,3 \\
De 12 a 15 anos & 1.014 & 8,4 \\
De 15 a 18 anos & 3.465 & 28,8 \\
\hline Estadual do Trabalho, Ano VIII. n. 31 e 32, $2^{\circ}$ e $3^{\circ}$ trimestres de $1919,203-204$.
\end{tabular}

ver: $A$ Plebe, SP, 10.06.1922, n ${ }^{\circ} 183$ e $A$ Plebe, SP, 08.04.1933, ${ }^{\circ}{ }^{19}$. Os documentos descritos são citados por Maria Alice Rosa Ribeiro. Condições de Trabalho na Indústria Têxtil Paulista (1870-1930). Editora da Unicamp/Huitec, São Paulo, 1998, p. 128, 131 e 143.

${ }^{73}$ Boletim do Departamento Estadual do Trabalho (DET), Ano VIII. n. 31 e $32,2^{\circ}$ e $3^{\circ}$ trimestres de 1919 , 203-204

${ }^{74}$ Idem, op. cit., p. 203-204. 
Já em trabalhos menos demandadores de força física - porém não necessariamente leves -, e pouco especializados, como aqueles realizados nos teares, na preparação das urdiduras, nas passadeiras, nas maçarocas e nas costuras, percebe-se o predomínio de mulheres e menores.

Tabela 1.9 - Participação (\%) dos operários discriminados por sexo e idade em alguns ofícios da indústria têxtil - Brasil (1920)

\begin{tabular}{cccc|cccc} 
Ofícios & Homens & Mulheres & Menores & Ofícios & Homens & Mulheres & Menores \\
\hline 1. Batedor & 93,6 & 1,2 & 5,0 & 11.Engomador & 90,8 & 3,4 & 5,7 \\
2. Cardador & 85,0 & 9,6 & 5,4 & 12.Alvejador & 62,1 & 0,0 & 37,8 \\
3. Passador & 6,5 & 91,2 & 2,1 & 13.Tintureiro & 92,3 & 1,4 & 6,2 \\
4. Maçaroqueiro & 18,0 & 78,3 & 3,6 & 14.Estampador & 98,3 & 0,0 & 1,6 \\
5.Fiandeiro & 20,4 & 37,8 & 41,6 & 15.Acabador & 23,9 & 51,5 & 24,4 \\
6.Carreteiro & 4,4 & 70,5 & 24,9 & 16.Costureira & 4,2 & 75,6 & 20,2 \\
7. Espulador & 0,4 & 29,4 & 70,1 & 17.Mestre & 94,2 & 5,7 & 0,0 \\
8. Bobinadeiro-meadeiro & 38,9 & 38,9 & 22,2 & 18.Contramestre & 93,5 & 6,4 & 0,0 \\
9.Urdidor & 2,4 & 91,8 & 5,7 & 19.Mecânico & 96,0 & 0,0 & 3,9 \\
10.Tecelão & 27,7 & 67,9 & 4,2 & & & & \\
\hline
\end{tabular}

Fonte: Recenseamento Geral de 1920 - Volume V (Indústria) - $2^{\circ}$ Parte (Salários), p. 32-41, 387 e 389 . Apud Maria Alice Rosa Ribeiro, op. cit., p. 136.

Quanto aos salários, evidencia-se uma grande desigualdade no que concerne ao sexo e à idade dos operários (Tabela 1.10). O homem adulto, na média, recebia o maior salário em 1919. As mulheres adultas, trabalhando com a mesma jornada, ganhavam cerca de $62 \%$ do salário do primeiro. Os meninos, por sua vez, recebiam aproximadamente $39 \%$ do ganho da mão-de-obra masculina adulta; e as meninas, um pouco mais, 40,5\%. Essa pequena disparidade de renda entre os menores do sexo masculino e do feminino se explica pelo fato de que, na média, o menino ganhava menos, todavia os salários mínimos recebidos pelas meninas eram menores ${ }^{75}$.

Tabela 1.10 - Média dos salários da Indústria Têxtil Paulista (1919) - Mil-réis*

\begin{tabular}{ccc} 
& Adultos & Menores \\
\hline Homens & $6,9(100)$ & $2,7(39,1)$ \\
Mulheres & $4,3(62,3)$ & $2,8(40,5)$ \\
\hline
\end{tabular}

Fonte: Boletim do Departamento Estadual do Trabalho, Ano VIII. n. 31 e $32,2^{\circ}$ e $3^{\circ}$ trimestres de 1919 , 203-204.* Com o intuito de facilitar o cálculo de comparação, transformou-se o cifrão do mil-réis em vírgula $(6 \$ 900$ para 6,9). Além disso, em parêntesis, encontra-se um índice cujo referencial (100) é o salário do homem adulto.

Assim, muito em razão dos baixos salários, pode-se compreender o porquê da indústria têxtil utilizar em grande escala a mão-de-obra feminina e infantil. Além desse

\footnotetext{
${ }^{75}$ No mínimo, um menino recebia $1 \$ 950$ mil-réis e, no máximo, $3 \$ 450$; por sua vez, as meninas ganhavam 4\$000 no máximo e $1 \$ 600$ no mínimo. Boletim do DET, Ano VIII, 1919, op. cit., p. 203-204.
} 
fator, pode-se citar também a questão da facilidade do controle e a possibilidade de empregar mulheres e menores em funções não-especializadas e não-demandadoras de força física ${ }^{76}$.

Passa-se, agora, para o segundo elemento característico do trabalho têxtil do período: a precariedade das condições de emprego do proletariado. Inicia-se com a questão salarial. Em 1919, os ganhos dos operários de tecidos eram insuficientes para a sua própria sobrevivência. Em outras palavras, a burguesia têxtil não pagava o valor socialmente necessário para a reprodução da sua força de trabalho na sociedade paulista no final dos anos (19)10. Estudos do Departamento Estadual do Trabalho demonstram que, em 1919, o gasto anual em alimentação de uma família com 5 membros na cidade de São Paulo era, aproximadamente, de 1:618\$622 $2^{77}$. O ganho médio anual de uma família cujos membros (um homem adulto, uma mulher adulta e três menores) trabalhavam em uma fábrica têxtil era de 235\$200 (Tabela 1.10), isto é, 14,5\% apenas do necessário em gastos alimentícios.

No que se refere às jornadas de trabalho, nota-se o predomínio da duração de 8 horas contínuas nas indústrias têxteis paulistas. Em inquérito realizado em 1919 com 30 fábricas, o Departamento Estadual do Trabalho constatou que 23 empresas possuíam jornadas de 8 horas. As restantes variavam entre 8 horas e meia e 10 horas e meia ${ }^{78}$. Não havia distinções entre as jornadas dos homens, mulheres e crianças. $\mathrm{O}$ trabalho noturno se dava de maneira indiscriminada, independentemente do sexo e da idade. Os repousos semanais, em 25 das empresas arroladas, ocorriam apenas aos domingos. Em quatro, aos domingos e feriados; e apenas em uma (Companhia Santista de Tecelagem) incluíam também os sábados ${ }^{79}$. No que condiz aos benefícios sociais, $26 \%$ das fábricas pesquisadas garantiam moradia, água e luz aos operários; $6 \%$ apenas forneciam gêneros alimentícios; e $23 \%$ proporcionavam escolas aos filhos dos trabalhadores. Entretanto, das empresas que forneciam tais benefícios, apenas duas os concediam gratuitamente. Nas restantes, retirava-se uma determinada porcentagem dos salários ${ }^{80}$.

Além desses aspectos, as condições de trabalho per si no interior de uma fábrica têxtil eram desumanas ${ }^{81}$. Não havia praticamente ventilação nelas, o que tornava o trabalho

\footnotetext{
${ }^{76}$ Maria Alice Rosa Ribeiro, op. cit., p. 159.

${ }^{77}$ Boletim do DET., op. cit.

${ }^{78}$ Boletim do DET. Condições gerais do trabalho na indústria têxtil do estado de São Paulo. Ano VIII, n. $31 \mathrm{e}$ 32,2 e 3 trimestres de $1919, \mathrm{~s} / \mathrm{p}$.

${ }^{79}$ Idem, op. cit.

${ }^{80}$ Idem, op. cit.

${ }^{81}$ As informações relatadas a seguir baseadas nos trabalhos de José Ribeiro de Oliveira Neto. Profilaxia das causas diretas de insalubridade das fábricas paulistas de fiar, tecer e tingir algodão. In: Boletim da Sociedade de Medicina e Cirurgia de São Paulo, n. 05, 1922; e Maria Alice Rosa Ribeiro, op. cit., 116-131.
} 
na fiação um verdadeiro martírio, em razão do desprendimento de poeiras e partículas da matéria-prima. Os problemas respiratórios e as irritações na pele eram comuns. Além disso, a iluminação das fábricas era muito irregular, ocasionando dores de cabeça e cansaço ocular entre os trabalhadores. Cita-se também o fato das instalações sanitárias fabris, na maioria dos casos, serem fétidas. As distâncias entre as máquinas eram muito reduzidas e não havia quaisquer tipos de telas nas suas engrenagens ou correias de transmissão de força. Facilitavam-se, assim, diversos tipos de acidentes. As mutilações de mãos e membros eram normais. Em 1920, após estudo feito pelo DET, constatou-se que, dos acidentes de trabalho ocorridos na capital - juntando-se fábricas, oficinas, depósitos e casas comerciais -, quase $6 \%$ se deram no subsetor têxtil. Destes, mais da metade estava relacionada com o manuseio de máquinas, peças e acessórios. ${ }^{82}$. Tal constatação é ratificada pelo conhecimento de casos individuais. Em 1925, na Cia. Fiação e Tecidos de Guaratinguetá, o operário Pedro Prateno perdeu quadro dedos após ter prendido a sua mão esquerda nas engrenagens de uma máquina ${ }^{83}$. No mesmo ano, na Fábrica de Tecidos Mãe dos Homens, em Porto Feliz, o menor José de Jesus Soares perdeu todo o antebraço direito em acidente semelhante ${ }^{84}$.

É inegável que as condições precárias de trabalho geraram movimentos reivindicatórios por parte do proletariado têxtil. Inúmeras greves se sucederam ao longo dos anos (19)20. A título de exemplo, cita-se a paralisação de janeiro de 1924, iniciada no Cotonifício Rodolfo Crespi e que se espraiou para diversas fábricas de tecidos da capital. Demandavam-se, entre outros fatores, reajustes salariais ${ }^{85}$. Assim, para conter os movimentos, inúmeras leis de proteção ao trabalhador foram criadas por intermédio da Comissão de Legislação Social da Câmara dos Deputados. Entre estas se destacaram a Lei de Férias ${ }^{86}$ de 1925 e o Código do Menor $^{87}$ de 1926. A primeira garantia quinze dias de descanso remunerado para os trabalhadores dos estabelecimentos comerciais, financeiros e industriais. A segunda, por sua vez, proibia o trabalho dos menores de quatorze anos nas fábricas. Para aqueles que possuíam entre quatorze a dezoito anos, limitava-se a jornada para seis horas diárias e proibia-se o trabalho noturno, isto é, entre as $19 \mathrm{~h}$ e $5 \mathrm{~h}$.

\footnotetext{
${ }^{82}$ Boletim do DET. Acidentes de trabalho no município da capital - Ano de 1919. Ano IX, n. 36, $3^{\circ}$ trimestre de 1920, p. 417-419.

${ }^{83}$ Boletim do DET. Acordo entre partes. Caso de incapacidade parcial e permanente. Ano XV, n. 57, $4^{\circ}$ trimestre de 1925, p. 425-426.

${ }^{84}$ Boletim do DET. Acordo entre partes. Caso de incapacidade parcial e permanente._Ano XV, n. 57, $4^{\circ}$ trimestre de 1925, p. 433.

${ }^{85}$ Marisa Saes Leme. A ideologia dos industriais brasileiros (1919-1945). Ed. Vozes, Petrópolis, 1978, p. 108.

${ }^{86}$ Decreto n. 4.982, 24.12.1925.

${ }^{87}$ Decreto n. $5.083,01.12 .1926$.
} 
Os burgueses têxteis paulistas, por intermédio das suas representações patronais ${ }^{88}$, colocaram-se contrários às leis. Afirmavam que “(...) nunca foram infensos ao bem estar físico, moral, higiênico e cultural dos operários (...)", porém, argumentavam que a legislação social aprovada pelo Congresso era impraticável ${ }^{89}$.

Contra a Lei de Férias, por exemplo, dizia-se que o descanso anual de quinze dias deveria ser concedido, apenas, aos empregados de comércio e de escritório, pois são "trabalhadores intelectuais". O operário, diferentemente, “(...) é um trabalhador braçal, cujo cérebro não despende energias. Ninguém ignora que as pessoas submetidas a intenso esforço cerebral esgotam-se dentro de curto prazo e que os indivíduos acostumados a trabalho manual, intenso e repetido, mas cujo cérebro está habitualmente em repouso, dificilmente conhecerão esse esgotamento" ${ }^{90}$. Além disso, o trabalhador intelectual “(...) como tomou férias para repousar, repousará realmente em ambiente próprio ao descanso, pois o seu lar é acolhedor e amável. Voltará para o escritório com a sua psicologia inalterada, pois não saiu do seu habitat costumeiro"91. O proletariado, por sua vez, diferentemente, “(...) tomará as férias compelido por lei. Não as quis nunca, nunca teve necessidade, real e inadiável, de um período de repouso para o revigoramento de suas forças que não se esgotaram. Que fará um trabalhador braçal durante um ócio de 15 dias? O seu lar, sem conforto, não o prenderá. Será forçado a matar as suas longas horas de inanição na rua (...), transformando-se, assim, as férias operárias em um verdadeiro perigo social (grifo nosso). O proletariado é um elemento da sociedade que as férias estragarão" 92 . Assim, a burguesia têxtil tenta argumentar que o "perigo social", ao invés de ser contido pelo Governo Federal, só se intensificará com a criação de leis sociais.

Todavia, paradoxalmente, apesar de serem "trabalhadores intelectuais", os empregados de comércio e escritório não são, segundo eles, insubstituíveis. Já os operários, "trabalhadores braçais", o são. Dessa maneira, a concessão de férias aos mesmos geraria uma enorme desorganização nas fábricas, paralisando-as ${ }^{93}$.

\footnotetext{
${ }^{88}$ As três representações patronais mais atuantes pela burguesia industrial paulista foram o Centro dos Industriais de Fiação e Tecelagem de São Paulo (CIFT-SP), o Centro das Indústrias do Estado de São Paulo (CIESP) e o Centro Industrial de Fiação e Tecelagem de Algodão do Rio de Janeiro (CIFTA-Rio). Esta última entidade, apesar de ser carioca, reunia fábricas têxteis algodoeiras de todo o país, especialmente paulistas, em razão da sua proximidade com o governo federal.

${ }^{89}$ CIFTA-Rio. Relatório da Diretoria (1929-1933).

90 CIFTA-Rio. Situação da indústria algodoeira. Memorial apresentado ao Sr. Ministro do Trabalho, Indústria e Comércio pelo Centro Industrial de Fiação e Tecelagem de Algodão, 28.11.1930.

${ }^{91}$ Idem, op. cit.

92 Ibidem, op. cit.

${ }^{93}$ Ibidem, op. cit.
} 
Além desses argumentos, afirmava-se também que a suavidade do trabalho fabril têxtil tornava dispensável a existência de um descanso anual ao proletariado. "O trabalhador brasileiro aplica a sua atividade (...) durante um horário suave e nas nossas fábricas não existe ainda aquela disciplina férrea em que o operário é compelido a dar sempre o máximo possível de rendimento. Somos um povo sentimental e o operário trabalha como pode e não conhece ainda aquela febre de trabalho que caracteriza as usinas dos antigos países estrangeiros" ${ }^{\text {. }}$. Cita-se também que o trabalhador “(...) comparece ao serviço livremente, sem grande preocupação com a assiduidade (grifo nosso)" ${ }^{\prime 95}$.

Por último, ainda contra a Lei de Férias, argumentava-se acerca dos prejuízos financeiros inevitáveis para as fábricas, os quais totalizariam, segundo eles, uma queda de $5 \%$ do valor produtivo anual das mesmas ${ }^{96}$. Marisa Saes Leme, em seu trabalho, já mostrou a improbidade dessa afirmação ${ }^{97}$.

O Código de Menores também foi alvo de muitas críticas por parte da burguesia têxtil. As principais demandas se referiam à necessidade de extinção de dois artigos do mesmo: o da jornada de 6 horas e o da proibição do trabalho noturno para os operários de 14 a $18 \operatorname{anos}^{98}$. Afirmava-se que, devido ao número excessivo de menores nas fábricas têxteis, a entrada em vigência do Código desorganizaria completamente o subsetor. Argumentava-se, também, sobre a impossibilidade de se manter horários de turnos diferentes para adultos e crianças, em razão da interdependência das funções que os mesmos realizavam na fábrica ${ }^{99}$. Comparações eram feitas entre a unidade fabril e um organismo vivo: “(...) qualquer parada em uma seção repercute na seção seguinte e na que a precede, formando, assim, o organismo fabril como um todo único" ${ }^{100}$. Repetiam-se as mesmas idéias acerca do perigo social utilizadas contra a Lei de Férias para rechaçar o Código, afirmando-se que a demissão em massa de menores geraria distúrbios públicos. A "imoralidade" dominaria as ruas com a presença de tantas crianças inativas ${ }^{101}$. Ratificam a idéia de que o trabalho do menor era muito suave e que, devido a isso, seria difícil encontrar adultos, “(...) já destros e dispostos a fazer trabalhos que, por levíssimos,

\footnotetext{
${ }^{94}$ Ibidem, op. cit.

${ }^{95}$ Circulares CIFTA-Rio. Carta do CIFTA e do Centro Industrial do Brasil ao Ministro do Trabalho Lindolfo Collor, 06.02.1931.

${ }^{96}$ CIFTA-Rio. Situação da indústria algodoeira, op. cit.

${ }^{97}$ Marisa Saes Leme, op. cit., p. 117.

${ }^{98}$ Compreendem-se tais criticar ao se observar, em 1919, a preponderância de menores entre 15 e 18 anos nas fábricas têxteis paulistas. Ver Tabela 1.8.

${ }^{99}$ CIFT-SP. Um ensaio de socialismo de Estado no Brasil e as Indústrias Nacionais. São Paulo, Liceu Coração de Jesus, 1927.

${ }^{100}$ CIFTA-Rio. Situação da indústria algodoeira, op. cit.

${ }^{101}$ Idem, op. cit.
} 
chegariam a ser humilhantes para um homem válido"102. Por último, sinalizam ao Estado a possibilidade de os pais operários se revoltarem ao saber que seus filhos, fundamentais para a constituição das rendas dos lares proletários, não poderiam mais trabalhar ${ }^{103}$.

Constata-se facilmente a improcedência das críticas da burguesia têxtil acerca da legislação social do governo. Em primeiro lugar, viu-se que as condições de trabalho precárias existentes nas fábricas de tecidos mais do que justificavam a concessão de férias aos operários e a criação de regras protetoras às crianças e adolescentes. Em despacho ao CIESP, o Juiz de Menores do Distrito Federal, Mello Matos, afirmou que “(...) o menor de 13 anos é contratado, em regra geral, como aprendiz; ganha salário de aprendiz; faz, porém, trabalho de operário adulto (...) O estado sanitário da população infantil das fábricas é sempre mau (...)" ${ }^{\text {104 }}$. Em segundo lugar, é uma inverdade a afirmação de que os operários não desejavam a Lei de Férias. Em 1931, por exemplo, a União dos Operários em Fábrica de Tecidos de São Paulo organizou bases para uma divulgação ampla de tal lei aos proletários têxteis paulistas. Visava-se, sobretudo, intensificar a pressão social contra os patrões a fim de se garantir descanso anual aos operários ${ }^{105}$. Em terceiro lugar, a questão da assiduidade dos trabalhadores ser flexível nas fábricas de tecidos era outra falácia. As faltas sempre eram descontadas nos salários, através de multas ${ }^{106}$. Em quarto, improcedente era também a afirmação de que a colocação em prática dessas leis desorganizaria a produção fabril. Algumas fábricas, minoritárias, chegaram até a respeitálas com receio das penalidades governamentais, gerando fúria nas associações patronais têxteis. O CIESP, por exemplo, ameaçou as empresas que implementassem o Código de Menores, alegando que “(...) ou todas (...) seguem a orientação aconselhada por este Centro, e o Congresso verá que o Código é realmente impraticável na parte que se refere ao horário, tratando de reformar esta parte; ou então o Código, com sacrifícios pesadíssimos, será observado por algumas fábricas e, neste caso, o Congresso nada fará pelas indústrias, alegando que o Código é exeqüível e, portanto, inútil a sua reforma"107. Além disso, o CIFTA e o CIFT-SP, em memorial enviado ao Congresso no ano de 1927,

\footnotetext{
${ }^{102}$ Circulares CIESP. Memorial apresentado pelo Centro das Indústrias do Estado de São Paulo ao presidente da Camada dos Deputados, 27.04.1929.

103 Idem, op. cit.

${ }^{104}$ Circulares CIESP. Reprodução do despacho feito pelo Juiz de Menores do Distrito Federal, Sr. Mello Matos, acerca do Código de Menores, 02.04.1929. Sobre a posição dos operários, que acusavam mestres e contramestres de explorar e maltratar menores dentro das fábricas têxteis, ver: A Plebe, SP, 12.04.1919, n. 8; e A Terra Livre, SP, 23.02.1907.

${ }^{105}$ O Estado de São Paulo. Comunicado da União dos Operários em Fábricas de Tecidos de São Paulo, 14.01.1931.

${ }^{106}$ Maria Alice Rosa Ribeiro, op. cit, p. 180-181.

${ }^{107}$ Circulares CIESP, 14.06.1929.
} 
visando reformar o Código de Menores, propuseram mudanças. Queriam que apenas os operários de doze a quatorze anos tivessem jornadas de seis horas, enquanto os de quatorze a dezoito, oito horas por dia. Ora, se a criação de turmas com horários diferentes desorganizaria o "organismo fabril”, como seria possível, agora, ter operários trabalhando seis horas e outros, oito horas? Mais uma vez, percebe-se que os argumentos utilizados, sem qualquer embasamento na realidade, visavam apenas esvaziar a legislação social criada pelo Estado. Por último, no que se refere ao "não-conforto" do lar proletário e à "imoralidade" que predominaria nas ruas com a vigência de tais leis, pretende-se aqui inverter as justificativas governamentais, que eram o de conter o "perigo social" das greves e manifestações proletárias mediante a concessão de benefícios. Para amedrontar o Estado, a burguesia afirmava que, com isso, o "perigo" não seria destruído, mas sim intensificado.

Apesar das críticas, o Governo Federal manteve as leis citadas, pelo menos até a Revolução de outubro de $1930^{108}$. Entretanto, os industriais têxteis, em sua maioria, foram negligentes em sua aplicação; e o Governo, na sua fiscalização. As associações patronais incentivavam a burguesia a não acatar as regras sociais recém-criadas pelo Estado. $\mathrm{O}$ CIESP, em circular confidencial dirigida aos seus membros em 1929, informava que todas as fábricas multadas pelos comissários do Juizado de Menores deveriam entrar em contato com o advogado do Centro, o qual, segundo eles, impediria a concretização da pena. “(...) nenhuma fábrica pagará multas impostas pelo Juízo de Menores", afirmavam ${ }^{109}$. No que se refere à Lei de Férias, os mesmos incentivos ao não-cumprimento se repetiam. O Centro Industrial do Brasil, em 1928, ratificava a idéia da "absoluta inexeqüibilidade" da lei ${ }^{110}$, enquanto o CIFTA assinalava aos seus associados que “(...) a execução da Lei de Férias pelas fábricas de fiação e tecelagem é absolutamente impossível"111. Em troca, propunhase a criação, por parte do Estado, de leis previdenciárias de auxílio à doença, à mulher grávida e à velhice ${ }^{112}$.

Percebe-se, portanto, em razão das precárias condições de trabalho no subsetor têxtil e da enorme relutância da sua burguesia industrial em garantir mínimas melhorias para o proletariado, que a extração de mais-valia absoluta era um elemento importante na

\footnotetext{
${ }^{108}$ Para maiores informações, ver: Edgard Carone. A República Nova (1930-1937). $3^{\circ}$ Edição. Ed. Difel, São Paulo, 1982.

${ }^{109}$ Circulares CIESP, 11.06.1929.

${ }^{110}$ Centro Industrial do Brasil. Última reunião do ano de 1928. In: Jornal do Comércio, RJ, 07.01.1929.

${ }^{111}$ CIFTA-Rio. Atas Reuniões de Diretoria, 15.05.1930.

${ }^{112}$ CIFTA-Rio. Situação da indústria algodoeira, op. cit.
} 
constituição dos lucros das fábricas de tecidos paulista ${ }^{113}$. Ou, em outras palavras, que o trabalho têxtil se fundamentava “(...) em uma intensa exploração da mão-de-obra"114. Os argumentos improcedentes utilizados pela burguesia para esvaziar a legislação social ("trabalhadores braçais" não necessitam de férias, as condições de trabalho para os menores nas fábricas são totalmente adequadas, entre outros) são apenas um demonstrativo da sede de valorização contínua do capital. A possibilidade de se pôr em prática tais leis existia; escasseava vontade para fazê-1o ${ }^{115}$.

\section{3 - A situação econômica do final da década de 1920}

A partir de 1926, a indústria têxtil paulista passa a viver situação delicada. O seu mais importante ramo - o algodoeiro - ingressa em forte crise econômica.

Entre 1926 e 1928, a produção de tecidos de algodão decresceu mais de $20 \%$ (Tabela 1.12). Muitas de suas indústrias encontravam-se em momentos difíceis. A S.A. Fábrica de Tecidos e Bordados Lapa, situada na capital, informou aos seus associados que a mesma estivera parada por cinco meses ao longo do ano de 1928, em razão da grande quantidade de estoques ${ }^{116}$. O Estabelecimento Fabril Pinotti Gamba, também localizado na cidade de São Paulo, julgava conveniente vender a fábrica, pois “a época era má para o comércio de tecidos" $" 117$. No interior do estado, a Cia. Fiação e Tecidos São Carlos dizia aos seus sócios que ainda perdurava "nesse período de 1928 a grave crise da nossa indústria"118.

Todavia, apesar desta evidente depressão no ramo algodoeiro, deve-se evitar dois tipos de generalizações. Em primeiro lugar, nem todas as fábricas têxteis de algodão sofreram as conseqüências da crise. Aquelas que produziam tecidos de maior qualidade conseguiram manter suas vendas e, assim, seus lucros. O Cotonificio Guilherme Giorgi, por exemplo - produtor de têxteis alvejados, colchas e toalhas -, informava aos seus

\footnotetext{
113 "Esse regime de produção especificamente capitalista é, por excelência, instrumento de extração de maisvalia relativa, o que não exclui, no entanto, que constitua meio de extração de mais-valia absoluta". In: Carlos Alonso Barbosa de Oliveira. Processo de industrialização. Do capitalismo originário ao atrasado. Ed. Unesp / Ed. Unicamp, Campinas, 2003, p. 61. Para maiores informações sobre a extração de mais-valia relativa e absoluta no modo de produção capitalista, ver: Karl Marx. O Capital. Crítica da Economia Política. Livro 1. $5^{\circ}$ Edição. Ed. Civilização Brasileira, Rio de Janeiro, 1980.

${ }^{114}$ Marisa Saes Leme, op. cit.

115 Viu-se o quanto a CIESP, em suas circulares, agiu energicamente contra as empresas que, em razão do medo de multas, começaram “(...) a reformar o seu aparelhamento, adotando o horário de 6 horas para menores e adultos”. Circulares CIESP, 04.07.1929. Isto é, a possibilidade de adequação às leis para algumas demonstra o quanto a maioria das empresas poderia fazer a mesma coisa.

${ }^{116}$ Relatório da Diretoria de 1928. S.A.Fábrica de Tecidos e Bordados Lapa, 19.02.1929.

${ }^{117}$ Relatório da Diretoria. Estabelecimento Fabril Pinotti Gambá, 08.02.1929.

${ }^{118}$ Relatório da Diretoria. Cia. Fiação e Tecidos São Carlos, 26.03.1929.
} 
acionistas que, apesar da "formidável crise por que passam todos os ramos de atividade (...) levamos a efeito a ampliação da fábrica (...), montamos novas máquinas, das mais modernas (...), além de proporcionar-vos um dividendo de 12\%""119. A S.A. Fábrica Votorantim - produtora de tecidos tintos, alvejados e estampados -, em 1928, renovou suas turbinas, aumentando em mais de 2.200 H.P. a sua força motriz. Distribuiu, ainda, $8 \%$ de dividendo aos sócios ${ }^{120}$. Em Jundiaí, a S.A. Fábrica Japy almejava sair da crise mediante a modernização do maquinário, a qual, segundo a diretoria, permitiria a fabricação de tecidos mais finos, de menor concorrência no mercado ${ }^{121}$.

Tabela 1.11 - Produção da indústria têxtil paulista discriminada por ramo - 1920 / 1925-1928*

\begin{tabular}{cccccc} 
& 1920 & 1925 & 1926 & 1927 & 1928 \\
\hline Algodão & 186.520 & 206.148 & 238.933 & 203.889 & 191.139 \\
Lã & 1.573 & 3.506 & 3.083 & 4.212 & 4.330 \\
Juta & 25.366 & 86.150 & 97.852 & 81.573 & 62.808 \\
Seda (Nat. e Art.) & 22.503 & 48.648 & 48.108 & 53.109 & 72.018 \\
\hline
\end{tabular}

Fonte: Villela e Suzigan. Política (...), p. 357 e 364; Wladimir Pereira. Evolução Industrial do Estado de São Paulo, p. 41, 42; M. Izilda Matos. Trama e poder, p. 55.

* Produção de algodão, lã e juta - 1.000 metros; produção de seda - quilos.

Em segundo lugar, não se pode generalizar a situação depressiva vivida por grande parte das indústrias têxteis de algodão para todo o subsetor de tecidos paulista. Exemplo disso é o ramo de seda natural e artificial, que passava por visível desenvolvimento. Entre 1926 e 1928, a produção de tecidos de seda elevou-se em quase 50\% (Tabela 1.11). A S.A. Tecelagem de Seda Ítalo-Brasileira, por exemplo, situada na capital, organizou bases para a constituição de um holding suíço, tendo em vista o crescimento das vendas. Em razão disso, aumentou seu capital social de 13 para 30 mil contos em 1928, adquirindo, assim, maioria acionária das empresas S.A. Amerital, S.A. Indústria Artefatos de Seda e S.A. Indústria de Seda Nacional ${ }^{122}$. Esta, única grande fiadora de seda natural do País, atravessava também um período próspero. Segundo sua diretoria, "durante o ano de 1928, a atuação da nossa indústria manteve a mesma eficiência dos anteriores (...)”. A produção de casulos aumentou de $192.000 \mathrm{kgs}$. para $204.000 \mathrm{kgs}$., criaram-se outras estações serícolas e distribuíram-se mais de 2.000 .000 de mudas de amoreiras no interior do estado de São Paulo ${ }^{123}$. Além da Ítalo-Brasileira e suas congêneres, outras fábricas de seda viviam também momentos de prosperidade. A Tecelagem de Seda N. S. da Penha, da

\footnotetext{
${ }^{119}$ Relatório da Diretoria. Cotonifício Guilherme Giorgi, 04.04.1929.

${ }^{120}$ Relatório da Diretoria. S.A. Fábrica Votorantim, 21.12.1928.

${ }^{121}$ Relatório da Diretoria. S.A. Fábrica Japy, 30.03.1929.

${ }^{122}$ Chamou-se tal união de "sociedade das sedas". Assembléia Geral Extraordinária. S.A. Tecelagem de Seda Ítalo-Brasileira, 18.06.1928 e 13.12.1928.

${ }^{123}$ Relatório da Diretoria. S.A. Indústria de Seda Nacional, 04.08.1929.
} 
capital, informou aos seus sócios que "os produtos de nossa fábrica têm tido grande aceitação (...) Isso nos leva a confiar em franca prosperidade"124.

O ramo da lã atravessava também período de desenvolvimento, apesar de menor que o da seda. A produção lanífera no estado de São Paulo cresceu em mais de $40 \%$ entre 1926 e 1928 (Tabela 1.11).

Entretanto, diferentemente dos casos da lã e da seda, o ramo têxtil da juta, tal qual o algodoeiro, atravessou momentos difíceis no final da década de 1920. Apesar do crescimento notável da sua produção entre 1920 e 1925 (mais de 230\%), nota-se uma queda superior a 35\% no período 1926-1928. A mesma diretriz decrescente é observada ao se analisar o valor de produção do ramo, o qual passa de 137 mil contos em 1926 para menos de 110 mil contos em 1928, isto é, redução de $20 \%{ }^{125}$. Assim, nada autoriza a ratificação da hipótese, levantada por alguns estudiosos, de que as fábricas jutíferas mantiveram a tendência de crescimento desde o alvorecer da década de 1920 até o crepúsculo da mesma ${ }^{126}$.

Passa-se, agora, aos possíveis fatores que permitiram a crise e/ou o crescimento dos ramos têxteis paulistas no período. Em primeiro lugar, deve-se lembrar que a década de 1920 constituiu momento de modernização e de ampliação da capacidade produtiva do subsetor de tecidos doméstico. Entre 1924 e 1926, a compra de máquinas têxteis no exterior ultrapassou o montante de 1 milhão de libras (Tabela 1.12). Estas consideráveis inversões podem ser explicadas em razão dos desgastes sofridos pelo maquinário ao longo da Primeira Guerra Mundial (1914-1918), momento este em que a demanda de tecidos cresceu muito, porém a disponibilidade de bens de capital foi praticamente nula. Além disso, os lucros acumulados no conflito e as perspectivas promissoras de manutenção dos mesmos ajudam também a elucidar o porquê dos altos investimentos nos anos (19)20. Por último, a política deflacionista implementada pelo Governo Arthur Bernardes entre os anos 1923 e 1926, propiciando valorização cambial, permitiu baratear bens de produção e insumos para as indústrias domésticas. Tal valorização do mil-réis também se deveu aos

\footnotetext{
${ }^{124}$ Relatório da Diretoria. Tecelagem de Seda N. S. da Penha, 31.01.1929.

${ }^{125}$ Maria Izilda Matos, op. cit., p. 55.

${ }^{126}$ A historiadora Maria Izilda, que recolheu dados demonstrativos acerca das dificuldades produtivas das fábricas de tecidos de juta no final dos anos (19)20, afirma que as mesmas, “(...) ao contrário de outros ramos têxteis (...) não sofreram imediatamente as dificuldades oriundas do descompasso entre a alta inversão ampliadora da capacidade produtiva e a expansão do mercado". Segundo ela, a crise só atingiria o ramo a partir de 1929, o que, como se pôde observar, não faz jus à realidade. Ver: Maria Izilda Matos, op. cit., p. 58-59.
} 
satisfatórios preços atingidos pelo café no período, especialmente no ano de 1924, em razão da política governamental de defesa do produto (Tabela 1.12) 127 .

Tabela 1.12 - Dados variados: Importação de bens de capital doméstica; preço café; e taxa de câmbio mil-réis/libra (1918-1930)

\begin{tabular}{c|cccc|cc|c} 
Anos & Têxtil (a) & Outros (a) & Total (a) & PRT (b) & Café (c) & Café (d) & T.C. M/L (e) \\
\hline 1918 & 314 & 760 & 1.074 & 29,2 & $10 \$ 750$ & 2,69 & 18,641 \\
1919 & 416 & 1.189 & 1.605 & 25,9 & $14 \$ 000$ & 3,64 & 16,678 \\
1920 & 752 & 3.587 & 4.339 & 17,3 & $8 \$ 000$ & 1,68 & 16,623 \\
1921 & 954 & 3.137 & 4.091 & 23,3 & $14 \$ 750$ & 1,92 & 28,981 \\
1922 & 839 & 1.443 & 2.282 & 36,8 & $20 \$ 200$ & 2,63 & 33,464 \\
1923 & 934 & 1.537 & 2.471 & 37,8 & $23 \$ 500$ & 2,35 & 44,651 \\
1924 & 1.128 & 2.744 & 3.872 & 29,1 & $37 \$ 000$ & 4,07 & 40,421 \\
1925 & 1.778 & 3.433 & 5.211 & 34,1 & $26 \$ 000$ & 3,12 & 39,385 \\
1926 & 1.050 & 3.306 & 4.356 & 24,1 & $22 \$ 800$ & 3,19 & 33,611 \\
1927 & 740 & 2.985 & 3.725 & 19,9 & $27 \$ 000$ & 3,24 & 41,070 \\
1928 & 755 & 3.415 & 4.170 & 18,1 & $30 \$ 500$ & 3,66 & 40,743 \\
1929 & 562 & 4.095 & 4.657 & 12,1 & $22 \$ 000$ & 2,64 & 41,015 \\
1930 & 283 & 2.220 & 2.503 & 11,3 & $16 \$ 250$ & 1,79 & 44,329 \\
\hline
\end{tabular}

Fonte: Werner Baer. A economia brasileira, p. 55; Thomas H. Holloway. Imigrantes para o café, p. 261-262.

(a) 1.000 libras; (b) participação relativa têxtil (\%); (c) mil-réis por saco de $10 \mathrm{~kg}$; (d) dólares por saco de $10 \mathrm{kgs;}$

(e) Taxa de câmbio mil-réis/libras.

Entretanto, concomitante a esse crescimento da capacidade produtiva têxtil, observou-se aumento da importação de bens de consumo não-duráveis do exterior, entre os quais tecidos. A mesma política valorizadora do câmbio que barateou máquinas e matérias-primas reduziu também os preços de bens finais similares aos domésticos, gerando forte concorrência aos últimos. Além disso, com a normalização das relações de comércio internacional após 1918, as potências têxteis globais, notadamente a Inglaterra, voltam a produzir tecidos em grande escala, lutando para reconquistar os mercados perdidos nas áreas periféricas.

A considerável valorização cambial do período 1925-1926 foi, porém, amenizada com o surgimento da Caixa de Estabilização, em 1927, durante o Governo Washington Luiz. Com esta, estabilizar-se-ia a taxa cambial a um nível relativamente desvalorizado (Tabela 1.12), propiciando o encarecimento de bens internacionais ${ }^{128}$. Assim, observa-se (Tabela 1.13) uma queda superior a $29 \%$ da importação de maquinário têxtil do exterior entre 1926 e 1927. Da mesma maneira, os tecidos estrangeiros ficaram mais caros. Vê-se, por exemplo, que a compra de bens têxteis de seda natural e artificial no porto de Santos decresceu no final dos anos (19)20 (Tabela 1.13), ajudando a explicar a ascensão da

\footnotetext{
${ }^{127}$ Para maiores informações sobre as políticas de defesa do café, especialmente após 1924, quando a mesma vira permanente, ver: Antônio Delfim Netto. O problema do café no Brasil. IPEA / FIPE, São Paulo, 1981. ${ }^{128}$ Villela e Suzigan, op. cit., 321-322.
} 
produção paulista da seda nesse período. Os tecidos de lã, diferentemente, tiveram suas importações e produção local crescentes. Este fato indica maior consumo desse bem por parte da população e a falta de capacidade das unidades laníferas paulistas em substituírem os tecidos estrangeiros: fosse isso por escassez de capacidade produtiva - menos provável, tendo em vista os investimentos realizados no subsetor têxtil na década de 1920 -, fosse por não produzirem lãs de qualidade comparável à externa.

Tabela 1.13 - Importação de tecidos diversos - Porto de Santos (1927 e 1928)

\begin{tabular}{lcccccc} 
& Tecidos & Algodão & Juta & Lã & Seda natural & Seda artificial \\
\hline 1927 & & & & & \\
$\quad$ Quilos & 3.355 .365 & 2.512 .429 & 179.517 & 422.711 & 29.435 & 3.174 \\
Contos - D* & 57.637 & 39.846 & 410 & 11.884 & 2.247 & 226 \\
1928 & & & & & 1.447 \\
Quilos & 4.346 .233 & 3.195 .815 & 166.516 & 545.170 & 18.308 & 74 \\
Contos - D & 74.730 & 50.398 & 455 & 14.661 & 2.235 & \\
\hline Fonte: Estatística do Comércio do Porto de Santos, $1927-1928 . / *$ Deflacionado
\end{tabular}

A importação de tecidos de juta por Santos, em quantidade, caiu 7\%, entre 1927 e 1928. Porém, em valor, ela aumentau 11\%. Vê-se que, mesmo com essa queda, a produção paulista desse ramo continuou decrescente (Tabela 1.11). Conclui-se, portanto, que as raízes da diminuição produtiva da indústria de juta em São Paulo não se encontravam na excessiva importação de tecidos similares do estrangeiro. Provavelmente, a resposta deve ser procurada no principal consumidor de sacarias de juta, isto é, o café. A safra de 1926/1927 foi excepcional (26,1 milhões de sacas). Apesar disso, o Instituto do Café do Estado de São Paulo comprou os excedentes ${ }^{129}$. Lembra-se, porém, que o produto era ensacado duas vezes: uma para transportes e armazenagens domésticas, e outra para a comercialização $^{130}$. Esta era feita, normalmente, só em Santos. Assim, mesmo com a manutenção dos altos preços do café até 1929, como a exportação do produto declinou entre 1927 e 1928 (de 10 milhões e 321 mil sacas para 8 milhões 874 mil) ${ }^{131}$, é provável que a demanda de sacos de juta pelos cafeicultores tenha decrescido, pois o segundo ensacamento, visando ao comércio internacional, reduziu-se.

Por último, passa-se para o caso dos tecidos de algodão paulista. Observa-se (Tabela 1.13) que, entre 1927 e 1928, a quantidade e o valor de têxteis algodoeiros importados pelo porto de Santos cresceram, respectivamente, 27\% e 26\%. Apesar da desvalorização cambial, a elevação do quantum importado foi maior que a do valor

\footnotetext{
${ }^{129}$ Antônio Delfim Netto. O problema do café no Brasil. IPEA / FIPE, São Paulo, 1981, pp. 132-133.

${ }^{130}$ Maria Izilda de Matos, op. cit., p. 34.

${ }^{131}$ Thomas H. Holloway. Imigrantes para o café. Paz e Terra, Rio de Janeiro, 1984, pp. 251-252.
} 
importado. Assim, é bastante provável que os produtores internacionais estivessem vendendo seus bens dentro do mercado doméstico por preços pouco acima, ou até mesmo abaixo, dos custos. Além disso, pode-se concluir também, em razão dessa enorme e crescente quantia de bens têxteis algodoeiros importados, que a concorrência externa era uma das responsáveis pela crise que abatia o ramo nesse período.

Reclamações e demandas realizadas pela burguesia algodoeira paulista apenas ratificam as conclusões anteriores. O CIFT-SP, em texto publicado no Correio Paulistano, afirmava que "(...) a crise têxtil, que nos assoberba, nasceu no Governo Arthur Bernardes, em razão de sua política financeira (...) Mal refeitas dessa crise, as fábricas de tecidos foram vítimas de dumpings desfechados contra elas por concorrentes estrangeiros" ${ }^{\prime 132}$. O CIESP, em memorial direcionado ao Chefe do Governo Civil de São Paulo, em 1930, assinalava que “(...) daí (1924) para cá, a imensa maioria das nossas fábricas só tem conhecido períodos de notáveis dificuldades. A Europa e os Estados Unidos, a braços com a tão conhecida superprodução de produtos manufaturados, promoveram dumpings contra

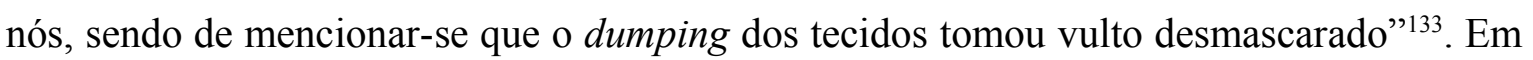
1928, a diretoria do CIFTA-Rio concluía que a importação de tecidos "é a principal causa da situação aflitiva da indústria algodoeira nacional"134.

Para debelar tal crise, considerava-se essencial (i) aumentar a exportação dos tecidos de algodão domésticos, em especial para os países latino-americanos; e (ii) realizar uma reforma aduaneira, protegendo a produção local dos dumpings externos.

No que concerne à primeira das ações propostas, tentativas e pressões junto ao governo foram realizadas para concretizá-la. Em meados de 1928, o CIFTA-Rio formou uma comissão para estudar as possibilidades de exportação de artigos têxteis para as “repúblicas vizinhas". Em julho de 1928, o Secretário-Geral do Centro, Vicente de Paulo Galliez e um dos líderes da comissão citada, Alfredo Besser, viajaram para Buenos Aires, visando estabelecer contatos com importadores da região ${ }^{135}$. Em agosto, o Secretário-Geral retornou. Em reunião com a diretoria do Centro, Vicente de Paulo Galliez explicou que “(...) a qualidade e variedade de nossa produção impressionaram otimamente”. Tudo dependia, disse ele, da "questão preço". Colocou-se a necessidade do governo brasileiro conceder prêmios para exportação e diminuir fretes marítimos. Segundo o Secretário, tal

\footnotetext{
${ }^{132}$ Correio Paulistano. CIFT-SP. A crise têxtil e o órgão oficial democrático, 09.04.1930.

133 CIESP. Memorial do CIESP para o Chefe do Governo Civil de São Paulo, Dr. Plínio Barreto, 07.11.1930.

${ }^{134}$ CIFTA-Rio. Ata da Reunião de Diretoria, 14.11.1928.

${ }^{135}$ CIFTA-Rio. Ata da Reunião de Diretoria, 13.07.1928.
} 
ação "poderá ser (...) a melhor e mais rápida solução para as futuras crises"136. No início de 1929, o CIFTA-Rio entrou com um pedido junto ao Centro de Navegação Transatlântica "a fim de estudar a possibilidade de uma redução nos fretes de tecidos de algodão (...)" do Brasil para a Argentina. Além disso, após leitura de uma carta do Cônsul do Brasil na França, discutiu-se a possibilidade de exportação têxtil para as colônias francesas na África. Segundo tal diplomata, “(...) a nossa indústria de tecidos, sobretudo as de algodão, poderá obter mercados de valia nas colônias francesas" ${ }^{137}$. Entretanto, os resultados de todas essas tentativas de exportação foram pífios. Em 1928, o valor dos tecidos algodoeiros exportados pelo porto de Santos atingiu apenas $0,04 \%$ do valor estadual do ramo ${ }^{138}$.

Além da questão exportadora, a burguesia têxtil paulista, notadamente a do algodão, fez fortes pressões junto ao governo no sentido de se reformar as tarifas aduaneiras. Argumentava-se que a tarifa vigente ${ }^{139}$ “(...) facilitava os dumpings, mercê das suas lacunas, das suas taxas, calculadas há bons 30 anos, no Governo Campos Sales"140. Pedia-se a elevação das tarifas, as quais deveriam ser continuamente renovadas "em função dos preços reais e das alterações do câmbio"141.

A partir de 1928, o CIFT-SP e o CIFTA-Rio juntaram forças para viabilizar a reforma aduaneira. Decidiu-se apresentar ao Governo Federal um "projeto de emergência, modificando as tarifas de fios e tecidos de algodão"142. Em setembro de 1928, tal projeto, feito essencialmente pelo CIFT-SP, foi entregue à Comissão de Finanças do Senado Federal $^{143}$. Ao longo do mês de outubro, os presidentes de ambos os Centros, Carlos da Rocha Faria (CIFTA) e Jorge Street (CIFT), reuniram-se com o senador Arnolfo Azevedo, presidente da Comissão de Finanças do Senado, com o deputado Manoel Villaboim, líder da maioria da Câmara dos Deputados, e com o próprio presidente da República, Washington Luiz. Todos os encontros visavam à obtenção de apoio para a aprovação do

\footnotetext{
${ }^{136}$ CIFTA-Rio. Ata da Reunião de Diretoria, 22.08.1928.

${ }^{137}$ CIFTA-Rio. Ata de Reunião da Diretoria, 03.01.1929.

${ }^{138}$ Estatística do comércio do porto de Santos, p. 130; e Estatística Industrial do Estado de São Paulo, 1928, p. 05.

139 A última reforma tarifária aconteceu no Governo Campos Sales, em 1898, quando se instituiu a tarifaouro (10\%). Ao longo da República Velha, a proporção aurífera foi aumentando: 25\% (1900), 40\% (1915), $55 \%$ (1916) e 60\% (1922). A maioria das taxas era baseada no princípio ad valorem. Para maiores informações, ver: Nícia Vilela Luz. A luta pela industrialização do Brasil. $3^{\circ}$ Edição. Ed. Alfa-Ômega, São Paulo, 2004, pp. 125-139.

${ }^{140}$ Correio Paulistano. CIFT-SP. A crise têxtil, op. cit.

${ }^{141}$ Jornal do Comércio. Centro Industrial do Brasil, 29.07.1926 e 28.08.1926. Apud: Marisa Saes Leme, op. cit, p. 81.

${ }^{142}$ CIFTA-Rio. Ata de Reunião da Diretoria, 22.08.1928.

${ }^{143}$ CIFTA-Rio. Ata de Reunião da Diretoria, 13.09.1928.
} 
projeto tarifário têxtil ${ }^{144}$. O resultado de toda essa pressão foi positivo para a burguesia. Em janeiro de 1929, o Congresso Nacional aprovou uma reforma das tarifas incidentes nos fios e tecidos de algodão ${ }^{145}$. A lei entrou em vigor em três meses. O CIFTA e o CIFT comemoraram. "Todas as principais sugestões do nosso Centro foram aceitas", afirmava o presidente do CIFTA, em reunião realizada logo após a passagem da reforma ${ }^{146}$. O lobby das associações patronais têxteis saiu vitorioso, mostrando a já considerável influência da burguesia industrial algodoeira nas estruturas governamentais desse período. Mal sabiam eles, porém, que as comemorações seriam em vão, tendo em vista a crise que assolará o setor a partir de 1929.

\section{4 - Conclusões parciais}

Viu-se, neste capítulo, que (i) o subsetor têxtil paulista possuía heterogeneidade marcante antes da crise mundial de 1929. Havia diferenças entre os seus ramos, seja em razão das suas distintas importâncias relativas (algodão como preponderante, seguido pela juta, seda, malha e lã), seja pelas especificidades de cada um dos mesmos (maior ou menor concentração industrial, localização, tamanho das fábricas, mercados consumidores particulares, etc.). Além disso, (ii) no que se refere ao trabalho têxtil, percebeu-se que, além da visível maioria de mulheres e menores, as condições de emprego nas fábricas de tecidos eram precárias. Ressaltou-se, também, a enérgica relutância de sua burguesia em aceitar a legislação trabalhista criada pelo governo, utilizando, para tanto, argumentos improcedentes. Por último, (iii) a heterogeneidade estrutural existente no subsetor também podia ser estendida à situação econômica dos seus ramos no período pré-depressão. Alguns, como o algodoeiro e o da juta, passavam por momentos delicados. O primeiro, em razão da concorrência estrangeira, organizadora de dumpings contra a produção doméstica; e o segundo, devido ao desaquecimento da economia cafeeira. Outros ramos, todavia, tais como o de malhas, lã e, notadamente, o da seda atravessavam período de

\footnotetext{
${ }^{144}$ CIFTA-Rio. Ata de Reunião da Diretoria, 03.10.1928 e 18.10.1928.

${ }^{145}$ Decreto n. 5.650, 09.01.1929. Essa reforma tarifária não foi a primeira dos anos (19)20 feita pelo Governo Federal para proteger o subsetor têxtil. Em 1926, modificaram-se as tarifas incidentes sobre linhas estrangeiras, visando proteger a indústria doméstica do ramo. Esta, por sua vez, vinha sofrendo ação de um dumping inglês, realizado por um truste da Machine Cottons Limited. Muitas empresas de linhas domésticas foram incorporadas pelo truste. Algumas são aproveitadas (Cia. Brasileira de Linhas de Coser, em São Paulo); já outras são compradas e destruídas (Cia. Agro-Fabril Mercantil, de Alagoas, pertencente a Delmiro Gouveia). Ver: Stanley Stein. Origens, op. cit., pp. 148-149.

${ }^{146}$ CIFTA-Rio. Ata de Reunião da Diretoria, 03.01.1929.
} 
crescimento, auxiliado pela desvalorização cambial do final dos anos (19)20 e pelo aumento do consumo dos seus produtos. 


\section{CAPÍTULO 2 - A crise (1929-1932)}

Feita a radiografia do subsetor têxtil paulista antes da grande depressão, utilizar-seão as informações concedidas acerca da sua estrutura produtiva e espacial, das condições de trabalho e da situação econômica das fábricas têxteis paulistas em 1928 como referencial para melhor se compreender as transformações por elas vivenciadas ao longo do período 1929-1932. Além disso, objetiva-se elucidar as maneiras pelas quais o Estado interveio para auxiliar os ramos têxteis considerados em crise, indagando-se sobre a eficácia das medidas tomadas.

\section{1 - A grande depressão e a economia doméstica.}

Em 1929, o Brasil se viu diante de forte depressão econômica. Os fatores determinantes dessa crise possuíam origens internas e externas.

Endogenamente, citam-se as implicações da política de valorização do café. Esta, no início periódica, passa a ser implementada de maneira permanente a partir de 1924, mediante a criação do Instituto Paulista da Defesa Permanente do Cafér ${ }^{147}$. Desde então, as compras do excedente cafeeiro realizadas pelo governo estadual seriam feitas conforme as necessidades, isto é, anualmente. Visava-se reduzir, de forma artificial, a oferta mundial do produto e, assim, manter seus preços elevados. Esse intervencionismo, alicerçado sobretudo em financiamentos externos, cristalizava a dependência doméstica para com o café. Nos anos (19)20, tal produto foi responsável, em média, por mais de 70\% das divisas de exportação locais ${ }^{148}$.

Entretanto, nada foi feito para se controlar a expansão dos cafezais, que eram continuamente estimulados a se expandir em razão dos preços convidativos ${ }^{149}$. As safras, ano a ano, mostravam-se cada vez mais volumosas. A de 1926/1927 foi imensa (26,1 milhões de sacas) ${ }^{150}$. Esperava-se, assim como ocorrera em momentos anteriores, que a próxima (1928/1929) fosse bem menor. Porém, no segundo semestre de 1929, percebeu-se 147

Delfim Netto, op. cit, p. 123. Lembra-se que, em 1925, tal instituição interventora muda de nome, passando a se chamar Instituto do Café do Estado de São Paulo.

${ }^{148}$ Marcelo de Paiva Abreu. O Brasil e a economia mundial (1930-1945). Ed. Civilização Brasileira, Rio de Janeiro, 1999, p. 52 e 58.

${ }^{149}$ Da mesma forma, em razão dos preços altos, a produção mundial de café cresceu. Assim, apesar dos esforços do governo brasileiro em se reduzir a oferta global do produto, esta se elevou, gerando uma grande concorrência para os cafeicultores domésticos. Para maiores informações, ver: Delfim Netto, op. cit., em especial 'Capítulo III - O mercado cafeeiro com a intervenção estatal: a defesa permanente'.

${ }^{150}$ Idem, op. cit., p. 133. 
que a mesma seria, no mínimo, tão considerável quanto o anterior. Muitos já especulavam sobre a impossibilidade do governo em obter empréstimos externos para a compra de tantos excedentes.

É exatamente nesse contexto local delicado que se agrega o fator exógeno determinante para a deflagração da crise doméstica: a depressão econômica iniciada nos Estados Unidos em outubro de 1929 e logo espalhada para todos os países capitalistas, em razão das suas interdependências comercial, produtiva e financeira ${ }^{151}$. Com isso, os bancos nacionais e, em especial, os internacionais, restringiram suas operações de crédito para o financiamento da produção cafeeira. O Governo Federal se negou a auxiliar o Instituto do Café $^{152}$. Os preços do produto decresceram vertiginosamente ${ }^{153}$. Vários cafeicultores, sem condições de arcar com os custos mínimos de suas fazendas, reduziram os salários dos seus trabalhadores e hipotecaram suas $\operatorname{posses}^{154}$. O mercado consumidor doméstico se retraiu, espalhando efeitos recessivos para os setores industrial, mercantil e financeiro.

Além disso, as quedas nas quantidades exportadas e nos preços cafeeiros, bem como a cessão brusca da entrada de capitais estrangeiros no Brasil, fizeram as reservas cambiais domésticas caírem rapidamente. Em setembro de 1929, a Caixa de Estabilização possuía mais de 31 milhões de libras esterlinas; em agosto de 1930, apenas 14 milhões; e, no início de 1931, as reservas estavam praticamente esgotadas ${ }^{155}$. Da mesma maneira, em razão da política de paridade cambial, teve-se uma redução do meio circulante interno, que passou de 3,4 milhões de contos em 1929 para 2,8 milhões em $1930^{156}$. Com isso, a recessão aprofundou-se ainda mais na economia. Por falta de créditos e pela retração do mercado consumidor local, diversos bancos e unidades produtivas fecharam as suas portas. A queda do PNB, entre 1928 e 1931, foi de 4\% (Gráfico 2.1).

\footnotetext{
151 "A Grande Depressão (...) provavelmente antecipou e, certamente, aprofundou uma crise que, de qualquer modo, seria inevitável”. João M. C. de Mello. O capitalismo tardio. Ed. Brasiliense, São Paulo, 1994, p. 168.

${ }^{152}$ Ibidem, op. cit., p. 135-136.

${ }^{153}$ Em outubro de 1929, o preço foi de 11 pence por libra-peso para 7. Em 1930, caiu para 5 e, em 1931, para apenas 4. Marcelo de Paiva Abreu, op. cit., p. 74.

${ }^{154}$ Segundo Carone, durante a crise (1929-1932), os cafeicultores reduziram entre 35 a $40 \%$ os salários dos seus empregados. Informa também que, em 1932, 651 fazendas paulistas de café estavam hipotecadas junto ao Banco do estado de São Paulo. Ver: Edgard Carone. A república nova (1930-1937). $3^{\circ}$ Edição. Difel, São Paulo, 1982, p. 26-27.

${ }^{155}$ Idem, op. cit., p. 77.

${ }^{156}$ Delfim Netto, op. cit., p. 136.
} 


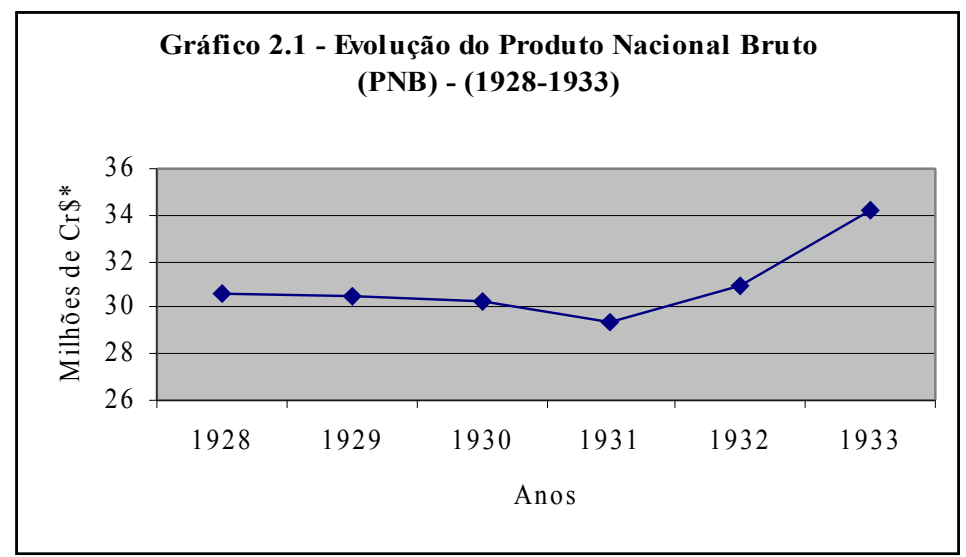

Fonte: A. Villela e W. Suzigan, op. cit., p. 412-454 / * Milhões de cruzeiros de 1939.

Esse foi o pano de fundo para a eclosão do movimento revolucionário de 1930, que permitiu a ascensão de Getúlio Dornelles Vargas ao poder federal. Logo, o governo recém-instalado extinguiu a Caixa de Estabilização (novembro / 1930). Impediu-se, assim, a queda contínua do meio circulante interno. Por outro lado, como o saldo líquido de reservas internacionais manteve-se negativo, a desvalorização cambial desabrochou como conseqüência inevitável ${ }^{157}$. Em 1929, $1 \$ 000$ comprava 0,12 dólar; em 1930, 0,11; e, em 1931, apenas 0,07. Assim, entre 1929 e 1931, a queda da moeda doméstica com relação à norte-americana foi superior a $41 \%$, encarecendo os preços dos bens importados e os valores dos compromissos brasileiros no exterior. A liquidação destes, por sua vez, estava cada dia mais difícil de ser mantida. A disponibilidade de divisas locais limitava-se, praticamente, aos saldos da balança comercial, os quais eram insuficientes ${ }^{158}$. Assim, em setembro de 1931, esgotado de recursos cambiais, o governo suspendeu os pagamentos da dívida externa e realizou conversações para renegociá-la ${ }^{159}$. Concomitantemente, iniciavase o controle do câmbio pelo Banco do Brasil ${ }^{160}$. Com isso, libertar-se-iam divisas conforme as prioridades do País, das quais se destacavam os compromissos externos e as importações consideradas essenciais. Facilitava-se, portanto, um processo substitutivo de importações doméstico.

\footnotetext{
${ }^{157}$ Aníbal Villela e Wilson Suzigan, op. cit., p. 49-50.

158 Lembra-se que os crescentes saldos da balança comercial brasileira (8.178.000 libras em 1929, 12.127.000 em 1930 e 20.788.000 em 1931) deveram-se, essencialmente, à brusca queda no valor das exportações domésticas, as quais foram maiores do que as reduções dos valores importados. Ver: Aníbal Villela e Wilson Suzigan, op. cit., pp. 412-454.

${ }^{159}$ Essas renegociações culminarão com a assinatura do Terceiro Funding em março de 1932. Para maiores informações, ver: Edgard Carone. A república nova, op. cit., p. 68.

${ }^{160}$ No 'apagar das luzes' da República Velha, o Governo Washington Luiz implementou o monopólio cambial pelo Banco do Brasil. Entretanto, após a ascensão de Getúlio Vargas no poder, reinstituiu-se a liberdade de câmbio (novembro de 1930). Ver: Marcelo de Paiva Abreu, op. cit., p. 77 e 115-117.
} 
Com relação ao café, estabeleceu-se, em 1931, a compra pelo Governo Federal de todo produto retido desde $30.06 .1930^{161}$. Criaram-se mecanismos impeditivos do crescimento dos cafezais. Além disso, uma taxa sobre cada saca de café exportada foi constituída, visando-se financiar tal política de aquisição de excedentes pelo poder público $^{162}$. Assim, a partir de 1932, muito em razão das medidas tomadas pelo governo, podia-se dizer que o pior da depressão já havia passado. O PNB desse ano (Gráfico 2.1) superou, pela primeira vez, o de 1928. Da mesma maneira, os índices setoriais da agricultura e da indústria domésticos apresentaram crescimentos $(6,04 \%$ e 1,38\%, respectivamente) ${ }^{163}$.

Após ter discutido os efeitos da depressão do ponto de vista macroeconômico, é preciso, nesse momento, verificar as implicações dessa crise na indústria têxtil paulista e em seus respectivos ramos.

\section{$\underline{2.2 \text { - A grande depressão e a indústria têxtil paulista }}$}

A crise econômica doméstica trouxe conseqüências negativas para a indústria do estado de São Paulo. Entre 1929 e 1930, quase três mil e quinhentos estabelecimentos fabris - isto é, $40 \%$ do total - fecharam as suas portas. Mais de vinte e nove mil operários dos cento e quarenta e oito mil existentes perderam seus empregos $(19,5 \%)$. O valor produtivo nominal reduziu-se em $23 \%$ e, o deflacionado, em $11 \%{ }^{164}$. Por outro lado, a força motriz estabilizou-se até 1930 (Tabela 2.1); em 1931, passou por leve crescimento $(11,6 \%)$; e, no ano seguinte, retraiu-se $(9,2 \%)$. O capital - tanto nominal, quanto real manteve-se crescente durante todo o período, apesar da crise. Conclui-se, portanto, que a concentração industrial aumentou em São Paulo. A relação capital-fábrica de 1932 era duas vezes maior que a de $1928^{165}$.

A indústria têxtil paulista, se comparada ao setor fabril estadual como um todo, sofreu implicações ainda mais drásticas (Tabela 2.1). Na maioria das variáveis arroladas, percebe-se pior desempenho daquelas perante estas. A queda do número de operários das indústrias têxteis de São Paulo, entre 1928 e 1929, foi superior a 28\%, isto é, dos vinte e nove mil empregados demitidos de todas as fábricas paulistas, aproximadamente vinte mil pertenciam ao subsetor de tecidos. O capital nominal têxtil cresceu, no início, em cifra

${ }^{161}$ Decreto n. 19.688, 11.02.1931.

${ }^{162}$ Delfim Netto, op. cit., pp. 144-146.

${ }^{163}$ Cláudio Haddad, op. cit., pp. 147-148.

${ }^{164}$ Anexo - Tabela 1.

${ }^{165}$ Idem. 
semelhante às demais unidades fabris do estado (23\% no período 1928-1929). Porém, após isso, evidencia-se queda do primeiro e contínua ascensão das segundas. No que se refere ao capital real, nota-se, entre 1928 e 1932, elevação em ambos os casos, todavia com taxas menores por parte das fábricas de tecidos (30\% destas contra $88 \%$ da média estadual).

Tabela 2.1 - Índices do número de estabelecimentos, capital, operários, força motriz e valor de produção - Indústrias Gerais e Têxteis - Estado de São Paulo (1928-1933, 1928=100)*

\begin{tabular}{lcccccccccccc} 
& \multicolumn{2}{c}{1928} & \multicolumn{2}{c}{1929} & \multicolumn{2}{c}{1930} & \multicolumn{2}{c}{1931} & \multicolumn{2}{c}{1932} & \multicolumn{2}{c}{1933} \\
& $\mathrm{G}$ & $\mathrm{T}$ & $\mathrm{G}$ & $\mathrm{T}$ & $\mathrm{G}$ & $\mathrm{T}$ & $\mathrm{G}$ & $\mathrm{T}$ & $\mathrm{G}$ & $\mathrm{T}$ & $\mathrm{G}$ & $\mathrm{T}$ \\
\hline Estabelecimentos & 100 & 100 & 128 & 135 & 78 & 170 & 83 & 177 & 88 & 178 & 95 & 193 \\
Capital (contos) & 100 & 100 & 123 & 123 & 134 & 105 & 135 & 102 & 144 & 100 & 173 & 119 \\
Capital (contos D) & 100 & 100 & 117 & 117 & 156 & 122 & 171 & 129 & 188 & 130 & 231 & 158 \\
Operários & 100 & 100 & 93 & 71 & 80 & 72 & 99 & 89 & 102 & 91 & 116 & 105 \\
Força Motriz H.P. & 100 & 100 & 105 & 115 & 105 & 116 & 117 & 126 & 106 & 124 & 117 & 132 \\
Valor Produção (contos) & 100 & 100 & 123 & 83 & 134 & 71 & 135 & 66 & 144 & 73 & 173 & 83 \\
Valor Produção (contos - D) & 100 & 100 & 92 & 79 & 89 & 83 & 102 & 83 & 104 & 95 & 112 & 111 \\
\hline
\end{tabular}

Fonte: Anexo - Tabelas 1 e $2 . / * \mathrm{G}=$ Indústrias Gerais; $\mathrm{T}=$ Indústrias Têxteis.

Essa crise profunda pela qual passou o subsetor têxtil deveu-se, entre outros fatores, à queda mais significativa do seu valor produtivo. As indústrias gerais do estado receberam, em mil-réis nominais, 44\% a mais pela venda dos seus bens em 1932 do que em 1928. Já as indústrias têxteis receberam 27\% a menos (Tabela 2.1). Deflacionando tais valores, vê-se que estes decresceram para as indústrias gerais entre 1928 e 1930. A partir daí, elevaram-se constantemente, atingindo, em 1932, cifra 4\% superior a de 1928. Por outro lado, sua queda para as fábricas de tecidos foi maior e mais longa (até 1931), sendo que, em 1932, ainda se situavam em patamar 5\% menor que no período anterior à crise. Assim, com uma produção valendo menos, as fábricas têxteis foram obrigadas a demitir mais operários e a investir menos capital.

As razões desse decréscimo significativo do valor de produção têxtil devem ser procuradas nas suas próprias especificidades produtivas e de seu mercado consumidor. Os principais compradores de tecidos domésticos eram trabalhadores de baixa renda, especialmente os do campo. Adquiriam, na maioria dos casos, tecidos grossos e baratos de algodão - daí o porquê desse ramo ter sido, até este momento, o mais importante entre todos do subsetor. Ora, com as implicações baixistas da crise sobre o nível de renda do proletariado e de trabalhadores rurais - seja por via demissionária, seja por reduções de salários -, teve-se uma queda de demanda dos itens de consumo desta classe. Reduziu-se, assim, a demanda por têxteis, abaixando-se sua produção e seus preços. Esta hipótese é confirmada pela própria diretoria do CIFTA, a qual, em uma de suas reuniões, afirmou que 
a "crise algodoeira" relaciona-se com “(...) a suspensão imediata do recebimento das respectivas encomendas por parte dos atacadistas de tecidos, em virtude da paralisação dos negócios, principalmente no interior, para onde é encaminhada a maior parte da produção dos nossos tecidos" (grifo nosso) ${ }^{166}$.

Deve-se ressaltar, ainda, mais dois aspectos. Em primeiro lugar, enquanto o número de estabelecimentos têxteis cresceu 78\% entre 1928 e 1932, no setor fabril agregado, teve-se uma queda de $12 \%$. Isto é, a concentração industrial das fábricas de tecidos diminuiu, enquanto, nas indústrias paulistas em geral, aumentou. Excetuando-se o ramo lanífero, houve queda nas relações capital-fábrica e trabalho-fábrica para o subsetor (Tabela 1.5 e 2.2). A composição orgânica do capital, diferentemente, apresentou leve crescimento, justificando, assim, o aumento de produtividade observado nas fábricas têxteis estaduais (Tabela 1.5 e 2.2$)^{167}$.

Tabela 2.2 - Composição orgânica do capital e índices de concentração e produtividade nos ramos da Indústria Têxtil Paulista (1932)

\begin{tabular}{ccccccc} 
& Algodão & Juta & Lã & Malha & Seda & Têxtil Geral \\
\hline Capital - Fábrica & 2.219 & 4.700 & 1.009 & 176 & 969 & 998 \\
Trabalho - Fábrica & 333 & 475 & 162 & 36 & 89 & 129 \\
Capital - Trabalho & 6,6 & 9,9 & 6,2 & 4,9 & 10,9 & 7,6 \\
Capital - Produto & 1,01 & 1,00 & 0,18 & 0,48 & 0,91 & 0,78 \\
Trabalho - Produto & 0,15 & 0,10 & 0,03 & 0,10 & 0,08 & 0,10 \\
\hline
\end{tabular}

Fonte: Estatística Indústria do Estado de São Paulo, 1932.

Em segundo lugar, deve-se pensar o momento de recuperação da indústria têxtil paulista. Nota-se (Tabela 2.1), inicialmente, que no ano de 1931 houve crescimento do número de operários $(23 \%)$, da força motriz $(8,8 \%)$ e do capital deflacionado $(6 \%)$ no subsetor, apesar da queda do valor produtivo real (-7,9\%). Todavia, em 1932, os índices de crescimento das variáveis citadas flutuaram (operários, 2,2\%; capital real, 0,7\%), ou até decresceram (força motriz, -1,5\%). A recuperação plena só veio mesmo em 1933. Nesse ano, observa-se crescimento do subsetor têxtil paulista em quaisquer das variáveis arroladas.

Confirma-se tal tendência por meio da verificação do número de paralisações ocorridas nas fábricas de tecidos do estado entre 1929-1933 (Tabela 2.3). Em 1929, havia

\footnotetext{
${ }^{166}$ CIFTA-Rio. Atas de Reunião da Diretoria, 08.11.1930.

${ }^{167}$ Confirma-se, portanto, até então, a perspectiva de Cano acerca da tendência de desconcentração têxtil, a qual aconteceria, segundo ele, em razão da maior disponibilidade de energia elétrica e de capacidade de fiação no estado de São Paulo, ocorrida ao longo dos anos (19)20 e início dos (19)30. Assim, as empresas de tecidos nascentes não teriam, obrigatoriamente, que empregar vultosos capitais na aquisição de força motriz a vapor e na instalação de fiações. Abria-se espaço para a entrada de pequenos investidores no ramo. Ver: Wilson Cano. Alguns aspectos da concentração industrial, op. cit., p. 89.
} 
22 estabelecimentos têxteis parados em São Paulo; em 1932, apenas 6; e, em 1933, não havia mais algum. Pode-se afirmar, portanto, que a partir deste último ano (1933), a indústria têxtil paulista já havia se levantado do tombo depressivo ${ }^{168}$.

Tabela 2.3 - Número de paralisações na Indústria Têxtil Paulista (1929-1932)*

\begin{tabular}{ccccc} 
& 1929 & 1930 & 1931 & 1932 \\
\hline Algodão & $15(13,3)$ & $26(21,8)$ & $9(7,9)$ & $4(3,5)$ \\
Juta & $1(14,2)$ & $0(0)$ & $0(0)$ & $0(0)$ \\
Lã & $1(5)$ & $2(9,5)$ & $2(9,5)$ & $2(10)$ \\
Malha & $1(0,6)$ & $6(4,3)$ & $5(3,3)$ & $0(0)$ \\
Seda Natural e Art. & $4(6)$ & $4(6,3)$ & $1(1,5)$ & $0(0)$ \\
Total & $22(6,1)$ & $38(8,4)$ & $17(3,6)$ & $6(1,2)$ \\
\hline
\end{tabular}

Fonte: Estatística Industrial do Estado de São Paulo, 1929 - 1933.

* Os números em parêntesis representam a porcentagem de fábricas paradas em relação ao total do ramo.

Visto os traços gerais da crise para o subsetor de tecidos, observar-se-ão, agora, as implicações da mesma para os seus diversos ramos.

\subsection{1 - Algodão}

O ramo têxtil de algodão foi um dos que mais sofreram as conseqüências da crise. Entre 1928 e 1929, demitiu-se mais de 1/3 da mão-de-obra empregada no mesmo, o que perfazia $87 \%$ do total de dispensas realizadas pela indústria têxtil paulista no período ${ }^{169}$. A queda do montante de capital algodoeiro, nos anos 1929-1930, foi a segunda maior entre os demais, sendo superada, apenas, pelas indústrias de juta (Tabela 2.4). Já no que se refere à quantidade produzida, houve, no interregno 1928-1930, decréscimo de 29\% (Tabela 2.5).

\footnotetext{
${ }^{168}$ Cálculos de Haddad demonstram também que, a partir de 1933, o índice de produção da indústria doméstica havia superado o de 1928. Ver: Cláudio Haddad, op. cit., p. 147-148.

${ }^{169}$ O ramo possuía, em 1928, 60\% dos operários empregados no subsetor de tecidos paulista (Tabela 1.3). Assim, como a participação relativa algodoeira nas demissões têxteis foi superior a tal porcentagem ( $87 \%)$, não se pode argumentar que seu respectivo tombo na crise 1929-1932 foi proporcional ao seu tamanho; viuse que foi maior.
} 
Tabela 2.4 - Indústria Têxtil Paulista - Índices de crescimento por ramo (1928-1933)

\begin{tabular}{|c|c|c|c|c|c|c|}
\hline & 1928 & 1929 & 1930 & 1931 & 1932 & 1933 \\
\hline \multicolumn{7}{|l|}{ Algodão } \\
\hline Estabelecimentos & 100,0 & 136,6 & 145,1 & 137,8 & 136,6 & 139,0 \\
\hline Capital & 100,0 & 119,8 & 90,1 & 85,1 & 80,0 & 89,1 \\
\hline Capital - D & 100,0 & 113,6 & 104,5 & 108,1 & 104,4 & 118,7 \\
\hline Operários & 100,0 & 63,2 & 55,8 & 76,5 & 80,6 & 92,6 \\
\hline Força Motriz & 100,0 & 114,8 & 107,0 & 113,2 & 109,2 & 113,6 \\
\hline Valor Produção & 100,0 & 72,1 & 67,2 & 49,6 & 59,3 & 72,9 \\
\hline Valor Produção -D & 100,0 & 68,4 & 77,9 & 63,0 & 77,3 & 97,2 \\
\hline \multicolumn{7}{|l|}{ Juta } \\
\hline Estabelecimentos & 100,0 & 140,0 & 180,0 & 200,0 & 220,0 & 220,0 \\
\hline Capital & 100,0 & 119,8 & 89,5 & 86,5 & 85,2 & 165,1 \\
\hline Capital-D & 100,0 & 113,6 & 103,8 & 109,9 & 111,0 & 220,1 \\
\hline Operários & 100,0 & 98,1 & 103,6 & 103,8 & 81,7 & 85,9 \\
\hline Força Motriz & 100,0 & 109,9 & 112,7 & 119,9 & 118,3 & 119,3 \\
\hline Valor Produção & 100,0 & 60,3 & 46,7 & 35,6 & 40,6 & 34,5 \\
\hline Valor Produção- D & 100,0 & 57,2 & 54,2 & 45,2 & 53,0 & 46,0 \\
\hline \multicolumn{7}{|l|}{ Malha } \\
\hline Estabelecimentos & 100,0 & 132,5 & 121,1 & 130,7 & 116,7 & 114,0 \\
\hline Capital & 100,0 & 110,1 & 95,1 & 70,2 & 66,5 & 94,5 \\
\hline Capital-D & 100,0 & 104,4 & 110,2 & 89,1 & 86,7 & 126,0 \\
\hline Operários & 100,0 & 73,8 & 65,0 & 69,2 & 66,4 & 74,1 \\
\hline \multirow[t]{2}{*}{ Força Motriz } & 100,0 & 96,8 & 72,2 & 89,3 & 52,9 & 57,7 \\
\hline & 1928 & 1929 & 1930 & 1931 & 1932 & 1933 \\
\hline \multicolumn{7}{|l|}{ Malha (cont.) } \\
\hline Valor Produção & 100,0 & 98,2 & 63,3 & 58,1 & 57,3 & 70,3 \\
\hline Valor Produção-D & 100,0 & 93,1 & 73,4 & 73,8 & 74,7 & 93,7 \\
\hline \multicolumn{7}{|l|}{ Lã } \\
\hline Estabelecimentos & 100,0 & 95,2 & 100,0 & 100,0 & 95,2 & 85,7 \\
\hline Capital & 100,0 & 145,7 & 130,3 & 149,1 & 126,6 & 131,6 \\
\hline Capital-D & 100,0 & 138,2 & 151,1 & 189,4 & 165,1 & 175,4 \\
\hline Operários & 100,0 & 96,4 & 112,3 & 115,1 & 141,1 & 189,7 \\
\hline Força Motriz & 100,0 & 144,5 & 122,2 & 130,7 & 131,1 & 151,6 \\
\hline Valor Produção & 100,0 & 64,8 & 48,6 & 103,2 & 106,0 & 56,8 \\
\hline Valor Produção-D & 100,0 & 61,4 & 56,4 & 131,1 & 138,2 & 75,8 \\
\hline \multicolumn{7}{|l|}{ Seda (Nat. e Art.) } \\
\hline Estabelecimentos & 100,0 & 157,1 & 150,0 & 150,0 & 176,2 & 250,0 \\
\hline Capital & 100,0 & 150,0 & 136,5 & 141,0 & 153,8 & 154,3 \\
\hline Capital - D & 100,0 & 142,3 & 158,4 & 179,1 & 200,6 & 205,7 \\
\hline Operários & 100,0 & 94,6 & 101,9 & 119,1 & 117,9 & 137,9 \\
\hline Força Motriz & 100,0 & 140,6 & 129,2 & 156,0 & 158,2 & 207,9 \\
\hline Valor Produção & 100,0 & 166,1 & 120,6 & 70,6 & 82,4 & 145,7 \\
\hline Valor Produção & 100,0 & 157,4 & 139,9 & 89,6 & 107,5 & 194,2 \\
\hline
\end{tabular}

Fonte: Anexo - Tabelas 2 a 7.

Além disso, em 1929, das vinte e duas empresas têxteis paralisadas em razão da depressão, quinze eram produtoras de tecidos de algodão, isto é, $68 \%$ do total ${ }^{170}$. Esta

${ }^{170}$ Repete-se, aqui, a mesma observação anterior: as fábricas têxteis de algodão representavam, em 1928, $31,5 \%$ dos estabelecimentos do ramo (Tabela 1.3). Dessa forma, a porcentagem de paralisações foi superior à sua participação setorial relativa. 
porcentagem foi mantida no ano seguinte (Tabela 2.3). Entre aquelas que pararam, encontram-se indústrias de grande porte, tais como a Cia. Fiação e Tecidos São Martinho (5 mil contos de capital aplicado); a Cia. Paulista de Tecidos de Algodão (13 mil contos); o Cotonifício Scarpa (35 mil contos), a unidade de São Bernardo da S.A. Boyes (4 mil contos) e a Cia. Industrial Mogyana de Tecidos (20 mil contos) ${ }^{171}$.

Da mesma maneira, muitas falências ocorreram no ramo algodoeiro, concentradas no ano de $1930^{172}$. Dentre elas, destaca-se o fechamento da Fiação de Algodão da Saúde S.A. (capital - 1930), da Cia. Fiação e Tecidos São Martinho (Tatuí - 1930), do Cotonifício Scarpa (capital - 1930), da S.A. Indústrias Gebara (capital - 1930) e da Cia de Indústrias Têxteis (São Paulo e Itatiba - 1931) ${ }^{173}$. A São Paulo Alpargatas Company S.A. teve bancarrota decretada em junho de 1930, porém, mediante acordo com credores, conseguiu renegociar suas dívidas ${ }^{174}$. Outras, que não quebraram, foram obrigadas a reduzir jornadas, dias de trabalho e salários dos empregados. Segundo o CIESP, em 1930, as fábricas do ramo produtoras de tecidos grossos estavam produzindo $30 \%$ de sua capacidade. Em média, funcionavam apenas três dias por semana. Já as indústrias de tecidos de algodão finos, fabricavam $50 \%$ do que poderiam ${ }^{175}$.

Como medida de auxílio à crise, o CIFTA propôs a criação de uma cooperativa entre as fábricas têxteis de algodão nacionais, que teria duas finalidades: (i) financiar as unidades produtivas em dificuldades; e (ii) regular a fabricação de fios e tecidos algodoeiros, através do conhecimento dos estoques das empresas participantes ${ }^{176}$. Assim, logo se descobriu, por intermédio dos questionários distribuídos às filiadas, que “(...), em 30 de setembro de 1929, o estoque de tecidos de algodão existente nas respectivas fábricas (do país) era de 154.269.050 metros" ${ }^{" 177}$. Da mesma maneira, visando aplacar a depressão,

\footnotetext{
${ }^{171}$ Estatística Industrial do Estado de São Paulo, 1929 e 1930, pp. $23-27$ e Relatório da Diretoria. Cia. Industrial Mogyana de Tecidos, 21.02.1931.

${ }^{172}$ Infelizmente, não há estatísticas sofre o número de falências em cada ramo têxtil no estado de São Paulo durante a crise. As informações aqui relatadas são fruto de duas fontes: (i) comparações entre listas das fábricas de tecidos ao longo dos anos de depressão (1929-1932), encontradas nas Estatísticas Industriais do Estado de São Paulo; e (ii) chamadas publicadas no Diário Oficial do Estado de São Paulo acerca da falência de empresas. Sabe-se, entretanto, que, da mesma forma que muitas fábricas fecharam, outras unidades produtivas - de porte menor - foram abertas. Pode-se verificar este crescimento do número das unidades têxteis do estado no Anexo (Tabela 2).

${ }^{173}$ Diário Oficial do Estado de São Paulo (DOESP). Editais de Falência, 04.02.1930, p. 1171; 13.09.1930, p. 7992; 21.12.1930, p. 10758; e 08.01.1933, p. 15. Lembra-se que, aqui, se informaram as datas de publicação dos editais no Diário Oficial e não as de homologação dos mesmos. Ver também: Ata Assembléia Geral Extraordinária. Cia. Indústrias Têxteis, 29.08.1931.

${ }^{174}$ DOESP. Edital de Falência, 10.06.1930, p. 5173 e Ata da Assembléia Geral Extraordinária. São Paulo Alpargatas Company S.A., 22.06.1930.

${ }^{175}$ CIESP. Memorial do CIESP para o Chefe do Governo Civil de São Paulo, op. cit.

${ }^{176}$ CIFTA. Ata de Reunião da Diretoria, 11.10.1929.

${ }^{177}$ CIFTA. Ata de Reunião da Diretoria, 16.02.1930.
} 
o CIFT-SP entrou com representação junto à Secretaria de Agricultura paulista indagando sobre a possibilidade de se produzir sacos de algodão para o café. A resposta dos técnicos foi desanimadora, em razão das inúmeras modificações produtivas que deveriam ser feitas nas fábricas para viabilizar tal proposta ${ }^{178}$. Além disso, objetivando reduzir custos, o CIFTA e o Sindicato Patronal das Indústrias Têxteis do Estado de São Paulo (antigo CIFT-SP) fizeram um acordo, em 1931, uniformizando os tamanhos, as quantidades e os tipos de amostras de tecidos que as fábricas deveriam fornecer, gratuitamente, aos $\operatorname{atacadistas}^{179}$.

Tabela 2.5 - Produção dos ramos têxteis paulistas (1928-1933) - metros

\begin{tabular}{ccccccc} 
& 1928 & 1929 & 1930 & 1931 & 1932 & 1933 \\
\hline Algodão & 191.139 .000 & 149.034 .000 & 135.314 .067 & 181.514 .996 & 200.592 .480 & 232.012 .047 \\
Juta & 62.808 .000 & $*$ & 39.517 .841 & 37.645 .054 & 42.933 .318 & 43.171 .578 \\
Malha & $*$ & $*$ & 15.184 .148 & 22.114 .836 & 18.796 .281 & 26.441 .591 \\
Lã & 4.330 .000 & $*$ & 2.889 .527 & 4.271 .993 & 4.318 .406 & 4.230 .635 \\
Seda Natural e Art.(1) & $173.157(2)$ & $291.560(2)$ & 317.358 & 354.256 & 443.367 & 966.891 \\
\hline
\end{tabular}

Fonte: Estatística Industrial do Estado de São Paulo, 1928-1933; Villela e Suzigan. Política de governo (...), op. cit., p. 357 e 364. (1) em quilos; (2) Calculados estatisticamente por intermédio da variável força motriz do ramo (ver Anexo Tabela 7). O índice de correlação entre as mesmas é superior a 0,94 .

Em 1931, a situação começou a mudar para as indústrias de tecidos de algodão paulistas. A tendência baixista da maioria de suas variáveis econômicas foi revertida. Entre 1930 e 1931, o montante de capital real investido no ramo cresceu 3\%. Da mesma maneira, a força motriz instalada elevou-se em 6\%; a quantidade têxtil produzida, em $34,1 \%$; e os operários empregados, em mais de $37 \%$. Isto não quer dizer que houve superação da crise. Pelo contrário: seu número de trabalhadores, no ano de 1931, ainda representava 76\% dos existentes nas mesmas em 1928. Além disso, observa-se uma redução de 19\% do seu valor de produção no interregno 1930-1931, indicativo da existência de um mercado consumidor ainda retraído no momento.

Apesar disso, é perceptível que, desde 1931, houve alteração de tendência no ramo algodoeiro. Muitas de suas indústrias ratificaram essa leve melhora ${ }^{180}$. Os diretores da Fábrica de Tecidos e Bordados 'Lapa', por exemplo, afirmaram que “(...) os resultados

\footnotetext{
${ }^{178}$ CIFTA. Ata de Reunião da Diretoria, 07.08.1930. Entre as modificações citadas pelos técnicos, destacase a maior retorção dos fios de algodão, tanto na trama, quanto na teia. Assim, facilitar-se-ia a ventilação essencial para o abrigo de bens alimentícios, tais como o café.

${ }^{179}$ CIFTA. Ata de Reunião da Diretoria, 15.10.1931.

${ }^{180}$ Lembra-se que a falência da Cia. de Indústrias Têxteis (1931) relacionou-se às obrigações financeiras contraídas pela empresa nos dois anos anteriores. Em sua assembléia de dissolução, a diretoria informou “(...) a situação da Cia. não lhe permite a continuação de sua atividade (...) (em razão do seu ) avultado serviço de juros, cuja cobertura não tem sido possível”. Ata Assembléia Extraordinária, Cia. Indústria Têxteis, op. cit.
} 
(de 1931), se não foram bons como se esperava, foram um tanto satisfatórios, pois nos permitiram um pequeno lucro" 181 , 67\% superior ao de $1930^{182}$. As fábricas de algodão e seda da Votorantim, por sua vez, trabalharam “(...) no máximo de sua capacidade”. O maquinário "foi aumentado e aperfeiçoado"183. Os lucros líquidos da empresa cresceram mais de $450 \%$ entre 1930 e $1931^{184}$. A Fábrica Japy elevou a jornada dos operários de 40 para 50 horas semanais. Segundo sua diretoria, "houve em 1931 uma sensível melhora nos negócios da fábrica. $\mathrm{O}$ volume de vendas atingiu o dobro do ano anterior. Apesar do aumento do horário de trabalho e, conseqüentemente, da produção fabril, realizamos uma diminuição de $40 \%$ na metragem do nosso estoque"185. A Cia Fiação e Tecidos São Bento coloca que, “apesar da situação difícil dos negócios em geral, obtivemos resultados que consideramos satisfatórios" ${ }^{\text {186 }}$. Em 1930, a empresa contabilizou déficit de 878 contos; em 1931, possuiu lucro líquido de 297 contos $^{187}$. O Cotonificio Guilherme Giorgi, em 1931, criou nova seção de fiação e ampliou o número de teares ${ }^{188}$. Já, o Cotonifício Rodolfo Crespi, que fechou o ano de 1930 com prejuízo superior a 1.320 contos, obteve, no exercício seguinte, lucro bruto de $638^{189}$.

Essa recuperação das fábricas algodoeiras paulistas perdeu fôlego em 1932. Do crescimento de 3\% do capital real investido no interregno 1930-1931, passou-se para queda de 3\% entre 1931 e 1932. A força motriz instalada recuou 4\% no período. O número de operários e a quantidade de tecidos produzidos cresceram a taxas bem inferiores ao ano precedente (de $37 \%$ para $5 \%$; e de $34 \%$ para $10 \%$, respectivamente). Muitas empresas paralisaram seus parques no final do exercício, em razão da Revolução Constitucionalista de 1932. Apesar disso, a tendência altista foi mantida, a níveis mais modestos. Relatos das indústrias do ramo confirmam os dados apresentados. A diretoria da São Bento, por exemplo, afirmou que “(...) apesar de persistir a situação difícil dos negócios em geral, agravada por três meses de paralisação, obtivemos (em 1932) um resultado que consideramos bom" ${ }^{190}$. Conclusão semelhante chegam os dirigentes da Labor : “(...) o Balanço do ano anterior (1932) se encerrou com lucro, apesar da quase

\footnotetext{
${ }^{181}$ Relatório de Diretoria. S.A. Fábrica de Tecidos e Bordados Lapa, 09.01.1932.

${ }^{182}$ Balanço 1931. S.A. Fábrica de Tecidos e Bordados Lapa, 20.01.1932.

${ }^{183}$ Relatório de Diretoria. S.A. Fábrica Votorantim, 23.02.1932.

${ }^{184}$ Balanço 1931. S.A. Fábrica Votorantim, 25.02.1932.

${ }^{185}$ Relatório de Diretoria. S.A. Fábrica Japy, 04.02.1932.

${ }^{186}$ Relatório de Diretoria. Cia. Fiação e Tecidos São Bento, 03.03.1932.

${ }^{187}$ Balanços 1930 e 1931. Cia. Fiação e Tecidos São Bento, 12.03.1931 e 06.03.1932.

${ }^{188}$ Relatório de Diretoria. Cotonificio Guilherme Giorgi, 12.04.1932.

${ }^{189}$ Balanços 1930 e 1931. Cotonificio Rodolfo Crespi, 27.05.1931 e 29.03.1932.

${ }^{190}$ Relatório de Diretoria. Cia. Fiação e Tecidos São Bento, 31.12.1932.
} 
completa paralisação dos negócios durante os 3 meses do movimento constitucionalista"191. A Fábrica Paulista de Roupas Brancas colocou que "(...) os negócios (têm) alcançado um vulto satisfatório", a despeito das diversas "anormalidades"192.

Em 1933, porém, a recuperação das fábricas algodoeiras do estado era visível. No período 1932-1933, houve crescimento do capital real investido (14\%), dos operários empregados $(15 \%)$, da força motriz instalada (4\%) e até da quantidade (15\%) e do valor produzidos (26\%). Pela primeira vez, o capital invertido superou o montante de 1928 . O número de operários e o valor da produção deflacionado ultrapassaram as quantias précrise em 1934. Por outro lado, devido à depressão, o ramo perdeu espaço relativo dentro do subsetor têxtil. Percebe-se (Tabela 2.6) que todas as variáveis econômicas algodoeiras decresceram no interregno 1928-1933, com destaque para o capital, cuja queda foi de $25 \%$.

Tabela 2.6 - Participação relativa entre ramos têxteis perante total do total ramo em termos de capital, estabelecimentos, operários, força motriz (H.P.) e valor de produção (contos - D) - Estado de São Paulo (1928 / 1933)

\begin{tabular}{c|cc|cc|cc|cc|cc} 
& \multicolumn{2}{|c|}{ Capital } & \multicolumn{2}{|c|}{ Estabelecimentos } & \multicolumn{2}{c|}{ Operários } & \multicolumn{2}{c|}{ Força Motriz } & \multicolumn{2}{c}{ Valor Produção } \\
& 1928 & 1933 & 1928 & 1933 & 1928 & 1933 & 1928 & 1933 & 1928 & 1933 \\
\hline Algodão & 66,2 & 49,6 & 31,1 & 22,4 & 68,4 & 60,0 & 75,3 & 64,8 & 49,9 & 43,6 \\
Juta & 12,9 & 18,0 & 1,9 & 2,2 & 9,4 & 7,7 & 11,4 & 10,3 & 15,3 & 6,3 \\
Malha & 7,5 & 6,0 & 43,2 & 25,5 & 10,6 & 7,4 & 4,6 & 2,0 & 10,2 & 8,6 \\
Lã & 3,4 & 3,8 & 8,0 & 3,5 & 3,4 & 6,1 & 4,2 & 4,8 & 13,1 & 8,9 \\
Seda Nat./Art. & 9,9 & 12,9 & 15,9 & 20,6 & 8,2 & 10,8 & 4,5 & 7,1 & 11,6 & 20,2 \\
\hline
\end{tabular}

Fontes: Anexo, Tabelas $1-7$.

2.2.2 - Juta

O ramo da juta paulista também foi duramente atingido pela crise. Possuiu, entre 1928 e 1930, a maior queda de capital real $(-8,7 \%)$ e de valor produtivo $(-45,8 \%)$ do subsetor têxtil (Tabela 2.4). No mesmo período, a quantidade de tecidos fabricados decresceu 37\% (Tabela 2.5). As duas maiores empresas de sacaria do estado - a Cia. Nacional de Tecidos de Juta e a Cia. Paulista de Aniagens - reduziram em 18\% e 58\%, respectivamente, seu capital nominal ${ }^{193}$. Afirma-se, ainda, que as fábricas do ramo produziram, em 1930, apenas 25 a $30 \%$ de sua capacidade máxima ${ }^{194}$.

\footnotetext{
${ }^{191}$ Relatório de Diretoria. S.A. Fábrica de Tecidos Labor, 08.04.1933.

${ }^{192}$ Relatório de Diretoria. S.A. Fábrica Paulista de Roupas Brancas, 28.06.1933.

${ }^{193}$ Estatística Industrial do Estado de São Paulo, 1929 e 1930, p. 27.

${ }^{194}$ CIESP. Memorial do CIESP ao Chefe do Governo Civil de São Paulo, op. cit.
} 
Não obstante, chama atenção o reduzido número de demissões nas suas indústrias, as quais foram as menores do subsetor têxtil. 1,9\% dos operários perderam seus empregos, perfazendo somente $0,006 \%$ do total entre as fábricas de tecidos paulistas. Além disso, praticamente não houve paralisações das empresas de juta ao longo da crise. Excetuandose uma única, ocorrida em 1929, o ramo não possuiu unidades paradas no interregno 1930-1932 (Tabela 2.3).

O ano de 1931 continuou delicado para as fábricas de juta, apesar da leve melhora em algumas variáveis. O capital real invertido e a força motriz instalada aumentaram entre 1930 e $1931,5,9 \%$ e 6,4\%, respectivamente. Por outro lado, os valores e as quantidades produzidas de tecidos decresceram $(-16,5 \%$ e $-4,7 \%)$, enquanto o número de operários manteve-se estável. Em 1932, permaneceram as dificuldades. Apesar de leve acréscimo das quantidades e valores confeccionados e do montante de capital real, houve queda dos operários empregados (Tabela 2.4). As fábricas de tecidos do estado, como um todo, contrataram mais de 3.400 proletários no período; já o ramo de juta demitiu $1.400^{195}$.

Em 1933, enquanto o subsetor têxtil superava o grande tombo depressivo, as fábricas de juta ainda se encontravam em dificuldades. Houve, é verdade, leve ascensão do número de operários empregados e da força motriz instalada $(5,1 \%$ e $0,8 \%)$. Porém, foram acréscimos pequenos demais se comparados às demais empresas têxteis de São Paulo. Além disso, sua quantidade de proletários situava-se, ainda, 14\% abaixo do patamar de 1928. O valor de produção dos seus tecidos atingiu um dos pontos mais baixos, $54 \%$ inferior ao momento precedente à crise. Mesmo assim, um fato chama a atenção: o ramo de juta possuiu o maior acréscimo de capital real entre todos do subsetor têxtil $(98,2 \%)$. De 45 mil contos, em 1932, as fábricas de juta passaram para mais de 90 mil no ano seguinte. Tal ascensão, entretanto, deveu-se unicamente a uma empresa (Cia. Nacional de Tecidos de Juta), a qual elevou seu capital nominal de 37 mil contos para 85 mil no período $^{196}$. Esta elevação foi de caráter corretivo. Não houve crescimento do número de operários, teares, fusos, ou força motriz. Assim, nada a justificou, a não ser o desespero de sua diretoria em confortar os credores da empresa de que a mesma estava com saúde financeira razoável. Em 1932, do capital de 37 mil contos da Cia., mais de 33 mil eram formados, apenas, por debêntures ${ }^{197}$.

Por final, no que se refere à participação relativa do ramo da juta no subsetor têxtil, percebe-se (Tabela 2.6) que a mesma decresceu na maioria das variáveis arroladas. A

\footnotetext{
$\overline{195}$ Ver Anexo - Tabelas 2 e 4.

${ }^{196}$ Estatística Industrial do Estado de São Paulo, 1932 e 1933, p. 27.

${ }^{197}$ Balanço 1932. Cia. Nacional de Tecidos de Juta, 22.01.1933.
} 
única que possuiu ascensão foi a variável capital invertido, que, como já foi explicado, teve caráter meramente especulativo.

\section{$\underline{2.2 .3-\text { Malhas }}$}

As malharias seguiram a mesma tendência do subsetor têxtil paulista: (i) drásticas reduções em suas variáveis econômicas entre 1928 e 1930; (ii) leve melhora em 1931; (iii) nova queda no ano seguinte; e (iv) recuperação a partir de 1933.

No que se refere ao primeiro momento, destaca-se o decréscimo ocorrido na força motriz instalada (27,8\%). Entre as demais fábricas, houve crescimento de 9.700 H.P.; já nas de malhas, observou-se redução de 796 H.P ${ }^{198}$. Além disso, mais de 2.500 operários foram demitidos, o que perfazia $34 \%$ do ramo (Tabela 2.4). O valor de produção, por sua vez, caiu $26,6 \%$.

Apesar disso, empresas como a Fiação para Malharia Indiana não sentiram os efeitos da depressão. Segundo sua diretoria, “(...) não obstante todas as vicissitudes oriundas da crise (...), devemos informar que o nosso produto, pela sua ótima qualidade, tem merecido a melhor preferência do mercado; preferência essa que determinou o trabalho normal e ininterrupto da nossa fábrica, durante todo o exercício de 1930"199. A Fiação e Malharia Assad, por sua vez, estava ampliando sua fábrica no período. Entre 1928 e 1930, inverteu mais de 6.500 contos de réis em obras e compras de maquinismos $^{200}$. Explica-se tal anomalia em razão das mesmas serem as grandes produtoras de fios de malha do estado. Assim, durante a crise, com a interrupção das compras de fios do exterior, tem-se uma oportunidade para ambas expandirem suas vendas.

Em 1931, seguindo a tendência do ramo, apesar das quedas dos capitais investidos e do valor de produção, houve ascensão do número de operários $(6,5 \%)$, da força motriz $(23 \%)$ e da quantidade de malhas confeccionadas (45\%). A diretoria da Indiana informava aos seus acionistas que “(...) o exercício de 1931 nada mais foi senão o desdobramento natural da boa marcha dos negócios sociais nos exercícios anteriores" ${ }^{\text {201 }}$. A empresa aumentou suas vendas em mais de 1.300 contos de réis, obtendo 478 contos de lucros líquidos $^{202}$. No mesmo ano, a Malharia N. S. da Conceição, de Jacareí, elevou seu capital

\footnotetext{
${ }^{198}$ Ver Anexo - Tabelas 2 e 5.

${ }^{199}$ Relatório da Diretoria. S.A. Fiação para Malharia Indiana, s/ data.

${ }^{200}$ Balanços 1929 e 1930. S.A. Fiação e Malharia Ypiranga Assad, 17.01 .1930 e 21.02.1931.

${ }^{201}$ Relatório da Diretoria. S.A. Fiação para Malharia Indiana, 28.02.1932.

${ }^{202}$ Balanço 1931. S.A. Fiação para Malharia Indiana, 19.04.1932.
} 
nominal e aprovou, em assembléia, a compra de máquinas ${ }^{203}$. Entretanto, houve a falência da Cia. de Tecidos de Malha Filinha (Jacareí - 1931), em razão da impossibilidade de pagamento de empréstimos contraídos antes da crise ${ }^{204}$.

Em 1932, observa-se queda do capital real investido $(2,7 \%)$, do número de operários $(4,0 \%)$, da força motriz $(40,7 \%)$ e da quantidade produzida (15\%) nas malharias do estado. A Malharia Assad, por exemplo, reduziu drasticamente os capitais investidos na ampliação da sua fábrica (de 2.267 contos, em 1931, para apenas 279 contos, em $1932)^{205}$. A Indiana, que teve lucros líquidos consideráveis no período (11\% maior do que em 1931 $)^{206}$, afirmou que a empresa foi salva pela compra de algodão antes da sua elevação de preços, ocorrida em razão do movimento revolucionário paulista de 1932. Mesmo assim, a venda de fios da fábrica reduziu-se em 909 contos, quando comparada com o exercício anterior ${ }^{207}$. A Malharia Conceição paralisou suas vendas nos quatro meses da Revolução Constitucionalista. Apesar disso, a fábrica continuou em funcionamento e a diretoria da empresa considerou que "(...) os resultados foram bons" 208 .

Em 1933, tal como no subsetor têxtil agregado, as malharias iniciam uma fase sólida de recuperação. Os montantes de capitais nominal e real de 1933 ultrapassaram, pela primeira vez, os de 1928 . O valor real produzido cresceu em $25 \%$, quase atingindo a cifra anterior à crise. A quantidade de malhas confeccionadas, por sua vez, se elevou em mais de 40\% (Tabela 2.5). Por outro lado, apesar dos acréscimos do número de operários $(11,6 \%)$ e da força motriz $(9,0 \%)$ entre 1932 e 1933, tais variáveis não alcançaram ainda os níveis pré-depressão.

Por último, no que condiz à participação relativa do ramo diante do subsetor têxtil, vê-se (Tabela 2.6) que a mesma decresceu em todas as variáveis, destacando-se para a queda do número de estabelecimentos, superior à $40 \%$.

\section{$\underline{2.2 .4-\mathrm{Lã}}$}

O ramo lanífero paulista foi um dos que menos sofreram as repercussões da depressão econômica. Na verdade, deve-se questionar até que ponto as fábricas de lã do estado passaram por uma crise propriamente dita.

\footnotetext{
${ }^{203}$ Ata Assembléia Geral Extraordinária. Malharia Nossa Senhora da Conceição, 03.06.1931.

${ }^{204}$ Ata Assembléia Geral Extraordinária. Cia. de Tecidos de Malha Filinha S.A., 16.05.1931.

${ }^{205}$ Balanços 1931 e 1932. S.A Fiação e Malharia Ypiranga Assad, 03.04.1932 e 25.02.1933.

${ }^{206}$ Balanços 1931 e 1932. S.A. Fiação para Malharia Indiana, 19.04.1932 e 21.02.1933.

${ }^{207}$ Idem, op. cit.

${ }^{208}$ Relatório de Diretoria. Malharia N. S. da Conceição, 23.02.1933.
} 
Entre 1928 e 1929, os capitais nominal e real investidos no ramo cresceram, respectivamente, $45,7 \%$ e $38,2 \%$ (Tabela 2.4 ). A força motriz elevou-se em 44,5\%. No interregno 1929-1930, apesar do decréscimo da força motriz $(15,4 \%)$ e do capital nominal $(10,6 \%)$, essas variáveis ainda se situavam em níveis muito maiores do que os do período pré-crise. O número de operários de 1930 era 12,1\% superior ao de 1928. Poucas foram as fábricas que paralisaram seus trabalhos (Tabela 2.3) ${ }^{209}$. Os únicos decréscimos consideráveis se dão nos valores e quantidades de lãs produzidas $(43,6 \%$ e $32,2 \%$, respectivamente, entre 1928 e 1930) - fato este devido à contração do mercado doméstico. A CIESP informava que, em 1930, as fábricas de lã do estado produziam somente $20 \%$ de sua capacidade máxima ${ }^{210}$. Porém, provavelmente em razão da fase próspera vivida pelo ramo antes de 1929, foi possível suportar essa contração das vendas sem maiores conseqüências para sua estrutura produtiva.

Em 1931, mesmo a retração produtiva foi superada. O valor da produção real já ultrapassava em mais de 22 mil contos o de 1928 (elevação de 132,7\%), e a quantidade confeccionada cresceu 47,8\% em relação ao ano precedente. Além disso, elevaram-se também o capital investido $(25,3 \%)$, os operários empregados $(2,5 \%)$ e a força motriz (7,0\%). O ramo possuía, em 1931, quase todas as variáveis econômicas acima dos níveis de 1928 , menos a quantidade produzida $(-1 \%)$.

Assim, viu-se que a queda ocorrida em alguns fatores produtivos no interregno 1929-1930 não rebaixou seus valores aos níveis pré-depressivos. Mostrou-se, também, que 1931 foi um ano de crescimento geral para as fábricas de lã. Daí o porquê de se falar em retração da produção, devido à delicada situação econômica doméstica, e não em uma crise do ramo per se.

Diferentemente, 1932 foi um ano de crescimento menor. O número de operários, a força motriz, o valor e as quantidades produzidas de lã elevaram-se no período (Tabela 2.4 e 2.5). Entretanto, houve redução do número de estabelecimentos $(4,8 \%)$ e do capital real investido (12,8\%). A subida contínua na compra de máquinas, feita pelo Lanifício AngloBrasileiro, entre 1929 e 1931, estancou em $1932^{211}$.

Em 1933, percebe-se que o ritmo de crescimento do mercado lanífero diminuiu bastante, porém a estrutura das fábricas do ramo manteve a tendência de aumento. $\mathrm{O}$ valor produtivo real caiu em $45,2 \%$ e a quantidade confeccionada em 2,0\%. Por outro lado,

\footnotetext{
${ }^{209} \mathrm{Da}$ mesma forma, poucas foram as falências. Encontrou-se, apenas, um caso documentado: o da Jacareí Industrial S.A., em Jacareí. Ver: DOESP. Edital de Falência, 22.05.1930, p. 4662.

${ }^{210}$ CIESP. Memorial da CIESP para o Chefe do Governo Civil de São Paulo, op. cit.

${ }^{211}$ Balanços 1929, 1930, 1931 e 1932. Lanifício Anglo-Brasileiro, 29.03.1930, 25.03.1931, 30.03.1932 e 28.03.1933.
} 
observa-se elevação no número de operários e na força motriz instalada. Além disso, neste ano, houve aumento no seu índice de concentração industrial, pois a retração da quantidade de estabelecimentos $(10,0 \%)$ não foi compensada pela queda do montante de capital. Ao contrário, a acumulação capitalista subiu nas fábricas laníferas em 6,2\%.

Por último, a inexistência de uma depressão no ramo lanífero é ratificada por meio da observação da participação relativa do mesmo perante o subsetor têxtil agregado. Vê-se (Tabela 2.6) que as fábricas de lã tiveram uma ascensão em quase todas as variáveis arroladas, exceto no que se refere ao número de estabelecimentos (já explicado pelo aumento da concentração industrial no ramo) e ao valor de produção (queda de 32\%).

\subsection{5 - Seda natural e artificial}

As fábricas de seda paulistas, tais como as de lã, não passaram por uma crise no período da Grande Depressão (1929-1932). Percebe-se crescimento significativo no interregno 1928-1929. Houve aumento do número de estabelecimentos (57\%), do capital real invertido (42,3\%), da força motriz $(40,6 \%)$ e dos valores e quantidades produzidas $(57,4 \%$ e $68,3 \%$, respectivamente - Tabela 2.4 e 2.5). Apenas no que se refere aos operários empregados, observa-se retração $(-5,4 \%)$.

Entre 1929 e 1930, verifica-se um recuo em algumas variáveis, tais como força motriz $(-8,1 \%)$ e valor produtivo (- $11,2 \%)$. Porém, seus níveis situavam-se ainda bem acima dos existentes em 1928 (29,2\% e 39,9\%, respectivamente). Cita-se, por outro lado, o contínuo crescimento da acumulação capitalista no ramo $(7,8 \%)$ e da quantidade de sedas confeccionadas $(8,8 \%)$, não obstante a taxas menores que as do ano precedente. $\mathrm{O}$ número de operários, por sua vez, que caíra de 1928 para 1929, subiu em 1930 (7,8\%).

Os relatórios e balanços das empresas do ramo ratificam os dados anteriores. A Cia. Tecidos de Seda Sta. Branca, por exemplo, elevou seu capital nominal em 1929, “(...) devido aos ampliamentos (sic) feitos, à criação de novas estações e, especialmente, ao volume de vendas nestes últimos anos (...."212. Os diretores da Tecelagem de Seda Lavínia informaram aos sócios que a empresa obteve "êxito” durante o exercício de 1930, “(...) não obstante as gravíssimas dificuldades do mercado industrial, atingidos pelos efeitos da crise atravessada pelo país" ${ }^{213}$. A diretoria da recém-instalada Cia. Brasileira de Sedas 'Rhodiaseta', produtora de fios e tecidos de rayon, afirmou, em 1930, que “(...) nossas

\footnotetext{
${ }^{212}$ Ata Assembléia Geral Extraordinária. Cia. Tecidos de Seda Santa Branca, 14.03.1929.

${ }^{213}$ Ata Assembléia Geral Ordinária. S.A. Tecelagem de Seda Lavínia, 17.01.1931.
} 
vendas têm aumentado e (...) (que) os nossos produtos encontram atualmente uma aceitação dia a dia mais favorável (...)" ${ }^{\text {214 }}$. A Cia. Paulista de Artigos de Seda elevou seu capital “(...) em virtude do importante desenvolvimento dos negócios e (d)o considerável aumento na quantidade, bem como na variedade dos artigos, cuja natureza exige um estoque elevado (...)"215.

As poucas empresas que paralisaram suas produções entre 1929 e 1930 eram pequenos estabelecimentos (Tabela 2.3), os quais, juntos, totalizavam apenas $5 \%$ do capital total das fábricas de seda paulistas ${ }^{216}$. Além disso, o recuo do crescimento do ramo em 1930 deveu-se, em grande parte, à crise da Tecelagem de Seda Ítalo-Brasileira. Esta, na época, além de ser uma das maiores tecelagens de seda do estado, tinha controle acionário sobre outras fábricas do ramo (S.A. Amerital, S.A. Santa Helena e S.A. Indústrias Artefatos de Seda), inclusive da mais importante produtora de fios de seda doméstica (S.A. Indústria de Seda Nacional) ${ }^{217}$. Para viabilizar financeiramente tais aquisições acionárias, realizadas no final dos anos (19)20, a diretoria da Ítalo-Brasileira organizou as bases de um holding, formado, em sua maioria, por capitais suíços. Entretanto, com a ocorrência da grande depressão, em 1929, o holding não foi concretizado. Com isso, a Ítalo-Brasileira ficou em uma situação delicada. Seu capital nominal teve de ser reduzido. Emitiram-se 40 mil contos em debêntures, mediante a garantia hipotecária de todos os equipamentos e imóveis da sociedade ${ }^{218}$. Nesse contexto conturbado, uma das empresas por ela controladas, a S.A. Amerital, entrou em liquidação ${ }^{219}$. Posteriormente, com o término da fase mais difícil da crise, a diretoria da Ítalo-Brasileira afirmou que o principal fator dos problemas vividos pela mesma, entre 1929 e 1930, fora “(...) as despesas gerais acrescidas pela aglomeração, que se tornara fatal, das diferentes sociedades, sem que (...) houvesse sido possível organizar pari passu uma centralização econômica" ${ }^{220}$.

\footnotetext{
${ }^{214}$ Relatório de Diretoria. Cia. Brasileira de Sedas 'Rhodiaseta', 14.03.1931.

${ }^{215}$ Ata Assembléia Geral Extraordinária. Cia. Paulista de Artigos de Seda S.A., 12.04.1930.

${ }^{216}$ Estatística Industrial do Estado de São Paulo, 1929 e 1930, p. 34.

${ }^{217}$ Ata Assembléia Geral Extraordinária. S.A. Tecelagem de Seda Ítalo-Brasileira, 21.02.1929. Chamavamse tais fusões de sociedade das sedas.

${ }^{218}$ Ata Assembléia Geral Extraordinária. S.A. Tecelagem de Seda Ítalo-Brasileira, 05.02.1930; e Balanço 1930. S.A. Tecelagem (...), op. cit., 28.03.1931.

${ }^{219}$ DOESP. Liquidação da S.A. Amerital, 10.03.1929, P. 2340.

${ }^{220}$ Ata Assembléia Geral Extraordinária. S.A. Tecelagem de Seda Ítalo-Brasileira, 01.08.1931. Apesar da fase mais complicada já ter sido superada em 1931, as dificuldades e as ações de ajuste na sociedade das sedas ocorreram, pelo menos, até 1933. Em 1931, a Indústria Artefatos de Seda S.A., uma das suas subsidiárias, reduziu seu capital de 3 mil para 300 contos. Em 1933, a Ítalo-Brasileira emitiu 12 mil contos em debêntures para consolidar sua dívida. Além disso, no mesmo período, outra subsidiária (Indústria de Seda Nacional) diminuiu seu capital social de 6 mil contos para 300 contos. Por último, no final de 1933, decidiu-se vender os imóveis e máquinas da Artefatos de Seda. Ver: Ata Assembléia Geral Extraordinária.
} 
Mesmo com esses problemas, o ramo de seda paulista foi o único, em 1930, a ter todas as variáveis econômicas a níveis superiores aos de 1928 (Tabela 2.4). Em 1931, o crescimento prosseguiu. Aumentaram-se o capital real investido $(13,1 \%)$, os operários empregados $(16,9 \%)$, a força motriz instalada $(20,8 \%)$ e a quantidade de tecidos de seda confeccionada (11,6\%). Houve, entretanto, um recuo brusco do valor de produção (35,9\%). Apesar desse revés, os dizeres das empresas comprovam a manutenção da tendência altista do ramo. A 'Rhodiaseta', por exemplo, afirmou que o desenvolvimento da sua indústria era "notável” no período. Prosseguiam seus diretores: “(...) tendo se tornado insuficiente a produção, fomos induzidos a duplicar as instalações, sendo que o consumo atual da nossa freguesia aumentou na mesma proporção"221. A Lavínia, por sua vez, pagou 130 contos de dividendos aos seus acionistas ${ }^{222}$. Os lucros líquidos da Sta. Branca foram 40\% maiores que os de 1930 (de 357 para 501 contos) ${ }^{223}$.

A expansão do consumo doméstico dos tecidos de seda explica, em grande parte, o crescimento do ramo. Rubens do Amaral, um dos principais colaboradores do jornal paulista Folha da Manhã, escrevia, em 1931: “(...) é universal o fenômeno que observamos aqui em São Paulo e no Brasil: o uso da seda generaliza-se cada vez mais. Tecido que d'antes valia por título de riqueza e fidalguia, porque só grandes senhoras podiam trazê-lo, hoje está se democratizando ao ponto de quase não se ver outro, não já nos bailes, mas nas ruas (...) Roupas brancas de algodão e linho fabricam-se muito menos agora. Dentre em pouco, dobrada que seja a produção de seda, mal chegará para as exigências de um consumo sempre maior, ante as solicitações da moda, que passa, mas deixa hábitos indeléveis"224.

Em 1932, houve um pequeno arrefecimento da expansão do ramo. De um lado, teve-se o contínuo aumento do capital investido (12\%) e da quantidade de tecidos confeccionada (25\%). Observou-se, também, a parcial recuperação dos valores de produção. Em outro curso, a força motriz estabilizou-se e o número de operários, pela primeira vez desde 1929, caiu (1,1\%). A diretoria da 'Rhodiaseta' colocou, na época, que “(...) apesar da situação bastante indecisa, as vendas têm aumentado regularmente" ${ }^{225}$. Os

S.A. Tecelagem de Seda Ítalo-Brasileira, 20.12.1932; Ata Assembléia Geral Extraordinária. S.A. Indústria de Seda Nacional, 29.06.1933; e Atas das Assembléias Extraordinárias. Indústria Artefatos de Seda S.A., 19.08.1931 e 01.08.1933.

${ }^{221}$ Relatório de Diretoria. Cia. Brasileira de Sedas 'Rhodiaseta', 24.03.1932.

${ }^{222}$ Balanço 1931. S.A. Tecelagem de Seda Lavínia, 23.02.1932.

${ }^{223}$ Balanço 1931. Cia. Tecidos de Seda Sta. Branca, 28.02.1932.

${ }^{224}$ Folha da Manhã. Rubens do Amaral. Mais valioso do que o café, 03.04.1931.

${ }^{225}$ Relatório de Diretoria. Cia. Brasileira de Sedas 'Rhodiaseta', 31.12.1932. 
lucros líquidos da Sta. Branca caíram em 97\%. ${ }^{226}$ Diferentemente, a Cia. Paulista de Artigos de Seda distribuiu 15\% de dividendo sobre o capital realizado de 3 mil de contos.

A partir de 1933, diferentemente do caso da lã, o ritmo acelerado de crescimento do ramo reaparece. É a primeira vez que todas as variáveis econômicas das fábricas de seda encontram-se em elevação: estabelecimentos (41,0\%); capital real investido (2\%); operários (17\%); força motriz $(31,4 \%)$; e, por último, valor e quantidade de produção $(80,7 \%$ e $118,1 \%$, respectivamente). Ao final do período depressivo, observou-se aumento na participação relativa das fábricas de seda junto ao subsetor têxtil em todas as variáveis arroladas (Tabela 2.6) - fato este comprovador do crescimento das primeiras durante a crise 1929-1932.

\subsection{6 - Análise da dinâmica dos ramos}

Apesar dos impactos específicos causados pela Grande Depressão (1929-1932) nos diversos ramos têxteis, pode-se perceber algumas semelhanças entre os mesmos: (i) o interregno 1929-1930 foi um período negativo para o subsetor de tecidos, seja pelo aparecimento de forte crise (algodão, juta e malhas), seja pela reversão de uma fase de crescimento precedente (lã e seda). Além disso, notou-se (ii) que, em 1931, as fábricas têxteis iniciaram tendência altista, com exceção do ramo da juta. O ano de 1932 (iii), por sua vez, constituiu uma era mesclada pela manutenção de bons índices econômicos e pelo regresso de características recessivas. Por último (iv), 1933 se distinguiu, na maioria dos casos, por um período de crescimento. Analisar-se-ão, a partir de agora, os fatores responsáveis pela constituição das três primeiras fases citadas e os motivos dos distintos desempenhos entre os ramos têxteis paulistas nas mesmas.

No que se refere à primeira delas (1929-1930), cita-se a recessão econômica doméstica como a principal causadora dessa retração têxtil. A queda do nível de renda interna - em razão das demissões de trabalhadores, da redução de salários e jornadas e da contenção de créditos - fez cair a demanda de tecidos. Fato comprovador dessa hipótese é a evolução das importações de têxteis estrangeiros pelo porto de Santos. Diferentemente do que ocorrera no final dos anos (19)20, quando se teve um acréscimo considerável da aquisição de tecidos exteriores (em especial, os de algodão), nota-se, agora, uma queda da compra de tais bens. Entre 1929 e 1930, a entrada de tecidos algodoeiros caiu 76,2\% (quilos); de lã, 57\%; de seda animal, 44,8\%; e de seda artificial, 88\% (Tabela 2.7). Vê-se

\footnotetext{
${ }^{226}$ Balanço 1932. Cia. Tecidos de Seda Sta, Branca, 02.03.1933.
} 
que a exceção foi a juta, que possuiu crescimento de 3,2\%. Porém, no interregno 1930-1931, seu decréscimo foi de 97,4\%.

Tabela 2.7 - Importação de tecidos no porto de Santos em metros e contos deflacionados (1927-1933)

\begin{tabular}{lrrrrrrr} 
& 1927 & 1928 & 1929 & 1930 & 1931 & 1932 & 1933 \\
\hline Algodão (1) & 2.512 .429 & 3.195 .815 & 2.134 .262 & 508.503 & 211.852 & 158.982 & 362.108 \\
Algodão (2) & 39.846 & 50.398 & 38.937 & 10.645 & 5.847 & 3.290 & 8.423 \\
Juta (1) & 179.517 & 166.516 & 174.592 & 180.230 & 4.653 & 5.355 & 6.148 \\
Juta (2) & 410 & 455 & 529 & 368 & 48 & 43 & 66 \\
Lã (1) & 422.711 & 545.170 & 473.035 & 203.283 & 103.097 & 60.140 & 124.986 \\
Lã (2) & 11.884 & 14.661 & 15.537 & 7.109 & 4.411 & 1.854 & 4.131 \\
Seda animal (1) & 29.435 & 18.308 & 13.563 & 7.484 & 3.661 & 925 & 2.292 \\
Seda animal (2) & 2.247 & 2.235 & 2.218 & 1.428 & 853 & 251 & 426 \\
Seda art.(1) & 3.174 & 1.447 & 5.386 & 645 & 355 & 111 & 181 \\
Seda art.(2) & 226 & 74 & 170 & 95 & 41 & 21 & 60 \\
\hline Tecidos (1) & 3.355 .365 & 4.346 .233 & 3.108 .467 & 1.033 .403 & 408.009 & 308.911 & 741.607 \\
Tecidos (2) & 57.637 & 74.730 & 63.564 & 22.422 & 13.233 & 7.143 & 18.786 \\
\hline Fonte: Estatistica
\end{tabular}

Fonte: Estatística do comércio do Porto de Santos, 1927-1933; (1) quilos, (2) contos deflacionados.

Percebe-se, portanto, que só uma queda da renda doméstica faria decrescer, concomitantemente, a demanda de tecidos internos e externos. Entretanto, essa redução da demanda não foi igual para todos os ramos. Aqueles que produziam, em sua maioria, têxteis mais baratos e voltados para os mercados proletários (algodão e malhas), sofreram fortes conseqüências negativas. Porém, os produtores de tecidos mais caros (seda e lã), dependentes de compradores de rendimento elevado, passaram por implicações menos graves. Lembra-se, todavia, que algumas fábricas têxteis de algodão e de malha atravessaram sem maiores problemas o período depressivo. Estas, normalmente, produziam fios ou bens acabados de melhor qualidade. Por último, nota-se que o caso da juta é específico. Sua demanda vincula-se diretamente com o desempenho da economia agroexportadora doméstica. Assim, em razão da crise cafeeira (1929), intensificada nos anos (19)30, as vendas de sacaria diminuíram bastante. Com isso, a depressão atingiu o ramo, que já passava por dificuldades no final dos anos (19)20. ${ }^{227}$

No que condiz ao segundo dos momentos (1931), em que a tendência baixista do subsetor têxtil é revertida, destacam-se alguns aspectos explicativos dessa mudança. Primeiramente, cita-se a forte desvalorização cambial ocorrida em 1931. Como decorrência, os bens estrangeiros ficaram mais caros, diminuindo a concorrência para com as indústrias domésticas. A implementação do monopólio cambial do Banco do Brasil, em setembro de 1931, que estabeleceu prioridades de importação, ainda aprofundou esse

\footnotetext{
${ }^{227}$ Maria Izilda de Matos, op. cit., p. 59-60.
} 
processo. A partir de então, a compra de têxteis no exterior seria dificultada não só pelo crescimento dos preços, mas também pela própria indisponibilidade de cambiais ${ }^{228}$.

Em segundo lugar, houve a recuperação da renda interna e, assim, da demanda local por bens de consumo. A política governamental de compra dos estoques cafeeiros, iniciada em fevereiro de 1931, foi fundamental no processo ${ }^{229}$. Mantinha-se, dessa forma, o nível de atividade e renda domésticas ${ }^{230}$. Lembra-se também que, em razão da desvalorização monetária, a queda do preço internacional do café foi menor do que a interna. Em média, seu valor, em dólares, foi reduzido 17,5\% entre 1929 e 1932; já, em mil-réis, tal decréscimo foi de $11,7 \%{ }^{231}$.

Entretanto, essa oportunidade histórica para a realização de um processo substitutivo de importações só poderia ser aproveitada se a indústria de tecidos paulista possuísse capacidade produtiva suficiente. Considera-se, tradicionalmente, a ociosidade existente no ramo como principal responsável pelo crescimento da produção têxtil a partir de $1931^{232}$. Observa-se (Tabela 2.8) que, nesse ano, a quantidade total de bens de capital importados pelo porto de Santos para a indústria têxtil foi $60,5 \%$ menor, em quilogramas, do que a comprada no período pré-depressão (1928). Contudo, em contos deflacionados, a primeira ultrapassou a segunda em 4,1\%.

Essa superação do valor em contos deveu-se a uma conjunção de fatores. Em março de 1931, o Governo Provisório criou decreto proibindo a importação de acessórios e máquinas para os subsetores fabris considerados em superprodução ${ }^{233}$. Permitia-se, porém, a compra de bens de capital para substituir os antigos e desgastados, contanto que não se aumentasse a capacidade produtiva. Em maio do mesmo ano, declarou-se os subsetores de tecidos, chapéus, calçados e açúcar em tal estado ${ }^{234}$. Nesse sentido, a obtenção de máquinas mais modernas - e, portanto, mais valiosas - justifica, em parte, o crescimento do valor em contos da importação de bens de capital entre 1930 e 1931. Lembra-se, também, que, em razão da desvalorização cambial, os bens estrangeiros

\footnotetext{
${ }^{228}$ Villela e Suzigan, op. cit., p. 325.

${ }^{229}$ No Capítulo III, discutir-se-ão melhor as posições historiográficas existentes acerca da política cafeeira de Vargas, bem como seu papel na recuperação econômica local.

${ }^{230}$ Celso Furtado. Formação econômica do Brasil. $27^{\circ}$ Edição. Cia. Ed. Nacional, São Paulo, 2000, p.201.

${ }^{231}$ Edgard Carone. A república nova, op. cit., p. 24.

${ }^{232} \mathrm{O}$ pai dessa interpretação é Celso Furtado. Para ele, a incipiente indústria de bens de capital doméstica também supriu de maquinismos as fábricas locais. Ver: Formação (...), op. cit., pp. 212-215.

${ }^{233}$ Decreto n. 19.739, 07.03.1931.

${ }^{234}$ Decreto n. $19.985,13.05 .1931$.
} 
tiveram seus preços acrescidos. Por último, cita-se a obrigatoriedade da marcação de tecidos como propulsora da compra de máquinas externas ${ }^{235}$.

Portanto, observando-se os dados, conclui-se que, apesar do alto valor dos bens de capitais ingressos no porto de Santos em 1931, cujas razões já foram elucidadas, pode-se dizer que o crescimento da produção de tecidos ocorrido no período esteve assentado, majoritariamente, na capacidade produtiva já instalada, ou na fabricação de máquinas pela embrionária indústria pesada local. Em outras palavras, o processo substitutivo de importações que terá lugar no subsetor têxtil paulista, a partir de 1931, fundamentou-se, essencialmente, em fatores de produção domésticos. As máquinas adquiridas do estrangeiro, substitutivas das antigas e desgastadas, eram aquelas cujas demandas não podiam ser satisfeitas internamente. Tal hipótese é ratificada por meio da observação da reduzida quantidade de teares ingressos em Santos no ano de 1931 (98,5\% menos do que em 1928). Lembra-se que já existia, em São Paulo, incipientes fábricas e oficinas construtoras de teares no período ${ }^{236}$.

Outro fator importante para se entender o crescimento da produção têxtil em 1931 vincula-se às medidas do Governo Provisório. Vários postos-chave estatais eram ocupados por pessoas vinculadas à indústria de tecidos. Destacam-se, nesse sentido, Manoel Guilherme da Silveira, presidente do Banco do Brasil, e Jorge Street, responsável pela chefia da Divisão Industrial do Ministério do Trabalho, Indústria e Comércio ${ }^{237}$.

Assim, no início dos anos (19)30, em razão desse forte lobby, muitas das demandas dos fabricantes têxteis continuariam a ser atendidas pelo governo ${ }^{238}$. Em carta enviada ao Ministro do Trabalho, em dezembro de 1930, o CIFTA requisitava algumas medidas estatais “(...) capazes de contribuir para a solução da crise da principal indústria

\footnotetext{
${ }^{235}$ Em abril de 1931, o Governo Federal criou um decreto (n. 19.901, 22.04.1931) obrigando as fábricas têxteis domésticas a marcar suas produções. Visava-se identificar aqueles que eram ou não tecidos locais. A marcação poderia ser feita de duas formas: "por meio de decalcomanias (...) contendo obrigatoriamente a declaração de 'Indústria Brasileira', (...) ou (através de uma) distintiva, (que) constará de três fios bem visíveis, situados em toda a extensão das ourelas, com as cores verde, azul e amarela". Com tal decreto, todas as indústrias, compulsoriamente, tiveram de adquirir máquinas marcadoras, a fim de não pagarem multas. Lembra-se, porém, que a lei só entrou em vigor a partir de 22.10.1932, em razão dos inúmeros pedidos de prorrogação feitos pelas associações patronais. Para maiores informações sobre os pedidos de prorrogação da lei de marcação de tecidos, ver: CIFTA. Atas de Reunião da Diretoria, 26.11.1931, 03.12.1931, 06.06.1932 e 28.09.1932.

236 Para maiores informações, ver: Correio Paulistano. A evolução da indústria nacional de teares, 13.05.1951. A primeira oficina produtora de teares no Brasil foi a Ribeiro S.A. - Indústria de Máquinas Têxteis, fundada em 1920 na cidade de São Paulo. A partir de 1930, ela iniciou a fabricação de teares para seda, algodão e lã.

${ }^{237}$ Stanley Stein, op. cit., p. 145.

${ }^{238}$ Lembrar a influência dos industriais têxteis paulistas e cariocas, especialmente os algodoeiros, no final da República Velha. Tal influência política manifestou-se não só por meio da aprovação da reforma alfandegária no início de 1929, mas também da negligência governamental com relação à aplicação das leis trabalhistas. Ver: Capítulo 1, p. 26.
} 
manufatureira do país". Dentre elas, destacavam-se (i) o estabelecimento de crédito industrial com prazos longos e juros acessíveis; (ii) "revisão urgente do sistema tributário", em especial dos impostos interestaduais, vistos como entraves ao intercâmbio da produção doméstica; (iii) "uniformização das horas de trabalho para toda a indústria algodoeira"; (iv) incentivo às exportações têxteis nacionais para os mercados sulamericanos (redução de fretes, isenção de impostos de exportação, prêmios, organização de dumping, etc.); e (v) melhoria dos transportes internos ${ }^{239}$. Acrescenta-se, também, a defesa pela homogeneização das jornadas de trabalho entre todas as fábricas têxteis do País ${ }^{240}$.

Tabela 2.8 - Importação de Bens de Capital - Indústria Têxtil (1927-1933)

\begin{tabular}{lrrrrrrr} 
& 1927 & 1928 & 1929 & 1930 & 1931 & 1932 & 1933 \\
\hline MNE* (1) & 1.026 .532 & 1.473 .384 & 1.001 .102 & 400.059 & 635.182 & 354.274 & 492.639 \\
MNE (2) & 3.028 & 3.722 & 2.213 & 847 & 3.741 & 1.871 & 3.201 \\
Teares (1) & 759.564 & 769.242 & 362.755 & 37.195 & 12.654 & $7.058(3)$ & 13.868 \\
Teares (2) & 1.234 & 1.309 & 733 & 103 & 76 & 61 & 639 \\
Acessórios (1) & 574.742 & 672.992 & 672.079 & 388.304 & 505.753 & 360.463 & 409.071 \\
Acessórios (2) & 3.407 & 3.519 & 3.634 & 2.780 & 5.089 & 3.653 & 4.823 \\
Total (1) & 2.360 .838 & 2.915 .618 & 2.035 .936 & 825.558 & 1.153 .589 & 714.737 & 915.578 \\
Total (2) & 7.668 & 8.549 & 6.579 & 3.730 & 8.906 & 5.585 & 8.663 \\
\hline
\end{tabular}

Fonte: Estatística do comércio do Porto de Santos, 1927-1933; (1) - quilos, (2) - contos deflacionados; (3) calculado estatisticamente através da variável Máquinas não-especificadas, cujo índice de correlação é de $0,90 /$ * Máquinas nãoespecificadas.

Destes pedidos, o mais prontamente atendido foi o primeiro ${ }^{241}$. Em razão da presidência do Banco do Brasil estar nas mãos de um indivíduo identificado com os interesses do subsetor, a concessão de créditos para as indústrias têxteis foi facilitada no interregno 1929-1932. Em outubro de 1929, quando se estabeleceu uma cooperativa entre as fábricas locais de algodão (União Industrial Algodoeira), o presidente do CIFTA, Carlos T. da Rocha Faria, ressaltou que “(...) o êxito desse projeto está dependente do amparo que, financeiramente, esse grande estabelecimento bancário (Banco do Brasil) possa conceder à indústria de fiação e tecelagem de algodão (...)”242. Na mesma reunião, o dirigente máximo do Centro informou aos sócios que recebera um comunicado do

${ }^{239}$ CIFTA. Carta do Centro Industrial de Fiação e Tecelagem de Algodão ao Ministro do Trabalho, Indústria e Comércio, Dr. Lindolfo Collor, 03.12.1930.

240 "A diversidade de horas de trabalho, entre as diferentes fábricas de tecidos do nosso país, constitui um regime injusto que não deve perdurar”. CIFTA. Situação da indústria algodoeira, op. cit.

${ }^{241}$ O segundo dos pedidos (reforma tributária) também foi contemplado, porém a eficácia dos decretos governamentais sobre o assunto foi mínima. Em 14.05.1931, o Governo Provisório criou um decreto (n. 19.995) proibindo os impostos interestaduais. Sua vigência deveria começar em 01.01.1932. Porém, em dezembro de 1932, a FIESP reclamava junto ao Estado a total negligência do decreto por parte de todas as regiões do país. Ver: Circulares FIESP n. 242, 12.12.1932.

${ }^{242}$ CIFTA. Ata de Reunião da Diretoria, 11.10.1929. 
presidente do banco, Guilherme da Silveira. Neste, afirmava-se que tal instituição “(...) via com grande satisfação o início desse movimento em defesa da indústria algodoeira nacional e o que o Banco do Brasil, com muito prazer, dava todo o seu apoio a essa iniciativa $(\ldots)^{, 243}$.

Além dos auxílios financeiros, lembra-se a criação do decreto proibitivo da importação de máquinas (março de 1931). As associações patronais têxteis do Centro-Sul aplaudiram a decisão.

Para o CIFTA, “(...) esse decreto mostra claramente os objetivos protecionistas do atual governo (...)" ${ }^{244}$. Afirmou-se, também, que essa legislação foi "fruto de uma iniciativa exclusivamente governamental" ${ }^{\prime 24}$. Isto, todavia, não correspondia à verdade. Em 1928, o próprio CIFTA aprovou a idéia de lutar pela suspensão da compra de máquinas têxteis do exterior, em razão da crise que se abatia no ramo algodoeiro ${ }^{246}$. Dois anos depois, o deputado pernambucano Eduardo de Lima e Castro apresentou um projeto de lei ao Congresso. Visava, exatamente, proibir a importação de teares pela indústria têxtil do algodão, além de limitar a entrada dos demais tipos de maquinário por meio da criação de um "Comitê Industrial". As jornadas de trabalho, por sua vez, seriam homogeneizadas em oito horas por dia. Tal projeto foi amplamente discutido nas associações patronais têxteis ${ }^{247}$. Houve divergências entre os industriais do Norte e do Centro-Sul, em especial no que se referiu à temática do tempo de trabalho. A Companhia de Tecidos Paulista (PE) chegou a denunciar as associações têxteis carioca (CIFTA) e paulista (CIFT) como organizadoras de uma "ditadura industrial" ${ }^{248}$. O projeto não foi aprovado pelo Congresso.

Com a criação de decreto de março de 1931, parte dos desejos da burguesia têxtil do Centro-Sul foram realizados. Somente a tão requisitada homogeneização das jornadas de trabalho não tinha sido atendida. Mesmo assim, compreende-se o porquê dos elogios feitos pelo CIFTA ao governo. Com o decreto, congelar-se-iam as posições relativas favoráveis das grandes indústrias urbanas do Centro-Sul perante as pequenas e médias fábricas do interior paulista e carioca, bem como dos demais estados domésticos. Somente as empresas de porte considerável teriam condições de trocar parte do seu maquinário para a compra de outros mais modernos. Na maioria dos casos, se pequenos e médios

\footnotetext{
${ }^{243}$ Idem, op. cit.

${ }^{244}$ CIFTA. Ata Reunião da Diretoria, 12.03.1931.

${ }^{245}$ Idem, op. cit.

${ }^{246}$ Stanley Stein, op. cit., p. 144.

${ }^{247}$ CIFTA. Ata de Reunião da Diretoria, 04.09.1930.

${ }^{248}$ Stanley Stein, op. cit.
} 
estabelecimentos fizessem o mesmo, seriam obrigados a paralisar temporariamente suas produções.

Além disso, outro aspecto chama a atenção. Diferentemente do projeto Lima e Castro, a lei de 1931 generalizou a proibição da importação de máquinas para todos os ramos (algodão, juta, seda, etc.) e seções de tecidos (fiação, tecelagem e acabamento). Deve-se questionar, no entanto, se o problema da superprodução ${ }^{249}$ também era generalizado. Para isso, faz-se necessário comparar a capacidade produtiva dos ramos e das seções têxteis do período antes da depressão (1928) com a do momento de publicação do decreto (1931).

Tabela 2.9 - Relação da quantidade de produção anual (1.000 metros) e número de teares - Indústria Têxtil do Algodão e da Juta - Estado de São Paulo (1925-1932) ${ }^{250}$

\begin{tabular}{c|ccc|ccc} 
& \multicolumn{3}{|c|}{ Algodão } & \multicolumn{3}{c}{ Juta } \\
Anos & $\mathrm{P}$ & $\mathrm{T}$ & $\mathrm{P} / \mathrm{T}$ & $\mathrm{P}$ & $\mathrm{T}$ & $\mathrm{P} / \mathrm{T}$ \\
\hline 1925 & 206.148 & 20.600 & 10 & 86.150 & 2.175 & 40 \\
1928 & 139.139 & 22.823 & 8,4 & 62.808 & 2.708 & 23 \\
1929 & 149.034 & 24.900 & 6 & $*$ & $*$ & $*$ \\
1930 & 135.314 & 26.100 & 5,2 & $*$ & $*$ & $*$ \\
1931 & 181.515 & 24.900 & 7,3 & $*$ & $*$ & $*$ \\
1932 & 200.592 & 24.900 & 8,1 & 42.933 & 2.988 & 14 \\
\hline
\end{tabular}

Fonte: Estatística Industrial do Estado de São Paulo, 1928-1932; Villela e Suzigan, op. cit., pp. 354 e 367; Stanley Stein, op. cit., p. 191; M. Izilda Matos, op. cit., pp. 55-57

Nota: $\mathrm{P}=$ Produção (1.000 metros); $\mathrm{T}$ = Teares; e $\mathrm{P} / \mathrm{T}=$ Relação produção / teares.

No que condiz à produção de tecidos de algodão e de juta, pode-se afirmar que tais ramos se encontravam com capacidade ociosa em 1931 (Tabela 2.9). Tomando-se o ano de 1928 como referência, percebe-se que a relação produção / teares caiu mais de $15 \%$ para as fábricas algodoeiras e foi superior a 39\% para as de juta (1928 - 1932). Porém, lembrase que, em 1928, ambos ramos já passavam por dificuldades. ${ }^{251}$ Assim, para melhor mensurar tal excesso produtivo, deve-se adotar como referencial o ano anterior às suas crises, isto é, 1925. Assim sendo, vê-se que, no período 1925-1931, o decréscimo da relação produção / teares para as indústrias do algodão foi de $27 \%$; já para as de juta, entre 1925 e 1932, foi de 65\%. Vale notar que, em 1932, o ramo algodoeiro praticamente igualou a produtividade do período pré-depressão (apenas 3,5\% a menos), mantendo-a, porém, distante ainda daquela de 1925 (-19\%).

\footnotetext{
${ }^{249}$ Considera-se em superprodução "a indústria cuja capacidade produtiva, dentro das horas normais de trabalho, for maior do que a exigida pelos mercados internos e externos do país (...)”. Projeto de Lei n. 149, Art. 1. In: Superprodução industrial? Observador econômico e financeiro, n. 14, março de 1937, p. 103.

${ }^{250}$ A utilização do símbolo (*) nesta tabela e nas demais do trabalho representa informação não-disponível.

${ }^{251}$ Ver Capítulo 1 (A radiografia da indústria têxtil paulista), em especial a seção 1.4 (A situação econômica do final da década de 1920).
} 
Tabela 2.10 - Relação da quantidade de produção anual e número de teares - Indústria Têxtil da Seda (Artificial e Natural) e da Lã - Estado de São Paulo (1928 e 1932)

\begin{tabular}{ccccc} 
& \multicolumn{2}{c}{1928} & \multicolumn{2}{c}{1932} \\
\hline & Seda & Lã & Seda & Lã \\
Produção* & $173.157(1)$ & 4.330 & 443.367 & 4.318 \\
Teares & 1.822 & 843 & 2.995 & 887 \\
Relação produção / Teares & $95,0(1)$ & 5,1 & 148,0 & 4,9 \\
\hline
\end{tabular}

Fonte: Estatística Industrial do Estado de São Paulo, 1928-1932; Villela e Suzigan, op. cit., pp. 354 e 367

* Seda = quilos; Lã = 1.000 metros / (1) Calculado estatisticamente através da variável força motriz (seda natural e artificial), que possui um índice de correlação da ordem de 0,94 com esta variável. Ver Anexo - Tabela 7. Sabe-se que tal dado não coincide com informações concedidas por Villela e Suzigan (Tabela 1.12). Entretanto, em razão da discrepância deste para com o valor declarado na Estatística de 1932, resolveu-se calcular estatisticamente, a partir de outros dados concedidos pela própria Estatística, a quantidade de seda produzida em 1928. Percebe-se que, no máximo, superestimou-se tal valor no ano citado - o que, para as finalidades dessa tabela, não traz problemas.

Em 1932, as tecelagens de lã, da mesma maneira, se encontravam em superprodução (Tabela 2.10). Esta, porém, era reduzida. No interregno 1928-1932, a relação produção / teares no ramo lanífero caiu apenas 5,2\%. Assim, não se pode comparála aos excessos de capacidade verificados nas fábricas de algodão (em especial no ano de 1931) e, principalmente, nas de juta.

As fábricas de tecidos de seda (natural e artificial), diferentemente, não se encontravam em superprodução ${ }^{252}$. Vê-se que, entre 1928 e 1932, o número de teares do ramo, abastecido essencialmente pela produção doméstica ${ }^{253}$, cresceu $64 \%$, enquanto a produção, $156 \%$. Isto é, mesmo com acréscimo considerável da capacidade produtiva ao longo do período depressivo (a qual não aconteceria nesses montantes se uma superprodução fosse realidade), fabricou-se, em 1932, mais do que o dobro de tecidos de seda confeccionados no ano de 1928. Ratifica-se essa constatação mediante dados fornecidos pelas próprias associações patronais. O CIESP, por exemplo, em memorial direcionado ao chefe do governo civil paulista (Plínio Barreto), em novembro de 1930, fez um resumo dos ramos têxteis que trabalhavam com capacidade ociosa. Mencionou o de algodão, o da lã e o da juta. Nada foi comentado sobre as fábricas de $\operatorname{seda}^{254}$. Da mesma forma, observando-se dados fornecidos pelas empresas paulistas do ramo, verificam-se suas prosperidades no período, apesar da depressão ${ }^{255}$.

\footnotetext{
${ }^{252}$ Infelizmente, não foram encontrados dados relativos ao ramo de malharias.

${ }^{253}$ A importação de teares do exterior caiu, entre 1928 e 1931, de 2.044 contos (769 toneladas) para 120 contos (37 toneladas). A partir de 1931, como já se assinalou, tal importação foi proibida. Ver: Estatística do Comércio do Porto de Santos, 1928 e 1931. Concomitantemente, a principal fábrica doméstica produtora de teares (Ribeiro S.A. - Indústria de Máquinas Têxteis) havia iniciado, em 1930, sua produção de teares de seda. In: Correio Paulistano. A evolução da indústria nacional na fabricação de máquinas têxteis, 13.05.1951.

${ }^{254}$ Memorial do CIESP para o Chefe do Governo Civil de São Paulo, Dr. Plínio Barreto, op. cit.

${ }^{255}$ Ver seção 2.2 .5 - Seda natural e artificial, pp. 45-47.
} 
Já no que se refere às fiações, não é possível inferir empiricamente acerca da existência ou não de um estado superprodutivo, pois não há dados específicos sobre a produção de fios paulistas no período em estudo. Assim, torna-se impossível verificar até que ponto a evolução da quantidade de fusos instalados nas fábricas têxteis do estado foi acompanhada (negativa ou positivamente) na esfera produtiva. Entretanto, apesar disso, algumas conjecturas se fazem possíveis.

No apagar das luzes de 1930, o Governo Provisório criou um decreto ${ }^{256}$ aumentando as tarifas aduaneiras para os fios de algodão e de juta. Depois, elevou também os direitos sobre fios de seda artificial ${ }^{257}$. Com isso, as tecelagens dos ramos citados, especialmente aquelas dependentes de fios de alta qualidade, protestaram. No estado de São Paulo, mais de 150 fábricas de tecidos entraram com representação junto às esferas governamentais pedindo o rebaixamento imediato das tarifas de algodão ${ }^{258}$. Argumentavase que a indústria doméstica não tinha capacidade para suprir o mercado interno de fios algodoeiros, notadamente os finos ${ }^{259}$. O mesmo se processou no caso da seda artificial. Os produtores têxteis de rayon afirmaram que tal elevação tarifária favoreceria apenas uma fábrica (Visco Seda Matarazzo) em detrimento de centenas de tecelagens ${ }^{260}$. No caso da juta, os protestos partiram não somente dos industriais, mas também dos compradores de sacaria doméstica. A Associação Comercial de São Paulo fez uma representação junto ao Ministério do Trabalho contra o aumento das taxas incidentes na juta bruta ${ }^{261}$. A Sociedade Rural Brasileira, por sua vez, argumentou que "as fábricas de tecidos de juta, tendo que despender mais com a aquisição do material estrangeiro (...), compensarão esse prejuízo com o aumento do preço da sacaria”262.

A pressão surtiu efeito. Em abril de 1931, o Governo Provisório baixou decreto reformando, mais uma vez, as tarifas aduaneiras para fios de algodão e de juta ${ }^{263}$. Abaixouas, porém não nos antigos patamares. Por outro lado, no mesmo dia, aumentaram-se os direitos sobre fios e tecidos de lã, bem como sobre roupas feitas (camisas, meias e malhas $)^{264}$. O protesto, dessa vez, ocorreu apenas por parte de membros da lavoura. O

\footnotetext{
$\overline{{ }^{256} \text { Decreto n. } 19.550,31.12 .1930 .}$

${ }^{257}$ O Estado de São Paulo. Direitos aduaneiros sobre a seda, 13.02.1931.

${ }^{258}$ Folha da Manhã. Agravação das tarifas aduaneiras sobre fios estrangeiros, 22.03.1931.

${ }^{259}$ O Estado de São Paulo. Importação de fios de algodão, 24.01.1931.

${ }^{260}$ O Estado de São Paulo. Agravação das tarifas aduaneiras sobre fios estrangeiros, 22.03.1931; e Folha da

Manhã. As tarifas sobre fios de seda artificial, 03.04.1931.

${ }^{261}$ Diário Nacional. A questão da juta, 12.03.1931.

${ }^{262}$ O Estado de São Paulo. Representação da Sociedade Rural Brasileira ao presidente acerca do imposto. sobre a importação de juta, 24.01.1931.

${ }^{263}$ Decreto n. 19.869, 15.04.1931. O decreto não modifica as tarifas incidentes sobre fios de seda artificial.

${ }^{264}$ Decreto n. $19.868,15.04 .1931$.
} 
jornal Folha da Manhã, claramente vinculado aos setores agrários, afirmou que o Governo Provisório está “(...) de braço dado com os capitães da indústria artificial, encarecedora do custo de vida"265. Alguns países também reclamaram dos aumentos. A Comissão Central do Comércio de Lãs da França, por exemplo, escreveu uma carta para a embaixada do país no Rio de Janeiro em tons de ameaça: "Esqueceu o Brasil, por acaso, que compramos enormes quantidades de café brasileiro? (...) não lhe convém adotar medidas de proteção totalmente injustificadas, especialmente com relação a um bom cliente como a França, que concedeu tarifas mínimas a quase todos os produtos brasileiros" ${ }^{266}$. Entretanto, apesar desses protestos, as taxas altas para lã (fios e tecidos) e para roupas prontas foram mantidas $^{267}$.

Vê-se, portanto, através dessas discussões, o quanto a produção doméstica de alguns tipos de fios (em geral, os de alta qualidade e os de seda artificial) não era suficiente para suprir o mercado local. No caso da lã, infelizmente, como não se encontrou reclamações das tecelagens do ramo, pouco se pode inferir. Apesar disso, é perceptível que o decreto relativo à proibição de maquinismos generalizou a superprodução para ramos (seda) e seções (fiação de algodão fino e de seda artificial) que não estavam com capacidade em excesso. Nos demais, aparentemente, tal ociosidade existia. Alguns em grandes, outros em pequenas escalas. Mesmo assim, O Estado de São Paulo chamou o decreto de "discutível", afirmando que "não há industrial conhecedor do legítimo funcionamento de sua indústria que não considere uma medida desta ordem como verdadeiro golpe de força desferido contra os seus interesses e contra os interesses da economia brasileira"268. Para aqueles industriais que, como já se disse, estavam em posições relativas melhores, nada de "discutível” havia nesse ato governamental.

Um último ato que colaborou para a melhora das condições têxteis em 1931 foi a modificação da tarifa-ouro, ocorrida em setembro desse ano. Conforme essa mudança, aumentou-se a proporção do ouro nas taxas alfandegárias domésticas para $80 \%$, o que, agregado à desvalorização cambial, ajudou a proteger mais ainda as unidades fabris locais $^{269}$. Junte-se a isso também a já mencionada elevação de tarifas incidentes em artigos

\footnotetext{
${ }^{265}$ Folha da Manhã. O comércio importador e as tarifas, 10.05.1931.

${ }^{266}$ Diário do Povo. O aumento dos direitos de importação sobre a lã em fíos, 14.03.1931.

${ }^{267}$ Houve, apenas, uma pequena modificação. Segundo o decreto n. 20.425 (21.09.1931), os fios de lã superiores ao número 90 (extra-finos) ficam liberados da alta tarifária realizada pelo decreto n. 19.868.

${ }^{268}$ O Estado de São Paulo. Restrição à importação de maquinismos para a indústria - Um decreto discutível da pasta do Trabalho, 11.03.1931.

${ }^{269}$ Lembra-se, porém, que tal modificação tarifária só incidiria nos países que não possuíssem acordo comercial com o Brasil. "A estratégia empregada (pelo Governo Provisório) consistiu em decretar um aumento geral das tarifas e, em seguida, negociar com cada parceiro comercial a redução das taxas individuais". Assim, vê-se que, inicialmente, tal tarifa era protecionista; porém, conforme os acordos
} 
têxteis prontos (camisas, meias e malhas), realizada em abril de 1931. Os relatos das próprias empresas sobre o período ratificam tais constatações.

Encerram-se, aqui, os fatores que contribuíram para tornar o ano de 1931 um período de reversão de tendência para as indústrias têxteis paulistas. Seja em razão de ações indiretas da administração federal com relação às fábricas (desvalorização monetária, controle cambial, política de auxílio ao café, etc.), seja devido a atos diretos (créditos às fábricas, decreto proibitivo da importação de máquinas, aumento das taxas sobre roupas feitas, etc.), vários são os porquês da mudança positiva vivida pelo subsetor de tecidos no momento. Excetua-se, nesse sentido, o da juta, que continuou em tendência baixista. Provavelmente, o encarecimento da sua matéria-prima (reformas tarifárias de $1930 / 1931)^{270}$ e a depressão cafeeira foram os fatores mais importantes da sua contínua crise.

Passa-se, agora, para a interpretação do terceiro dos momentos: o ano de 1932. Este, como se viu, fez retornar uma leve tendência baixista para as indústrias têxteis paulistas. Cita-se como uma das causas dessa redução, ao menos para o ramo algodoeiro, o crescente preço da sua matéria-prima no início do ano. O CIFTA assinalou, em janeiro de 1932, que a cotação do algodão nos mercados do Centro-Sul era 70\% mais alta do que nas praças estrangeiras ${ }^{271}$. Segundo o Centro, esse aumento se deveu "a manobras especulativas de compradores sulistas"272. Uma representação foi enviada para 0 Ministério da Agricultura a fim de solucionar o caso ${ }^{273}$.

Entretanto, o principal motivo da desaceleração do crescimento de 1931 foi, na verdade, a Revolução Constitucionalista, deflagrada em julho e finalizada em outubro de 1932. São Paulo ficou, por um pouco mais de três meses, ilhado do resto do Brasil. Várias fábricas foram obrigadas a paralisar suas produções, seja por falta de matéria-prima, seja por não poderem entregar seus bens no mercado. Encomendas de atacadistas foram suspensas em razão da guerra civil. As cotações do algodão, bem como de outras fibras, dispararam. Assim, as unidades fabris que não possuíam reservas passaram por dificuldades.

\footnotetext{
comerciais iam sendo realizados, ela perdia seu efeito. Ver: Edgard Carone. A república nova, op. cit., pp. 58-59.

${ }^{270}$ Lembra-se que o ramo da juta possuía uma dependência quase que completa da compra de matériasprimas do exterior. Assim, o aumento das taxas aduaneiras da juta bruta, mesmo com seu rebaixamento na revisão tarifária de abril de 1931, foi decisivo para tornar ainda mais difícil a situação econômica de suas fábricas. Ver também: Wilson Suzigan, op. cit., 169.

${ }^{271}$ Circulares CIFTA, 15.01.1932.

${ }^{272}$ Circulares CIFTA, 10.12.1931.

${ }^{273}$ Idem, op. cit.
} 
Foi nesse sentido que a CIFTA mandou uma representação ao Banco do Brasil, logo em julho de 1932, pedindo auxílio. Segundo sua diretoria, “(...) o interesse das fábricas seria paralisar seus trabalhos em virtude da impossibilidade de venderem ou entregarem a sua produção. Entretanto, ( $a$ diretoria do Centro) se sentia na obrigação de chamar a atenção do Banco do Brasil e do Governo Federal para as conseqüências desagradáveis de um possível fechamento das fábricas de tecidos em virtude do qual ficariam sem trabalho milhares de operários (...) As fábricas de tecidos não desejavam (...) concorrer ou criar qualquer dificuldade à ordem pública (grifo nosso). Entretanto, viamse embaraçadas em prosseguir no seu funcionamento em virtude da ausência de recursos financeiros, proveniente da suspensão das encomendas (...)"274. Sabe-se que o auxílio creditício demandado pela burguesia têxtil visava, apenas, contemplar seus fins privados; porém, a argumentação aqui utilizada junto ao Banco do Brasil adentra nas temáticas públicas. Isto é, fala-se da necessidade de se conceder créditos para as fábricas a fim de se impedir suas quebras. Com isso, evitar-se-iam, segundo eles, tumultos populares, em razão do pauperismo das massas têxteis desempregadas. Ao final, devido a esta pressão, o Banco decidiu liberar empréstimos para as indústrias de tecidos domésticas ${ }^{275}$.

Em São Paulo, por outro lado, a FIESP tentava mobilizar as fábricas têxteis do estado para suprir as necessidades do exército constitucionalista. Sua diretoria afirmou, em julho de 1932, que estava consciente das dificuldades financeiras pelas quais passavam as indústrias de tecidos paulistas, em razão do conflito. Porém, “(...) vimos fazer um caloroso apelo a toda indústria para que, a todo o transe, seja evitada qualquer interrupção de sua atividade. Neste momento, o trabalho das fábricas é uma demonstração de patriotismo" 276 . Diversos donativos também foram requisitados. Em agosto, por exemplo, a FIESP pediu doações às fábricas de lã para a confecção de roupas para as tropas constitucionalistas ${ }^{277}$.

Apesar dos esforços da Federação, muitas unidades têxteis foram obrigadas a paralisar sua produção durante o conflito. Isso, por outro lado, não significou que o ano de 1932 fosse totalmente ruim para o subsetor de tecidos paulista. Mesmo com tais interrupções, muitas fábricas interpretaram esse período como sendo positivo. A Brasital, por exemplo, assinalou que o exercício de 1932 “(...) teve começo bastante promissor (...), até que os acontecimentos políticos de julho vieram interromper as relações do nosso estado com os demais, obrigando-nos a reduzir consideravelmente o ritmo de nossa

\footnotetext{
${ }^{274}$ Circular CIFTA, 22.07.1932.

${ }^{275}$ Idem, op. cit.

${ }^{276}$ Circulares FIESP, 13.07.1932.

${ }^{277}$ Circulares FIESP, 05.08.1932.
} 
atividade". Terminado o conflito, porém, houve "(...) um período de franca animação em todos os ramos de negócios" ${ }^{278}$. A diretoria da Fábrica Japy informou aos seus acionistas que "devido ao movimento constitucionalista, que praticamente suprimiu três meses de vendas no ano, fomos obrigados a fazer reduções sucessivas do horário, de modo que trabalhamos no (segundo) semestre apenas 797 horas, em vez de 1.080 como fora previsto. A grande atividade dos negócios que se seguiu ao período revolucionário nos permitiu retomar a atividade fabril em dezembro dentro do horário do programa de previsão (...) em outubro e novembro (de 1932), devido à abertura das comunicações (...), fizemos um extraordinário volume de negócios que reduziu bastante a quantidade de tecidos em nosso estoque, aumentado durante três meses de trabalho sem vendas" ${ }^{279}$. A Rhodiaseta, por sua vez, veio aos seus acionistas “(...) confirmar a perfeita aceitação de nossa seda. Apesar da situação bastante indecisa, as vendas têm aumentado regularmente" ${ }^{\text {280 }}$.

Assim, a Revolução Constitucionalista apenas adiou a consolidação de uma tendência que já se tornara visível para o subsetor têxtil paulista em 1931. Isto é, a tendência da recuperação, para aqueles ramos que sofreram negativamente as conseqüências da crise, ou a do crescimento, para aqueles cujo abalo foi menor.

\section{3 - A grande depressão e os operários têxteis}

\subsection{1 - As greves}

As implicações da depressão (1929-1932) para o subsetor têxtil geraram fortes tensões sociais entre a burguesia e o proletariado. Em razão das diminuições de salários ${ }^{281}$ e jornadas, da negligência dos industriais com relação às leis trabalhistas e das demissões, várias paralisações operárias eclodiram no período.

A primeira das greves têxteis registradas nesse contexto ocorreu na Fábrica de Tecidos Sociedade Comercial de Gênova (capital), em outubro de 1930. Devido à crise, no final de 1929, tal empresa reduziu a jornada dos seus trabalhadores para quatro dias semanais. Descontaram-se, assim, 25\% dos salários. Em abril de 1930, a fábrica voltou a operar seis dias por semana. Entretanto, os ordenados foram mantidos nos mesmos

\footnotetext{
${ }^{278}$ Relatório do Conselho Administrativo. Brasital - S.A. para o desenvolvimento industrial e comercial do Brasil, 18.03.1933.

${ }^{279}$ Relatório de Diretoria. S.A. Fábrica Japy, 18.03.1933.

280 Relatório de Diretoria. Cia. Brasileira de Sedas 'Rhodiaseta', 31.12.1932. Para outros relatos semelhantes, ver: 2.2.1 - O algodão, p. 39 .

${ }^{281} \mathrm{O}$ ordenado médio do trabalhador têxtil paulista caiu em mais de 30\% no interregno 1929-1930 (isto é, de $10 \$ 206$ para 7\$820). Ver: Edgard Carone. A república nova, op. cit., p. 102.
} 
patamares. Em outubro de 1930, após a revolução, os patrões propuseram pagar as diferenças salariais protestadas pelos operários em cobertores. Explodiu, aqui, a greve na empresa $^{282}$. No mês seguinte, várias paralisações proletárias têxteis ocorreram na capital paulista por motivos semelhantes. Na Fábrica de Tecidos Assunção, por exemplo, o protesto vinculou-se à diminuição da jornada de trabalho (de 8 para 6 horas diárias), com conseqüente queda salarial $(10 \%)^{283}$. Na Cia. Brasileira de Linhas para Coser, os 1.500 operários que interromperam seus trabalhos pediram aumento de ordenados ${ }^{284}$. Greves irromperam também na Fábrica de Tecidos Labor, na Tecelagem Santana e na Fiação, Tecelagem e Estamparia Ypiranga Jafet. Afora os motivos conhecidos (decréscimo salarial e acréscimo das jornadas), demandavam também o retorno dos trabalhadores dispensados ${ }^{285}$. Nas IRMF (Fábricas Belenzinho e Mariângela), os salários foram cortados pela metade ${ }^{286}$, gerando violento piquete. Seus operários dirigiram-se para outras indústrias têxteis da capital paulista (Moinho Santista, Fábrica de Tecidos Tatuapé, Cotonifício Adelina, Fábrica de Tecidos Belém, etc.), pedindo solidariedade na luta - e a obtiveram. As paralisações se multiplicaram rapidamente, em especial no ramo algodoeiro, que sofreu forte baque depressivo. A Repartição Geral do Trabalho de São Paulo, em comunicado às principais associações operárias do estado, ameaçou-as dizendo que "qualquer assalto aos estabelecimentos industriais, com o fito de conseguir adesão para a greve, será repelido com a máxima energia, porque ao governo compete garantir a propriedade particular"287. A repressão acabou arrefecendo os ânimos.

No início de 1931, as greves perderam intensidade. Em junho, porém, os operários da Fábrica Brasileira de Seda paralisaram seus trabalhos. Protestavam contra a brutalidade do mestre, contra as reduções salariais e contra o fato das proletárias serem obrigadas a cuidar concomitantemente de dois teares, trabalhando nove horas a fio ${ }^{288}$. Chama-se a atenção aqui para o fato de que, nesta fábrica de seda, o protesto não era contra a diminuição do trabalho e das jornadas, mas sim contra seu aumento excessivo. Em julho, o movimento ganhou força, impulsionado pela Federação Operária de São Paulo. O governo, mais uma vez, interveio. O interventor paulista (Cel. João Alberto Lins de Barros) afirmou que garantiria a "liberdade daqueles que trabalham"289. No dia

\footnotetext{
${ }^{282}$ Idem, op. cit., p. 107.

${ }^{283}$ Ibidem, op. cit., p. 108.

${ }^{284}$ O Estado de São Paulo. Greves, 22.11.1930.

${ }^{285}$ Edgard Carone. A república nova, op. cit., p. 108.

${ }^{286}$ Marisa Saes Leme, op. cit., p. 126.

${ }^{287}$ O Estado de São Paulo. Comunicado da Repartição Geral do Trabalho de São Paulo, 27.11.1930.

${ }^{288}$ Edgard Carone. A república nova, op. cit., 110.

${ }^{289}$ Circulares FIESP, 21.07.1931.
} 
seguinte, a FIESP informou aos seus associados que, após reunião com o General Miguel Costa (secretário da Segurança Pública de São Paulo) e o Major Lobato Valle (diretor do Departamento do Trabalho Industrial), “a política guarnecerá as fábricas ameaçadas de perturbação da ordem, dia e noite, durante as próximas 48 horas, no mínimo (...) ${ }^{\text {"290 }}$. Em agosto, com o término das greves, a Federação enviou uma carta ao Major Valle agradecendo os auxílios prestados e oferecendo um banquete em "homenagem" ao mesmo e aos seus homens ${ }^{291}$. A partir desse momento, a Delegacia de Ordem Social, em ação preventiva, destacaria para as fábricas agentes infiltrados, com o intuito de prender os elementos subversivos ${ }^{292}$.

Apesar disso, as tensões prosseguiram. Em fevereiro de 1932, os 800 operários da Tecelagem de Seda Ítalo-Brasileira entraram em greve após decisão da diretoria de aumentar as jornadas da empresa (de 8 para 10 horas diárias). Manifestações de rua ocorreram, sendo que a mais grave se deu na frente da Fábrica de Seda Libanesa (capital), por motivos semelhantes ${ }^{293}$. Mais uma vez se percebe que a demanda operária nas indústrias de seda era a de impedir o aumento do trabalho, e não a sua diminuição; fato este exemplificativo do quanto o ramo passava por uma crise tal qual o algodoeiro ${ }^{294}$. Em março, as reivindicações dos trabalhadores da Ítalo-Brasileira foram atendidas e, assim, a greve terminou ${ }^{295}$.

Em maio de 1932, impulsionados pelos protestos do dia do trabalho, os ferroviários da São Paulo Railway entraram em paralisação por questões salariais e pela readmissão de companheiros de trabalho. Por motivos semelhantes, os operários de calçados e de vidros da capital também iniciaram greve ${ }^{296}$. A União dos Operários em Fábricas de Tecidos solidarizou-se com o movimento ${ }^{297}$. Logo, tinha-se uma greve geral na cidade de São Paulo - fato que não acontecia desde $1919^{298}$. As principais demandas eram: (i) elevação dos salários de $20 \%$ a $30 \%$; (ii) efetivação da legislação trabalhista; e (iii) reconhecimento das entidades de classe operárias. Atos enérgicos do Estado, que garantiram forçosamente

\footnotetext{
${ }^{290}$ Circulares FIESP, 22.07.1931.

${ }^{291}$ Carta da Federação das Indústrias do Estado de São Paulo ao Major Heitor Lobato Valle, Diretor do Departamento do Trabalho Industrial, 21.08.1931.

${ }^{292}$ Circulares FIESP, 19.01.1932.

${ }^{293}$ O Estado de São Paulo. Movimento operário, 20.02.1932.

${ }^{294}$ Apenas para exemplificar essas diferenças de demandas entre os operários da seda e do algodão nas suas respectivas greves, lembra-se que, em abril de 1932, os trabalhadores da Fábrica de Tecidos Oriente (algodão) paralisaram suas operações. Eles pediam, basicamente, o retorno da tabela salarial pré-crise e a possibilidade de trabalhar com mais de um tear. Ver: Edgard Carone. A república nova, op. cit., 111.

${ }^{295}$ O Estado de São Paulo. Greve resolvida, 13.03.1932.

${ }^{296}$ O Estado de São Paulo. Greves, 03.05.1932.

${ }^{297}$ O Estado de São Paulo. As greves, 06.05.1932.

${ }^{298}$ Marisa Saes Leme, op. cit., p. 129.
} 
o retorno aos trabalhos em muitas unidades fabris ${ }^{299}$, e a eclosão da Revolução Constitucionalista arrefeceram o movimento proletário.

Percebeu-se, ao longo desse período de greves (1930-1932), o quanto a estrutura repressiva estatal representava e defendia o capital. A Revolução de 1930, portanto, não mudara nada nesse sentido. Todos os movimentos do proletariado têxtil foram contidos por meio de enérgica ação do governo. Dever-se-ia, nas palavras do interventor paulista, garantir a "liberdade do trabalho" aos operários que desejavam realizar suas funções. E, na maioria dos casos, tal "liberdade" foi assegurada. Enquanto isso, os salários dos trabalhadores não supriam suas "despesas mais necessárias" ${ }^{300}$. As condições de higiene das fábricas mantinham-se "péssimas". "Somos tratados pelos patrões como escravos", concluía o panfleto do Socorro Vermelho Internacional ${ }^{301}$. Assim, apesar da grande combatividade demonstrada pelos proletários no período, vê-se que suas principais reivindicações não foram atendidas.

\subsection{2 - As leis trabalhistas pós-1930 e a burguesia têxtil}

As reações da burguesia têxtil paulista perante as reformulações trabalhistas realizadas pelo Governo Provisório foram ambíguas. Ora as criações e mudanças legais receberam apoio, ora críticas. Em alguns casos, a negligência com relação à aplicabilidade das leis prosseguiu; em outros, foi estancada. A crescente participação dos industriais na estrutura estatal pós-1930 auxiliou nesse processo dialético de aceitação / adequação das regras trabalhistas por parte dos primeiros. Apesar disso, a resistência patronal ainda se fazia visível em certas questões.

Por um lado, a burguesia aprovou o anteprojeto sobre o trabalho feminino, que garantia proteções à mulher grávida e limites às tarefas noturnas. A FIESP caracterizou-o "no seu gênero, tão perfeito quanto possível" 302 . Foram motivos de elogios também a criação da carteira profissional ${ }^{303}$, que sistematizou o controle burguês contra os operários

\footnotetext{
${ }^{299}$ Circulares FIESP, 17.05.1932.

${ }^{300}$ Arquivo DOPS. Trabalhadores Têxteis. Panfleto do Socorro Vermelho Internacional (Sub-seção de São. $\underline{\text { Paulo), }}$, julho de 1932.

${ }^{301}$ Idem.

${ }^{302}$ Circulares FIESP, 05.11.1931.

${ }^{303}$ Decreto n. 21.175, 21.03.1932.
} 
ditos subversivos ${ }^{304}$, e o novo Código de Menores $^{305}$. Este foi reformulado, atendendo os principais interesses dos industriais. A idade mínima para admissão nas fábricas foi elevada de 12 para 14 anos. Aboliu-se o teto de 6 horas para os menores e o trabalho noturno, antes considerado a partir das $19 \mathrm{~h}$, começaria apenas às $22 \mathrm{~h}$. Assim, fica fácil compreender o porquê da FIESP ter afirmado que, com este novo Código, o governo "prestou um serviço às indústrias" ${ }^{306}$. Já no que se refere à Lei da Jornada Fabril, apesar da regulamentação de 8 horas diárias para o trabalho nas indústrias, havia a possibilidade de estendê-la para 10 e, até, para 12 horas $^{307}$. Isso agradou a burguesia paulista. A FIESP chegou a mandar aos seus associados modelos de preenchimento para as fábricas que desejassem justificar a ampliação das jornadas dos seus operários junto ao Ministério do Trabalho ${ }^{308}$.

Por outro lado, a questão do descanso anual para os operários continuou sendo tema de discórdia. Em abril de 1931, o Governo Provisório suspendeu a antiga Lei de Férias $^{309}$. Estabeleceram-se, assim, normas provisórias para a concessão de descanso anual aos proletários até que a Comissão Revisora da Lei de Férias ${ }^{310}$ concluísse seus trabalhos e apresentasse nova legislação sobre o tema. Tais normas mantinham os 15 dias de descanso, porém, por sugestão do CIFTA, eles poderiam ser subdivididos em períodos menores (no mínimo, três dias cada) ${ }^{311}$. Mesmo com a proposta aceita, argumentava-se que “(...) a presente situação de crise intensa de toda a indústria (têxtil) não permite absolutamente um encargo tão elevado que constituirá a pena de morte para muitas empresas (...) ${ }^{\sharp 12}$. Além das críticas, a negligência na aplicação da lei prosseguiu. Na maioria das greves ocorridas entre 1930 e 1932, demandou-se dos patrões respeito às leis trabalhistas, dentre elas a de férias. A FIESP, por sua vez, continuou incentivando seu desleixo. Em circular enviada aos associados em outubro de 1932, a Federação

\footnotetext{
${ }^{304}$ Apesar de que as associações têxteis (paulista e carioca) possuíam sistemas eficientes de informações sobre operários subversivos. Desde 1921, o CIFT-SP, por intermédio do seu secretário-geral (Otávio Pupo Nogueira) já tinha criado uma "lista de indesejáveis", a qual era enviada regularmente para todas as fábricas têxteis associadas. No início dos anos (19)30, os sistemas de informações do CIFT (agora, SPITESP) e do CIFTA-Rio foram agregados. Para maiores informações, ver: Circulares CIFTA, 20.06.1931; e Maria Alice Rosa Ribeiro, op. cit., pp. 84-85.

${ }^{305}$ Decreto n. ?, 14.11.1932.

${ }^{306}$ Circulares FIESP, 26.10.1931.

${ }^{307}$ Decreto n. 21.364, 04.05.1932.

${ }^{308}$ Circulares FIESP, 23.06.1932.

${ }^{309}$ Decreto n. $19.908,18.04 .1931$.

${ }^{310}$ Os dois representantes da indústria nessa comissão pertenciam ao subsetor têxtil: Vicente Galliez e Carlos Teles da Rocha Faria, secretário-geral e presidente do CIFTA-Rio, respectivamente.

${ }^{311}$ CIFTA. Ata de Reunião da Diretoria, 29.05.1931.

312 CIFTA. Representação enviada ao Sr. Ministro do Trabalho, Indústria e Comércio pelo CIFTA e subscrita por todas as principais associações industriais e comerciais do Distrito Federal, 06.02.1931.
} 
aconselhava “(...) as indústrias paulistas a suspender as atuais e inúteis tentativas de aplicação da Lei de Férias, explicando aos operários que apresentarem reclamações que o Sr. Governador (...) tem em estudos um grande plano de assistência ao trabalhador"313.

No que se refere à Lei de Sindicalização $o^{314}$, percebem-se elogios e críticas. Aplaudiu-se, principalmente, o controle dos operários possibilitado pelo decreto. A diretoria do CIFTA admitiu que havia uma “(...) certa conveniência (...) de ficarem as associações proletárias sob o imediato controle do Ministério do Trabalho (...)”315. Porém, a idéia de se criar comissões coletivas do trabalho ${ }^{316}$ - formadas por representantes do governo, da burguesia e do proletariado -, e que decidiria questões concernentes, por exemplo, aos salários, não agradou aos industriais. Segundo o CIFTA, “(...) é preciso evitar (...) ser comprometidos os princípios da disciplina e autoridade que devem presidir as relações de operários e patrões, sob pena de perigar até a ordem pública (grifo nosso) (...) (a diretoria do CIFTA) manifesta seu pensamento francamente contrário à intromissão de operários ou de associações operárias nas administrações das fábricas"317. A FIESP compartilhava da mesma opinião: "uma lei dessa natureza virá provocar entre nós graves complicações facilmente destruidoras da harmonia que deve reinar no seio do trabalho fabril. Teme a Federação das Indústrias que a lei em projeto venha criar a ditadura dos sindicatos operários (...)"318. Nota-se, mais uma vez, a utilização burguesa do argumento de que as garantias trabalhistas, se colocadas em prática, desnorteariam a própria ordem pública. Entretanto, apesar das críticas, as comissões coletivas do trabalho foram criadas $^{319}$.

Portanto, vê-se que, mesmo com o maior acesso burguês às estruturas governamentais, algumas das leis criadas pelo Estado nesse momento ainda desagradaram o capital. Outras, por sua vez, que foram modificadas em sua essência pela própria influência burguesa (Código dos Menores, Lei das Jornadas Fabris, etc.), não protagonizaram mais controvérsias.

\footnotetext{
${ }_{313}$ Circulares FIESP, 28.10.1932.

${ }^{314}$ Decreto n. 19.770, 19.03.1931.

${ }^{315}$ CIFTA. Ata de Reunião da Diretoria, 09.04.1931.

${ }^{316}$ Nesta Lei de Sindicalização, as Comissões Coletivas do Trabalho ainda eram facultativas.

${ }^{317}$ Idem.

318 FIESP. Memorial da Federação das Indústrias do Estado de São Paulo acerca das leis trabalhistas dirigido ao Ministro do Trabalho, Indústria e Comércio, dezembro de 1931.

${ }^{319}$ Decreto n.?, 23.08.1932.
} 


\section{$\underline{2.4-\text { Conclusões parciais }}$}

Dos dados e análises apresentados neste capítulo, pode-se concluir que (i) o subsetor têxtil paulista passou por forte depressão entre 1929-1932, maior do que a média dos demais setores fabris do estado; (ii) apesar desta crise agregada, não se pode afirmar que todos os ramos de tecidos a sentiram com a mesma intensidade. Alguns, como o de algodão e o de juta, sofreram fortes conseqüências negativas; outros (lã e, principalmente, seda) possuíram apenas retrações produtivas, mas que não poderiam ser caracterizadas como crises; (iii) o ano de 1931 significou um momento de alteração de tendência para o subsetor têxtil, a qual foi freada em 1932 devido, essencialmente, à Revolução Constitucionalista; (iv) a depressão do subsetor de tecidos aguçou as tensões entre burguesia e proletariado. Tais conflitos, expressados por diversas greves ao longo do período, foram resolvidos por enérgica ação estatal, protetora dos interesses da primeira classe; e, por último, (v) apesar do acolhimento de algumas questões concernentes às leis trabalhistas pós-1930, as quais foram modificadas em suas essências, a burguesia têxtil ainda relutou em aceitar muitas interferências governamentais nas relações capitaltrabalho. 


\section{CAPÍTULO 3 - A recuperação têxtil paulista (1933-1939)}

Neste capítulo, objetiva-se apresentar e analisar o processo de recuperação da indústria têxtil paulista pós-crise 1929-1932. Questionar-se-ão, em especial, (i) os fatores que possibilitaram tal ascensão; (ii) a linearidade temporal da mesma; (iii) a homogeneidade do processo no tocante aos diferentes ramos de tecidos do estado; e (iv) as possíveis mudanças ocorridas nas relações entre capital e trabalho durante o período.

\section{$\underline{3.1 \text { - A recuperação da economia brasileira }}$}

A recuperação da economia doméstica da crise de 1929 deu-se de maneira relativamente rápida. A maioria dos estudiosos considera o período 1932-1933 como marco nesse processo, o que é verificável por meio da observação de dados econômicos locais (Tabela 3.1.) . $^{320}$.

Em 1932, o PNB já havia alcançado o de 1928, enquanto o de 1933 situou-se num patamar 11,7\% superior ao do período pré-depressivo. A partir de então, seu crescimento foi contínuo ao longo dos anos (19)30. Os índices setoriais da agricultura e da indústria cresceram, respectivamente, $12,9 \%$ e 4,5\% entre 1928-1933. Da mesma maneira, eles mantiveram sua ascensão durante toda a década citada, excetuando-se o caso agrícola dos anos 1938-1939.

Várias explicações foram dadas para essa recuperação. A clássica é a de Celso Furtado $^{321}$. Segundo ele, a desvalorização do numerário local, decorrente da Grande Depressão, encareceu os bens externos, desestimulando importações. Por outro lado, a demanda agregada interna foi mantida em razão de políticas de caráter keynesiano, tais como as ações governamentais de auxílio aos cafeicultores, mediante a compra de estoques do produto com emissão de papel-moeda ${ }^{322}$. Assim, sustentou-se a renda do setor

\footnotetext{
320 Dentre estes estudiosos, pode-se citar Maria da Conceição Tavares. Acumulação de capital e industrialização no Brasil. $3^{\circ}$ Edição. Ed. da Unicamp, Campinas, 1998, p. 132; Wilson Cano. Desequilibrios regionais e concentração industrial no Brasil (1930-1970 / 1970-1995). Ed. da Unicamp, Campinas, 1998, p. 72; Barjas Negri, op. cit., p. 60; Wilson Suzigan, op. cit., p. 67; Fishlow, op. cit., p. 26; entre outros.

${ }^{321}$ Celso Furtado. Formação (...), op. cit., especialmente o capítulo XXXII - Deslocamento do centro dinâmico.

322 Em fevereiro de 1931, o Governo Federal autoriza a compra de sacas de café estocadas desde 30.06.1930. No Primeiro Convênio Cafeeiro (24.02.1931), decide-se criar uma taxa de 10 shillings para cada saca exportada, visando financiar a política de compras de estoques colocada em prática pelo estado. Em maio de 1931, o Convênio Cafeeiro transforma-se em Conselho Nacional do Café (CNC). No Segundo Convênio Cafeeiro, aumenta-se de 10 para 15 shillings a taxa por saca de café exportada. Em fevereiro de 1933, o CNC é extinto, sendo substituído pelo Departamento Nacional de Café (DNC). Para maiores informações
} 
cafeeiro em patamares mais altos do que teriam sido possíveis sem elas, seja devido às aquisições dos excedentes em si, seja em razão do impedimento de quedas maiores nos preços internacionais do café. A depreciação monetária, acentuada por tal política emissionista, amorteceu as reduções de preços do produto para os fazendeiros ${ }^{323}$.

Dessa forma, com as importações caras e a procura local conservada, possibilitouse um genuíno processo de substituição de importações, inicialmente realizado por intermédio da utilização da capacidade ociosa das indústrias já existentes. Os setores vinculados ao mercado interno passaram, então, a oferecer maiores perspectivas de lucro do que aqueles ligados ao mercado externo. A economia doméstica criava, pela primeira vez, estímulos dentro dela mesma para fomentar seu crescimento econômico.

Tabela 3.1 - Dados Econômicos Domésticos I - PNB, Índices Setoriais de Produção e Balança Comercial - Brasil (1932-1939)

\begin{tabular}{cccccccccc} 
& 1928 & 1932 & 1933 & 1934 & 1935 & 1936 & 1937 & 1938 & 1939 \\
\hline 01 - PNB (Milhões de Cr\$)* & 30,6 & 31 & 34,2 & 36,5 & 37,1 & 41,2 & 42,2 & 44,2 & 45,6 \\
02 - ÍSPA (1939=100)a & 76,7 & 77,3 & 86,6 & 92 & 89,7 & 98,2 & 98,3 & 102,4 & 100 \\
03 - ÍSPI (1939=100)b & 54,9 & 51,4 & 57,4 & 63,8 & 71,4 & 83,7 & 88,2 & 91,5 & 100 \\
04 - ÍPT (1939=100)c & 65,2 & 65,1 & 70,9 & 77,4 & 79,7 & 89,3 & 93,4 & 97,6 & 100 \\
05 - Exportações (1.000 Libras & & & & & & & 35.94 & 5 & 37.298 \\
Est.) & 97.426 & 36.630 & 35.790 & 35.240 & 33.012 & 39.069 & 42.530 & 5 \\
06 - Importações (1.000 Libras & & & & & & & 35.91 & 6 & 31.801 \\
Est.) & 90.669 & 21.744 & 28.132 & 25.467 & 27.431 & 30.066 & 40.608 & 6 \\
07 - Saldo (1.000 Libras Est.) & 6.757 & 14.886 & 7.658 & 9.773 & 5.581 & 9.003 & 1.922 & 29 & 5.497 \\
\hline
\end{tabular}

Fonte: Villela e Suzigan, op. cit., p. 412-454 e Haddad, op. cit., p. 147-148. / * Milhões de Cr\$ de 1939; a - Índice Setorial do Produto Agrícola; b - Índice Setorial do Produto Industrial; c - Índice do Produto Total

Essa interpretação de Furtado foi contestada por alguns trabalhos posteriores, especialmente o de Peláez ${ }^{324}$. De acordo com este, o governo getulista do início dos anos (19)30 não implementou quaisquer políticas de caráter keynesiano para sustentar a demanda agregada doméstica, pois suas diretrizes orçamentárias caracterizaram-se pelo respeito às práticas econômicas ortodoxas, isto é, pela manutenção do equilíbrio fisscal do setor público. Assim, o programa de auxílio ao café foi financiado não mediante criação de moeda - gerador de déficits nos balanços governamentais -, mas sim pelos próprios impostos de exportação das sacas de café. Por último, essa recuperação econômica - não

sobre a política cafeeira do Governo Federal no início dos anos (19)30, ver: Antônio Delfim Neto, op. cit.; e Edgard Carone. A República Nova, op. cit.

${ }^{323}$ Entre 1930 e 1931, o preço internacional da saca de café (10 kg.) caiu de 1,79 dólares para 0,97 (-45,8\%), enquanto que, em mil-réis, decresceu de $16 \$ 250$ para $13 \$ 900(-14,4 \%)$. Ver: Thomas H. Holloway, op. cit., p. 261-262 e Edgard Carone. A República Nova, op. cit., p. 24-25.

${ }^{324}$ Carlos Manuel Peláez. História da Industrialização Brasileira. Crítica à Teoria Estruturalista no Brasil. APEC Editora, Rio de Janeiro, 1972. O grupo de estudiosos que acompanhou Peláez nas suas críticas às idéias de Furtado é chamado na historiografia econômica brasileira de revisionista. 
tão acelerada como muitos apregoam, afirma Peláez - aconteceu essencialmente devido aos superávits da balança comercial, permitindo a manutenção da demanda agregada em níveis razoáveis. Percebe-se, portanto, que tal estudioso defende a manutenção, mesmo no período pós-crise, da linearidade entre o desempenho econômico dos setores externo e interno locais.

Fishlow foi o primeiro a relativizar as teses dos revisionistas ${ }^{325}$. Ele demonstrou que os impostos de exportação citados por Peláez não oneravam o produtor doméstico, mas sim o consumidor estrangeiro, em razão da relativa inelasticidade-preço ${ }^{326}$ da demanda cafeeira. Além disso, segundo dados apresentados por Silber ${ }^{327}$, no período 1931-1933, 65\% da renda do Conselho Nacional do Café foi auto-financiada pelo próprio setor cafeeiro por meio dos impostos de exportação, enquanto $35 \%$ tiveram como recursos os créditos do Banco do Brasil e do Tesouro Nacional. A partir de 1933, todavia, essa proporção foi invertida: $52 \%$ dos recursos do Departamento Nacional do Café provieram de emissões monetárias e $48 \%$ dos impostos de exportação ${ }^{328}$.

No que concerne à possível política econômica ortodoxa realizada pelo Governo Federal no início dos anos (19)30, pode-se perceber na Tabela 3.2 que essa posição também era difícil de ser sustentada. Observa-se que houve uma nítida expansão dos meios de pagamentos desde 1931, cujo pico aconteceu em 1935. Da mesma maneira, o numerário mantido em caixa no Banco do Brasil tendeu ao decréscimo ao longo do período, ampliando o papel-moeda extra em circulação. A desvalorização do mil-réis ocorrida nesta década - fundamental para o encarecimento das importações, tornando cativo o mercado doméstico para as indústrias locais - acentuou-se com tal política monetária expansionista ${ }^{329}$.

A explicação revisionista de que a recuperação econômica doméstica ocorreu em razão dos superávits da balança comercial parte de pressuposto equivocado. Não é o saldo

\footnotetext{
${ }^{325}$ Albert Fishlow, op. cit., p. 26-27.

${ }^{326}$ Elasticidade-preço da demanda "é a variação percentual na quantidade demandada, dada uma variação percentual no preço do bem, coerteris paribus. Mede a sensibilidade, a resposta dos consumidores, quando ocorre uma variação no preço de um bem ou serviço". No caso de uma demanda inelástica aos preços, significa que os consumidores são pouco sensíveis a variações (aumentos / quedas) de preço. In: Marco Antônio Sandoval de Vasconcelos. Economia. Micro e macro. Ed. Atlas, São Paulo, 2001, p. 75.

327 Simão Silber. Análise da política econômica e do comportamento da economia brasileira durante o. período 1929/1939. In: Flávio Rabelo Versiani e José Mendonça de Barros (Org.). Formação Econômica do Brasil. A experiência da industrialização. Edição Saraiva, São Paulo, 1978, p. 173-209.

${ }^{328}$ Simão Silber, op. cit., p. 195.

${ }^{329}$ Como bem salientou Wilson Cano, Peláez chegou a conclusões diametralmente opostas àquelas que se podiam inferir dos dados em razão de dois equívocos: (i) tomou como referencial para sua análise um ano anormal (1929), marcado por forte retração econômica, ao invés de usar como parâmetro um ano pré-crise (como, por exemplo, 1928); e (ii) não levou em consideração a deflação ocorrida no início dos anos (19)30. Para maiores informações, ver: Wilson Cano. Desequilíbrios (...), op. cit., p. 165.
} 
positivo da balança comercial em si que impulsiona a demanda agregada, mas sim o aumento quantitativo das exportações. Os superávits mercantis ocorridos no início dos anos (19)30 deveram-se a uma queda maior das importações perante um decréscimo menos acentuado das exportações (Tabela 3.1). Assim, o impacto desses saldos na renda interna foi bastante reduzido ${ }^{330}$.

Tabela 3.2 - Dados econômicos II - Taxa de Câmbio e Papel-Moeda Emitido / Circulação (1931-1939)*

\begin{tabular}{|c|c|c|c|c|c|c|c|c|c|c|}
\hline & 1928 & 1931 & 1932 & 1933 & 1934 & 1935 & 1936 & 1937 & 1938 & 1939 \\
\hline 02b - Papel-moeda emitido (D) a & 2282 & 2523 & 2850 & 2734 & 2804 & 3144 & 2931 & 2807 & 2993 & 3154 \\
\hline 03b - Caixa em moeda corrente (D) b & 341 & 239 & 403 & 341 & 277 & 241 & 153 & 246 & 344 & 230 \\
\hline 04 - Papel-moeda extra em circulação - ** & 2874 & 2663 & 2780 & 2658 & 2845 & 3335 & 3839 & 4151 & 4271 & 4609 \\
\hline
\end{tabular}

Fonte: Villela e Suzigan, op. cit., p. 412-454 / Notas: * As variáveis 2, 2b, 3, 3b, 4 e 4b estão em Cr\$ 1.000; ** Esta variável é resultado da operação: 02 - 03; a - Saldo do final do ano; $\mathbf{b}$ - Banco do Brasil.

Portanto, mesmo que Furtado tenha superestimado a participação dos créditos do Banco do Brasil e do Tesouro Nacional no processo de recuperação econômica citado, é inegável que essa política monetária expansionista foi fundamental para a manutenção da demanda agregada. Nesse contexto de encarecimento das importações, em razão das contínuas desvalorizações monetárias, as inversões nos setores voltados para o mercado interno guiaram a tônica do crescimento local pós-1932. Dessa maneira, pode-se afirmar que a dominação que antes as exportações exerciam sobre o nível de atividade e renda domésticos passaram para segundo plano, confirmando as conclusões furtadianas. Prova disso foi a crescente diversificação agrícola, cuja produção, cada vez mais, destinava-se ao mercado interno ${ }^{331}$ e o aumento da importância do setor industrial na economia. Apenas a título de exemplo, lembra-se que no interregno 1920-1929, 79\% do produto físico nacional devia-se à agricultura, enquanto $21 \%$ à indústria; já no período 1933-1939, a primeira teve sua participação reduzida para $57 \%$ e a segunda aumentada para $43 \%{ }^{332}$. Além disso, devese citar que no ano de 1933, em termos de valores, a produção fabril local superou a agrícola pela primeira vez na história brasileira ${ }^{333}$.

\footnotetext{
${ }^{330}$ Wilson Cano. Desequilíbrios (...), op. cit., p. 169-170.

331 Para maiores informações sobre o crescimento das culturas agrícolas abastecedoras do mercado doméstico, ver: Villela e Suzigan, op. cit., p. 58-61.

332 Pedro Cezar Dutra Fonseca. Vargas: O capitalismo em construção. Editora Brasiliense, São Paulo, 1999, p. 202.

${ }^{333}$ Edgard Carone. A República Nova, op. cit., p. 13-14.
} 
Para além dos fatores já assinalados (desvalorização monetária e política de auxílio ao café), deve-se lembrar também outras causas explicativas importantes para a recuperação econômica doméstica pós-1932. Entre elas destaca-se a criação do monopólio cambial do Banco do Brasil em setembro de 1931, por três anos. Com este, as importações de produtos só se faziam possíveis por meio da compra de cambiais junto ao Banco, que as venderia no mercado com preços distintos, conforme as prioridades de aquisição locais ${ }^{334}$. Dessa maneira, dificultou-se ainda mais a compra de bens no exterior, o que, agregado à desvalorização do mil-réis, auxiliou os setores vinculados ao mercado interno.

Além do monopólio cambial, pode-se citar, por último, a ajuda dada pelo governo aos agricultores em geral. Em fevereiro de 1933, estabeleceu-se que as dívidas dos produtores rurais contraídas antes de 30.06.1932 seriam reduzidas em 50\%, e seus respectivos credores, pagos em apólices do Governo Federal resgatáveis em, no máximo, trinta anos. Depois, criou-se outro decreto (abril de 1933) limitando os juros considerados exorbitantes nos empréstimos agrícolas ${ }^{335}$. Tais ações governamentais permitiram não só um menor rebaixamento do nível de renda rural no contexto pós-crise 1929-1932, mas também possibilitaram a manutenção de investimentos em culturas agrícolas fundamentais para o abastecimento do mercado interno ${ }^{336}$.

Vistos os dados macroeconômicos comprovadores do crescimento econômico local após 1932-1933 e seus principais fatores explicativos, faz-se necessário, agora, apresentar e analisar o desempenho do subsetor têxtil paulista nesse contexto.

\section{$\underline{3.2-\text { A recuperação da indústria têxtil paulista }}$}

\subsection{1 - O subsetor têxtil agregado}

A partir de 1932-1933, acompanhando o desempenho da economia doméstica, observou-se a recuperação da indústria paulista (Tabela 3.3). Em 1932, o número de operários, a força motriz e o valor de produção deflacionado ${ }^{337}$ do subsetor já haviam

\footnotetext{
${ }^{334}$ A ordem de prioridades seria: (1) compras do governo e pagamento da dívida externa; (2) importações essenciais; e (3) procura de cambiais para demais fins, inclusive remessas. Ver: Villela e Suzigan, op. cit., p. 325. Para maiores informações sobre a política cambial da Era Vargas, ver também: Marcelo de Paiva Abreu. O Brasil e a economia mundial, op. cit., especialmente o Capítulo 4 (Problemas e políticas cambiais). ${ }^{335}$ Para maiores informações sobre ambos decretos, ver: Edgard Carone. A Segunda República (1930-1937). Difel, São Paulo, 1978, p. 119-124.

${ }^{336}$ Edgard Carone. A República Nova, op. cit., p. 28-29.

${ }^{337}$ No texto, analisar-se-ão apenas as variáveis capital e valor produtivo deflacionados. Assim, para efeito de melhor leitura, a palavra deflacionado não será mais citada quando tais variáveis forem novamente mencionadas.
} 
igualado os índices de 1928, com a exceção do número de estabelecimentos (decréscimo de $12,3 \%$ ) e do montante de capital (acréscimo de 44,3\%). Nos anos seguintes, a ascensão tornou-se evidente. Em 1935, por exemplo, todas as variáveis arroladas apresentavam resultados superiores ao do período pré-crise: estabelecimentos (13\%); capital (273\%); operários (44\%); força motriz (31,2\%); e valor de produção $(54,1 \%)$.

Em 1936, verificou-se certa retração no parque fabril estadual. Houve decréscimo do montante de capital $(-42,3 \%)$ e do valor produtivo $(-8,98 \%)$. As demais variáveis apresentaram crescimentos modestos, excetuando-se o número de estabelecimentos $(8,69 \%)$. No entanto, essa tendência baixista logo foi dissipada em 1937. Houve ascensão em todas as variáveis citadas, destacando-se a recuperação das inversões em capital real (33,3\%). Nos anos seguintes (1938 e 1939), o crescimento fabril paulista prosseguiu inalterado (Tabela 3.4). O consumo de energia elétrica nesse período elevou-se em 22,9\%; o número de operários, em 16,1\%; e o valor produtivo, em $22,8 \%$.

Tabela 3.3 - Índices do número de estabelecimentos, capital, relação capital-fábrica, operários, relação capital-operári força motriz, valor de produção e relação capital-valor de produção das indústrias gerais e têxteis paulistas (1928, 1932 1928=100)*

\begin{tabular}{ccccccccccccccc} 
& \multicolumn{1}{c}{1928} & \multicolumn{2}{c}{1932} & \multicolumn{2}{c}{1933} & \multicolumn{1}{c}{1934} & \multicolumn{1}{c}{1935} & \multicolumn{1}{c}{1936} \\
\hline & $\mathrm{G}$ & $\mathrm{T}$ & $\mathrm{G}$ & $\mathrm{T}$ & $\mathrm{G}$ & $\mathrm{T}$ & $\mathrm{G}$ & $\mathrm{T}$ & $\mathrm{G}$ & $\mathrm{T}$ & $\mathrm{G}$ & $\mathrm{T}$ & $\mathrm{G}$ & $\mathrm{T}$ \\
Número de Fábricas & 100 & 100 & 87,7 & 178,0 & 94,7 & 193,2 & 123,9 & 212,5 & 113,2 & 209,1 & 123,1 & 223,1 & 130,7 & 230,3 \\
Capital (contos) & 100 & 100 & 144,3 & 100,0 & 173,0 & 118,9 & 264,3 & 183,9 & 289,4 & 203,5 & 200,8 & 196,7 & 314,1 & 205,2 \\
Capital (contos - D) & 100 & 100 & 188,1 & 130,4 & 230,7 & 158,4 & 347,6 & 241,9 & 373,0 & 262,3 & 215,2 & 210,8 & 286,9 & 187,4 \\
Operários & 100 & 100 & 101,6 & 91,1 & 115,7 & 105,5 & 136,7 & 113,0 & 144,0 & 121,2 & 148,6 & 127,1 & 165,6 & 131,8 \\
Força Motriz (H.P.) & 100 & 100 & 106,1 & 123,9 & 117,1 & 132,0 & 128,1 & 139,4 & 131,2 & 143,7 & 140,3 & 146,5 & 154,4 & 161,6 \\
VP (contos) a & 100 & 100 & 79,7 & 72,8 & 84,4 & 83,5 & 96,1 & 97,0 & 119,5 & 110,3 & 130,9 & 115,7 & 157,8 & 133,0 \\
VP (contos - D) & 100 & 100 & 103,9 & 94,9 & 112,5 & 111,3 & 126,4 & 127,5 & 154,1 & 142,2 & 140,2 & 124,0 & 144,1 & 121,5 \\
\hline
\end{tabular}

Fonte: Anexos - Tabelas 1 e 2; * Mesma notação da Tabela 2.1 / ** Infelizmente, não foi possível juntar os dados das Estatísticas Industriais do Estado de São Pa de 1928-1937 com os das Estatísticas de 1938 - 1939. Os métodos de recolhimento e apresentação estatística dos mesmos foram alterados de 1937 para 1938 , inviabilizando comparações. Apenas a título de ilustração, no primeiro grupo de Estatísticas (1928-1937), o montante de capital foi calculado levando-se em consideração o universo das empresas gerais e têxteis do estado; no segundo grupo (1938-39, 1943-44), apresenta-se apenas o capital das empresas que respondera aos questionários da Diretoria de Estatística do estado de São Paulo; $\mathbf{a}-\mathrm{VP}=$ Valor da Produção.

No que se refere ao subsetor têxtil como um todo, pode-se tecer as seguintes considerações (Tabelas 3.3 e 3.4). Em 1932, a recuperação das fábricas de tecidos paulistas, apesar de iniciada, ainda não havia sido completa. Entre 1928 e 1932, verificaram-se acréscimos no número de estabelecimentos (78\%), no capital real empregado $(30,4 \%)$ e na força motriz $(23,9 \%)$. Por outro lado, houve diminuição no número de operários $(-8,92 \%)$ e no valor produtivo (-5,14\%). Em 1933, diferentemente, todas as variáveis arroladas já tinham superado os índices do período pré-depressivo. $\mathrm{O}$ interregno 1933-1935 foi marcado por considerável ascensão do subsetor, destacando-se, nesse sentido, a elevação do capital investido $(65,6 \%)$ e do valor de produção $(27,8 \%)$. 
Entretanto, em 1936, acompanhando a tendência baixista das indústrias paulistas, as fábricas têxteis apresentaram retrações nestas mesmas variáveis: capital empregado $(-19,6 \%)$ e valor produtivo (-12,8\%). Nas demais, observaram-se crescimentos apenas modestos. No ano seguinte, houve descompasso dos desempenhos fabris geral e têxtil. Enquanto o primeiro, como se viu, recuperou-se, o segundo manteve-se em recessão. As inversões em capital e os valores de produção das fábricas de tecidos estaduais continuaram caindo $(-11,1 \%$ e $2 \%$, respectivamente). As elevações nas variáveis restantes permaneceram reduzidas, excetuando-se o caso da força motriz $(10,3 \%)$. No período 1938-1939, a situação mudou (Tabela 3.4). Verificaram-se acréscimos consideráveis na energia elétrica consumida $(18,7 \%)$, no número de operários $(12,9 \%)$ e no valor de produção $(15,2 \%)$ das empresas têxteis paulistas.

Tabela 3.4 - Consumo de energia, número de operários e valor da produção das indústrias gerais e têxteis paulistas (1938 e 1939)

\begin{tabular}{ccccc} 
& \multicolumn{2}{c}{ Gerais } & \multicolumn{2}{c}{ Têxteis } \\
& 1938 & 1939 & 1938 & 1939 \\
\hline Consumo energia $(\mathrm{Kw} / \mathrm{h})$ & 427.916 .543 & 525.855 .814 & $148.253 .230,00$ & $176.020 .063,00$ \\
Operários & 218.993 & 254.144 & 84.582 & 95.516 \\
Valor da Produção $(\mathrm{Cr} \$ 1.000-\mathrm{D})$ & 2.991 .270 & 3.673 .271 & 707.844 & 815.579 \\
\hline
\end{tabular}

Fonte: Estatística Industrial do Estado de São Paulo (1938 e 1939).

Uma primeira conclusão importante passível de ser inferida dos dados é a de que o crescimento das fábricas paulistas agregadas e têxteis não foi contínuo ao longo do período 1932-1939. O ano de 1936 marcou, mesmo que temporariamente, um momento de estancamento da ascensão até então verificada. Poucos foram os estudiosos que salientaram esse aspecto ${ }^{338}$.

Outra conclusão fundamental é a de que, apesar das semelhanças nas tendências dos desempenhos econômicos apresentados entre tais grupos de fábricas (agregadas e têxteis), houve também diferenças importantes entre os mesmos no período. Suas respectivas taxas geométricas de crescimento $^{339}$ (Tabela 3.5) são representativas desse aspecto. Observa-se que as indústrias gerais do estado apresentaram acréscimos maiores em todas as variáveis arroladas ao longo dos anos 1932-1937. No momento de arranque

\footnotetext{
${ }^{338}$ Destacam-se, nesse sentido: Carlos Manuel Peláez e Wilson Suzigan. História monetária do Brasil. Ed. Universidade de Brasília, Brasília, 1981, P. 211; e Marisa Saenz Leme. A ideologia (...), op. cit., p. 63. Entretanto, a primeira, como se mostrará posteriormente, comete equívoco ao identificar apenas a deterioração dos termos de troca como fator da recessão.

${ }^{339}$ Taxa geométrica de crescimento (TGC) é o cálculo da taxa média anual de crescimento de uma variável por método geométrico em determinado período. Assim, se a TGC da variável operários têxteis paulistas no interregno $1932-1937$ foi de 10,3\%, diz-se que o número de trabalhadores em tal ramo cresceu, em média, $10,3 \%$ ao ano.
} 
(1932-1935), as elevações das primeiras foram mais consideráveis (exceto no que condiz ao valor de produção); enquanto, no interregno recessivo (1935-1937), seus decréscimos caracterizaram-se por quedas menos acentuadas. Assim, comprova-se o maior dinamismo das empresas vinculadas à produção dos ditos bens pesados (intermediários, capital e consumo durável), em comparação com as fabricantes de bens leves (consumo nãodurável, como o caso dos tecidos). Lembra-se, no entanto, que as elevações percentuais do subsetor têxtil paulista significaram acréscimos quantitativos consideráveis, em razão da sua elevada participação na estrutural fabril do estado nesse período. O oposto aconteceu com os subsetores fabris, cuja representatividade no parque fabril paulista antes de 1929 era pequena (bens pesados): grandes elevações percentuais constituíram menores resultados do ponto de vista quantitativo. Esse é o principal motivo que explica as disparidades nas taxas de crescimento geométricas assinaladas.

Tabela 3.5 - Taxas geométricas de crescimento - Indústrias Gerais e Têxteis Paulistas (1932-37, 1932-35 e 1935-37), em \%

\begin{tabular}{ccccccc} 
& \multicolumn{2}{c}{$1932-37$} & \multicolumn{2}{c}{$1932-35$} & \multicolumn{2}{c}{$1935-37$} \\
& $\mathrm{G}$ & $\mathrm{T}$ & $\mathrm{G}$ & $\mathrm{T}$ & $\mathrm{G}$ & $\mathrm{T}$ \\
\hline Número de Fábricas & 8,30 & 5,28 & 8,90 & 5,50 & 7,45 & 4,88 \\
K - Total (contos - D) & 8,81 & 7,53 & 26,00 & 26,20 & $-12,30$ & $-15,15$ \\
Operários & 10,30 & 7,67 & 12,30 & 9,98 & 7,23 & 4,26 \\
Força Motriz (H.P.) & 7,79 & 5,45 & 7,14 & 5,06 & 8,49 & 6,05 \\
Produção (contos - D) & 6,77 & 5,08 & 14,10 & 14,46 & $-3,05$ & $-7,26$ \\
\hline Fonte: Tabela 3.3 & & & & & &
\end{tabular}

Outra distinção importante entre as empresas fabris agregadas e têxteis do estado refere-se aos índices de concentração e produtividade e à composição orgânica do capital (Tabela 3.3). As indústrias gerais paulistas, quando vistas como um todo, apresentaram índices de concentração crescentes até 1935 (excetuando-se a queda na relação trabalhofábrica no período 1933-1934) e, daí por diante, especialmente no que condiz à relação capital-fábrica, recuos. Mesmo assim, pode-se afirmar que elas estavam mais concentradas em termos de capital e trabalho em 1937 do que no período pré-crise. As empresas têxteis do estado, diferentemente, sofreram um processo de desconcentração nas duas variáveis analisadas, apesar de certa tendência altista no interregno 1933-1935. Percebe-se (Tabela 3.7) que tal desconcentração se deveu ao maior crescimento dos estabelecimentos medianos perante os de grande e pequeno portes em termos de número de operários (de $28 \%$ passam a possuir mais de $75 \%$ dos trabalhadores têxteis paulistas) e à ligeira 
ascensão das empresas de tamanho reduzido no que condiz ao montante de capital investido (de $7,87 \%$ para quase $10 \%$ do capital do ramo).

No que se refere à composição orgânica do capital, infere-se que a proporção de capital constante perante o variável cresceu no período para ambos grupos considerados, porém, a ascensão não foi contínua (recuo em 1936), nem uniforme (cresceu mais para as indústrias paulistas agregadas do que paras as têxteis isoladamente).

Por último, analisa-se a variação dos índices de produtividade. Vê-se que a produtividade cresceu nos dois casos e para as duas variáveis arroladas (capital-produto e trabalho-produto). Todavia, mais uma vez, o desempenho destas não foi linear no período. A relação capital-produto apresentou crescimento seguido de queda a partir de 1936. A relação trabalho-produto, por sua vez, caracterizou-se por grande instabilidade (avanços e recuos) para as indústrias paulistas agregadas no interregno 1932-1935, seguida de acréscimo a partir de 1936; para as têxteis, por decréscimo contínuo até 1935, acompanhada de elevação daí para frente. Além disso, observa-se que o setor fabril paulista reunido apresentou índices de produtividade maiores em 1937 do que o têxtil quanto tomado de maneira isolada.

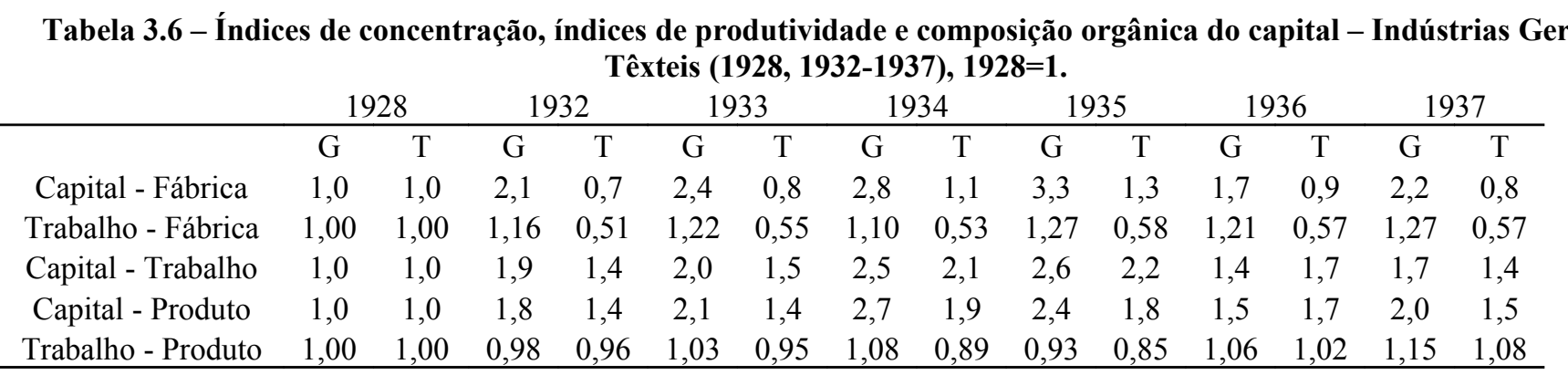

Fonte: Tabela 3.3

Conclui-se, desses dados, (i) que a concentração fabril cresceu nas indústrias do estado de São Paulo entre 1928 e 1937 e decresceu para o subsetor de tecidos; (ii) que os índices de produtividade e a composição orgânica de capital aumentaram para ambos grupos, porém mais para as empresas fabris como um todo; (iii) que a evolução destas variáveis não foi linear ao longo do período; e (iv) que o recuo verificado na indústria paulista (agregada e têxtil) em 1936 trouxe conseqüências - seja de acréscimo, seja de queda - para os índices citados. 
Tabela 3.7 - Participação relativa dos pequenos, médios e grandes estabelecimentos em termos de capital e operários - indústria têxtil paulista (1932, 1935 e 1937), em \%.*

\begin{tabular}{c|ccc|ccc|ccc}
\multicolumn{3}{c}{ Pequeno } & \multicolumn{3}{c}{ Médio } & \multicolumn{3}{c}{ Grande } \\
\hline & 1932 & 1935 & 1937 & 1932 & 1935 & 1937 & 1932 & 1935 & 1937 \\
\hline Fábricas & 69,85 & 66,34 & 69,91 & 21,49 & 22,52 & 19,00 & 8,66 & 11,14 & 11,09 \\
Capital & 12,98 & 7,87 & 9,86 & 31,94 & 26,34 & 24,87 & 55,08 & 65,79 & 65,28 \\
Operários & 11,51 & 10,85 & 3,58 & 32,76 & 28,74 & 75,54 & 55,73 & 60,42 & 20,89 \\
\hline
\end{tabular}

\subsection{2 - Os ramos}

Analisar-se-ão, agora, os desempenhos dos ramos têxteis paulistas separadamente ao longo do período, comparando-os com o do subsetor agregado. Iniciar-se-á pelo ramo algodoeiro do estado.

Observa-se (Tabela 3.8) que, em 1933, as fábricas de tecidos de algodão já haviam superado a recessão. Se, por um lado, o número de operários e o valor produtivo ainda apresentavam índices inferiores aos do período pré-crise $(-7,4 \%$ e $-2,8 \%$, respectivamente), por outro, o montante de capital $(18,7 \%)$, a força motriz instalada $(13,6 \%)$ e o número de estabelecimentos $(39 \%)$ encontravam-se em níveis mais altos. A recuperação algodoeira era apresentada também pelos jornais. O Estado de São Paulo, por exemplo, assinalou: “(...) essa indústria vinha lutando com sérias dificuldades, mas está vencendo-as (...) O progresso apresenta-se bem sensível”340. Nos dois anos seguintes, manteve-se o crescimento do ramo, porém a taxas maiores. Entre 1933 e 1935, o capital algodoeiro aumentou em 104,1\%; a força motriz, em 19,1\%; os operários empregados, em $21,2 \%$; e o valor produtivo, em $34,1 \%$. As altas taxas de crescimento geométricos do interregno 1932-1935 - especialmente das variáveis capital, operários e produção - são exemplificativas desse arranque (Tabela 3.9).

As diretorias das empresas têxteis de algodão também comprovavam em seus relatórios a melhora da situação econômica das suas respectivas fábricas. Os representantes da S.A. Fábrica de Tecidos e Bordados Lapa, por exemplo, afirmaram que “(...) o ano de 1934 decorreu em condições bem favoráveis para os negócios em geral, permitindo-nos obter um resultado satisfatório e encerrar o balanço com lucro razoável"341. Os membros da Jafet assinalaram que "o país já está saindo da crise econômica (e que) os negócios já estão reanimados (...)"342. A Labor distribuiu 8\% de dividendo aos acionistas

\footnotetext{
${ }^{340}$ O Estado de São Paulo. A Indústria Algodoeira Paulista, 11.08.1933.

${ }^{341}$ Relatório de Diretoria. S.A. Fábrica de Tecidos e Bordados Lapa, 08.03.1935.

${ }^{342}$ Ata da $49^{\circ}$ Assembléia Geral Extraordinária. S.A. Fiação, Tecelagem e Estamparia Ypiranga Jafet, 09.03.1935.
} 
e informou-os de que "os algarismos do balanço exprimem com clareza a excelente situação financeira da fábrica" ${ }^{\text {"33 }}$.

Além disso, percebe-se (Tabela 3.10) que a concentração industrial aumentou no ramo entre 1933 e 1935. A relação capital-fábrica, por exemplo, cresceu 97,2\% nesse período. O cálculo da composição orgânica do capital, por sua vez, demonstrou maior participação do capital constante em detrimento do variável. Apesar disso, a produtividade têxtil algodoeira declinou (acréscimo substancial da relação capital-produto e quase estabilidade da relação trabalho-produto).

Entre 1936-1937, acompanhando a tendência do subsetor têxtil, as fábricas de tecidos de algodão paulistas começaram a passar por problemas (Tabela 3.8). O montante de capital e o valor produtivo decresceram $37,3 \%$ e $21,2 \%$, respectivamente, no período. $\mathrm{O}$ número de operários e a força motriz instalada elevaram-se, porém de maneira quase imperceptível (Tabela 3.9).

Os documentos empresariais são bastante elucidativos da nova fase baixista do ramo. A diretoria da Japy, em 1936, afirmou que só “(...) foi possível manter a fábrica trabalhando normalmente (...) graças ao grande número de pedidos que passou do ano de 1935 para o de 1936. Entretanto, o total vendido durante o período alcançou somente $76,9 \%$ da produção, o que significa que vendemos realmente apenas 9,2 meses do ano (...) Esse fato reflete uma situação geral da indústria algodoeira, sendo possivelmente o prenúncio de uma nova fase de restrições dos negócios (...)"344. No ano seguinte, os diretores da fábrica colocaram que “(...) infelizmente, a tendência para uma depressão (...) manteve-se com persistência (...) terminamos o ano de 1937 na presença de sintomas claros de uma nova crise na indústria têxtil, caracterizada por grande retração no seu comércio" 345 . Os representantes da fábrica Lapa assinalaram, em 1937, que “(...) os resultados obtidos não compensaram (...) os nossos esforços" ${ }^{346}$. A Argos Industrial S.A., por sua vez, informou aos seus acionistas, no mesmo período, que “(...) a situação geral da indústria têxtil (é) difícil (...), em virtude do retraimento do mercado que, como conseqüência, produziu uma diminuição no volume das vendas e baixa dos preços"347.

Tabela 3.8 - Índices variados dos ramos da indústria têxtil paulista (1928, 1932-1937)

$\begin{array}{lllllll}1928 & 1932 & 1933 & 1934 & 1935 & 1936 & 1937\end{array}$

\footnotetext{
${ }^{343}$ Relatório de Diretoria. Fábrica de Tecidos Labor, 06.03.1935.

${ }^{344}$ Relatório de Diretoria. S.A. Fábrica Japy, 02.03.1936.

${ }^{345}$ Relatório de Diretoria. S.A. Fábrica Japy, 22.01.1938.

${ }^{346}$ Relatório de Diretoria. Fábrica de Tecidos Labor, 30.03.1938.

${ }^{347}$ Relatório de Diretoria. Argos Industrial S.A., 09.03.1938.
} 


\begin{tabular}{|c|c|c|c|c|c|c|c|}
\hline \multicolumn{8}{|l|}{ Algodão } \\
\hline Número de Fábricas & 100,0 & 136,6 & 139,0 & 151,2 & 143,9 & 143,9 & 157,3 \\
\hline $\mathrm{K}$ - Total (contos) & 100,0 & 80,0 & 89,1 & 152,6 & 188,0 & 175,7 & 166,3 \\
\hline $\mathrm{K}$ - Total (contos - D) & 100,0 & 104,4 & 118,7 & 200,7 & 242,3 & 188,3 & 151,9 \\
\hline Operários & 100,0 & 80,6 & 92,6 & 102,0 & 112,3 & 112,9 & 112,4 \\
\hline Força Motriz (H.P.) & 100,0 & 109,2 & 113,6 & 120,5 & 135,4 & 134,4 & 141,2 \\
\hline Produção (contos) & 100,0 & 59,3 & 72,9 & 95,4 & 101,2 & 106,9 & 112,4 \\
\hline Produção (contos-D) & 100,0 & 77,3 & 97,2 & 125,5 & 130,4 & 114,5 & 102,7 \\
\hline \multicolumn{8}{|l|}{ Juta } \\
\hline Número de Fábricas & 100,0 & 220,0 & 220,0 & 260,0 & 200,0 & 220,0 & 220,0 \\
\hline $\mathrm{K}-$ Total (contos) & 100,0 & 85,2 & 165,1 & 235,0 & 60,3 & 68,0 & 75,1 \\
\hline $\mathrm{K}-$ Total $($ contos $-\mathrm{D})$ & 100,0 & 111,0 & 220,1 & 309,0 & 77,7 & 72,9 & 68,6 \\
\hline Operários & 100,0 & 81,7 & 85,9 & 87,9 & 68,1 & 64,9 & 75,5 \\
\hline Força Motriz (H.P.) & 100,0 & 118,3 & 119,3 & 124,5 & 65,0 & 64,6 & 69,7 \\
\hline Produção (contos) & 100,0 & 40,6 & 34,5 & 36,6 & 44,7 & 35,3 & 54,4 \\
\hline Produção (contos-D) & 100,0 & 53,0 & 46,0 & 48,1 & 57,7 & 37,9 & 49,7 \\
\hline \multicolumn{8}{|l|}{ Malha } \\
\hline Número de Fábricas & 100,0 & 116,7 & 114,0 & 114,9 & 100,0 & 97,4 & 100,9 \\
\hline $\mathrm{K}-$ Total (contos) & 100,0 & 66,5 & 94,5 & 115,9 & 124,1 & 121,0 & 150,3 \\
\hline $\mathrm{K}-$ Total (contos - D) & 100,0 & 86,7 & 126,0 & 152,4 & 159,9 & 129,6 & 137,3 \\
\hline Operários & 100,0 & 66,4 & 74,1 & 77,1 & 76,0 & 76,4 & 82,7 \\
\hline Força Motriz (H.P.) & 100,0 & 52,9 & 57,7 & 67,5 & 69,1 & 55,8 & 56,1 \\
\hline Produção (contos) & 100,0 & 57,3 & 70,3 & 73,2 & 76,3 & 78,3 & 92,4 \\
\hline Produção (contos-D) & 100,0 & 74,7 & 93,7 & 96,2 & 98,3 & 83,9 & 84,5 \\
\hline \multicolumn{8}{|l|}{ Lã } \\
\hline Número de Fábricas & 100,0 & 95,2 & 85,7 & 100,0 & 90,5 & 85,7 & 100,0 \\
\hline $\mathrm{K}$ - Total (contos) & 100,0 & 126,6 & 131,6 & 178,7 & 232,1 & 208,4 & 222,8 \\
\hline $\mathrm{K}-$ Total (contos - D) & 100,0 & 165,1 & 175,4 & 235,1 & 299,2 & 223,3 & 203,6 \\
\hline Operários & 100,0 & 141,1 & 189,7 & 200,9 & 177,8 & 245,2 & 203,5 \\
\hline Força Motriz (H.P.) & 100,0 & 131,1 & 151,6 & 180,7 & 136,8 & 169,3 & 153,2 \\
\hline Produção (contos) & 100,0 & 106,0 & 56,8 & 59,5 & 63,8 & 69,4 & 77,7 \\
\hline Produção (contos- D) & 100,0 & 138,2 & 75,8 & 78,3 & 2,2 & 74,4 & 71,0 \\
\hline \multicolumn{8}{|l|}{ Seda Natural e Art. } \\
\hline Número de Fábricas & 100,0 & 176,2 & 250,0 & 307,1 & 335,7 & 419,0 & 419,0 \\
\hline K - Total (contos) & 100,0 & 153,8 & 154,3 & 215,0 & 337,0 & 353,7 & 446,8 \\
\hline $\mathrm{K}-$ Total (contos - & & & & & & & \\
\hline D) & 100,0 & 200,6 & 205,7 & 282,8 & 434,4 & 379,1 & 408,2 \\
\hline Operários & 100,0 & 117,9 & 137,9 & 143,7 & 181,4 & 215,9 & 275,5 \\
\hline Força Motriz (H.P.) & 100,0 & 158,2 & 207,9 & 257,0 & 298,2 & 370,6 & 572,2 \\
\hline Produção (contos) & 100,0 & 82,4 & 145,7 & 154,7 & 211,4 & 223,8 & 271,5 \\
\hline Produção (contos-D) & 100,0 & 107,5 & 194,2 & 203,4 & 272,5 & 239,9 & 248,1 \\
\hline
\end{tabular}

Tabela 3.9 - Taxas de crescimento geométricos - Ramos da Indústria Têxtil (1932-1937)

\begin{tabular}{|c|c|c|c|c|c|c|c|c|c|c|c|c|c|c|}
\hline & \multicolumn{3}{|c|}{ Algodão } & \multicolumn{3}{|c|}{ Juta } & \multicolumn{3}{|c|}{ Lã } & \multicolumn{3}{|c|}{ Malha } & \multicolumn{2}{|c|}{ Seda (Nat. e Art.) } \\
\hline & $\mathrm{A}^{*}$ & $\mathrm{~B}$ & $\mathrm{C}$ & $\mathrm{A}$ & $\mathrm{B}$ & $\mathrm{C}$ & $\mathrm{A}$ & $\mathrm{B}$ & $\mathrm{C}$ & $\mathrm{A}$ & $\mathrm{B}$ & $\mathrm{C}$ & $\mathrm{A}$ & $\mathrm{B}$ \\
\hline Fábricas & 2,8 & 1,8 & 4,6 & 0,0 & $-3,1$ & 4,9 & 1,0 & $-1,7$ & 5,1 & $-2,7$ & 22,5 & 0,4 & 18,8 & 23,9 \\
\hline Capital a & 7,7 & 32,4 & $-20,6$ & $-9,1$ & $-11,2$ & $-5,7$ & 4,3 & 21,9 & $-22,5$ & 9,6 & 22,6 & $-7,3$ & 15,2 & 29,3 \\
\hline Operários & 6,8 & 11,7 & 0,1 & $-1,4$ & $-5,6$ & 5,3 & 7,6 & 8,0 & 7,0 & 4,5 & 4,6 & 4,3 & 18,4 & 15,2 \\
\hline Força Motriz b & 5,3 & 7,4 & 2,1 & -10 & $-18,1$ & 3,6 & 3,2 & 1,4 & 5,8 & 1,2 & 9,3 & $-9,4$ & 29,3 & 23,5 \\
\hline Produção a & 5,9 & 19,0 & $-11,1$ & $-1,2$ & 2,9 & $-6,7$ & $-12,3$ & $-15,7$ & $-6,7$ & 2,5 & 9,6 & $-7,3$ & 18,1 & 36,3 \\
\hline
\end{tabular}

Fonte: Tabela 3.8 / * A - Período 1932-1937; B - Período 1932-1935; e C - Período 1935-1937; a - contos (D); b - H.P. 
Em termos de concentração fabril, vê-se que, apesar do crescimento do número de fábricas algodoeiras no período 1935-1937, responsáveis pela brusca diminuição da variável capital-fábrica (Tabela 3.10), as porcentagens do montante de capital investido e do número de operários das grandes empresas do ramo cresceram mais do que se comparado às mesmas elevações verificadas nas pequenas firmas (Tabela 3.11). Tais acréscimos se deram em detrimento das fábricas medianas, que perderam participação em ambas variáveis. Assim, diferentemente do que aconteceu no subsetor têxtil, não se pode afirmar que a concentração no ramo algodoeiro diminuiu no interregno 1932-1937.

Tabela 3.10 - Índices de concentração, produtividade e composição orgânica do capital - Ramos da indústria têxtil paulis (1933, 1935 e 1937)

\begin{tabular}{|c|c|c|c|c|c|c|c|c|c|c|c|c|c|c|c|}
\hline & \multicolumn{3}{|c|}{ Algodão } & \multicolumn{3}{|c|}{ Juta } & \multicolumn{3}{|c|}{ Lã } & \multicolumn{3}{|c|}{ Malha } & \multicolumn{3}{|c|}{ Seda (Nat. e Art.) } \\
\hline & 1933 & 1935 & 1937 & 1933 & 1935 & 1937 & 1933 & 1935 & 1937 & 1933 & 1935 & 1937 & 1933 & 1935 & 1937 \\
\hline Capital - Fábrica & 0,9 & 1,7 & 0,7 & 1,0 & 0,4 & 1,1 & 2,0 & 3,3 & 1,0 & 1,1 & 1,6 & 0,6 & 0,8 & 1,3 & 0,7 \\
\hline Trabalho - Fábrica & 0,7 & 0,8 & 0,7 & 0,4 & 0,3 & 0,3 & 2,2 & 2,0 & 2,0 & 0,7 & 0,8 & 0,8 & 0,6 & 0,5 & 0,7 \\
\hline Capital - Trabalho & 1,3 & 2,2 & 0,8 & 2,6 & 1,1 & 1,1 & 0,9 & 1,7 & 1,3 & 1,7 & 2,1 & 1,5 & 1,5 & 2,4 & 0,5 \\
\hline Capital - Produto & 1,2 & 1,9 & 1,5 & 4,8 & 1,3 & 1,4 & 2,3 & 3,6 & 2,9 & 1,1 & 1,6 & 1,4 & 1,1 & 1,6 & 1,6 \\
\hline Trabalho - Produto & 1,0 & 0,9 & 1,1 & 1,9 & 1,2 & 1,5 & 2,5 & 2,2 & 2,9 & 0,8 & 0,8 & 1,0 & 0,7 & 0,7 & 1,1 \\
\hline
\end{tabular}

Fonte: Tabela 3.8

Além disso, vê-se que, entre 1932 e 1935, houve crescimento da participação do ramo têxtil de algodão dentro do subsetor de tecidos paulista, exceto no que condiz ao número de estabelecimentos (Tabela 3.12). Destaque para seu aumento na participação do montante de capital investido, o qual passou de $53 \%$ para mais de $61 \%$ do total empregado entre as fábricas têxteis do estado no período. Todavia, durante o interregno recessivo (1936-1937), houve nítida inversão de tendência. Essas empresas algodoeiras perderam espaço, notadamente para o ramo da seda, em todas as variáveis arroladas. A liderança histórica do ramo de algodão no interior do subsetor têxtil paulista, apesar de ser ainda incontestável, foi diminuída.

A partir de 1938, começou-se a superar a recessão iniciada dois anos antes. Apesar de não se poder comparar os dados das Estatísticas Industriais do interregno 1928-1937 com as posteriores (1938, 1939, 1943 e 1944), por diferenças no processo de recolhimento de dados e de apresentação estatística, pode-se evidenciar o início da recuperação do ramo entre 1937-1938 por meio (i) da análise dos balanços ${ }^{348}$ e (ii) dos relatórios de diretoria e

${ }^{348}$ Não havia, nesse momento, qualquer legislação que obrigasse as sociedades anônimas a publicar balanços minimamente padronizados. Citam-se exemplos: algumas empresas indicam em seus ativos o valor agregado de seus maquinários, terreno(s), fábrica(s) e acessórios em geral, enquanto outras desagregam tais 
atas de assembléia de algumas empresas algodoeiras importantes. Observa-se (Gráfico 3.1) que, de 1934 para 1935, as inversões em máquinas das fábricas integrantes do Grupo $I^{349}$ elevaram-se (5,7\%). Seguiram-se, a partir de então, dois anos consecutivos de quedas (decréscimo de 27,9\% no período 1935-1937). Em 1938, os investimentos em bens de capital voltaram a subir, apesar do nível pré-depressivo (1935) não ter sido atingido ainda. Mesmo assim, a elevação foi indicativa de certa recuperação das mais importantes fábricas do ramo ${ }^{350}$. No ano seguinte, essa tendência ascendente foi mantida, igualando o valor de 1936.

Além dos dados apresentados, os próprios documentos oficiais das empresas direcionados aos acionistas são elucidativos dessa melhora do ramo entre 1937 e 1938. A diretoria do S.A. Moinho Santista assinalou, por exemplo, que “(...) quanto à indústria de tecelagem de algodão, ainda se verificou (em 1938) certo retraimento de parte dos compradores, mas já se nota que a crise está passando e tudo tende a estabilizar-se. Felizmente, a idéia de redução de horas de trabalho foi afastada" ${ }^{\text {351 }}$. A Argos anunciou que “(...) pelo simples exame das contas e documentos (da empresa), fica evidenciada a normalidade do nosso trabalho nesse exercício administrativo". No segundo semestre de 1938, a nova fiação da fábrica iniciou seu funcionamento, demonstrando o tal retorno à "normalidade" anunciado ${ }^{352}$. Mesmo assim, vale lembrar que algumas empresas ainda reclamavam da manutenção depressiva no período. Os diretores das Indústrias Reunidas Francisco Matarazzo, a título de ilustração, assinalaram que “(...) o ano de 1938 foi caracterizado por uma situação intranqüila" no ramo algodoeiro ${ }^{353}$.

informações; algumas firmas assinalam separadamente o valor dos seus estoques de produtos acabados, inacabados e matérias-primas; outras não; algumas empresas fazem acompanhar a conta de lucros e perdas junto com seu balanço (permitindo a discriminação dos lucros líquidos, brutos, etc.), outras não; etc. Assim, em razão da sua multiplicidade, inviabilizam-se comparações entre balanços distintos. Por esse motivo, toda vez que se realizar referência a esta fonte documental, utilizar-se-á a metodologia de agrupá-los, conforme suas respectivas semelhanças em estrutura organizacional e informativa das finanças empresariais.

${ }^{349}$ Grupo I - Argos Industrial S.A.; Cia. Fiação e Tecelagem Tatuí; Cia. Fiação e Tecidos São Bento; Cia. Nacional de Estamparia; Cia. Têxtil Brasileira; Cotonifício Guilherme Giorgi; Cotonifício Rodolfo Crespi; Fábrica de Tecidos Labor; Fábrica de Tecidos Tatuapé; Fiação e Tecelagem Santana; Fiação e Tecelagem São Paulo; S.A. Boyes; S.A. Cotonifício Paulista; S.A. Fábrica de Tecidos e Bordados Lapa; S.A. Fábrica Votorantim. Estas empresas possuíam, em 1934, capital nominal de 85.000 contos, que representava 17,9\% do total empregado no ramo algodoeiro paulista.

${ }^{350}$ Pode-se argumentar que a ascensão dos investimentos em bens de capital no interregno 1937-1938 nestas empresas deveu-se ao fim da proibição de importação de maquinismos para a indústria têxtil. Todavia, como se sabe, esse decreto não proibiu a substituição de máquinas obsoletas por outras tecnicamente superiores. Assim, como se trata de fábricas de médio e grande portes (Grupo I), que poderiam trocar parte dos seus maquinismos sem parar a produção, a possibilidade para inversões das empresas desse grupo específico existia mesmo antes de 1937, como comprovou sua ascensão no período 1934-1935.

${ }^{351}$ Relatório de Diretoria. S.A. Moinho Santista, 25.02.1939.

${ }^{352}$ Relatório de Diretoria. Argos Industrial S.A., 20.12.1938.

${ }^{353}$ Relatório de Diretoria. IRFM, 27.04.1939. 
Tabela 3.11 - Participação relativa das pequenas, médias e grandes empresas em termos de capital e operários - ramos da indústria têxtil paulista $(1932,1935$ e 1937), em \%.

\begin{tabular}{|c|c|c|c|c|c|c|c|c|c|}
\hline & \multicolumn{3}{|c|}{ Pequeno } & \multicolumn{3}{|c|}{ Médio } & \multicolumn{3}{|c|}{ Grande } \\
\hline & 1932 & 1935 & 1937 & 1932 & 1935 & 1937 & 1932 & 1935 & 1937 \\
\hline \multicolumn{10}{|l|}{ Algodão } \\
\hline Fábricas & 41,28 & 30,47 & 38,58 & 40,37 & 42,97 & 32,28 & 18,35 & 26,56 & 29,13 \\
\hline Capital & 4,89 & 1,71 & 2,78 & 39,42 & 28,47 & 23,67 & 55,69 & 69,82 & 73,55 \\
\hline Operários & 4,19 & 3,59 & 3,77 & 33,13 & 27,83 & 19,03 & 62,67 & 68,59 & 77,2 \\
\hline \multicolumn{10}{|l|}{ Juta } \\
\hline Fábricas & 27,27 & 20,00 & 36,36 & 36,36 & 40,00 & 36,36 & 36,36 & 40,00 & 27,27 \\
\hline Capital & 0,93 & 1,12 & 5,77 & 8,94 & 13,39 & 27,94 & 90,13 & 85,49 & 66,29 \\
\hline Operários & 3,35 & 0,34 & 4,69 & 18,61 & 13,77 & 21,53 & 78,04 & 85,89 & 73,79 \\
\hline \multicolumn{10}{|l|}{ Malha } \\
\hline Fábricas & 92,97 & 89,47 & 89,38 & 7,03 & 10,53 & 10,62 & 0 & 0 & 0 \\
\hline Capital & 69,9 & 48,61 & 44,31 & 30,1 & 51,39 & 55,69 & 0 & 0 & 0 \\
\hline Operários & 54,2 & 49,69 & 1,54 & 45,8 & 50,31 & 98,46 & 0 & 0 & 0 \\
\hline \multicolumn{10}{|l|}{ Lã } \\
\hline Fábricas & 50,00 & 47,37 & 35,00 & 38,89 & 36,84 & 50,00 & 11,11 & 15,79 & 15,00 \\
\hline Capital & 32,47 & 15,99 & 10,56 & 27,69 & 42,95 & 57,39 & 39,84 & 41,06 & 32,04 \\
\hline Operários & 11,58 & 12,31 & 6,79 & 55,71 & 43,83 & 57,23 & 32,71 & 43,86 & 35,98 \\
\hline \multicolumn{10}{|l|}{ Seda Natural e Art. } \\
\hline Fábricas & 84,06 & 85,92 & 86,55 & 11,59 & 10,56 & 9,94 & 4,35 & 3,52 & 3,51 \\
\hline Capital & 24,85 & 16,82 & 19,96 & 23,32 & 11,45 & 13,31 & 51,84 & 71,72 & 66,73 \\
\hline Operários & 32,06 & 29,05 & 26,12 & 19,62 & 21,93 & 22,00 & 48,32 & 49,02 & 51,88 \\
\hline
\end{tabular}

Fonte: Anexos - Tabelas 9b, 9c e 9d

Tabela 3.12 - Participação relativa dos ramos da indústria têxtil paulista no subsetor têxtil agregado do Estado de São Pau (1932, 1935 e 1937), em \%.

\begin{tabular}{|c|c|c|c|c|c|c|c|c|c|c|c|c|c|c|}
\hline & \multicolumn{3}{|c|}{ Algodão } & \multicolumn{3}{|c|}{ Juta } & \multicolumn{3}{|c|}{ Malha } & \multicolumn{3}{|c|}{ Lã } & \multicolumn{2}{|c|}{$\begin{array}{l}\text { Seda (Nat. e } \\
\text { Art.) }\end{array}$} \\
\hline & 1932 & 1935 & 1937 & 1932 & 1935 & 1937 & 1932 & 1935 & 1937 & 1932 & 1935 & 1937 & 1932 & 1935 \\
\hline Fábricas & 23,83 & 21,38 & $\begin{array}{c}21,2 \\
2 \\
53,6\end{array}$ & 2,34 & 1,81 & 1,81 & 28,30 & 20,65 & 18,91 & 4,26 & 3,44 & 3,45 & 15,74 & 25,54 \\
\hline Capital & 53,00 & 61,17 & $\begin{array}{c}6 \\
58,3\end{array}$ & 11,02 & 3,84 & 4,74 & 4,99 & 4,57 & 5,50 & 4,30 & 3,88 & 3,69 & 15,28 & 16,45 \\
\hline $\begin{array}{l}\text { Operários } \\
\text { Força }\end{array}$ & 60,53 & 63,35 & $\begin{array}{c}1 \\
65,8\end{array}$ & 8,46 & 5,30 & 5,40 & 7,71 & 6,63 & 6,63 & 5,26 & 4,98 & 5,24 & 10,67 & 12,34 \\
\hline Motriz & 66,37 & 70,96 & $\begin{array}{c}0 \\
42,1\end{array}$ & 10,87 & 5,15 & 4,91 & 1,97 & 2,21 & 1,60 & 4,44 & 3,99 & 3,97 & 5,78 & 9,39 \\
\hline Produção & 40,62 & 45,70 & 3 & 8,55 & 6,21 & 6,26 & 8,04 & 7,06 & 7,10 & 19,02 & 7,55 & 7,63 & 13,11 & 22,16 \\
\hline
\end{tabular}




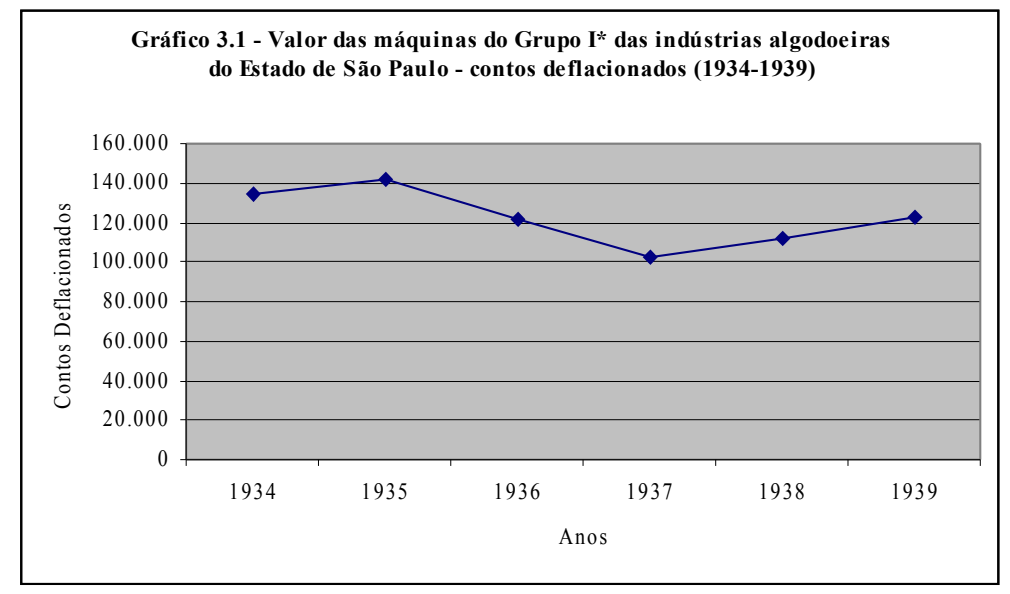

Fonte: Diário Oficial do Estado de São Paulo. Balanços de empresas do Grupo I 1934-1940. * Ver nota 349.

Em 1939, a recuperação das fábricas de tecidos paulista solidificou-se. Vê-se (Tabela 3.13) que seu consumo de energia aumentou em 11,6\% no interregno 1938-1939; seu número de operários, em 8,2\%; e, por último, seu valor produtivo, em 13,6\%. Os documentos empresariais, por sua vez, são quase unânimes na constatação dessa melhora. Os diretores da Japy, por exemplo, afirmaram que "registrou-se um resultado inesperadamente satisfatório. Depois de três anos de depressão progressiva nas vendas e de aumento constante dos estoques, tivemos pedidos em 1939 que atingiram com folga a quota normal da nossa fábrica (...); a situação financeira desta sociedade é realmente muito boa (...)"354. A Fiação Extra-Fina de Algodão “(...) terminou o seu terceiro ano de funcionamento sob os melhores auspícios $(e)(\ldots)$ conseguiu colocar toda sua produção (no mercado) (...)"355. A S.A. Indústria de Meias Eterna colocou que o “(...) o resultado (de 1939) foi promissor. Neste exercício, a fábrica trabalhou normalmente nas suas seções recém-instaladas" ${ }^{\prime 356}$.

Passa-se, agora, para a análise das empresas de juta paulistas. Observa-se (Tabela 3.8) uma assimetria em suas variáveis entre 1932 e 1934. O número de fábricas mais do que dobrou de 1928 para 1932, diminuindo ligeiramente a concentração do ramo (Tabelas 3.10 e 3.11). As participações de pequenas e médias empresas, em termos de capital, cresceram no período. Condizente com essa elevação no número de estabelecimentos, vêse que, repetindo o que acontecera no interregno 1931-1932 357 , as fábricas jutíferas apresentaram maior ascensão na variável capital invertido em todo subsetor têxtil paulista (acréscimo superior a 178\% entre 1932 e 1934, Tabela 3.8). Entretanto, no mesmo

\footnotetext{
${ }^{354}$ Relatório de Diretoria. S.A. Fábrica Japy, 07.02.1940.

${ }^{355}$ Relatório de Diretoria. Fiação Extra-Fina de Algodão, 21.02.1940.

${ }^{356}$ Relatório de Diretoria. S.A. Indústria de Meias Eterna, 31.07.1940.

${ }^{357}$ Ver Capítulo II, especialmente sub-item 2.2.2 - Juta.
} 
momento, os crescimentos da quantidade de operários empregados e da força motriz foram bem menores (7,5\% e 5,2\%, respectivamente), sendo que a mão-de-obra do ramo ainda era, em 1934, 12,1\% inferior à do nível pré-crise. Por último, o valor de produção dos tecidos de juta não só decresceu nesse interregno (-9,2\%), como se situava em patamar $51,9 \%$ abaixo do de 1928.

Há duas explicações para tal assimetria. Em primeiro lugar, lembra-se que no interregno 1928 e 1934 surgiram algumas empresas de juta de porte reduzido no estado de São Paulo, tais como o Jutifício Maria Luiza (200 contos de capital - São Paulo); a Fábrica de Maggi (200 contos - Santa Izabel); a firma Assunção \& Cia (165 contos - São Paulo); dentre outras ${ }^{358}$. Estas fábricas eram, na maioria dos casos, apenas tecelagens - o que possibilitou a pequenez de seus tamanhos - e surgiram, provavelmente, muito mais voltadas para o ensacamento de itens alimentícios para o mercado doméstico do que para o externo, em razão da crise do setor primário-exportador. Assim, esse primeiro comentário explica a elevação no número de estabelecimentos fabris de juta no período e, como se argumentará mais a frente, os módicos aumentos nas variáveis operários e força motriz.

Tabela 3.13 - Consumo de energia (Kw/h), número de operários e produção (Cr\$ 1.000 - D) dos ramos da indústria têxtil paulista (1938-1939)

\begin{tabular}{c|cc|cc|cc|} 
& \multicolumn{2}{|c|}{ Consumo energia $(\mathrm{Kw} / \mathrm{h})$} & \multicolumn{2}{c|}{ Operários } & \multicolumn{2}{c|}{ Produção (Cr\$ 1.000 D) } \\
\hline & 1938 & 1939 & 1938 & 1939 & 1938 & 1939 \\
\hline Algodão & 101.495 .117 & 113.287 .999 & 52.479 & 56.795 & 317.542 & 360.947 \\
Juta & 10.695 .142 & 14.148 .743 & 6.241 & 6.142 & 48.364 & 73.234 \\
Malha & 2.595 .922 & 3.843 .977 & 4.350 & 5.838 & 47.187 & 66.338 \\
Lã & 9.016 .019 & 10.118 .005 & 6.677 & 7.334 & 75.601 & 91.830 \\
Seda (nat. e artificial) & 15.730 .543 & 25.192 .906 & 9.336 & 12.985 & 169.498 & 187.835 \\
Têxtil geral & 148.253 .230 & 176.020 .063 & 84.582 & 95.516 & 707.844 & 815.579 \\
\hline
\end{tabular}

Fonte: Estatística Industrial do Estado de São Paulo, 1938-1939.

Em segundo lugar, para se compreender a assimetria, deve-se lembrar o caso específico da Companhia Nacional de Tecidos de Juta (CNTJ). Assim como ocorrera em 1931-1932, essa empresa foi responsável quase que sozinha pela ascensão do capital invertido no ramo entre 1932 e 1934. De 37.000 contos (1932), ela passou para 85.798 (1933) e, finalmente, 110.000 (1934). Isto é, em apenas três anos, o capital da empresa cresceu $197,2 \%{ }^{359}$. Por outro lado, observa-se que sua força motriz, operários, fusos e teares permaneceram estáticos no período ${ }^{360}$. Só há algo a inferir desses dados: a elevação

\footnotetext{
${ }_{358}$ Estatística Industrial do Estado de São Paulo, 1933, p. 36.

${ }^{359}$ Estatística Industrial do Estado de São Paulo, 1932, 1933 e 1934.

${ }^{360}$ Idem, op. cit.
} 
de capital citada foi puramente nominal. Ela não significou quaisquer acréscimos em ativos reais para a empresa. A prova mais cabal do que foi dito aconteceu no ano de 1935: a falência da Companhia Nacional de Tecidos de Juta ${ }^{361}$.

O desaparecimento da maior empresa de juta paulista foi um duro golpe para o ramo. Entre 1934 e 1935, houve redução de 74,5\% no seu montante de capital; 47,7\% na sua força motriz; e 22,5\% no seu número de operários. Em pleno pico produtivo da indústria têxtil paulista (1935), o ramo jutífero estadual passava pela maior queda em ativos reais da sua história. Além disso, vê-se (Tabela 3.10) que sua produtividade diminuiu, especialmente no que condiz à relação capital-produto. A composição orgânica também foi alterada em razão do brusco decréscimo do montante de capital. Assim, a participação do capital variável no ramo cresceu bastante. Por outro lado, nesse mesmo ano, os valores dos tecidos de juta aumentaram 19,9\%, apesar de ainda não representarem nem $60 \%$ do que haviam sido em 1928.

A recessão têxtil de 1936 agravou mais a situação desse já debilitado ramo. Entre 1935 e 1936, observam-se decréscimos em seus montantes de capital, número de operários, força motriz e valor produtivo. No ano seguinte, diferentemente do subsetor têxtil, as empresas de juta apresentaram leves crescimentos na mão-de-obra empregada, na força motriz e no seu valor de produção, os quais ainda estavam muito longe dos níveis anteriores aos da crise. Finalmente, entre 1938-1939, notam-se elevações na energia consumida e no valor produtivo, porém queda em seu número de operários (Tabela 3.13).

Viu-se, portanto, que as empresas fabris de juta do estado de São Paulo permaneceram em posição recessiva ao longo de toda década de (19)30. Excetuando-se a anomalia da elevação de seu capital já analisada e o surgimento de algumas pequenas fábricas - as quais permitiram acréscimos em alguns de seus ativos -, a tendência do ramo foi a de permanecer em patamares produtivos inferiores aos do período pré-1929. Como conseqüência, teve-se queda da sua participação relativa no subsetor têxtil paulista (Tabela 3.12). Apenas a título de ilustração: de segundo lugar em termos de montante de capital no ano de 1928 (Tabela 1.3), o ramo caiu para penúltimo, em 1937.

Analisar-se-ão, neste momento, as malharias. Percebe-se (Tabela 3.8) que, de 1932 a 1935, seu crescimento foi contínuo. Uma das mais importantes empresas do estado, a Malharia Nossa Senhora da Conceição, por exemplo, considerou que 1933 “(...) correu para a nossa indústria de maneira regular e satisfatória. Ambas as fábricas trabalharam em

\footnotetext{
${ }^{361}$ Ato de Falência da Companhia Nacional de Tecidos de Juta, 10.03.1935. Para informações mais
} específicas da empresa em sua fase já decadente, ver: Maria Izilda Matos de. Trama e poder, op. cit., p. 40. 
toda sua plenitude, sem perturbações e a sua produção encontrou sempre franca aceitação no mercado consumidor" ${ }^{\prime 362}$. Os relatórios dos dois anos seguintes mantiveram os mesmos comentários positivos $^{363}$. Além disso, entre 1934 e 1935, a S.A. Fiação para Malharia Indiana obteve os maiores volumes de vendas da sua história até então ${ }^{364}$.

Saindo do nível microeconômico e observando-se o ramo de maneira agregada, percebe-se que apenas as variáveis capital e estabelecimentos superaram os valores anteriores aos da depressão. As restantes, por sua vez, situaram-se em montantes menores, o que indica a superação incompleta da crise 1929-1932. Esse interregno também foi caracterizado pelo aumento da concentração e produtividade nas malharias paulistas (Tabela 3.10 e 3.11 ).

Em 1936, acompanhando a tendência do subsetor têxtil, observa-se certo retraimento das fábricas de malhas. Apenas o número de operários manteve-se estável entre 1935 e 1936. As demais variáveis arroladas apresentaram decréscimos, com destaque para a queda substancial do valor produtivo (-34,3\%). Em 1937, a recuperação já se fazia presente. Ao contrário do que ocorrera no ano de 1936, agora todas as variáveis assinalaram ascensões. Essa tendência de crescimento permaneceu no ramo nos anos seguintes. Vê-se (Tabela 3.13) que o consumo de energia elétrica, o número de trabalhadores e o valor produtivo das malharias tiveram acréscimos consideráveis no interregno 1938-1939 (48\%, 34,2\% e 40,5\%, respectivamente).

Por último, faz-se necessário notar dois aspectos importantes. Em primeiro lugar, essa superação incompleta da crise em grande parte da década de (19)30 explica o porquê do ramo ter perdido participação relativa em comparação com o subsetor têxtil paulista (Tabela 3.12). Em segundo, vê-se (Tabela 3.11) que, durante o período recessivo (1936), houve uma concentração industrial considerável nas malharias. $O$ dado mais impressionante refere-se à mudança na proporção em termos de operários que ocorreu nesse período entre as pequenas e as médias empresas. Aquelas, que possuíam quase $50 \%$ dos trabalhadores empregados no ramo em 1935, ficaram com um pouco menos de $2 \%$, em 1937. Enquanto isso, as fábricas de médio porte, que antes tinham 50,3\% dos operários (1935), concentravam, dois anos depois, 98,4\% dos mesmos.

Após análise das malharias paulistas, verticalizar-se-á, agora, nas empresas laníferas do estado. Estas, diferentemente dos casos anteriores (algodão, juta e malha), não sofreram conseqüências tão drásticas durante a Depressão. Vê-se (Tabela 3.8) que, em

\footnotetext{
${ }^{362}$ Relatório de Diretoria. Malharia Nossa Senhora da Conceição, 22.01.1934.

${ }^{363}$ Ver, por exemplo: Relatório de Diretoria. Malharia Nossa Senhora da Conceição, 28.02.1936.

${ }^{364}$ Relatórios de Diretoria. S.A. Fiação para Malharia Indiana, 19.03.1935 e 18.02.1936.
} 
1932, todas as variáveis arroladas, com exceção do número de estabelecimentos, situavam-se em níveis superiores aos de 1928. Em alguns casos, como no capital real investido $(65,1 \%)$ e no valor de produção $(38,2 \%)$, as ascensões foram consideráveis. Em 1933, tal tendência de crescimento permaneceu, apesar do decréscimo do número de estabelecimentos $(-9,9 \%)$ e, especialmente, do valor produtivo $(-45,1 \%)$. No ano seguinte, todas as variáveis apresentaram elevações, algumas em maior escala (capital, 34\%), outras em menor (operários, 5,9\%). O valor produtivo dos tecidos de lã, apesar de também ter crescido $(3,2 \%)$, ainda estava mais de $21 \%$ abaixo dos patamares de 1928 . Uma das mais importantes empresas do ramo, o Lanificio Anglo-Brasileiro, informou aos seus acionistas, em 1934, que “(...) a Diretoria não tem poupado esforços para o engrandecimento do lanifício; hoje consideravelmente aumentado com aquisição de novos maquinismos, novos prédios e com o melhoramento de todos os seus produtos (...)"365.

A partir desse momento, o ramo ingressará em certas instabilidades. Como se pode observar (Tabela 3.8), apesar do montante de capital e do valor produtivo continuarem crescendo de 1934 para 1935 (27,2\% e 4,9\%, respectivamente), houve quedas nada insignificantes no que se refere ao número de operários $(-11,4 \%)$ e, em especial, à força motriz instalada (-24,2\%). Assim, o ritmo de crescimento lanífero em São Paulo, que já não era dos maiores (Tabela 3.9), sofreu abalos em pleno auge produtivo do subsetor têxtil estadual (1935). No ano seguinte, a situação entre as variáveis se inverteu: capital e valor produtivo decresceram $(-25,3 \%$ e $-9,4 \%$, respectivamente); e operários e força motriz se elevaram $(37,9 \%$ e $23,7 \%$, respectivamente). Em 1937, todas as variáveis sofreram quedas, com exceção do número de estabelecimentos. Dessa vez, a recessão atingira o ramo plenamente. Por último, entre 1938 e 1939, acompanhando o desempenho do subsetor têxtil (Tabela 3.13), as fábricas de lã apresentaram recuperações: consumiram mais energia elétrica $(12,2 \%)$, contrataram mais operários $(9,8 \%)$ e obtiveram ganhos superiores com suas vendas $(21,4 \%)$.

Durante o período, percebeu-se que seus índices de produtividade cresceram, apesar de leve queda no interregno 1935-1937 (Tabela 3.10), enquanto sua concentração diminuiu (Tabelas 3.10 e 3.11). Houve decréscimo da participação de pequenos e grandes estabelecimentos em termos de capital e trabalho. Por outro lado, as empresas de porte mediano, que representavam menos de $44 \%$ do número de operários e do capital invertido no ramo em 1935, superavam já os 57\% em ambas variáveis no ano de 1937.

Observa-se, também, (Tabela 3.12) que as fábricas laníferas perderam espaço

${ }^{365}$ Ata Assembléia Geral Ordinária. Lanifício Anglo-Brasileiro, 31.03.1934. 
dentro do subsetor têxtil estadual no período em foco. Em todas as variáveis arroladas, houve decréscimo de participação relativa. Destaca-se, nesse sentido, a queda de representatividade do valor produtivo dos tecidos de lã. Em 1932, 19\% do valor de produção têxtil paulista devia-se às empresas laníferas; enquanto, em 1937, tal porcentagem caiu para $7,63 \%$.

Por último, analisar-se-á o desempenho do ramo têxtil das sedas (natural e artificial). Semelhante ao caso lanífero, como já se mostrou, as fábricas de seda paulistas não vivenciaram, entre 1929 e 1932, uma crise econômica comparável aos demais ramos têxteis do estado, tais como o algodoeiro, o jutífero e o de malhas. Melhor seria dizer que aquelas passaram por uma retração produtiva, que pouco afetou aqui suas variáveis econômicas fundamentais (capital empregado, operários e força motriz).

Assim, observa-se (Tabela 3.8) que, em 1932, as empresas de seda paulistas já se encontravam em níveis superiores aos do momento pré-depressivo em todas as variáveis apresentadas. Destaca-se, aqui, o capital real invertido, que dobrou nesse interregno $(100,6 \%)$. Entre 1932 e 1935, o ramo cresceu como nunca em sua história. As porcentagens de expansão das variáveis impressionam pela magnitude: estabelecimentos (90,5\%); capital (116,5\%); operários $(53,8 \%)$; força motriz $(88,4 \%)$; e valor produtivo $(153,4 \%)$. Percebe-se que as taxas geométricas de crescimento do ramo foram as maiores do subsetor, em quaisquer dos períodos considerados (Tabela 3.9).

Os relatórios de diretoria das empresas e seus dados em balanço são bastante elucidativos dessa realidade expansionista. No caso das tecelagens de seda natural, citamse alguns exemplos. O presidente da Lavínia, em 1934, “(...) salientou o excelente andamento dos negócios sociais, que permitiu a obtenção de lucros compensadores (...)"366. Afirmou ainda que “(...) é de prever-se que os negócios, neste ano (1934), apresentarão resultados equivalentes e, quiçá, superiores aos do ano anterior, mesmo porque se nota, em todos os negócios, uma indisfarçável tendência de melhora" 367 . E, realmente, como fora previsto, a empresa se expandiu entre 1933 e 1934. Sua capacidade produtiva foi ampliada em 3,7\%; seus lucros líquidos foram 6\% maiores e distribuíram-se dividendos aos acionistas equivalentes a mais de $13 \%$ do capital social da fábrica ${ }^{368}$. Os diretores da Tecelagem de Seda N. S. da Penha S.A., por sua vez, lembravam aos seus proprietários, em 1935, que os resultados obtidos pela empresa no período foram "ótimos" e que isso se deveu, “(...) principalmente, a boa aceitação que o nosso produto tem

\footnotetext{
${ }^{366}$ Ata Assembléia Geral Ordinária. S.A. Tecelagem de Seda Lavínia, 08.02.1934.

${ }^{367}$ Idem.

${ }^{368}$ Balanço. S.A. Tecelagem de Seda Lanívia, 23.03.1935.
} 
encontrado no mercado" 369 . Os jornais paulistas também assinalaram esse boom do ramo no período. O Estado de São Paulo, por exemplo, lembrava aos leitores, em 1935, que, “embora seja das mais novas em território paulista, a indústria de tecidos de seda cresceu e prosperou maravilhosamente nos últimos três anos" ${ }^{\text {"370. }}$.

Deve-se lembrar que nem todas as tecelagens de seda natural do estado passaram por tal situação expansionista. Houve uma notável exceção: a S.A. Tecelagem de Seda Ítalo-Brasileira, cuja situação econômica, crítica em razão da impossibilidade de concretização do holding suíço previsto antes da ocorrência da crise mundial de 1929, piorou nesse momento. Seu capital teve de ser bruscamente reduzido. De 25.000 contos (1928) passou para menos de $14.000(1933)^{371}$. O mesmo aconteceu com várias das suas subsidiárias, tal como S.A. Indústria de Seda Nacional, cujo capital decresceu 95\% no interregno citado $^{372}$. A S.A. Indústria Artefatos de Seda, pertencente ao grupo, entrou em liquidação ${ }^{373}$. Assim, impossibilitada de pagar seus compromissos, a Ítalo-Brasileira, incluindo toda sociedade das sedas, foi vendida para o grupo Matarazzo, em $1935^{374}$. Apesar da importância dessa empresa em termos de tamanho, vale lembrar que a situação vivida pela mesma foi um caso isolado dentro do ramo das sedas, como os próprios dados agregados demonstraram (Tabela 3.8). Fruto de decisões empresariais equivocadas, inseridas num contexto financeiro internacional delicado (1929-1932), o desempenho econômico catastrófico desse grupo fabril foi a exceção e não a regra vivida pelas demais fábricas no período.

Se as empresas de seda natural vivenciavam boa situação entre 1932-1935, nada diferente poderia ser dito das produtoras de seda artificial, especialmente para as duas fiações de rayon existentes no estado. A Rhodiaseta, por exemplo, em seu relatório de 1933, anunciou aos acionistas: "Confirmando as promessas auspiciosas obtidas pelos resultados do exercício anterior (1932), é com real satisfação que vimos informar-vos do crescente desenvolvimento das vendas, que ultrapassaram rapidamente as previsões" ${ }^{\text {375 }}$. A outra produtora, Visco Seda Matarazzo, trabalhava com “(...) toda sua capacidade de produção, $(e)$ seus artigos encontram a mais lisonjeira aceitação nos mercados de consumo" 376 .

\footnotetext{
${ }^{369}$ Relatório de Diretoria. Tecelagem de Seda N. S. da Penha S.A., 26.05.1934.

${ }^{370}$ O Estado de São Paulo. A indústria de seda, 31.08.1935.

${ }^{371}$ Balanço. S.A. Tecelagem de Seda Ítalo-Brasileira, 17.04.1929 e 24.03.1934.

${ }^{372}$ Balanço. S.A. Indústrias de Seda Nacional S.A., 04.08.1929 e 24.03.1933.

${ }^{373}$ Ata Assembléia Geral Extraordinária. S.A. Indústrias Artefatos de Seda, 21.12.1936.

${ }^{374}$ Ata Assembléia Geral Extraordinária. S.A. Tecelagem de Seda Ítalo-Brasileira, 15.09.1935.

${ }^{375}$ Relatório de Diretoria. Cia. Brasileira de Sedas 'Rhodiaseta', 31.12.1933.

${ }^{376}$ Ata Assembléia Geral Extraordinária. Indústrias Reunidas Francisco Matarazzo, 14.10.1933.
} 
A expansão das tecelagens de seda no período era fonte de crescente mercado para ambas empresas. Lembra-se, entretanto, que essa estrutura oligopolista da oferta de fios de rayon em São Paulo gerou diversos protestos dos compradores em razão dos supostos preços excessivos do produto. Em 1934, José Ermírio de Moraes, presidente da S.A. Fábricas Votorantim, acusou a Visco Seda de "monopolista"377. Matias Ayres, representante das Indústrias Reunidas Francisco Matarazzo, rebateu as críticas. Afirmou que “(...) a indústria de seda artificial é livre no país (...) Nenhuma patente impede de fabricar ou importar seus fios (...) A própria Votorantim, ao que se diz, já projetou a instalação de uma (fiação de rayon) em seus domínios (...)"378. De maneira irônica, chamou José Ermírio de Moraes de "cavaleiro andante das liberdades do comércio e da indústria”, o qual, segundo ele, apesar do mesmo defender a não-interferência estatal na economia, havia feito naquele próprio ano requerimentos ao governo para obtenção de duas patentes: uma para indústria do óleo e outra para a utilização da água do mar em certos processos químicos da empresa ${ }^{379}$.

Independentemente desse embate, Ayres acertou quando se referiu ao interesse da Votorantim em abrir a sua própria fiação de seda artificial. Em 1935, a Companhia NitroQuímica Brasileira, em consórcio com a própria Votorantim e os Klabin, fundou uma terceira fábrica produtora de fios de rayon em São Paulo. Construída nos dois anos seguintes, ela entrou em funcionamento em $1937^{380}$.

Em 1936, diferentemente do que ocorrera no subsetor têxtil paulista, o ramo das sedas manteve razoável crescimento, apesar das quedas no capital real investido $(-2,7 \%)$ e no valor produtivo $(-11,9 \%)$. Por outro lado, o número de estabelecimentos $(24,8 \%)$; a quantidade de operários empregados $(19 \%)$; e força motriz instalada $(24,2 \%)$ cresceram consideravelmente. A Tinturaria de Seda Arnaldo Pessina S.A., por exemplo, fundada em 1934, assinalou que “(...) os negócios sociais correram com toda normalidade e com resultados satisfatórios”381. Seu capital social foi ampliado de 800 para 2.000 contos de réis entre 1935 e $1936^{382}$. Neste último ano, fundou-se também uma fábrica de seda de grande porte no estado: a Textila S.A. (6.600 contos de capital $)^{383}$. Em seu primeiro relatório, os diretores afirmaram que “(...) considerando apenas os dez meses de trabalho e

\footnotetext{
${ }^{377}$ O Estado de São Paulo. A propalada ameaça ao algodão sintético, 14.11.1934.

${ }^{778}$ O Estado de São Paulo. Discurso pronunciado pelo Sr. Matias Ayres, representante das Indústrias Reunidas Francisco Matarazzo na reunião da Câmara de Produção, Tarifas e Transportes, 25.11.1934.

${ }^{379}$ Idem.

${ }^{380}$ Wilson Suzigan. Indústria brasileira (...), op. cit., p. 348.

${ }^{381}$ Relatório de Diretoria. Tinturaria de Seda Arnaldo Pessina S.A., 28.02.1937.

${ }^{382}$ Balanço. Tinturaria de Seda Arnaldo Pessina S.A., 05.03.1936.

${ }^{383}$ Escritura de Constituição. Textila S.A., 12.03.1936.
} 
as despesas excepcionais do primeiro ano de constituição (...)", devia-se olhar com "otimismo o exercício (de 1936)"384.

Em 1937, percebia-se claramente que não existia recessão nas fábricas paulistas de sedas. O ramo se expandiu em todas as variáveis arroladas entre 1936 e 1937 (Tabela 3.8), menos no que condiz ao número de estabelecimentos. Destacaram-se os crescimentos na força motriz $(54,3 \%)$ e na mão-de-obra empregada (27,6\%). A diretoria da Rhodiaseta afirmou, naquele ano, que “(...) o nosso produto tem sempre boa procura, graças ao aumento considerável de fábrica de tecidos de seda (grifo nosso) ${ }^{\prime 385}$. Os diretores da Arnaldo Pessina, por sua vez, assinalaram que “(...) o aumento constante das encomendas (em 1937), assim como as amistosas relações que nos prendem aos nossos clientes, são indícios certos de que os negócios sociais hão de trilhar sempre pelo caminho da prosperidade" ${ }^{\sharp 86}$. Por fim, entre 1938 e 1939, vê-se que seu crescimento prosseguiu (Tabela 3.13). O consumo de energia elétrica (60,1\%); o número de operários (39\%); e o valor produtivo real $(10,8 \%)$ das fábricas de seda do estado mantiveram-se em ascensão.

Ao longo do período, observou-se (Tabela 3.10) que sua produtividade cresceu, apesar do brusco decréscimo, entre 1935 e 1937, da composição orgânica de capital. Por outro lado, apesar dos índices agregados de concentração (capital-fábrica e trabalhofábrica) também terem apresentado quedas, percebe-se (Tabela 3.11) que não houve uma desconcentração no ramo. As grandes empresas, que possuíam, em 1932, 51,8\% do capital empregado e 48,3\% do número de operários das fábricas de seda paulistas, passaram a representar, em 1937, 66,73\% e 51,8\%, respectivamente. Essa assimetria pode ser explicada pela incorporação, nos cálculos da Tabela 3.11, das fiações de seda, em especial as de rayon, que são poucas empresas, porém de grande porte. Com isso, maximiza-se a importância destas últimas em detrimento das pequenas e médias.

Além desse aspecto, lembra-se também que o boom do ramo de seda paulista nos anos (19)30 trouxe mudanças na sua participação relativa em comparação com o subsetor têxtil do estado. Percebe-se (Tabela 3.12) que, em número de estabelecimentos, ele já era, em 1937, o maior. Nas variáveis restantes (capital investido, operários, força motriz e valor de produção), encontrava-se em segundo, perdendo apenas para aquele que fora o pioneiro dentre os ramos de tecidos domésticos: o algodão. A grande distância que separava as fábricas algodoeiras paulistas das de seda em 1928, todavia, foi diminuída nesse momento.

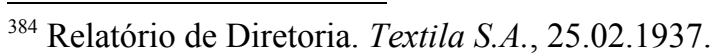

${ }^{385}$ Relatório de Diretoria. Cia. Brasileira de Sedas 'Rhodiaseta', 25.03.1937.

${ }^{386}$ Relatório de Diretoria. Tinturaria de Seda Arnaldo Pessina S.A., 19.02.1938.
} 
Analisados todos ramos têxteis paulistas, far-se-á, por fim, breve comentário sobre a distribuição espacial das empresas entre a capital e o interior do estado no período (Tabela 3.14). Em termos de número de empreendimentos e de capital investido, vê-se que houve maior crescimento das unidades produtivas têxteis do interior do que as da cidade de São Paulo. Aquelas, que não representavam nem 38\% do capital das fábricas de tecidos estaduais em 1932, passaram a concentrar, cinco anos depois, quase 50\% do mesmo. Todavia, no que condiz ao número de operários, a situação era inversa. Em 1932, as fábricas paulistanas possuíam 55,6\% dos trabalhadores empregados no subsetor têxtil agregado; em 1937, tal porcentagem cresceu para 84,5\%. Como a proporção entre número de estabelecimentos variou bem menos entre interior e capital, pode-se afirmar que na cidade de São Paulo predominaram, nesse período, investimentos intensivos em trabalho (labour intensive), enquanto, no interior paulista, teve-se, principalmente, inversões intensivas em capital (capital intensive).

Tabela 3.14 - Localização das indústrias têxteis paulistas - Capital (C) e Interior (I) - 1932, 1935 e 1937

\begin{tabular}{|c|c|c|c|c|c|c|c|c|c|c|c|c|}
\hline & \multicolumn{12}{|c|}{1932} \\
\hline & \multicolumn{2}{|c|}{ Geral } & \multicolumn{2}{|c|}{ Algodão } & \multicolumn{2}{|c|}{ Juta } & \multicolumn{2}{|c|}{ Lã } & \multicolumn{2}{|c|}{ Malha } & \multicolumn{2}{|c|}{ Sedas } \\
\hline & $\mathrm{C}$ & I & $\mathrm{C}$ & 1 & $\mathrm{C}$ & I & $\mathrm{C}$ & I & $\mathrm{C}$ & I & $\mathrm{C}$ & I \\
\hline Fábricas & 74,3 & 25,7 & 50,5 & 49,5 & 63,6 & 36,4 & 91,4 & 8,6 & 72,2 & 27,8 & 82,6 & 17,4 \\
\hline Capital & 62,6 & 37,4 & 53,5 & 46,5 & 93,2 & 6,8 & 81,1 & 18,9 & 52,0 & 48,0 & 68,9 & 31,1 \\
\hline Operários & 55,6 & 44,4 & 47,5 & 52,5 & 81,1 & 18,9 & 80,7 & 19,3 & 62,5 & 37,5 & 60,3 & 39,7 \\
\hline & \multicolumn{12}{|c|}{1935} \\
\hline Fábricas & 75,8 & 24,2 & 57,0 & 43,0 & 60,0 & 40,0 & 89,5 & 10,5 & 68,4 & 31,6 & 83,8 & 16,2 \\
\hline Capital & 59,0 & 41,0 & 57,2 & 42,8 & 71,7 & 28,3 & 76,6 & 23,4 & 63,2 & 36,8 & 56,5 & 43,5 \\
\hline Operários & 56,2 & 43,8 & 51,7 & 48,3 & 65,4 & 34,6 & 78,2 & 21,8 & 55,9 & 44,1 & 62,8 & 37,2 \\
\hline & \multicolumn{12}{|c|}{1937} \\
\hline Fábricas & 71,7 & 28,3 & 47,2 & 52,8 & 54,5 & 45,5 & 89,4 & 10,6 & 65,0 & 35,0 & 80,1 & 19,9 \\
\hline Capital & 50,7 & 49,3 & 45,7 & 54,3 & 60,4 & 39,6 & 78,3 & 21,7 & 50,5 & 49,5 & 54,1 & 45,9 \\
\hline Operários & 84,5 & 15,5 & 45,0 & 55,0 & 60,2 & 39,8 & 99,4 & 0,6 & 57,2 & 42,8 & 61,0 & 39,0 \\
\hline
\end{tabular}

Observando-se os ramos isoladamente, percebe-se que as unidades têxteis interioranas ganharam participação, na maioria dos casos, perante as da capital. $\mathrm{O}$ caso mais drástico foi o da juta. Em 1932, mais de 93\% do capital invertido e $81 \%$ dos operários das fábricas jutíferas encontravam-se na cidade de São Paulo; em 1937, tais porcentagens eram pouco superiores a $60 \%$ apenas. A mudança espacial dos fatores de produção no ramo das sedas também foi grande. No ano de 1932, as fábricas de seda paulistanas concentravam $68,9 \%$ do capital do subsetor estadual; cinco anos depois, possuíam $54,1 \%$ do mesmo. Interessante observar que tal modificação não aconteceu com 
a variável operários. Nesta, as unidades interioranas perderam ligeiramente para as da capital. Compreende-se essa assimetria ao se lembrar que as fiações de seda, em especial as de rayon - que eram empresas de grande porte e possuíam altas relações orgânicas de capital -, situavam-se em São Bernardo do Campo e em São Caetano. No que condiz às fábricas de tecidos de algodão e às malharias, vê-se que o processo de interiorização se deu em menor escala. Por fim, o ramo lanífero apresenta-se, de certa maneira, como exceção. De um pouco mais de $80 \%$ do número de operários das unidades produtoras de lã (1932), as empresas paulistanas passaram a concentrar, em 1937, 99,4\% dos mesmos. Entretanto, em termos de capital investido, vê-se que as fábricas laníferas do interior aumentaram sua participação no total estadual de 18,9\% (1932) para 21,7\% (1937). Confirma-se, aqui, a tendência das unidades produtivas maiores, portadoras de técnicas do tipo capital intensive, situarem-se no interior, em vários dos ramos estudados.

\subsection{3 - Análise da evolução têxtil paulista no período 1932-1939}

Apesar das diferenças de desempenho econômico entre os ramos têxteis paulistas durante o período 1932-1939, evidencia-se que (i) entre 1932 e 1935, excetuando-se as empresas de juta, processou-se a recuperação do subsetor de tecidos estadual diante da crise - ou da retração produtiva, nos casos lanífero e das sedas - desencadeada em 1929; (ii) o interregno 1936-1937, para a maioria deles, com exceção das fábricas de sedas, significou um momento de recessão econômica; e que (iii) os anos de 1938 e 1939 se caracterizaram pela recuperação da tendência baixista anterior. Assim, neste tópico, objetiva-se analisar os fatores responsáveis pela ocorrência desses três distintos momentos.

\section{$\underline{3.2 .3 .1-1932-1935}$}

A compreensão do processo de recuperação das fábricas de tecidos paulista no interregno 1932-1935 passa pelo entendimento da própria recuperação econômica doméstica. Em outras palavras, os fatores explicativos da superação da crise depressiva de 1929 pela economia local também lançam luz sobre o crescimento têxtil estadual no mesmo período. Dessa maneira, a política governamental de auxílio ao café, fomentadora da renda interna, como já fora assinalado, possibilitou reerguer o mercado diante da conjuntura econômica baixista vivenciada no período. Concomitantemente, o processo de desvalorização do mil-réis, ao encarecer as mercadorias importadas do estrangeiro, tornou 
tal mercado local em recuperação cativo para as unidades fabris internas.

Além desses fatores já citados, acrescenta-se também a modificação da tarifa-ouro realizada pelo Governo Federal em setembro de $1931^{387}$. Esta reduziu, em média, as taxas alfandegárias locais em $20 \%$, porém aumentou a proporção em ouro nelas para $80 \%$. Assim, devido à depreciação cambial, houve aumento real de $24 \%$ nos impostos sobre bens externos, quando comparado às pautas anteriores. Todavia, essa reforma tarifária foi uma faca de dois gumes para as indústrias. A nova taxa só incidiria nas mercadorias dos países que não possuíam acordos comerciais com o Brasil. Aqueles que realizassem tais acordos teriam direito a outra taxa, 20\% menor do que a pauta antecessora. Vê-se, portanto, que a reforma em questão visava realizar uma política de pressão sobre os países compradores dos bens locais, notadamente o café. "Assim, inicialmente, a revisão propiciou proteção às indústrias, mas, à medida que os acordos comerciais eram feitos, a taxa mínima foi sendo colocada para vários países, prejudicando o setor fabril nacional”388. Independentemente disso, é inegável que, ao menos no início, a reforma também foi responsável, juntamente com a desvalorização monetária, pelo encarecimento dos bens estrangeiros aqui ingressos no início dos anos (19)30.

Dessa maneira, pode-se dizer que (a) importações com preços altos e (b) mercado doméstico em recuperação foram os fatores fundamentais que propiciaram o processo de substituição de importações pelas unidades fabris locais. As fábricas têxteis, possuidoras de capacidade produtiva ociosa, aproveitaram esse período sui generis da economia brasileira para expandir sua produção, recuperando-se da crise.

Pode-se constatar o que foi dito anteriormente observando as Tabelas 3.15 e 3.16. As produções de tecidos de algodão, malhas e sedas cresceram consideravelmente no interregno 1928-1935, em detrimento das importações. Destaca-se, nesse sentido, a ascensão das sedas, cuja elevação produtiva naquele momento foi superior a $850 \%$, enquanto as compras desses tecidos do exterior decresceram em $61 \%$. Comparativamente, o ramo lanífero apresentou crescimento mais modesto em sua produção (17\%, no período 1928-1934), apesar da queda considerável nas suas importações entre 1928 e 1932 $(-88,9 \%)$. Por outro lado, as fábricas de juta paulistas assinalaram, no interregno 1928-1932, quedas produtivas superiores a 99\%, enquanto, ao mesmo tempo, reduziramse as importações desses tecidos pelo porto de Santos (-96,7\%). Nesse caso, a crise do setor primário-exportador, como já foi assinalado, justifica o mau desempenho.

\footnotetext{
${ }^{387}$ Edgard Carone. A República Nova, op. cit., p. 58.

${ }^{388}$ Idem, op. cit., p. 58-59.
} 
Tabela 3.15 - Produção têxtil paulista discriminada por ramos (1932-1937), em metros

\begin{tabular}{cccccccc} 
& 1928 & 1932 & 1933 & 1934 & 1935 & 1936 & 1937 \\
\hline Algodão & 191.139 .000 & 200.592 .480 & 232.012 .047 & 278.490 .007 & 273.112 .314 & 296.249 .647 & 287.220 .638 \\
Juta & 62.808 .000 & 42.933 .318 & 43.171 .578 & 50.675 .292 & 45.395 .788 & 34.498 .874 & 44.042 .290 \\
Malha & $*$ & 18.796 .281 & 26.441 .591 & 26.519 .239 & 24.079 .851 & 28.137 .672 & 22.574 .708 \\
Lã & 4.330 .000 & 4.318 .406 & 4.230 .635 & 5.048 .000 & 4.192 .095 & 4.427 .352 & 4.358 .201 \\
Sedas(1) & 173.157 & 443.367 & 966.891 & 1.247 .444 & 1.650 .570 & $*$ & $*$ \\
Sedas(2) & $*$ & 10.095 .991 & 22.017 .252 & 19.781 .723 & 25.541 .276 & 24.036 .532 & 39.842 .685 \\
\hline
\end{tabular}

Fonte: Estatística Industrial do Estado de São Paulo, 1928 e 1932-1937; Anexo - Tabela 7. (1) quilos; (2) metros.

Para além desse aspecto, vê-se (Tabela 3.17) que a relação peso / preço de tecidos importados pelo porto de Santos decresceu para todos ramos no interregno 1928-1935. Tal desempenho deveu-se a dois fatores: (a) encarecimento das importações e (b) importações têxteis de maior valor agregado, ou seja, predominância da compra de tecidos de luxo do exterior.

Tabela 3.16 - Importação de Tecidos - Porto de Santos (1932-1937), em quilos

\begin{tabular}{cccccccc} 
& 1928 & 1932 & 1933 & 1934 & 1935 & 1936 & 1937 \\
\hline Algodão & 3.195 .815 & 158.982 & 362.108 & 289.651 & 305.253 & 310.934 & 351.419 \\
Juta & 166.516 & 5.355 & 6.148 & 8.220 & 9.058 & 11.017 & 12.297 \\
Lã & 545.170 & 60.140 & 124.986 & 126.924 & 148.424 & 155.298 & 195.084 \\
Seda Natural & 18.308 & 925 & 2.292 & 1.816 & 6.426 & 1.694 & 5.046 \\
Seda Artificial & 1.447 & 111 & 181 & 367 & 1.266 & 226 & 1.271 \\
Tecidos em geral & 4.366 .233 & 308.911 & 741.607 & 619.060 & 649.409 & 734.505 & 909.086 \\
\hline Fonte: Estatística do Comércio do Porto de Santos, 1928 e 1932-1937. & & &
\end{tabular}

Por outro lado, apesar das tabelas acima mencionadas demonstrarem a ocorrência da substituição de importações têxteis nos ramos paulistas de algodão, malha e sedas no período 1928-1935, há ainda certos problemas que não podem ser explicados apenas por essa tese. Cita-se, por exemplo, a disparidade no crescimento das produções desses ramos quando comparados com suas respectivas importações. $\mathrm{O}$ caso das sedas é o mais perceptível nesse aspecto. Enquanto as compras desses tecidos do exterior decresceram 17.282 quilos entre 1928-1933, sua produção doméstica elevou-se em 793.734 quilos. Infelizmente, em razão das variáveis produção e importação de têxteis algodoeiros se encontrarem em unidades distintas (metros e quilos, respectivamente), não se pode fazer as mesmas considerações para tal ramo. No entanto, vê-se que, no interregno 1932-1933, enquanto as aquisições estrangeiras de tecidos de algodão pelo porto de Santos mais do que dobraram (apesar de ainda se encontrarem em patamar muito inferior ao de 1928), a produção estadual não permaneceu estagnada. Pelo contrário, houve elevação em mais de 
30 milhões de metros. Já no que se refere às malharias, a possibilidade de inferência proporcionada pelos dados existentes é baixa, pois as Estatísticas do Comércio do Porto de Santos não discriminavam a importação do que eram malhas. Mesmo assim, o crescimento de sua produção superior a 7.600 milhões de metros entre 1932 e 1933 é um indício de que tal ascensão possivelmente não se destinou apenas a substituir importações.

Tabela 3.17 - Relação peso / preço de tecidos importados pelo porto de Santos (1928, 1932-1937)

\begin{tabular}{cccccccc} 
& 1928 & 1932 & 1933 & 1934 & 1935 & 1936 & 1937 \\
\hline Algodão & 63,4 & 43,5 & 38,2 & 37,2 & 33,4 & 38,2 & 35,8 \\
Juta & 366,3 & 111,6 & 83,1 & 66,8 & 80,9 & 153,0 & 99,2 \\
Lã & 37,2 & 29,2 & 26,9 & 23,8 & 18,0 & 19,5 & 19,7 \\
Seda Nat. & 8,2 & 3,3 & 4,8 & 4,3 & 6,9 & 4,3 & 6,1 \\
Seda Art. & 19,7 & 4,8 & 2,7 & 9,2 & 7,6 & 7,5 & 19,3 \\
Tecidos & 58,4 & 38,9 & 35,1 & 32,6 & 24,6 & 27,1 & 7,4 \\
\hline
\end{tabular}

Fonte: Comércio de Cabotagem pelo Porto de Santos, 1928 e 1933-1937.

Dessa maneira, deve-se procurar outros fatores, para além do processo substitutivo de importações, que possam explicar os acréscimos substanciais nesse período das produções de tecidos de algodão, malhas e, principalmente, sedas paulistas. Para Paul Singer, a chamada "expansão têxtil" deveu-se, sobretudo, ao "crescimento da demanda interna”, gerada pelo aprofundamento da divisão inter-regional do trabalho doméstica ${ }^{389}$. Esta se caracterizou pela integração de regiões à economia de mercado que antes, devido ao seu isolamento, estavam estruturadas em regime de subsistência. Segundo ele, a integração foi promovida, em grande parte, pelo desenvolvimento do transporte rodoviário, iniciado no final dos anos (19)20 e impulsionado a partir da década de 1930.

Tal análise procede em partes. Sabe-se que entre os anos (19)20 e (19)40 iniciou-se uma considerável expansão rodoviária local. Dentre as estradas construídas nesse período, destacam-se a Rio-Petrópolis; São Paulo-Campinas; São Paulo-Rio; São Paulo-Santos; a nova São Paulo-Jundiaí; as vias Anchieta e Anhangüera e a Campinas-Riberão Preto ${ }^{390}$. Dessa maneira, houve, no momento estudado, uma ampliação do mercado interno mediante a incorporação de áreas de subsistência à economia mercantil, principalmente em São Paulo. Por outro lado, sabe-se também que o verdadeiro boom rodoviário local aconteceu somente a partir dos anos (19)50 391 . Inviabiliza-se, assim, creditar apenas a isso o crescimento têxtil paulista do interregno 1932-1935.

\footnotetext{
389 Paul Singer.Interpretação do Brasil: uma experiência histórica de desenvolvimento. In: Boris Fausto (org). História Geral da Civilização Brasileira. Tomo III. Volume 4. Ed. Difel, São Paulo, 1994, p. 217. ${ }^{390}$ Barjas Negri, op. cit., p. 63 e 79.
} 
$\mathrm{Na}$ verdade, além da substituição de importações e da ampliação do mercado doméstico, houve, por grande parte das indústrias de tecidos de São Paulo, uma conquista de mercados regionais já estabelecidos, especialmente na região Nordeste do País. As unidades têxteis dos demais estados da Federação foram perdendo espaço em seus próprios territórios de origem para as congêneres paulistas. Essa conquista foi processada, principalmente, pelo comércio de cabotagem, apesar de não se poder fazer inferências empíricas acerca do papel das ferrovias neste processo, por falta de informações estatísticas. Vê-se (Tabela 3.18) que o comércio costeiro local cresceu consideravelmente entre 1928 e 1934, especialmente no que se refere ao valor transacionado (27,5\%). O jornal Folha da Manhã, em 1933, assinalou que era “(...) patente (...) a marcha ininterrupta do escambo de produtos entre os estados brasileiros (...)"392.

Dentro desse contexto de crescente intercâmbio interno por vias de cabotagem, São Paulo começava a se destacar como vendedor de bens manufaturados para as demais unidades federativas. Em 1928, o estado, que possuía balança comercial doméstica deficitária tanto em termos quantitativos quanto em valores, passou, no início dos anos (19)30, a apresentar superávits nestes e menores déficits naqueles. As exportações de cabotagem paulistas, em cruzeiros deflacionados, dobraram entre 1928 e 1935. Confirmase, assim, o fato de que, em tal período, os bens exportados por São Paulo para o resto do País possuíam valores agregados maiores do que os por ele importados.

Tabela 3.18 - Comércio de Cabotagem - São Paulo / Brasil (toneladas - 1.000 Cr\$)

\begin{tabular}{ccccccccc} 
& 1928 & 1933 & 1934 & 1935 & 1936 & 1937 & 1938 & 1939 \\
\hline São Paulo & & & & & & & \\
Exportações (ton.) & 101.679 & 135.246 & 139.609 & 140.448 & 157.117 & 171.952 & 197.668 & 229.375 \\
Exportações (Cr\$ 1.000 D) & 258.115 & 398.394 & 421.250 & 513.663 & 458.237 & 410.016 & 433.620 & 519.540 \\
Importações (ton.) & 454.449 & 326.676 & 337.924 & 358.098 & 472.167 & 478.002 & 513.606 & 557.752 \\
Importações (Cr\$ 1.000 D) & 338.458 & 270.743 & 291.609 & 337.524 & 353.156 & 337.456 & 313.395 & 362.577 \\
Saldo (Cr\$ 1.000 D) & -80.343 & 127.651 & 129.641 & 176.139 & 105.082 & 72.560 & 120.225 & 156.963 \\
Brasil & & & & & & & \\
Toneladas & 1.898 .752 & 1.865 .641 & 2.087 .376 & 2.179 .652 & 2.365 .322 & 2.523 .284 & 2.606 .695 & 2.892 .550 \\
1.000 Cr\$ D & 1.937 .515 & 2.296 .232 & 2.470 .724 & 1.999 .592 & 2.745 .622 & 2.625 .022 & 2.543 .689 & 2.873 .361 \\
\hline
\end{tabular}
Fonte: Comércio de Cabotagem pelo Porto de Santos, 1928 e 1933-1939.

O crescente domínio paulista nas trocas mercantis domésticas por cabotagem logo virou destaque na imprensa da época. A Folha da Manhã, por exemplo, salientou no ano

\footnotetext{
${ }^{391}$ Ver, principalmente: Josef Barat. O investimento em transportes como fator de desenvolvimento regional - Uma análise da expansão rodoviária no Brasil. In: Revista Brasileira de Economia, setembro de 1969.

${ }^{392}$ Folha da Manhã. Comércio interestadual e unidade econômica, 21.10.1933.
} 
de 1933 “(...) o alargamento do mercado interno nacional (...) (e) o aumento crescente das nossas vendas (paulistas) aos estados irmãos”393. Afirmou ainda que “(...) até 1931, São Paulo era deficitário perante outras unidades da Federação (...) (e que) a instauração, todavia, da policultura em nosso meio e a expansão industrial paulista, coincidindo com a retração dos mercados exteriores, não só permitiram que dispensássemos os produtos de outros estados, como encaminhássemos nossas correntes exportadoras de artigos industriais e mesmo matérias-primas para fora das nossas fronteiras estaduais" ${ }^{394}$. Em outro artigo, o mesmo jornal destacou que “(...) as forças de expansão do gigantismo paulista encontram, no resto do país, o seu campo de expansão predileta" ${ }^{\text {395 }}$. São Paulo, segundo outro órgão da imprensa local, transformava-se na década de $1930 \mathrm{em}$ "aglutinante econômico por excelência da nação"396. O Correio Paulistano teceu comentários semelhantes: "Nunca, na vida econômica de São Paulo, o comércio de cabotagem acusou números tão expressivos e tão indicadores da vitalidade e do expansionismo do nosso estado"397.

Tabela 3.19 - Exportação têxtil paulista por cabotagem - 1928-1931 e 1933-1935.

\begin{tabular}{cccccccc} 
& 1928 & 1929 & 1930 & 1931 & 1933 & 1934 & 1935 \\
\hline Toneladas & 7.713 .174 & 4.660 .357 & 6.295 .463 & 7.859 .719 & 11.659 .417 & 12.878 .915 & 15.464 .222 \\
Contos (D) & 47.314 & 40.950 & 54.307 & 77.300 & 120.796 & 133.057 & 150.399 \\
\hline Fonte: Comércio de Cabotagem pelo Porto de Santos, $1928-1931$ e $1933-1935$.
\end{tabular}

No que se refere especificamente ao subsetor têxtil paulista, percebe-se (Tabela 3.19) que, em 1930, o valor transacionado de tecidos com as demais unidades federativas já havia superado o do nível pré-crise. No ano seguinte, ambas variáveis apresentaram patamares maiores do que os de 1928. Em 1933, a ascensão tornara-se visível. Vendeu-se, em termos de quantidade e de valores, $48 \%$ e $56,2 \%$ a mais, respectivamente, do que dois anos antes. O interregno 1934-1935 manteve a tendência altista das vendas têxteis de São Paulo para os demais estados do País.

A Tabela 3.20 apresenta, por sua vez, dados desagregados sobre tais exportações têxteis. Vê-se que, quantitativamente, o ramo que mais apresentou crescimento no período 1933-1935 foi o das sedas (110\%), seguido de perto pelo da lã (109\%). Já, no que se refere aos valores, as fábricas laníferas assinalaram maior ascensão (90\%).

\footnotetext{
${ }^{393}$ Folha da Manhã. Comércio externo de cabotagem, 01.12.1933.

${ }^{394}$ Idem.

${ }^{395}$ Folha da Manhã. A cabotagem e o comércio externo paulista, 24.12.1933.

${ }^{396}$ O Estado de São Paulo, Comércio Interestadual, 21.10.1933.

${ }^{397}$ Correio Paulistano. Comércio de cabotagem, 18.04.1937.
} 
Tabela 3.20 - Exportação têxtil paulista por cabotagem discriminada por ramos - 1933-1939.

\begin{tabular}{cccccccc} 
& $1933 *$ & 1934 & 1935 & 1936 & 1937 & 1938 & 1939 \\
\hline Algodão (ton.) & 7.908 & 9.968 & 11.860 & 7.887 & 7.668 & 6.531 & 6.624 \\
Algodão (contos D) & 90.909 & 107.887 & 139.203 & 88.744 & 73.236 & 63.745 & 58.985 \\
Lã (ton.) & 259 & 393 & 542 & 342 & 351 & 507 & 413 \\
Lã (contos D) & 6.959 & 8.724 & 13.249 & 8.193 & 7.617 & 11.062 & 10.056 \\
Seda (ton.) & 226 & 293 & 474 & 417 & 397 & 624 & 143 \\
Seda (contos D) & 10.384 & 10.877 & 15.716 & 15.502 & 13.909 & 19.213 & 4.794 \\
Total (ton.)** & 8.393 & 10.654 & 12.876 & 8.646 & 8.416 & 7.662 & 7.180 \\
Total (contos D) & 108.253 & 127.488 & 168.168 & 112.439 & 94.762 & 94.020 & 73.835 \\
\hline
\end{tabular}

Fonte: Comércio de Cabotagem pelo Porto de Santos, 1933-1939. / * Infelizmente, não há dados desagregados para a exportação de cabotagem entre os ramos antes da crise de 1929. ** O total aqui mencionado refere-se apenas à soma das exportações dos tecidos de algodão, lã e seda. Os tecidos de juta, por exemplo, que também possuem participação nas exportações de cabotagem paulistas, não puderam ser agregados pela inexistência de dados no interregno 1936-1939, o que impossibilitaria a comparação deste com o período 1933-1935.

É evidente, portanto, que a conquista de mercados regionais foi outro fator fundamental para o processo de recuperação têxtil paulista pós-crise 1929-1932. Faz-se necessário, no entanto, questionar o porquê da supremacia das fábricas de tecidos de São Paulo sobre suas congêneres estaduais. Em primeiro lugar, lembra-se que, do ponto de vista tecnológico, as unidades têxteis paulistas eram, em média, superiores às suas concorrentes regionais. Os índices de produtividade são comprovadores dessa supremacia. No ano de 1920, por exemplo, a relação produto-operário das fábricas de tecidos domésticas era de 6,61; já a das paulistas, 8,68 ${ }^{398}$. Em outras palavras, o operário têxtil de São Paulo era mais produtivo do que o da média nacional. Da mesma maneira, a relação capital-produto das primeiras era de 0,96 ; das segundas, de $0,73^{399}$. Isto é, as fábricas internas precisavam utilizar mais unidades de capital para produzir tecidos do que as paulistas. Dessa maneira, se houvesse livre concorrência entre tais empresas (paulistas e as restantes dos demais estados), as primeiras, por questões técnicas, tendiam a predominar perante as segundas.

Em segundo lugar, além de mais produtivas, as indústrias têxteis de São Paulo concentravam grande parte dos estabelecimentos, capital, operários e produção domésticas no período pré-crise (Tabela 1.2). As maiores empresas de tecidos de todos os ramos encontravam-se no estado, o que permitia a elas ganhos em escala impossíveis de serem realizados pelas suas concorrentes de outras localidades.

Em terceiro, recorda-se que, até o final dos anos (19)20, não havia um mercado local constituído, mas sim "ilhas regionais" $"$. Junto com a expansão rodoviária já citada,

\footnotetext{
${ }^{398}$ Sinopse do censo industrial e do censo de serviços, p. 02-03.

${ }^{399}$ Idem, op. cit., p. 02-03.

${ }^{400}$ Wilson Cano. Desequilíbrios (...), op. cit., p. 176.
} 
outra barreira para essa integração começou a ser quebrada também na década de 1930: os impostos interestaduais. Estes, teoricamente, já estavam proibidos por lei federal desde 1904, porém tal legislação não era respeitada. Com a ascensão do Governo Provisório de Getúlio Vargas, em 1930, a questão voltou a ser discutida. Em 1931, proíbem-se com novo decreto os tributos entre as unidades da Federação ${ }^{401}$. Ao que parece, todavia, mais uma vez o desrespeito às regras pelos estados predominou. Menos de um ano depois, o governo voltou a legislar sobre o assunto, proibindo novamente o que já estava proibido ${ }^{402}$. E, de novo, não logrou êxito. Com isso, intensificaram-se as pressões patronais para a revogação efetiva da dita taxa. A FIESP, por exemplo, afirmou que "a proibição deveria começar a vigorar desde 01 de janeiro deste ano (1932), mas aqueles impostos continuam a ser cobrados abusivamente, com grave dano de estados como São Paulo, que recebem de outros estados matérias-primas e que para outros estados mandam produtos manufaturados. Esta Federação deseja fazer uma grande campanha em prol da proibição de tais impostos (...)"403. A partir de então, apesar de ainda continuarem existindo, tais tributos começaram a diminuir gradativamente, até serem totalmente extintos em $1943^{404}$. Isso facilitou o intercâmbio interno, favorecendo as unidades industriais daqueles que estavam melhor preparados para a concorrência local.

E, por final, em quarto, cita-se a importância da lei que obstou a importação de máquinas para as indústrias consideradas em superprodução (março / 1931). O subsetor têxtil foi um dos que ficou impossibilitado de aumentar sua capacidade produtiva em razão da suposta "superprodução" nele existente. Congelaram-se, com isso, posições relativas entre as unidades têxteis domésticas, favorecendo aquelas que possuíam melhor e maior aparelhamento técnico. Recorda-se, porém, que tal legislação permitia a substituição dos bens de capital obsoletos por outros tecnologicamente superiores, desde que a capacidade de produção da fábrica não fosse alterada. Assim, empresas pequenas, que não podiam desobstruir seu maquinário à espera de novos em razão do reduzido tamanho, viam-se impossibilitadas de se modernizarem. Já as fábricas grandes, cuja paralisação parcial de certos tipos de máquinas pouco influiria na produção agregada da mesma, podiam realizar tais modificações e, dessa forma, melhorar ainda mais sua produtividade. Além disso, a substituição de maquinismos antigos por novos só poderia acontecer com autorização do Ministério do Trabalho. Não há dúvida, portanto, de que as empresas localizadas próximas

\footnotetext{
${ }^{401}$ Decreto n. 19.995, 14.05.1931.

${ }^{402}$ Decreto n. 21.418, 17.01.1932.

${ }^{403}$ FIESP. Circular n. 242, 12.12.1932.

${ }^{404}$ Wilson Cano. Desequilíbrios (...), op. cit., p. 179-180.
} 
ao centro de poder político - notadamente as do Centro-Sul - e representadas por associações patronais muito influentes nas esferas governamentais (CIFTA e SPITESP, por exemplo) eram favorecidas com maiores autorizações pró-substituição do que outras que se encontravam longe da capital federal e cujos grupos patronais possuíam pouca inserção nos órgãos do Estado ${ }^{405}$.

No final de 1933, pressionado pelas associações patronais centro-sulistas, o Governo Federal publicou decreto prorrogando a proibição de se importar máquinas para os setores fabris considerados em superprodução - que vencia no início de 1934 - para março de 1937. As tecelagens de todos os ramos têxteis foram mantidas na restrição. No caso das fiações, apenas as de algodão permaneciam impossibilitadas de comprarem livremente bens de capital do exterior ${ }^{406}$. Os grupos representativos da burguesia industrial do Sudeste apoiaram com furor tal prorrogação. O CIFTA, por exemplo, em carta ao Ministro do Trabalho, afirmou que “(...) o controle da importação de maquinismos tem merecido sempre aplausos desde Centro, pois essa iniciativa tem o alto mérito de regularizar a entrada de máquinas que poderão vir perturbar ainda mais a situação de crise que atravessa muitas das nossas indústrias manufatureiras (grifo nosso)" ${ }^{\natural 07}$. O SPITESP, por sua vez, prestou elogios semelhantes ao decreto governamental citado ${ }^{408}$.

Tabela 3.21 - Relação produção têxtil paulista (1925, 1928 e 1932-1937) / número de teares (1932)

\begin{tabular}{ccccccccc} 
& $1925(3)$ & $1928(4)$ & 1932 & 1933 & 1934 & 1935 & 1936 & 1937 \\
\hline Algodão & 10,0 & 8,4 & 7,8 & 9,0 & 10,8 & 10,6 & 11,5 & 11,2 \\
Juta & 40,0 & 23,0 & 14,4 & 14,4 & 17,0 & 15,2 & 11,5 & 14,7 \\
Lã & $*$ & 5,1 & 4,9 & 4,8 & 5,7 & 4,7 & 5,0 & 4,9 \\
Sedas (1) & $*$ & 95,0 & 148,0 & 322,8 & 416,5 & 551,1 & $*$ & $*$ \\
Sedas (2) & $*$ & $*$ & $*$ & 7,4 & 6,6 & 8,5 & 8,0 & 13,3 \\
\hline
\end{tabular}

Fonte: Estatística Industrial do Estado de São Paulo, 1932-1937; Villela e Suzigan, op. cit., p. 357-364. (1) cálculo realizado a partir da produção em quilos (ver Tabela 3.15); (2) cálculo realizado a partir da produção em metros (ver Tabela 3.15); (3) produção de 1925 / teares de 1925; (4) produção de 1928 / teares de 1928.

\footnotetext{
405 Exemplo máximo dessa influência das associações patronais do Centro-Sul dentro dos órgãos governamentais foi o caso do pedido de importação de 35 máquinas de fiar realizado pela Cia. Brasileira de Linhas para Coser junto ao Ministério do Trabalho em maio de 1934. Tal fábrica, pertencente à empresa britânica Machine Cottons Limited, começou a receber grande oposição das congêneres domésticas após sua tentativa, no final dos anos (19)20, de monopolizar o mercado de linhas de coser local, por meio de uma política de preços agressiva (caracterizada pelas demais fábricas de dumping) e da compra de concorrentes. O pedido da Companhia, inicialmente, tinha sido atendido pelo Ministério do Trabalho. A partir de então, o CIFTA e o SPITESP realizaram forte pressão sobre o Estado para impedir que se concretizasse essa autorização. Ao final, revogou-se o pedido citado. Para maiores informações, ver: CIFTA. Memorial ao Ministro do Trabalho, 02.05.1934 e 10.05.1934. Sobre as ações da Companhia nos anos (19)20, ver: Stanley Stein. Origens (...), op. cit., p. 149.

${ }^{406}$ Decreto n. 23.486, 22.11.1933.

${ }^{407}$ CIFTA. Carta do CIFTA ao Ministro do Trabalho, 19.04.1934.

${ }^{408}$ SPITESP. Ata Assembléia Geral Extraordinária, 27.10.1934.
} 
Mostrou-se anteriormente ${ }^{409}$ que, quando tal legislação foi criada (1931), apenas os ramos algodoeiro, jutífero e, em parte, o lanífero poderiam ser considerados em superprodução. Observou-se também, no que se refere às fiações, que, apesar da escassez de dados, as mesmas não poderiam ser enquadradas de maneira homogênea no rótulo mencionado, especialmente as fábricas de fios finos e as de seda. Em 1934, ano do término da vigência desse decreto, tornou-se ainda mais complicado sustentar o posicionamento de que o subsetor têxtil paulista encontrava-se com capacidade produtiva ociosa (Tabela 3.21). Em razão da inexistência de dados sobre seu montante de máquinas nesse momento, partiu-se do pressuposto reducionista ${ }^{410}$ de que o número de teares dos ramos permaneceu relativamente estável de 1932 até 1937 - período da proibição formal da importação de máquinas têxteis no País. Assim sendo, pode-se evidenciar que, em 1934, excetuando-se o caso da juta, que passou por forte recessão ao longo dos anos (19)30, todos os demais ramos de tecidos encontravam-se com relações produção / teares superiores ao do período pré-crise (1928). Destacam-se, mais uma vez, as empresas de sedas, cuja relação, em 1934, era 338\% maior do que em 1928. Mesmo no caso algodoeiro, quando recuado para 1925 (período de prosperidade para o ramo), percebe-se crescimento de $8,4 \%$ nessa variável.

Tabela 3.22 - Importação de bens de capital para a indústria têxtil paulista pelo porto de Santos (1928, 1932-1939)

\begin{tabular}{|c|c|c|c|c|c|c|c|c|c|}
\hline & 1928 & 1932 & 1933 & 1934 & 1935 & 1936 & 1937 & 1938 & 1939 \\
\hline Bens de Capital (quilo) & 2.915 .618 & 714.737 & 915.578 & 2.150 .969 & 1.526 .535 & 3.364 .816 & 3.543 .454 & 4.295 .928 & $\begin{array}{c}2.176 . \\
877 \\
14.52\end{array}$ \\
\hline Bens de Capital (contos - D) & 8.549 & 5.585 & 8.663 & 13.523 & 9.797 & 16.454 & 21.352 & 28.252 & $\begin{array}{c}1 \\
2.176 .\end{array}$ \\
\hline MNE (quilos) (1) & 1.473 .384 & 354.274 & 492.639 & 1.350 .113 & 1.103 .253 & 2.089 .009 & 2.881 .304 & 4.295 .928 & $\begin{array}{c}877 \\
14.52\end{array}$ \\
\hline MNE (contos - D) & 3.722 & 1.871 & 3.201 & 7.166 & 9.491 & 10.877 & 16.666 & 28.252 & 1 \\
\hline Teares (quilos) & 769.242 & $*$ & 13.868 & 215.483 & 45.525 & 153.454 & 253.405 & $*$ & $*$ \\
\hline Teares (contos - D) & 1.309 & 61 & 639 & $*$ & 307 & 994 & 1.008 & $*$ & $*$ \\
\hline Acessórios (quilos) & 672.992 & 360.463 & 409.071 & 585.373 & 377.757 & 1.122 .353 & 408.745 & $*$ & $*$ \\
\hline Acessórios (contos - D) & 3.519 & 3.653 & 4.823 & 6.357 & $*$ & 4.584 & 3.678 & $*$ & $*$ \\
\hline
\end{tabular}

Fonte: Estatística do Comércio do Porto de Santos, 1928 e 1932-1939. (1) Máquinas não especificadas.

Outras fontes primárias comprovam a inexistência de superprodução no subsetor de tecidos paulista nesse período. Vê-se (Tabela 3.22) que a quantidade de bens de capital têxteis importados pelo porto de Santos em 1934 foi apenas 25\% inferior à do período pré-

\footnotetext{
${ }^{409}$ Ver Capítulo 2, principalmente 2.2.6 - Análise da dinâmica dos ramos.

${ }^{410}$ Diz-se "reducionista" porque, como se verá posteriormente, os investimentos em bens de capital na indústria têxtil paulista não permaneceram estáticos durante o interregno 1932-1937.
} 
crise. Além disso, percebe-se que o valor desses bens, em 1934, foi 58\% maior do que o observado em 1928. Essa situação, provavelmente, decorreu não só do encarecimento generalizado das importações ocorrido nos anos (19)30, mas também do fato desses bens possuírem valores agregados maiores, por serem tecnologicamente superiores. Nesse contexto de proibição da importação de máquinas têxteis estrangeiras, excetuando-se as que visavam substituir aquelas consideradas obsoletas, é plausível que tais bens importados possuíssem valores mais elevados. Porém, muito em razão desse próprio decreto proibitivo, fica difícil supor que um subsetor fabril teoricamente em estado de superprodução realizasse um montante de inversões tão considerável como os dados apresentam. Em outras palavras, as fábricas de tecidos paulista tinham incentivo para investir porque havia mercado doméstico crescente e capaz de absorver uma produção quantitativamente maior e qualitativamente superior.

Os relatórios de diretoria das empresas têxteis do estado ratificam as inferências anteriores. Citar-se-ão alguns, apenas a título de exemplo. O Lanificio Anglo-Brasileiro, segundo seus administradores, foi “(...) consideravelmente aumentado com aquisição de novos maquinismos, novos prédios e com o melhoramento de todos os seus produtos (grifo nosso) ${ }^{״ 411}$. O S.A. Moinho Santista informou aos seus acionistas, em fevereiro de 1935, que “(...) instalamos uma máquina para beneficiamento de algodão destinado às nossas fábricas de fiação e tecelagem, cujos serviços estão em plena atividade e correspondendo às expectativas (...) (além disso), foram ampliadas (...) as seções de fiação e tecelagem de lã da Fábrica de Tecidos Cambucy (...) (grifo nosso)" "412. Em outro relatório, os diretores do Moinho prosseguiam: "No decurso de 1935, montamos, completamente, uma nova fábrica para lavagem e fiação de lã penteada, a qual está, hoje (1936), em plena atividade" ${ }^{413}$. A Malharia N. S. da Conceição, por sua vez, assinalou em 1934 que "ambas as fábricas trabalharam em toda sua plenitude sem perturbações e (que) a sua produção encontrou sempre franca colocação no mercado consumidor (...) Com o fim principal de aumentar a produção dos artigos que podem nos oferecer uma melhor margem de compensação, montamos máquinas modernas que concorrerão, certamente, para compensar (...) nosso esforço (grifo nosso)" ${ }^{\text {"414 }}$. A diretoria da Tecelagem de Seda $\mathrm{N}$. S. da Penha colocou aos acionistas que “(...) nesse exercício (1935) ampliamos nossas instalações com lucros próprios, elevando a conta de valores imobilizados (...) (grifo

\footnotetext{
${ }^{411}$ Ata Assembléia Geral Ordinária. Lanifício Anglo-Brasileiro, 31.03.1934.

${ }^{412}$ Relatório de Diretoria. S.A. Moinho Santista, 25.02.1935.

${ }^{413}$ Relatório de Diretoria. S.A. Moinho Santista, 20.02.1936.

${ }^{414}$ Relatório de Diretoria. Malharia N. S. da Conceição, 22.01.1934.
} 
nosso) ${ }^{\$ 415}$. Inúmeros outros exemplos semelhantes poderiam ser concedidos.

Percebe-se, nas partes destacadas desses relatórios, que não só muitas empresas têxteis ampliaram suas produções - contrariando, aparentemente, a legislação, que permitia apenas a substituição de máquinas obsoletas por outras superiores tecnologicamente sem alterar a capacidade produtiva -, como também afirmavam aos seus acionistas que estavam trabalhando com capacidade máxima, o que contraria absolutamente a idéia de superprodução. Excetua-se o caso jutífero que, como se sabe, em razão da crise do setor primário-exportador, passava por sérias dificuldades nesse período. Os demais, diferentemente, expandiam-se, conquistando mercados em áreas recém-abertas do estado e também em regiões fora de São Paulo.

No que se refere às fiações de algodão, apesar da escassez de dados estatísticos sobre número de fusos e sobre a produção específica de fios, evidencia-se também que o ramo não passava por problemas superprodutivos no interregno 1932-1935. Os relatórios das associações patronais e das empresas são bastante concludentes.

Em representação feita junto ao Ministério do Trabalho em abril de 1934, por exemplo, o CIFTA demandou “(...) um critério mais liberal na apreciação de certos pedidos de importação de máquinas auxiliares da fiação (...), tais como cardas, passadores, massaroqueiras, etc." ${ }^{416}$. Essas máquinas, segundo o centro, não aumentariam a produção de fios das empresas. Visavam apenas equilibrar a potencialidade de trabalho das suas diferentes seções. A própria associação, porém, logo reconheceu posteriormente “(...) que os estabelecimentos fabris poderão trabalhar extraordinariamente com as máquinas de fiação (adquiridas) (...), aumentando, assim, a sua produção. Entretanto, esse trabalho extraordinário tanto poderá ser executado com o serão das máquinas intermediárias, como sem ele" $"$. O Departamento Nacional da Indústria e do Comércio deu aval ao pedido, mesmo reconhecendo que tal concessão permitia “(...) o industrial de, com o trabalho suplementar nos outros grupos, restabelecer o equilíbrio em plano mais elevado, com evidentes possibilidades de aumento da produção" ${ }^{418}$.

E foi assim que se sucedeu. O "critério mais liberal" para a importação de máquinas de fiação significou, na maioria dos casos, aumento produtivo e não somente “equilíbrio" entre ramos. Apenas a título de ilustração, lembra-se que, em dois anos consecutivos (1934 e 1935), a S.A. Fiação para Malharia Indiana, uma das maiores

\footnotetext{
${ }^{415}$ Relatório de Diretoria. Tecelagem de Seda N. S. da Penha S.A., 24.01.1936.

${ }^{416}$ CIFTA. Relatório de Diretoria, 1934.

${ }^{417}$ CIFTA. Carta ao Ministro do Trabalho, 19.04.1934.

${ }^{418}$ CIFTA. Carta do Departamento Nacional da Indústria e Comércio ao CIFTA, 05.05.1934.
} 
empresas do estado, apresentou quantias inéditas de vendas. Em seus relatórios, os diretores afirmavam que a empresa estava trabalhando a todo vapor, praticamente 24 horas por dia $^{419}$. Com isso, aumentou-se a distribuição de dividendos em quase $50 \%{ }^{420}$. Caso semelhante foi o da Cia. Brasileira de Linhas para Coser. Esta, que já havia demandado junto ao Ministério do Trabalho uma licença para importar 35 máquinas de fiação, apresentou "lucros consideráveis" no exercício de 1934, permitindo, assim, a cessão de consideráveis dividendos aos acionistas ${ }^{421}$.

Por fim, cita-se também que, durante as discussões acerca da reforma tarifária de 1934, por várias vezes malharias chegaram a reclamar junto à Comissão de Tarifas no sentido de se impedir aumento de taxas sobre fios estrangeiros, pois, segundo elas, as fábricas locais não tinham capacidade produtiva para abastecer todo mercado interno ${ }^{422}$. E exatamente por esse motivo, afirmavam, tais empresas demandavam "critérios mais liberais" para a importação de maquinismos. Todos esses elementos, portanto, demonstram claramente a inexistência de superprodução nas fiações de algodão paulistas.

\section{$\underline{3.2 .3 .2-1936-1937}$}

Passar-se-á, agora, para a análise do interregno 1936-1937, caracterizado, como já se viu, pela recessão econômica das fábricas têxteis. Vários foram os fatores que contribuíram para tal retração. Em primeiro lugar, menciona-se o fim do monopólio cambial do Banco do Brasil, que facilitou a entrada de bens estrangeiros no País, inclusive tecidos. Em setembro de 1934, houve a permissão da venda livre ao mercado de todos os câmbios de exportação, exceto os do café ${ }^{423}$. No ano seguinte, estabeleceu-se que os bancos deveriam repassar ao governo $35 \%$ dos cambiais adquiridos à taxa oficial, enquanto os $65 \%$ restantes estariam liberados ${ }^{424}$.

Além da liberalização cambial, outro elemento facilitador da entrada de bens estrangeiros no mercado interno foi o tratado comercial realizado entre Brasil e Estados Unidos em $1935^{425}$. Neste, os norte-americanos garantiam a permanência da isenção de

\footnotetext{
${ }^{419}$ Relatório de Diretoria. S.A. Fiação para Malharia Indiana, 19.03.1935 e 18.02.1936.

${ }^{420}$ Balanço. S.A. Fiação para Malharia Indiana, 20.02.1935 e 18.02.1936.

${ }^{421}$ Relatório de Diretoria. Cia. Brasileira de Linhas para Coser, 03.04.1935.

${ }^{422}$ CIFTA. Carta do CIFTA ao presidente e demais membros da 'Comissão Revisora das Tarifas Aduaneiras`, 11.01.1933.

${ }^{423}$ Marcelo de Paiva Abreu. O Brasil (...), op. cit., p. 130.

${ }^{424}$ Idem, op. cit., p. 138-139.

${ }^{425}$ Sobre esse tratado, ver: Marcelo Paiva Abreu. O Brasil (...), op. cit., p. 212-225; Marisa Saenz Leme, op. cit., p. 95 .
} 
taxas alfandegárias para as exportações brasileiras - em especial, as do café - e, em troca, o Brasil incluía aquele país na cláusula de Nação Mais Favorecida (NMF) para questões comerciais e cambiais e reduzia várias tarifas para bens estadunidenses aqui ingressos, como camisas de algodão. Muitos industriais criticaram o acordo. Roberto Simonsen, por exemplo, que na época era membro do Conselho Federal de Comércio Exterior (CFCE), chegou a afirmar que o Brasil trocou "algo por nada"426.

Assim, apesar das importações têxteis do período 1935-1937 não atingirem nem de perto os níveis pré-depressivos, percebe-se que a liberalização cambial e o rebaixamento de tarifas para bens norte-americanos contribuíram para contínua elevação da compra de tecidos no exterior nesse interregno (Tabela 3.16).

Para além desses fatores, cita-se também como elemento contribuinte da recessão têxtil de 1936-1937 o brusco aumento dos preços dos gêneros de primeira necessidade. O boom algodoeiro paulista dos anos (19)30 - incentivado, principalmente, pela crise cafeeira, pelo desenvolvimento da indústria têxtil estadual e pelos crescentes preços internacionais do algodão $0^{427}$ - diminuiu as áreas de produção agrícola de bens básicos ${ }^{428}$. A inflação destes últimos foi tão considerável que o governo estadual nomeou uma comissão para tabelar seus preços ${ }^{429}$. Iniciou-se também campanha visando aumentar a produção estadual de cereais. Membros do governo argumentavam que “(...) essa carestia é devida, em grande parte, ao fato dos nossos agricultores terem abandonado quase por completo a cultura dos cereais, para se entregarem a outras lavouras que lhes oferecem perspectivas de maiores lucros". Classificavam o ato de "plantar cereais" como uma "dever" do agricultor paulista para com seu estado ${ }^{430}$.

Apesar de todo esse esforço, os preços dos bens de primeira necessidade mantiveram-se altos no interregno 1936-1937. Com isso, o mercado interno, especialmente para tecidos mais grossos, diminuiu consideravelmente, “(...) pois a classe consumidora pobre, obrigada a pagar preços elevadíssimos pelos gêneros alimentícios, não está (...) em condições de suportar despesas de artigos de necessidades secundárias, tais como tecidos para indumentária (grifo nosso) (...)"431. A despeito do consumo de roupas não ser, estritamente, uma necessidade secundária dos proletários, é fato que, com a

\footnotetext{
${ }^{426}$ Marcelo Paiva Abreu, op. cit., p. 223.

${ }^{427}$ Sobre o boom algodoeiro paulista, ver: Rui H. P. Albuquerque. Capital comercial, indústria têxtil e produção agrícola. As relações de produção na Cotonicultura Paulista (1920-1950). Huitec, São Paulo, 1982; e O Estado de São Paulo. O algodão em São Paulo, 08.05.1935.

${ }^{428}$ O Estado de São Paulo. Gêneros de primeira necessidade, 29.07.1936.

${ }^{429}$ O Estado de São Paulo. Gêneros de primeira necessidade, 14.08.1936.

${ }^{430}$ O Estado de São Paulo. É preciso plantar cereais, 18.08.1936.

${ }^{431}$ Ata Assembléia Ordinária. Cotonificio Rodolfo Crespi, 22.03.1937.
} 
manutenção dos salários em níveis de subsistência, a elevação dos preços de bens alimentícios propiciou uma queda na compra de outros tipos de produtos, mesmo que fundamentais, como é o caso dos tecidos. Membros da burguesia têxtil paulista admitiram que a renda dos trabalhadores era baixa e que se fazia necessário garantir aos mesmos “(...) maiores meios de aquisição, pois o incremento de consumo (...) é o meio mais eficiente para evitar a superprodução agrícola e industrial”432. O próprio Cotonifício Rodolfo Crespi colocou em pauta no SPITESP a idéia de se proceder a um aumento imediato de salários da ordem de 20 a 30\%, porém, não obteve sucesso. Resolveu-se, apenas, “(...) facultar a cada industrial entender-se com os próprios operários a respeito desse assunto" ${ }^{\circ 33}$.

A diminuição das vendas por parte das fábricas têxteis paulistas no interregno 1936-1937 deveu-se não somente ao aumento das importações de bens similares e a essa redução do consumo estadual, mas também à perda de mercados nas demais unidades da Federação.

Observa-se (Tabela 3.20) que, entre 1935 e 1937, as exportações de tecidos de São Paulo via cabotagem decresceram, do ponto de vista quantitativo, em mais de $35 \%$. Já, no que condiz ao valor das mesmas, a queda foi ainda maior (-44\%). Dentre os ramos analisados, vê-se que o algodoeiro sofreu os mais drásticos decréscimos, enquanto o das sedas apresentou modesta redução (Tabela 3.20).

Diferentemente, ao se analisar a evolução do comércio de cabotagem nacional, percebe-se que houve acréscimos das quantidades e do valores de bens cambiados nesse mesmo período (Tabela 3.18). Da mesma maneira, o comércio agregado de tecidos via cabotagem, apesar de também ter sofrido reduções no interregno 1936-1937, apresentou quedas bem menos substanciais quando comparadas às remessas paulistas (Tabela 3.23). As exportações de tecidos de algodão de São Paulo, por exemplo, decresceram, em termos quantitativos, 35,3\% entre 1935 e 1937, enquanto as do País caíram apenas 4\%. As vendas laníferas domésticas de cabotagem apresentaram ascensão em 1936 (53\%), tal como o caso das sedas (3,58\%). Já as paulistas sofreram decréscimos de $37 \%$ e $12 \%$, respectivamente. Não foi à toa, portanto, que a participação de São Paulo nas exportações têxteis de cabotagem nacional foi reduzida em todos os ramos nesse momento.

Tabela 3.23 - Comércio têxtil de cabotagem - Brasil (1933-1939)

\footnotetext{
432 Idem

${ }^{433}$ Ibidem.
} 


\begin{tabular}{cccccccc} 
& 1933 & 1934 & 1935 & 1936 & 1937 & 1938 & 1939 \\
\hline Algodão (ton.) & 32.689 & 40.443 & 42.737 & 39.722 & 40.961 & 36.582 & 37.057 \\
Algodão (1.000 Cr\$ D) & 371.653 & 439.318 & 498.607 & 412.098 & 362.576 & 321.185 & 313.548 \\
Lã (ton.) & 629 & 620 & 615 & 938 & 876 & 1.688 & 935 \\
Lã (1.000 Cr\$ D) & 16.578 & 16.419 & 17.098 & 23.154 & 20.067 & 24.771 & 23.125 \\
Seda animal (ton.) & 213 & 280 & 531 & 550 & 572 & 809 & 211 \\
Seda animal (1.000 Cr\$ D) & 12.167 & 12.738 & 20.400 & 21.586 & 20.059 & 24.689 & 7.576 \\
\hline
\end{tabular}

Grande parte dessa perda de mercado sofrida pelas indústrias têxteis paulistas se deveu ao melhor aparelhamento das suas congêneres domésticas. No interregno 1935-1937, percebe-se (Tabela 3.24) que a importação de máquinas de tecidos no Brasil apresentou grande crescimento (123\%). O montante adquirido em 1937 superou em mais de $38 \%$ a quantidade comprada no período pré-crise. Tendo em vista, no entanto, que quase $42 \%$ dos bens de capital têxteis importados pelo País dirigiram-se às empresas paulistas, poder-se-ia argumentar, nesse sentido, que as fábricas de São Paulo compensaram tecnologicamente as melhorias realizadas pelas suas concorrentes. A desconcentração industrial ocorrida no subsetor de tecidos paulista entre 1935 e 1937, todavia, indicia que tal aparelhamento não se destinou, em sua maioria, às grandes fábricas - que exportavam seus produtos para outros estados -, mas sim às médias e pequenas, muitas delas localizadas em áreas interioranas. Estas tornavam-se cada vez mais competitivas dentro dos seus mercados regionais, acirrando-se, assim, a disputa com as grandes empresas situadas na capital do estado e nas cidades vizinhas à mesma.

É inegável que esse aumento da compra de máquinas pelas indústrias têxteis locais só foi possível em razão do fim da lei que proibia aquisições de bens de capital para o subsetor. Tal legislação expirou em março de 1937 e não foi prorrogada. A pressão realizada pelas associações patronais do Centro-Sul - representantes das maiores empresas paulistas e cariocas - sobre o Governo Federal, visando mantê-la, demonstra, mais do que qualquer estatística, a verdadeira disputa de mercados domésticos existente na época entre as grandes fábricas têxteis centro-sulistas e suas concorrentes intra e interestaduais.

Em memorial apresentado ao Ministério do Trabalho no ano de 1936, o CIFTA colocava que era “(...) evidente a superprodução de grande maioria dos artigos têxteis (...) ${ }^{9434}$, tornando necessário, dessa maneira, manter a proibição da compra de máquinas do exterior. Segundo o Centro, a fabricação de maquinários de tecidos locais, porém, não deveria ser tolhida. Outra medida pleiteada pela associação era a de uniformizar em 60 horas semanais as jornadas de trabalho das fábricas do subsetor, “(...) evitando, assim, que

\footnotetext{
${ }^{434}$ CIFTA. Memorial apresentado ao Sr. Ministro do Trabalho, da Indústria e do Comércio. 09.10.1936.
} 
a produção possa ser aumentada com serviço extraordinário e organização de várias turmas de trabalho". Por outro lado, no que concerne às fiações, a posição era diferente. O Centro admitiu “(...) que tem recebido reiterados pedidos de vários estabelecimentos fabris no sentido de ser permitida a importação de, pelo menos, uma pequena quantidade de fusos capaz de habilitar a fabricação nacional a suprir (...) as necessidades de consumo, principalmente na parte que diz respeito à fabricação de fios médios e finos (...)". Colocavam, contudo, que tal importação deveria ser previamente determinada pelo governo, totalizando, no máximo, $15 \%$ dos fusos existentes no País ${ }^{435}$.

Tabela 3.24 - Importação de máquinas têxteis - Brasil (1928, 1933-1939), quilos

\begin{tabular}{|c|c|c|c|c|c|c|c|c|}
\hline & 1928 & 1933 & 1934 & 1935 & 1936 & 1937 & 1938 & 1939 \\
\hline Fiação-Tecelagem* & 3.507 .184 & 971.626 & 2.455 .935 & 2.015 .534 & 3.703 .121 & 6.818 .524 & 11.137 .000 & 5.855 .000 \\
\hline Teares & 1.227 .143 & 75.877 & 310.099 & 347.928 & 232.614 & 969.234 & * & $*$ \\
\hline Acessórios não-numerados & 1.482 .186 & 975.833 & 1.318 .179 & 1.489 .231 & 1.407 .621 & 859.130 & * & $*$ \\
\hline Total & 6.243 .754 & 2.051 .134 & 4.111 .690 & 3.875 .148 & 5.346 .388 & 8.646 .908 & $*$ & $*$ \\
\hline
\end{tabular}

Fonte: Stanley Stein, op. cit., p. 195. / Legenda: * não-numeradas

Como demandado pelo CIFTA, o Ministério do Trabalho publicou uma portaria, em dezembro de 1936, flexibilizando importações de máquinas de fiar. Estas aquisições, porém, obedeceriam a certas regras. De acordo com a nova lei, o maquinário obtido do exterior deveria produzir fios de título 60 ou superior e não ultrapassar $15 \%$ do total dos fusos instalados localmente. Permitia-se, também, a compra de máquinas de fiar às tecelagens, contanto que se respeitasse a proporção máxima de 50 fusos por tear e que tais máquinas visassem produzir fios para consumo próprio das mesmas. Por fim, estabeleceuse uma hierarquia da quantidade de fusos que poderiam ser importados pelas fiações, segundo seus respectivos tamanhos ${ }^{436}$.

O não-cumprimento de todas as propostas do CIFTA na nova lei citada logo suscitou críticas ao governo. Em exposição realizada ao Conselho Federal de Comércio Exterior, o Secretário-Geral do Centro, Vicente Galliez, afirmou que “(...) seria mais conveniente não se indicar o número do título do fio que obrigatoriamente deve ser exigido para o trabalho das novas máquinas de fiação”. Além disso, posicionou-se contrário à permissão da compra de fusos por parte das tecelagens. "Da mesma maneira que não é permitido às fiações que não têm tecelagens importar teares (...) não se deve permitir que as tecelagens que não possuem fiações importem máquinas de fiação". As

\footnotetext{
${ }^{435}$ Idem.

436 As fábricas de fiação com até 5.000 fusos poderiam importar até $50 \%$ do número dos mesmos; estabelecimentos com 5.000 a $10.000,30 \%$; estabelecimentos com 10.000 a 15.000 , 20\%; e, finalmente, estabelecimentos com 15.000 a mais, 10\%. Portaria do Ministério do Trabalho, 14.12.1936
} 
reações mais veementes, porém, concentraram-se contra a regra que estipulava uma hierarquia da compra de fusos conforme o tamanho da empresa: “(...) parece-nos que seria mais justo e eqüitativo que a porcentagem fosse invariável, pois se é certo que as fábricas maiores terão direito de importar uma quantidade menor de fusos também não é menos certo que essas fábricas necessitam maior quantidade de fio para o abastecimento de suas tecelagens" ${ }^{\prime 3}$.

Essa foi a primeira vez que o feitiço das grandes empresas têxteis do Sudeste se voltou contra os próprios feiticeiros. Ao invés de favorecê-las, a lei que flexibilizou a importação de máquinas fiatórias permitiu às pequenas e médias fábricas acrescerem suas capacidades produtivas em proporção maior que as das então dominantes no mercado, acirrando, assim, a concorrência. Além disso, a regra que permitia às tecelagens a compra de máquinas de fiação contemplava, principalmente, o interesse das empresas de reduzido porte, pois as maiores já as possuíam, salvo algumas exceções. Dessa maneira, isso não só reduziria as vendas das grandes empresas de fiação - abastecedoras de tais tecelagens -, como também traria maior competitividade a estas últimas, em razão do rebaixamento de custos, contra as fábricas têxteis já integradas.

Após essa derrota, a principal meta da grande burguesia têxtil do Centro-Sul concentrou-se na prorrogação da lei proibitiva da importação de máquinas têxteis, que venceria em março de 1937. No mês de janeiro deste ano, os centros patronais do Rio de Janeiro, de São Paulo e de Juiz de Fora montaram uma comissão que objetivava realizar estudos sobre a superprodução de tecidos, a qual, segundo eles, era uma "realidade incontestável" no País ${ }^{438}$. Argumentavam que, para debelar esse problema, fazia-se necessário a realização de algumas medidas, tais como (a) a permissão de se importar máquinas de fiar que correspondessem, no máximo, a 5\% dos fusos instalados, sem quaisquer discriminações acerca do tamanho das fábricas; (b) "a proibição da instalação de teares, seja de fabricação estrangeira, seja nacional" (grifo nosso); (c) a uniformização das horas de trabalho nas seções de tecelagem para 60 horas semanais; (d) e a manutenção da anuência para a compra de bens de capital têxteis que viessem substituir aqueles quebrados ou desgastados ${ }^{439}$.

Percebe-se que, quando comparado às demandas feitas pelo CIFTA em 1936, esse relatório apresentou duas mudanças importantes: a proposta da quantidade máxima de ${ }^{437}$ CIFTA. Exposição apresentada ao Conselho Federal de Comércio Exterior pelo Secretário-Geral do Centro, Sr. Vicente de Paulo Galliez, sobre a importação de máquinas para a indústria de fiação e tecelagem de algodão, 15.01.1937.

${ }^{438}$ CIFTA. Relatório de Diretoria, 1937.

${ }^{439}$ Idem. 
fusos que poderiam ser importados, cuja porcentagem diminuiu de $15 \%$ para $5 \%$; e a proibição da fabricação de teares por fábricas domésticas, antes aceita. Ao que parece, essas alterações foram realizadas devido a pressões do SPITESP ${ }^{440}$. Para além desse aspecto, ressalta-se a ausência da participação das demais associações patronais têxteis do País na confecção do relatório citado. Lembra-se que o Sindicato dos Industriais de Algodão de Pernambuco, um dos mais importantes do ramo no Nordeste, chegou a ser convidado, porém não teve interesse em participar $^{441}$. Ratifica-se, assim, a tese de que essa comissão não representava "as aspirações da indústria têxtil nacional", tal como ela própria apregoava, mas sim apenas as de um grupo dessa burguesia, notadamente as grandes empresas do Sudeste.

Concedeu-se também aos representantes das indústrias ditas em superprodução um espaço no Conselho Federal de Comércio Exterior, para que os mesmos expusessem diretamente aos membros do governo as condições econômicas dos seus respectivos subsetores. No caso têxtil, houve hegemonia dos burocratas das associações patronais do Centro-Sul nas discussões. Segundo tais representantes, todos os ramos analisados (fiação de algodão e tecelagens de algodão, de juta, de lã e das seda) encontravam-se em superprodução ${ }^{442}$. Firmo Dutra, enviado do SPITESP no Conselho, por exemplo, afirmou que a fabricação local de teares era a principal responsável pela existência de estoques invendáveis nas empresas algodoeiras, laníferas e nas de seda. De acordo com ele, por esse motivo, “(...) as fábricas existentes aumentaram o número de teares e muitas fábricas novas surgiram (grifo nosso)" ${ }^{443}$. Já o presidente do Sindicato Patronal das Indústrias de Malharia de São Paulo, Turenne Cunha, ressaltou que, durante a vigência do decreto proibitivo da compra de bens de capital do exterior (1931-1937), “(...) os maiores abusos e as maiores facilidades foram praticados na Alfândega de Santos (...) Máquinas eram desembarcadas sem se fazer a inutilização prévia que este sindicato tanto exige para encaminhar os requerimentos dos seus associados. Máquinas (...) eram importadas sob uma denominação e qualidade e eram retiradas outras de tipos completamente diferentes e de importação proibida" ${ }^{444}$. Para ele, portanto, a manutenção de tal decreto era fundamental, mas tinha de ser acompanhada de maior fiscalização

\footnotetext{
${ }^{440}$ Ibidem.

${ }^{441}$ Ibidem.

${ }^{442}$ As discussões do CFCE podem ser encontradas nos seguintes artigos: O Estado de São Paulo. Aquisição de máquinas para a indústria de fiação de algodão, 16.01.1937 e O Estado de São Paulo. Continua o inquérito sobre as indústrias em superprodução; 27.01.1937.

${ }_{443}$ O Estado de São Paulo. Continua (...), op. cit.

${ }^{444}$ Idem.
} 
Apesar de toda essa pressão da grande burguesia têxtil centro-sulista, o governo não prorrogou a lei citada. Para justificar seu posicionamento, o Ministério do Trabalho lançou, em março de 1937, nota oficial afirmando que "durante esse período de intervenção, a indústria têxtil (...) entrou em uma fase de franca recuperação. Logrou não só ajustar a capacidade de produção ao consumo, como aperfeiçoar-se (...) Verificou-se, ultimamente, que o tecido grosso estava em superprodução (...) (que) resultava do fato das fábricas trabalharem três turnos, isto é, 24 horas, todos os dias, a fim de vencer a concorrência na produção daqueles tecidos (...) Chegava-se, assim, ao paradoxo de uma indústria declarada em superprodução funcionar além das horas normais de trabalho (...) Não era possível considerar em superprodução uma indústria cujas fábricas, para vencer a concorrência, trabalham além de suas horas normais" $" 445$.

Derrotada mais uma vez, a grande burguesia têxtil - notadamente a paulista continuou, de maneira insistente, por meio de cartas e memoriais, sua campanha em prol da proibição da instalação de máquinas nas indústrias locais e da limitação das jornadas de trabalho. Criou-se verdadeira disputa de interesses. Os grupos contrários a esse excesso intervencionista começaram a denunciar as tentativas monopolistas das fábricas de tecidos do Sudeste. O deputado Martinho Prado, por exemplo, em discurso no Congresso Nacional, afirmou que “(...) em vez de limitarmos a produção industrial, como almeja o projeto, devemos, ao contrário, alargá-la, para melhorar a média do consumo nacional (...) se estabilizarmos as indústrias nas mãos dos seus atuais detentores, estaremos estabelecendo um monopólio que nada tem de constitucional" ${ }^{\prime 46}$. O jornal Correio da Manhã foi enfático em suas críticas: "As fábricas de tecidos (...) trabalham sem cessar, dia e noite, para atender às exigências de sua freguesia. Portanto, não há excessos de tecidos no mercado, nenhuma superprodução existe. Muito pelo contrário, o que se observa é procura maior do que a oferta. O mercado consumidor absorve tudo o que se está fabricando. Limitar a entrada de maquinismos, para uma atividade aquém das necessidades do país, constitui o mesmo que garantir a meia dúzia de cidadãos o direito de desfrutarem, só eles, o mercado consumidor, isto é, o privilégio, o monopólio"447. Em outro editorial, o periódico afirma que "no Brasil, ninguém mais pode montar uma fábrica (de tecidos), porque os poderes públicos resolveram garantir a prosperidade dos indústrias que já a fruem e que têm amigos ou advogados na Câmara e no seio do próprio governo

\footnotetext{
${ }^{445}$ O Estado de São Paulo. A importação de maquinismos para a indústria nacional, 19.03.1937.

${ }^{446} O$ Estado de São Paulo. $\underline{\mathrm{O} \text { projeto que regulamenta as indústria em superprodução, }}$ 15.10.1937.

${ }^{447}$ Correio da Manhã. Indústrias em superprodução, 20.03.1937.
} 
(...) Aqui, sob a capa de economia dirigida, o que se está fazendo é favorecer os trusts, é a engorda dos magnatas, à custa do sacrifício do consumidor" ${ }^{\prime 48}$.

Após tantos embates entre os grupos favoráveis e contrários ao intervencionismo estatal nas indústrias consideradas em superprodução, o governo resolveu abrir inquérito no Ministério do Trabalho para chegar a posições concludentes sobre o assunto. Esse relatório, entregue às mãos do presidente Getúlio Vargas em outubro de 1938, nunca veio a público. Mesmo assim, por intermédio de deputados, alguns jornais tiveram acesso a alguns dos seus trechos. Nestes, atentava-se para a "precariedade científica da superprodução que os industriais têxteis de algodão alegavam". Afirmava-se que, ao invés de superprodução, mais correto seria dizer que houve "saturamento de certos mercados de tecidos" em regiões específicas, tais como no Rio de Janeiro e em São Paulo. O inquérito propunha, como medidas para solucionar esse problema, a adoção do salário mínimo, que elevaria a média de consumo doméstico; a criação de taxas cambiais favoráveis à exportação têxtil; e, em especial, a divisão do Brasil em duas zonas de trabalho. A primeira dessas zonas, formada pelos estados do Rio de Janeiro, São Paulo e Minas Gerais - cujas associações burguesas alegavam, de forma insistente, a existência de superprodução -, teria jornadas de 48 horas semanais; a segunda delas, formada pelos estados restantes, "de onde provém as mais insistentes queixas contra a presumida superprodução", não teriam limitação de horas de trabalho ${ }^{449}$.

Mais uma vez o feitiço voltou-se contra o feiticeiro. A proposta de limitação das jornadas, tão apregoada pelas fábricas sulistas, tornou-se pesadelo para as mesmas. O abalo desse inquérito oficial nos centros patronais foi tão grande que o CIFTA e o SPITESP resolveram unir forças para realizar levantamento entre as fábricas têxteis locais sobre o assunto. Visava-se, com isso, provar que o relatório governamental havia atingido falsas conclusões. Segundo o levantamento burguês, das 213 empresas têxteis de algodão pesquisadas, 165 (66.012 teares) eram favoráveis à limitação das jornadas, por se considerarem em superprodução, enquanto 48 (16.123 teares), não ${ }^{450}$. Assinalava-se, dessa maneira, embasado em "dados científicos", que "a limitação do trabalho nas tecelagens de algodão é (...) a medida mais urgente e a mais eficaz (contra o problema da superprodução)". Colocavam, porém, que "a uniformização do trabalho nas tecelagens

\footnotetext{
${ }_{448}$ Correio da Manhã. A superprodução, 23.03 .1937$. 449

Stanley Stein, op. cit., p. 158.

${ }^{450}$ CIFTA. Memorial apresentado ao Conselho Técnico de Economia e Finanças (CTEF) sobre a crise da indústria têxtil pelo CIFTA e pelo SPITESP, 23.12.1938.
} 
não pode ser resolvida por simples convênio, não só em virtude de haver fábricas de tecidos em quase todos os estados do Brasil, como também pelas naturais dificuldades que uma providência dessa ordem infalivelmente encontraria. É certo que surgiram vários protestos contra a limitação das horas de trabalho nas seções de tecelagem de algodão. Esses protestos, entretanto, não conseguiram invalidar ou destruir os argumentos apresentados em apoio a essa salutar providência. Está claro que um assunto dessa ordem não pode reunir a unanimidade de opiniões, tendo em vista a existência de interesses divergentes. No entanto, como se demonstrou, a limitação das horas de trabalho representa efetivamente as aspirações e o desejo da grande maioria da indústria têxtil do algodão (grifo nosso)". Por final, argumentou-se que a proposta de criação de duas zonas de trabalho era “(...) contrária à unidade econômica prevista na Carta Constitucional de 11 de novembro de 1937 e igualmente contrária aos interesses econômicos do país" ${ }^{451}$.

Vários aspectos chamam atenção nesse levantamento patronal sulista. Em primeiro lugar, a mudança tática de tal burguesia. Passado mais de um ano do fím da lei proibitiva de importações de máquinas, estancaram-se os pedidos para seu restabelecimento. Provavelmente se percebeu que o governo não cederia. Os esforços foram concentrados, dessa maneira, na tese da limitação das jornadas. Em segundo lugar, é fundamental relativizar a representatividade dos dados estatísticos apresentados pelos centros patronais citados. Das 165 empresas favoráveis à limitação, 108 (65\% do total) eram do Centro-Sul (SP, RJ e MG), possuidoras de 46.612 teares (70,6\% do total). Além disso, lembra-se que, apesar da inexistência de dados sobre a indústria têxtil de algodão doméstica em 1938, sabe-se que, em 1932, havia, no País, 355 fábricas desse ramo com 83.312 teares ${ }^{452}$. Devido ao crescimento têxtil algodoeiro no interregno 1932-1935, à produção local de teares e à liberação da compra dessas máquinas do exterior a partir de 1937, é evidente que, em 1938, o número dessas empresas já deveria ser muito maior do que 355 e a quantidade de teares também muito superior a 83.312. Vê-se, portanto, a duvidosa validade "científica" dessa pesquisa burguesa cujo universo resumia-se a 213 fábricas possuidoras de 82.135 teares. E, por final, recorda-se que o relatório em questão negligenciou totalmente as inúmeras cartas e telegramas recebidas pelo CIFTA de pequenas e médias empresas têxteis sulistas e nordestinas, nos quais se criticava a posição do Centro, defensora, segundo elas, apenas das grandes fábricas do Sudeste. A companhia

\footnotetext{
${ }^{451}$ Idem.

${ }^{452}$ Stanley Stein, op. cit., p. 191.
} 
Carlos Renaux S.A., de Santa Catarina, por exemplo, afirmou em telegrama ao CIFTA que a proibição de se importar máquinas e a limitação das jornadas são medidas que "ferem os pequenos fabricantes e beneficiam os grandes" ${ }^{\prime 453}$.

A divulgação desse relatório ${ }^{454}$ que se considerava "representante" da indústria têxtil doméstica revoltou alguns empresários nordestinos. Caso notável foi o memorial apresentado ao governo pela Cia. de Tecidos Paulista (PE), no qual se afirmava claramente que o tão apregoado problema superprodutivo era uma "ilusão" criada pelas fábricas sulistas, objetivando dominar o mercado interno mediante leis restritivas que as favorecessem. A companhia também assinalou que não possuía estoques e que estava trabalhando a todo vapor para suprir a demanda por tecidos ${ }^{455}$. O CIFTA rebateu as críticas no começo de 1939. Pretendeu-se isolar a dita companhia das demais fábricas domésticas. Argumentou-se que tal empresa não poderia ser comparada às demais porque possuía uma rede de comércio varejista distribuída por todo o País (as Casas Pernambucanas) para escoar sua produção. Segundo o Centro, “o antagonismo de interesses entre o Norte e o Sul é a Companhia de Tecidos Paulista, quem procura confundir, de uma forma aliás bastante lamentável, os seus interesses com os do Norte, os quais são completamente diferentes" $"$ "

É interessante destacar que as críticas feitas pelo CIFTA à empresa pernambucana não atingiram o cerne da questão. Ao se destacar as atividades comerciais da Cia. de Tecidos Paulista, tentava-se explorar o histórico conflito entre fabricantes e intermediários de tecidos no Brasil. Não se respondeu, todavia, ao porquê da fábrica citada, mesmo produzindo a todo vapor, ter conseguido vender todos seus tecidos em um mercado saturado pela "superprodução"; ou, ao porquê das demais empresas têxteis - notadamente as grandes do Centro-Sul - não terem também organizado sua própria rede de comércio varejista. O liberal Correio da Manhã não perdoou esse deslize do CIFTA: “Os outros que façam o mesmo (que a companhia pernambucana). E os que não puderem que se dêem por vencidos. O poder público não pode ser tutor dos industriais em situação de fraqueza" ${ }^{\circ 57}$.

453 CIFTA. Telegrama Carlos Renaux S.A., Santa Catarina, 17.11.1938. Outras cartas e telegramas possuidoras das mesma tônica: Cia. Fiação e Tecidos Goyanna, Pernambuco, 18.11.1938 e Cia. Industrial Pirapama, Pernambuco, 16.11938.

${ }^{454}$ Apesar de o relatório do CIFTA e do SPITESP ter saído oficialmente em dezembro de 1938, já se conhecia parcialmente seu conteúdo, pelo menos, desde setembro, em razão de divulgações jornalísticas.

455 CIFTA. Memorial apresentado pela Cia. de Tecidos Paulista ao Diretor Geral do Departamento Nacional de Indústria e Comércio, 01.10.1938.

${ }^{456}$ CIFTA. Memorial apresentado ao Conselho Técnico de Economia e Finanças, rebatendo acusações feitas ao CIFTA-Rio, 07.01.1939.

${ }^{457}$ Correio da Manhã. Remédio paliativo, 25.01.1939. 
Em janeiro de 1939, outro parecer oficial ratificava as decisões de não-intervenção estatal afirmando que “(...) um dos pontos essenciais para que uma indústria possa ser declarada em superprodução é que a mesma, em sua maioria, não esteja trabalhando além das horas normais ( 8 horas diárias). E isso não se verifica nas fábricas de tecidos de algodão (...) Há fabricas que trabalham 24 horas por dia; muitas trabalham com duas equipes de operários; poucas são as que trabalham menos de dez horas e raras as que estão abaixo das 8 horas normais" ${ }^{\prime 458}$. Tinha-se aqui, portanto, a comprovação de que o governo federal não reeditaria a lei de 1931 e muito menos estipularia uma redução das jornadas de trabalho nas fábricas de tecidos locais. A grande burguesia têxtil, principalmente a paulista, havia perdido o combate.

Essa longa rememoração dos conflitos entre as burguesias de tecidos domésticas tornou evidente, portanto, que a tão apregoada superprodução era apenas um dos meios utilizados pelos empresários têxteis do Centro-Sul para manter e ampliar seu domínio sobre os mercados internos, mediante leis restritivas que os favorecessem. Vários são os indícios que negam a existência de um estado superprodutivo do subsetor de tecidos local. Em primeiro lugar, citam-se os grandes investimentos realizados pela indústria têxtil no interregno 1937-1938 (Tabela 3.24), muito acrescidos após a liberação da importação de máquinas. Lembra-se também, nesse mesmo sentido, o crescimento das vendas de teares produzidos por fábricas domésticas, ocorrido muito em razão da proibição importadora $\operatorname{citada}^{459}$. Assim, como assinalou o jornal Correio da Manhã, "uma atividade industrial em crise não solicita novas inversões de capital (...) O aumento, pois, do capital aplicado na indústria de tecidos é uma prova de que, ao invés de retração, de timidez, se verifica arrojo, iniciativa dos que vivem nesse setor da economia nacional. A menos que admitíssemos estar toda a gente que contribui para aumentar o acervo das indústrias de tecidos sofrendo das faculdades mentais, teremos de ver na afluência maior de riqueza (...) uma prova que os seus interessados diretos não visionam (...) nenhuma crise (...) Se os teares aumentam, é porque a procura de tecidos por eles fabricados também aumentou $(\ldots){ }^{\natural 60}$. Concluem, ironicamente, que os industriais têxteis do Sudeste “(...) pleiteiam dos poderes públicos medidas que a outros impeçam fazer o que estão fazendo, isto é, aceitar o

458 CIFTA. Parecer do Conselheiro Dr. Aloysio de Lima Campos, membro do Conselho Técnico de Economia e Finanças, sobre a questão da limitação das horas de trabalho nas seções de tecelagem de algodão, 20.01.1939.

${ }^{459}$ Para maiores informações sobre esse tema, ver: Correio Paulistano. A evolução da indústria nacional na fabricação de máquinas têxteis, 13.05.1951.

${ }^{460}$ Correio da Manhã. A superprodução, 23.03.1937. 
encargo pesado que os está arruinando! O negócio é péssimo, mas eles querem ficar sozinhos, provavelmente com pena dos concorrentes" ${ }^{\$ 461}$.

Um segundo fator que comprova a inexistência superprodutiva são as altas jornadas de trabalho verificadas na maioria das empresas têxteis domésticas, em especial nas pequenas e médias do Centro-Sul e, em grande parte, nas outras dos demais estados, as quais se viram prejudicadas pela impossibilidade de elevar sua capacidade produtiva em razão da lei de 1931. Como afirmou o próprio Ministério do Trabalho, "não era possível considerar em superprodução uma indústria cujas fábricas (...) trabalham além de suas horas normais" ${ }^{\prime 462}$.

E, por final, em terceiro lugar, recorda-se a reação enfática das empresas, principalmente sulistas e nordestinas, diante da suposta existência de uma superprodução têxtil no País. Até mesmo algumas grandes fábricas do Centro-Sul contestavam a visão do CIFTA e do SPITESP. Rocha Vaz, por exemplo, presidente da Cia. Nacional de Tecidos 'Nova América', afirmou no CFCE que, apesar da concorrência têxtil ter-se tornado intensa nos anos (19)30, a "terapêutica" utilizada para curá-la foi equivocada: "suprimir a importação de máquinas para a indústria têxtil (era) como se para a cura de uma forte dor de cabeça fossemos aconselhar cortar a cabeça (...) Quem pensaria, em tão angustiosa situação (1929-1932), importar máquinas para fabricar tecidos, quando era clara e notória a precária situação desta indústria? (...) Passaram-se os meses e a indústria têxtil foi readquirindo seu ritmo costumeiro, porém o fantasma da importação de máquinas não saía da cabeça dos que já foram vítimas de sua imprevisão, muito embora já tenhamos provas absolutas e confortadoras das possibilidades de ampliação produtiva dos nossos tecidos (...)". Como conclusão, afirmou que "interesses privativos não poderiam se sobrepor aos interesses gerais da nação"463.

O máximo que se pode inferir dessa questão, portanto, é que alguns ramos da indústria têxtil paulista (algodoeiro e lanífero, principalmente), em razão da redução de mercados regionais, passaram por fase de retração no interregno 1936-1937. Ou, nas palavras do inquérito oficial de 1938, houve "saturamento de certos mercados de tecidos" (grifo nosso) ${ }^{464}$, notadamente os do Centro-Sul, mas não de todos. As pequenas e médias empresas do Sudeste - muitas delas localizadas no interior dos seus respectivos estados - e as outras fábricas das demais unidades federativas - podendo, desde 1937,

\footnotetext{
${ }^{461}$ Idem.

${ }^{462}$ O Estado de São Paulo. A importação de maquinismos para a indústria nacional, 19.03.1937.

${ }^{463}$ Jornal do Comércio. Conselho Federal de Comércio Exterior, 16.01.1937.

${ }^{464}$ Stanley Stein, op. cit., p. 191.
} 
acrescer sua capacidade produtiva - começaram a abastecer de maneira crescente seus mercados regionais. Uma das suas principais vantagens perante as grandes empresas paulistanas, nesse sentido, era a de não ter que arcar com quaisquer tipos de custos de transportes, já que vendiam seus produtos para consumidores das suas próprias localidades.

De tudo o que se afirmou, conclui-se, dessa maneira, que a recessão têxtil paulista de 1936-1937 deveu-se a um tripé: (i) aumento das importações de tecidos, (ii) diminuição do mercado consumidor estadual e (iii) queda das vendas para os demais estados, verificável mediante redução do volume do comércio de cabotagem paulista.

\section{$\underline{3.2 .3 .3-1938-1939}$}

A retomada do crescimento da indústria têxtil paulista, ocorrida no interregno 1938-1939, deveu-se, essencialmente, a dois fatores. Em primeiro lugar, cita-se a recuperação do mercado consumidor estadual. O índice geral de preços caiu em $78 \%$ entre 1937 e $1939^{465}$. No estado de São Paulo, esse decréscimo esteve muito relacionado à melhor oferta de bens alimentícios - especialmente cereais -, o que possibilitou a diminuição dos seus preços. No interregno 1937-1939, a área de cultivo algodoeiro no estado decresceu de 1.043.441 para 902.448 hectares, viabilizando, provavelmente, o aumento da produção de bens de consumo básico ${ }^{466}$. É possível que a queda dos preços do algodão no mercado internacional (-31\%, durante o interregno 1937-1939) (67 $^{46}$ agregado à política de fomento de produção cerealífera no estado promovida pela Secretaria da Agricultura mediante distribuição de sementes ${ }^{468}$, tenham sido os fatores mais importantes para explicar tal situação.

Enquanto os preços gerais dos produtos decresciam, percebeu-se relativa melhoria do nível de salários interno. A instituição do salário mínimo, em abril de 1939, foi fundamental nesse sentido ${ }^{469}$. O ganho real dos trabalhadores na indústria têxtil estadual, por exemplo, aumentou em mais de $8 \%$ entre 1938 e $1939^{470}$. A diminuição dos gastos

\footnotetext{
${ }^{465}$ M. de Paiva Abreu. A ordem do progresso, p. 398.

${ }^{466}$ Apesar dessa redução de área cultivada, a produção algodoeira paulista cresceu em $23 \%$ no período, o que denota melhoras das técnicas de cultivo. É provável que tais melhorias se deveram à necessidade de se reduzir custos em razão da queda dos preços do algodão. Para maiores informações, ver: Rui H. P. Albuquerque. Capital comercial (...), op. cit., p. 173.

${ }^{467}$ Idem, op. cit., p. 164.

${ }^{468}$ O Estado de São Paulo. É preciso plantar cereais, 18.08.1936.

${ }^{469}$ Decreto-Lei n. 399, 30.04.1939.

${ }^{470}$ Estatística Industrial do Estado de São Paulo, 1938-1939, p. 134-135.
} 
proletários na compra de bens alimentícios reverteu-se no aumento do consumo de outros bens fundamentais, como tecidos. Atacadistas voltaram a demandar têxteis em quantidade considerável junto às empresas. Não é a toa, portanto, que os diretores da S.A. Fábrica Japy afirmaram que “(...) tivemos pedidos em 1939 que atingiram com folga a quota normal da nossa fábrica" ${ }^{\natural 71}$.

O segundo fator explicativo para recuperação dessas indústrias refere-se ao início da Segunda Guerra Mundial, ocorrido em setembro de 1939. Várias fábricas têxteis assinalaram em seus relatórios anuais esse ponto como determinante para a elevação das suas vendas, as quais, segundo muitas delas, vinham em ritmo ainda lento até o mês de agosto daquele ano. Apenas a título de exemplo, cita-se trecho do balanço da S.A. Fábrica de Tecidos e Bordados Lapa. Conforme seus diretores, “(...) ao deflagrar o conflito europeu (...), tivemos facilidade em colocar quase todos os produtos que tínhamos em estoque (...) ${ }^{» 472}$. Novamente, uma guerra entre imperialismos fomentará crescimentos em economias periféricas. A indústria têxtil de São Paulo, como se mostrará no próximo capítulo, também tirou proveitos dessa situação sui generis.

Por final, deve-se citar que, apesar da perda de mercados regionais ocorrida a partir de 1936 e da derrota em torno das questões da proibição da compra de máquinas do exterior e da limitação das jornadas de trabalho, a indústria têxtil paulista era, no final dos anos (19)30, muito mais hegemônica do que já era no início da década de 1920.

Percebe-se (Tabela 3.25) que, em 1940, a indústria têxtil paulista concentrava quase a metade do número de estabelecimentos $(45,2 \%)$, do capital invertido $(45,4 \%)$, dos trabalhadores empregados $(43,6 \%)$ e da força motriz $(44,1 \%)$ existente nas fábricas de tecidos locais. O valor produtivo praticamente dobrou no interregno 1920-1940. Passou de $36,6 \%$ para mais de $60 \%$ do total doméstico. Apesar da inexistência de dados que possibilitem mensurações, é inegável, devido à recessão sofrida pelo ramo da metade até o final dos anos (19)20, que grande parte desse crescimento participativo se deu durante a década de 1930, especialmente no interregno 1932-1935.

\footnotetext{
$\overline{{ }^{471} \text { S.A. Fábrica Japy, 07.02 }} .1940$.

${ }^{472}$ S.A. Fábrica de Tecidos e Bordados Lapa, 29.03.1940.
} 
Tabela 3.25 - Participação relativa da indústria têxtil nas unidades da Federação (1920-1940), em \%.

\begin{tabular}{|c|c|c|c|c|c|c|c|c|c|c|}
\hline & \multicolumn{2}{|c|}{ Estabelecimentos } & \multicolumn{2}{|c|}{ Capital } & \multicolumn{2}{|c|}{ Operários } & \multicolumn{2}{|c|}{ Força Motriz } & \multicolumn{2}{|c|}{ Valor Produção } \\
\hline & 1920 & 1940 & $1920(1)$ & $1940(2)$ & 1920 & 1940 & $1920(3)$ & $1940(4)$ & $1920(1)$ & $1940(2)$ \\
\hline Alagoas & 7,9 & 2,4 & 3,8 & 2,5 & 4,9 & 2,9 & 5,5 & 2,7 & 3,8 & 1,8 \\
\hline Amazonas & 0,0 & 0,0 & 0,0 & 0,0 & 0,0 & 0,0 & 0,0 & 0,0 & 0,0 & 0,0 \\
\hline Bahia & 1,2 & 3,4 & 4,0 & 1,4 & 4,8 & 2,6 & 3,7 & 3,2 & 3,4 & 1,1 \\
\hline Ceará & 10,4 & 5,7 & 1,1 & 1,3 & 2,4 & 1,2 & 1,5 & 1,5 & 2,1 & 1,5 \\
\hline Distrito Federal & 6,0 & 4,0 & 27,1 & 15,4 & 17,0 & 9,9 & 21,5 & 12,2 & 16,8 & 8,3 \\
\hline Espírito Santo & 0,2 & 0,0 & 0,2 & $*$ & 0,4 & $*$ & 0,0 & 0,1 & 0,3 & * \\
\hline Goiás & 0,0 & 0,1 & 0,0 & $*$ & 0,0 & $*$ & 0,0 & $*$ & 0,0 & $*$ \\
\hline Maranhão & 4,2 & 2,7 & 1,9 & 0,8 & 2,8 & 1,4 & 2,5 & 1,8 & 2,1 & 0,7 \\
\hline Mato Grosso & 0,0 & 0,0 & 0,0 & * & 0,0 & * & 0,0 & * & 0,0 & * \\
\hline Minas Gerais & 6,4 & 5,6 & 5,5 & 6,0 & 8,5 & 7,7 & 8,2 & 7,6 & 6,2 & 4,7 \\
\hline Pará & 0,2 & 0,7 & 0,2 & 0,4 & 0,3 & 0,4 & 0,1 & 0,4 & 0,3 & 0,4 \\
\hline Paraíba & 14,0 & 9,6 & 0,9 & 3,0 & 1,8 & 4,2 & 1,1 & 2,6 & 2,5 & 3,3 \\
\hline Paraná & 1,2 & 0,8 & 0,1 & 0,4 & 0,3 & 0,3 & 0,2 & 0,3 & 0,2 & 0,4 \\
\hline Pernambuco & 7,8 & 3,8 & 5,9 & 8,3 & 6,8 & 10,1 & 7,1 & 7,5 & 5,9 & 6,0 \\
\hline Piauí & 0,4 & 1,1 & 0,2 & 0,1 & 0,3 & 0,2 & 0,3 & 0,3 & 0,3 & 0,1 \\
\hline Rio de Janeiro & 2,6 & 2,8 & 10,5 & 6,9 & 9,1 & 8,0 & 11,2 & 7,7 & 9,8 & 4,6 \\
\hline R. G. do Norte & 9,5 & 6,5 & 0,7 & 1,0 & 1,2 & 0,6 & 0,5 & 1,1 & 2,1 & 1,5 \\
\hline R. G. do Sul & 1,7 & 2,0 & 3,5 & 3,2 & 3,3 & 1,9 & 3,1 & 3,0 & 3,7 & 1,8 \\
\hline Santa Catarina & 1,5 & 1,8 & 0,8 & 2,0 & 1,2 & 2,3 & 0,7 & 1,6 & 1,0 & 1,7 \\
\hline São Paulo & 20,4 & 45,2 & 31,7 & 45,4 & 30,9 & 43,6 & 31,0 & 44,1 & 36,6 & 60,6 \\
\hline Sergipe & 4,5 & 1,8 & 1,9 & 1,7 & 3,8 & 2,8 & 1,8 & 2,4 & 2,9 & 1,3 \\
\hline Território do Acre & 0,0 & 0,0 & 0,0 & 0,0 & 0,0 & 0,0 & 0,0 & 0,0 & 0,0 & 0,0 \\
\hline Brasil & 100 & 100 & 100 & 100 & 100 & 100 & 100 & 100 & 100 & 100 \\
\hline
\end{tabular}

Outro aspecto que também chama atenção na Tabela 3.25 refere-se aos estados que tiveram suas participações diminuídas em prol da ascensão têxtil paulista. De todas as quedas, destaca-se a fluminense (Distrito Federal e estado do Rio de Janeiro). Poder-se-ia argumentar, nesse sentido, que esses dados são contraditórios com a atuação do mais importante centro patronal carioca (CIFTA), que, em todos momentos, formou bloco com o centro paulista (SPITESP) nas questões referentes ao subsetor. Na verdade, isso só vem ratificar o que já fora dito sobre o CIFTA: essa associação, apesar de estabelecida na capital federal, passou a defender cada vez mais os interesses da indústria têxtil paulista, em razão do crescimento da importância desta no cenário doméstico. $\mathrm{O}$ número crescente de associados de São Paulo em tal centro ao longo dos anos (19)20 e (19)30 é bastante elucidativo desse aspecto.

Observa-se, também, que muitos estados nordestinos (Sergipe, Rio Grande do Norte, Alagoas, Bahia, Maranhão e Ceará) perderam participação no subsetor têxtil local no período citado. Em outros, porém, principalmente no de Pernambuco, nota-se limitado crescimento. É provável que o fim da intervenção estatal em 1937 no que concerne à importação de máquinas, favorecedora das grandes fábricas têxteis paulistas, tenha 
contrabalançado perdas anteriores. Lembra-se, também, que o estado de Santa Catarina apresentou elevações em todas variáveis estudadas no período. Nesse caso, foi a especialização das empresas catarinenses em bens têxteis finos que possibilitou não só sua manutenção de grande parte dos mercados locais, como também a exportação de seus produtos para outras unidades da Federação ${ }^{473}$.

Apesar desse evidente crescimento paulista, é necessário salientar a existência de certos problemas no parque têxtil do estado, principalmente no que concerne à idade média das suas máquinas no final da década de 1930. Observa-se (Tabela 3.26) que, em quase todos os ramos, com exceção das sedas, há predominância de bens de capital com mais de 10 anos. Vale lembrar que a variável desconhecido provavelmente indica máquinas também com idade bastante avançada. As inversões recentes em maquinário (menos de 5 anos) realizadas pelas empresas, devido ao fato da contabilização ter sido feita há pouco tempo, dificilmente eram ignoradas. Situação diferente ocorria com os antigos investimentos (mais de 10 anos). A pequenez das sedes administrativas das fábricas tornava, às vezes, impossível a manutenção de dados, livros de contabilidade, relatórios de diretoria e atas de assembléia dos seus tempos iniciais. Considerando, assim, que grande parte das máquinas incluídas na variável desconhecido provavelmente tinha mais do que 10 anos, vê-se o quanto a lei restritiva de importação de maquinários, vigente no País entre 1931 e 1937, sucateou o parque da maior indústria têxtil local.

Tabela 3.26 - Distribuição relativa das máquinas da indústria têxtil paulista, segundo a idade (1939), em \%.

\begin{tabular}{ccccc} 
& Menos 5 & De 5 a 10 & Mais de 10 & Desconhecido \\
\hline Algodão & 1,9 & 1,9 & 45,2 & 51,0 \\
Juta & 8,0 & 1,2 & 54,0 & 36,8 \\
Malha & 12,2 & 23,6 & 42,7 & 21,6 \\
Lã & 9,7 & 5,3 & 15,1 & 69,9 \\
Seda (natural e artificial) & 42,2 & 24,8 & 14,7 & 17,5 \\
\hline
\end{tabular}

Fonte: Estatística Industrial do Estado de São Paulo, 1938-1939.

A partir de 1939, portanto, as fábricas de tecidos paulistas se depararam com uma situação distinta da dos anos (19)30: agora, apesar da vontade e da necessidade de renovar seu parque fabril, em razão de seu sucateamento e da elevação das vendas têxteis

\footnotetext{
473 Sobre essa especificidade da indústria têxtil catarinense, ver: Antônio Barros de Castro. A industrialização descentralizada no Brasil. In: Antônio Barros de Castro. Sete ensaios sobre a economia brasileira. Volume II. Forense Universitária, Rio de Janeiro, 1975, p. 107-158; e Maria Luiza Renaux Hering. Colonização e indústria no Vale do Itajai. O Modelo Catarinense de Desenvolvimento. Ed. da FURB, Blumenau, 1987.
} 
fomentadas pelo conflito mundial, as oportunidades de fazê-lo, devido à própria guerra, tornar-se-iam bem mais complicadas.

\section{$\underline{3.3 \text { - As relações de trabalho no período 1932-1939 }}$}

A recuperação econômica das indústrias têxteis, visível a partir de 1933, não implicou quaisquer melhorias das condições de trabalho nas fábricas. Ao contrário, podese afirmar até que grande parte dessa recuperação se deveu à manutenção, pelo menos até 1935, da negligência burguesa diante da maioria das leis trabalhistas; à crescente substituição de operários adultos por mulheres e crianças - cujos ganhos pecuniários eram bem menores do que os dos primeiros -; e à permanência de pagamentos salariais irrisórios aos trabalhadores.

A documentação operária e as inúmeras greves do interregno 1933-1937 são bastante elucidativas dos aspectos mencionados. A União dos Operários em Fábricas de Tecidos de São Paulo (UOFTSP), por exemplo, bradou em manifesto datado de 1933: "Não é preciso muito esforço para dizer a cada operário em fábrica de tecidos que os salários que recebemos são cada vez mais miseráveis. Que os operários adultos estão sendo dispensados em massa, e substituídos por mulheres e menores que, embora realizem as mesmas tarefas dos adultos, trabalhando 8, 9, 10 e mais horas por dia, recebem salários duas e mais vezes menores (...) Que a lei de férias e a de 8 horas não são respeitadas, salve uma e outra fábrica, mesmo assim com muita restrição dos patrões" ${ }^{\text {"47 }}$. Outro manifesto do mesmo grupo sindical afirmou, em março de 1933, que "milhares de pais de família são despedidos e, ao mesmo tempo (...), substituídos por menores e mulheres, e com ordenados reduzidos (...) e ganhando um miserável salário, que chega ao fim do mês não temos o suficiente para o sustento de nossas famílias, nem mesmo para pagar o aluguel de casa ${ }^{475}$.

Ao se observar relatos proletários de fábricas específicas, percebem-se os mesmos problemas. Os trabalhadores das Indústrias Reunidas Francisco Matarazzo (seção Água Branca), por exemplo, afirmavam: "Não podendo por mais tempo suportar a situação em que nos encontramos, ganhando 700 e 800 réis por hora, trabalhando 12 horas e até mais horas diariamente (...), reunimo-nos e decidimos pleitear juntamente com as férias a que

\footnotetext{
${ }^{474}$ Arquivo DOPS. Manifesto da UOFTSP, fevereiro de 1933.

${ }^{475}$ Arquivo DOPS. Manifesto da UOFTSP, março de 1933.
} 
temos direito, algumas reivindicações mínimas (...) ${ }^{\$ 476}$. Os trabalhadores da Cia. AngloBrasileira de Juta, por sua vez, assinalavam em panfleto que recebiam "salários de fome" ${ }^{477}$. Segundo os operários da Fábrica Jafet, suas condições de vida eram de "extrema miséria". Reclamavam contra os desrespeitos às leis trabalhistas. Afirmavam que "os tecelões da turma da noite trabalham 12 horas", sem receber quaisquer diferenças salariais por isso ${ }^{478}$.

Para além desses aspectos, percebe-se, nesses relatos, a manutenção de antigos problemas das indústrias têxteis paulistas, como as péssimas condições de higiene das fábricas, o alto número de acidentes de trabalho e a permanência dos maus-tratos e abusos feitos pelos gerentes sobre os operários. Um panfleto proletário da Fábrica Mariângela (IRFM) afirmava, em 1934: "Não há nenhuma higiene na fábrica”. Demandavam, entre outros pedidos, maior limpeza nos banheiros, especialmente nas privadas ${ }^{479}$. Os operários da Cia. Anglo-Brasileira de Juta ressaltavam suas "péssimas condições de trabalho", em especial no que se referia à sujeira e ao pó que se concentravam nas seções de fiação ${ }^{480}$. Na Fábrica Jafet, segundo seus trabalhadores, "nossas companheiras são obrigadas a mudar de roupa na privada e a comer na rua debaixo de chuva e de sol”481.

Os acidentes de trabalho e os desrespeitos às indenizações mantinham-se regulares. Na Mariângela, por exemplo, denunciava-se freqüentemente o descaso patronal para com os ferimentos dos proletários, bem como a negligência burguesa no pagamento de indenizações aos acidentados. Em 1934, naquela fábrica, uma operária morreu devido ao tratamento inadequado lhe concedido. Ela havia prensado uma de suas mãos no maquinário e, devido a isso, contraiu forte infecção. Outra trabalhadora, no mesmo período, ficou com um dos seus membros deformados por motivo semelhante. Não houve qualquer pagamento indenizatório em ambos os casos. No ano de 1935, o operário José Santiago da São Paulo Alpargatas Company teve sua cabeça prensada em uma das máquinas. Sofreu "lesões graves" e também não recebeu indenização pelo acidente ${ }^{482}$.

\footnotetext{
${ }^{476}$ Arquivo DOPS. Panfleto do Comitê Geral da Greve dos trabalhadores da IRFM (Seção Água Branca), dezembro de 1932.

${ }^{477}$ Arquivo DOPS. Panfleto do Comitê de Luta dos Operários da Cia. Anglo-Brasileira de Juta, julho de 1934.

${ }^{478}$ Arquivo DOPS. Panfleto da Federação da Juventude Comunista do Brasil da Fábrica Jafet, 1933.

${ }^{479}$ Arquivo DOPS. Panfleto do Comitê de Luta dos Operários da Mariângela, 1934.

${ }^{480}$ Arquivo DOPS. Panfleto do Comitê de Luta dos Operários da Cia. Anglo-Brasileira de Juta, julho de 1934.

${ }^{481}$ Arquivo DOPS. Panfleto da Federação da Juventude Comunista do Brasil da Fábrica Jafet, 1933.

${ }^{482}$ O Estado de São Paulo. Acidente no trabalho, 05.05.1935.
} 
Exemplos parecidos se sucederam em diversas fábricas têxteis paulistas ao longo da década de $1930^{483}$.

Os abusos e maus-tratos praticados pelos gerentes eram também motivo de assíduas reclamações. Os trabalhadores da Votorantim, por exemplo, levantaram-se em vários momentos contra o autoritarismo do chefe da seção têxtil, Henrique Cervone. Este é caracterizado como "esfomeador de operários", "perseguidor", "malvado" e responsável por "nos negar até o dinheiro que é exclusivamente nosso, o da caixa médica" ${ }^{484}$. Na Fábrica Mariângela, os operários se revoltaram com as atitudes despóticas dos dois gerentes trazidos da Itália em 1935 pelo Conde Matarazzo. “Os dois fascistas (...) pensam que aqui é a Itália, aonde tem o regime do fascio". Afirmam que um deles puxava com freqüência a orelha das trabalhadoras durante o expediente, xingando-as ${ }^{485}$. Assédios sexuais cometidos pelos chefes mantinham-se comuns. Na própria Mariângela, assinalava-se que "o safado do gerente quer forçar as operárias a tirarem o casaco para ver seus seios, e chama as operárias para o escritório para corrompê-las, prometendo $10 \$ 000$ e outras coisas" $" 486$.

Vê-se que, ainda no início dos anos (19)30, os desrespeitos às leis trabalhistas e as péssimas condições de vida dos operários eram regra nas indústrias têxteis paulistas. Compreende-se, assim, a eclosão de diversas greves no período 1933-1937, cujas demandas, salvo exceções, praticamente se repetiam: (a) aumento salarial; (b) melhoria da higiene fabril; (c) cumprimento das leis referentes às férias, aos acidentes de trabalho e às jornadas; e (d) punição dos gerentes responsáveis por maus-tratos.

Os movimentos paredistas mais sérios ocorreram entre 1933 e 1935. Apenas a título de ilustração, citam-se alguns exemplos. Em julho de 1933, os operários da S.A. Fábrica de Tecidos e Bordados Lapa iniciaram greve demandando, entre outras coisas, aumento salarial de $20 \%$ e cumprimento da jornada de 8 horas. Vários trabalhadores foram demitidos, a polícia interveio na empresa garantindo o "direito de trabalho" aos que queriam fazê-lo e, com isso, esvaziou-se o movimento ${ }^{487}$. Em 1934, a Fábrica Mariângela foi paralisada. Repetiram-se as mesmas reivindicações. Para além desses aspectos, os

\footnotetext{
${ }^{483}$ Para maiores informações, ver: Relatórios de Diretoria da Sociedade Cooperativa de Seguros contra acidentes de trabalho 'A TÊXTIL'.

${ }^{484}$ Arquivo DOPS. Panfleto feito por um grupo de operários anônimo aos trabalhadores da Fábrica Votorantim, 01.05.1937.

${ }^{485}$ Arquivo DOPS. Carta de um grupo de operários anônimos da Fábrica Mariângela ao Conde Francisco Matarazzo, 06.02.1935.

${ }_{487}^{486}$ Arquivo DOPS. Panfleto do Comitê de Luta dos Operários da Mariângela, 1934.
}

Arquivo DOPS. Relatório do Gabinete de Investigações do DOPS, agosto de 1933. 
operários salientavam o desrespeito à lei de acidentes do trabalho e à necessidade de se pagar ordenados iguais aos homens, mulheres e crianças que realizassem serviços semelhantes. Acusava-se o "Ministério Tapeador do Trabalho" de "instrumento dos patrões, para melhor nos explorarem"488. Outras empresas têxteis paulistas iniciaram paralisações incitadas pela Mariângela. Foram os casos, por exemplo, da Cia. AngloBrasileira de Juta e da Fiação e Tecelagem de Juta Sant'Anna ${ }^{489}$. Sucederam-se, mais uma vez, diversas demissões, bem como prisões de operários que impediram os demais de retornarem ao trabalho. As demandas não foram atendidas. Ao final, como de costume, as empresas agradeceram solenemente ao DOPS pelos serviços prestados durante o período de "instabilidade" 490 .

Em 1935, as agitações se intensificaram, fomentadas pelo projeto da Lei de Segurança Nacional (LSN), em trâmite no Congresso. No mês de janeiro, diversas malharias e fábricas de costura paulistas levantaram-se como forma de protesto contra a LSN. Formaram-se aglomerações de operários na frente das fábricas. A polícia atuou com cavalaria para dispersá-los e reforçou o policiamento nos bairros operários. Em poucos dias, as paralisações já haviam sido encerradas ${ }^{491}$. A partir dessa repressão, a seção têxtil do Partido Comunista do Brasil (PCB) lançou uma onda de panfletos incitando os trabalhadores a se revoltarem contra a chamada "lei monstro". Afirmavam, por exemplo, que "o governo trata sempre de reprimir da maneira mais brutal qualquer movimento nosso. Todo protesto e reivindicação são recebidos a patas de cavalo. O Ministério (do Trabalho) coloca policiais em nossos sindicatos para impedir nossa luta (...) Agora, mais do que nunca, devemos lutar contra essa lei dos ricaços, que visa exclusivamente o aniquilamento das liberdades populares e o fechamento dos sindicatos que lutam em prol dos seus associados (...)"492.

Desde então, além das reivindicações tradicionais (aumento de salários, cumprimento das leis trabalhistas, etc.), agregou-se nas greves de 1935 a demanda da nãoaprovação do projeto legislativo citado. Entre os movimentos paredistas têxteis ocorridos

\footnotetext{
${ }^{488}$ Arquivo DOPS. Panfleto da Federação da Juventude Comunista aos trabalhadores de São Paulo, julho de 1934.

489 Arquivo DOPS. Panfleto do Comitê de Luta dos Operários da Cia. Anglo-Brasileira de Juta, julho de 1934.

${ }^{490}$ Arquivo DOPS. Comunicado da IRFM ao Dr. Ignácio da Costa Ferreira, Delegado da Ordem Política e Social de São Paulo, 31.07.1934; Carta da Diretoria da Cia. Anglo-Brasileira de Juta ao Delegado de Ordem Política e Social de São Paulo, 31.07.1934.

${ }^{491}$ O Estado de São Paulo. Greves, 30.01.1935.

${ }^{492}$ Arquivo DOPS. Panfleto do Comitê do Setor Têxtil do Partido Comunista do Brasil - Trabalhadores Têxteis! De pé contra a Lei Monstro, março de 1935.
} 
nesse ano, destacou-se o da S.A. Tecelagem Ítalo-Brasileira de Seda, iniciado no mês de junho $^{493}$. Em agosto, o Sindicato dos Operários em Fiação e Tecelagem de São Paulo (SOFTSP) conclamou aos demais trabalhadores do ramo não apenas que ajudassem financeiramente os companheiros da Ítalo-Brasileira, mas também que realizassem paralisações em solidariedade aos primeiros ${ }^{494}$. E assim se sucedeu. Inúmeras fábricas entraram em greve, dentre as quais a Fábrica de Meias Mousseline, os Lanificios Filipo e Armênia e a Estamparia Matarazzo ${ }^{495}$. A derrota proletária, de novo, foi flagrante. A contratação de novos operários pela Ítalo-Brasileira, que retomaram os trabalhos fabris sob proteção policial, esvaziou o coração do movimento. Logo, uma a uma, as greves foram sendo encerradas sem que as principais demandas tivessem sido atendidas.

As agitações operárias de 1934 e 1935 justificaram, entre outros motivos - tais como a Intentona Comunista - a aprovação da LSN pelo Congresso em novembro de 1935 $5^{496}$. A repressão estatal contra as lideranças proletárias e os sindicatos mais combativos, desde então, cresceu vertiginosamente. Mesmo assim, antes do golpe criador do Estado Novo, observou-se a eclosão de movimentos grevistas têxteis importantes em São Paulo. No interregno 1936-1937, devido ao aumento dos preços alimentícios, ocorrem paralisações em diversas fábricas. Estas se centraram, essencialmente, nas demandas salariais. As questões referentes aos desrespeitos às leis trabalhistas não foram mencionadas. O melhor cumprimento destas pelos patrões e a eliminação dos elementos operários mais esquerdistas foram os principais fatores dessa alteração.

Em 1936, por exemplo, os trabalhadores da Cia. Anglo-Brasileira de Juta e da S.A. Fábrica de Tecidos Calfat entraram em greve após negativa das diretorias em realizar aumentos salariais de $20 \%$ e $25 \%$, respectivamente ${ }^{497}$. No ano seguinte, a Fábrica de Tecidos Tatuapé, a São Paulo Alpargatas, o Cotonifício Rodolfo Crespi, a Fábrica Votorantim, a S.A. Fiação, Tecelagem e Estamparia Jafet e a Cia. Paulista de Aniagem, entre outras, foram paralisadas pelo mesmo motivo ${ }^{498}$. O Sindicato dos Tecelões de São Paulo, de caráter reformista, laçou nota afirmando que as greves de 1937 são um “(...) prelúdio de outras que virão a seu tempo, porque a vida encareceu extraordinariamente e os salários continuaram a ser os mesmos de há anos"499. As agitações generalizaram-se

\footnotetext{
${ }^{493}$ O Estado de São Paulo. Greve, 06.06.1935.

${ }^{494}$ Arquivo DOPS. Apelo do SOFTSP aos operários têxteis do Estado de São Paulo, 01.07.1935.

${ }^{495}$ O Estado de São Paulo. Greves, 18.07.1935.

${ }^{496}$ Marisa Saes Leme, op. cit., p. 148 e SPITESP. Ata Assembléia Extraordinária, 11.03.1937.

${ }^{497}$ Arquivo Dops. Relatório do Investigador Mário Teixeira Coelho ao Delegado de Ordem Social, Sr. Venâncio Ayres, 16.09.1936; Relatório de Investigação - DOPS, 11.02.1936.

${ }^{498}$ Marisa Saes Leme, op. cit., p. 149.

${ }^{499}$ Diário de São Paulo. Está em greve a seção de tecelagem da Fábrica Jafet, 01.10.1937.
} 
tanto que o centro patronal paulista resolveu mandar aos associados uma circular conclamando aos mesmos "estudarem a possibilidade de aumentar os salários dos seus operários, para que eles possam fazer face à atual carestia de vida" ${ }^{900}$. De fato, devido a essa pressão, houve reajustes reais nos ordenados dos trabalhadores entre 1938 e $1939^{501}$.

Com o golpe de novembro de 1937, que instaurou a ditadura estado-novista, a repressão ao movimento operário atingiu seu ápice. Proibiram-se greves e domesticaramse por completo as associações trabalhistas ${ }^{502}$. O mesmo Sindicato dos Operários em Fiação e Tecelagem de São Paulo que, em 1935, conclamava aos proletários ajudarem a greve da Ítalo-Brasileira e se insurgirem contra a "lei monstro" afirmou, em 1939, que Getúlio Vargas "tem em cada operário um amigo e, em cada amigo, um admirador" partir de então, tais associações, legalizadas pelo Ministério do Trabalho, pediam autorização estatal para realização de quaisquer atos, desde a ratificação da nova diretoria eleita até a publicação de boletins aos operários ${ }^{504}$.

Além desses aspectos concernentes à combatividade e à domesticação dos trabalhadores têxteis no período 1933-1939, deve-se analisar também a relação entre burguesia e Estado no que se refere à aceitação e ao cumprimento das leis trabalhistas então criadas. Viu-se que, entre 1933 e 1935, estas continuaram sendo desrespeitadas pelo patronato têxtil. As freqüentes acusações proletárias relativas aos abusos da lei das jornadas de trabalho e ao não-cumprimento das leis de férias e de acidentes são por demais exemplificativas desse aspecto.

Lembra-se, também, que muitas das antigas leis trabalhistas foram reformadas nesse período. Em janeiro de 1934, por exemplo, publicou-se a nova lei de férias, que assegurou quinze dias de descanso anual a todos os operários sindicalizados ${ }^{505}$. As críticas burguesas à concessão deste benefício aos trabalhadores mantiveram-se idênticas às do período pré-depressivo ${ }^{506}$. Muito se comentou também acerca da inviabilidade de se garantir férias apenas aos proletários sindicalizados e de se assegurar a estes sindicatos o

\footnotetext{
${ }^{500}$ SPITESP. Ata Assembléia Extraordinária, 11.03.1937.

${ }^{501}$ Estatística Industrial do Estado de São Paulo, 1938-1939, p. 134-135.

${ }^{502}$ Ver, nesse sentido: Zélia Lopes da Silva. A domesticação dos trabalhadores nos anos 1930. Ed. Marco Zero, São Paulo, 1990.

${ }^{503}$ Homenagem ao Sr. Getúlio Vargas. In: O trabalhador têxtil. Órgão oficial do Sindicato dos Operários em Fiação e Tecelagem de São Paulo, julho de 1939.

${ }^{504}$ Ver, nesse sentido, por exemplo, a Carta do presidente do SOFTSP, Paulo Liteiro, ao Delegado do DOPS, Venâncio Ayres, 18.04.1938. Nesta, em dado momento, o presidente do SOFTSP afirma: "Em nome do Sindicato (...), venho pela presente solicitar de V. Excia. a permissão para a impressão e distribuição de boletins, cuja cópia segue anexa".

${ }^{505}$ Decreto n. 23.768, 22.01.1934.

${ }^{506}$ Ver, nesse sentido, CIFTA. Relatórios de Diretoria, 1933 e 1934.
} 
poder de fiscalização da lei citada ${ }^{507}$.

Além disso, estabeleceram-se novas regras acerca das obrigações patronais na ocorrência de acidentes de trabalho ${ }^{508}$. Dentre estas, destaca-se a obrigatoriedade em manter contratos de seguro para os trabalhadores ${ }^{509}$, os quais, por sua vez, deveriam ser realizados com empresas cujo capital fosse superior a 500:000\$000 réis. Apesar de se permitir às associações burguesas a organização de tais seguradoras, criticou-se o piso de capital proposto para as mesmas ${ }^{510}$. Logo, porém, em razão dessas pressões, o governo abaixou aquele montante para 200:000\$000 51 . Em 1936, nesse sentido, o SPITESP estabeleceu a Sociedade cooperativa de seguros contra acidentes de trabalho 'A TÊXTIL', criada, segundo ele, “(...) para trazer a nossa modesta contribuição para que fosse resolvido um problema social de notável relevância, qual seja o amparo e a assistência do trabalhador ferido no exercício do seu mister (e) acolher as vítimas do trabalho com largo espírito de solidariedade humana (...)" ${ }^{\$ 12}$. Percebe-se, mais uma vez, o quanto uma lei aceita com relutância pela burguesia têxtil transformou-se, em seus discursos, em ato humano concedido voluntariamente aos proletários.

Criou-se também, em 1936, o Instituto de Aposentadoria e Pensões dos Industriários. Novamente, as críticas patronais fizeram-se sentir. O representante do CIFTA na Comissão de Legislação Social da Câmara dos Deputados, Vicente Galliez, propôs uma redução na contribuição previdenciária mensal de patrões e trabalhadores fabris de 3 a $8 \%$ dos salários destes - intervalo percentual estipulado na lei - para 3 a 5\%. Além disso, ele sugeriu “(...) que fosse abolida a concessão da chamada aposentadoria ordinária, isto é, o pagamento de uma pensão pelo simples fato de ter atingido uma determinada idade ou de ter trabalhado durante determinado número de anos no mesmo estabelecimento. Pelas experiências já observadas nos Institutos em funcionamento, verificou-se que a concessão de aposentadorias ordinárias é extremamente perigosa por consumir a maior parte das receitas dos Institutos de previdência. Só deverá haver pagamento de aposentadorias por invalidez. É preciso que o empregado esteja impossibilitado de trabalhar para que tenha direito ao recebimento de uma pensão. $\mathbf{O}$

\footnotetext{
${ }^{507}$ Marisa Saes Leme, op. cit., p. 142-143.

${ }^{508}$ Decreto n. 24.637, 10.07.1934.

${ }^{509}$ Caso a empresa optasse por não contratar uma empresa de seguro, ela seria obrigada a fazer depósitos mensais de 20:000\$000 por cada grupo de 50 empregados nas repartições federais (Caixas Econômicas da União ou Banco do Brasil).

${ }^{510}$ CIFTA-Rio. Circular, 18.09.1934.

${ }^{511}$ CIFTA-Rio. Relatório de Diretoria, 30.05.1935.

${ }^{512}$ Relatório de Diretoria. Sociedade cooperativa de seguros contra acidentes de trabalho 'A TÊXTIL', 16.02.1937.
} 


\section{objetivo da lei não deve ser a concessão de prêmio e sim a reparação de danos (grifo} nosso)" ${ }^{\text {"513 }}$. As normas da recém-criada previdência operária, apesar dessas críticas patronais, foram mantidas. Independente disso, observou-se que a mesma burguesia têxtil que se considerou "humanitária", por ter criado compulsoriamente cooperativas de seguro para acidentes de trabalho, concluiu, no trecho acima citado, ser um "perigo" conceder aposentadoria para operários pelo "simples" fato dos mesmos terem atingido certa idade, caracterizando tal ato como "prêmio". A suposta "solidariedade" burguesa para com os trabalhadores, tão apregoada nos discursos daqueles, desaparece quando o capital está lutando, no processo de criação legislativa, pela manutenção das suas taxas de exploração.

Apesar das críticas patronais às reformas e criações de leis trabalhistas, é fato que, a partir de 1935, evidenciou-se maior cumprimento das mesmas por parte da burguesia têxtil de São Paulo. Inúmeros fatores comprovam tal mudança. Em primeiro lugar, recorda-se que as reivindicações operárias das paralisações ocorridas desde então foram essencialmente salariais. As freqüentes acusações do início dos anos (19)30 contra o desrespeito às leis de férias, dos acidentes e das jornadas de trabalho desapareceram dos panfletos proletários. Em segundo lugar, lembra-se que o número de empresas associadas à cooperativa de seguro organizada pelo SPITESP cresceu ano a ano. Além disso, a observação da contabilidade das fábricas de tecidos paulista demonstrou que, de $1935 \mathrm{em}$ diante, a maioria delas inseriu em seus passivos os débitos relativos às férias, à seguridade social e ao pagamento de mensalidades às seguradoras.

Duas razões, possivelmente, explicam essa mudança de atitude burguesa: (a) a domesticação efetiva do movimento operário por parte do Estado, intensificada após a criação da Lei de Segurança Nacional, em novembro de 1935; e (b) a maior fiscalização governamental com relação ao não-cumprimento das leis trabalhistas, concretizada mediante (i) a criação das Inspetorias Regionais do Ministério do Trabalho, em $1934^{514} \mathrm{e}$ (ii) a crescente delegação de responsabilidades fiscalizadoras para os novos sindicatos operários, que podiam denunciar com maior eficácia as empresas que agiam ilegalmente. É evidente que a identificação pura e simples desses atos ilícitos não era suficiente para solucionar o problema. Houve, concomitantemente a isso, uma crescente aplicação de penalidades - em especial multas e penhoras - às fábricas desrespeitadoras da $1 \mathrm{ei}^{515}$.

Esse cumprimento da nova legislação trabalhista não significou, entretanto, que a

\footnotetext{
${ }^{513}$ CIFTA. Relatório de Diretoria, 03.10.1936.

${ }^{514}$ As Inspetorias foram criadas pelo decreto n. 22.224 (22.12.1932). Todavia, entraram em vigor apenas em 01.01.1934.

${ }^{515}$ Ver, nesse sentido, Correio da Manhã. Penhorada a Tecelagem de Seda Ítalo-Brasileira S.A., 04.11.1936; Correio da Manhã. Uma fábrica penhorada, 01.11.1936; etc.
} 
burguesia têxtil de São Paulo aceitou passivamente as demais regras criadas pelo Ministério do Trabalho de 1935 em diante. Pelo contrário, evidencia-se manutenção das críticas, mesmo sob o regime estado-novista. Dois exemplos são muito ilustrativos desse aspecto. A publicação do ante-projeto que criaria a Justiça do Trabalho, em abril de 1937, exacerbou ânimos nos centros patronais têxteis. O CIFTA afirmou, entre outros pontos, que aquele "(...) representa a mais grave ameaça para a estabilidade e harmonia das relações entre empregadores e empregados" ${ }^{\prime 16}$. As pressões, nesse caso, surtiram efeito. As atribuições da Justiça do Trabalho foram limitadas quando do seu estabelecimento efetivo em 1939. Manteve-se, porém, a paridade entre os representantes burgueses e operários em sua administração ${ }^{517}$.

Outro exemplo importante de crítica patronal refere-se à criação do salário mínimo, que estabeleceu pisos de ordenados distintos para cada estado, de acordo com seu respectivo custo de $v^{5} a^{518}$. Segundo o CIFTA, essa lei condenaria “(...) ao desaparecimento o sistema de tarefas e empreitadas, pois, se o operário que é pago por esse regime tiver sempre garantido o salário mínimo do dia normal de serviço, não mais existirá estímulo na intensificação da produção, nem interesse em se dedicar ao serviço (...) Isso seria nivelar o bom e o mau operário e estimular a negligência e a violência (...) "519. Para além desse aspecto, criticou-se a metodologia de cálculo das Comissões Fixadoras do Salário Mínimo para as regiões do País. "É interessante observar que as características econômicas de zonas que possuem salários mínimos extremamente diferentes não possuem acentuada diversidade, o que torna as aludidas zonas verdadeiramente privilegiadas (...)" ${ }^{\oplus 20}$. Percebe-se, nesse trecho, não só a contínua pressão burguesa para manutenção de altos níveis de extração de mais-valia dos operários levemente limitados com a criação desse piso salarial -, mas também o receio de que a institucionalização de ordenados menores nas fábricas têxteis nordestinas e sulistas pudesse significar um aumento do poder de competição destas perante as do Centro-Sul. Independentemente disso, nesse caso, as pressões da burguesia paulista não geraram modificações na lei original do salário mínimo.

De tudo o que foi dito sobre as relações de trabalho nas fábricas de tecidos paulistas entre 1933 e 1939, extraem-se algumas conclusões importantes: (a) o movimento

\footnotetext{
${ }^{516}$ CIFTA. Relatório de diretoria, 1938.

${ }^{517}$ Marisa Saes Leme, op. cit., p. 154.

${ }^{518}$ Decreto-lei n. 399, 30.04.1939.

${ }^{519}$ CIFTA. Memorial enviado ao Sr. Ministro do Trabalho, Indústria e Comércio sobre a aplicação do salário mínimo nos serviços pagos por tarefa ou empreitada, na indústria têxtil, 12.06.1939.

${ }^{520}$ Idem.
} 
operário têxtil foi bastante combativo no período 1933-1935 em razão das precárias condições de vida dos proletários, sendo, a partir de então, cada vez mais domesticado mediante emprego da força, da violência e da concretização de certas benesses estatais; e (b) a burguesia do subsetor continuou, no interregno 1933-1935, a descumprir e a criticar a maioria das leis trabalhistas. De 1935 em diante, porém, devido a inúmeros fatores, percebeu-se crescente respeito patronal à tal legislação, apesar da permanência das críticas às novas leis promulgadas sobre o tema.

\section{$\underline{3.4-\text { Conclusões parciais }}$}

A indústria têxtil paulista apresentou notável crescimento no período 1933-1939. Este, porém, não foi nem linear (recessão 1936-1937), nem homogêneo (maior ascensão do ramo das sedas e contínua crise do ramo jutífero). Além disso, caracterizou-se pela desconcentração fabril e espacial. No final da década de (19)30, o peso das pequenas e médias empresas, bem como o das fábricas do interior de São Paulo, já se fazia perceptível no ramo.

Observou-se igualmente que essa expansão têxtil paulista foi fomentada por um processo substitutivo de importações e pelo acréscimo e obtenção de mercados regionais. Fundamental nesse sentido foi a manutenção da lei que proibia a importação de bens de capital para o subsetor de tecidos interno. Assim, as grandes empresas de São Paulo, que possuíam capacidade produtiva para atender às necessidades de consumo domésticas, expandiram enormemente suas vendas para os demais estados da Federação, enfraquecendo concorrentes regionais.

No interregno 1936-1937, com a maior entrada de bens importados, com o encarecimento dos bens alimentícios de primeira necessidade e, em especial, com o fim da proibição da compra de máquinas têxteis do exterior - que desencadeou uma verdadeira batalha ideológica entre os centros patronais do Sudeste e muitas empresas de tecidos sulistas e nordestinas -, as fábricas paulistas viram diminuir seus mercados intra e interestadual. Desencadeou-se, com isso, uma recessão na maioria dos ramos, superada a partir de 1938.

A supressão da lei proibitiva de 1931, porém, não impediu que a indústria têxtil paulista aumentasse consideravelmente sua participação no total das fábricas de tecidos locais. Na verdade, foi na década de 1930, em razão do início dessa conquista dos mercados regionais, que essa indústria se tornou hegemônica no País. A predominância de 
máquinas obsoletas em seu parque fabril, no entanto, apareceu como subproduto desse arranque estadual.

Por final, viu-se que os anos (19)30 foram marcados, no que refere às relações capital-trabalho, pela domesticação dos movimentos operários; pelo gradativo, porém relutante, cumprimento da legislação trabalhista por parte dos patrões; e pela permanência das críticas burguesas às novas leis sociais criadas pelo governo. Em alguns casos, como se observou, os centros patronais obtiveram sucesso mediante reforma das mesmas (lei dos acidentes, do instituto previdenciário, da Justiça do Trabalho, etc.); em outros (lei do salário mínimo), foram fragorosamente derrotados. 


\section{CAPÍTULO 4 - A indústria têxtil paulista e a guerra (1939-1945)}

Visa-se, neste capítulo, apresentar e analisar a evolução da indústria têxtil paulista durante o contexto da Segunda Guerra Mundial (1939-1945). Para tanto, questionar-se-ão, principalmente, (a) os impactos do conflito em tal subsetor fabril e em seus diferentes ramos no que condiz ao aumento da produção e da capacidade produtiva; (b) a problemática do abastecimento têxtil doméstico em contexto de grande expansão das exportações locais de tecidos; e (c) a dinâmica das relações capital-trabalho e capitalestado ao longo desse interregno.

\section{$\underline{4.1-\text { A economia brasileira e a guerra }}$}

A eclosão da Segunda Guerra Mundial, em setembro de 1939, trouxe consideráveis modificações nas relações econômicas entre as nações centrais e periféricas.

As potências imperialistas viram-se impossibilitadas durante o conflito de produzir bens manufaturados para as nações primário-exportadoras. Nesse sentido, abriu-se espaço, em muitas destas, para o aprofundamento de processos substitutivos de importações. Os países periféricos que já possuíam uma estrutura industrial considerável no setor de bens de consumo não-duráveis chegaram até a exportar bens fabris para outras nações pobres, que eram ainda insuficientemente preparadas para fomentar sua industrialização de produtos de consumo.

Além desse aspecto, o conflito mundial fez aumentar consideravelmente a demanda dos países centrais por matérias-primas e alimentos. Os preços desses produtos, com isso, elevaram-se. A conjunção de importações decrescentes com exportações elevadas e valorizadas no mercado internacional propiciou aos países periféricos a acumulação de vultosos saldos comerciais.

A evolução da economia brasileira ao longo da guerra é um bom exemplo das transformações antes descritas. Percebe-se (Tabela 1.4) que, entre 1939 e 1945, o produto doméstico elevou-se em 20\%, guiado, essencialmente, pelas ascensões da produção industrial $(39,1 \%)$ e das exportações. Estas, em termos de valores, mais do que dobraram no período (de quase 300 para mais de 655 milhões de dólares), permitindo o acúmulo de consideráveis superávits. As reservas de ouro domésticas, por exemplo, elevaram-se em 990\% entre 1938 e 1945 (Gráfico 4.1). 
Tabela 4.1 - Dados econômicos - PNB, Índice Setorial do Produto, Balança Comercial e Índices de Preços e de Quantum das exportações e importações (1939-1945)

\begin{tabular}{cccccccc} 
& 1939 & 1940 & 1941 & 1942 & 1943 & 1944 & 1945 \\
\hline 001 - PNB (Milhões de Cr\$)* & 45,6 & 46,9 & 51,3 & 49 & 52,7 & 53,7 & 55 \\
002 - ÍSP - Agricultura (1939=100) & 100 & 98,2 & 104,4 & 99,8 & 107,1 & 109,7 & 107,3 \\
003 - ÍSP - Indústria (1939=100) & 100 & 97,3 & 103,5 & 104,9 & 119,1 & 131,9 & 139,1 \\
004 - Exportações (milhões de US\$) & 299,9 & 252,1 & 367,7 & 409,8 & 472,6 & 580,3 & 655,1 \\
005 - Importações (milhões de US\$) & 218 & 200,7 & 222,5 & 177,4 & 226,9 & 310,4 & 322,6 \\
006 - Índice Quantum Exportações (1928=100) & 196,6 & 157,3 & 177,4 & 142,6 & 154,2 & 156,9 & 156,5 \\
007 - Índice Quantum Importações (1928=100) & 65,8 & 58,1 & 60,9 & 35,7 & 45,7 & 56,7 & 60,2 \\
008 - Índice Preços Exportações (1928=100) & 72,0 & 79,4 & 95,5 & 132,4 & 142,6 & 172,2 & 196,3 \\
009 - Índice Preços Importações (1928=100) & 205,5 & 231,3 & 245,5 & 356,0 & 368,7 & 388,1 & 393,4 \\
\hline
\end{tabular}

Fonte: Vilela e Suzigan, op. cit., p. 412-454. / Villela e Suzigan, op. cit., p. 412-454 e Haddad, op. cit., p. 147-148. / * Milhões de Cr\$ de 1939.

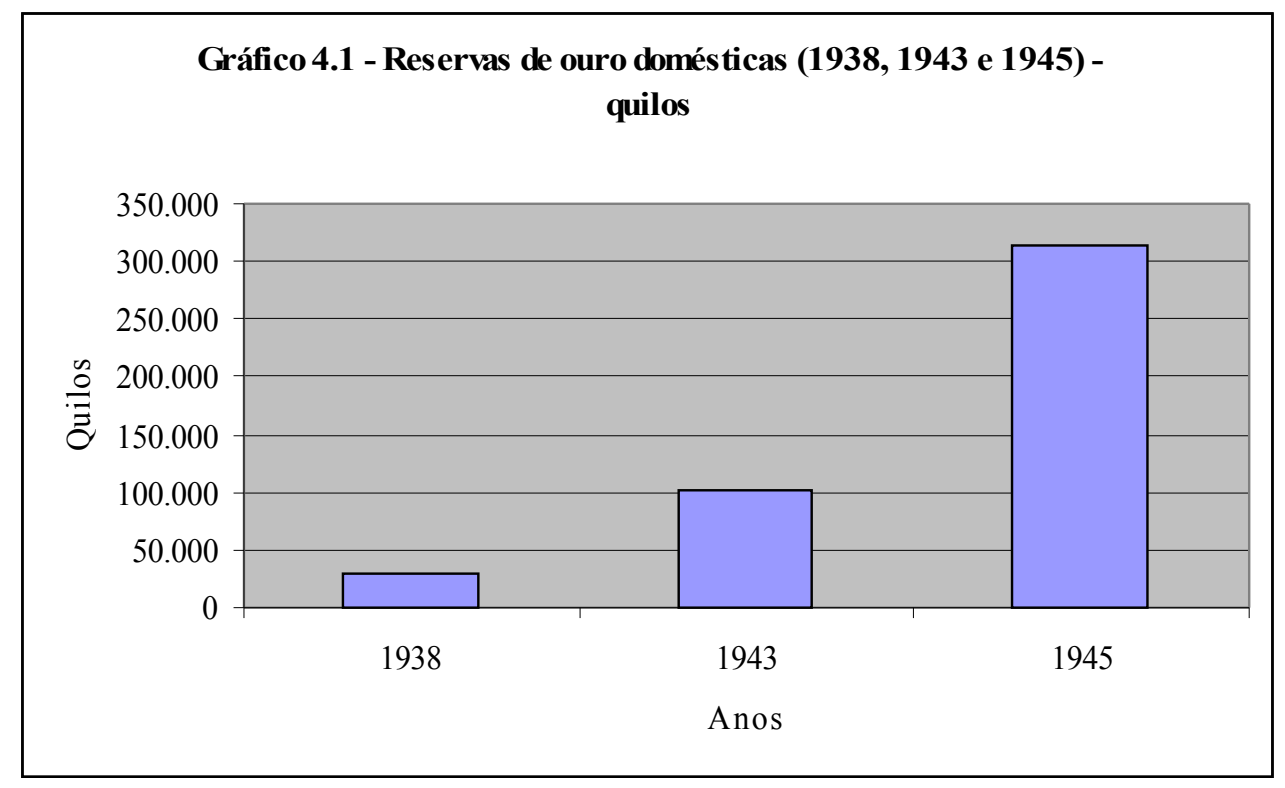

Fonte: Edgard Carone. O Estado Novo, p. 96.

Não há dúvida de que o crescimento do produto industrial local deveu-se a uma maior complexidade do processo substitutivo de importações, que atingiu nesse momento, com maior intensidade, as fábricas ditas pesadas. A maior elevação dos índices de produção fabril no interregno 1939-1945 para os setores de bens intermediários e de capital confirmam tal assertiva. Enquanto, por exemplo, a indústria metalúrgica apresentou ascensão produtiva de 76,9\% nesse período, a química e farmacêutica, de 120,5\%, a da borracha, de 392\%, a de minerais não-metálicos, de 120,5\%; as fábricas de bens de consumo não-duráveis situaram-se em patamares mais modestos, porém ainda consideráveis em alguns casos: alimentos $(0,4 \%)$, bebidas $(54,1 \%)$ e têxteis $(46,3 \%)^{521}$. Lembra-se, também, que a exportação de bens manufaturados para países latino-

\footnotetext{
${ }^{521}$ IBGE. Estatísticas do Século XX (www.ibge.gov.br).
} 
americanos e africanos ao longo da guerra, notadamente tecidos, foi outro fator que propiciou o acréscimo da produção industrial local.

No que se refere às exportações domésticas, percebe-se diminuição do quantum vendido internacionalmente (-20\%, entre 1939 e 1945 - Tabela 1.4), enquanto o valor dos bens exportados ascendeu em mais de $118 \%$. Essa aparente contradição vincula-se a dois fatores: (a) encarecimento de commodities e alimentos em razão das suas crescentes demandas no contexto bélico ${ }^{522}$; e (b) acréscimo de itens de maior valor agregado na pauta exportadora local. De fato, no interregno 1939-1945, os ditos bens tradicionais de exportação doméstica (café, açúcar, cacau, entre outros) cederam espaço para os chamados produtos não-tradicionais (Tabela 4.1b), sejam manufaturados (especialmente tecidos) ${ }^{523}$, sejam matérias-primas (minério de ferro, borracha, algodão em rama, etc.) e alimentos (carne congelada) $)^{524}$.

Tabela 4.1b - Exportação por classes de produtos - Brasil (1940 / 1944), em \%

\begin{tabular}{c|cc|cc} 
& \multicolumn{2}{|c|}{1940} & \multicolumn{2}{c}{1944} \\
& quilogramas & contos & quilogramas & $1.000 \mathrm{Cr} \$$ \\
\hline Matérias-Primas & 25,1 & 35,6 & 22,4 & 22,9 \\
Genêros Alimentícios & 74,1 & 62,6 & 76,0 & 65,0 \\
Manufaturas & 0,8 & 1,8 & 1,6 & 12,1 \\
\hline
\end{tabular}

Fonte: Estatística do Comércio do Porto de Santos, 1940-1941 e 1943-1944.

Os expressivos saldos acumulados na balança comercial doméstica no interregno 1939-1945 ficaram, em grande parte, retidos nos países Aliados, que se encontravam em dificuldades para quitar seus débitos devido ao contexto bélico. O Estado, porém, pagou aos exportadores com moeda nacional. Recorda-se, também, que os problemas encontrados pelos produtores agrícolas tradicionais no escoamento dos seus bens durante a guerra foram amenizados por diversos atos governamentais, tais como as moratórias cedidas aos agricultores e, especialmente, os financiamentos de parte das safras por preços mínimos estipulados. O café, o açúcar e o algodão foram alguns dos bens agrícolas beneficiados por tais medidas ${ }^{525}$.

\footnotetext{
${ }^{522}$ Apenas a título de exemplo, citam-se preços médios de alguns produtos por tonelada: carne de boi $\mathrm{Cr}$ \$2.634 (1939) e Cr\$ 6.137 (1944); banha, Cr\$ 3.118 (1939) e Cr\$ 7.062 (1944); feijão Cr\$ 1.118 (1939), Cr \$ 1.693 (1944); e arroz Cr\$ 746 (1939), Cr\$ 2.210 (1944). Ver: Conselho Federal de Comércio Exterior. Boletins. Ano IX, janeiro de 1946, n. 01, p. 20.

${ }^{523}$ Em 1943, as exportações têxteis representaram 14,2\% do valor total exportado pelo país. Ver: Conselho Federal de Comércio Exterior. Boletins. Ano IX, n. 04-09, abril-setembro de 1946, p. 02.

${ }^{524}$ Marcelo de Paiva Abreu. Crise, crescimento e modernização autoritária (1930-1945). In: Marcelo de Paiva Abreu (org.). A ordem do progresso: cem anos de política econômica republicana (1989-1989). Ed. Campus, Rio de Janeiro, 1990, p. 96.
} 
O crescimento das exportações e as políticas de auxílio estatal aos produtos agrícolas tradicionais levaram a uma expansão considerável dos meios de pagamento domésticos, que ascenderam em mais de 266\% no interregno 1938-1945 (Tabela 4.2). Esse fortalecimento do mercado interno, todavia, não possuiu como contrapartida uma elevação correspondente das ofertas agrícola e industrial locais. O resultado disso foi um crescimento considerável do nível de preços doméstico. O índice do custo de vida de um operário paulista, por exemplo, cresceu em 132,3\% entre 1939 e $1945^{526}$.

Tabela 4.2 - Meios de pagamento - Brasil (1938-1945), milhões de Cr\$

\begin{tabular}{c|c|c} 
& Milhões Cr\$ & Crescimento \% \\
\hline 1938 & 10.949 & \\
1939 & 11.144 & 1,8 \\
1940 & 14.191 & 27,3 \\
1941 & 17.512 & 23,4 \\
1942 & 26.876 & 53,5 \\
1943 & 33.644 & 25,2 \\
1944 & 40.024 & 19,0 \\
\hline \multicolumn{2}{|c|}{ Fonte: IBGE. Estatísticas do Século XX (www.ibge.gov.br). }
\end{tabular}

A insuficiência da oferta agregada local diante da ascensão do mercado interno deveu-se, essencialmente, (a) às crescentes exportações de alimentos, matérias-primas e bens manufaturados, incentivadas pelos compensadores preços internacionais; e (b) aos problemas vinculados à queda da importação de bens intermediários, bens de capital e matérias-primas no contexto bélico, que impediram o aumento da capacidade produtiva das unidades fabris domésticas. Observa-se (Tabela 4.3), por exemplo, que as compras internacionais feitas pelo Brasil de várias matérias-primas importantes decresceram no interregno 1939-1945, tais como carvão $(-41,8 \%)$, coque $(-67,7 \%)$, petróleo bruto $(-78 \%)$ e querosene $(-42,7 \%)$.

\footnotetext{
${ }^{525}$ Para maiores informações sobre os auxílios governamentais para os produtores de bens tradicionais que tiveram perda de mercados durante a Segunda Guerra, ver: Edgard Carone. O Estado Novo, p. 15-57. Lembra-se que o algodão, apesar de ter sido comprado em escala considerável pelos países Aliados entre 1939 e 1945, perdeu todo o mercado das nações do Eixo ao longo do conflito. Antes de 1939, em razão das políticas do marco e da lira compensadas, Itália e Alemanha eram os principais compradores do algodão doméstico. Para maiores informações, ver: Edgard Carone. A Terceira República (1937-1945). Difel, São Paulo, 1976, p. 286.

${ }^{526}$ Brasil. Conselho Nacional de Estatística. Instituto Brasileiro de Geografia e Estatística. Anuário Estatístico do Brasil, ano X - 1949, p.416.
} 
Tabela 4.3 - Importação de carvão, coque, petróleo bruto e querosene - Brasil (1939-1945)

\begin{tabular}{c|c|c|c|c} 
& Carvão $(\mathrm{t})$ & Coque $(\mathrm{t})$ & Petróleo bruto $(\mathrm{Cr} \$ 1.000-\mathrm{D})$ & Querosene (m cúbico) \\
\hline 1939 & 1.201 & 54.240 & 48.171 & 119.850 \\
1940 & 1.150 & 23.338 & 20.312 & 128.830 \\
1941 & 1.013 & 24.623 & 17.817 & 115.525 \\
1942 & 593 & 23.888 & 14.737 & 66.698 \\
1943 & 538 & 43.535 & 27.007 & 87.905 \\
1944 & 468 & 24.452 & 15.515 & 81.402 \\
1945 & 698 & 17.517 & 10.565 & 68.652 \\
\hline
\end{tabular}

Fonte: IBGE. Estatísticas do Século XX (www.ibge.gov.br)

A impossibilidade de acrescer a capacidade produtiva doméstica em quantidade desejada no interregno 1939-1945 fez a intensificação da produção fabril se dar, principalmente, mediante a sobreutilização das máquinas já existentes. Muitas foram as fábricas que, no ápice do conflito, trabalharam 24 horas por dia $^{527}$. O resultado disso foi o sucateamento e desgaste de parte considerável do parque industrial interno ${ }^{528}$.

Por fim, nota-se que os anos de 1941 e 1942 significaram uma inflexão na economia doméstica. Entre 1939 e 1940, os produtos agrícola e fabril decresceram em $1,8 \%$ e $2,7 \%$, respectivamente. $\mathrm{O}$ valor exportado também sofreu queda $(-15,9 \%)$. $\mathrm{O}$ produto local, por sua vez, apresentou leve ascensão no período (2,8\%). A partir de então, apesar da relativa instabilidade na produção agrícola, cujos reflexos no produto nacional tornaram-se visíveis entre 1941 e 1942 (-4,4\%), a tendência foi de crescimento. A produção fabril, por exemplo, elevou-se em 34\% no interregno 1941-1945, influenciando nos resultados do produto local (17\%). O valor exportado, apenas entre 1940 e 1941, apresentou alta superior a $45 \%$ e manteve-se ascendente em todo o período. A explicação para essa guinada encontra-se na própria dinâmica do conflito mundial. É a partir de 1941 que recrudesceram os bloqueios marítimos britânicos contra o Eixo e, principalmente, que se deu o ingresso dos Estados Unidos na guerra. Assim, todas as transformações desencadeadas pelo conflito na economia brasileira - e que já foram anteriormente analisadas - intensificaram-se desde então.

\footnotetext{
${ }^{527}$ Edgard Carone. O Estado Novo, op. cit., p. 68.

${ }^{528}$ Idem, op. cit., p. 62-63.
} 
Os quadros gerais do agregado da indústria paulista e do seu subsetor têxtil no contexto da Segunda Guerra Mundial são apresentados nas Tabelas 4.4 e 4.5.

Tabela 4.4 - Número de estabelecimentos, capital, operários, energia elétrica consumida e valor da produção das indústrias gerais do Estado de São Paulo (1939, 1943 e 1944)

\begin{tabular}{cccc} 
& 1939 & 1943 & 1944 \\
\hline Número de Fábricas & 26.619 & 29.549 & 31.722 \\
Capital Total (1.000 Cr\$) & 2.270 .961 & 4.892 .777 & 7.499 .977 \\
Capital Total (1.000 Cr\$ D) & 1.440 .965 & 1.927 .049 & 2.597 .844 \\
Operários & 254.144 & 362.165 & 400.553 \\
Energia elétrica consumida (Kwh) & 525.855 .814 & 692.625 .294 & 867.739 .000 \\
Valor da Produção (1.000 Cr\$) & 6.135 .386 & 18.537 .462 & 25.927 .914 \\
Valor da Produção (1.000 Cr\$ D) & 3.893 .011 & 7.301 .088 & 8.980 .919 \\
\hline Fonte: Estatística Industrial do Estado de São Paulo, 1938-1939,1943 e 1944.
\end{tabular}

Nota-se, em primeiro lugar, que o período 1939-1944 foi de considerável expansão industrial em São Paulo. Mais de cinco mil empresas foram fundadas nesse interregno. $O$ capital fabril paulista elevou-se em mais de 33\%; os operários, em $42 \%$; e a energia elétrica consumida, em $31,7 \%$. O valor produtivo apresentou o maior crescimento percentual entre todas as variáveis arroladas: $87,5 \%$.

Tabela 4.5 - Número de estabelecimentos, capital, operários, energia elétrica consumida e valor da produção das indústrias têxteis do Estado de São Paulo (1939, 1943 e 1944)

\begin{tabular}{cccc} 
& 1939 & 1943 & 1944 \\
\hline Número de Fábricas & 831 & 1.025 & 1.154 \\
Capital Total (1.000 Cr\$) & 632.632 & 1.104 .200 & 1.874 .268 \\
Capital Total (1.000 Cr\$ D) & 401.416 & 434.896 & 649.210 \\
Operários & 95.516 & 117.542 & 125.624 \\
Energia elétrica consumida (Kwh) & 176.020 .063 & 232.552 .361 & 306.726 .000 \\
Valor da Produção (1.000 Cr\$) & 1.285 .353 & 3.803 .104 & 4.613 .708 \\
Valor da Produção (1.000 Cr\$ D) & 815.579 & 1.497 .875 & 1.598 .098 \\
\hline \multicolumn{4}{l}{ Fonte: Estatística Industrial do Estado de São Paulo, 1938-1939,1943 e 1944. }
\end{tabular}

Quadro semelhante pode ser observado nas fábricas têxteis estaduais. Entre 1939 e 1944, fundaram-se mais de 323 unidades produtivas em São Paulo. No interregno 1933-1935, caracterizado por grande expansão no subsetor de tecidos paulista, apenas 42 novas fábricas haviam sido criadas (Tabela 2a). Percebe-se, assim, a expressividade das fundações no período da guerra ${ }^{529}$. Além disso, houve crescimento das demais variáveis:

\footnotetext{
${ }^{529} \mathrm{Em}$ anexo, pode-se encontrar uma lista das fábricas têxteis fundadas durante a Segunda Guerra Mundial. Nota-se, porém, que tal relação enumera apenas as sociedades anônimas. Não foram encontrados
} 
capital $(8,3 \%)$, operários $(23,1 \%)$, energia elétrica consumida $(32,1 \%)$ e, com a elevação mais significativa, valor produtivo $(83,7 \%)$.

Em segundo lugar, observa-se que o desempenho da indústria paulista agregada foi, no geral, superior ao do subsetor têxtil isolado. Apenas no que condiz ao número de estabelecimentos e à energia elétrica consumida é que as fábricas de tecidos estaduais assinalaram melhor evolução do que as indústrias de São Paulo como um todo. Nas variáveis restantes (capital, operários e valor da produção), houve preponderância destas perante aquelas. Como conseqüência, teve-se decréscimo da participação relativa têxtil dentro do setor fabril paulista agregado (Tabela 4.5b). Confirma-se, assim, o fato de que o aprofundamento do processo substitutivo de importações propiciado pela guerra estimulou em maior montante os subsetores fabris ditos pesados em detrimento dos chamados leves.

\section{Tabela 4.5b - Participação relativa do subsetor têxtil paulista - indústrias gerais do Estado de São Paulo (1939, 1943 e 1944)}

\begin{tabular}{lrrr} 
& 1939 & 1943 & 1944 \\
\hline Número de Fábricas & 3,1 & 3,5 & 3,6 \\
Capital Total (1.000 Cr\$) & 27,9 & 22,6 & 25,0 \\
Capital Total (1.000 Cr\$ D) & 27,9 & 22,6 & 25,0 \\
Operários & 37,6 & 32,5 & 31,4 \\
Energia elétrica consumida (Kwh) & 33,5 & 33,6 & 35,3 \\
Valor da Produção (1.000 Cr\$) & 20,9 & 20,5 & 17,8 \\
Valor da Produção (1.000 Cr\$ D) & 20,9 & 20,5 & 17,8 \\
Média Geral & 24,5 & 22,2 & 22,3 \\
\hline \multicolumn{4}{c}{ Fonte: Tabelas 4.4 e 4.5 }
\end{tabular}

Além disso, percebe-se, em ambos casos, que o crescimento dos valores produtivos foram superiores aos acréscimos de capital, diferentemente do que ocorrera nos anos (19)30 (Tabela 3.3). É inegável que as elevações daqueles refletem, principalmente, ascensão das vendas, já que tais valores foram deflacionados. A apresentação de taxas menos expressivas de aumento de capital, por sua vez, resultou das maiores dificuldades de importação de máquinas ao longo da guerra. Em outras palavras, as indústrias paulistas intensificaram suas produções no período 1939-1945 sem acréscimos proporcionais em sua capacidade produtiva. Nota-se que, em 1944, mais de 79\% do maquinário da indústria têxtil de São Paulo possuía mais de 10 anos de uso (Tabela 4.6). Chama atenção, principalmente, o envelhecimento fabril do ramo das sedas, que, nos anos (19)30, possuía máquinas majoritariamente novas (Tabela 3.26).

documentos referentes às criações de empresas limitadas e sociedades de capital fechado. Ver: Tabela 14a. 
Tabela 4.6 - Distribuição das máquinas têxteis paulistas segundo a idade (1944) - \%

\begin{tabular}{cccc} 
& Menos 5 & De 5 a 10 & Mais de 10 \\
\hline Algodão & 4,2 & 4,9 & 90,9 \\
Juta & 2,2 & 7,0 & 90,8 \\
Malha & 18,4 & 20,3 & 61,3 \\
Lã & 5,6 & 9,7 & 84,8 \\
Sedas & 15,5 & 15,5 & 69,0 \\
Total & 9,8 & 10,8 & 79,5 \\
\hline \multicolumn{2}{l}{ Fonte: Estatística Industrial do Estado de São Paulo, 1944. }
\end{tabular}

A dificuldade na importação de bens de capital para a indústria doméstica durante a guerra não significou, porém, o estancamento total da entrada de máquinas no País. Observa-se, por exemplo, que o maquinário têxtil ingressado no porto de Santos em 1942 foi 56\% inferior ao similar do ano de 1938 (Tabela 4.7), porém totalizou, ainda, mais de 2.000 toneladas, quantia nada desprezível. A partir de 1942, no entanto, a queda da importação foi significativa. Esta se deveu ao recrudescimento do bloqueio naval britânico, que trouxe maiores dificuldades ao comércio marítimo internacional, e à entrada dos Estados Unidos na guerra, grandes vendedores de máquinas têxteis para o Brasil e que, agora, devido ao conflito, teriam que mobilizar sua economia para o esforço bélico. Em 1944, São Paulo importou apenas 470 toneladas de bens de capital têxteis do exterior, quantia essa 90\% inferior às importações de 1938 (Tabela 4.7).

Tabela 4.7 - Importação de bens de capital para a indústria têxtil paulista (1938-1944) - quilos

\begin{tabular}{cccccccc} 
& 1938 & 1939 & 1940 & 1941 & 1942 & 1943 & 1944 \\
\hline Fiação - Tecelagem não especificadas & 4.295 .928 & 2.176 .877 & 1.531 .242 & 1.924 .220 & 886.357 & 340.964 & 312.954 \\
Teares & 253.405 & $*$ & 206.288 & 147.349 & 83.886 & 386 & 45.119 \\
Acessórios não especificados & 408.745 & $*$ & 161.257 & 106.373 & 115.946 & 338.987 & 112.154 \\
Total - Bens de Capital & 4.958 .078 & 2.176 .877 & 1.898 .787 & 2.177 .942 & 1.086 .189 & 680.337 & 470.227 \\
\hline
\end{tabular}

Fonte: Estatística do Comércio do Porto de Santos, 1938-1944.

A necessidade de acréscimo da capacidade produtiva têxtil paulista, impossibilitada de ser satisfeita pela oferta internacional, incentivou o desenvolvimento de indústrias de bens de capital de fiação e de tecelagem domésticas (Tabela 4.8). Mais de quarenta novas empresas foram criadas no período 1939-1944. O capital investido no subsetor aumentou em mais de 260\%; o número de operários, em 174\%; e o valor produtivo, em 221\%. Mesmo assim, a produção local de máquinas têxteis era ainda muito pequena diante das necessidades internas. A título de exemplo, lembra-se que o valor da produção nominal dessas indústrias no ano de 1944, que totalizou Cr\$97.996.000 (Tabela 4.8), representava apenas o capital reunido de quatro empresas têxteis paulistanas: S.A. 
Fiação, Tecelagem e Estamparia Ypiranga Jafet, Cotonificio Rodolfo Crespi S.A., Indústria Têxtil Calfat S.A. e Cotonifício Guilherme Giorgi ${ }^{330}$.

Tabela 4.8 - Número de estabelecimentos, capital, operários, energia elétrica consumida e valor da produção da indústria de bens de capital de fiação e de tecelagem do Estado de São Paulo (1939, 1943 e 1944)

\begin{tabular}{c|cc|cc|cc} 
& \multicolumn{2}{c}{1939} & \multicolumn{2}{c}{1943} & \multicolumn{2}{c}{1944} \\
& Fiação & Tecelagem & Fiação & m & Fiação & Tecelagem \\
\hline Número de Fábricas & 1 & 17 & 12 & 35 & 9 & 51 \\
Capital Total (1.000 Cr\$) & 2.650 & 2.838 & 4.615 & 8.377 & 5.374 & 31.700 \\
Capital Total (1.000 Cr\$ D) & 1.681 & 1.801 & 1.818 & 3.299 & 1.861 & 10.980 \\
Operários & 64 & 722 & 606 & 790 & 557 & 1.604 \\
Energia elétrica consumo (Kwh) & $*$ & 484.023 & 669.244 & 392.059 & 400.951 & 756.609 \\
Valor da Produção (1.000 Cr\$) & 1.874 & 14.806 & 15.007 & 30.895 & 24.163 & 73.833 \\
Valor da Produção (1.000 Cr\$ D) & 1.189 & 9.395 & 5.911 & 12.168 & 8.370 & 25.574 \\
\hline
\end{tabular}

Fonte: Estatística Industrial do Estado de São Paulo, 1938-1939, 1943 e 1944.

Assim, a insuficiente quantidade de máquinas têxteis importadas - acentuada no período 1942-1945 - e a reduzida oferta doméstica desses bens de capital, explicam a manutenção da obsolescência do parque fabril paulista de tecidos, mesmo em um contexto de acelerada expansão da demanda por têxteis (Tabela 4.6).

Além desses aspectos, tendo em vista os dados apresentados pelas Tabelas $4.4 \mathrm{e}$ 4.5, salienta-se ainda o fato de que, em ambos grupos (indústrias paulistas agregadas e têxteis), o número de operários cresceu mais significativamente do que os acréscimos de capitais constantes. As fábricas de São Paulo contrataram, apenas entre 1939 e 1944, mais de 140.000 pessoas, isto é, o número de trabalhadores existentes no parque fabril estadual no ano de 1928 (Tabelas 4.4 e 1.1). No que se refere às têxteis, vê-se que, no mesmo período, mais de 30.000 novos operários ingressaram no subsetor (Tabela 4.5).

Tabela 4.9 - Tempo médio de trabalho nas seções de fiação e tecelagem de algodão - Brasil e São Paulo (1945) - em horas

\begin{tabular}{ccccc} 
& Cardas & Fusos & Teares & Média Geral \\
\hline Brasil & 14,55 & 15,3 & 12,2 & 14,01 \\
São Paulo & 21,18 & 16,58 & 13,13 & 16,96 \\
\hline
\end{tabular}

Fonte: CETex. Indústria Têxtil Algodoeira, p. 118.

Além disso, observa-se que, em 1945, o maior ramo têxtil doméstico - o algodoeiro - trabalhava, em média, mais de quatoreze horas diárias (Tabela 4.9). As fábricas de

\footnotetext{
${ }^{530}$ Departamento Estadual de Estatística do Estado de São Paulo. Catálogo das Indústrias do Município da Capital, 1945, p. 52-83.
} 
tecidos de algodão paulistas, por sua vez, ficavam quase dezessete horas por dia trabalhando. Destaca-se, nessa indústria, a seção das cardas, que funcionavam quase o dia inteiro (21 horas e 18 minutos, em média).

Verifica-se, dessa maneira, que a intensificação do uso da mão-de-obra no subsetor têxtil paulista veio compensar a pequena disponibilidade de máquinas no mercado em contexto de clara expansão da demanda por bens fabris. Tal intensificação, porém, não se deu apenas mediante novas contratações, mas também por meio do aumento das jornadas de trabalho dos operários já contratados. Lembra-se que, em 1944, após pressões patronais, o Estado permitiu a extensão do tempo de trabalho nas fábricas em razão da necessidade de mobilizar o parque fabril para o esforço bélico ${ }^{531}$.

Tabela 4.10 - Índices de concentração e de produtividade nas Indústrias Gerais e Têxteis do Estado de São Paulo (1939, 1943 e 1944)

\begin{tabular}{|c|c|c|c|c|c|c|}
\hline & \multicolumn{2}{|c|}{1939} & \multicolumn{2}{|c|}{1943} & \multicolumn{2}{|c|}{1944} \\
\hline & Gerai & & & & & \\
\hline & $\mathrm{s}$ & Têxteis & Gerais & Têxteis & Gerais & Têxteis \\
\hline Capital - Fábrica & 54 & 483 & 65 & 424 & 82 & 563 \\
\hline Trabalho - Fábrica & 10 & 115 & 12 & 115 & 13 & 109 \\
\hline Capital - Trabalho & 5,7 & 4,0 & 5,3 & 3,7 & 6,5 & 5,2 \\
\hline Capital - Produto & 0,37 & 0,49 & 0,26 & 0,29 & 0,29 & 0,41 \\
\hline Trabalho - Produto & 0,07 & 0,12 & 0,05 & 0,078 & 0,04 & 0,079 \\
\hline
\end{tabular}

Nota-se também que, ao final da guerra, as indústrias paulistas estavam mais concentradas. Houve acréscimos nas relações capital-fábrica e trabalho-fábrica (Tabela 4.10). No caso têxtil, observa-se tendência contrastante entre as variáveis. As indústrias de tecidos estavam mais concentradas em termos de capital constante, mas não no que se referia ao capital variável. Ao que parece, o surgimento de inúmeras pequenas unidades têxteis durante o contexto bélico (Tabela 15a) e o crescimento acelerado da formação de capital das grandes empresas explicam esse aparente paradoxo.

Percebe-se, por último, que os índices de produtividade, seja na indústria paulista agregada, seja na indústria têxtil, sofreram reduções (Tabela 4.10). Tais decréscimos se deveram, essencialmente, à impossibilidade de importação de bens de capital em quantidade suficiente para suprir a demanda. Sobrecarregaram-se, assim, as máquinas existentes, as quais, em muitos casos (como no subsetor têxtil), já se encontravam em estado de obsolescência.

\footnotetext{
${ }^{531}$ Decreto-Lei n. 6.688, 13.07.1944 (Lei de Mobilização Industrial).
} 


\section{$\underline{4.3-\text { Os ramos }}$}

Ao se observar os desempenhos econômicos dos mais importantes ramos têxteis paulistas no contexto da Segunda Guerra Mundial (Tabela 4.11), percebem-se diferenças consideráveis entre os mesmos.

Analisar-se-á, primeiramente, o ramo algodoeiro. Este, durante 1939-1944, apresentou as terceiras maiores porcentagens de crescimento do subsetor no que se refere ao número de estabelecimentos (31,3\%), energia elétrica consumida $(30 \%)$ e valor de produção $(70,4 \%)$. Por outro lado, protagonizou os últimos lugares no que condiz ao capital invertido $(2,6 \%)$ e ao número de operários $(-3,7 \%)$.

A análise dos dados da Tabela 4.11, porém, não permite a observação dos desempenhos dos ramos em cada um dos anos do conflito mundial ${ }^{532}$. Para preencher tal lacuna, utilizar-se-ão dados dos balanços das sociedades anônimas fabris do estado de São Paulo. Em grande parte dos ramos têxteis, as $S A$ 's formam as maiores empresas. Busca-se, dessa forma, uma representatividade significativa dos dados compilados diante do universo das empresas.

Observando-se a Tabela 4.12, pode-se notar que o capital das fábricas algodoeiras paulistas cresceu constantemente durante o período bélico. Em termos percentuais, as maiores elevações se deram nos anos entre 1940 e 1944. O valor das máquinas, por outro lado, após leve ascensão no período 1939-1940, apresentou quedas constantes, até atingir, em 1945, apenas 58\% daquele existente antes da guerra. Lembra-se, porém, que, em termos nominais, o valor dos maquinários algodoeiros cresceu 23,6\%. Isto é, possivelmente houve aperfeiçoamento desse parque fabril durante a guerra, porém em valores e quantidades muito menores do que o ritmo de desvalorização monetária local ${ }^{533}$. Os lucros brutos, por sua vez, que se elevaram regularmente até 1944, demonstraram acréscimo considerável entre 1941 e 1942. Já os dividendos atingiram seu ápice em 1942. Distribuíram-se aos acionistas, naquele ano, valores equivalentes a mais de 1/4 do capital nominal das empresas de algodão estaduais.

\footnotetext{
${ }^{532}$ Lembra-se que o Departamento Estadual de Estatística não publicou as Estatísticas Industriais de 1940, 1941 e 1942 em razão da guerra. A partir de 1944, não houve mais publicação das Estatísticas Industriais.

${ }^{533}$ Utiliza-se aqui o advérbio possivelmente porque muitas empresas têxteis paulistas, mediante assembléias gerais extraordinárias, atualizaram os valores das suas máquinas conforme o aumento dos preços das mesmas no mercado. Houve, no entanto, como já se mostrou, compra e aperfeiçoamento de máquinas têxteis mesmo durante a guerra.
} 
Tabela 4.11 - Estabelecimentos, capital, operários, energia elétrica consumida e valor de produção dos Ramos da indústria têxtil paulista (1939, 1943 e 1944)

\begin{tabular}{|c|c|c|c|}
\hline & 1939 & 1943 & 1944 \\
\hline \multicolumn{4}{|l|}{ Algodão } \\
\hline Número de Fábricas & 144 & 183 & 189 \\
\hline Capital Total (1.000 Cr\$) & 358.660 & 512.108 & 673.882 \\
\hline Capital Total (1.000 Cr\$ D) & 227.576 & 201.697 & 233.419 \\
\hline Operários & 56.795 & 58.921 & 54.686 \\
\hline Energia elétrica consumida (Kwh) & 113.287 .999 & 130.528 .237 & 147.257 .811 \\
\hline Valor da Produção (1.000 Cr\$) & 568.853 & 1.618 .098 & 1.775 .262 \\
\hline Valor da Produção (1.000 Cr\$ D) & 360.947 & 637.297 & 614.916 \\
\hline \multicolumn{4}{|l|}{ Juta } \\
\hline Número de Fábricas & 18 & 21 & 23 \\
\hline Capital Total (1.000 Cr\$) & 46.639 & 46.835 & 130.996 \\
\hline Capital Total (1.000 Cr\$ D) & 29.593 & 18.446 & 45.374 \\
\hline Operários & 6.142 & 5.602 & 6.770 \\
\hline Energia elétrica consumida (Kwh) & 14.148 .743 & 7.441 .026 & 5.225 .232 \\
\hline Valor da Produção (1.000 Cr\$) & 115.417 & 135.711 & 271.645 \\
\hline Valor da Produção (1.000 Cr\$ D) & 73.234 & 53.451 & 94.092 \\
\hline \multicolumn{4}{|l|}{ Malha } \\
\hline Número de Fábricas & 139 & 161 & 168 \\
\hline Capital Total (1.000 Cr\$) & 45.254 & 66.056 & 87.415 \\
\hline Capital Total (1.000 Cr\$ D) & 28.073 & 26.017 & 30.279 \\
\hline Operários & 5.838 & 6.697 & 7.511 \\
\hline Energia elétrica consumida (Kwh) & 3.843 .977 & 2.466 .741 & 3.809 .996 \\
\hline Valor da Produção (1.000 Cr\$) & 104.548 & 214.680 & 308.765 \\
\hline Valor da Produção (1.000 Cr\$ D) & 66.338 & 84.553 & 106.950 \\
\hline \multicolumn{4}{|l|}{ Lã } \\
\hline Número de Fábricas & 41 & 47 & 61 \\
\hline Capital Total (1.000 Cr\$) & 53.520 & 87.254 & 154.276 \\
\hline Capital Total (1.000 Cr\$ D) & 33.959 & 34.365 & 53.438 \\
\hline Operários & 7.334 & 10.659 & 12.249 \\
\hline Energia elétrica consumida (Kwh) & 10.118 .005 & 17.642 .639 & 19.435 .331 \\
\hline Valor da Produção (1.000 Cr\$) & 144.724 & 539.614 & 778.842 \\
\hline Valor da Produção (1.000 Cr\$ D) & 91.830 & 212.530 & 269.776 \\
\hline \multicolumn{4}{|l|}{ Sedas } \\
\hline Número de Fábricas & 256 & 315 & 354 \\
\hline Capital Total (1.000 Cr\$) & 70.074 & 271.366 & 442.452 \\
\hline Capital Total (1.000 Cr\$ D) & 44.463 & 106.879 & 153.257 \\
\hline Operários & 12.985 & 23.530 & 26.680 \\
\hline Energia elétrica consumida (Kwh) & 25.192 .906 & 56.314 .185 & 84.287 .459 \\
\hline Valor da Produção (1.000 Cr\$) & 296.028 & 1.088 .911 & 1.479 .194 \\
\hline Valor da Produção (1.000 Cr\$ D) & 187.835 & 428.874 & 512.364 \\
\hline
\end{tabular}

Fonte: Estatística Industrial do Estado de São Paulo, 1938-1939, 1943 e 1944.

Desses dados, algumas inferências se fazem possíveis: (a) o crescimento do capital constante dessas fábricas, em grande parte, não ocorreu em razão da compra de novos maquinários, mas sim, provavelmente, devido ao acréscimo dos fundos de reserva, da conta de lucros suspensos e dos estoques de matérias-primas. Em alguns casos, a aquisição 
de terrenos e áreas agrícolas e a realização de benfeitorias nas empresas - tais como a construção de vilas operárias, refeitórios e a ampliação de usinas hidroelétricas - também contribuíram para tal elevação; (b) o período 1941-1942 caracterizou-se como ponto de inflexão para o ramo têxtil algodoeiro paulista. Até 1941, apesar das dificuldades, foi possível a aquisição de máquinas. A partir de então, devido aos motivos já enunciados (recrudescimento do bloqueio marítimo britânico e entrada dos Estados Unidos na guerra), tais importações se tornaram complicadas (vide Tabela 4.7). Por outro lado, se a ampliação da capacidade produtiva ficou mais difícil após 1941-1942, o afastamento dos países centrais dos mercados periféricos permitiu crescimento das vendas, tanto do ponto de vista interno, quanto externo. As constantes elevações de capital, as grandes porcentagens de acréscimo dos lucros brutos ${ }^{534}$ e o ápice da distribuição de dividendos aos acionistas pós-1941 - perceptíveis na compilação apresentada dos balanços - são altamente representativos dessa prosperidade.

Tabela 4.12 - Capital, máquinas, lucros brutos e dividendos das empresas têxteis algodoeiras do Estado de São Paulo correspondentes aos Grupos II, III e IV - em Cr\$ 1.000 deflacionados (1939-1945) ${ }^{535}$

\begin{tabular}{cccccccc} 
& 1939 & 1940 & 1941 & 1942 & 1943 & 1944 & 1945 \\
\hline Capital - Grupo IV & $*$ & 65.561 & 96.793 & 112.875 & 126.703 & 149.013 & 142.062 \\
Máquinas - Grupo II (A) & 125.737 & 128.900 & 123.067 & 112.614 & 97.342 & 86.185 & 73.191 \\
Máquinas - Grupo II (valor nominal) & 198.161 & 213.717 & 229.273 & 232.885 & 247.152 & 248.817 & 264.146 \\
Lucros Brutos - Grupo III (B) & $*$ & $*$ & 93.469 & 142.354 & 153.009 & 171.140 & 142.242 \\
Dividendos - Grupo IV (C) & $*$ & 6.245 & 12.932 & 28.520 & 28.387 & 35.091 & 25.401 \\
\% Dividendos / K - Grupo IV & & 9,5 & 13,4 & 25,3 & 22,4 & 23,5 & 17,9 \\
\hline
\end{tabular}

Fonte: Diário Oficial do Estado de São Paulo, 1939-1945. / (A) Representatividade do Grupo II em termos de capital constante no ano de $1939=29,3 \%$; (B) Representatividade do Grupo III em termos de capital constante no ano de $1943=$ 80,8\%; (C) Representatividade do Grupo IV em termos de capital constante no ano de $1943=96,2 \%$.

Além desses dados, a observação dos relatórios de diretoria e das atas de assembléia das empresas de algodão paulistas ratificam as inferências citadas anteriormente.

No que se refere à importação de máquinas, percebe-se que, até 1942, os documentos empresariais demonstram a viabilidade em adquiri-las. Após isso, porém,

\footnotetext{
${ }^{534}$ Não há informações acerca dos lucros líquidos. Mesmo assim, ver-se-á, posteriormente, que os custos das fábricas têxteis (matérias-primas, tributos, salários, etc.) cresceram em proporções menores do que os valores das suas respectivas vendas ao longo da guerra. $\mathrm{O}$ acréscimo dos lucros brutos, portanto, nesse caso, é bastante significativo da prosperidade das empresas estudadas.

${ }^{535}$ A referência das empresas que formam cada um dos grupos citados encontra-se nos Anexos. Indicou-se, abaixo da Tabela 4.12, o quanto cada grupo representa, em termos de capital constante, no total das empresas têxteis algodoeiras do estado de São Paulo.
} 
inúmeras são as reclamações referentes às dificuldades na compra de matérias-primas e de bens de capital do exterior.

A diretoria da S.A. Fábrica Votorantim, por exemplo, destacou no seu relatório referente ao ano de 1939 que “(...) novos maquinismos, dos mais aperfeiçoados, foram instalados, entre os quais a nova tecelagem (...)"536. No ano seguinte, os mesmos diretores anunciaram a construção de uma nova fábrica de algodão em Boituva, cujas máquinas já estavam a disposição da empresa ${ }^{537}$. A partir daí, porém, a situação se alterou. No relatório referente ao ano de 1943, reclamou-se da dificuldade na obtenção de combustíveis para o funcionamento da empresa. Além disso, colocou-se que o governo “(...) deveria criar maiores facilidades (...) para a importação de máquinas, sem a qual jamais realizaremos a nossa emancipação" 538 .

A Companhia Nacional de Estamparia, por sua vez, assinalou em 1941 que havia adquirido doze novas penteadeiras e duzentos e oitenta teares automáticos. "Com agradecimentos, devemos proclamar a maneira (...) com que os fabricantes ingleses, nestes tempos anormais e a despeito de embaraços sem fim, tem dado cumprimento religioso às nossas encomendas (grifo nosso)", diziam seus diretores ${ }^{539}$. No relatório de 1944 , entretanto, afirmou-se que “(...) a guerra marítima pôs em perigo a navegação (e que) as dificuldades de importação tem se acentuado a ponto de dificultar (...) os serviços de reparação de nosso maquinário, tornados imperativos pelo desgaste oriundo do aumento de produção" ${ }^{540}$. Da mesma maneira, a Fiação Extra-Fina de Algodão anunciou aos seus acionistas, em 1940, a compra de três mil fusos. No ano seguinte, adquiriu mais três mil e seissentos, além de ter ampliado o edifício da fábrica para comportar as novas máquinas. Após 1942, diferentemente, seus diretores assinalam as "dificuldades no transporte marítimo" como responsáveis pela reduzida oferta de bens de capital em São Paulo ${ }^{541}$. Por último, cita-se o caso da Cia. Fiação e Tecidos Sta. Maria. Os diretores da empresa, em 1940, informaram os acionistas acerca “ $(d)$ a aquisição de novas máquinas”. No ano seguinte, porém, eles foram obrigados a reconhecer “(...) a circunstância de ser presentemente impossível adquirir em boas condições maquinários nos mercados

\footnotetext{
${ }^{536}$ Relatório de Diretoria. S.A. Fábrica Votorantim, 26.02.1940.

${ }^{537}$ Relatório de Diretoria. S.A. Fábrica Votorantim, 08.03.1941.

${ }^{538}$ Relatório de Diretoria. S.A. Fábrica Votorantim, 28.02.1944.

${ }^{539}$ Relatório de Diretoria. Cia. Nacional de Estamparia, 07.04.1942.

${ }^{540}$ Relatório de Diretoria. Cia. Nacional de Estamparia, 02.03.1944.

${ }^{541}$ Ver: Relatórios de Diretoria. Fiação Extra-Fina de Algodão, 24.02.1941, 24.02.1942 e 16.01.1945.
} 
estrangeiros" ${ }^{\$ 42}$. Exemplos semelhantes podem ser encontrados em diversas outras fábricas $^{543}$.

Já no que condiz aos acréscimos de capitais vinculados não à compra de máquinas, mas ao engrandecimento de outros ativos (terrenos, fundos de reserva, etc.), vários também são os casos que podem ser citados. Em 1943, a Fiação e Tecelagem Pirassunuga S.A., devido às dificuldades de aquisição de maquinários e de matérias-primas, resolveu aplicar seus lucros na compra de "uma magnífica gleba de terras (...) a fim de assegurar à fábrica um abastecimento próprio e regular de lenha" ${ }^{544}$. Para tanto, aumentou seu capital nominal de 3.200 para 7200 milhões de cruzeiros $^{545}$. Segundo os diretores do Cotonificio Guilherme Giorgi, “(...) em vista das dificuldades anuais como conseqüência do encarecimento geral da vida, com reflexo direto na indústria e no comércio (aquisição de matérias-primas, aumento de tributos, etc.) e da criação de novos encargos legais, o capital social (...) já se torna insuficiente (...)". Aumentou-se, assim, o capital da empresa de 2 para 15 milhões de cruzeiros entre 1942 e 1943, utilizando-se os lucros acumulados $^{546}$. A Fiação e Tecelagem Sant'Ana, por sua vez, elevou seu capital de 1 para 4 milhões de cruzeiros entre 1944 e 1945, mediante uso da conta do Fundo de Reservas e dos Lucros Suspensos, visando se preparar para a revitalização do seu parque fabril pósguerra $^{547}$. Por motivos semelhantes aos da Sant'Ana, a Brasital S.A. também fez acréscimos em seu capital entre 1943 e 1945. Segundo seus diretores, o projeto de renovação dos maquinismos da empresa "foi interrompido pelas circunstâncias do atual estado de guerra. Devemos fazer votos para que, com um rápido fim da mesma, seja possível utilizar tais disponibilidades, reiniciando-se (...) a compra de maquinismos para substituir os atuais que, além de serem em sua maioria obsoletos, estão sendo agora sendo submetidos a um desgaste excessivo"548.

Apesar de todos esses exemplos mencionados, não há dúvida, porém, de que algumas empresas de algodão paulistas aumentaram seu capital devido à aquisição de

\footnotetext{
${ }_{542}$ Atas Assembléias Gerais Extraordinárias. Cia. Fiação e Tecidos Sta. Maria, 14.04.1941 e 10.11.1941.

${ }^{543}$ Ver, nesse sentido, os casos da Têxtil Paulo Abreu S.A., da Cia. Fiação e Tecelagem São Pedro, da S.A. Indústria de Meias Eterna; da S.A. Fábrica de Tecidos N. S. Mãe dos Homens; dentre outras.

${ }^{544}$ Relatório de Diretoria. S.A. Fiação e Tecelagem Pirassununga, 08.02.1944. Exemplos semelhantes aos da Pirassununga podem ser encontrados nos relatórios de diretoria do S.A. Cotonifício Adelina, que construiu armazéns com desvios ferroviários e realizou diversas benfeitorias na fábrica em 1944 (24.03.1945); nos da Cia. Fabril Sta. Basilissa, que, também em 1944, erigiu uma usina elétrica e iniciou uma seção de silvicultura nas terras pertencentes à fábrica para a obtenção de lenha (08.01.1945); etc.

${ }^{545}$ Balanços. S.A. Fiação e Tecelagem Pirassununga, 05.02.1943 e 09.02.1944.

546 Atas Assembléias Gerais Extraordinárias. Cotonificio Guilherme Giorgi, 21.02.1942, 05.08.1943 e 18.12.1943.

${ }^{547}$ Atas Assembléias Gerais Extraordinárias. Fiação e Tecelagem Sant'Ana, 10.02.1944 e 01.09.1945.

${ }^{548}$ Relatório de Diretoria. Brasital S.A., 04.01.1944.
} 
máquinas, mesmo nos momentos difíceis da guerra. Em 1944, a São Paulo Alpargatas Company S.A. investiu quase 3 milhões de cruzeiros na obtenção de novos maquinismos $^{549}$. As Indústrias Reunidas Francisco Matarazzo, provavelmente em razão da sua força e influência, conseguiram, também em 1944, aperfeiçoar as máquinas das suas seções têxteis “(...) através de oportunas substituições (...), apesar das atuais dificuldades de se conseguir maquinário das casas especializadas (...)"550. Esses casos, no entanto, figuram muito mais como exceção do que regra entre as indústrias têxteis paulistas pós-1942.

Por final, nota-se também nesses documentos empresariais a sensível melhoria nas vendas a partir de 1941-1942, apesar das dificuldades na obtenção de matérias-primas e de bens de capital.

Os diretores da Brasital, por exemplo, afirmaram, em 1944, que "as circunstâncias excepcionalmente favoráveis em que os negócios estão decorrendo, nestes últimos dois anos, contrabalançaram com inegável vantagem, também no exercício transato ( $\mathrm{sic}$ ), os esforços expendidos na solução dos problemas inerentes ao abastecimento de materiais e de combustíveis, aos transportes, à mão-de-obra e dos outros muitos que dificultaram o trabalho (...) (grifos nossos)" ${ }^{\prime 551}$.

A diretoria da Fábrica de Tecidos Tatuapé S.A. comemorou, em 1942, os "resultados auspiciosos do nosso esforço industrial, não obstante as dificuldades oriundas da falta de certas matérias-primas, transportes e combustíveis (...)". Segundo ela, "a marcha da nossa produção foi ininterrupta e (...) com uma procura sempre superior às nossas possibilidades industriais" $" 552$.

Os diretores da Companhia Nacional de Estamparia, por sua vez, afirmaram, em 1941, que "ao contrário do ano anterior (1940), em que os negócios se mantiveram restritos e os preços sob pressão de baixa, devido à concorrência e à falta de escoamento da produção têxtil, o exercício do ano passado (1941) (...) melhorou consideravelmente, com a grande expansão das vendas pela procura de vários mercados externos (...) ${ }^{{ } 553}$.

Vista a situação do ramo algodoeiro durante a guerra, analisar-se-á, agora, o caso jutífero. Tal como ocorrera na década de 1930, o ramo da juta, entre 1939 e 1945, caracterizou-se pelo pior desempenho entre todos os demais do subsetor têxtil paulista (Tabela 4.11). Apresentou forte decréscimo no consumo de energia elétrica $(-63,1 \%)$ e

\footnotetext{
${ }^{549}$ Relatório de Diretoria. São Paulo Alpargatas Company S.A., 15.02.1945.

${ }^{550}$ Relatório de Diretoria. IRFM, 10.03.1945.

${ }^{551}$ Relatório de Diretoria. Brasital S.A., 08.01.1945.

${ }_{552}$ Relatório de Diretoria. Fábrica de Tecidos Tatuapé S.A., 23.02.1943.

${ }^{553}$ Relatório de Diretoria. Cia. Nacional de Estamparia, 02.04.1942.
} 
índices de acréscimo modestos - quando comparados com os demais - do número de estabelecimentos $(27,8 \%)$ e de operários $(10,2 \%)$. A forte dependência da juta indiana que bruscamente deixou de ser importada em quantidades significativas devido à Segunda Guerra (Gráfico 4.2) - e o aprofundamento da crise do setor primário-exportador tradicional (café, açúcar, algodão, cacau, etc.) pós-1939, consumidor nato de sacaria, são os principais fatores explicativos para esse fraco desempenho do ramo. $\mathrm{O}$ reduzido crescimento da procura doméstica dos bens produzidos pelo setor pode ser evidenciado pela observação dos menores acréscimos do valor da produção jutífera $(28,5 \%)$, quando comparado aos demais.

Gráfico 4.2 - Importação de juta - Brasil (1938-1945), em toneladas

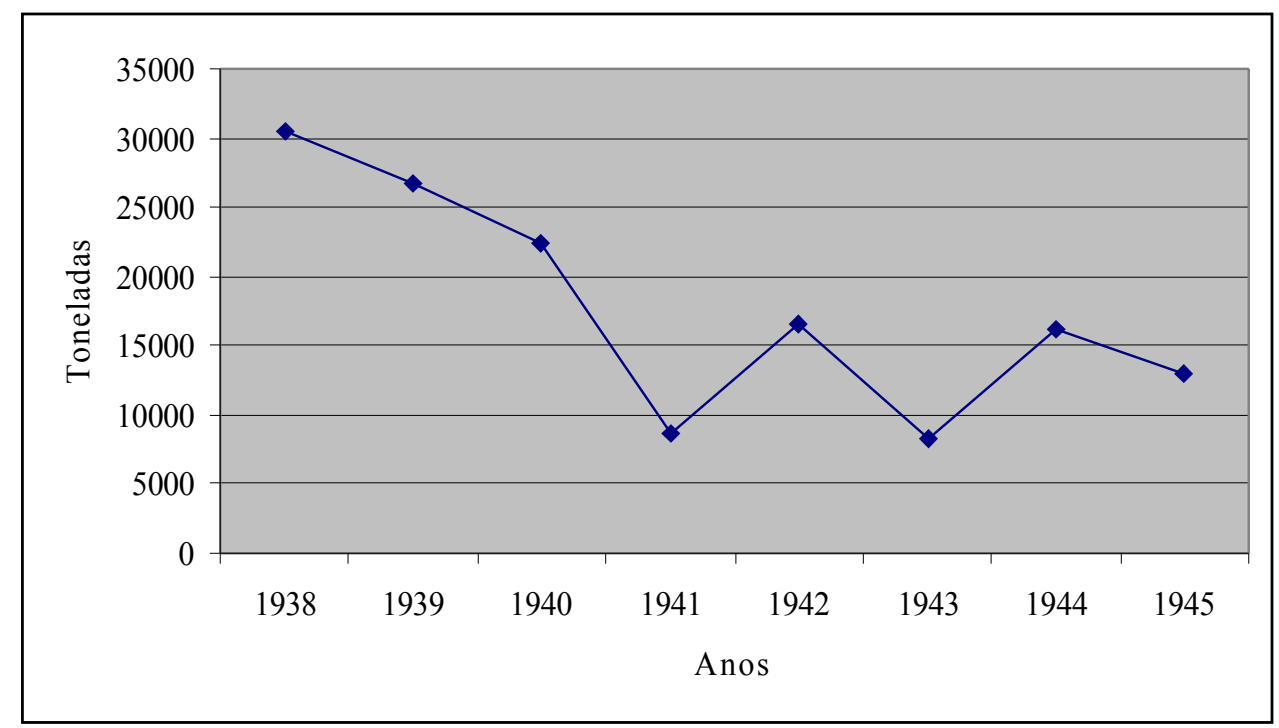

Fonte: Ministério da Agricultura. Juta, p. 23; e SIFTESP. Convenção Nacional de Economia da Juta e demais fibras congêneres industrializáveis, 1947, p. 06.

Uma das conseqüências dessas menores taxas de crescimento foi a diminuição da participação relativa do ramo em relação ao subsetor têxtil paulista em todas as variáveis arroladas. Destacaram-se, nesse sentido, as quedas no número de operários (-16,6\%) e no valor de produção $(-34,4 \%)$.

Apesar de tudo, não se pode afirmar que as fábricas de juta paulistas estavam em crise entre 1939-1945. Seus crescimentos foram, apenas, menores do que os da média têxtil estadual. Além dos dados já analisados (Tabela 4.11), no qual se pôde observar os acréscimos nos montantes de capital, operários, estabelecimentos e valor da produção, a Tabela 4.13, embasada nos balanços das algumas empresas de juta sob o estatuto jurídico de S.A., vem completar o quadro do ramo durante a guerra. 
Tabela 4.13 - Capital, máquinas, lucros brutos e dividendos das indústrias de juta do Estado do São Paulo correspondentes ao Grupo V - em Cr\$1.000 deflacionados (1939-1945)

\begin{tabular}{cccccccc} 
& 1939 & 1940 & 1941 & 1942 & 1943 & 1944 & 1945 \\
\hline Capital (A) & 6.726 & 6.393 & 7.032 & 6.335 & 5.160 & 4.538 & 4.350 \\
Máquinas - Valor nominal & 14.248 & 14.229 & 14.210 & 14.821 & 14.872 & 14.773 & 15.486 \\
Máquinas & 9.041 & 8.582 & 7.627 & 7.167 & 5.857 & 5.117 & 4.291 \\
Lucros Brutos & $*$ & 2.345 & 2.610 & 3.717 & 5.999 & 6.122 & 4.829 \\
Dividendos & $*$ & 769 & 434 & 826 & 920 & 641 & 466 \\
\% Dividendos / K & $*$ & 12,0 & 6,2 & 13,0 & 17,8 & 14,1 & 10,7 \\
\hline
\end{tabular}

Fonte: Diário Oficial do Estado de São Paulo, 1939-1945 / (A) Representatividade do Grupo V (ramo da juta) em termos de capital constante $=22,7 \%$.

Percebe-se, tal como no caso algodoeiro, decréscimo contínuo do valor das máquinas, acentuado pós-1942. Mesmo em termos nominais, a ascensão foi bem reduzida (8,8\%). Os lucros brutos, porém, ao menos até 1944, apresentam crescimento contínuo. No que concerne aos dividendos, atingiu-se um auge em 1943, quando se distribuíram aos acionistas das empresas desse grupo o equivalente a mais de $17 \%$ do capital social das mesmas. Ao que parece, da mesma forma que para o caso algodoeiro, confirmam-se aqui as inferências de que o período 1941-1942 foi um ponto de inflexão para o ramo, seja em razão das maiores dificuldades na obtenção de máquinas e matérias-primas, seja devido ao crescimento das vendas, expressos na melhoria das contas de lucros brutos e da maior distribuição de dividendos. Observa-se, no entanto, que houve queda considerável no montante de capital investido nas empresas do Grupo V (-35,3\%, 1939-1945 - Tabela 4.13). Esse decréscimo contrasta com a elevação verificada no subsetor agregado entre 1939 e 1944 (53,3\% - Tabela 4.11). Isso demonstra que as fábricas de tal grupo - que eram as maiores do ramo antes da guerra - perderam participação em termos de capital para empresas menores, sinalizando, possivelmente, um processo de desconcentração.

Deve-se questionar, porém, como foi possível o crescimento do ramo no período 1939-1945, tendo em vista as dificuldades vividas pelo setor primário-exportador tradicional - base de consumo para tais empresas - e das quedas de importação da juta em decorrência da guerra.

Para se compreender tal problema, deve-se lembrar, em primeiro lugar, da importância do intervencionismo estatal no ramo. Em dezembro de 1940, a Comissão de Defesa da Economia Nacional - órgão criado no ano de 1939 e que tinha como um dos principais objetivos a regulação dos estoques dos produtores domésticos durante a Segunda Guerra ${ }^{554}$ - editou uma portaria obrigando os fabricantes de tecidos de juta locais

\footnotetext{
${ }^{554}$ Para maiores informações sobre o CDEN, ver: Edgard Carone. O Estado Novo, op. cit., p. 85.
} 
a coordenarem sua produção. Além disso, estipularam-se cotas para cada uma das empresas, de acordo com seus respectivos potenciais produtivos e com as condições de mercados regionais ${ }^{555}$.

A eficácia dessa política pode ser comprovada pelos dados das Tabelas 4.11 e 4.13, que indicam, para maioria das variáveis arroladas, elevações percentuais. Afora isso, os relatórios das empresas também ratificam a importância do intervencionismo governamental citado. Os diretores da Cia. Paulista de Aniagens, por exemplo, assinalaram que “(...) a partir de maio (de 1940) sobreveio uma extraordinária crise de sub-consumo, que começou a acarretar prejuízos à indústria de juta”. A concorrência entre as fábricas do ramo, segundo eles, levou a uma queda de preços, tornando-os "inferiores aos custos de produção". De 1941 em diante, porém, a melhora foi considerável, "graças a uma módica elevação dos preços de venda, em razão do entendimento entre as empresas (...) Em 06.03.1941, foi lavrada a escritura de mútuo compromisso entre as dez fábricas de fiação e tecelagem de juta do estado e, a partir de então, nossa indústria entrou em nova fase de trabalho coordenado. Mas os bons resultados desse novo regime só se manifestaram no decorrer do segundo semestre (de 1941), que apresentou um lucro apreciável” ${ }^{556}$. No relatório do ano seguinte, os mesmos diretores afirmaram que “(...) as condições da nossa indústria no decorrer de 1942 melhoraram consideravelmente em confronto com os dois anos anteriores" ${ }^{557}$. A Cia. Fabril de Juta, por sua vez, congratulou seus acionistas pelos bons resultados obtidos pela empresa em 1943. "Só temos motivos de satisfação a constatar", diziam ${ }^{558}$. No ano anterior, ampliaram-se as instalações das fábricas de Taubaté, Pindamonhangaba e Caçapava e, além disso, construíra-se uma tecelagem em Tremembé 559 . Os mesmos comentários de prosperidade foram feitos pelos diretores da Cia. Brasileira de Juta após os acordos entre os produtores coordenados pelo Governo Federal ${ }^{560}$.

Além desse fator, lembra-se também o crescimento significativo da produção de juta doméstica no interregno 1939-1945. Permitiu-se, assim, amenizar a enorme dependência dos produtores locais diante das fibras indianas.

\footnotetext{
${ }^{555}$ Comissão de Defesa da Economia Nacional. Portaria n. 113, 09.12.1940.

${ }^{556}$ Relatório de Diretoria. Cia. Paulista de Aniagens, 09.03.1942.

${ }^{557}$ Relatório de Diretoria. Cia. Paulista de Aniagens, 10.02.1943.

${ }^{558}$ Relatório de Diretoria. Cia. Fabril de Juta, 27.01.1944.

${ }^{559}$ Idem.

${ }^{560}$ Relatório de Diretoria. Cia. Brasileira de Juta, 16.01.1942.
} 
As primeiras tentativas de produção de juta no Brasil datam de $1929^{561}$. Nesse ano, um agrônomo japonês chamado Kotaro Tuji, incentivado financeiramente por uma fábrica de aniagens nipônica, chegou ao País com intuito de encontrar um local adequado para iniciar o plantio da fibra. Os resultados mais animadores foram apresentados pela produção amazonense. O reduzido cumprimento das fibras, entretanto, ainda inviabilizaram seu uso pelas fábricas do ramo. Tais experiências, levadas a cabo por colonos japoneses e por nativos, prosseguiram na Amazônia ao longo dos anos (19)30. No final da década, a produção apresentou sensível melhora, especialmente no que condizia à resistência e ao cumprimento das fibras. A partir de então, devido à crescente diminuição das importações de juta indiana no contexto bélico, a produção doméstica só se fez crescer.

Tabela 4.14 - Produção local e importação de juta - Brasil (1938-1945), em toneladas

\begin{tabular}{ccccc} 
& Produção & Importação & Relação Produção / Importação & Soma Produção - Importação \\
\hline 1938 & 52 & 30.552 & 0,2 & 30.604 \\
1939 & 171 & 26.746 & 0,6 & 26.917 \\
1940 & $*$ & 22.412 & $*$ & 22.412 \\
1941 & 1.072 & 8708 & 12,3 & 9.780 \\
1942 & 3.204 & 16.634 & 19,3 & 19.838 \\
1943 & 5.221 & 8.275 & 63,1 & 13.496 \\
1944 & 6.357 & 16.207 & 39,2 & 22.564 \\
1945 & 6.598 & 12.958 & 50,9 & 19.556 \\
\hline
\end{tabular}

Fonte: Ministério da Agricultura. Serviço de Estatística de Produção. Juta, Rio de Janeiro, 1950 (mimeo)

Observa-se (Tabela 4.14) que a produção de juta local quintuplicou entre $1941 \mathrm{e}$ 1945. Em 1943, 63,1\% das fibras de juta consumidas pelas fábricas domésticas eram de proveniência interna, porcentagem notável quando comparada com as relações pré-guerra. O plantio de juta amazônica, porém, por mais que tenha crescido nesse contexto, não conseguiu manter o mesmo nível de consumo da fibra anterior a 1939. No ano de 1943, por exemplo, o consumo doméstico representou apenas 44\% daquele realizado em 1938.

Dentre os atos governamentais realizados para incentivar a produção local de juta, destacam-se as portarias que obrigavam as fábricas a utilizarem uma certa porcentagem de fibras domésticas nos seus processos produtivos. Em agosto de 1940, tal porcentagem foi estipulada em 10\%. Depois, sofreu diversas elevações: $25 \%$, $40 \%$ e $60 \%{ }^{562}$.

\footnotetext{
${ }^{561}$ Para maiores informações sobre o início dos plantios de juta no Brasil, ver: Ministério do Trabalho, Indústria e Comércio. Comissão Executiva Têxtil (CETex). A juta brasileira. Rio de Janeiro, 1948 e Ministério da Agricultura. Serviço de Estatística de Produção. Juta, Rio de Janeiro, 1950 (mimeo).

${ }^{562}$ Para maiores informações, ver: CDEN. Resolução n. 04, 28.08.1940; CDEN. Portaria n. 286, 30.06.1942; e CME. Portaria n. 57, 14.05.1943.
} 
Além desses incentivos oficiais, várias fábricas de juta paulistas iniciaram produções próprias da fibra no vale do rio Amazonas. A Cia. Paulista de Aniagens, por exemplo, comunicou aos seus acionistas, em 1942, que “(...) a importação de juta indiana causou-nos sérias apreensões devido à extraordinária irregularidade dos transportes marítimos. Para felicidade de nossa indústria, já hoje se pode contar com mais de 1/3 de fibra nacional (...) e as perspectivas nesse sentido são as mais promissoras (...) resolvemos fomentar, por nossa própria conta, estabelecendo na cidade na região de Obidos (Pará), um novo centro de cultura, de classificação e embalagem. Aí se acha em construção um grande armazém em que se instalará uma prensa e o necessário maquinário para a fabricação de cordas toscas para a enfardagem (...), provada, como se acha, a boa qualidade da juta amazônica (...)" ${ }^{963}$. Da mesma maneira, os diretores da Cia. Fabril de Juta assinalavam, em 1943, que “(...) grandes trabalhos foram executados em Manaus, onde já estão terminadas nossas instalações que contam de grandes armazéns com porto próprio e grande prensa de enfardagem. Continuamos a intensificar o financiamento dos lavradores, a fim de incentivar ainda mais a cultura da juta (...)"564.

Tendo em vista, portanto, os intervencionismos estatais estimuladores da coordenação entre os produtores fabris e a intensificação da cultura de juta local substituta, em grande parte, das importações indianas -, entende-se, assim, o porquê do crescimento do ramo no interregno 1939-1945.

Passar-se-á, agora, para as malharias. Estas, entre 1939 e 1945, apesar de terem apresentado crescimento em quase todas as variáveis arroladas - com exceção da energia elétrica consumida $(-0,9 \%)$-, esteveram, como no caso jutífero, abaixo da média têxtil estadual (Tabela 4.11). No que se refere ao número de estabelecimentos criados, apresentaram menor crescimento (20,9\%). Nas demais variáveis, percebem-se elevações modestas diante das demais fábricas ${ }^{565}$.

Seguindo o exemplo das fábricas de juta, as malharias perderam espaço no subsetor têxtil estadual para outros ramos (Tabela 4.11). Em termos de capital, as fábricas de malhas paulistas representavam, no ano de 1939, mais de 7\% do subsetor; cinco anos depois, totalizavam apenas $4,7 \%$ do total de capital investido no mesmo. Situação semelhante aconteceu com todas as outras variáveis arroladas. A perda foi insignificante apenas no que se refere ao número de operários. Em 1939, 6,1\% dos trabalhadores têxteis

\footnotetext{
${ }^{563}$ Relatório de Diretoria. Cia. Paulista de Aniagens, 10.03.1942.

${ }^{564}$ Relatório de Diretoria. Cia. Fabril de Juta, 27.01.1944.

${ }^{565}$ Não se utilizarão dados de balanços de malharias, pois o grupo que se conseguiu reunir com os balanços existentes possuía uma representatividade muito pequena dentro do ramo.
} 
de São Paulo trabalhavam nas malharias; no ano de 1944, essa porcentagem foi reduzida para $6 \%$.

Um dos principais fatores desse menor crescimento das malharias paulistas referese ao problema da falta de fios no mercado doméstico ${ }^{566}$. Como já se mostrou anteriormente ${ }^{567}$, esse ramo era formado, em grande parte, por pequenas e médias empresas, possuidoras apenas de tecelagens. A dependência destas perante as fábricas produtoras de fios - seja de algodão, lã, seda ou rayon - já havia suscitado árduos debates nos anos (19)30. Com a eclosão da Segunda Guerra, os problemas se aguçaram. A demanda interna e externa por têxteis - e, conseqüentemente, por fios - cresceu de forma inversamente proporcional às possibilidades de importação de máquinas e matériasprimas. Para piorar, como os preços internacionais dos fios eram superiores aos domésticos, grande parte da produção local era escoada para o exterior, dificultando ainda mais a situação das tecelagens e das malharias.

A gravidade do problema tornou necessária uma intervenção do Estado. Em setembro de 1941, a Comissão de Defesa da Economia Nacional publicou uma resolução condicionando a exportação de fios de algodão e de rayon ao abastecimento prévio do mercado interno ${ }^{568}$. Para que tal lei fosse cumprida pelas fábricas, criou-se uma Junta Reguladora do Comércio de Fios e Tecidos ${ }^{569}$, a qual, por sua vez, tinha por finalidade controlar as exportações de fios de algodão e rayon domésticas mediante licenças oficiais, bem como tomar todas as medidas necessárias para o abastecimento normal do mercado local de fios. Em janeiro de 1942, a Junta promoveu um acordo entre produtores e consumidores, estabelecendo uma tabela de preços e quotas de vendas para as tecelagens e malharias internas. $\mathrm{O}$ excesso produtivo poderia ser exportado livremente ${ }^{570}$.

Como os desrespeitos ao acordo prosseguiram por parte das fiações, especialmente no que se referia à tabela de preços e ao não-cumprimento das quotas destinadas ao

\footnotetext{
${ }^{566}$ Sabe-se que a restrição da oferta de fios locais foi maléfica para todas as fábricas possuidoras apenas de tecelagens, sejam elas de algodão, de lã ou de seda. Entretanto, como o ramo das malharias era o que concentrava o maior número de fábricas em tal situação, foi, certamente, aquele que mais sofreu com tal escassez de fios no mercado doméstico. Essa hipótese é comprovada pelo grande número de cartas, telegramas e ofícios enviados pelas malharias paulistas e cariocas aos seus respectivos sindicatos patronais, reclamando ações junto ao governo para a solução do problema. Para maiores informações, ver: SIFTERJ. Relatório da Diretoria, 1940-1941.

${ }^{567}$ Ver Capítulo 1, especialmente seção 1.1.1 - Os ramos.

${ }^{568}$ CDEN. Resolução n. 15, 23.09.1941.

${ }^{569}$ CDEN. Resolução n. 18, 17.12.1941.

${ }^{570}$ SIFTERJ. Circular n. 7/42, 27.01.1942.
} 
mercado local, o Estado decidiu limitar ainda mais as exportações de fios de algodão (1942), proibindo-as em $1944^{571}$.

O ritmo de crescimento da demanda por têxteis, porém, ainda tornou insuficiente a produção de fios locais. A diretoria da S.A. Fiação para Malharia Indiana, por exemplo, afirmou, em 1944, que “(...) embora a produção tenha atingido o máximo da capacidade de nosso aparelhamento industrial, assim mesmo não nos foi possível satisfazer inteiramente as necessidades cada vez maiores do mercado (...) (grifo nosso)" ${ }^{3572}$. Independentemente disso, não há dúvidas de que o intervencionismo estatal na questão dos fios domésticos foi de suma importância para garantir as taxas de crescimento do ramo de malhas paulista.

A conjuntura se altera radicalmente ao se observar o desempenho do ramo lanífero paulista durante o interregno 1939-1945 (Tabela 4.11). Este apresentou as maiores taxas de crescimento do subsetor no que se refere ao número de estabelecimentos $(48,8 \%)$ e ao valor da produção (193,8\%). Nas demais variáveis, foi responsável também por consideráveis elevações percentuais: capital (57,4\%); operários (67\%); e energia elétrica consumida $(92,1 \%)$.

Em razão desse considerável crescimento, as fábricas de lã aumentaram ainda mais seu peso no subsetor têxtil estadual (Tabela 4.11). Destacam-se, nesse sentido, os acréscimos no número de operários e no valor produtivo. Em 1939, de cada 100 trabalhadores das fábricas de tecidos, 7,7 estavam empregados no ramo das lãs. Em 1944, este número havia subido para quase 10 operários (crescimento de $26,9 \%$ ). Já o valor de produção lanífero ascendeu de $11,3 \%$ (1939) do total têxtil paulista para quase $17 \%$ (1944); elevação superior a 49\%.

Observando-se a evolução do ramo em cada ano do período 1941-1945, pode-se compreender melhor algumas características desse crescimento acelerado (Tabela 4.15). Percebe-se elevações substanciais no que se refere ao capital invertido (163\%), especialmente entre 1944 e 1945 (90,2\%). Os lucros brutos apresentaram ascensão notável pós-1943 (96\%, 1943-1944). Os dividendos, por sua vez, atingiram um pico em 1942, quando se distribuiu o correspondente a $21 \%$ do capital social das empresas de lã do Grupo VII aos acionistas. Em termos reais, houve queda apenas no valor das máquinas (26,5\%, 1941-1945). Entre 1941 e 1942, porém, verificou-se ligeiro crescimento (1,9\%),

\footnotetext{
${ }^{571} \mathrm{Em} 1942$, proibiram-se as exportações de fios de algodão com título superior ao número 40. Além disso, limitaram-se as vendas a $25 \%$ da produção de fios da fábrica. Dois anos depois foi suspensa também a exportação de fios de rayon. Ver: CDEN. Portaria n. 280, 09.05.1942; CEIBB. Aviso n. 69, 30.06.1944; e CME. Portaria n. 307, 23.11.1944.

${ }^{572}$ Relatório de Diretoria. S.A. Fiação para Malharia Indiana, 01.03.1944.
} 
compensado depois por contínuas quedas. Além disso, lembra-se que tal decréscimo foi o menor entre todos os ramos analisados e que, nominalmente, o valor maquinal cresceu em $42 \%$ no período analisado.

Tabela 4.15 - Capital, máquinas, lucros brutos e dividendos das fábricas de lã do Estado de São Paulo pertencentes ao Grupo VII (1939-1945) - Cr\$ 1.000 deflacionados

\begin{tabular}{cccccc} 
& 1941 & 1942 & 1943 & 1944 & 1945 \\
\hline Capital (A) & 5.636 & 10.880 & 8.862 & 7.794 & 14.824 \\
Máquinas (B) & 11.779 & 13.325 & 14.373 & 15.304 & 16.767 \\
Máquinas & 6.323 & 6.443 & 5.661 & 5.301 & 4.646 \\
Lucros Brutos & 8.120 & 8.666 & 8.525 & 16.708 & 16.221 \\
Dividendos & 419 & 109 & 1.861 & 78 & 554 \\
\% Dividendos / Capital & 7,4 & 1,0 & 21,0 & 1,0 & 3,7 \\
\hline
\end{tabular}

Fonte: Diário Oficial do Estado de São Paulo, 1939-1945 / (A) Representatividade do Grupo em termos de capital constante no ano de $1943=25,8 \%$; (B) valor nominal.

Em razão da reduzida representatividade, não houve condições de recuar os dados de balanços das empresas laníferas para antes de 1941. Mesmo assim, notam-se diferenças de desempenhos marcantes entre os períodos 1941-1942 e 1943-1945. Mais uma vez, como ocorreu em outros ramos já analisados, o período referente ao início até a metade da guerra caracterizou-se por condições de produtividade mais modestas (lucros brutos e dividendos menos significativos), porém propício a um certo aumento da capacidade de produção (compra de máquinas). Os anos finais do conflito trouxeram maiores dificuldades na aquisição de matérias-primas e bens de capital, mas, por outro lado, embasaram forte elevação produtiva.

Os relatórios de diretoria e as atas de assembléia das empresas de lã paulistas ratificam ainda mais tais hipóteses. O Lanificio Anglo-Brasileiro, por exemplo, em seus relatórios referentes aos anos de 1940 e 1942, destaca o aperfeiçoamento das máquinas de seu parque fabril, enquanto, em documentos posteriores (1943, 1944 e 1945), centra seus comentários mais nas "produções recordes" que o lanifício atingiu em razão do crescimento dos mercados local e estrangeiro ${ }^{573}$. O S.A. Moinho Santista, por sua vez, ampliou sua fiação de lã em 1941. No relatório da diretoria do ano seguinte, porém, o que mais chamou atenção dos diretores foi a “(...) contínua procura dos nossos produtos tanto no mercado interno, como nos externos (...)"574. Situação semelhante ocorreu com o S.A. Lanifício Lapa. Fundado em $1940^{575}$, a empresa conseguiu ampliar ainda mais seu parque

\footnotetext{
573 Ver, nesse sentido: Relatórios de Diretoria. Lanifício Anglo-Brasileiro, 22.02.1941, 22.03.1942, 20.02.1943, 26.03.1944 e 26.02.1945.

${ }^{574}$ Relatórios de Diretoria. S.A. Moinho Santista S.A., 18.03.1942 e 05.03.1943.

${ }^{575}$ Ata Assembléia Geral de Constituição. S.A. Lanificio Lapa, 02.10.1940.
} 
fabril em 1942. Segundo seus diretores, "no ano passado (1942), os negócios da sociedade prosseguiram em plena prosperidade, o que nos animou a empregar apreciáveis somas em benfeitorias; no aumento do edifício da fábrica, na instalação de novos maquinismos e, principalmente, na montagem de uma fiação (...)"576. De 1943 em diante, porém, as inversões mudaram de caráter. Ao invés de máquinas, comprou-se novo terreno para a construção de uma fábrica maior, que pudesse, assim, abrigar melhor os bens de capital da empresa $^{577}$. Cita-se, por último, o caso do Lanificio Argos S.A., outro exemplo bastante representativo da dificuldade em se obter maquinismos a partir de 1942. Constituído em $1944^{578}$, já no final da guerra, a empresa assinalava em seu relatório referente ao ano de 1945 que "o período de instalação da nossa indústria, dada as dificuldades de construção e equipamento, levou bem mais tempo do que o previsto (...) só nos últimos meses (de 1945) é que se firmou o ritmo de nossa produção (...)"579.

Independentemente dessas restrições na compra de novos maquinários, todavia, viu-se que o ramo da lã se expandiu de maneira grandiosa nos anos do conflito mundial.

Chegou-se, por último, no caso das sedas. Observa-se que seu crescimento ultrapassou o das próprias fábricas laníferas estaduais (Tabela 4.11). Em termos de capital investido, número de operários e energia elétrica consumida, as empresas de seda apresentaram as maiores taxas de acréscimo entre todos os ramos têxteis paulistas. Destacou-se, nesse sentido, a elevação do capital invertido, o qual mais do que triplicou em cinco anos (244,7\%, 1939-1944). Além disso, contrataram-se, no período em questão, mais de 13.600 operários - número equivalente aos trabalhadores das fábricas de juta e de malhas reunidos em 1944. A energia consumida pelo ramo das sedas nesse ano (84.287.459 kwh) superou em $66 \%$ as consumidas pelas empresas de juta, malha e lã somadas no mesmo momento (28.470.559 kwh).

Tamanha prosperidade ficou refletida no aumento da sua participação relativa no subsetor têxtil agregado (Tabela 4.11). A elevação mais surpreendente deu-se em termos de capital. No ano de 1939, as fábricas de seda paulistas correspondiam a 1/10 (11\%) de todo capital investido nas empresas de tecidos paulistas. Cinco anos depois, tais empresas já perfaziam quase $1 / 4(23,6 \%)$ do total. Nas demais variáveis arroladas, elevações substanciais também se fizeram sentir. A única exceção residiu no número de estabelecimentos, que apresentou leve recuo no período. Em 1939, 30,8\% das fábricas

\footnotetext{
${ }^{576}$ Relatório de Diretoria. S.A. Lanifício Lapa, 13.05.1944.

${ }^{577}$ Relatórios de Diretoria. S.A. Lanifício Lapa, 13.05.1944 e 06.04.1945.

${ }^{578}$ Ata Assembléia Geral de Constituição. Lanifício Argos S.A., 04.07.1944.

${ }^{579}$ Relatório de Diretoria. Lanifício Argos, 09.02.1946.
} 
têxteis estaduais pertenciam ao ramo das sedas; em 1944, estas completavam 30,7\%. Infere-se, assim, em razão dos notáveis crescimentos do montante de capital, do número de operários e do valor produtivo por elas apresentados, que a concentração fabril - seja em termos de capital constante, seja no que condiz ao capital variável - cresceu nas fábricas de seda ao longo da guerra.

Tabela 4.16 - Capital, máquinas, lucros brutos e dividendos das fábricas de seda natural e artificial do Estado de São Paulo pertencentes ao Grupo VI (1939-1945) - Cr\$ 1.000 deflacionados

\begin{tabular}{cccccccc} 
& 1939 & 1940 & 1941 & 1942 & 1943 & 1944 & 1945 \\
\hline Capital (A) & 19.695 & 18.721 & 16.582 & 18.009 & 15.972 & 19.432 & 20.144 \\
Máquinas (B) & 28.712 & 29.257 & 36.367 & 34.428 & 40.697 & 40.180 & 39.238 \\
Máquinas & 18.218 & 17.646 & 19.521 & 16.648 & 16.029 & 13.918 & 10.872 \\
Lucros Brutos & $*$ & 12.455 & 9.519 & 12.987 & 14.918 & 18.060 & 19.333 \\
Dividendos & 95 & 441 & 185 & 1.937 & 980 & 3.443 & 3.663 \\
Dividendos / Capital & 0,5 & 2,4 & 1,1 & 10,8 & 6,1 & 17,7 & 18,2 \\
\hline
\end{tabular}

Fonte: Diário Oficial do Estado de São Paulo, 1939-1945 / (A) Representatividade do grupo em termos de capital constante no ano de $1939=44,3 \%$; (B) valor nominal.

No que se refere à dinâmica do ramo em cada um dos anos do período 1939-1945, notam-se semelhanças com os casos já analisados anteriormente: (a) decréscimo do valor real das máquinas - apesar da ascensão ocorrida entre 1941 e 1942 (10,6\%), que, em termos nominais, foi considerável $(24,3 \%)$-; e (b) forte elevação dos lucros brutos e da distribuição de dividendos após 1942. Ratifica-se aqui, mais uma vez, o período 1941-1942 como ponto de inflexão para o subsetor têxtil paulista.

Apesar de todo esse crescimento, faz-se necessário ressaltar, porém, que as dificuldades encontradas pelo ramo de seda artificial na obtenção de matérias-primas acarretaram sérios problemas na manutenção da sua produtividade durante o contexto bélico. As reclamações dos produtores de fios de rayon, nesse sentido, foram constantes, principalmente pós-1941. Os diretores das Indústrias Reunidas Francisco Matarazzo, por exemplo, em 1942, teceram comentários sobre os "problemas de aprovisionamento de alguns ingredientes básicos para a fabricação de rayon (...)" ${ }^{\$ 80}$. A Cia. Nitro-Química Brasileira, por sua vez, assinalou no ano de 1943 que os custos de produção da seda artificial elevaram-se “(..) sensivelmente (...) pela falta de transportes marítimos (...)" Já em outubro de 1941, o sindicato patronal têxtil do Rio de Janeiro havia enviado ofício ao diretor da Carteira de Exportação e Importação do Banco do Brasil “(...) solicitando

\footnotetext{
${ }^{580}$ Relatório de Diretoria. IRFM, 15.03.1943.

${ }^{581}$ Relatório de Diretoria. Cia. Nitro-Química Brasileira, 24.03.1944.
} 
providências para (...) importação de produtos químicos indispensáveis ao trabalho na indústria de tecidos", notadamente na de rayon $^{582}$.

A manutenção dessas dificuldades na obtenção de matérias-primas para as fábricas de seda artificial trouxe duas conseqüências importantes: (a) a proibição da exportação dos fios de rayon; e (b) o crescente incentivo estatal e interesse particular no desenvolvimento do ramo da seda natural.

Sobre a primeira delas, lembra-se que os sindicatos patronais têxteis do Rio de Janeiro e de São Paulo receberam, entre 1940 e 1941, diversas reclamações por parte de tecelagens e malharias acerca das irregularidades nos fornecimentos de fios de rayon. Naquelas, muitas fábricas também afirmaram que as três empresas produtoras de fios artificiais no País (Indústrias Reunidas Francisco Matarazzo, Cia. Nitro-Química Brasileira e Cia. Brasileira Rhodiaseta) não aceitavam “(...) reclamação de espécie alguma a respeito da qualidade do produto fornecido, informando da possibilidade de ser cortado completamente o suprimento de fios àqueles que, na defesa dos seus direitos e interesses, ousarem fazer qualquer reclamação sobre o produto recebido"583. Em razão disso, o SIFTERJ convocou uma reunião entre as três fábricas citadas visando discutir o problema. As Cia. Nitro-Química e a Rhodiaseta informaram ao sindicato que suas vendas ao mercado interno mantiveram-se regulares e que as reclamações não possuíam qualquer fundamento. As IRFM, por sua vez, não mandaram representantes para o encontro. A negligência dos Matarazzo, ratificando uma posição não-conciliadora diante das tecelagens de rayon, fez o sindicato carioca levar a questão para as instâncias governamentais. Em carta ao próprio Presidente da República, dizia-se que “(...) a produção dessas matérias-primas (rayon) representa um interesse nacional (...) (e que) a S.A. Indústrias Reunidas F. Matarazzo, justamente a maior produtora de fios de rayon e a única produtora de rayon cortado, deliberou reter a sua produção com o objetivo evidente de forçar uma alta de preços (...)". No final do documento, pedia-se a proibição da exportação de fios artificiais objetivando solucionar o problema ${ }^{584}$. Nesse momento, o governo já havia condicionado às vendas internacionais de rayon ao abastecimento regular de todas necessidades do mercado doméstico. Além disso, o Estado criara cotas e tabelas

\footnotetext{
${ }^{582}$ SIFTERJ. Oficio dirigido ao diretor da CRIBB, 20.10.1941.

${ }^{583}$ Carta SIFTRJ às empresas Indústrias Reunidas Francisco Matarazzo, Cia. Nitro-Química Brasileira e Cia. Brasileira Rhodiaseta acerca do problema da irregularidade na distribuição de fios de seda artificial no mercado doméstico, 18.09.1941.

${ }^{584}$ Carta SIFTERJ ao Presidente da República, 20.11.1941.
} 
de preços para o produto ${ }^{585}$. Os contínuos desrespeitos a esse tabelamento de preços $^{586}$, entretanto, levaram a ações mais radicais por parte do governo, tais como a realização de controles mais rígidos sobre a distribuição dos fios no mercado interno e a proibição total da venda do produto internacionalmente ${ }^{587}$.

Mesmo com essas proibições e controles estatais, a escassez dos fios de rayon no mercado doméstico continuou problemática, devido, principalmente, à falta de matériasprimas $^{588}$. Propiciaram-se, assim, condições para o fomento da produção de seda natural internamente. Das 58 novas sociedades anônimas têxteis criadas ao longo da guerra, 14 vinculavam-se a este ramo (isto é, mais de $24 \%)^{589}$. Os diretores da Indústria de Seda de Marília, por exemplo, afirmaram, em 1943, que era “(...) com satisfação que consignamos neste relatório o esplêndido desenvolvimento da fábrica (...) Iniciando nossos trabalhos com 20 bacias de fiação de seda natural, aumentamos as nossas instalações (ao longo da guerra) para 120 bacias e o produto de nossa fabricação foi sempre vendido aos melhores preços do mercado (...)" ${ }^{\Perp 900}$. A Fiação e Tecelagem São Joanense S.A. assinalou, no ano de 1944, que “(...) a indústria de seda natural apresenta-se como um dos melhores ramos de negócio do momento (...) (e que) o maquinário necessário a estas indústrias é inteiramente constituído por fábricas nacionais (...)", proporcionando, assim, possibilidades "seguras" de investimento aos interessados, pois as mesmas poderiam se desenvolver independentes do conflito mundial ${ }^{591}$. Lembra-se, também, que muitas dessas empresas se voltaram não apenas para a produção industrial em si, mas também para a fabricação da matéria-prima. Quando foi constituída, a Indústria de Seda Fidasil S.A. expressou em sua escritura de fundação que, além da produção de fios, a empresa teria como objetivo “(...) a plantação de amoreira e a cultura e criação do bicho-de-seda" ${ }^{\$ 92}$. Da mesma forma, a Cia. Industrial de Sericultura $(C I S)$ dedicar-se-ia às culturas agrícolas vinculadas à produção de seda

\footnotetext{
${ }^{585}$ CDEN. Resolução n. 15, 23.09.1941.

${ }^{586}$ Uma das táticas mais utilizadas pelas empresas produtoras de rayon para burlar os preços tabelados consistia na maquiagem do produto, isto é: o fio artificial Standard, conforme a tabela oficial, custava $28 \$ 000$ por quilo. Criou-se, além deste, um outro tipo de fio denominado Especial, cujo preço era de $35 \$ 500$ por quilo. Quando as tecelagens e malharias demandavam o tipo Standard, aquelas empresas declaravam que não poderiam fornecê-lo em razão da falta de estoques. Muitas chegaram a comprar, portanto, o fio Especial. "No entanto, examinando esse tipo Especial, se verifica que o mesmo nada mais é do que o tipo Standard; sendo essa uma maneira capciosa de fraudar a lei e procurar receber $35 \$ 500$ por uma mercadoria que aquela empresa só poderia vender por 28\$000". Maiores informações, ver: Carta SIFTRJ à Junta Reguladora do Comércio de Fios e Tecidos, 12.02.1942.

${ }^{587}$ Ver: CME. Portaria n. 131, 11.09.1943; CETex. Portaria n. 21-44, 07.12.1944; e CETex. Resolução n. 09, 09.07.1945.

${ }^{588}$ Relatórios de Diretoria. Cia. Nitro-Química Brasileira, 24.03.1944 e 20.03.1945.

${ }^{589}$ Tabela 15a.

${ }^{590}$ Relatório de Diretoria. Indústria de Seda de Marília, 24.01.1944.

${ }^{591}$ Ata Assembléia Geral Extraordinária. Fiação e Tecelagem São Joanense S.A., (?).03.1944.

${ }^{592}$ Escritura de Constituição de S.A. Indústria de Seda Fidasil S.A., 27.04.1944.
} 
natural, bem como à criação de institutos de pesquisas no interior do estado de São Paulo, visando obter melhores sementes de amoreira, fios de seda mais longos e a distribuir ovos aos agricultores interessados ${ }^{593}$. Exemplo semelhante é fornecido pela Cia. Nacional de Sericultura, fundada em $1945^{594}$.

O crescente interesse na produção de seda natural também pode ser explicado pelos incentivos governamentais concedidos ao ramo. Dentre eles, destacam-se os planos de fomento à sericultura ${ }^{595}$, que incluíam a distribuição de sementes de amoreira e de ovos do bicho-de-seda aos interessados; a concessão de empréstimos subsidiados às empresas, os quais estariam incluídos no próprio orçamento da União; e a liberação da exportação dos fios de seda natural. Esta medida, para muitos, era uma verdadeira faca de dois gumes: se, por um lado, poderia estimular ainda mais capitalistas a inverterem no ramo, por outro, facultaria aos mesmos a possibilidade de escoar essa produção para o exterior, mantendo subabastecido o mercado local ${ }^{596}$.

Grande parte das dificuldades encontradas na produção de rayon ao longo do contexto bélico foi suprida, portanto, pelo engrandecimento do ramo de seda natural, cujo fomento dependeu bem menos de canais externos, seja no que condizia à produção de máquinas - fabricadas, em sua maioria, por empresas domésticas -, seja no que se referia ao cultivo das suas matérias-primas essenciais (amoreira e bicho-da-seda). Entende-se, assim, como o boom do ramo das sedas entre 1939 e 1945 foi possível.

\section{4 - Análise da dinâmica dos ramos}

Analisar-se-ão empiricamente, neste tópico, as bases do crescimento têxtil paulista do período 1939-1945. Em sua essência, tal ascensão fundamentou-se em dois pilares, motivados de forma direta pela Segunda Guerra Mundial: (a) aprofundamento do processo substitutivo de importações; e (b) exportação de tecidos para mercados periféricos.

No que se refere à primeira das bases mencionadas, pode-se perceber que o início do conflito mundial acarretou bruscas quedas nas importações de tecidos paulistas (Tabela 4.17). Entre 1937 e 1944, a redução total foi de 57,8\% e 71,1\%, em termos de quantidades e valores, respectivamente. Destacam-se, nesse sentido, os decréscimos na importação de

\footnotetext{
${ }^{593}$ Escritura de Constituição de S.A. Cia. Industrial de Sericultura (CIS), 17.02.1945.

${ }^{594}$ Escritura de Constituição de S.A. Cia. Nacional de Sericultura, 11.09.1945.

${ }^{595}$ Entre 1937 e 1943, a produção de casulos domésticos cresceu de 300.000 para mais de 1.000 .000 quilos. No estado de São Paulo, havia, em 1937, 7 milhões de amoreiras. Seis anos depois, elas já ultrapassavam 40 milhões. Maiores informações, ver: Folha da Manhã. A sericultura, 18.04.1943.

${ }^{596}$ Decreto-Lei n. 3.148, 26.03.1941 e CETex. Resolução n. 03, 25.11.1944.
} 
tecidos de juta (-99\%, quantidade; e $-99,5 \%$, valores), seda natural $(-87 \%$ e $-79 \%)$ e lã $(-72 \%$ e $-78 \%)$.

Tabela 4.17 - Importação têxtil paulista - Porto de Santos (1937, 1940 - 1944), em quilos e Cr\$1.000 deflacionados

\begin{tabular}{ccccccc} 
& 1937 & 1940 & 1941 & 1942 & 1943 & 1944 \\
\hline Algodão (1) & 351.419 & $1.259 .639(3)$ & $697.461(4)$ & 134.009 & $679.388(5)$ & 182.069 \\
Algodão (2) & 6.081 & 9.680 & 7.803 & 3.637 & 6.555 & 1.592 \\
Lã (1) & 195.084 & 92.741 & 120.830 & 128.339 & 158.607 & 54.405 \\
Lã (2) & 6.142 & 4.011 & 5.959 & 5.458 & 5.333 & 1.357 \\
Juta (1) & 12.297 & 3.610 & 1.746 & 868 & 471 & 120 \\
Juta (2) & 77 & 32 & 27 & 18 & 4 & 0,4 \\
Seda Natural (1) & 5.046 & 1.170 & 1.558 & 1.457 & 640 & 638 \\
Seda Natural (2) & 514 & 195 & 458 & 461 & 371 & 110 \\
Seda Artificial (1) & 1.271 & 825 & 1.217 & 1.478 & 339 & 973 \\
Seda Artificial (2) & 41 & 46 & 233 & 304 & 67 & 159 \\
Total (1) & 565.117 & 1.357 .985 & 822.812 & 266.151 & 839.445 & 238.205 \\
Total (2) & 12.855 & 13.964 & 14.481 & 28.774 & 16.589 & 3.706 \\
\hline
\end{tabular}

Fonte: Estatística do Comércio do Porto de Santos, 1937, 1940-1944 / (1) quilos; (2) Cr\$ 1.000 deflacionados; (3) 1.094.911 quilos de lonas importadas dos Estados Unidos; (4) 614.655 quilos de lonas importadas dos Estados Unidos; (5) 640.598 quilos de lonas importadas dos Estados Unidos. Nos demais anos, a importação de lonas norteamericanas apresentou quantias insignificantes, não sendo, por esse motivo, mencionadas.

Mais drásticas ainda foram as quedas nas importações de fios paulistas (Tabela 4.18). No período 1937-1944, houve redução geral de $97 \%$, no se que refere às quantidades compradas do exterior, e de $91 \%$, no que condiz aos valores. Em outras palavras, tais importações praticamente deixaram de ocorrer no contexto da guerra. Nos casos da juta, seda natural e rayon, elas foram interrompidas por completo a partir de 1941, 1942 e 1943, respectivamente. Entende-se, assim, (i) o porquê da necessidade dos produtores domésticos de juta incentivarem a produção dessa matéria-prima no Norte do País; (ii) o porquê das tecelagens e malharias de rayon tornarem-se tão dependentes das únicas produtoras de fio artificial internos; (iii) e o porquê de se incentivar a cultura das amoreiras e do bicho-da-seda nesse período.

Por outro lado, percebe-se, num primeiro momento, elevação das exportações têxteis de cabotagem do estado de São Paulo (Tabela 4.19). Entre 1939 e 1941, apesar das quedas dos ramos de juta e de seda natural, as vendas de tecidos de algodão e de lã cresceram, respectivamente, em 95\% e 75\%. A ascensão das exportações paulistas de têxteis de rayon, porém, foi a mais considerável. Em 1935, São Paulo praticamente não exportava esse tipo de tecido para outras unidades da Federação; seis anos depois, venderam-se mais de 1.500 toneladas do produto. Após 1941, em razão das maiores dificuldades no transporte marítimo - inclusive de cabotagem -, observam-se quedas nas 
quantidades de tecidos paulistas vendidas para outros estados. Mesmo assim, nos casos do algodão, da lã e da seda artificial, tais vendas se mantiveram em patamares maiores do que as do período pré-guerra. Infere-se, dos dados apresentados, que a perda de mercados domésticos sofrida pela indústria têxtil paulista nos demais estados brasileiros, depois do fim da lei proibitiva da importação de máquinas (março de 1937), foi, em grande parte, compensada pelo afastamento dos concorrentes estrangeiros daqueles mercados durante a guerra.

Tabela 4.18 - Importação de Fios Paulista - Porto de Santos (1937, 1940 - 1944), em quilos e Cr\$ 1.000 deflacionados

\begin{tabular}{ccccccc} 
& 1937 & 1940 & 1941 & 1942 & 1943 & 1944 \\
\hline Algodão (1) & 788.559 & 694.568 & 508.079 & 314.010 & 269.625 & 143.746 \\
Algodão (2) & 14.070 & 17.669 & 13.875 & 10.711 & 9.026 & 5.003 \\
Lã (1) & 642.338 & 454.574 & 168.796 & 29.518 & 45.689 & 2.518 \\
Lã (2) & 15.450 & 9.343 & 3.579 & 819 & 1.419 & 80 \\
Juta (1) & 2.201 .437 & 7.661 & 0 & 0 & 0 & 0 \\
Juta (2) & 3.426 & 4.621 & 0 & 0 & 0 & 0 \\
Seda Natural (1) & 300.042 & 85.386 & 113.609 & 0 & 4 & 0 \\
Seda Natural (2) & 15.162 & 8.643 & 60.982 & 0 & 1,4 & 0 \\
Seda Artificial (1) & 877.988 & 98.112 & 51.378 & 7.234 & 0 & 0 \\
Seda Artificial (2) & 11.666 & 1.212 & 825 & 142 & 0 & 0 \\
Total (1) & 4.810 .364 & 1.340 .301 & 841.862 & 350.762 & 315.318 & 146.264 \\
Total (2) & 59.345 & 36.919 & 26.897 & 11.672 & 10.446 & 5.083 \\
\hline
\end{tabular}

Fonte: Estatística do Comércio do Porto de Santos, 1937, 1940-1944 / (1) quilos; (2) Cr\$ 1.000 deflacionados.

Importações de fios e tecidos decrescentes, produção têxtil local em ascensão e crescimento das vendas desses produtos para outros estados brasileiros constituem, portanto, prova empírica cabal do aprofundamento do processo substitutivo de importações do subsetor têxtil paulista.

Tabela 4.19 - Exportações têxteis paulistas de cabotagem - Porto de Santos (1939, 1941-1944), em quilos

\begin{tabular}{cccccc} 
& 1939 & 1941 & 1942 & 1943 & 1944 \\
\hline Algodão & 6.624 .000 & 12.939 .707 & 8.380 .907 & 6.343 .770 & 9.687 .191 \\
Juta & $2.571 .387(\mathrm{~A})$ & 1.514 .962 & 1.977 .943 & 180.927 & 1.030 .760 \\
Lã & 413.000 & 725.239 & 412.743 & 440.418 & 329.270 \\
Seda natural & $474.083(\mathrm{~A})$ & 50.634 & 7.903 & 16.863 & 6.535 \\
Seda artificial & $98(\mathrm{~A})$ & 1.562 .799 & 1.148 .304 & 802.221 & 816.549 \\
\hline
\end{tabular}

Fonte: Estatística do comércio de cabotagem pelo porto de Santos, 1935, 1939, 1941-1944; (A) dados referentes ao ano de 1935.

Essa elevação produtiva, entretanto, não se deveu apenas à substituição importadora citada. O esforço bélico dos países centrais fez diminuir suas vendas de manufaturados em todos os mercados periféricos. Abriu-se, assim, uma oportunidade sui 
generis para a indústria têxtil de São Paulo - que, apesar de obsoleta, possuía um dos maiores parques fabris do subsetor na América Latina ${ }^{597}$-, a saber: exportar tecidos para nações primário-exportadoras.

Observa-se que a venda de têxteis paulistas para o exterior no período 1937-1945 cresceu de forma significativa (Tabela 4.20). Antes da guerra, São Paulo praticamente não exportava tecidos para o mercado internacional. Em 1942, entretanto, venderam-se mais de 8.600 toneladas para vários países do mundo, dentre eles Argentina, Bolívia, Equador, Guianas Francesa e Holandesa, Paraguai, Peru, Uruguai, Venezuela, União Sul-Africana, Palestina, Síria, etc ${ }^{598}$. Sobressaíram-se as exportações para a América Latina. Observa-se (Tabela 4.21), exceto em 1943, que o continente latino-americano absorveu a maior parte das vendas de têxteis algodoeiros domésticos, com destaque para os anos de 1940 e 1941 (98,7\% e 90,7\% do total, respectivamente). A África ficou em segundo lugar como principal ponto de destino para esses produtos. Em 1943, tal continente chegou a ultrapassar a procura da América Latina, consumindo 56,5\% dos tecidos de algodão vendidos pelo Brasil ao mundo. Vale lembrar que a União Sul-Africana praticamente monopolizou as compras de têxteis brasileiros ao longo da guerra ${ }^{599}$. Europa e Ásia tiveram participações pouco significativas nesse comércio.

Tabela 4.20 - Exportação têxtil paulista (1937, 1940-1945), em quilos e Cr\$ 1.000 deflacionados

\begin{tabular}{cccccccc} 
& 1937 & 1940 & 1941 & 1942 & 1943 & 1944 & 1945 \\
\hline Algodão (1) & 172.517 & 1.428 .102 & 2.877 .641 & 7.220 .987 & 8.268 .861 & 7.309 .399 & 5.397 .128 \\
Algodão (2) & 1.352 & 11.856 & 27.516 & 82.035 & 108.792 & 97.887 & 83.184 \\
Lã (1) & 471 & 8.555 & 130.158 & 300.167 & 179.355 & 86.823 & 212.793 \\
Lã (2) & 6 & 369 & 4.757 & 12.555 & 7.068 & 2.859 & 8.741 \\
Juta (1) & 0 & 275.789 & 838.725 & 1.129 .878 & 4.436 & 529 & 0 \\
Juta (2) & 0 & 1.002 & 3.015 & 3.990 & 19 & 3 & 0 \\
Seda Natural (1) & 0 & 949 & 12.981 & 6.347 & 35.921 & 14.111 & 16.510 \\
Seda Natural (2) & 0 & 162 & 2.390 & 1.421 & 4.636 & 2.283 & 3.796 \\
Seda Artificial (1) & 0 & 10.090 & 8.547 & 39.400 & 89.116 & 62.774 & 130.046 \\
Seda Artificial (2) & 0 & 108 & 336 & 2.236 & 5.236 & 3.268 & 6.513 \\
Total (1) & 172.988 & 1.723 .485 & 3.868 .052 & 8.696 .779 & 8.577 .689 & 7.473 .636 & 5.756 .477 \\
Total (2) & 1.358 & 13.498 & 38.014 & 102.237 & 125.751 & 106.301 & 102.234 \\
\hline
\end{tabular}

Fonte: Estatística do Comércio do Porto de Santos, 1937, 1940-1945 / (1) quilos; (2) Cr\$ 1.000 deflacionados.

É importante destacar que as exportações têxteis paulistas apresentaram salto substancial após 1941. As vendas realizadas no ano de 1942 foram quase sete vezes maiores, em termos de valores, do que as de 1940 (Tabela 4.20). Tem-se aqui, portanto,

\footnotetext{
${ }^{597}$ Edgard Carone. O Estado Novo, op. cit., p. 60-63.

${ }^{598}$ Ver: Estatística do Comércio do Porto de Santos, 1940-1945.

${ }^{599}$ Idem, op. cit.
} 
mais um argumento empírico que caracteriza o período 1941-1942 como ponto de inflexão no crescimento do produto têxtil doméstico, cujas razões já foram analisadas anteriormente.

Esse processo de crescimento das exportações têxteis paulistas é ratificado pelos documentos empresariais. Os diretores das IRFM, por exemplo, destacaram que "(...) os resultados conseguidos em 1941 foram os mais brilhantes (...) (e que) a exportação de tecidos de algodão, que tinha começado a tomar consistência em 1940, firmou-se decisivamente em 1941 (...) (pois) além do Brasil, só o México tem um aparelhamento têxtil suficiente às suas atuais necessidades; os outros países da América Latina - alguns dos quais não produtores ou insuficientemente produtores - importam, no todo ou em parte, os produtos têxteis de que necessitam" ${ }^{600}$. No mesmo ano, a Cia. Nacional de Estamparia destacou que houve “(...) grande expansão das vendas, provocada pela procura de vários mercados externos, desamparados de antigos fornecedores, em virtude da situação mundial, notadamente o do Prata e o das Índias Orientais Neerlandesas. Em conseqüência desse movimento, os preços subiram, os pedidos se multiplicaram e a produção cresceu, acarretando, logicamente, melhora nos lucros" ${ }^{601}$. Os diretores da Cia. Fabril Sta. Basilissa assinalaram que “(...) os nossos negócios comerciais, em 1943, pela primeira vez, não se limitaram ao mercado nacional (e que, em razão disso) (...) o volume de produção atingiu novo recorde (...)" ${ }^{902}$. O relatório referente ao ano de 1941 da S.A. Fábrica Japy, por último, salienta que os bons resultados do exercício se deveram à “(...) considerável melhoria do poder aquisitivo do mercado interno (e) (...) graças também à exportação para mercados sul-americanos, que recebeu grande impulso no segundo semestre $(\ldots)^{\natural 603}$.

Tabela 4.21 - Exportação de tecidos algodoeiros locais discriminada por continente de destino (1940-1945), em metros.

\begin{tabular}{cccccc} 
& Total & América & África & Europa & Ásia \\
\hline 1940 & 39.583 .710 & 39.065 .690 & 412.140 & 105.880 & 0 \\
1941 & 92.379 .320 & 83.806 .140 & 7.876 .180 & 5.980 & 691.020 \\
1942 & 251.686 .410 & 208.197 .280 & 38.335 .430 & 461.470 & 4.692 .230 \\
1943 & 260.458 .180 & 111.357 .160 & 147.085 .980 & 2.011 .530 & 0 \\
1944 & 198.947 .040 & 155.405 .430 & 29.859 .740 & 13.679 .380 & 2.490 \\
1945 & 242.460 .000 & 172.440 .000 & 43.130 .000 & 23.690 .000 & 3.200 .000 \\
\hline Fonte: CETex. Indústria Têxtil Algodoeira, p. $232-233$.
\end{tabular}

\footnotetext{
${ }^{600}$ Relatório de Diretoria. IRFM, 14.03.1942.

${ }^{601}$ Relatório de Diretoria. Cia. Nacional de Estamparia, 02.04.1942.

${ }^{602}$ Relatório de Diretoria. Cia. Fabril Sta. Basilissa, 12.01.1944.

${ }^{603}$ Relatório de Diretoria. S.A. Fábrica Japy, 24.01.1942.
} 
Havia forte consciência, no entanto, por parte da burguesia têxtil paulista, de que essa fase de prosperidade estava relacionada a uma situação sui generis do cenário global. Muitos industriais ratificavam em seus relatórios a necessidade de se renovar o parque fabril como forma de manter os mercados - domésticos e, especialmente, externos conquistados no período bélico ${ }^{604}$. As IRFM, por exemplo, lembravam aos seus acionistas, em 1943, que “(...) a indústria nacional (...) não pode e não deve deleitar-se na contemplação destes resultados decorrentes de um momento anormal (...) A conjuntura fez-nos tornar rapidamente exportadores de produtos industriais, mas não nos iludamos em poder manter depois da guerra para as nossas manufaturas a posição que hoje ocupam no exterior se não se fizerem esforços para proporcional evolução à nossa produção" ${ }^{605}$. Comentários semelhantes foram feitos por outras empresas ${ }^{606}$. O sindicato têxtil paulista (SIFTGESP), apesar de ter reconhecido a importância da Segunda Guerra como impulsionadora dessas exportações, assinalou que “(...) se a indústria têxtil do estado não estivesse preparada (...) não seria possível improvisar um resultado desta magnitude" ${ }^{907}$.

Outro elemento que ratifica essa consciência da burguesia têxtil paulista de que as exportações de tecidos eram atípicas e não decorrentes da "excelente qualidade de seus produtos" 608 era sua preocupação em renovar o parque fabril estadual após a guerra. Inúmeras empresas elevaram seus capitais com esse intuito entre 1944 e 1945. Os diretores da Cia. Fiação e Tecidos N. S. do Carmo, por exemplo, afirmaram que o término do conflito trará “(...) paulatina normalização do tráfego marítimo e o restabelecimento, em toda sua amplitude, do comércio internacional; e havendo necessidade, em futuro bem próximo, de se competir com a concorrência estrangeira, cuja qualidade de produção é por demais conhecida, e sendo nosso maquinário de fabricação a mais remota, torna-se imperioso que o mesmo seja substituído por maquinário moderno (que) (...) viria a baratear o custo dos nossos tecidos (...) (grifo nosso)". Para tanto, aumentou-se o capital

\footnotetext{
${ }^{604}$ Discorda-se, dessa maneira, da inferência de S. Stein acerca da “(...) confiança dos empresários (têxteis) na eficácia dos seus métodos de distribuição e produção" em razão das crescentes exportações de tecidos ocorridas durante a guerra. O equívoco cometido pelo estudioso explica-se pelo fato do mesmo ter tomado uma posição particular (a do Sindicato Têxtil do Rio de Janeiro) como expressão geral da burguesia de tecidos doméstica. Tal sindicato, em um dos seus relatórios, chegou realmente a afirmar que "o notável desenvolvimento das exportações de artigos têxteis constitui motivo de justificado regozijo e uma eloqüente demonstração da capacidade da indústria têxtil brasileira e da excelente qualidade dos seus produtos". O posicionamento do empresariado têxtil paulista, como se verá, foi diferente nessa questão. Maiores informações, ver: SIFTRJ. Relatório de Diretoria, 1941-1942.

${ }^{605}$ Relatório de Diretoria. IRFM, 15.03.1945.

${ }^{606}$ Ver, nesse sentido, os relatórios da S.A. Fiação para Malharia Indiana (01.03.1944); da S.A. Fábrica Japy (24.01.1942); do S.A. Moinho Santista (17.02.1941); dentre outros.

${ }^{607}$ SITEGSP. Relatório de Diretoria, 1945.

${ }^{608}$ SIFTRJ. Relatório de Diretoria, 1941-1942.
} 
social da empresa de 5 para 15 milhões de cruzeiros $^{609}$. O Lanificio F. Kowarick S.A. justificou o acréscimo em seu capital de 12 para 30 milhões de cruzeiros mediante a necessidade de aquisição de novas máquinas. Com isso, diziam seus diretores, “(...) objetivamos (...) melhorar os nossos produtos na livre-concorrência a se estabelecer, fatalmente, dentro de pouco tempo, com a paralisação das hostilidades (...)" ${ }^{\text {610 }}$. O Têxtil Paulo Abreu S.A. realizou medida semelhante, pois, segundo sua diretoria, desejava-se “(...) dar maior incremento às atividades industriais e comerciais; isto por força da imperativa necessidade ditada pelo término da guerra européia que, não há dúvida, provocará competições acentuadas na indústria de tecidos"611. Por último, lembra-se que o próprio sindicato têxtil paulista, em seu relatório anual de 1944, afirmou que “(...) a importação de máquinas para o reequipamento da nossa indústria (...) é fato que não pode ser adiado ou postergado para época mais afastada. Todo o nosso equipamento técnico exige modificações profundas, mesmo radicais (grifo nosso)" ${ }^{\prime 12}$. Mesmo nos jornais observava-se essa consciência do empresariado têxtil paulista de que era necessário "modernizar" suas indústrias para manter os mercados externos no pós-guerra ${ }^{613}$.

Não há dúvida, porém, de que essa excessiva preocupação em renovar o parque fabril estadual não se deveu apenas a uma conjectura burguesa acerca do que poderia acontecer no pós-guerra com o restabelecimento da concorrência internacional. Como os trechos citados acima bem demonstraram, a obsolescência dessa indústria era algo reconhecido publicamente pelos próprios empresários do subsetor. Vivenciavam-se, agora, as conseqüências da realização de uma política que permitiu, ao longo de quase toda década de 1930 (1931 a 1937), um crescente domínio dos pólos têxteis mais bem equipados do País perante os menos preparados. O impedimento na importação de máquinas nesse interregno, que favoreceu amplamente a burguesia têxtil paulista no início do processo de conquista dos mercados regionais domésticos, tornou-se problemático em razão do extremo desgaste dos maquinismos locais e da impossibilidade de renová-los durante a guerra. Com exceção dos anos de 1937 e 1938, pode-se afirmar que, por doze

\footnotetext{
${ }^{609}$ Ata Assembléia Geral Extraordinária. Cia. Fiação e Tecidos N. S. do Carmo, 14.07.1945.

${ }^{610}$ Ata Assembléia Geral Extraordinária. Lanificio F. Kowarick S.A., 27.07.1945.

${ }^{611}$ Assembléia Geral Extraordinária. Têxtil Paulo Abreu S.A., 14.07.1945. Outros exemplos de empresas que aumentaram seu capital social pelos mesmos motivos: Cotonificio Guilherme Giorgi; Indústria Brasileira de Meias; Cia. Fiação e Tecidos Sta. Maria; S.A. Moinho Santista; S.A. Cotonifício Adelina; Tecelagem Brasileira de Seda (antiga S.A. Tecelagem de Seda Ítalo-Brasileira); entre inúmeras outras.

${ }^{612}$ SIFTGESP. Relatório da Diretoria, 1945.

${ }^{613}$ Ver, principalmente: Diário de São Paulo. Ao Brasil impõe-se modernizar a sua indústria de tecidos para não perder o mercado argentino, 16.05 .1944$.
} 
anos (1931-1937; 1939-1945), não houve importações substanciais de bens de capital para o subsetor de tecidos paulista.

O interessante é que a mesma burguesia que pedira ao Estado para manter, nos anos (19)30, a proibição da importação de máquinas, afirmava, em 1944, que “(...) não seria possível levar avante um programa de renovação (...) de reforma radical dos métodos de produção e também nos métodos de negócio (das indústrias têxteis), sem contar com a capacidade de compreensão e com a decidida boa vontade do Governo Federal, que nunca se negou a amparar justas aspirações que se traduzem em vantagens para o Brasil (grifo nosso) ${ }^{\text {"614 }}$. Essa postura antagônica foi alvo de inúmeras críticas nos meios de comunicação, principalmente na imprensa representante dos interesses da lavoura ${ }^{615}$.

Além dessa questão da consciência do sucateamento do parque fabril, havia outros indícios que demonstravam aos empresários têxteis paulistas que a manutenção dos mercados externos pós-guerra dependia de uma significativa melhoria produtiva. Eram constantes, por exemplo, as reclamações dos compradores internacionais acerca dos altos preços e da baixa qualidade dos tecidos brasileiros. Em 1942, o SIFTGESP recebeu a visita do presidente da Associación Textiles Del Uruguai. Este, entre outras medidas, demandou aos industriais de São Paulo uma redução dos preços de fios e tecidos locais, considerados excessivos pelos comerciantes platinos ${ }^{616}$. Três anos depois, por motivos semelhantes, o representante do governo palestino no Rio de Janeiro reclamou ao sindicato têxtil regional dos "preços exorbitantes" cobrados pelos tecidos brasileiros no Oriente Médio ${ }^{617}$. Além desses aspectos, muitas vezes faltava ética comercial aos produtores paulistas e cariocas, os quais, de forma proposital, exportavam tecidos de tipos e qualidades diferentes aos das amostras previamente enviadas. Em novembro de 1943, compradores sul-africanos entraram em contato com o SIFTGESP pedindo providências acerca da venda de brins de qualidades inferiores às amostras recebidas ${ }^{618}$. Problemas semelhantes aconteceram nos mercados sul-americanos. Chegou-se até a propor um “código de conduta (...) visando moralizar as negociações mantidas entre os exportadores de fios e tecidos brasileiros e seus importadores (...)" ${ }^{\text {619 }}$. Os desrespeitos aos contratos estabelecidos, de tão aviltantes, tornaram-se públicos. Em 1943, o editorial de um

\footnotetext{
${ }^{614}$ SIFTGESP. Relatório da Diretoria, 1945.

${ }^{615}$ Ver, principalmente: Correio da Manhã. Importação de máquinas, 01.05.1945.

${ }^{616}$ SIFTESP. Ata da Reunião da Diretoria e do Conselho Consultivo, 22.10.1942.

${ }^{617}$ Stanley Stein, op. cit., p. 171.

${ }^{618}$ SIFTESP. Ata da Reunião da Diretoria e do Conselho Consultivo, 18.11.1943.

${ }^{619}$ SIFTESP. Ata da Reunião da Diretoria e do Conselho Consultivo, 12.11.1942.
} 
periódico carioca caracterizou os industriais têxteis de "tubarões de mangas arregaçadas", possuidores de uma "cobiça estúpida e desenfreada" ${ }^{20}$.

Afora as questões analisadas, recorda-se também que, de 1943 em diante, observou-se decréscimo na quantidade têxtil exportada (Tabela 4.20). Dentre os fatores que explicam tal queda destacam-se (a) a crescente normalização das rotas de comércio marítimo, especialmente a partir de 1945, as quais permitiram o retorno gradual das vendas de bens manufaturados dos países centrais aos periféricos; (b) a intensificação de industrializações substitutivas de importações em países latino-americanos ${ }^{621}$; e (c) as crescentes dificuldades impostas pelo governo brasileiro às exportações têxteis, devido ao subabastecimento do mercado local ${ }^{622}$. Ficaram nítidas, portanto, já ao final da guerra, as dificuldades que seriam encontradas na manutenção das exportações têxteis. Isso justifica, mais do que qualquer outro fator, a preocupação burguesa em renovar e ampliar seu parque fabril após o conflito.

\section{5 - O intervencionismo estatal no subsetor têxtil durante a guerra}

Entre 1939 e 1945, houve significativo crescimento da inflação doméstica ${ }^{623}$. O índice do custo de vida da classe operária paulistana cresceu em 132,3\% no período 1939-1945 (Tabela 4.22). Os gastos em habitação sofreram a menor elevação percentual (9\%), em razão do tabelamento sofrido pelos aluguéis em $1939^{624}$. Por outro lado, os custos dos combustíveis e do vestuário apresentaram as maiores ascensões: 340,8\% e 200,6\%, respectivamente. Compreende-se a elevação dos preços daqueles em razão da brusca queda da importação de petróleo e de carvão ao longo da guerra (Tabela 4.3). No segundo caso, porém, não há dúvida de que as exportações têxteis, ao reduzirem a oferta local de tecidos, foram uma das grandes responsáveis pelo crescimento.

O constante encarecimento do custo de vida fez o Estado tomar algumas providências. Em janeiro de 1943, a Coordenação da Mobilização Econômica ${ }^{625}$ publicou

\footnotetext{
${ }^{620}$ O Jornal. Tubarões de mangas arregaçadas, 23.11.1943. Apud Stanley Stein, op. cit., p. 168.

${ }^{621}$ Ver, nesse sentido: Celso Furtado. A economia latino-americana, op. cit.

${ }^{622}$ A partir de setembro de 1945, o Estado começou a proibir a exportação de certos tecidos, tal como os de algodão e os de seda artificial. A análise dessas proibições, porém, será feita no próximo item.

${ }^{623}$ Ver item 4.1 - A economia brasileira e a guerra.

${ }^{624}$ Edgard Carone. O Estado Novo, op. cit., p. 97.

${ }^{625}$ Criada em setembro de 1942, a Coordenação da Mobilização Econômica (CME) veio substituir a Comissão da Defesa da Economia Nacional, extinta no mesmo período. Aquela possuía atribuições muito amplas, relativas ao planejamento e mobilização dos meios de produção domésticos, conforme as necessidades geradas pela guerra. Assim sendo, ela poderia (a) "orientar" os setores produtivos a fabricarem os bens agrícolas e industriais mais necessários ao país; (b) controlar as importações e exportações de matérias-primas e manufaturados; (c) coordenar o sistema de transportes; (d) planejar políticas de
} 
uma portaria fixando os preços das mercadorias domésticas - sejam as de origem local, sejam as de proveniência estrangeira - nos níveis existentes em 01.12.1942 $2^{626}$. Para executar e fiscalizar essa medida, criou-se uma Comissão Federal de Preços, a qual possuía congêneres estaduais (Comissões Estaduais de Preços) ${ }^{627}$.

Tabela 4.22 - Índices ponderados do custo de vida da classe operária na cidade de São Paulo $(1939-1945), 1939=100$

\begin{tabular}{cccccccc} 
& 1939 & 1940 & 1941 & 1942 & 1943 & 1944 & 1945 \\
\hline Alimentação & 100,0 & 106,8 & 121,0 & 133,6 & 153,0 & 200,8 & 245,3 \\
Habitação & 100,0 & 100,9 & 102,3 & 103,6 & 103,6 & 104,0 & 109,0 \\
Vestuário & 100,0 & 106,3 & 121,9 & 143,5 & 182,6 & 233,0 & 300,6 \\
Combustível & 100,0 & 106,1 & 121,1 & 171,1 & 205,3 & 294,3 & 440,8 \\
Assistência médica & 100,0 & 106,4 & 118,0 & 134,3 & 137,5 & 183,5 & 206,5 \\
Artigos de limpeza doméstica & 100,0 & 97,8 & 105,8 & 147,0 & 207,3 & 235,7 & 243,3 \\
Móveis & 100,0 & 111,0 & 118,0 & 126,0 & 153,3 & 257,5 & 284,8 \\
Transporte & 100,0 & 100,0 & 100,0 & 100,0 & 100,0 & 107,3 & 115,0 \\
\hline Total & 100,0 & 105,2 & 116,5 & 130,4 & 150,0 & 191,0 & 232,3 \\
\hline
\end{tabular}

Fonte: Anuário Estatístico do Brasil, Ano X - 1949, p. 416.

A medida suscitou críticas por parte da burguesia têxtil contra o governo. Os sindicatos patronais do Rio e de São Paulo uniram forças mais uma vez, visando barrar essa fixação de preços. Segundo o SIFTRJ, era evidente “(...) a impossibilidade de serem tomadas medidas uniformes e permanentes no sentido de estabilizar os preços de todos os artigos têxteis" ${ }^{" 28}$. Em razão disso, representantes dos órgãos patronais citados elaboraram uma proposta “(...) para realização de um Convênio entre a referida Coordenação e a indústria têxtil, no sentido de ser reservada uma parte da fabricação de tecidos para a produção de tipos populares, que seriam vendidos por preços reduzidos, em benefício das classes mais necessitadas (grifo nosso) ${ }^{\$ 629}$. Nascia aqui, portanto, sob a égide burguesa, o chamado Convênio Têxtil ${ }^{630}$.

Segundo tal Convênio, cada empresa algodoeira destinaria $10 \%$ da sua produção total para fabricar os chamados tecidos populares; isto é, artigos têxteis cujos preços, além de fixados, representariam, para os fabricantes, apenas o custo relativo às matérias-primas e à mão-de-obra. Os atacadistas e varejistas, por sua vez, seriam obrigados a vendê-los com lucros máximos de $8 \%$ a 30\%, respectivamente. As qualidades desses tecidos também

racionamento de produtos essenciais à população; (e) fixar preços máximos e mínimos e determinar condições de venda de mercadorias; entre outras coisas. Para maiores informações, ver: Decreto-Lei n. 4.750, 28.09.1942; e Edgard Carone. A Terceira República, op. cit., 205-208.

${ }^{626}$ CME. Portaria n. 36, 08.01.1943.

${ }^{627}$ CME. Instrução n. 01 para a execução da Portaria n. 36, 20.01.1943.

${ }^{628}$ SIFTRJ. Relatório da Diretoria, 1943.

${ }^{629}$ Idem.

${ }^{630}$ CME. Portaria n. 83, 15.06.1943. 
seriam previamente definidas pelo governo. Estipularam-se, no início, 14 tipos diferentes de tecidos populares de algodão ${ }^{631}$. "Em compensação, todos os demais artigos (têxteis) vendidos ficariam liberados da aplicação da portaria n. 36, tendo industriais e comerciantes, assim, liberdade de preços" ${ }^{\text {632 }}$. A execução desse acordo, por sua vez, ficou sob responsabilidade da Comissão Fiscalizadora e Executiva do Convênio Têxtil (CFECT) - composta por representantes dos sindicatos patronais e por membros do Estado -, a qual teria como sede o próprio escritório do SIFTRJ, localizado na Rua México.

A aprovação do Convênio não trouxe melhorias significativas para as massas populares no que se refere ao consumo têxtil. As reclamações acerca da má qualidade dos artigos conveniados eram constantes. Afirmava-se, por exemplo, que os cobertores e tecidos de algodão vendidos como populares eram excessivamente finos e de curta durabilidade ${ }^{633}$. Havia reclamações também de que as fábricas enviavam aos comerciantes tecidos de qualidade muito inferior às amostras aprovadas previamente pela Comissão Fiscalizadora e Executiva do Convênio ${ }^{634}$. Em outubro de 1943, apenas a título de ilustração, lembra-se que o comandante Mário de Oliveira Pena, presidente da comissão citada, fez uma visita oficial ao sindicato têxtil paulista, objetivando acabar com esses problemas. Em seu discurso, alertou os empresários do subsetor “(...) no sentido de que os panos populares fossem feitos o mais caprichosamente possível, oferecendo, assim (...) um produto que viesse suprir as necessidades mais prementes das classes menos favorecidas pela fortuna (...)"635. Além disso, no que se refere às quantidades fabricadas de artigos populares, percebe-se que estas se encontravam muito aquém das necessidades de consumo das massas. Em janeiro de 1943, quando o Convênio foi estabelecido, as empresas têxteis de algodão prometeram ao Estado produzir 100 milhões de metros de tecidos por ano. Em 1944, foram entregues apenas 26 milhões e 832 mil metros à Comissão Fiscalizadora, isto é, $73 \%$ a menos do que fora estipulado inicialmente ${ }^{636}$.

\footnotetext{
${ }^{631}$ Vale lembrar que as fábricas de juta, malha, lã e seda não ficaram obrigadas a produzir tecidos populares. Ver: Comissão Fiscalizadora e Executiva do Convênio Têxtil. Resolução n. 04, 17.08.1943. Esse fator é outro que ajuda a explicar o porquê das taxas de crescimento mais significativas dos ramos de lã e das sedas em comparação com os demais no período 1939-1945. A isenção da obrigatoriedade em produzir tecidos populares suscitou menores efeitos no ramo da juta em razão das dificuldades vividas pelo setor primárioexportador tradicional e dos problemas na obtenção de matéria-prima, parcialmente substituída pela produção doméstica. Já no caso das malhas, as conseqüências também foram mais modestas devido ao subabastecimento do mercado de fios local. Lembra-se que as taxas de malharias paulistas que só possuíam tecelagens eram maiores do que nos ramos lanífero e das sedas.

${ }^{632}$ SIFTRJ. Circular n. 39/43, 21.06.1943.

${ }^{633}$ Edgard Carone. O Estado Novo, op. cit., p. 88.

${ }^{634}$ CFECT. Resolução n. 09, 22.10.1943.

${ }^{635}$ SIFTESP. Ata da Reunião da Diretoria e do Conselho Consultivo, 14.101.943.

${ }^{636}$ SIFTESP. Relatório da Diretoria, 1944, p. 80.
} 
Apesar de todos esses desrespeitos aos termos do acordo, a concepção publicamente divulgada pelos empresários têxteis era a de que o Convênio representava uma ação filantrópica por eles promovida, visando apenas o bem-estar das massas. O sindicato patronal paulista, por exemplo, destacou o "espírito de sacrifício" da indústria têxtil ao aceitar a "missão assistencialista" de produzir tecidos com preços subsidiados para os populares ${ }^{637}$. O SIFTRJ, por sua vez, em carta ao presidente da CME, afirmou que a “(...) indústria têxtil, tendo em consideração os respeitáveis interesses das classes menos favorecidas, não hesitou em concordar na obrigatoriedade da fabricação de artigos populares, para serem vendidos por preços excepcionalmente reduzidos (...) (grifo nosso) ${ }^{9638}$.

Embasado apenas nesses discursos, tem-se a impressão de que o Convênio foi um enorme "sacrifício" para a indústria têxtil e fruto de pura imposição governamental, patrioticamente aceita pelos empresários. Não se lembra, porém, que tal acordo foi proposto pela própria burguesia, visando escapar do tabelamento geral dos preços dos tecidos, caracterizado como uma ação “(...) altamente lesiva aos interesses da indústria têxtil (...) ${ }^{939}$. Na realidade, o Convênio nada mais foi do que um mal menor diante das possibilidades de fixação generalizada de preços dos artigos têxteis. Ele significou, portanto, mais uma vitória burguesa. Mantinham-se as possibilidades de altos lucros em razão da liberação dos preços dos restantes $90 \%$ da produção, os quais poderiam ser exportados sem quaisquer restrições. Observando-se a questão por esse ângulo, compreende-se o porquê de esses empresários terem a necessidade de ratificar sua postura "filantrópica" diante dos trabalhadores, já que esta justificava ideologicamente os consideráveis lucros auferidos por tal indústria durante a guerra.

A manutenção da liberdade dos preços têxteis, permitida pelo Convênio, logo suscitou problemas. Apenas entre 1943 e 1945, houve elevação de 64,6\% no custo dos itens de vestuário para o operário paulistano (Tabela 4.22). O aumento do mercado doméstico, a insuficiente oferta de tecidos - em grande parte escoada para o exterior - e os crescentes custos produtivos foram os fatores que mais contribuíram para essa ascensão de preços. No período 1943-1945, os lucros brutos e a distribuição de dividendos nas fábricas desse subsetor atingiram proporções recordes ${ }^{640}$. Ficava cada vez mais difícil continuar defendendo a tese de que as cotas de tecidos populares eram um "sacrifício" para as

\footnotetext{
${ }^{637}$ SIFTESP. Relatório da Diretoria, 1944.

${ }^{638}$ SIFTRJ. Carta ao Sr. Presidente da CME, 05.12.1945.

${ }^{639}$ SIFTRJ. Circular 39 / 43, 21.06.1943.

${ }^{640}$ Ver item $\underline{4.3-\text { Os ramos. }}$.
} 
empresas têxteis, ou que os preços não poderiam ser reduzidos devido aos custos inflexíveis das matérias-primas, diante de ganhos tão expressivos.

Em razão disso, houve mudança da política governamental com relação às indústrias. Entre 1944 e 1945, (a) criou-se uma lei sobre os chamados lucros extraordinários; e (b) editaram-se portarias e resoluções que controlavam diretamente os preços dos artigos têxteis e proibiam as suas exportações.

Analisar-se-á, primeiramente, a questão dos lucros. Ao longo da guerra, devido à publicação dos balanços de muitas empresas têxteis, iniciou-se, nos jornais, ferrenha campanha contra o excesso desses ganhos ${ }^{641}$. O fato de tais contabilidades serem públicas no caso das sociedades anônimas - tornava impossível aos empresários negarem os faustosos lucros auferidos no período. A S.A. Fiação, Tecelagem e Estamparia Ypiranga Jafet S.A., por exemplo, distribuiu, entre 1943 e 1945, mais de 58 milhões e 600 mil cruzeiros em forma de dividendos aos acionistas, isto é, o equivalente a $147 \%$ do capital social da empresa naquele momento ${ }^{642}$. A S.A. Calfat, no mesmo interregno, distribuiu 27 milhões e 750 mil cruzeiros, que representava $185 \%$ do seu capital social ${ }^{643}$; o Cotonifício Crespi, 27 milhões (90\% do capital) ${ }^{644}$; a S.A. Cotonifício Paulista, 18 milhões e 750 mil (125\% do capital) ${ }^{645}$; a S.A. Fiação para Malharia Indiana, 11 milhões e 156 mil (159,3\% do capital) ${ }^{646}$; dentre outros inúmeros exemplos.

A publicidade desses dados gerou preocupações nos centros patronais têxteis. Em fevereiro de 1943, o sindicato paulista externou “(...) receio de que, à vista desses balanços, o Ministério da Fazenda voltasse ao plano já alvitrado de taxar fortemente os lucros, como que tomando participação neles (...)”. Considerava-se tal idéia “(...) absolutamente inconveniente, anti-econômica e antipatriótica" ${ }^{\text {647 }}$. Meses depois, em outra reunião, o presidente do SIFTESP discursou sobre a “(...) campanha injusta e imerecida que se vem fazendo contra a nossa indústria, esquecendo-se dos longos períodos de sacrifício pelos quais passou a indústria têxtil sem outro amparo senão o da sua própria energia, o do seu trabalho, o da sua tenacidade. Sem reclamações ou lamúrias, a indústria de fios e tecidos enfrentou ameaçadoras crises, defrontando-se com obstáculos quase intransponíveis, com resultados financeiros deficitários (...); a indústria têxtil vem

\footnotetext{
${ }^{641}$ Ver, principalmente: O Jornal. Tubarões de mangas arregaçadas, 23.11.1943.

${ }^{642}$ Balanços. S.A. Fiação, Tecelagem e Estamparia Ypiranga Jafet, 09.02.1944, 04.03.1945 e 12.03.1946.

${ }^{643}$ Balanços. S.A. Calfat S.A., 18.02.1944, 06.03.1945 e 09.03.1946.

${ }^{644}$ Balanços. Cotonifício Rodolfo Crespi, 19.03.1944, 17.03.1945 e 12.03.1946.

${ }^{645}$ Balanços. S.A. Cotonifício Paulista, 25.02.1944, 25.02.1945 e 07.03.1946.

${ }^{646}$ Balanços. S.A. Fiação para Malharia Indiana, 29.03.1944, 14.03.1945 e 19.03.1946.

${ }^{647}$ SIFTESP. Relatório da Diretoria e do Conselho Consultivo, 11.02.1943.
} 
procurando no momento refazer-se dos prejuízos sofridos, sendo de se considerar que os lucros constatados nos balanços do último exercício são absolutamente justos, porque representam o fruto de esforços empregues nos últimos dez anos (grifos nossos)" ${ }^{\text {"48 }}$. Diante da impossibilidade de negá-los, a burguesia têxtil paulista tenta justificar seus enormes lucros sob ótica de que estes eram compensações pelos anos consecutivos de crise que a ela atravessou sem quaisquer auxílios. Essa justificativa, porém, é totalmente infundada. Viu-se, em primeiro lugar, o quanto a década de 1930 se caracterizou por notável expansão das empresas de tecidos de São Paulo, apesar das recessões de 1929-1932 e de 1936-1937. Além disso, mostrou-se o quanto o Estado amparou tais indústrias naquele período, muito em razão das "reclamações" e "lamúrias" desses próprios empresários.

Apesar das tentativas burguesas para evitá-lo, o Governo Federal decretou o Imposto sobre Lucros Extraordinários em janeiro de $1944^{649}$. Justificou-se a criação desse novo tributo em razão das despesas estatais crescentes dos tempos de guerra e da necessidade de se reequipar as indústrias após o conflito ${ }^{650}$. Mesmo assim, logo as críticas dos industriais se fizeram sentir. O relatório anual da Cia. Nacional de Estamparia exemplifica os argumentos utilizados: ratifica-se a tese da "compensação dos lucros" e ressalta-se o caráter supostamente "filantrópico" dessas empresas nos momentos de crise e da sua importância na formação da "riqueza" local. Segundo as palavras dos próprios diretores da companhia, “(...) agora que as circunstâncias da guerra proporcionaram às nossas classes manufatureiras oportunidade para (...) usufruírem lucros de importância e, conseqüentemente, acumularem fundos capazes de possibilitar a expansão e a renovação dos seus parques, uma injusta campanha aponta à execração pública como exploradoras e criminosas as que fomentam a grandeza e a riqueza do Brasil (...) Esquecem-se da tremenda luta que sustentamos em dias que não são longínquos, luta de vida ou morte, com as nossas fábricas semiparalisadas, apenas funcionando periodicamente para não deixar o trabalhador passar fome e com os nossos depósitos atulhados de produtos que não encontravam consumidores. Então ninguém se lembrou de pregar medidas protetoras para o industrial (...) (grifos nossos) ${ }^{9651}$. A campanha dos industriais pela

\footnotetext{
${ }^{648}$ SIFTESP. Relatório da Diretoria e do Conselho Consultivo, 01.04.1943.

${ }^{649}$ Decretos-Leis n. 6.224 e 6.225, 24.01.1944. A lei considera como lucros extraordinários “(...) os lucros que excederem a média dos verificados em dois anos consecutivos ou não, à escolha do contribuinte, desde que compreendidos no período de 1936 a 1940, inclusive, com o acréscimo de $50 \%$ ".

${ }^{650}$ Guardar-se-iam $30 \%$ do imposto para financiar a compra de máquinas no pós-guerra. Ver: Decreto-Lei n. 6.224, 24.01.1944.

${ }^{651}$ Relatório da Diretoria. Cia. Nacional de Estamparia, 03.02.1945. Argumentos semelhantes podem ser encontrados em: SIFTRJ. Exposição feita pelo Dr. Vicente de Paulo Galliez, Secretário Geral do Sindicato
} 
revogação da lei foi em vão. Apesar disso, o tributo não foi posto em prática, devido à queda de Getúlio Vargas do poder em $1945^{652}$.

Além da criação desse imposto, a partir de 1945, o Governo Federal começou a impor diversas restrições aos preços e às exportações de produtos têxteis. Em agosto daquele ano, proibiram-se exportações de tecidos por 12 meses aos países considerados industrialmente estruturados para produzi-los, a saber: Suécia, Noruega, Egito, Turquia, Estados Unidos, Espanha, Suíça, Canadá, Bélgica e Palestina ${ }^{653}$. Em outubro, estabeleceram-se preços-teto para os tecidos de algodão, referentes ao dia $01.09 .1945^{654}$. No mês seguinte, reduziram-se os preços desse produto em $10 \%{ }^{655}$.

Essas ações acirraram os ânimos entre os industriais têxteis e o governo. Em dezembro de 1945, os sindicatos de fiação e tecelagem dos estados do Rio de Janeiro, São Paulo, Alagoas, Sergipe e Maranhão enviaram um memorial ao presidente da Coordenação da Mobilização Nacional criticando duramente as medidas recémpromulgadas, especialmente no que condizia aos preços. Os principais argumentos burgueses referiam-se ao descumprimento do Convênio Têxtil por parte do governo e a majoração dos custos fabris (matérias-primas, salários, tributos, etc.) como justificativa para a elevação dos preços dos tecidos. Segundo tais sindicatos, “(...) ficou perfeitamente acentuado que a fabricação de tipos populares excluiria essa indústria de qualquer outro compromisso ou intervenção da Coordenação em matéria de preços (...) As publicações dessas portarias importam em denúncia e rescisão do Convênio celebrado, e na cessação da obrigatoriedade da entrega de tipos populares por parte da indústria têxtil (...) Forçoso é relembrar que, durante o funcionamento do Convênio Têxtil, os preços dos artigos populares não sofreram modificação. Entretanto, o custo da fabricação se tem elevado de forma considerável (grifo nosso)"

No que se refere ao primeiro argumento, há procedência na acusação de que o Estado, ao tabelar preços e limitar exportações, descumpriu os termos do Convênio. Essa quebra, porém, só aconteceu porque, antes, ele já estava sendo descumprido pelos próprios industriais têxteis. Viu-se que as quantidades de tecidos populares entregues à Comissão

das Indústrias de Fiação e Tecelagem do Rio de Janeiro, em nome deste sindicato e do Sindicato da Indústria de Fiação e Tecelagem em Geral do Estado de São Paulo perante a 'Comissão de Investigação Econômica e Social , da Assembléia Nacional Constituinte, 29.04.1946.

${ }^{652}$ Edgard Carone. O Estado Novo, op. cit., 102-103.

${ }^{653}$ CETex. Resolução n. 10, 16.08.1945.

${ }^{654}$ CME. Portaria n. 411, 09.10.1945.

${ }^{655}$ CME. Portaria n. 424, 30.11.1945.

${ }^{656}$ SIFTRJ. Memorial dos Sindicatos Têxteis do Rio de Janeiro, São Paulo, Alagoas, Sergipe e Maranhão ao Presidente da Coordenação de Mobilização Econômica, 05.12.1945. 
Fiscalizadora foram muito menores do que as inicialmente prometidas e que as qualidades desses produtos estavam aquém das amostras aprovadas pelo Convênio.

Já sobre o aumento dos custos produtivos, observa-se que, no estado de São Paulo, o argumento não procede, pelo menos no que condiz às matérias-primas e aos salários (Tabela 4.23). Em todos os ramos, a participação dos ordenados no valor produtivo apresentou queda entre 1939 e 1944 . Houve aumento no custo das matérias-primas apenas para os ramos jutífero e de malhas. Nos demais, perceberam-se quedas significativas: algodão (-16,9\%); lã (-19,6\%); e sedas $(-22,6 \%)$. O único item no qual se pode falar em elevação de custos refere-se aos tributos. No período 1939-1944, a participação dos impostos no valor de produção têxtil aumentou de 0,06 para $0,07(18,9 \%)$. Nesse caso, porém, o grande crescimento percentual é enganoso. Em 1944, o peso dos tributos no produto têxtil total era pequeno $(7 \%)$ quando comparado com o das matérias-primas $(43 \%)$ e com o dos salários $(10 \%)$.

Tabela 4.23 - Resumo dos custos relativos dos ramos da indústria têxtil paulista (1939, 1943 e 1944)*

\begin{tabular}{cccc|ccc|ccc} 
& \multicolumn{4}{c|}{1939} & \multicolumn{4}{|c|}{1943} & \multicolumn{3}{|c}{1944} \\
& $\mathrm{~A}$ & $\mathrm{~B}$ & $\mathrm{C}$ & $\mathrm{A}$ & $\mathrm{B}$ & $\mathrm{C}$ & $\mathrm{A}$ & $\mathrm{B}$ & $\mathrm{C}$ \\
\hline Algodão & 0,43 & 0,05 & 0,15 & 0,36 & 0,05 & 0,11 & 0,36 & 0,07 & 0,11 \\
Juta & 0,52 & 0,04 & 0,12 & 0,65 & 0,08 & 0,11 & 0,56 & 0,06 & 0,10 \\
Malhas & 0,45 & 0,11 & 0,13 & 0,50 & 0,07 & 0,09 & 0,54 & 0,07 & 0,11 \\
Lã & 0,62 & 0,05 & 0,14 & 0,53 & 0,06 & 0,07 & 0,50 & 0,06 & 0,08 \\
Sedas & 0,56 & 0,08 & 0,11 & 0,13 & 0,06 & 0,07 & 0,43 & 0,08 & 0,09 \\
Total & 0,47 & 0,06 & 0,13 & 0,32 & 0,05 & 0,09 & 0,43 & 0,07 & 0,10 \\
\hline Fonte: Estatística Industrial do Estado de São Paulo, 1938-1939, 1943 e 1944; * A $=$ Matérias-primas
\end{tabular}

Ao contrário do que apregoavam os industriais, infere-se que, durante a guerra, os valores da produção de tecidos paulistas cresceram mais rapidamente do que os custos produtivos. Entendem-se, assim, os lucros significativos auferidos pelo setor nesse contexto.

\section{$\underline{4.6 \text { - As relações de trabalho nas fábricas têxteis durante a guerra }}$}

O forte crescimento da demanda por tecidos no período 1939-1945 trouxe à tona o problema da intensificação produtiva nas fábricas. De um lado, tinha-se um parque industrial caracterizado pela obsolescência e que não poderia, naquele momento, ser renovado ou muito menos ampliado; do outro, encontravam-se leis restritivas no que condizia às jornadas e ao emprego de mulheres e menores. 
No meio desse impasse, iniciaram-se, a partir de 1941, pressões da burguesia têxtil diante do Estado em prol da flexibilização das leis trabalhistas. Demandava-se, principalmente, (a) aumento das jornadas nas fábricas; (b) liberalização do trabalho noturno de mulheres e menores; e (c) a criação de medidas que coibissem faltas, garantindo maior assiduidade dos operários ${ }^{657}$. Justificavam-se os pedidos em razão da crescente demanda estrangeira por têxteis e da importância destas para o enriquecimento "nacional". Segundo os sindicatos patronais do Rio e de São Paulo, "diariamente chegam cartas e telegramas de casas importantíssimas querendo comprar fios e tecidos, pedidos esses que não podem ser totalmente atendidos por excederem à capacidade de produção do nosso aparelhamento industrial no ritmo atual de trabalho (...); não (se pode) desperdiçar essa feliz oportunidade de intensificar a entrada de ouro para o país (...)" ${ }^{958}$.

Logo, porém, surgiram críticas nos jornais a respeito dessa situação. O mais incisivo foi o diário Correio da Manhã. Em um dos seus artigos, afirmou que "(...) se erros do passado não houvessem impedido o desenvolvimento da indústria de tecidos, o país se encontraria hoje em outras condições. As encomendas se multiplicam, mas a capacidade de produção não as poderá atender (...) Hoje, a dificuldade em atender a expansão do comércio de tecidos provém justamente dessa política que impedia a ampliação e a instalação da indústria têxtil em maior escala (lei proibitiva de importações de máquinas, 1931-1937)" ${ }^{659}$.

Independentemente das críticas, muitos industriais começaram a aumentar as jornadas dos seus trabalhadores sem autorização governamental. Soube-se de algumas greves que aconteceram no período em razão desses desrespeitos, apesar da forte repressão e da censura à imprensa ${ }^{660}$. No final de 1939, por exemplo, 300 operárias da Cia. Nacional de Estamparia tentaram se insurgir contra a elevação do tempo de trabalho nas tecelagens de 8 para 10 horas diárias. No entanto, devido às "enérgicas providências" do DOPS, "nada de anormal se verificou"661. Nesse mesmo ano, o presidente do Sindicato dos

\footnotetext{
${ }^{657}$ Ver, em especial: SIFTRJ. Memorial dirigido ao Sr .Ministro do Trabalho, Indústria e Comércio, relativamente ao trabalho nos dias feriados e afixação do quadro para registro do horário, 22.01.1941; e SIFTRJ/ Memorial dirigido ao Sr. Ministro do Trabalho, Indústria e Comércio a propósito da duração do trabalho de menores, 22.07.1942.

${ }^{658}$ SIFTRJ e SIGFTESP. Memorial dirigido ao Sr. Ministro das Relações Exteriores, Dr. Oswaldo Aranha, 30.09.1941.

${ }^{659}$ Correio da Manhã. Exportação de tecidos, 04.10.1941. Ver também: Correio da Manhã. Falta de tecidos, 15.07.1941.

${ }^{660}$ Segundo Carone, "a feroz censura da imprensa e a falta de informações mais particulares permitem levantamento parcial da rebeldia durante os anos de maior repressão, porém suficientes para verificar o seu conteúdo real". Edgard Carone. O Estado Novo, op. cit., p. 121.

${ }^{661}$ DOPS. Radiograma do Delegado Regional de Polícia de Sorocaba, João Guedes Tavares Delgado, ao Delegado Auxiliar de São Paulo, 22.09.1939.
} 
Operários em Fiação e Tecelagem declarou que era “(...) deplorável que (...) se pretenda adotar um horário superior ao normal”. Ainda segundo ele, “ (...) inúmeras fábricas trabalham mais de 10 horas diárias, sem que nada tenham valido os protestos dos sindicato" ${ }{ }_{662}$. Nos anos de 1940 e 1941, irromperam duas paralisações na S.A. Fábrica Votorantim por motivos semelhantes ${ }^{663}$. A forte atuação policial e a demissão dos líderes do movimento esvaziaram ambas. Em 1943, no Lanificio Varam, os trabalhadores se recusaram a aceitar as novas jornadas impostas pelos patrões. Mais uma vez, porém, a presença de investigadores do DOPS fez os operários retornarem às suas funções ${ }^{664}$.

Em 1944, surgiu a oportunidade que os industriais aguardavam para legalizar a intensificação do uso da mão-de-obra nas fábricas. Em maio daquele ano, o governo brasileiro foi convidado para participar de uma reunião em Washington "a fim de estudar assuntos relativos às exportações de tecidos" ${ }^{\prime 665}$. Enviou-se uma missão composta de representantes da indústria têxtil. No encontro, concluiu-se que “(...) era necessário um esforço especial dos cinco principais países têxteis do mundo no momento atual (Estados Unidos, Inglaterra, Índia, Brasil e México) para a normalização do abastecimento de tecidos de algodão não só aos demais países e respectivas colônias, mas também aos países e regiões reconquistadas, cujas populações serão socorridas pela United Relief and Rehabilitation Administration (UNRRA) ${ }^{666 "}$. Ao Brasil, coube fornecer 90 milhões de jardas de tecidos de algodão a preços pré-fixados à UNRRA e mais 60 milhões de jardas à French Colonial Supply Mission (FCSM) ${ }^{667}$.

A aceitação desses encargos pela burguesia têxtil doméstica ficou condicionada a alterações nas leis trabalhistas. O governo cedeu. Em julho de 1944, criou-se um decreto que autorizava a mobilização da indústria de tecidos para o esforço de guerra ${ }^{668}$. Aumentaram-se, com isso, as jornadas para 10 horas $^{669}$; praticamente se proibiram os dissídios coletivos; as mudanças de emprego só poderiam acontecer mediante autorização do Ministério do Trabalho; permitiu-se trabalho noturno de mulheres e de menores; e ainda se possibilitou a transformação das férias em indenização. Para “orientar e dirigir” a

\footnotetext{
${ }^{662}$ Folha da Manhã, 12.02.1939 e 17.02.1939; Apud Edgard Carone. O Estado Novo, op. cit., p. 123.

${ }_{663}$ DOPS. Telegramas do Delegado Regional de Polícia de Sorocaba, João Guedes Tavares, ao Superintendente da Segurança Política e Social de São Paulo, 24.01.1940, 31.01.1940 e 02.02.1940; e DOPS. Carta do Delegado Regional de Polícia de Sorocaba, João Guedes Tavares, ao Delegado Especialíssimo da Ordem Política e Social, 09.06.1941.

${ }^{664}$ DOPS. Relatório de investigação, 04.06.1943.

${ }^{665}$ SIFTRJ. Relatório da Diretoria, 1944.

${ }^{666}$ Administração da Assistência a Reabilitação das Nações Unidas.

${ }^{667}$ Missão Colonial Francesa de Suprimento.

${ }^{668}$ Decreto-Lei n. 6.668, 13.06.1944.

${ }^{669}$ Haveria possibilidade de maiores acréscimos diante de prévia autorização do Ministério do Trabalho.
} 
referida mobilização, criou-se a Comissão Executiva Têxtil (CETex) ${ }^{670}$. Esta, com o tempo, também ficou incumbida de administrar o Convênio Têxtil ${ }^{671}$.

Apesar de todas essas modificações, o País não conseguiu cumprir os termos do acordo com a UNRRA e com a FCSM. À primeira, até o final da guerra, haviam sido fornecidas apenas 21 milhões e 400 mil jardas das 90 milhões prometidas (isto é, 24\% do total); à segunda, por sua vez, concederam-se 19 milhões e 900 mil jardas das 60 milhões acertadas $(33,1 \% \text { do total })^{672}$. Tendo em vista a prosperidade apresentada pelas empresas têxteis paulistas no período 1942-1945, infere-se que estas se valeram da condição de “indústrias mobilizadas” para intensificar suas produções visando fins privados, isto é, venda para mercado. Ignoram-se, em grande parte, os objetivos originais que motivaram tal "mobilização". O fato da presidência da CETex ter permanecido nas mãos de um dos maiores industriais têxteis do País - Guilherme da Silveira - esclarece o porquê da negligência do órgão.

Tabela 4.24 - Salário per capita dos operários da indústria têxtil paulista (1939, 1943 e 1944)

\begin{tabular}{ccc|cc|cc} 
& \multicolumn{2}{c|}{1939} & \multicolumn{2}{c|}{1943} & \multicolumn{2}{c}{1944} \\
& Cr\$ & Índice & Cr\$ & Índice & Cr\$ & Índice \\
\hline Algodão & 1.552 & 100 & 3.065 & 197 & 3.528 & 227 \\
Juta & 2.304 & 100 & 2.785 & 121 & 3.843 & 167 \\
Malhas & 2.373 & 100 & 2.982 & 126 & 4.567 & 192 \\
Lã & 2.745 & 100 & 3.771 & 137 & 5.138 & 187 \\
Sedas & 2.486 & 100 & 3.464 & 139 & 4.772 & 192 \\
Total & 1.892 & 100 & 3.205 & 169 & 4.111 & 217 \\
\hline
\end{tabular}

Fonte: Estatística Industrial do Estado de São Paulo, 1938-1939, 1943 e 1944.

Além dos aspectos referentes à flexibilização das leis trabalhistas, deve-se observar também a evolução da renda dos operários. Segundo Vicente de Paula Galliez, representante do SIFTRJ, o "paralelismo" entre o custo de vida e os salários dos trabalhadores têxteis foi "perfeito" e "quase rigoroso" no período da guerra ${ }^{673}$. A análise dos dados, porém, não corrobora tal posicionamento. Entre 1939 e 1944, percebe-se que o crescimento dos salários dos operários de tecidos paulistas (117\%) não compensou o aumento do custo de vida na cidade de São Paulo (132,3\%). No caso específico de itens como alimentação $(145,3 \%)$ e vestuário $(200,6 \%)$, a diferença foi ainda maior.

A insuficiência da renda operária diante do aumento do custo de vida também é ratificada pelo alto número de greves que ocorreram nesse período vinculadas à questão

\footnotetext{
${ }^{670}$ Decreto-Lei n. 6.688, 15.06.1944.

${ }^{671}$ CME. Portaria n. 249, 31.07.1944.

${ }^{672}$ CETex. Indústria Têxtil Algodoeira, p. 193 e 198.

${ }^{673}$ SIFTRJ. Exposição do Dr. Vicente de Paula Galliez, op. cit.
} 
salarial. Em 1943, por exemplo, os trabalhadores da S.A. Calfat cruzaram os braços devido à suspensão de um abono salarial no valor de 10\%. Investigadores do DOPS foram enviados à fábrica para tentar mostrar aos operários “(...) que eles deveriam regressar ao trabalho, pois (...) a greve está fora da lei. Essa advertência pouco valeu". O fím do movimento aconteceu após a prisão de vários trabalhadores ${ }^{674}$. Em setembro de 1944, houve paralisação na Cia. Brasileira Rhodiaseta em razão da "insuficiência de ordenados" e da "carestia de vida". A pronta ação dos membros do DOPS, porém, "convenceu" os trabalhadores a voltar ao trabalho ${ }^{675}$. Em maio de 1945, várias fábricas têxteis do Rio e de São Paulo entraram em greve por motivos semelhantes. Após acordos com os interventores estaduais, os operários conseguiram acréscimos de 20 a $40 \%$ em seus salários ${ }^{676}$.

Por último, no que se refere ao relacionamento entre a burguesia têxtil e o Estado, percebe-se que a harmonização foi grande nesse período. As críticas dos industriais às leis trabalhistas restringiram-se bastante. Alguns temas ainda suscitavam discussões no seio do empresariado, tais como o salário mínimo, a Justiça do Trabalho e a lei da sindicalização ${ }^{677}$. Os elogios às ações dos governantes, porém, especialmente a Getúlio Vargas, preponderaram. Apenas a título de ilustração, citar-se-ão fragmentos de um texto produzido por inúmeros grupos burgueses paulistas - dentre eles, o Cotonificio Crespi, as IRFM, a Cia. Brasileira de Juta, a Cia. Fabril de Juta e a própria FIESP - em homenagem ao Presidente da República, no dia de seu aniversário, em 19.04.1942. "Há doze anos que o Dr. Getúlio Vargas representa a Ordem para o Brasil. Ser contra ele, se isso hoje ainda fosse possível, seria colocar-se contra a Ordem. Seria colocar-se contra o Brasil, seria colocar-se contra si mesmo"678. Não há dúvida, portanto, de que as relações entre burguesia e Estado, nesse momento, são bem distintas dos enfrentamentos característicos do início dos anos (19)30. Isso fica claro não apenas em razão da fraseologia citada, mas também devido à própria aceitação das leis trabalhistas implementadas por Getúlio. Estas, agora, eram vistas como um preço pequeno a ser pago diante do bem maior proporcionado pelo governo, a saber: o "desarme" dos operários que pregavam "o evangelho da luta" ${ }^{679}$.

\footnotetext{
${ }^{674}$ DOPS. Relatório do Sub-chefe da Ordem Social, Carlos Marques, ao Delegado Adjunto à Seção de Investigação da Ordem Social, Carlos da Fonseca, 28.01.1943.

${ }^{675}$ DOPS. Questionário, 06.09.1944.

${ }^{676}$ Edgard Carone. O Estado Novo, op. cit., p. 130.

${ }^{677}$ Idem, op. cit., p. 136-137.

${ }^{678}$ O Estado de São Paulo, 19.04.1942.

${ }^{679}$ Idem.
} 
A domesticação do proletariado mediante as repressões policiais e ao sindicalismo pelego foi a grande responsável pela efetivação desse bom relacionamento.

\section{$\underline{4.7-\text { Conclusões parciais }}$}

A indústria têxtil paulista, durante a Segunda Guerra Mundial (1939-1945), apresentou grande crescimento produtivo. $\mathrm{O}$ aprofundamento do processo substitutivo de importações doméstico e as exportações de tecidos para mercados periféricos estrangeiros - em razão do afastamento das potências industriais dos mesmos durante o conflito - foram os motores dessa ascensão.

Tal crescimento não se processou de maneira homogênea. Do ponto de vista temporal, pode-se dividi-lo em dois momentos: (a) 1939-1940, caracterizado por elevações mais modestas da produção e pela manutenção da possibilidade de acréscimo do parque fabril; e (b) 1941-1945, marcado pelo auge produtivo, pelos faustosos lucros e pelas distribuições recordes de dividendos por parte das empresas têxteis, em detrimento das pequenas oportunidades da compra de máquinas e de bens intermediários para o setor. A dinâmica do conflito mundial - arrefecimento do bloqueio marítimo britânico e entrada dos Estados Unidos na guerra - foi o principal fator explicativo para essa divisão. Já, de um ponto de vista mais particular, as fábricas de seda e de lã apresentaram resultados mais significativos do que as demais. Não houve, porém, desempenhos negativos. A produção de todos os ramos cresceu, porém em proporções distintas.

No que se refere ao abastecimento têxtil local, lembra-se que as vendas internacionais de tecidos, aliada à ascensão do mercado doméstico, geraram rápidas elevações dos preços desses produtos. O Convênio Têxtil, além de ter sido ineficaz na resolução do problema (baixa qualidade e entregas irregulares e insuficientes de tecidos), mostrou-se interessante aos industriais na medida em que $90 \%$ da produção destes estaria completamente livre de quaisquer controles de preços. Viu-se, como resultado, a obtenção de lucros recordes por parte das fábricas têxteis paulistas.

Lembra-se também que esse crescimento da produção de tecidos estadual baseouse muito na intensificação do fator mão-de-obra. As dificuldades na aquisição de máquinas e necessidade de se fomentar a produção impossibilitavam qualquer outro tipo de saída. A flexibilização das leis trabalhistas (maiores jornadas, permissão do trabalho noturno de menores e mulheres, restrição dos dissídios coletivos, etc.), mascarada pela justificativa do 
"estado de guerra", foi fundamental para viabilizar essa superexploração dos trabalhadores.

Por último, no que se refere ao movimento operário, apesar da repressão e da censura aos jornais, diversas greves eclodiram no estado de São Paulo devido às jornadas excessivas a aos baixos salários. A simbiose do Estado com a burguesia têxtil paulista, porém, evidenciada nas ações do DOPS, aniquilou a maioria desses movimentos. 


\section{CAPÍTULO 5 - A indústria têxtil paulista no pós-guerra (1946-50)}

O principal objetivo deste capítulo é o de analisar a evolução da indústria têxtil de São Paulo após a Segunda Guerra Mundial, destacando possíveis alterações (a) em seu desempenho econômico; (b) na sua estrutura espacial e referente às participações entre os ramos; e (c) no que condiz às relações de trabalho e às relações Estado e burguesia.

\section{$\underline{5.1 \text { - A economia brasileira no pós-guerra }}$}

Pode-se identificar dois momentos bem distintos da economia doméstica após a Segunda Guerra Mundial: (a) 1946-1947 e (b) 1948-1950. No primeiro deles, apesar da elevada taxa de crescimento do produto entre 1945 e 1946, evidencia-se conjuntura recessiva. O ano de 1947 apresentou as mais baixas ascensões do PIB (2,4\%) e dos produtos industrial $(3,3 \%)$ e agrícola $(0,7 \%)$ do período em estudo (Tabela 5.1). Além disso, no mesmo ano, verificou-se déficit superior a U\$\$ 180 milhões na balança de pagamentos. No segundo período (1948-1950), porém, observa-se acréscimo significativo do produto interno (média de $8 \%$ ao ano). Os desempenhos das produções industrial e agrícola melhoraram, especialmente daquela, cujo crescimento foi superior a $10 \%$ ao ano. Impulsionado pelos saldos comerciais, reduziu-se também o déficit da balança de pagamentos, o qual, em 1950, transformou-se em leve superávit (Tabela 5.1).

A análise da política econômica implementada pelo Governo Dutra (1946-1951) explica, em grande parte, esses diferentes desempenhos da economia doméstica no pósguerra. Em 1946, segundo os princípios liberais expressos na Conferência de Bretton Woods $(1944)^{680}$, aboliram-se todas restrições à movimentação de capitais e às importações de bens estrangeiros no País. Ao mesmo tempo, fixou-se o câmbio à paridade

\footnotetext{
${ }^{680}$ Conferência monetária e financeira realizada para criar a Organização das Nações Unidas em julho de 1944 no balneário de Bretton Woods (New Hampshire, EUA). Visava planejar a estabilização das economias nacionais e de suas respectivas moedas no contexto pós-Segunda Guerra. Liderada pelos Estados Unidos, tal conferência estipulou, dentre outras coisas, a criação de câmbios fixos ajustáveis entre seus países membros; a conversabilidade monetária internacional; e a necessidade de ampliação do comércio multilateral como forma de superação dos problemas econômicos então vigentes em grande parte do mundo. Como resultado desses acordos, criaram-se o Fundo Monetário Internacional (FMI) e o Banco Internacional para Reconstrução e Desenvolvimento (BIRD). Para maiores informações, ver: Barry Eichengreen. A globalização do capital. Uma história do sistema monetário internacional. Editora 34, São Paulo, 2002; especialmente Cap. 4 -O sistema de Bretton Woods, p. 131 - 182.
} 
de 1939 (Cr\$ 18,5 / US\$), taxa nitidamente sobrevalorizada ${ }^{681}$. Esperava-se, com tais medidas, (a) atender à demanda de bens de capital e matérias-primas, restringida no contexto bélico; (b) aumentar a oferta de bens de consumo no mercado local mediante importações, possibilitando, dessa forma, uma queda no nível geral dos preços; e (c) estimular ingressos de capitais estrangeiros. Junto com esse processo de liberalização econômica, realizaram-se também políticas monetárias e fiscais contracionistas. Objetivava-se, com isso, diminuir o déficit orçamentário federal, visto como um dos principais responsáveis pela inflação vigente. A observação das taxas de crescimento dos meios de pagamento locais $(-1,8 \%)$, do papel-moeda em circulação $(0,6 \%)$ e do salário mínimo real $(-18,4 \%)$ no período 1946-1947 demonstra a efetivação da ortodoxia monetarista.

Tabela 5.1 - Dados econômicos variados - Brasil (1945-1950)

\begin{tabular}{ccccccc} 
& 1945 & 1946 & 1947 & 1948 & 1949 & 1950 \\
\hline PIB (crescimento \%) & 3,2 & 11,6 & 2,4 & 9,7 & 7,7 & 6,8 \\
Produto industrial (crescimento \%) & 5,5 & 18,5 & 3,3 & 12,3 & 11 & 12,7 \\
Produto agrícola (crescimento \%) & $-2,2$ & 8,4 & 0,7 & 6,9 & 4,5 & 1,5 \\
Exportações (milhões US\$) & 655 & 985 & 1.157 & 1.183 & 1.100 & 1.359 \\
Importações (milhões US\$) & 323 & 594 & 1.027 & 905 & 947 & 934 \\
Saldo Balança Comercial (milhões US\$) & 333 & 391 & 130 & 278 & 153 & 425 \\
Saldo Balança Pgtos. (milhões U\$\$) & 62 & 96 & -182 & -24 & -74 & 52 \\
Meios de pagamento (crescimento \%) & 19,0 & 10,2 & $-1,8$ & 7,6 & 17,6 & 31,4 \\
Papel-moeda em poder do público (cres. \%) & 22,8 & 17,3 & 0,6 & 4,7 & 9,6 & 29,9 \\
Salário mínimo real (crescimento \%) & $-14,4$ & $-14,6$ & $-18,4$ & $-3,2$ & $-3,3$ & 9,4 \\
\hline Fonte: Marcelo Paiva Abreu (org.). A ordem do progresso, op. cit., p. 388-412.
\end{tabular}

Os resultados dessa liberalização logo se fizeram sentir. Entre 1946 e 1947, as importações de bens alienígenas cresceram vertiginosamente (72,8\% - Tabela 5.1). Mesmo assim, estas ainda não superavam as exportações. Recorda-se, porém, que os superávits da balança comercial apresentados no período foram enganosos, pois o País acumulava saldos com áreas de moedas inconversíveis e déficits com regiões de moeda forte ${ }^{682}$. Além disso, o esperado ingresso de capitais estrangeiros não aconteceu. O descumprimento dos termos do acordo de Bretton Woods por vários dos seus signatários - principalmente por parte de alguns países europeus, que mantiveram políticas de controle da saída de capitais e a inconversabilidade monetária -, aliado à sobrevalização do cruzeiro, gerou fuga maciça

\footnotetext{
${ }^{681}$ Durante a Segunda Guerra Mundial, os preços dos produtos domésticos cresceram duas vezes mais do que os dos Estados Unidos. Sérgio Besserman Vianna. Política econômica externa e industrialização (1946-1951). In: Marcelo de Paiva Abreu. A ordem do progresso, op. cit., p. 108.

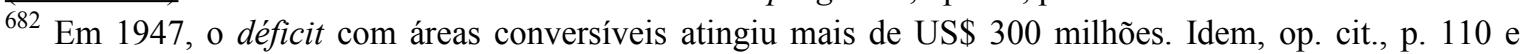
Pedro Malan. Relações econômicas internacionais do Brasil (1945-1964). In: Boris Fausto. História Geral da Civilização Brasileira. Tomo III. Volume 4. Difel, São Paulo, 1984, p. 63-65.
} 
de ativos externos. As reservas internacionais domésticas conversíveis ${ }^{683}$, por esses motivos, diminuíram de US\$ 100 para menos US\$ 33 milhões no período 1946-1947 ${ }^{684}$.

As crescentes importações de bens de consumo estrangeiros, notadamente gêneros alimentícios e manufaturas (Tabela 5.2), trouxeram outras conseqüências danosas para o País, afora os problemas nas contas externas. Os produtos industrial e agrícola domésticos, em razão da concorrência alienígena, apresentaram decréscimos substanciais entre 1946 e 1947 (-82,1\% e $-91,6 \%$, respectivamente). A preferência do consumidor local por bens estrangeiros - seja em razão da sua melhor qualidade, seja devido ao menor preço desbaratou vários produtores internos. Associações comerciais e fabris assinalavam a incongruência do Governo Dutra, o qual, segundo eles, "nadava" contra a corrente. Enquanto diversos países desrespeitavam os termos do acordo de Bretton Woods, desvalorizando suas moedas para incentivar exportações e dificultar importações, o Brasil, argumentavam, dirigia-se no sentido oposto ${ }^{685}$.

Tabela 5.2 - Importações domésticas discriminadas por classe de produtos - Brasil - Cr\$1.000 deflacionados

\begin{tabular}{ccccccc} 
& 1945 & 1946 & 1947 & 1948 & 1949 & 1950 \\
\hline Animais vivos & 19.865 & 13.345 & 9.992 & 7.535 & 8.782 & 30.869 \\
Matérias-primas & 13.345 & 9.992 & 7.535 & 8.782 & 30.869 & 1.034 .915 \\
Gêneros alimentícios & 827.890 & 1.100 .563 & 1.024 .561 & 1.002 .237 & 1.034 .915 & 615.784 \\
Manufaturas & 603.025 & 903.158 & 816.851 & 698.584 & 615.784 & 1.922 .910 \\
Total & 1.705 .896 & 3.041 .440 & 2.546 .610 & 2.291 .332 & 1.922 .910 & 3.604 .478 \\
\hline
\end{tabular}

Fonte: Anuário Estatístico do Brasil, 1945-1951.

Devido aos problemas citados e ao esfriamento da agenda mundial de implementação das políticas liberalizantes acertadas em Bretton Woods ${ }^{686}$, o Governo Dutra alterou as diretrizes da sua política econômica. Em julho de 1947, foram criados mecanismos de controle do câmbio e de importações. A partir de então, as casas bancárias autorizadas a operar em câmbio eram obrigadas a vender ao Banco do Brasil 30\% dos seus cambiais a uma taxa oficial subvalorizada. Estes, por sua vez, seriam administrados pela recém-criada Carteira de Exportação e Importação (Cexim) do Banco do Brasil, a qual os

\footnotetext{
${ }^{683}$ Grande parte das reservas internacionais acumuladas durante a Segunda Guerra Mundial eram formadas por moedas não-conversíveis ao dólar e, portanto, ao ouro. Em 1946, dos US\$ 730 milhões de reservas locais, apenas US\$ 100 milhões eram conversíveis. Sérgio Besserman Vianna, op. cit., p. 109.

${ }^{684}$ Idem, op. cit., p. 109-110.

${ }^{685}$ Edgard Carone. A República Liberal. Instituições e Classes Sociais (1945-1964). Volume 1. Ed. Difel, São Paulo, 1985, p. 97.

${ }^{686}$ Após a crise da conversabilidade da libra esterlina em 1947, os próprios Estados Unidos, principais defensores do cumprimento imediato da agenda de liberalização de Bretton Woods, passam a concordar com as propostas européias de alongamento da transição. A partir desse momento, os Estados Unidos aceitaram pequenas discriminações contra suas exportações e propuseram um programa de ajuda financeira ao continente europeu (Plano Marshall, US\$ 13 bilhões). Ver: Barry Eichengreen, op. cit., p. 144.
} 
venderia ao mercado conforme uma escala de prioridades. Privilegiavam-se os compromissos do Governo e a aquisição de bens considerados essenciais para a economia doméstica, tais como máquinas e matérias-primas ${ }^{687}$.

Os efeitos dessa mudança foram visíveis. O déficit comercial com a área conversível reduziu-se rapidamente. De US\$ 313 milhões (1947) passou para US\$ 108 milhões (1948). Em 1949, houve pequeno superávit (US\$ 18 milhões) ${ }^{688}$. Além disso, o sistema de licenciamento de importações também estimulou a ascensão do produto industrial, que apresentou taxas de crescimento notáveis no período 1948-1950 (Tabela 5.1). Este estímulo deveu-se a três fatores: (a) preços relativos artificialmente mais baratos para matérias-primas e bens de capital; (b) protecionismo, mediante restrição à importação de produtos similares; e (c) alteração da estrutura das rentabilidades relativas locais, tornando a produção para mercado doméstico, em razão do câmbio sobrevalorizado, mais lucrativa do que a produção para o mercado exterior.

Por último, as próprias políticas fiscal e monetária ortodoxas, características dos dois primeiros anos do Governo Dutra, cederam lugar, a partir de 1949, a ações heterodoxas. Determinante nesse sentido foi a substituição do Ministro da Fazenda Correa e Castro, em junho de 1949, por Guilherme da Silveira, vinculado ao setor fabril doméstico. Incentivou-se, desde então, forte política de créditos às indústrias. Os empréstimos do Banco do Brasil, por exemplo, cresceram 6\% ao ano em termos reais entre 1949 e $1950^{689}$. As ascensões dos meios de pagamentos $(31,4 \%)$ e do papel-moeda em circulação $(29,9 \%)$, nesse mesmo período, são outros indícios representativos dessa mudança (Tabela 5.1). Até o salário mínimo apresentou alta $(9,4 \%)$, após anos consecutivos de queda real. Assim, vê-se que o crescimento das taxas do produto interno no final dos anos (19)40 também está relacionado com essa alteração da política econômica governamental.

\section{$\underline{5.2-\text { A indústria têxtil paulista no pós-guerra }}$}

A indústria paulista apresentou crescimento no qüinqüênio posterior à Segunda Guerra Mundial. Entre 1944 e 1950, o capital das fábricas estaduais ascendeu em 56,9\%; o número de operários, em 22\%; e o valor da produção, em 9,02\% (Tabela 5.3). A

\footnotetext{
${ }^{687}$ Edgard Carone. A República Liberal, op. cit., p. 99-100.

${ }^{688}$ Vale lembrar que a alta dos preços do café estimulou esse superávit. Sérgio Besserman Vianna, op. cit., p. 111-112.

${ }^{689}$ Idem, op. cit., p. 121.
} 
quantidade de estabelecimentos fabris, porém, decresceu em $21,1 \%$, o que indica aumento na concentração industrial.

Tabela 5.3 - Dados das indústrias gerais e têxteis do Estado de São Paulo (1939, 1944 e 1950)

\begin{tabular}{c|cc|cc|cc} 
& \multicolumn{2}{|c|}{1939} & \multicolumn{2}{c|}{1944} & \multicolumn{2}{c}{1950} \\
\hline & Geral & Têxtil & Geral & Têxtil & Geral & Têxtil \\
\hline Fábricas & 26.619 & 831 & 31.722 & 1.154 & 25.016 & 1.543 \\
Capital & 1.440 .965 & 401.416 & 2.597 .844 & 649.210 & 4.077 .218 & 889.259 \\
Operários & 254.144 & 95.516 & 400.553 & 125.624 & 488.633 & 142.047 \\
Valor de produção & 3.893 .011 & 815.579 & 8.980 .919 & 1.598 .098 & 9.811 .092 & 2.084 .070 \\
\hline
\end{tabular}

Fonte: Estatísticas Industriais do Estado de São Paulo, 1938-1939 e 1944; Recenseamento Geral do Brasil de 1950.

Dois comentários, no entanto, devem ser feitos sobre essas taxas de crescimento. Em primeiro lugar, nota-se que o ritmo de ascensão fabril verificado no estado de São Paulo durante o contexto bélico foi maior do que no período pós-guerra. Ao se comparar os momentos 1939-1944 e 1944-1950, percebe-se que o primeiro apresentou maiores elevações em todas as variáveis arroladas (Tabela 5.3).

Além desse aspecto, deve-se notar também que, em razão da inexistência de dados contínuos sobre a indústria paulista entre 1946 e 1950, não é possível fazer inferências sobre sua evolução econômica de maneira mais detalhada. Sabe-se que houve crescimento, mas não se conhecem as prováveis flutuações ocorridas nesse período ${ }^{690}$. Considerando-se, todavia, os dados relativos ao produto industrial doméstico (Tabela 5.1) - e tendo em vista a importância das fábricas de São Paulo no setor fabril local -, é bem possível que as mesmas tendências encontradas nas indústrias do País também tenham-se verificado nas indústrias de São Paulo.

No que condiz às fábricas têxteis paulistas, observa-se que o subsetor também apresentou crescimento entre 1944 e 1950 nas suas principais variáveis econômicas: número de estabelecimentos (33,7\%); operários (13,1\%); capital $(37 \%)$; e valor da produção $(30,4 \%)$. O desempenho das indústrias agregadas do estado no período foi, no geral, superior às de tecidos. Mantém-se, dessa maneira, a tendência de perda progressiva do espaço dos setores produtores de bens de consumo não-duráveis diante dos demais na estrutura fabril paulista. Além disso, verifica-se que, no subsetor têxtil, não houve concentração industrial significativa, pois as porcentagens de acréscimo do número de estabelecimentos e do capital aplicado praticamente se equivaleram. Tomando-se como base do índice de concentração, no entanto, o crescimento da quantidade de operários têxteis empregada, vê-se que, sob esse viés, houve desconcentração. 
A comparação entre os momentos 1939-1944 e 1944-1950, por sua vez, demonstrou que as indústrias têxteis de São Paulo também apresentaram melhor desempenho no primeiro período. Verifica-se, tal como se observou no setor fabril agregado, que todas as variáveis em estudo cresceram a taxas maiores durante a Segunda Guerra. Após o término do conflito, as ascensões foram menos significativas.

No que se refere aos ramos têxteis paulistas, percebe-se que o algodoeiro, pela primeira vez desde os anos (19)20, apresentou as maiores taxas de crescimento do subsetor. As fábricas de tecidos de algodão superaram suas congêneres em todas as variáveis arroladas (Tabela 5.4). O ramo das sedas situou-se em segundo lugar. Em termos de estabelecimentos, do número de operários e do capital aplicado, observaram-se ascensões significativas, inferiores apenas às empresas de algodão. Em terceiro lugar, encontraram-se as malharias, que apresentaram elevações, mesmo que modestas, em todas as variáveis estudadas. O ramo lanífero, por sua vez, teve o pior desempenho. Apesar dos acréscimos no que condiz à quantidade dos seus estabelecimentos $(19,6 \%)$ e ao capital nele aplicado $(42,8 \%)$, as fábricas de lã sofreram quedas em seu número de operários $(-9 \%)$ e, principalmente, em seu valor de produção $(-34,8 \%)^{691}$.

Tabela 5.4 - Dados dos ramos têxteis paulistas (1944 e 1950)

\begin{tabular}{c|cc|cc|cc|cc} 
& \multicolumn{2}{|c|}{ Estabelementos } & \multicolumn{2}{c|}{ Capital $(\mathrm{Cr} \$ 1.000-\mathrm{D})$} & \multicolumn{2}{c}{ Operários } & \multicolumn{2}{c}{ Valor da produção (Cr\$ 1000 - D) } \\
& 1944 & 1950 & 1944 & 1950 & 1944 & 1950 & 1944 & 1950 \\
\hline Algodão & 189 & 306 & 233.419 & 448.348 & 54.686 & 72.832 & 614.916 & 766.682 \\
Malha & 168 & 223 & 30.279 & 34.024 & 7.511 & 8.388 & 106.950 & 107.422 \\
Lã & 61 & 73 & 53.438 & 76.360 & 12.249 & 11.136 & 269.776 & 175.788 \\
Sedas & 354 & 478 & 153.257 & 260.647 & 26.680 & 32.090 & 512.364 & 501.899 \\
\hline
\end{tabular}

Fonte: Estatística Industrial do Estado de São Paulo, 1944 e Recenseamento Geral de 1950.

Por último, mediante utilização dos dados extraídos dos balanços das sociedades anônimas têxteis, analisar-se-á a evolução dos ramos de tecidos paulistas em cada um dos anos do momento 1945-1948.

Inicia-se pelo algodoeiro. Vê-se que as fábricas de algodão dos Grupos VII e IX apresentaram crescimento em todo o período no que condiz ao capital (Tabela 5.5). O valor das suas máquinas, também sempre ascendente, é uma comprovação desse fato. No que condiz aos lucros e aos dividendos, porém, a situação se altera. Nota-se que a lucratividade das empresas do ramo não possuiu elevação contínua. Pelo contrário, sofreu ${ }^{691}$ Infelizmente, não se pôde fazer quaisquer inferências sobre o ramo da juta na Tabela 5.4. A forma de
apresentação dos dados no Recenseamento Geral de 1950 difere bastante da Estatística Industrial do Estado
de São Paulo no que condiz ao ramo jutífero. Assim, informações sobre o desempenho das fábricas de juta
no pós-guerra ficaram limitadas aos balanços e relatórios das empresas e aos informativos diversos das
associações patronais. 
queda superior a 20\% entre 1945 e 1947. O ano de 1948 representou uma virada. Os lucros brutos e líquidos aumentaram nesse momento, respectivamente, 19,9\% e 7,8\%. Os dividendos, por sua vez, apresentaram perfil descendente em todo interregno. Se eles representaram 35,9\% do capital nominal das empresas de algodão em 1945, três anos depois, todavia, perfaziam apenas $9,9 \%$ do mesmo. Esses dados demonstram o quanto o crescimento do ramo algodoeiro não possuiu estabilidade no pós-guerra. A diminuição da distribuição de dividendos assinala, para além de uma redução no seu ritmo de ascensão, a preocupação burguesa em renovar seu obsoleto e desgastado parque fabril.

Os relatórios de diretoria e atas de assembléias das fábricas de algodão paulistas ratificam as inferências proporcionadas pelos dados. No tocante à expansão do capital nominal e à aquisição de novas máquinas, várias foram as empresas que anunciaram programas de renovação de seu capital constante no pós-guerra. O S.A. Moinho Santista, por exemplo, ampliou sua fiação de lã em $1946^{692}$. No mesmo ano, a Argos Industrial S.A. construiu um novo prédio para abrigar máquinas encomendadas do exterior ${ }^{693}$. A S.A. Fábrica de Tecidos e Bordados Lapa, também em 1946, aumentou seu capital de Cr\$ 10 para 30 milhões, visando implementar seu plano de "renovação e ampliação dos maquinismos" $"$. A São Paulo Alpargatas Company S.A. gastou, em 1945, mais de Cr\$ 1 milhão para a construção de um novo prédio e Cr\$ 2 milhões para a aquisição de máquinas têxteis $^{695}$. A Fiação Extra-Fina de Algodão adquiriu, no ano de 1948, 50 teares automáticos, objetivando "modernizar" sua produção ${ }^{696}$. A S.A. Votorantim, por último, montou uma nova fábrica de fiação de algodão em Boituva, “(...) aumentando nossas atividades naquele local, onde já possuímos uma tecelagem" ${ }^{967}$.

No que se refere à queda da sua lucratividade no período 1946-1947, tem-se, mais uma vez, apoio documental nos relatórios e atas das empresas. Muitas delas caracterizaram 1947 como um ano de crise. A diretoria da Brasital S.A., por exemplo, assinalou que "em 1947, os negócios passaram por período de depressão (...) que chegou a alarmar largos setores das classes produtoras (...)" ${ }^{" 698}$. Os diretores da Sociedade Anônima

\footnotetext{
${ }^{692}$ Relatório de Diretoria, S.A. Moinho Santista, 18.01.1947.

${ }^{693}$ Relatório de Diretoria. Argos Industrial S.A., 31.12.1946.

${ }^{694}$ Ata Assembléia Geral Extraordinária e Relatório de Diretoria. S.A. Fábrica de Tecidos e Bordados Lapa, 04.12.1946 e 28.02.1946.

${ }^{695}$ Relatório de Diretoria. São Paulo Alpargatas Company S.A., 15.02.1946.

${ }^{696}$ Relatório de Diretoria. Fiação Extra-Fina de Algodão, 02.02.1949.

${ }^{697}$ Relatório de Diretoria. S.A. Fábrica Votorantim, 30.01.1951. Os exemplos de fábricas de algodão que ampliaram seu capital nominal e adquiram novas máquinas são inúmeros nesse período. Para maiores informações, ver: Ata Assembléia Extraordinária. Fiação Sul-Americana, 07.03.1946; Ata Assembléia Extraordinária. S.A. Boyes, 12.04.1946; Relatório de Diretoria. S.A. Cotonifício Adelina, 31.12.1946; Ata Assembléia Extraordinária. Fiação e Tecelagem São Paulo, 15.07.1946; etc.

${ }^{698}$ Relatório de Diretoria. Brasital S.A., 30.12.1947.
} 
Têxtil Algodoeira (SATA), por sua vez, ressaltaram que “(...) a crise em decorrer no ano findo (1947) assoberbou a indústria têxtil (...) A queda vertical de cerca de 50\% nos preços dos tecidos, a paralisação das vendas durante seis meses trouxeram conseqüências que hoje influem sobre o andamento da indústria" ${ }^{999}$. Segundo os proprietários da S.A. Fábrica de Tecidos e Bordados Lapa, "o exercício de 1947 foi para a indústria nacional, principalmente (para) as de tecidos, um ano de surpresa e apreensões. Mesmo contando com grande número de representantes instalados em todos os estados e inúmeras cidades do interior, sentimos sensivelmente a diminuição das vendas (...)"700. Inúmeros são os exemplos de empresas que assinalaram a recessão por elas sofrida entre 1946 e $1947^{701}$.

Tabela 5.5 - Dados do ramo algodoeiro paulista referente aos grupos VIII e IX (1945-1948)

\begin{tabular}{lrrrr} 
& 1945 & 1946 & 1947 & 1948 \\
\hline Capital - Grupo VIII (D) & 145.941 & 273.097 & 289.588 & 288.326 \\
Capital - Grupo IX (D) & 67.830 & 117.539 & 172.679 & 169.022 \\
Máquinas - Grupo VIII (D) & 111.003 & 134.670 & 194.391 & 208.260 \\
Lucros brutos - Grupo VIII (D) & 176.721 & 152.028 & 140.350 & 168.385 \\
Dividendos - Grupo VIII (D) & 24.413 & 22.719 & 21.680 & 16.805 \\
Lucros Líquidos - Grupo IX (D) & 40.967 & 32.749 & 33.049 & 35.658 \\
\hline
\end{tabular}

Fonte: Diário Oficial do Estado de São Paulo, 1945-1949 / Representatividade do Grupo VIII em termos de capital constante no ano de $1945=78,15 \%$ / Representatividade do Grupo IX em termos de capital constante no ano de $1945=36,3 \%$.

Por último, a recuperação vivida pelo ramo a partir de 1948, tal como os dados sobre os lucros demonstraram, também encontra embasamento nos documentos empresariais. A Argos Industrial S.A., por exemplo, que em 1947 reclamara sobre o "retraimento da produção", afirmou, no ano seguinte, que "o trabalho decorreu normalmente"702. A São Paulo Alpargatas, a qual também passara por maus momentos entre 1946 e 1947, destacou "o extraordinário desenvolvimento dos nossos negócios" no ano de $1950^{703}$. A Fiação e Tecelagem Pirassununga, em 1949, adquiriu "uma nova e moderníssima fiação" devido ao aumento de suas vendas ${ }^{704}$. Outras empresas assinalaram melhorias econômicas semelhantes pós- $1947^{705}$.

\footnotetext{
${ }^{699}$ Relatório de Diretoria. SATA, 20.02.1948.

${ }^{700}$ Relatório de Diretoria. S.A. Fábrica de Tecidos e Bordados Lapa, 31.03.1948.

${ }^{701}$ Para maiores informações, ver: Relatório de Diretoria. Fiação e Tecelagem São Paulo S.A., 20.01.1947; Relatório de Diretoria. Argos Industrial S.A., 31.12.1948; Relatório de Diretoria. Companhia Nacional de Estamparia, 28.04.1947; Relatório de Diretoria. S.A. Moinho Santista, 08.03.1947; etc.

${ }^{702}$ Relatório de Diretoria. Argos Industrial S.A., 31.12.1949.

${ }^{703}$ Relatório de Diretoria. São Paulo Alpargatas Company S.A., 14.03.1951.

${ }^{704}$ Relatório de Diretoria. Fiação e Tecelagem Pirassunuga S.A., 28.02.1950.

${ }^{705}$ Ver, por exemplo, os casos da Companhia Nacional de Estamparia, das Indústrias Reunidas Francisco Matarazzo, do Moinho Santista, da Cia. Fiação e Tecidos N. S. do Carmo, etc.
} 
Já no que se refere ao ramo jutífero paulista, percebe-se que, entre 1945 e 1946, as fábricas dos Grupos X e XI apresentaram fortes elevações em termos de capital e máquinas (Tabela 5.6). A partir desse momento, entretanto, notam-se ascensões pouco significativas ou até decréscimos em ambas variáveis. No que condiz aos lucros, observase tendência distinta que do ramo algodoeiro. Os lucros líquidos das empresas de juta apresentaram queda em 1946 (-27,1\%), crescimento em 1947 (39,4\%) e novo declínio em $1948(-13,1 \%)$; ou seja, verifica-se tendência instável. Os relatórios de diretoria das empresas jutíferas, infelizmente, são por demais sucintos ${ }^{706}$. Impede-se, assim, sua utilização como forma de embasar os dados antes apresentados.

Tabela 5.6 - Dados do ramo de juta paulista referente aos Grupos X e XI* (1945-1948), em Cr\$ 1.000 deflacionados

\begin{tabular}{ccccc} 
& 1945 & 1946 & 1947 & 1948 \\
\hline Capital - Grupo X & 19.618 & 34.648 & 36.867 & 36.907 \\
Capital - Grupo XI & 15.461 & 31.021 & 30.212 & 30.624 \\
Máquinas - Grupo X & 17.772 & 23.656 & 24.461 & 23.178 \\
Lucros Brutos - Grupo X & 9.149 & 11.234 & 15.866 & 13.778 \\
Lucros Líquidos - Grupo XI & 4.077 & 2.968 & 4.138 & 3.191 \\
\hline
\end{tabular}

Fonte: Diário Oficial do Estado de São Paulo, 1945 - 1949 / Representatividade do Grupo X em termos de capital constante no ano de $1945=54,04 \%$ / Representatividade do Grupo XI em termos de capital constante no ano de $1945=42,5 \%$ / * A relação das empresas que compõem os Grupos X e XI está nos Anexos.

As fábricas de lã paulistas do Grupo XII, por sua vez, apresentaram fortes elevações no que se refere ao capital, às máquinas e aos lucros brutos no período 1945-1946 (Tabela 5.7). Após isso, todavia, nota-se perfil recessivo nas variáveis estudadas: estagnação (capital), crescimentos pouco significativos (máquinas) e queda considerável (lucros brutos, -36\% entre 1946 e 1947). A distribuição de dividendos, diferentemente, atingiu seu pico no mesmo ano em que a sua lucratividade demonstrou sensível declínio (1947).

Tabela 5.7 - Dados do ramo lanífero paulista referente ao Grupo XII* (1945-1948), em Cr\$ 1.000 deflacionados

\begin{tabular}{ccccc} 
& 1945 & 1946 & 1947 & 1948 \\
\hline Capital & 43.946 & 61.534 & 58.561 & 59.069 \\
Máquinas & 11.350 & 19.219 & 22.828 & 23.519 \\
Lucros Brutos & 57.406 & 64.170 & 40.807 & 45.709 \\
Dividendos & 4.417 & 3.658 & 6.025 & 5.570 \\
\hline
\end{tabular}

Fonte: Diário Oficial do Estado de São Paulo, 1945 - 1949 / Representatividade do Grupo XII em termos de capital constante no ano de $1945=57,75 \%$ / A relação das empresas que compõem o Grupo XII está nos Anexos.

\footnotetext{
${ }^{706}$ Ver, por exemplo, os relatórios da Cia. Fabril de Juta, Cia. Anglo-Brasileira de Juta, Cia. Brasileira de Juta, Fiação e Tecelagem de Juta, Jutifício Maria Luiza S.A., dentre outros.
} 
Os relatórios de diretoria e atas das empresas laníferas ratificam os dados extraídos dos balanços. Sobre a ascensão verificada no ramo entre 1945 e 1946, por exemplo, podem-se citar alguns casos. O S.A. Lanificio Minerva assinalou, em 1946, que "os negócios da sociedade têm seu curso cada vez mais progressivo, especialmente agora que estamos (...) em novas instalações"707. Também em 1946, devido ao "apreciável desenvolvimento conseguido no ano passado", concluíram-se as obras de instalação da tinturaria e estamparia do Lanifício Paramount ${ }^{708}$. Os diretores do S.A. Lanifício Lapa destacaram, no mesmo ano, que "os negócios (...) têm se desenvolvido satisfatoriamente, e o seu curso cada vez mais progressivo, especialmente agora que estamos com uma produção superior e que tende paulatinamente a aumentar (...)"709. O Lanifício Masber S.A., segundo seus proprietários, apresentou "resultados satisfatórios" no ano de $1946^{710}$.

A partir de 1947, no entanto, a tônica dos relatórios das empresas de lã é modificada. Os diretores do Lanificio Anglo-Brasileiro destacaram, nesse ano, os "fatores adversos" que se abateram sob o ramo ${ }^{711}$. A Fiação Brasileira de Lã advertiu seus acionistas acerca da "forte crise reinante" no mercado ${ }^{712}$. O Lanificio Masber, por sua vez, destacou as "inúmeras dificuldades" vividas pelas empresas de lã no momento em estudo $^{713}$. Comentários semelhantes podem ser encontrados em outros relatórios dos demais lanifícios paulistas ${ }^{714}$. A constatação da crise de 1947 foi praticamente geral ${ }^{115}$.

Por fim, no que condiz ao ramo das sedas paulista, percebe-se, nas fábricas pertencentes ao Grupo XIII, tendência semelhante a do subsetor têxtil agregado, a saber: contínuo crescimento do montante de capital e do valor das máquinas entre 1945 e 1948 (apesar da leve queda apresentada pela primeira variável no período 1947-1948); e tendência recessiva em 1947 - visível em termos da queda da lucratividade e da distribuição de dividendos no ramo -, acompanhada de recuperação a partir do ano seguinte (Tabela 5.8).

\footnotetext{
${ }^{707}$ Relatório de Diretoria. S.A. Lanifício Minerva S.A., 15.04.1946.

${ }^{708}$ Relatório de Diretoria. Indústria de Tecidos Paramount S.A., 22.02.1947.

${ }^{709}$ Relatório de Diretoria. S.A. Lanifício Lapa, 08.04.1947.

${ }^{710}$ Relatório de Diretoria. Lanifício Masber S.A., 21.12.1946.

${ }^{711}$ Relatório de Diretoria. S.A. Lanificio Anglo-Brasileiro, 12.02.1948.

${ }^{712}$ Ata Assembléia Geral Extraordinária. Fiação Brasileira de Lã, 28.101.1947.

${ }^{713}$ Relatório de Diretortia. S.A. Lanificio Masber, 15.01.1948.

${ }^{714}$ Ver, nesse sentido, relatórios referentes ao ano de 1947 das seguintes empresas: Lanifício F. Kowarick, Lanifício Fileppo S.A., Lanificio Inglês, Lanifício Sta. Branca, Lanifício Ítalo-Adami S.A., dentre outros.

${ }^{715}$ Uma exceção refere-se ao Lanificio Record S.A. que, nesse período, aumentou seu capital nominal visando à compra de novos maquinismos. A diretoria do lanifício não destaca, em seus relatórios e atas, quaisquer aspectos da crise. Para maiores informações, ver: Ata Assembléia Geral Extraordinária. Lanifício Record S.A., 14.12.1948.
} 
Tabela 5.8 - Dados do ramo das sedas paulista referente ao Grupo XIII* (1945-1948), em Cr\$ 1.000 deflacionados

\begin{tabular}{ccccc} 
& 1945 & 1946 & 1947 & 1948 \\
\hline Capital & 46.617 & 69.382 & 75.498 & 74.434 \\
Máquinas & 23.981 & 36.774 & 49.039 & 53.762 \\
Lucros Brutos & 64.389 & 70.785 & 54.283 & 65.794 \\
Dividendos & 9.154 & 9.184 & 5.056 & 7.976 \\
\hline
\end{tabular}

Fonte: Diário Oficial do Estado de São Paulo, 1945 - 1949 / Representatividade do Grupo XIII em termos de capital constante no ano de $1945=38,02 \%$ / A relação das empresas que compõem o Grupo XIII está nos Anexos.

Um aspecto importante, e que não pode ser inferido dos dados apresentados acima, refere-se à perda de dinamismo das fábricas produtoras de seda natural em detrimento daquelas especializadas na produção de seda artificial após 1945. No capítulo anterior, viu-se o quanto a Segunda Guerra Mundial acarretou dificuldades às indústrias têxteis no tocante à compra de matérias-primas e máquinas. $\mathrm{O}$ ramo de rayon, nesse sentido, mais dependente de insumos estrangeiros, passou por dificuldades produtivas, abrindo maiores espaços para as empresas têxteis de seda natural. Com o fim do conflito, a situação se inverteu. A normalização das relações comerciais externas permitiu o crescimento produtivo das fábricas de rayon, que passaram a concorrer e a desbancar os fabricantes de seda natural do mercado interno. Os tecidos artificiais possuíam preços menores e qualidades semelhantes aos naturais.

Inúmeros documentos ratificam esse aspecto. Pode-se, no que se refere às empresas de seda natural, citar o caso da Cia. Industrial de Sericultura (CIS). Esta, fundada em 1945, com o objetivo de organizar a produção de amoreiras, bichos-de-seda e instalar um "parque industrial” em Sorocaba, "compreendendo fiação, torção, tecelagem e estamparia de seda" ${ }^{" 716}$, faliu no ano seguinte sem reunir capital suficiente para iniciar seus projetos ${ }^{717}$. Outro exemplo se refere à S.A. Indústrias de Seda Nacional, cujos lucros caíram sensivelmente no período pós-guerra. Os ganhos brutos auferidos pela empresa em 1950 situaram-se em patamares 40\% inferiores aos de $1945^{718}$. Pode-se também verificar a perda de dinamismo desse ramo após a Segunda Guerra, mediante observação da queda produtiva dos casulos do bicho-da-seda em São Paulo. Vê-se que, entre 1945 e 1950, a produção decresceu de quase 5.000 para pouco mais de 750 toneladas $(-84,4 \%$ - Gráfico 5.1). A crise vivida era tão séria que o sindicato patronal têxtil do estado de São Paulo afirmou, em 1948, devido à negligência do Governo Federal para com o mesmo, que era “(...) lamentável vermos o perecimento de uma atividade (indústria de seda natural) que,

\footnotetext{
${ }^{716}$ Escritura de Constituição. Cia Industrial de Sericultura (CIS), 17.02.1945.

${ }^{717}$ Balanço. Cia. Industrial de Sericultura (CIS), 26.02.1946.

${ }^{718}$ Balanços. S.A. Indústrias de Seda Nacional, 31.02.1946 e 20.04.1951.
} 
se devida e carinhosamente planejada, poderia exaurir da terra o maior filão de riquezas, libertando o homem do campo e da fábrica dos métodos primitivos e rotineiros" ${ }^{\text {"719. }}$.

Gráfico 5.1 - Casulos de bicho-de-seda produzidos no Estado de São Paulo (1945-1950), em toneladas

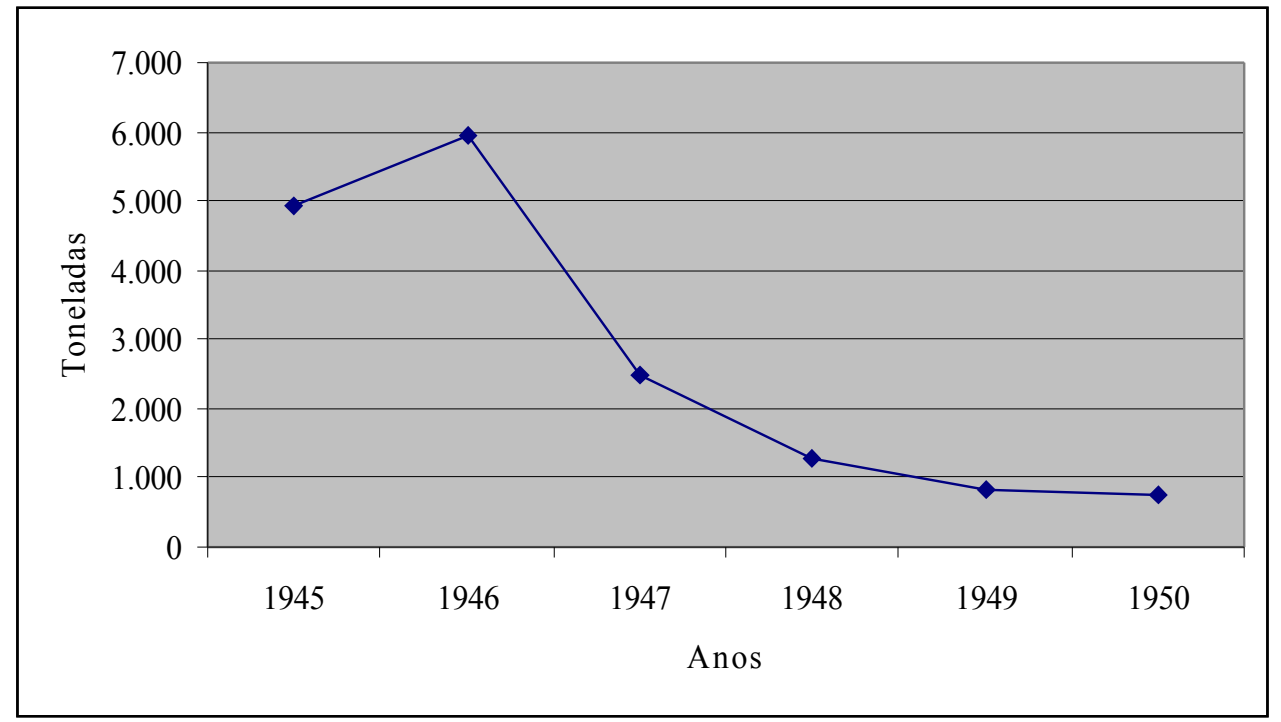

Fonte: Anuário Estatístico do Brasil, 1950 e 1951.

Por outro lado, as fábricas de seda artificial passavam por notável prosperidade. A Beneficiadora Nacional de Tecidos S.A., especializada em rayon, aumentou seu capital social de Cr\$ 5 para 10 milhões em 1946, visando completar as obras do novo prédio que estava sendo construído em Santo Amaro ${ }^{720}$. Os diretores da Rhodiaseta afirmaram, em plena crise fabril de 1947, que a elevação do capital da empresa de Cr\$ 18 para 36 milhões, mediante utilização das reservas, fazia-se necessário devido “(...) à crescente procura dos nossos produtos durante os últimos anos (...)”. As ampliações recémrealizadas “(...) não bastaram para permitir atender, nem de longe, a todos os insistentes pedidos da nossa freguesia (...) (grifo nosso)" ${ }^{\text {"721 }}$. A Tecelagem Calux S.A. apontou, também referente ao ano de 1947, que o curso dos negócios “(...) se desenvolveu normalmente e, apesar da crise que afetou seriamente a indústria têxtil, os nossos esforços foram coroados de pleno êxito (...) (grifo nosso)" "722. A Cia. Nitro-Química Brasileira abriu nova fábrica de rayon em 1948, a qual, segundo seus diretores, "é a expressão do que melhor existe na técnica moderna"723. Por último, as Indústrias Reunidas

\footnotetext{
${ }^{719}$ SIFTESP. Relatório das atividades sociais do exercício de 1948, p. 34.

${ }^{720}$ Ata Assembléia Geral Extraordinária. Beneficiadora Nacional de Tecidos S.A., 23.05.1946.

${ }^{721}$ Ata Assembléia Geral Extraordinária. Cia. Brasileira de Sedas Rhodiaseta, 01.12.1947.

${ }^{722}$ Relatório de Diretoria. Tecelagem Calux S.A., 25.02.1948.

${ }^{723}$ Relatório de Diretoria. Cia. Nitro-Química Brasileira, 06.04.1949.
} 
Francisco Matarazzo assinaram um contrato com firmas inglesas, em 1949, “(...) para aplicação exclusiva no Brasil do processo Nelson para fiação contínua de rayon (...) Dessa maneira, as IRFM serão a primeira firma, em toda América do Sul e uma das primeiras do mundo, a introduzir em seus processos de fabricação um sistema contínuo (...)”, em razão das crescentes demandas do produto ${ }^{724}$.

Vê-se, portanto, que o crescimento das empresas de seda no período do pós-guerra deveu-se, sobretudo, aos progressos das fábricas produtoras de seda artificial. Estas se tornavam, assim, cada vez mais dominantes no interior desse ramo. Por outro lado, caso as indústrias de seda natural tivessem mantido seu ritmo de ascensão semelhante ao do contexto bélico, provavelmente as fábricas de algodão não teriam apresentado as maiores taxas de crescimento do subsetor têxtil paulista no período 1946-1950.

\section{$\underline{5.3 \text { - Análise da dinâmica do subsetor têxtil e dos seus ramos }}$}

Apesar das diferenças entre ramos, pode-se dividir a evolução do subsetor têxtil paulista no qüinqüênio posterior à Segunda Guerra Mundial em dois momentos: (a) 1946-1947, caracterizado, sobretudo, por tendência recessiva; e (b) 1948-1950, marcado pela recuperação econômica e por importações consideráveis de bens de capital. Neste tópico, objetiva-se analisar os fatores determinantes dessas diferenças. Visa-se, também, compreender os distintos desempenhos dos ramos têxteis no período em estudo.

\section{$\underline{\text { 5.3.1 - O período 1946-1947 }}$}

Sobre o primeiro dos momentos citados (1946-1947), não há dúvida de que a recessão das fábricas têxteis paulistas vinculou-se, essencialmente, a dois fatores: (a) ao término da Segunda Guerra; e (b) à política liberalizante do início do Governo Dutra.

\section{(A) Os efeitos do fim da Segunda Guerra Mundial no subsetor têxtil}

O fim do conflito mundial, em setembro de 1945, permitiu a normalização das relações de comércio internacional. As enormes dificuldades na obtenção de máquinas e matérias-primas, que tantos obstáculos trouxeram à produção manufatureira doméstica durante a guerra, acabaram. Por outro lado, a oferta de bens fabris estrangeiros, diminuta

\footnotetext{
${ }^{724}$ Relatório de Diretoria. Indústrias Reunidas Francisco Matarazzo, 15.03.1950.
} 
no contexto bélico - permitindo, assim, reserva de mercado para os produtores locais -, poderia voltar aos antigos patamares.

Para além desses aspectos, lembra-se que os países centrais, antes ocupados em canalizar sua estrutura produtiva para o esforço de guerra, agora poderiam reocupar seus antigos espaços no mercado internacional. Inviabilizava-se, assim, a manutenção de um dos principais motores do crescimento têxtil no início dos anos (19)40: as exportações para países periféricos. Observa-se que, entre 1945 e 1950, a venda de tecidos paulistas para o estrangeiro, em quilos, decresceu quase 90\% (Tabela 5.9). Alguns tipos de têxteis, tais como seda natural e artificial, deixaram totalmente de ser exportados no final da década de 1940.

Tabela 5.9 - Exportações têxteis - Porto de Santos e São Paulo via aérea (1945-1946 e 1948-
\begin{tabular}{ccccccc} 
& 1945 & $1946^{* *}$ & 1948 & 1949 & 1950 \\
\hline Algodão (1) & 6.430 .338 & 5.315 .972 & 1.044 .212 & 966.158 & 295.286 \\
Algodão (2) & 94.554 & 59.988 & 10.088 & 3.216 & 670 \\
Juta (1) & 242 & 8.845 & 0 & 0 & 358.639 \\
Juta (2) & 3 & 39 & 0 & 0 & 85 \\
Lã (1) & 299.480 & 260.409 & 48.994 & 69.217 & 54.064 \\
Lã (2) & 11.204 & 7.498 & 504 & 205 & 56.456 \\
Seda natural (1) & 54.425 & 39.517 & 126 & 0 & 0 \\
Seda natural (2) & 16.297 & 11.499 & 13 & 0 & 0 \\
Seda artificial (1) & 144.808 & 78.485 & 8.932 & 1.169 & 0 \\
Seda artificial (2) & 7.531 & 4.429 & 277 & 44 & 0 \\
\hline Total (1) & 6.929 .293 & 5.703 .228 & 1.102 .264 & 1.036 .544 & 707.989 \\
Total (2) & 129.589 & 83.453 & 10.882 & 3.465 & 57.212 \\
\hline
\end{tabular}

Fonte: Anuário Estatístico do Brasil, 1945-1951 / * (1) quilos; (2) Cr\$ 1.000 deflacionados / Referem-se apenas aos meses de janeiro, fevereiro e dezembro de 1946.

As associações patronais de tecidos do Centro-Sul logo identificaram na redução das vendas externas um dos principais fatores para a recessão vivida pelo subsetor no pósguerra. Os motivos dessa queda exportadora, porém, segundo eles, não estavam na incapacidade das fábricas têxteis domésticas em produzirem bens com qualidade e preços competitivos internacionalmente. Pelo contrário, afirmavam que as indústrias locais “(...) conseguiram atingir um nível de produção em qualidade e preço capaz de impor o produto nacional nos mercados internos e fora do país"725.

O grande culpado dessa situação, de acordo com as associações têxteis, era o próprio Estado. No final de fevereiro de 1946, O governo federal proibiu exportações de tecidos locais para o estrangeiro ${ }^{726}$. O argumento das autoridades públicas - endossado

\footnotetext{
${ }_{725}$ Carta SIFTRJ ao Diretor do Correio da Manhã, 25.05.1947.

${ }^{726}$ CETex. Resolução n. 23, fevereiro de 1946. SIFTRJ. Relatório da Diretoria referente ao exercício de 1946, p. 03-07.
} 
pelo presidente da CETex, Guilherme da Silveira Filho, ligado à burguesia industrial - era de que os empresários têxteis canalizavam grande parte dos seus produtos para o exterior, deixando o mercado interno subabastecido. Afirmava-se, também, que os altos preços dos tecidos exportados inflacionavam os preços domésticos ${ }^{727}$. Apesar do protesto dos industriais - que negavam quaisquer desfalques de têxteis no mercado local e que atribuíam a alta de preços não às exportações, mas aos crescentes custos produtivos ${ }^{728}$-, a proibição foi mantida até dezembro de $1946^{729}$.

O retorno da liberdade para exportar, no entanto, não fez as vendas têxteis voltarem aos mesmos patamares do período bélico. Observa-se que, entre 1945 e 1948, o decréscimo das exportações de tecidos para mercados estrangeiros, em quilos, foi de $84 \%$ (Tabela 5.9). É nesse contexto, portanto, que a burguesia do setor passa a culpar o Estado pela queda exportadora. Em ofício enviado ao Presidente da República no mês de julho de 1947, inúmeras associações patronais têxteis do País, inclusive a paulista, afirmaram que “a suspensão das exportações (...) interrompeu, repentina e completamente, os negócios de tecidos que vinham sendo realizados, com notável sucesso, nos mercados externos, desde o ano de 1940 (...) Essa longa interrupção impossibilitou os fabricantes e exportadores nacionais de manterem contato com os mercados externos, os quais, por sua vez, foram perdendo confiança nos fornecedores brasileiros, por isso não se sentem seguros quanto ao recebimento das mercadorias que aqui vierem a adquirir (grifo nosso)" ${ }^{\text {"730. }}$.

Diferentemente do que as associações patronais argumentaram, deve-se salientar que a queda das exportações têxteis não se deveu à "falta de confiança" no recebimento de mercadorias por parte dos compradores. Se assim fosse, no médio prazo, as vendas de tecidos domésticos para o mercado exterior teriam retornado a patamares, no mínimo, pouco inferiores aos do período bélico. No entanto, vê-se que, em 1950, praticamente não havia mais vendas de tecidos locais para o exterior (Tabela 5.9). Na verdade, depois de 1945, o País retornou ao seu papel de semi-colônia na divisão de trabalho internacional, isto é, o de ser preponderantemente exportador de bens primários para as nações centrais. A participação relativa das manufaturas na pauta exportadora interna passou, em termos de valores, de 18,2\% (1945) para apenas 1,2\% (1950 - Tabela 5.10). A obsolescência do parque têxtil doméstico não era capaz de produzir bens competitivos no exterior, seja do

\footnotetext{
${ }^{727}$ Stanley Stein, op. cit., p. 174-175.

${ }^{728}$ Carta do SIFTRJ ao Diretor do Correio da Manhã, 12.06.1947

${ }^{729}$ SIFTRJ. Relatório da Diretoria referente ao exercício de 1946, p. 03-07.

730 SIFTRJ. Ofício dirigido ao Sr. Presidente da República, Eurico Gaspar Dutra, pelas associações patronais têxteis do Rio de Janeiro, São Paulo, Minas Gerais, Pernambuco, Alagoas, Sergipe, Ceará, Maranhão, Juiz de Fora, Brusque e Rio Grande do Sul, 16.07.1947.
} 
ponto de vista da qualidade, seja no que se refere ao preço. O próprio sindicato patronal paulista, posteriormente, chegou a reconhecer em seu relatório tal motivador como sendo o principal responsável pelo fim das exportações manufatureiras domésticas ${ }^{731}$.

Tabela 5.10 - Exportações domésticas discriminadas por classes de produtos (1945 e 1950), em \%

\begin{tabular}{c|cc|cc} 
& \multicolumn{2}{|c|}{1945} & \multicolumn{2}{c}{1950} \\
\hline & Toneladas & Cr\$ 1.000 & Toneladas & Cr\$ 1.000 \\
\hline Matérias-primas & 51,2 & 37,2 & 58,7 & 23,9 \\
Gêneros alimentícios & 46,7 & 44,6 & 40,8 & 75,0 \\
Manufaturas & 2,1 & 18,2 & 0,5 & 1,2 \\
Total & 100,0 & 100,0 & 100,0 & 100,0 \\
\hline
\end{tabular}

Fonte: Anuário Estatístico do Brasil, 1946 e 1951.

Pode-se questionar, nesse sentido, o porquê da insistência patronal em manter um discurso responsabilizando o Estado pelo decréscimo das exportações têxteis se tais mercados estrangeiros já estavam perdidos devido à impossibilidade da concorrência com produtores internacionais. A manutenção desse discurso era fundamental por dois motivos. Em primeiro lugar, o reconhecimento público, por parte da burguesia têxtil, da ineficiência produtiva das suas fábricas daria sustentação aos argumentos daqueles que defendiam ou o tabelamento dos preços dos tecidos locais, ou a abertura do mercado interno para produtos alienígenas mais baratos ${ }^{732}$. Em segundo lugar, a retórica da culpabilidade governamental nessa questão daria força a uma das mais importantes demandas da burguesia têxtil no pós-guerra: a necessidade de incentivos públicos para viabilizar novamente as vendas de tecidos para o exterior. Dentre os subsídios demandados, destacam-se a eliminação dos tributos de exportação; a adoção de taxas múltiplas de câmbio; e a efetivação do drawback $k^{733}$, instituído oficialmente na reforma alfandegária de $1934^{734}$.

Independentemente dessa retórica patronal, o fato é que, com o fim da Segunda Guerra, a concorrência da burguesia têxtil estrangeira retornou, fosse no mercado doméstico, fosse no mercado externo. Naquele, políticas governamentais protecionistas poderiam diminuí-la; neste, não havia o que fazer. Por esse motivo, as exportações de

\footnotetext{
731 "Relativamente às exportações de tecidos (...), as fábricas nacionais sofreram a influência de concorrentes estrangeiros, cujos preços ofereceram diferenças destacadas com os nossos. Trabalhando com maquinaria ainda em grande parte obsoleta, com o custo da matéria-prima em ascensão e acima da paridade internacional, salários elevados e outros encargos da mesma ordem, nossas fábricas não poderiam propor negócios de tecidos (...) em bases que atraíssem o interesse do consumidor estrangeiro". SIFTESP. Relatório das atividades sociais do exercício de 1948.

${ }^{732}$ Ver, nesse sentido: Correio da Manhã. Encilhamento das indústrias, 25.05.1947.

733 "Palavra inglesa (que significa devolução; reembolso) utilizada internacionalmente para designar a devolução de impostos alfandegários pagos por mercadorias importadas e que são reexportadas para um terceiro país". In: Paulo Sandroni. Dicionário de economia, op. cit., p. 124.

${ }^{734}$ SIFTESP. Conclusões da Segunda Convenção da Indústria Têxtil Brasileira, São Paulo, 1949.
} 
tecidos domésticas caíram abruptamente, interrompendo o considerável crescimento produtivo vivenciado pelo subsetor entre 1939 e 1945.

(B) A política liberalizante do Governo Dutra e o subsetor têxtil

A recessão das fábricas de tecidos paulistas, ocorrida no período 1946-1947, deveu-se não apenas à diminuição das exportações, mas também à maior concorrência no mercado doméstico. Os grandes produtores de tecidos do mundo, após o conflito mundial, voltaram a vender seus bens em áreas periféricas. A política econômica do início do Governo Dutra, por sua vez, que manteve o câmbio artificialmente sobrevalorizado e acabou com quaisquer discriminações no comércio exterior, facilitou enormemente o ingresso de tecidos estrangeiros no mercado doméstico. $\mathrm{O}$ valor das importações têxteis cresceu mais de 450\% entre 1945 e 1947 (Tabela 5.11). Logo, em razão desse quadro, as associações patronais do Centro-Sul (SIFTRJ e SIFTESP) passaram a pressionar o Estado visando uma reforma das tarifas alfandegárias, caracterizadas como "as mais baixas do mundo"735.

Tabela 5.11 - Importações têxteis - Brasil (1945-1950) - Cr\$ 1.000 deflacionados

\begin{tabular}{c|c|c|c|c|c|c} 
& 1945 & 1946 & 1947 & 1948 & 1949 & 1950 \\
\hline Algodão & 6.610 & 13.056 & 30.149 & 22.558 & 9.636 & 2.122 \\
Lã & 6.874 & 11.027 & 22.132 & 31.463 & 33.367 & 5.811 \\
Outros & 8.313 & 48.160 & 69.538 & 64.680 & 53.590 & 18.482 \\
Total & 21.797 & 72.243 & 121.819 & 118.701 & 96.594 & 26.416 \\
\hline
\end{tabular}

Fonte: Anuário Estatístico do Brasil, 1946-1951.

Além desse aspecto, a implementação de medidas econômicas de caráter ortodoxo pelo Governo Dutra, que objetivava a redução do déficit orçamentário federal, trouxe ainda mais dificuldades para as fábricas domésticas. A retração do crédito aos industriais e as medidas de controle de preços adotadas pela Comissão Central de Preços $(\mathrm{CPP})^{736}$ completam os fatores que explicam o quadro recessivo então vigente. Segundo os industriais têxteis, em ofício dirigido ao Presidente da República no ano de 1947, “os mercados internos (em 1947) se acham completamente paralisados (...)"737. A formação de

\footnotetext{
${ }_{735}$ SIFTRJ. O encilhamento das indústrias. In:Relatório da Diretoria, 1947.

${ }^{736}$ A Comissão Central de Preços foi criada em março de 1946 pelo Governo Dutra. No que se refere ao subsetor têxtil, a Comissão estabeleceu, em 1947, a obrigatoriedade da marcação dos preços dos tecidos nas ourelas dos mesmos. Criou, além disso, limites de lucros para grossistas, atacadistas e varejistas. Para maiores informações, ver: Comissão Central dos Preços. Portaria n. 13, 15.04.1947 e Sônia Draibe. Rumos e metamorfoses, op. cit., p. 140.

737 SIFTRJ. Ofício dirigido ao Sr. Presidente da República, Eurico Gaspar Dutra, pelas associações patronais têxteis do Rio de Janeiro, São Paulo, Minas Gerais, Pernambuco, Alagoas, Sergipe, Ceará,
} 
excedentes produtivos apareceu, portanto, como conseqüência natural desse estado de crise. "Esses estoques representam um câncer na economia nacional", afirmava o relatório da diretoria do SIFTRJ referente ao exercício de 1947738. Argumentava-se que "o problema têxtil (era) o problema $\mathrm{n}^{\circ} 1$ da economia nacional" e que uma débâcle nas fábricas de tecidos locais significaria aumento do déficit orçamentário - em razão da cessão do pagamento de tributos dessas empresas ao Estado - e do nível de "insegurança social”, devido à demissão de milhares de trabalhadores ${ }^{739}$. A ajuda ao subsetor têxtil mediante políticas de fomento ao crédito industrial; reforma das tarifas alfandegárias; incentivo às exportações; etc. - significaria a melhor maneira de evitar o "empobrecimento do país" ${ }^{\text {740. }}$.

Apesar de não estar diretamente relacionada com essa pressão do empresariado têxtil, o Governo Dutra efetuou mudanças importantes nas diretrizes de sua política econômica a partir de 1947, as quais surtiram efeitos positivos no setor industrial. O momento baixista de 1946-1947, assim, cedeu lugar à recuperação observada no período 1948-1950.

\section{$\underline{5.3 .2-O \text { período } 1948-1950}$}

O crescimento apresentado pelo subsetor têxtil paulista a partir de 1948 está vinculado a dois fatores correlatos: (a) a política de controle de importações efetuada pela administração Dutra em julho de 1947; e (b) a política de fomento ao crédito industrial iniciada pela gestão Guilherme da Silveira no Ministério da Fazenda, em junho de 1949.

A primeira dessas políticas possibilitou uma queda do nível de importações de têxteis no País. Destinou-se, assim, uma certa reserva de mercado aos fabricantes domésticos, mesmo que a níveis menores do que aqueles observados no período bélico. Entre 1947 e 1950, a compra de tecidos estrangeiros decresceu de Cr\$121.819.000 (1947) para menos Cr\$26.500.000 (1948), isto é, queda superior a 78\% (Tabela 5.11).

A elevação dos empréstimos fabris, por sua vez, aliado à manutenção do câmbio sobrevalorizado, permitiu às indústrias têxteis paulistas a compra de quantidades consideráveis de bens de capital. Pode-se observar que, entre 1945 e 1948, houve

\footnotetext{
Maranhão, Juiz de Fora, Brusque e Rio Grande do Sul, 16.07.1947.

${ }^{738}$ SIFTRJ. Relatório da Diretoria, 1947.

${ }^{739}$ Idem.

740 Ofício dirigido à Confederação Nacional da Indústria pelo Sindicato das Indústrias de Fiação e Tecelagem do Rio de Janeiro e pelo Sindicato das Indústrias de Fiação e Tecelagem em Geral do Estado de São Paulo, 16.04.1947.
} 
crescimento superior a 390\%, em termos de valores, na aquisição de máquinas e acessórios para o subsetor de tecidos de São Paulo (Tabela 5.12). Por mais que tais ingressos tenham viabilizado apenas uma renovação parcial do obsoleto e desgastado maquinário têxtil paulista, a sua ocorrência foi de extrema importância para a compreensão do crescimento econômico verificado no subsetor nesse interregno.

Tabela 5.12 - Importação de bens de capital têxteis - Porto de Santos e São Paulo via aérea (1945-1946; 1948-1950)*

\begin{tabular}{rccccc} 
& 1945 & 1946 & 1948 & 1949 & 1950 \\
\hline Máq. fiação e tecelagem não-especificadas (1) & 1.547 .080 & 2.026 .994 & 8.800 .892 & 7.045 .854 & 6.137 .942 \\
Máq. fiação e tecelagem não-especificadas (2) & 9.480 & 11.506 & 57.330 & 43.449 & 37.142 \\
Teares (1) & 241.348 & 363.135 & 801.788 & 2.092 .774 & 1.149 .652 \\
Teares (2) & 1.276 & 1.397 & 3.696 & 8.862 & 5.564 \\
Acessórios não-especificados (1) & 378.498 & 410.371 & 1.166 .745 & 1.199 .374 & 599.279 \\
Acessórios não-especificados (2) & 5.502 & 5.286 & 9.524 & 9.780 & 4.696 \\
Total (1) & 2.166 .926 & 2.800 .500 & 10.769 .425 & 10.338 .002 & 7.886 .873 \\
Total (2) & 16.257 & 18.188 & 70.550 & 62.091 & 47.401 \\
\hline
\end{tabular}

Fonte: Anuário Estatístico do Brasil, 1945-1951 / * (1) Toneladas; (2) Cr\$ 1.000 deflacionados

\section{$\underline{\text { 5.3.3. - Os ramos }}$}

Neste tópico analisar-se-ão os fatores explicativos dos distintos desempenhos apresentados pelos ramos têxteis paulistas no período 1946-1950. Maior atenção será concedida para o caso algodoeiro - que, como já se assinalou, desde o início do século XX não apresentava as maiores taxas de crescimento do subsetor - e para as fábricas laníferas, cuja perda de participação relativa no total das indústrias têxteis estaduais foi notável nesse período.

No que se refere às empresas de algodão, sua ascensão no pós-guerra deveu-se, em grande parte, à política de tabelamento e marcação de preços de seus tecidos posta em prática pela $\mathrm{CCP}^{741}$. O custo de vestuário para a classe operária em São Paulo - cujo índice é formado, essencialmente, pelos preços de têxteis algodoeiros - cresceu 51\% no período 1945-1950, enquanto, durante a guerra, elevou-se em mais de $200 \%{ }^{742}$. O salário dos trabalhadores têxteis paulistas, por outro lado, ascendeu em 149\% no momento 1944-1950 ${ }^{743}$. Como as majorações salariais eram realizadas por dissídios coletivos de cada categoria, presume-se que elevações de ganhos não muito diferentes devem ter sido concedidas para outros grupos proletários. Um aumento nos salários das classes mais

\footnotetext{
${ }^{741}$ Comissão Central dos Preços. Portaria n. 13, 15.04.1947.

${ }^{742}$ Ver tabela 4.22

${ }^{743}$ Ver tabela 5.14.
} 
pobres das cidades superior ao crescimento dos preços dos tecidos de algodão foi, provavelmente, o principal fator explicativo da elevação do consumo desse tipo de têxtil no período. Entende-se, assim, o porquê da sua maior ascensão diante dos demais ramos dessa indústria.

No que condiz às fábricas de seda, cujo crescimento apareceu em segundo lugar no período, identifica-se, nas empresas produtoras de seda natural - que, como já seanalisou, apresentaram forte declínio entre 1946-1950 -, as principais responsáveis pelo ramo não ter sido o primeiro em desempenho entre os demais. As indústrias de rayon, ao contrário, mantiveram-se em alta. Mesmo com o crescimento de sua capacidade produtiva no final da década de 1940 (nova fábrica da Cia. Nitro-Química Brasileira; utilização do processo de filamento contínuo pela $I R M F$, etc.), muitas empresas, tais como a Rhodiaseta, notificavam seus acionistas em relatórios acerca da impossibilidade em atender todas as demandas $^{744}$.

O baixo desempenho apresentado pelas empresas laníferas, por sua vez, está diretamente relacionado com a promulgação, em janeiro de 1946, do decreto-lei $n^{\circ}$ 8.819 ${ }^{745}$. Este reduziu as tarifas alfandegárias incidentes nas importações de lã bruta e manufaturada. A taxa paga pelos tecidos laníferos de origem externa passou de Cr\$117,00 para Cr\$ 58,50 por quilograma (-50\%), enquanto a tarifa referente aos fios decresceu de Cr\$ 20,00 para $\mathrm{Cr} \%$ 4,60 por quilograma (-77\%). Como resultado, houve aumento considerável das importações de produtos de lã no pós-guerra. No período 1945-1949, em termos de valores, a ascensão foi superior a 385\% (Tabela 5.11). Percebe-se que a compra de têxteis estrangeiros foi crescente entre 1945 e 1947 (458\%). A partir deste ano, no entanto, nota-se mudança de tendência. As importações agregadas de tecidos caíram em $20 \%$ no período 1947-1949, diferentemente dos produtos de lã, que continuaram apresentando alta $(50,7 \%)$, mesmo após a alteração da política econômica efetuada pelo Governo Dutra em 1947.

A pressão dos industriais têxteis laníferos sobre o governo começou logo após a criação do decreto citado. Segundo o sindicato fluminense, “(...) criou-se uma situação verdadeiramente absurda e incompreensível em relação à tributação alfandegária da lã e de seus produtos"746 . Em 1948, as associações patronais de São Paulo e do Rio enviaram uma carta ao presidente da Carteira de Exportação e Importação do Banco do Brasil.

\footnotetext{
${ }_{744}$ Relatório de Diretoria. Cia. Brasileira de Sedas Rhodiaseta, 01.12.1947.

${ }^{745}$ Decreto-lei n. 8.819, 24.01.1946.

${ }^{746}$ SIFTRJ. Ofício do Sindicato das Indústrias de Fiação e Tecelagem do Rio de Janeiro ao Presidente do Senado Federal a propósito da emenda ao Projeto 1.383 da Câmara dos Deputados, 06.09.1949.
} 
Assinalaram, entre outras assertivas, que "a prevalecer essa situação (isto é, a manutenção do Decreto 8.819), será inevitável a acentuada redução ou mesmo a paralisação do trabalho das fiações e tecelagens com reflexo danoso para a colocação da safra da lã nacional (...) que, na sua quase totalidade, é consumida pela nossa indústria"747. A Federação das Indústrias do Rio Grande do Sul, por sua vez, em memorial dirigido à Comissão de Finanças da Câmara dos Deputados, afirmou que tal decreto prejudicava o "trabalho nacional". Segundo o documento, "sua revogação pura e simples" era a única maneira de restabelecer o "indispensável e justo escalonamento da cobrança de direitos de artigos importados" $" 748$.

Mesmo com todas essas pressões, as tarifas alfandegárias incidentes nos produtos de lã estrangeiros mantiveram-se inalteradas até 1949. Neste ano, porém, o Congresso Nacional promulgou legislação que restabeleceu as antigas taxas pagas por tais bens, as quais eram significativamente menores ${ }^{749}$. O resultado logo se fez sentir. As importações de têxteis laníferos caíram em mais de 82\% entre 1949 e 1950 (Tabela 5.11). A situação das empresas do ramo, por sua vez, melhorou. Em 1950, o sindicato patronal paulista informou os seus membros em relatório anual da diretoria acerca do "desenvolvimento da produção" apresentado pelas fábricas de lã estaduais ${ }^{750}$. Todos esses dados apenas ratificam o quanto esse baixo desempenho do ramo no período 1946-1950 esteve vinculado ao problema tarifário descrito.

Por último, apesar da escassez de dados, deve-se fazer uma observação no que se refere às fábricas de juta paulistas pós-1945. Sabe-se que a demanda doméstica por sacaria cresceu nesse período, principalmente a partir de 1949, quando os preços cafeeiros cresceram no mercado internacional ${ }^{751}$. As associações patronais reclamavam, porém, que não era possível suprir todos os pedidos em razão da escassez de matéria-prima. O principal produtor mundial de juta - a Índia - passava, neste período, por sérias conturbações político-sociais. O movimento de independência do país, que alcançou êxito em 1947, intensificou os conflitos entre os grupos hinduísta e muçulmano locais, prejudicando as plantações jutíferas. As exportações indianas do produto decresceram, afetando várias regiões consumidoras, entre elas o Brasil. A produção de juta amazônica,

${ }^{747}$ SIFTRJ. Carta SIFTRJ e SIFTESP à Carteira de Exportação e Importação do Banco do Brasil, 29.11.1948.

${ }^{748}$ SIFTRJ. Memorial dirigido ao Sr. Deputado Arthur de Souza Costa, Presidente da Comissão de Finanças da Câmara dos Deputados, pela Federação das Indústrias do Rio Grande do Sul, s/d.

${ }^{749}$ Lei n. 911, 08.11.1949.

750 SIFTESP. Relatório das Atividades Sociais do Exercício de 1950.

751 Para maiores informações sobre os motivadores dessa alta dos preços cafeeiros, ver: Sérgio Besserman Vianna, op. cit., p. 111-112. 
por sua vez, ainda era insuficiente para abastecer todo mercado doméstico. Em 1947, realizou-se um congresso (Congresso Nacional de Economia da Juta), que reuniu autoridades públicas e representantes patronais, objetivando fomentar a fibricultura interna $^{752}$. Os resultados, porém, foram reduzidos. A quantidade de juta demandada pelas fábricas paulistas ainda se manteve muito superior às possibilidades produtivas domésticas. Em 1950, dos 23 milhões de quilos da fibra consumidos pelas empresas de São Paulo, 14 milhões eram provenientes da Amazônia ${ }^{753}$. Independentemente da questão da escassez de dados, portanto, pode-se inferir que a taxa de crescimento do ramo, em razão das dificuldades de obtenção de matéria-prima, não deve ter sido muito alta nesse período.

\section{4 - As relações de trabalho nas fábricas têxteis no pós-guerra}

Pode-se dividir a atuação do movimento operário têxtil em São Paulo no período 1946-1950 em duas fases: (a) 1946; e (b) 1947-1950.

A primeira delas caracterizou-se, sobretudo, por intensas agitações operárias. A redemocratização do País, concretizada mediante promulgação de nova Carta Constitucional em 1946, garantiu aos trabalhadores, entre outros pontos, o direito de greve. Permitiram-se, assim, maiores possibilidades de contestação do proletariado diante das precárias condições de trabalho vigentes. As paralisações fabris "explodiram" nos dois primeiros anos logo após o término da Segunda Guerra ${ }^{754}$.

O proletariado têxtil paulista, como não poderia deixar de ser, participou ativamente em muitas das greves e manifestações que ocorreram no período. Nota-se, porém, que sua antiga hegemonia na liderança dos movimentos paredistas estaduais deixou de existir. A partir de 1946, houve uma atuação cada vez maior, em termos de comando, dos trabalhadores das chamadas indústrias pesadas (metalúrgicas, química, petrolífera, etc.) nos atos contestatórios ao patronato ${ }^{755}$. Essa mudança refletia as próprias alterações ocorridas na estrutura industrial paulista. Ao longo das décadas de 1930 e 1940, as fábricas têxteis perderam participação relativa no total fabril estadual para ramos produtores de bens intermediários e de capital. Compreende-se, assim, o porquê da alteração citada.

\footnotetext{
${ }_{752}$ SIFTESP. Relatório das Atividades Sociais do Exercício de 1948.

${ }^{753}$ SIFTESP. Relatório das Atividades Sociais do Exercício de 1950.

${ }^{754}$ Edgard Carone. A República Liberal, op. cit., p. 199.

${ }^{755}$ Idem, op. cit., p. 176.
} 
Independentemente disso, houve movimentos grevistas importantes realizados pelos trabalhadores têxteis no estado de São Paulo, especialmente em 1946. Neste ano, no mês de fevereiro, eclodiram paralisações em diversas fábricas da capital. Ao todo, mais de cem mil operários cruzaram os braços. Destes, 50.000 eram tecelões. Reivindicavam-se, entre outros, aumentos salariais e tabelamento de preços para os produtos de consumo básico ${ }^{756}$.

A burguesia têxtil paulista decidiu resistir às demandas dos paredistas. $O$ presidente do SIFTESP, Humberto Reis Costa, foi contundente em afirmar que os reajustes salariais eram impossíveis em razão da "crise" pela qual passava o subsetor e que, por esse motivo, não seriam concedidos ${ }^{757}$. Planejou-se, por outro lado, uma ação comum contra "esses elementos agitadores" "758. A recomendação era para que o empresariado não cedesse a quaisquer reivindicações dos seus trabalhadores. Caso contrário, a "ordem" na fábrica seria rompida. Conforme Oscar Camargo, importante membro do patronato têxtil, “(...) a indústria não está absolutamente alheia às necessidades de seus operários, nem tão pouco deixa de ouvir os seus legítimos anseios - por isso que, a par do justo salário que paga, desenvolve obras sociais apreciáveis e cumpre plenamente as suas obrigações legais (...)". No entanto, segundo ele, "a fim de salvagardar o necessário espírito de disciplina que deve imperar nas fábricas”, não se pode negociar, nem ceder a qualquer imposição dos grevistas (grifo nosso) $)^{759}$.

A unidade de ação da burguesia têxtil paulista e a forte repressão desencadeada pela polícia estadual contra o movimento operário explicam a derrota dos trabalhadores. Não foram concedidos quaisquer reajustes salariais. Como de praxe, após a normalização do trabalho, os diretores das fábricas congratularam o diretor do DOPS pelos "eficientes serviços prestados" ${ }^{760}$.

Em dezembro de 1946, houve novo movimento grevista nas fábricas têxteis do estado. Mais uma vez, os trabalhadores demandavam aumentos de salários e reclamavam contra a carestia de vida. Entre as empresas que tiveram seus trabalhos paralisados, destacam-se as IRFM, o Moinho Santista e o Cotonifício Rodolfo Crespi ${ }^{761}$.

\footnotetext{
${ }^{756}$ Ibidem, op. cit., p. 204.

${ }^{757}$ SIFTESP. Ata da reunião de diretoria, 03.01.1946.

${ }^{758}$ SIFTESP. Ata da reunião de diretoria, 10.01.1946.

${ }^{759}$ Idem.

${ }^{760}$ Ver, nesse sentido: Arquivo DOPS. Carta do presidente da S.A. Fiação e Tecelagem Ypiranga Assad ao Delegado do DOPS, 10.01.1946; Carta da Diretoria do Cotonifício Adelina ao Delegado Especializado de Ordem Social, João Cataldi Júnior, 11.02.1946; Carta da Cia. Brasileira de Linhas para Coser para o Delegado de Ordem Política e Social, 04.01.1946; Relatório do Delegado Adjunto ao Delegado Especializado de Ordem Social referente à Cia. Nitro-Química Brasileira, 12.03.1946.

${ }^{761}$ SIFTESP. Ata da reunião de diretoria, 15.12.1946.
} 
O empresariado, no início, manteve sua postura de não aceitar negociações com os paredistas. Segundo o presidente do SIFTESP, não havia “(...) remédio para o caso atual se não a união das indústrias, em benefício não de nós mesmos, mas da nossa própria terra (...) eu sou obrigado a dizer que estamos a caminho da calamidade final se formos nos submeter a todas as exigências (...) Eu tenho segurança que aqui não são Estados Unidos. O operário daqui não tem fundo de reserva para agüentar 30 dias (grifos nossos) ${ }^{\$ 762}$.

Devido à manutenção do movimento paredista e da possibilidade de eclosão de uma greve geral na cidade de São Paulo, porém, o posicionamento burguês mudou. $\mathrm{O}$ presidente da FIESP, Morvan Figueiredo, por exemplo, ao discursar para os industriais têxteis dias depois, já defendeu posicionamento menos duro. Conforme ele, era necessário "dar os anéis, ou parte dos anéis, para tentar salvar os dedos", isto é, ceder às pressões salariais dos operários. Isso porque “(...) de um lado estamos nós tentando salvar uma Democracia Liberal. De outro lado, está um grupo subvencionado por Moscou, recebendo ordens de Moscou, procurando se apossar do Governo (...) Tenho a impressão de que o Chefe da Nação é positivamente anticomunista (...) Mas sinto que não há da parte do Chefe da Nação a força necessária para reprimir o comunismo como provavelmente era o seu desejo (...) Se não conseguirmos união dos nossos dirigentes, não sei se daqui a 6 meses, ou 1 ano, restarão alguns dos que aqui estão presentes, porque imagino que teremos todos nós passado por um paredão de fuzilamento, tal é situação (...) Para nós combatermos essa invasão comunista, entendo que devemos dar alguma coisa mais. Estamos no momento de não ganhar mais (...) Mas só temos este meio para nos salvar (...) Eu sugeria que fosse feito um reajustamento de salários (...) (grifos nossos) ${ }^{9763}$.

Apesar disso, Morvan Figueiredo propôs a necessidade de se constituir uma comissão de industriais para viajar ao Rio e conversar com o Presidente da República. Enquanto isso, continua, falar-se-ia aos operários que foi montado um grupo para estudar a possibilidade de aumentos salariais. "É uma medida ótima como medida de ganhar tempo (...) Não constar nada disso em ata". Humberto Reis Costa, presidente do SIFTESP, emendou: "Constar em ata não tem importância. Não deve ser dado à publicidade. É tudo secreto. É preciso ir um representante da indústria têxtil, mas é preciso (também) ir representantes de todas as indústrias (...) O operário brasileiro é de boa índole, maleável, é

\footnotetext{
${ }^{762}$ Idem.

${ }^{763}$ SIFTESP. Ata da reunião de diretoria, 18.12.1946.
} 
nosso amigo. Os perigosos são os que os estão explorando, estão subvertendo a ordem"764. As movimentações burguesas visando evitar os reajustes salariais não surtiram efeito dessa vez. Em reunião realizada no dia de Natal, acertou-se o fim da greve dos trabalhadores têxteis mediante concessão de $30 \%$ de aumento nos ordenados ${ }^{765}$.

As paralisações de 1946 ilustraram o quanto o discurso do empresariado (democrático e liberal) não condizia com suas respectivas ações (autoritárias e caluniosas). Viu-se, ao mesmo tempo, como a burguesia têxtil vinculou o não-reajuste salarial com atitudes que, teoricamente, beneficiariam não apenas a ela, mas também ao País, devido à contenção do "crescimento de grupos moscovitas locais". Camuflavam-se, dessa maneira, mais uma vez, interesses particulares em coletivos.

A partir de 1947, no entanto, em razão do endurecimento do Governo Dutra contra quaisquer organizações que, direta ou indiretamente, tinham vínculos com o comunismo $^{766}$, houve arrefecimento da movimentação operária. Isso não significa, porém, que inexistiram contestações trabalhistas ao patronato no período 1947-1950. Afirmou-se, somente, que as tentativas se tornaram mais difíceis devido à maior repressão policial, mas, mesmo assim, elas aconteceram.

Em abril de 1948, por exemplo, iniciou-se greve nas Fábricas Brasileiras de Rayon. Logo, porém, os líderes foram presos. Um dos operários detidos, Antônio do Nascimento, em depoimento no DOPS, afirmou que a paralisação era "justa" pois, segundo ele, “(...) o que ganha não dá pra viver"767. No mesmo ano, ocorreram greves por motivos semelhantes no Lanifício Varam, na Cia. Sta. Basilissa e na Fábrica Votorantim. Todos os movimentos foram rapidamente reprimidos por forças regionais ${ }^{768}$. Em 1949, houve, nesta última empresa, deflagração de outra manifestação paredista. Os operários invadiram a fábrica, paralisando a produção. Passaram, além disso, óleo, graxa e sabão nos

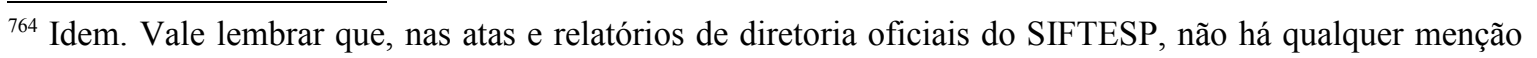
dessa discussão. As atas aqui mencionadas eram de caráter extra-oficial e não circulavam para o público. Elas permaneciam nos escritórios do sindicato em São Paulo, em área restrita.

${ }^{765}$ SIFTESP. Ata da reunião de diretoria, 25.12.1946.

${ }^{766}$ Entre as medidas colocadas em prática pelo governo, o qual se alinhou diretamente com os Estados Unidos nesse contexto de crescente bipolarização mundial, destacam-se: fechamento do Partido Comunista Brasileiro e da sua respectiva sindical operária (Confederação dos Trabalhadores do Brasil); e destituição de mais de 400 diretorias de sindicatos proletários, as quais foram consideradas "comunistas". O governo, por sua vez, voltou a tutelar de maneira mais direta as eleições sindicais. Para maiores informações, ver: Edgard Carone. A república liberal, op. cit., p. 181.

${ }^{767}$ Arquivo DOPS. Auto de Qualificação do operário Antônio do Nascimento feito pelo DOPS, 08.04.1948.

${ }^{768}$ Para maiores informações, ver: Arquivo DOPS. Auto de qualificações de Oswaldo Lopes (tecelão do Lanificio Varam) - DOPS, 24.03.1948; Comunicado da Chefia da Ordem Social ao Delegado Especializado de Ordem Social, 10.10.1948; Comunicado da Chefia da Ordem Social ao Delegado Especializado de Ordem Social, 03.11.1948; e Telegrama do Delegado Regional de Polícia de Sorocaba, Francisco Franco do Amaral, ao DOPS, 12.10.1948.
} 
trilhos da estrada de ferro que ligam a indústria às regiões distribuidoras, impedindo a manutenção das suas vendas. A polícia de Sorocaba atuou mais uma vez "contendo" os trabalhadores ${ }^{769}$. As crescentes repressões governamentais, que dificultavam contestações abertas contra os patrões, incitavam os trabalhadores a protestar de maneiras indiretas contra a burguesia têxtil, tais como mediante sabotagens. Em 1949, por exemplo, o delegado do DOPS foi informado de que na Fiação e Tecelagem Ypiranga Assad S.A. houve "atos de sabotagem". Diversos fusos foram quebrados propositalmente pelos operários $^{770}$.

Todos esses movimentos contestatórios do proletariado têxtil paulista tinham uma razão de ser. Os constantes aumentos nos preços de bens de consumo básico forçavam os trabalhadores a lutar por melhores salários. Vê-se que, entre 1945 e 1950, houve acréscimo de $68 \%$ no custo de vida do operário paulistano (Tabela 5.13). Alguns itens, tais como alimentação e habitação, apresentaram crescimento superior a 78\%.

Tabela 5.13 - Índices ponderados do custo de vida da classe operária na cidade de São Paulo, $1945-1950(1939=100)$

\begin{tabular}{ccccccc} 
& 1945 & 1946 & 1947 & 1948 & 1949 & 1950 \\
\hline Alimentação & 245,3 & 312,4 & 373,2 & 425,1 & 409,1 & 437,8 \\
Habitação & 270,0 & 357,6 & 482,5 & 477,4 & 456,9 & 481 \\
Vestuário & 300,6 & 368,5 & 459,5 & 431,4 & 444,2 & 456,8 \\
Combustível & 440,8 & 316,3 & 318,5 & 389,2 & 393,8 & 400,3 \\
Assistência médica & 206,5 & 279,8 & 353,3 & 393 & 406,4 & 407,1 \\
Artigos de limpeza doméstica & 243,3 & 252,7 & 317,1 & 373,9 & 439,9 & 457,3 \\
Móveis & 284,8 & 290,8 & 350,8 & 367,3 & 411 & 439,2 \\
Transporte & 115,0 & 122,6 & 147 & 177,7 & 184,8 & 277,8 \\
\hline Total & 259,1 & 296,2 & 385,9 & 418 & 411,2 & 435,4 \\
\hline Fonte: Anuário Estatístico do Brasil, 1951. & & & & &
\end{tabular}

Fonte: Anuário Estatístico do Brasil, 1951.

Dessa vez, porém, o aumento do custo de vida foi compensado pelos reajustes salariais. Vê-se que a combatividade operária têxtil, principalmente em 1946, apresentou resultados práticos. Os salários dos trabalhadores das fábricas de tecidos cresceram em mais de 218\% no momento 1945-1950, enquanto o custo de vida ascendeu em 68\% (Tabela 5.14). Nota-se, por outro lado, que, durante o contexto bélico, quando houve proibição de greves e forte amordaçamento dos movimentos proletários, os acréscimos salariais $(60,5 \%)$ foram inferiores ao encarecimento dos itens de consumo básico (91\%). Lembra-se também que, durante o período de endurecimento do Governo Dutra (a partir

\footnotetext{
769 Arquivo DOPS. Relatório nos autos de inquérito policial sobre a greve deflagrada na S.A. Indústrias Votorantim realizado pelo Delegado Adjunto de Ordem Social, Francisco Petrarca Ielo. DOPS, 1949.

${ }^{770}$ Arquivo DOPS. Ato de Sabotagem na S.A. Fiação e Tecelagem Ypiranga Assad, 05.05.1949.
} 
de 1947), os dissídios coletivos, tutelados pela Justiça do Trabalho, repuseram, em alguns casos até a mais, as perdas do poder de compra dos trabalhadores ${ }^{771}$.

Vale ressaltar, também, que muitas das greves do período reivindicavam melhores condições de trabalho no interior das fábricas, seja em termos de segurança, seja no que se referia às condições de higiene. Detido durante a paralisação ocorrida na Cia. Têxtil Sta. Basilissa em 1946, o operário Bento Bernardes de Almeida alegou em seu depoimento ao DOPS “(...) que o serviço da indústria correspondia a uma verdadeira Bastilha (e que) (...) o gerente da mesma era nazista e fascista (...)"772. Os operários da Votorantim, durante a greve ocorrida no mesmo ano, fizeram reclamações semelhantes contra os gerentes da empresa $^{773}$.

Tabela 5.14 - Salários totais e per capita dos operários têxteis paulistas (1940, 1944 e 1950)

\begin{tabular}{cccc} 
& 1940 & 1944 & 1950 \\
\hline Operários & 94.161 & 125.624 & 142.047 \\
Salários operários (Cr\$ 1.000) & 207.092 & 443.526 & 1.597 .988 \\
Salários per capita (Cr\$ 1.000) & 2,2 & 3,5 & 11,2 \\
Crescimento salários \% & $*$ & 60,5 & 218,6 \\
Crescimento custo de vida \% & $*$ & 91,0 & 68,0 \\
\hline
\end{tabular}

Fonte: Recenseamento Geral de 1940 e 1950; Estatísticas Industriais do Estado de São Paulo, 1944.

Além disso, observa-se que as condições de segurança existentes nas fábricas de tecidos de São Paulo no pós-guerra estavam longe de "satisfatórias", como alegavam os industriais $^{774}$. Vê-se que, em 1946, houve 13 mortes decorrentes de acidentes de trabalho no subsetor (Tabela 5.15). Os operários que sofreram invalidez permanente em razão dos problemas de segurança nas fábricas aumentaram de 127 (1945) para 162 (1949), isto é, acréscimo superior a $27 \%$. A única variável que apresentou baixa refere-se ao número de trabalhadores que sofreram invalidez permanente (de 7.630 para 5.306 casos no interregno 1945-1949).

\footnotetext{
${ }^{771}$ SIFTESP. Relatório das Atividades Sociais do Exercício de 1950. Sobre as reclamações patronais relativas aos dissídios coletivos favoráveis à classe trabalhadora, ver: Relatório de Diretoria. S.A. Moinho Santista, 08.03.1947; Relatório de Diretoria. Cia. Nacional de Estamparia, 28.04.1947; e Relatório de Diretoria. Argos Industrial S.A., 31.12.1948.

${ }^{772}$ Arquivo DOPS. Relatório de investigação - DOPS, 11.03 .1946

773 Arquivo DOPS. Relatório nos autos de inquérito policial sobre a greve deflagrada na S.A. Indústrias Votorantim realizado pelo Delegado Adjunto de Ordem Social, Francisco Petrarca Ielo. DOPS, 1949.

${ }^{774}$ SIFTESP. Ata da reunião de diretoria, 10.01.1946.
} 
Tabela 5.15 - Acidentes sofridos por operários na indústria têxtil paulista (1945-1949)

\begin{tabular}{cccccc} 
& 1945 & 1946 & 1947 & 1948 & 1949 \\
\hline Invalidez temporária & 7.630 & $*$ & 5.809 & 5.142 & 5.306 \\
Invalidez permanente & 127 & $*$ & 161 & 150 & 162 \\
Mortes & 5 & 13 & 1 & 3 & 3 \\
Total & 7.762 & $*$ & 5.971 & 5.295 & 5.471 \\
\hline
\end{tabular}

Fonte: Diário Oficial. Balanços da Sociedade Coopertativa de Seguros contra Acidentes de Trabalho A TÊXTIL, 29.03.1946, 27.04.1947, 04.03.1948, 09.03.1949 e 18.03.1950.

Por último, far-se-á breve comentário acerca do relacionamento entre burguesia têxtil e Estado no pós-guerra. Afora os aspectos relativos à repressão aos movimentos operários, os quais demonstraram grande sintonia entre os interesses do empresariado e do governo, lembra-se que, no tocante às leis trabalhistas, ainda houve atritos entre esses pólos.

Entre as discordâncias mais notáveis, destacaram-se as questões referentes aos direitos de greve e do descanso semanal remunerado, ambos garantidos pela Carta Constitucional de 1946. Sobre o primeiro deles, muitas associações patronais consideraram inadequado garantir possibilidades legais de paralisação aos trabalhadores, pois, segundo elas, já havia instâncias jurídicas no País capazes de resolver os conflitos entre capital e trabalho pacificamente. Conforme o Instituto de Direito Social (IDS), órgão identificado com os interesses da burguesia centro-sulista, a greve é um “(...) direito que os operários devem ter em países onde não exista legislação que ofereça aos empregados e empregadores meios pacíficos para resolver os conflitos de trabalho de natureza econômica" ${ }^{\text {775 }}$. O jornal Correio da Manhã foi mais categórico ainda, ao comentar a questão: "é crime instigar lutas de classe em uma democracia que não existem classes, mas o povo"776. Sobre o segundo dos direitos mencionados, os sindicatos patronais têxteis do Rio e de São Paulo mantinham argumentos antigos para debelá-lo: os salários já eram suficientes e as condições de trabalho, satisfatórias. Segundo eles, o descanso semanal remunerado, além disso, só aumentaria os custos incidentes nas fábricas de tecidos domésticas, obrigando-as a repassá-los para os preços dos produtos e, assim, a prejudicar a população consumidora ${ }^{777}$.

Vale lembrar que, mesmo com as pressões patronais, os direitos citados foram mantidos pelo Governo Federal. Da mesma maneira que o operariado têxtil perdeu a

\footnotetext{
${ }_{775}$ Instituto de Direito Social. Ordem econômica e social, vol. 6, n. 01, p. 41-42. Apud Edgard Carone. A república liberal, op. cit., p. 161.

${ }^{776}$ Correio da Manhã, 13.04.1946.

777 SIFTRJ. Memorial do SIFTRJ e SIFTESP apresentado ao Presidente da República, solicitando a revogação do artigo 13 do decreto 27.048, de 12 de agosto de 1949, que aprovou o Regulamento da Lei de Repouso Semanal Remunerado, 27.10.1949.
} 
hegemonia nos movimentos contestatórios locais em razão da diminuição do peso relativo das fábricas de tecidos no estado, os industriais do setor também já não possuíam mais, nesse período, a influência que detinham nas esferas governamentais no início dos Novecentos.

\section{$\underline{5.5 \text { - Conclusões parciais }}$}

A indústria têxtil paulista continuou apresentando crescimento após a Segunda Guerra Mundial. Essa ascensão, porém, (a) foi bem menos expressiva do que a observada no período bélico e (b) não foi contínua. O período 1946-1947 caracterizou-se por tendência depressiva, em razão do decréscimo das exportações têxteis e da política de liberalização implementada no início do Governo Dutra. Entre 1948 e 1950, as fábricas de tecidos estaduais voltaram a crescer. Isso se deveu, principalmente, às alterações na política econômica governamental, mediante criação de mecanismos que dificultaram as importações e mantiveram o câmbio artificialmente valorizado. Este, por sua vez, facilitou a aquisição de bens intermediários e de capital pelas empresas têxteis, que, apesar de não ter permitido uma renovação total do seu obsoleto capital constante, foi fundamental como propulsor do desenvolvimento do subsetor no período.

Quanto aos ramos, viu-se que estes não tiveram crescimento homogêneo no período. As fábricas de algodão e seda apresentaram os melhores desempenhos, enquanto as empresas laníferas, de malha e, ao que parece, de juta, não se desenvolveram no mesmo ritmo.

No que se refere às relações de trabalho, observou-se que a combatividade do movimento operário têxtil foi grande no momento 1946-1950. Motivadas, especialmente, por questões salariais, algumas das greves, tais como a de dezembro de 1946, terminaram vitoriosas para os trabalhadores. A repressão policial, porém, a partir de 1947, fez arrefecer a contestação proletária. A relação entre a burguesia têxtil e o Estado manteve-se cordial nesse momento, apesar das reclamações inócuas da primeira no que condizia ao direito de greve e de descanso semanal remunerado para os operários.

Para finalizar, faz-se necessário apresentar breve balanço das estruturas de produção e de trabalho da indústria têxtil paulista em 1950. Será possível, assim, ter uma visão das importantes transformações apresentadas pelo subsetor ao longo das décadas de 1930 e 1940. 


\section{CAPÍTULO 6 - Radiografia da indústria têxtil paulista (1950)}

Neste capítulo, realizar-se-á breve panorama da estrutura produtiva e das relações de trabalho das indústrias têxteis de São Paulo em 1950. Mediante utilização de dados referentes ao ano de 1928, analisados no primeiro capítulo, visa-se observar as transformações ocorridas no subsetor ao longo das décadas de 1930 e 1940. Será possível, com isso, compreender melhor o papel do período estudado (1929-1950) para a própria formação têxtil paulista.

\section{1 - A participação das indústrias têxteis paulistas no agregado fabril estadual e nacional}

As indústrias de tecidos paulistas perderam participação relativa no total fabril estadual entre 1928 e 1950. Vê-se que, das variáveis arroladas na Tabela 6.1, apenas no que se refere ao número de estabelecimentos houve elevação participativa das empresas têxteis. Nas restantes, notam-se quedas significativas. Em alguns casos, como no que condiz ao capital aplicado, a redução foi superior a 48\%. Percebe-se, assim, que as taxas médias de crescimento do subsetor têxtil paulista no período 1928-1950, apesar de terem sido consideráveis em diversos momentos (1933-1935; 1939-1945; e 1948-1950), foram menores do que as apresentadas pelas indústrias gerais do estado.

Tabela 6.1 - Participação relativa das indústrias têxteis paulistas no agregado fabril estadual (1928 e 1950), em \%

\begin{tabular}{ccc} 
& 1928 & 1950 \\
\hline Estabelecimentos & 3,8 & 6,2 \\
Capital & 42,6 & 21,8 \\
Operários & 45,7 & 29,1 \\
Força Motriz & 34,4 & 21,9 \\
Valor da Produção & 34,0 & 21,2 \\
\hline
\end{tabular}

Fonte: Estatística Industrial do Estado de São Paulo, 1928; e Recenseamento Geral de 1950.

A situação se inverte, porém, quando se faz uma comparação entre as fábricas de tecidos paulistas e suas congêneres domésticas. Vê-se que aquelas aumentaram sua participação de maneira considerável diante destas entre 1928 e 1950 (Tabela 6.2). Antes da Grande Depressão (1929-1932), a liderança exercida pelas empresas paulistas perante suas concorrentes já era mais do que perceptível. Em 1950, no entanto, o cenário não era apenas de dianteira, mas sim de hegemonia. Mais da metade dos estabelecimentos, do 
capital aplicado e do valor de produção têxtil local encontrava-se em São Paulo. Percebese, portanto, que houve aumento da concentração espacial no setor de tecidos doméstico entre 1928 e 1950. Isso se deve, entre outros fatores, ao processo de integração do mercado interno - iniciado nos anos (19)30 - e à política proibitiva de importação de máquinas para o subsetor implementada no período 1931-1937. A indústria têxtil paulista que possuía, em 1928, o maior e melhor parque fabril do País - aproveitou-se da impossibilidade das suas concorrentes regionais modernizarem seus capitais constantes para conquistar seus respectivos mercados. Isso, por sua vez, só foi viável em razão (a) do aumento do comércio de cabotagem local e do fim dos impostos interestaduais; e (b) da pequena concorrência de produtores estrangeiros existente no período.

Tabela 6.2 - Participação das indústrias têxteis paulistas no agregado têxtil nacional (1928 e 1950)

\begin{tabular}{ccc} 
& 1928 & 1950 \\
\cline { 2 - 3 } & & 52,0 \\
Estabelecimentos & 28,6 & 56,1 \\
Capital & 27,3 & 56,9 \\
Operários & 33,5 & 45,9 \\
Falor da Produção & 44,0 & 58,9 \\
\cline { 2 - 2 } Fonte: Estatística Industrial do Estado de São Paulo, 1928; e Recenseamento Geral de 1950.
\end{tabular}

As conseqüências dessa conquista de mercados interestaduais não se refletiram apenas no aumento da participação das empresas de tecidos paulista no agregado têxtil doméstico. Mesmo quando se comparam aquelas com as fábricas internas totais, percebese aumento participativo das primeiras perante as segundas. Houve queda apenas no que se refere à variável força motriz (de 9,43 para 9,33\%, isto é, decréscimo de -1,05\%). Nas demais, observa-se ascensão: estabelecimentos (335\%); capital (6,68\%); operários $(25,4 \%)$; e valor de produção $(55,81 \%$ - Tabela 6.3$)$.

Tabela 6.3 - Participação das indústrias têxteis paulistas no agregado fabril nacional (1928 e 1950)

\begin{tabular}{ccc} 
& 1920 & 1950 \\
\hline Estabelecimentos & 0,40 & 1,73 \\
Capital & 9,09 & 9,70 \\
Força Motriz & 9,43 & 9,33 \\
Operários & 9,01 & 11,30 \\
Valor da Produção & 6,46 & 10,06 \\
\hline
\end{tabular}

Fonte: Estatística Industrial do Estado de São Paulo, 1928; e Recenseamento Geral de 1950.

Os dados da Tabela 6.3 ilustram o quanto o crescimento têxtil paulista foi considerável nos anos (19)30 e (19)40. As fábricas de tecidos do estado apresentaram, nesse período, desempenho superior às indústrias locais agregadas. Não se pode, portanto, 
interpretar a queda de participação relativa sofrida pelo subsetor em São Paulo (Tabela 6.1) como indício de reduzido desenvolvimento. De fato, as empresas paulistas produtoras de bens intermediários e de capital vivenciaram no período ascensões mais significativas do que as do subsetor têxtil. Estas, porém, em termos domésticos, foram altas, como provaram as Tabelas 6.2 e 6.3 .

\section{$\underline{6.2-\text { Os ramos }}$}

Verifica-se que, entre 1928 e 1950, houve mudanças na participação relativa dos ramos têxteis de São Paulo. As fábricas de algodão, apesar de ainda constituírem maioria no subsetor, viram seu domínio decrescer. Em todas as variáveis arroladas na Tabela 6.4, apenas no que se refere ao valor produtivo houve crescimento de participação desse ramo perante o total (10\%). Nas demais, observa-se queda. Destaque, nesse sentido, foi a redução sofrida por tais empresas em termos de capital (-17\%).

Tabela 6.4 - Participação relativa dos ramos têxteis paulistas na indústria têxtil estadual (1928 e 1950), em \%

\begin{tabular}{ccccccccccc} 
& \multicolumn{2}{c}{ Algodão } & \multicolumn{2}{c}{ Juta } & \multicolumn{3}{c}{ Lã } & \multicolumn{2}{c}{ Malha } & \multicolumn{2}{c}{ Seda } \\
& 1928 & 1950 & 1928 & 1950 & 1928 & 1950 & 1928 & 1950 & 1928 & 1950 \\
\hline Estabelecimentos & 31,5 & 28,1 & 2,0 & 0,7 & 5,6 & 6,7 & 42,4 & 20,5 & 18,5 & 43,9 \\
Capital & 64,5 & 53,5 & 12,6 & 2,2 & 4,0 & 9,1 & 6,7 & 4,1 & 12,1 & 31,1 \\
Operários & 60,6 & 56,4 & 13,0 & 3,1 & 4,6 & 8,6 & 10,9 & 6,5 & 10,9 & 25,4 \\
Força Motriz & 74,6 & 60,6 & 10,8 & 3,4 & 5,2 & 7,2 & 3,8 & 2,4 & 5,5 & 26,4 \\
Produção & 43,4 & 47,8 & 11,1 & 3,2 & 10,2 & 11,0 & 12,1 & 6,7 & 23,2 & 31,3 \\
\hline Fontes: Estatistica Industrial do Estado de São Paulo, 1928; e Recenseamento Geral de 1950
\end{tabular}

Os ramos da seda e lanífero apresentaram ascensão participativa, especialmente aquele. Em 1928, menos de $20 \%$ dos estabelecimentos têxteis do estado produziam bens de seda. Duas décadas depois, quase metade das fábricas paulistas pertenciam a ele (Tabela 6.4). As ascensões das demais variáveis também foram significativas: capital (157\%); operários (132\%); força motriz (381\%); e valor de produção (35\%). Já no que condiz aos lanifícios, nota-se que o crescimento da sua participação no total têxtil estadual foi menos considerável. Deve-se destacar, no entanto, sua elevação em termos de capital. Antes da Grande Depressão, o capital do ramo contemplava apenas 4\% do agregado têxtil paulista. Em 1950, tal porcentagem mais que dobrou, atingindo 9,1\%.

Os ramos das malhas e da juta perderam participação relativa no subsetor têxtil estadual. Ambos apresentaram decréscimo em todas as variáveis arroladas. Salienta-se, em 
especial, a queda sofrida pelas empresas jutíferas. Estas, em 1928, encontravam-se em segundo lugar no que se refere ao capital aplicado, número de operários e força motriz. No ano de 1950, porém, o ramo detinha as menores participações em todos os quesitos observados. Vale a pena lembrar que, apesar das imprecisões existentes nos dados da Tabela 6.4 no que condiz às fábricas jutíferas ${ }^{778}$, a queda participativa destas no total têxtil paulista é fato incontestável. As recessões sofridas pelo ramo, especialmente nos anos (19)30, em decorrência da crise do setor agrário-exportador doméstico, que resultaram na falência de importantes empresas - tais como a Companhia Nacional de Tecidos de Juta, em 1934 -, ratificam as inferências proporcionadas pelos dados.

Além dessas transformações, o período 1928-1950 também foi marcado por mudanças nos índices de produtividade e de concentração apresentadas pelo subsetor têxtil paulista. Vê-se que, em todos os ramos, houve aumento da relação capital - fábrica, da composição orgânica do capital e, excetuando-se o caso lanífero, decréscimo da razão trabalho - fábrica (Tabela 6.5). Isso demonstra que, em termos de capital, houve concentração nas empresas de tecidos estaduais. Já no que condiz ao fator trabalho, verifica-se desconcentração. Pode-se explicar esse aparente paradoxo lembrando-se que a taxa de inversão em capital constante das grandes empresas foi provavelmente maior do que a ascensão do número de estabelecimentos no período, especialmente no final dos anos (19)40. Por outro lado, tais fábricas inverteram proporcionalmente menos no que condiz ao capital variável. O número de unidades fabris constituídas no momento, nesse sentido, superou a quantidade de operários contratada pelo subsetor.

Verifica-se, porém, que esse aumento de inversão em termos de capital constante realizado, majoritariamente, pelas empresas de grande porte - foi insuficiente para elevar a produtividade têxtil paulista. A relação trabalho - produto decresceu para todos os ramos, enquanto a razão capital - produto apresentou queda para as empresas de algodão, juta e para as indústrias de tecidos agregadas (Tabela 6.5).

Vê-se, portanto, devido aos decréscimos dos índices de produtividade, que o aumento da concentração de capital nas fábricas têxteis paulistas não significou, majoritariamente, inversões em melhores tipos de maquinário. As elevações no montante de capital do ramo tiveram, provavelmente, em sua maioria, outros destinos, seja acréscimos das reservas fabris, seja imobilização em ativos que pouco ou nada acrescentaram às empresas no que condiz à produtividade no curto prazo (refeitórios, vilas operárias, usinas hidroelétricas, máquinas usadas, etc.).

\footnotetext{
${ }^{778}$ Ver nota ${ }^{\circ} 691$
} 
Tabela 6.5 - Índices de produtividade, de concentração e composição orgânica do capital da indústria têxtil paulista discriminada por ramo (1928 e 1950)

\begin{tabular}{|c|c|c|c|c|c|c|c|c|c|c|c|c|}
\hline & \multicolumn{2}{|c|}{ Algodão } & \multicolumn{2}{|c|}{ Juta } & \multicolumn{2}{|c|}{ Lã } & \multicolumn{2}{|c|}{ Malha } & \multicolumn{2}{|c|}{ Sedas } & \multicolumn{2}{|c|}{ Têxtil Geral } \\
\hline & 1928 & 1950 & 1928 & 1950 & 1928 & 1950 & 1928 & 1950 & 1928 & 1950 & 1928 & 1950 \\
\hline (1) Capital - Fábrica & 3.787 & 8.257 & 12.140 & 12.684 & 759 & 5.895 & 309 & 860 & 1.136 & 3.073 & 1.783 & 3.248 \\
\hline (2) Trabalho - Fábrica & 565 & 238 & 1.278 & 500 & 110 & 153 & 63 & 38 & 113 & 68 & 257 & 92 \\
\hline (3) Capital - Trabalho & 7 & 35 & 10 & 25 & 7 & 39 & 5 & 23 & 8 & 45 & 7 & 35 \\
\hline (4) Capital - Produto & 0,75 & 0,58 & 0,48 & 0,35 & 0,42 & 0,43 & 0,15 & 0,32 & 0,49 & 0,52 & 0,57 & 0,43 \\
\hline (5) Trabalho - Produto & 0,11 & 0,02 & 0,05 & 0,01 & 0,08 & 0,01 & 0,02 & 0,01 & 0,06 & 0,01 & 0,08 & 0,01 \\
\hline
\end{tabular}

Fonte: Estatística Industrial do Estado de São Paulo, 1928; e Recenseamento Geral de 1950.

A citação de alguns dados pode ratificar a hipótese descrita acima. Lembra-se que os períodos correspondentes à vigência do decreto proibitivo da importação de máquinas (1931-1937) e à Segunda Guerra Mundial (1939-1945) dificultaram a modernização do parque têxtil estadual. As consideráveis importações de bens de capital realizadas nos períodos 1937-1939 e 1948-1950, por outro lado, não possibilitaram, nem de longe, uma renovação majoritária do maquinário de tecidos paulista. Prova disso são as inúmeras demandas dos sindicatos patronais têxteis junto ao Governo Federal, no sentido de incentivar a importação de máquinas mediante créditos com juros subsidiados, isenção de tributos e fomento à própria produção doméstica de bens pesados ${ }^{779}$. Além disso, em estudo feito pela CEPAL no ano de 1951, constatou-se a obsolescência do parque têxtil doméstico, notadamente o algodoeiro, e a urgente necessidade de renová-10 ${ }^{780}$.

Em suma, apesar do aumento da concentração em termos de capital, houve desconcentração no que se refere ao fator trabalho e queda dos índices de produtividade nas empresas têxteis paulistas entre 1928 e 1950.

\section{$\underline{6.3-\text { A localização das fábricas }}$}

As fábricas têxteis paulistas apresentaram, além das modificações nos ramos já analisadas, importantes alterações em termos espaciais. Vê-se na Tabela 6.6 que as indústrias do interior aumentaram sua participação no total estadual de maneira notável. A cidade de São Paulo ainda possuía, em 1950, a maior quantidade de estabelecimentos

\footnotetext{
$\overline{779}$ Sobre as demandas do patronato têxtil relativas à necessidade de renovação do maquinário do subsetor mediante incentivos públicos, ver: SIFTRJ. Conclusões da Segunda Convenção da Indústria Têxtil Brasileira, 26.11.1949.

${ }^{780}$ Para maiores informações, ver: United Nations. Economic Commission for Latin America. Productividad de la mano de obra en la industria textil algodonera de cinco países latinoamericanos., Naciones Unidas, Dept. de asuntos Económicos, Nova York, 1951.
} 
têxteis do estado $(55,5 \%)$. Sua hegemonia nessa variável, porém, diminuiu bastante no período 1928-1950 (-25,5\%). Já no que condiz ao número de operários, percebe-se que as regiões interioranas, que detinham 40,4\% dos trabalhadores totais em 1928, concentravam, duas décadas depois, mais de $51 \%$ dos mesmos.

Tabela 6.6 - Estabelecimentos e números de operários dos ramos da indústria têxtil paulista na cidade de São Paulo e interior (1928 e 1950)

\begin{tabular}{c|cc|cc|cc|cc} 
& \multicolumn{4}{|c|}{ Capital } & \multicolumn{4}{c}{ Interior } \\
\hline & \multicolumn{2}{|c|}{ Estabelecimentos } & \multicolumn{2}{|c|}{ Operários } & \multicolumn{2}{c}{ Estabelecimentos } & \multicolumn{2}{c}{ Operários } \\
\hline & 1928 & 1950 & 1928 & 1950 & 1928 & 1950 & 1928 & 1950 \\
\hline Algodão & 50,0 & 29,1 & 46,7 & 29,2 & 50,0 & 70,9 & 55,3 & 70,8 \\
Lã & 85,7 & 76,7 & 66,7 & 88,6 & 14,3 & 23,3 & 33,3 & 11,4 \\
Sedas & 82,9 & 54,6 & 82,7 & 60,0 & 17,1 & 45,4 & 17,3 & 40,0 \\
Malha & 86,8 & 83,0 & 84,3 & 91,9 & 13,2 & 17,0 & 15,6 & 8,1 \\
Total & 74,5 & 55,5 & 59,6 & 48,1 & 25,4 & 44,4 & 40,4 & 51,8 \\
\hline
\end{tabular}

Fonte: Estatística Industrial do Estado de São Paulo, 1928; e Recenseamento Geral de 1950.

Observando-se a questão sob o viés dos ramos, encontram-se situações parecidas. As fábricas de algodão, que já eram numericamente importantes no interior paulista em 1928 (55,3\% dos operários e 50\% dos estabelecimentos), ampliaram sua hegemonia no período 1928-1950. Mais de 70\% dos trabalhadores e das empresas têxteis de algodão estaduais situavam-se em áreas interioranas em 1950. No caso das sedas, houve decréscimo do domínio existente na capital paulista. Vê-se que, em 1928, mais de 80\% dos estabelecimentos e operários do ramo estavam localizados na cidade de São Paulo. No ano de 1950, porém, percebeu-se notável declínio dessa preponderância. O interior do estado já concentrava, naquele período, $45 \%$ das empresas de seda e $40 \%$ dos trabalhadores. No que se refere, por último, aos casos das fábricas laníferas e de malhas, pode-se afirmar que não houve modificações significativas na estrutura espacial delas. As primeiras, por exemplo, apresentaram redução do número de estabelecimentos na cidade de São Paulo entre 1928 e 1950 (de 85,7\% para 66,7\%). Por outro lado, as empresas de lã da capital concentraram mais operários nesse período (66,7\% para 88,6\%). No que condiz às segundas, por sua vez, nota-se que o interior paulista ainda detinha participações muito reduzidas em termos de número de empresas e de operários no ano de 1950. O centro das malharias estaduais manteve-se, portanto, na cidade de São Paulo ao longo do momento estudado.

Não são apenas os dados da Tabela 6.6 que ratificam essa mudança espacial das indústrias de tecidos paulistas entre 1928 e 1950. Na década de 1940 - período caracterizado, entre outras coisas, pelo boom do número de estabelecimentos têxteis no 
estado -, percebe-se que, das sociedades anônimas do subsetor que notificaram sua localização em suas escrituras constitutivas, a maioria encontrava-se ou na chamada Grande São Paulo, ou nas demais regiões interioranas (Tabelas 15 e 15b - Anexos).

Além disso, observam-se muitas empresas têxteis paulistas deslocando parques fabris para o interior do estado nesse período, em especial nos anos (19)40. Maior exemplo desse deslocamento foi o programa de "descentralização têxtil" implementado pelas Indústrias Reunidas Francisco Matarazzo a partir de 1946. Conforme os diretores da empresa, foram instalados teares em Bauru; transferidos 20.000 fusos e 1.000 teares para Ribeirão Preto; criadas tecelagens de seda e rayon em Rio Claro e Ribeirão Preto; ampliaram-se os retorcedores de Campinas e teares também foram transferidos para Caçapava" "781. Dizia-se, ainda, que o objetivo do programa era “(...) o de criar, nos centros urbanos menores, novas fontes de trabalho acessíveis a braços não utilizáveis eficientemente nos campos (...) (grifo nosso)". Leia-se: visava-se, com tal descentralização produtiva, entre outras coisas, diminuir custos com mão-de-obra. Os "braços não utilizáveis" das áreas rurais - isto é, um verdadeiro exército industrial de reserva residente no campo - permitiriam o pagamento de salários menores do que os gastos com os trabalhadores paulistanos ${ }^{782}$.

Vale lembrar que esse processo de descentralização fabril têxtil também podia ser observado nas fábricas paulistas como um todo. Nota-se que as indústrias do interior do estado já superavam as da cidade de São Paulo, em 1950, no que condiz aos estabelecimentos (70,5\%), ao capital aplicado (52,4\%) e à força motriz $(56,4 \%$ - Tabela 6.7). Percebe-se, em especial, a crescente importância da região da Grande São Paulo no que se refere às indústrias paulistas. Mais de $10 \%$ do capital, da força motriz, dos salários pagos aos trabalhadores e do valor de produção concentravam-se nessa área no ano de 1950 (Tabela 6.7). Várias empresas têxteis importantes localizavam-se no entorno da capital paulista. No que condiz ao subsetor têxtil, destacam-se as fábricas produtoras de rayon. Em 1949, mais de $80 \%$ das empresas de seda artificial estavam instaladas na Grande São Paulo ${ }^{783}$, como por exemplo a Cia. Brasileira de Sedas 'Rhodiaseta' (São Bernardo) e a filial das Indústrias Reunidas Francisco Matarazzo (São Caetano).

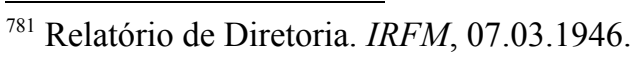

${ }^{782}$ Idem.

${ }^{783}$ Barjas Negri, op. cit., p. 88.
} 
Tabela 6.7 - Indicadores econômicos das indústrias gerais paulistas discriminados por região: Capital, Grande São Paulo (GSP) e Interior do estado (1950), em \%.

\begin{tabular}{ccccc} 
& Capital & GSP & Interior & Total \\
\hline Estabelementos & 29,5 & 3,9 & 70,5 & 100 \\
Capital & 47,6 & 11,2 & 52,4 & 100 \\
Operários & 52,4 & 9,3 & 47,6 & 100 \\
Força Motriz & 43,6 & 12,4 & 56,4 & 100 \\
Salários & 60,3 & 10,2 & 39,7 & 100 \\
Valor produção & 51,7 & 10,9 & 48,3 & 100 \\
\hline
\end{tabular}

Fonte: Recenseamento Geral de 1950.

A descentralização espacial das indústrias paulistas está relacionada a diversos fatores. O menor custo da mão-de-obra rural, como se identificou no relatório da diretoria dos Matarazzo, contemplava apenas um deles. A melhoria da rede de transportes estaduais, a maior proximidade das fontes produtoras de matérias-primas e, especialmente, o surgimento das chamadas "deseconomias de aglomeração" 784 nas metrópoles (neste caso, na cidade de São Paulo) são outros fatores que também ajudam a explicar esse processo de dispersão espacial.

\section{$\underline{6.4-\text { As relações de trabalho }}$}

As relações de trabalho das fábricas de tecidos paulistas também apresentaram algumas modificações durante o período 1928-1950. Alguns aspectos, porém, permaneceram semelhantes aos existentes na década de 1920 .

No que concerne às mudanças, destaca-se, em primeiro lugar, a questão da participação de homens e mulheres na mão-de-obra têxtil estadual. Em 1919, o sexo feminino perfazia mais de $57 \%$ do total dos trabalhadores empregados no subsetor (Tabela 1.8). No ano de 1950, tal porcentagem havia sido reduzida para 33.7\% (Tabela 6.8). Diferentemente da década de 1920, vê-se que a participação das mulheres nas indústrias gerais do estado (31\%), em 1950, diferiu muito pouco da proporção apresentada pelas fábricas de tecidos. Essa modificação relacionou-se, provavelmente, às garantias trabalhistas obtidas por mulheres e menores ao longo dos anos (19)30 e (19)40. Estas, por sua vez, ao aumentar os custos dos trabalhos feminino e infantil, tornaram menos rentáveis

\footnotetext{
${ }^{784}$ Segundo Barjas Negri, entende-se por deseconomias de aglomeração “ (...) um conjunto de variáveis, entre as quais se destacam os maiores custos de transportes, de terrenos, de serviços e de infra-estruturaurbana, incluindo-se outras que provocavam alteração na organização da produção e na sua produtividade, como maiores dispêndios com tempo de transporte, ampliação do poder sindical da classe trabalhadora, questões ambientais, com deterioração das condições de vida nos grandes centros urbanos, etc (...)", as quais tornam mais rentáveis investimentos produtivos em áreas urbanas menores - localizadas no interior - do que nas metrópoles. Para maiores informações, ver: Barjas Negri, op. cit., p. 14-16.
} 
seus usos. Explica-se, assim, a queda do número de operárias nas empresas têxteis de São Paulo. Não há nesse período, por outro lado, estatísticas que permitam discriminar os proletários do subsetor segundo a idade. É bastante provável, no entanto, que o número de menores empregados nas fábricas de tecidos tenha apresentado queda participativa semelhante à das mulheres no interregno estudado.

Em segundo lugar, apesar da inicial resistência burguesa à legislação trabalhista criada na Era Vargas, é inegável que, com sua aplicação, houve melhora das condições de vida do operariado. Isso não significa, porém, que as mesmas pudessem ser consideradas satisfatórias em 1950. Os movimentos grevistas têxteis do final dos anos (19)40 demonstraram, ao contrário, que elas ainda estavam longe desse patamar. Mesmo assim, é importante salientar que a garantia de férias, do salário mínimo, de institutos de seguridade social e de infra-estruturas fabris mais adequadas - em especial, no que se refere à construção de vilas operárias, refeitórios e creches - significaram certa avanço nas condições de trabalho e da produtividade a longo prazo.

Tabela 6.8 - Número de trabalhadores das indústrias gerais e têxteis paulistas discriminados por sexo (1950)

\begin{tabular}{ccccc} 
& Geral & \% Geral & Têxtil & \% Têxtil \\
\hline Homens & 337.175 & 69,0 & 297.672 & 66,3 \\
Mulheres & 151.458 & 31,0 & 151.412 & 33,7 \\
Total & 488.633 & 100,0 & 449.084 & 100,0 \\
\hline \multicolumn{5}{c}{ Fonte: Recenseamento Geral de 1950. }
\end{tabular}

Vários documentos comprovam o cumprimento dessa legislação trabalhista. A efetivação da Lei de Férias, por exemplo, pode ser observada nos próprios balanços das sociedades anônimas, as quais começaram a contabilizar em seus passivos, principalmente a partir da metade dos anos (19)30, os gastos com recessos anuais do seu operariado. A criação da Sociedade Cooperativa de Seguros contra Acidentes de Trabalho 'A TÊXTIL', em 1937, representou o respeito à legislação referente aos acidentes de trabalho. O mesmo se pode dizer com relação ao surgimento do Instituto de Aposentadoria e Pensões dos Industriários no ano de 1936, que estabeleceu contribuições obrigatórias por parte de patrões e empregados fabris no sentido de permitir uma previdência social aos segundos. No que tange à criação de vilas operárias, creches e refeitórios - instalações estas que se tornaram obrigatórias no final dos anos (19)30 para todas empresas que possuíssem mais de quinhentos operários -, pode-se observar sua efetivação nos próprios relatórios de diretoria das empresas têxteis paulistas. O S.A. Moinho Santista, por exemplo, inaugurou 
seus restaurantes em $1946^{785}$. No final da guerra, a Cia. Nacional de Estamparia já havia construído toda sua infra-estrutura social (creches, refeitórios e escolas maternais) ${ }^{786}$. A S.A. Fiação para Malharia Indiana ampliou suas reservas no ano de 1945, visando aumentar a creche da fábrica e instalar uma colônia de férias para os trabalhadores ${ }^{787}$. Exemplos semelhantes podem ser observados nas demais empresas têxteis de grande porte do estado ${ }^{788}$.

Tais benefícios, por outro lado, eram apresentados pela burguesia têxtil como produto da sua solidariedade e consciência social para com os proletários. Negligenciavam-se, nos relatórios patronais, quaisquer referências à obrigatoriedade legal dessas benesses e às resistências burguesas - especialmente na década de 1920 - no que se referia às férias, às limitações ao trabalho da mulher e do menor, entre outros. No primeiro relatório da Sociedade Cooperativa de Seguros contra Acidentes de Trabalho 'A TÊETIL', por exemplo, apresentado em 1938 aos acionistas, alegava-se que, com essa instituição, “(...) quisemos trazer a nossa modesta contribuição para que fosse resolvido um problema social de notável relevância qual (sic) seja o amparo e a assistência ao trabalhador ferido no exercício do seu mister (...) acolhendo as vítimas do trabalho com largo espírito de solidariedade humana (...)”. No final, concluem: “(...) praticamos uma obra social, deixando, pois, em segundo plano, as preocupações econômicas". Da mesma maneira, os diretores da Cia. Nacional de Estamparia mostravam aos acionistas que, no exercício de 1944, "a assistência ao filho do nosso colaborador mereceu, como sempre, particular carinho. Aliás, o nosso organismo nesse ramo de assistência social é perfeito (...)". Segundo a diretoria da empresa, “(...) estaremos bem compensados de todas as despesas e prejuízos motivados pelo fornecimento de alimentos aos nossos colaboradores, com a melhoria das suas condições físicas e, por conseqüência, com a sua melhor aptidão para o trabalho (...)" $)^{9789}$.

Deve-se ressaltar, dos trechos acima, dois aspectos importantes. Em primeiro lugar, a mudança na designação do operário: de trabalhador para "colaborador". A burguesia têxtil ratificava, assim, a concepção corporativista do Estado Novo, isto é, a de que inexistiam no Brasil classes sociais - e, portanto, lutas de classes - e de que capital e

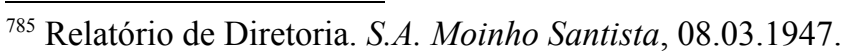

${ }^{786}$ Relatório de Diretoria. Cia. Nacional de Estamparia, 03.02.1945.

${ }^{787}$ Relatório de Diretoria. S.A. Fiação para Malharia Indiana.

${ }^{788}$ Para maiores informações, ver os relatórios de diretoria das Indústrias Reunidas Francisco Matarazzo, da S.A. Fábrica Votorantim, da Cia. Brasileira de Seda 'Rhodiaseta', do Cotonifício Rodolfo Crespi, entre outros.

${ }^{789}$ Relatório de Diretoria. Cia. Nacional de Estamparia, 03.02.1945.
} 
trabalho não podiam ser inimigos, mas sim colaboradores para o engrandecimento do produto social. Em segundo lugar, percebe-se que o cumprimento das leis trabalhistas não se deu apenas em razão do endurecimento da fiscalização governamental e das políticas de controle dos sindicatos operários e das greves por parte do Estado, mas também do próprio interesse patronal em potencializar a "melhor aptidão" dos seus trabalhadores, ou seja, aumentar a produtividade dos operários mediante concessão de melhores refeições e de aprendizado técnico. Entende-se, assim, o porquê da criação do SENAI (Serviço Nacional de Aprendizagem Industrial), em 1942, ter sido tão aplaudida pela burguesia têxtil doméstica ${ }^{790}$.

A concessão desses benefícios sociais acarretou, como conseqüência, crescente domesticação dos movimentos operários pelo Estado. Ao longo dos anos (19)30 e (19)40, observou-se como o controle governamental sobre os sindicatos aumentou. As eleições dos diretores sindicais, por exemplo, passaram a ser, além de supervisionadas por agentes estatais, ratificadas pelo próprio governo. Até os boletins informativos das agremiações trabalhistas tinham de receber o aval do poder público para circularem ${ }^{791}$. No Estado Novo, proibiram-se greves, legalizadas apenas com a redemocratização de 1946. Mesmo assim, durante a administração Dutra, houve forte repressão contra os grupos mais radicais do proletariado doméstico. Esse processo de crescente domesticação dos trabalhadores têxteis paulistas explica, em grande parte, não apenas a aceitação das leis sociais promulgadas pelo Governo Vargas por parte dessa burguesia, mas também a própria estreiteza da relação entre empresários e Estado ao longo desse período.

Por último, no que condiz aos salários, vê-se que a reposição dos ganhos trabalhistas têxteis na década de 1940 foi superior ao custo de vida dos operários paulistanos. Este, entre 1939 e 1950, elevou-se em 335,4\% (Tabela 5.13), enquanto

\footnotetext{
${ }^{790}$ Ver: SIFTRJ. Relatório de Diretoria, 1942. Para maiores informações sobre a criação do SENAI, ver: Sônia Draibe, op. cit., 71 e Renato Perim Colistete. Labour relations and industrial performance in Brazil : Greater São Paulo, 1945-1960. Tese de doutoramento, Oxford, 1998

791 Ver, no que se refere ao controle das eleições sindicais e dos boletins informativos das agremiações trabalhistas: Arquivo DOPS. Carta do presidente do Sindicato dos Operários de Fiação e Tecelagem de São Paulo, Paulo Liteiro, ao Delegado do DOPS, Venâncio Ayres, 18.04.1938; Carta do presidente do Sindicato dos Operários de Fiação e Tecelagem de São Paulo, Melchiades dos Santos, ao $5^{\circ}$ Delegado Auxiliar do DOPS, 13.01.1940; Carta do informante do DOPS junto ao Sindicato dos Operários de Fiação e Tecelagem de Juta ao DOPS, 22.02.1938; Carta do chefe substituto do Departamento Estadual do Trabalho, Adriano Negreiros, ao Superintendente da Segurança Política e Social referente às eleições no Sindicato dos Trabalhadores de Malharias e Meias do Estado de São Paulo, 28.11.1941.
} 
aqueles apresentaram aumento de $411 \%^{792}$. Apesar disso, não se pode daí inferir que os salários dos trabalhadores eram satisfatórios. Além das greves e manifestações do final dos anos (19)40, as quais claramente reivindicavam melhores condições salariais, outros dados ratificam a hipótese da insuficiência dos ganhos proletários têxteis para a manutenção das suas subsistências.

Em 1950, um operário do subsetor de tecidos paulista recebia, em média, Cr\$ 11.000 ao ano (Cr\$ 937,00 / mês $)^{793}$. Para se verificar o poder de compra desse salário, somaram-se os preços de varejo de alguns bens considerados essenciais para a sobrevivência desse trabalhador, a saber: açúcar, arroz, banha, batata, café em pó, carne de vaca, cebola, charque, farinha de mandioca, farinha de trigo, feijão, leite, manteiga, milho, ovos, pão, sal e toucinho. A somatória de apenas um quilograma de cada um desses produtos resultou no valor de $\mathrm{Cr} \$ 173,1^{794}$, isto é, $18,46 \%$ do ganho mensal desse operário. Supondo-se um consumo de $10 \mathrm{~kg}$. / mês da cesta de produtos citada por pessoa ${ }^{795}$ e considerando-se que o número de membros de uma família paulista girava em torno de 4 indivíduos no período, segundo os dados do próprio Censo de 1950, vê-se que o salário do trabalhador têxtil representava apenas 13,53\% desses gastos. Presumindo-se, agora, que todos esses quatro membros trabalhem em uma fábrica de tecidos de São Paulo - e abstraindo-se as diferenças salariais ainda existentes entre homens, mulheres e crianças, cujos dados não são disponíveis para esse momento -, tem-se que tais remunerações somadas representam quase $50 \%$ dos seus gastos alimentícios. Também não há, infelizmente, estimativa das despesas realizadas pelos operários com transportes, habitação e vestuário no período em questão. Mesmo assim, é plausível deduzir que estes não poderiam ser satisfatoriamente contemplados com os apenas $50 \%$ restantes dos salários dessa família. A renda do operário têxtil, portanto, mesmo com os acréscimos salariais ocorridos ao longo dos anos (19)30 e (19)40, ainda se encontrava em patamares insuficientes para sua subsistência em 1950.

\footnotetext{
${ }^{792}$ Recenseamentos Gerais de 1940 e 1950.

${ }^{793}$ Recenseamento Geral de 1950.

${ }^{794}$ Idem.

795 Supôs-se que as estimativas da necessidade de consumo de bens alimentícios realizada pelo DET (Departamento Estadual do Trabalho) no final dos anos (19)10, em termos de quantidade, ainda se mantiveram semelhantes mesmo em 1950. Lembra-se, também, que tal estimativa leva em consideração o maior consumo desses bens por parte dos adultos e o menor por parte das crianças. A avaliação $10 \mathrm{~kg}$. / mês por pessoa é, portanto, apenas uma média. Ver: Boletim do DET. Condições gerais do trabalho na indústria têxtil do Estado de São Paulo. Ano VIII, n. 31 e 32, 2 e 3 trimestres de 1919, s/p.
} 


\section{$\underline{6.5-\text { Conclusões parciais }}$}

A indústria têxtil paulista apresentou significativas modificações no decorrer do período 1928-1950. Dentre estas, destacam-se: (a) a consolidação da hegemonia da indústria de tecidos de São Paulo perante suas concorrentes domésticas; (b) a ocorrência de um processo de descentralização espacial, certa desconcentração produtiva e alterações nas participações relativas dos ramos de tecidos no agregado estadual; e (c), por último, a observação de melhorias nas condições de operariado têxtil - apesar da manutenção de salários insuficientes para a subsistência desse trabalhador -, bem como mudanças nas relações burguesia - Estado, as quais, antes preponderantemente conflituosas, tornaram-se, ao longo desse interregno, cada vez mais amistosas. De um lado, viu-se um empresariado menos reticente com relação às leis trabalhistas; do outro, um Estado que domesticou os movimentos proletários locais, reprimindo duramente aqueles que ainda mantinham projetos de transformação revolucionária da sociedade. 


\section{Conclusão}

Em 1928, a indústria têxtil paulista era hegemônica no parque fabril estadual. Cinco a cada dez operários trabalhavam no subsetor de tecidos em São Paulo. Além disso, ele se caracterizava por forte concentração setorial, produtiva e espacial. Em outras palavras, havia nítido predomínio de um ramo perante os demais (algodoeiro); das grandes empresas em detrimento das médias e pequenas; e das fábricas localizadas na cidade de São Paulo em comparação com as do interior do estado. No que tange às relações de trabalho, percebeu-se, nesse momento, forte relutância da burguesia têxtil em acatar a legislação trabalhista - tais como a Lei de Férias e o Código dos Menores -, bem como condições de vida precárias por parte do operariado, em razão, principalmente, dos salários insuficientes, das altas jornadas, dos acidentes de trabalho, dos maus-tratos realizados pelos mestres e contra-mestres e da falta de higiene nas unidades fabris.

Durante os anos (19)30, houve sensível modificação da estrutura produtiva e das relações de trabalho têxteis no estado. A depressão de 1929-1932 abriu oportunidade para o aprofundamento do processo substitutivo de importações doméstico, incentivando, dessa maneira, o crescimento do subsetor de tecidos paulista. Intensificou-se também, nesse período, a integração do mercado interno local, mediante extinção dos impostos interestaduais e intensificação das ligações domésticas. Criaram-se novas rodovias. O comércio de cabotagem entre as unidades federativas foi intensificado.

Aproveitando-se desse processo de integração, a burguesia têxtil paulista iniciou forte pressão sobre o Estado, visando aprovar - e, depois, manter - a proibição da importação de máquinas para o subsetor de tecidos local. Mediante justificativa de superprodução, as fábricas paulistas, mais bem preparadas em termos técnicos para abastecer o mercado doméstico com produtos mais baratos e de maior qualidade, conseguiram impedir, assim, que suas concorrentes estaduais pudessem reequipar seus respectivos parques fabris. Sem renovação e ampliação suficientes dos seus maquinários, estas empresas não eram páreo para enfrentar o ingresso de bens têxteis paulistas em seus estados. $\mathrm{Na}$ conquista desses mercados regionais residiu outro fator explicativo para o crescimento das empresas têxteis de São Paulo na década de 1930. Estas ampliaram sua hegemonia diante das congêneres nacionais. Por outro lado, a política proibitiva de importação de máquinas - apesar da permissão da substituição dos bens de capital obsoletos por outros modernos de igual capacidade produtiva - manteve o parque têxtil doméstico bastante atrasado em termos tecnológicos. 
Os anos (19)30 também viram o início do processo de desconcentração produtiva, espacial e entre os ramos do subsetor têxtil paulista. Os ramos da lã e das sedas, além de terem sido menos afetados pela Depressão de 1929-1932, apresentaram taxas de crescimento mais expressivas do que as dos demais nesse período. Como a maioria dos lanifícios e das tecelagens de seda eram empresas de pequeno e médio porte, a mudança na participação relativa desses ramos no subsetor gerou reflexos também em termos de concentração industrial. Houve aumento participativo das fábricas menores no que condizia ao capital aplicado, ao número de operários e ao valor produtivo em detrimento das maiores. Por último, percebeu-se também que as empresas têxteis do interior de São Paulo começaram a ganhar espaço perante as paulistanas.

O período correspondente ao conflito mundial (1939-1945) é de crucial importância para se compreender a evolução do subsetor de tecidos paulista na década de 1940. Nele, as fábricas têxteis apresentaram elevadas taxas de crescimento devido à inexistência de concorrência estrangeira no mercado doméstico e às consideráveis vendas para o exterior. As exportações de tecidos de algodão chegaram a representar, nesse momento, o segundo lugar em termos de valores da nossa pauta exportadora.

A impossibilidade de se importar bens intermediários e de capital do estrangeiro em quantidade suficiente, por outro lado, impediu que as fábricas têxteis locais aumentassem sua capacidade produtiva. Sem condições para abastecer toda demanda dos mercados interno e externo, deu-se preferência ao último, em razão dos maiores lucros nele auferidos. Como conseqüência, houve séria escassez de tecidos, acarretando acréscimo nos preços. Para evitar quaisquer tabelamentos, os industriais fecharam acordo com o governo no sentido de se estabelecer a fabricação de têxteis populares, cujas vendas seriam feitas mediante preços subsidiados (Convênio Têxtil). Além disso, aproveitando-se da assinatura de contratos internacionais de abastecimento de tecidos por parte do governo (UNRRA e FCSM), os empresários do subsetor conseguiram embutir o status de "esforço de guerra" às suas fábricas - o que, na prática, legalizava uma intensificação do trabalho dos operários, bem como quaisquer repressões a movimentos de contestação.

O resultado de todo esse intervencionismo estatal foi propiciar ganhos inéditos para o subsetor têxtil paulista. A divulgação dos faustosos lucros das sociedades anônimas contrastava com as recorrentes explicações dos empresários acerca dos porquês dos altos preços dos tecidos domésticos, os quais, segundo eles, se davam em razão do acréscimo dos custos produtivos. Além disso, a baixa qualidade dos itens destinados ao Convênio Têxtil gerou maior insatisfação popular para com o empresariado do subsetor. Eram 
constantes também as reclamações dos compradores internacionais, que se queixavam das fraudes realizadas pelos produtores domésticos no que condizia às quantidades e aos tipos de têxteis exportados. Pululavam, entre 1944 e 1945, críticas nos principais jornais do País contra a ganância e a irresponsabilidade social do empresariado têxtil doméstico.

Com o término do conflito mundial, houve notáveis modificações nesse quadro de prosperidade. A partir de então, além dos problemas relativos à diminuição das exportações e à crescente concorrência estrangeira no mercado doméstico, os empresários de tecidos tiveram também de enfrentar um governo cada vez mais relutante em manter os antigos privilégios do subsetor. Tabelaram-se os preços dos tecidos. Proibiram-se as exportações. A redemocratização política de 1946 explica, de uma certa forma, em razão da necessidade de legitimação social, o porquê do acatamento governamental de antigas demandas da sociedade concernentes ao subsetor têxtil, tais como a questão do tabelamento de preços.

As tendências recessivas apresentadas pelo subsetor têxtil estadual no pós-guerra acabaram a partir de 1948. Um ano antes, em razão dos déficits na Balança de Pagamentos, o Governo Dutra decidiu intervir na economia, implementando forte política discriminatória no que se referia às importações. Protegida novamente da concorrência internacional, ao mesmo tempo em que se mantiveram taxas cambiais favoráveis à compra de máquinas e de bens intermediários, a indústria de tecidos paulista pôde crescer quantitativa e qualitativamente.

No entanto, apesar da importação de bens de capitais têxteis ter sido considerável no interregno 1948-1950, não houve uma modernização completa do obsoleto parque fabril estadual. Ao longo das décadas de 1930 e 1940, a crescente produção de tecidos não foi acompanhada pela elevação e aperfeiçoamento da capacidade produtiva do subsetor. Ao contrário, nos períodos 1931-1937 e 1939-1945, houve impossibilidade de importação de máquinas em quantidades razoáveis para as fábricas têxteis domésticas. Apenas entre os anos de 1937-1939 e 1948-1950, percebe-se forte ingresso de bens de capital, que se deu em proporções nitidamente insuficientes.

Assim, com o esgotamento das reservas acumuladas no período bélico no final dos anos (19)40, as associações patronais têxteis começaram a demandar mais uma vez auxílios governamentais. Pediam-se, entre outros pontos, uma política de créditos especifica para o setor fabril, bem como facilidades cambiais e tarifárias para a importação de máquinas e bens intermediários. Em outras palavras, os mesmos empresários que afirmavam, na década de 1930, que o ingresso de bens de capital estrangeiros aniquilaria o 
subsetor local, imploravam ao Estado, em 1949, a criação de políticas que possibilitassem a reestruturação produtiva das fábricas de tecidos. Agora, porém, o contexto era bem diverso. Parte considerável da opinião pública punha-se contrária a qualquer tipo de subsídio para os empresários têxteis. Além disso, no período 1930-1950, subsetores fabris pesados ganharam importância relativa no agregado industrial doméstico. Fortaleciam-se, nesse sentido, as demandas de outras burguesias fabris no seio do Estado que não a têxtil.

Por outro lado, apesar da obsolescência, a indústria de tecidos paulista obteve hegemonia incontestável entre suas concorrentes locais no período 1928-1950. Mais da metade do número de estabelecimentos, dos capitais aplicados e do valor produtivo têxtil doméstico pertencia ao estado de São Paulo em 1950. Tais fábricas, porém, estavam menos concentradas em termos espacial e setorial do que no período pré-depressivo. $\mathrm{O}$ ramo algodoeiro perdeu espaço. As empresas de seda artificial (rayon), no entanto, apresentaram notável ascensão. As fábricas têxteis paulistanas, por sua vez, foram ultrapassadas pelas do interior, no que tange ao número de operários. E, em termos produtivos, vê-se concentração produtiva nos índices referentes ao capital constante e desconcentração naqueles vinculados ao capital variável.

No que se refere às relações de trabalho, observam-se, entre 1928 e 1950, melhorias significativas das condições de vida dos operários têxteis paulistas. $\mathrm{O}$ respeito às leis trabalhistas por parte da burguesia do subsetor foi a principal responsável por essa melhora. Os salários dos trabalhadores, porém, ainda se mantinham em patamares insuficientes para a subsistência de uma família operária. Além disso, as benesses sociais geraram, em contrapartida, perda de autonomia do movimento sindical, complementado por forte repressão aos trabalhadores que não se enquadrassem no corporativismo varguista.

Tendo em vista as considerações feitas e as hipóteses apresentadas na introdução do trabalho, pode-se, agora, tecer algumas conclusões sobre o objeto pesquisado. Percebese, em primeiro lugar, que o processo substitutivo de importações doméstico ocorrido entre as décadas de 1930 e 1940 não apresentou características homogêneas. O estudo empírico sobre as indústrias têxteis paulistas - a mais importante do País no que se referia ao capital empregado, ao número de operários e ao valor da produção no final dos anos (19)20 - permite dividi-lo em dois períodos: (a) 1929-1939 e (b) 1940-1950.

No primeiro deles, nota-se que, apesar de as indústrias de bens intermediários, de capital e de consumo duráveis terem apresentado forte acréscimo percentual em suas variáveis econômicas, a grande característica foi a expansão dos subsetores fabris leves, 
notadamente o têxtil. Entre 1932 e 1939, a taxa de crescimento geométrica da produção de tecidos locais foi de $13 \%$, enquanto o conjunto da indústria de transformação apresentou ascensão de $10 \%{ }^{796}$. No estado de São Paulo, entretanto, o setor fabril agregado cresceu em ritmo superior; o que, por sua vez, não desqualifica a elevação produtiva vivenciada pelo subsetor têxtil no período. Essas indústrias, ao contrário, mantiveram a mesma parcela do produto fabril do estado entre 1920 e 1940 (31\%), segundo dados do Recenseamento Geral. Quando se compara, por outro lado, o desempenho das fábricas têxteis de São Paulo com as indústrias agregadas domésticas entre as décadas de 1920 e 1930, percebe-se notável acréscimo da participação destas no total do produto e emprego fabris locais.

No segundo período (1940-1950), o processo substitutivo de importações avançou consideravelmente nos setores industriais produtores de bens de capital e de bens intermediários. As taxas geométricas de crescimento do produto e do emprego das fábricas locais agregadas, por exemplo, foram bem maiores do que as apresentadas pelo subsetor doméstico e paulista isoladamente. Entre 1940 e 1950, pela primeira vez, a participação relativa das indústrias de tecidos de São Paulo no total fabril do País diminuiu. Quando se observam apenas os resultados estaduais - que já apresentaram leves quedas em termos de emprego nos anos (19)40 -, vê-se que o decréscimo foi ainda mais abrupto. No que se refere ao produto, por exemplo, o valor de produção têxtil paulista, em 1940, equivalia a $29 \%$ do total fabril estadual; dez anos depois, representava apenas $21 \%$.

Vários fatores explicam essa diferença entre as décadas de 1930 e 1940, no que condiz ao processo de industrialização. Em primeiro lugar, o considerável crescimento do setor de bens de consumo não-duráveis nos anos (19)30, do qual as fábricas têxteis paulistas representavam a parcela mais significativa, resultou da expansão da demanda interna desses produtos. Esta se vinculou não apenas à necessidade de substituição dos bens importados, mas também à própria expansão do mercado local ocorrida no período.

A necessidade de ampliação da capacidade produtiva das indústrias leves, por outro lado, derivada do próprio aumento da demanda doméstica ocorrido na década de 1930, criou estímulos para o fortalecimento de fábricas produtoras de máquinas e demais insumos fabris. Como, em razão do estrangulamento do setor externo, as importações desses produtos não se podiam fazer em quantidades suficientes, a demanda não-satisfeita deveria provir da economia local. A existência de parcas indústrias de base no País, porém, impossibilitaram uma oferta adequada dos produtos por elas fabricados. Para as

\footnotetext{
${ }^{796}$ Paul Singer. Interpretação do Brasil, op. cit., p. 217.
} 
indústrias de bens de consumo não-duráveis - e os dados empíricos relativos às fábricas têxteis paulistas demonstraram que elas se enquadraram nisso -, a saída foi a adoção de funções produtivas que priorizavam a diminuição da composição orgânica do capital. Não se pode, dessa maneira, interpretar os altos incrementos percentuais das indústrias de base nos anos (19)30 como indício de que o processo substitutivo de importações local foi capitaneado, desde então, pelos setores ditos pesados. Observando-se as variáveis econômicas em termos absolutos, percebe-se que estes incrementos foram ínfimos perto da ascensão produtiva dos setores leves, notadamente o têxtil paulista. Mesmo em termos relativos, como se viu, este só apresentou taxas menores quando compararas às fábricas gerais do estado, mas não às indústrias agregadas locais.

Nos anos (19)40, diferentemente, o crescimento dos setores de base suscitou um genuíno processo de industrialização. Propiciaram-se, pela primeira vez, condições mínimas para uma auto-reprodução do capital fixo local. Os fatores fundamentais dessa modificação foram (a) a ocorrência da Segunda Guerra Mundial, que aprofundou a substituição de importações de bens de capital e de intermediários no País; (b) a política econômica implementada pelo Estado Novo ao longo do conflito e pelo Governo Dutra a partir de 1947, que priorizaram incentivos a tais setores; e (c) a própria manutenção dos efeitos endógenos derivados da expansão da demanda interna por bens de consumo, já evidenciada na década anterior.

Além desses aspectos, o estudo empírico sobre a indústria têxtil paulista demonstrou também que, nos anos (19)30, o subsetor vivenciou certas transformações que só seriam percebidas nitidamente no setor fabril doméstico a partir da metade do século XX. A concentração fabril no estado de São Paulo, por exemplo, foi um fenômeno que, pelo menos que se refere às fábricas de tecidos, já se processava de maneira intensa na década de 1930. Não há dúvida de que a integração mercantil nacional e a política proibitiva da importação de máquinas de tecidos foram fundamentais para a ocorrência dessa transformação. Da mesma maneira, o processo de desconcentração fabril espacial que caracterizou a indústria paulista da metade para o final do século XX - já era perceptível no subsetor têxtil paulista entre as décadas de 1930 e 1940.

No que se refere à problemática das condições de trabalho, explica-se a concessão de melhorias salariais aos operários têxteis nesse período - agregada às demais conquistas trabalhistas - não apenas em função do objetivo governamental de controlar o movimento proletário, mas também devido à necessidade de adequar a estrutura da demanda doméstica com o tipo de produção das indústrias locais. Em outras palavras, “(...) como os 
bens produzidos (pelas fábricas) seguem sendo de consumo generalizado (...), a produção e a realização de um maior excedente interno e a ampliação do consumo dos trabalhadores não só são compatíveis como necessárias. Nesse sentido, vão em favor da dinâmica de acumulação (...) as políticas salarial e assistencial de corte populista"797.

Como se viu, entretanto, as melhorias salariais obtidas pelos operários têxteis nas décadas de 1930 e 1940 não significaram, nem de perto, obtenção de condições de vida satisfatórias para a classe. As constantes demandas por aumentos remuneratórios no final dos anos (19)40 são bastante demonstrativas desse aspecto. Dessa maneira, os problemas de realização vivenciados pela indústria têxtil paulista entre 1929-1932, 1938-1939 e 1945-1947 evidenciavam, entre outros pontos, a inadequação da estrutura da procura doméstica para o consumo de toda capacidade produtiva de bens-salários das fábricas locais.

Fazia-se necessário, portanto, uma modificação do próprio padrão de acumulação têxtil, que permitisse uma relação mais sustentável entre a estrutura produtiva setorial e a distribuição social da renda - esta de natureza historicamente desigual. Em outras palavras, tornava-se premente utilizar parte da capacidade produtiva para fabricar tecidos de luxo, capazes de suprir a demanda das classes ricas. Essa procura, antes satisfeita mediante importações, passou a ser direcionada para o mercado local em razão das dificuldades financeiras domésticas pós-crise de 1929. É com base nesse prognóstico que se deve compreender as modificações nas participações relativas no interior do subsetor têxtil paulista durante as décadas de 1930 e 1940. O crescimento das fábricas produtoras de tecidos de algodão finos, de lã e, especialmente, das de seda devem, portanto, ser contextualizadas em algo mais amplo do que uma aparente mudança entre ramos.

Com essa mudança no padrão de acumulação, observa-se, novamente, uma antecipação da tendência por parte das fábricas têxteis paulistas. Nestas, já nos anos (19)30, evidenciava-se uma característica que só seria vislumbrada na formação industrial brasileira a partir da metade da década de 1950 - especialmente após a administração Juscelino Kubitschek (1956-1961) -, a saber: um padrão de acumulação industrial assentado em bens de luxo para consumo de capitalistas e classes médias altas urbanas.

O peso da participação relativa do subsetor têxtil de São Paulo no agregado industrial doméstico é, talvez, o principal fator explicativo para esse processo de

${ }^{797}$ Maria da Conceição Tavares. Distribuição de renda, acumulação e padrões de industrialização. In: Ricardo Tolipan e Arthur Carlos Tinelli. A controvérsia sobre distribuição de renda e desenvolvimento. Zahar Editores, Rio de Janeiro, 1975, p. 58. 
antecipação de tendências. A hipótese levantada no início do trabalho - a de que um estudo das fábricas de tecidos paulistas entre as décadas de 1930 e 1940 seria essencial para a compreensão das transformações estruturais vividas pelo setor no período, em razão de seu peso participativo no todo fabril - sugere-se, portanto, confirmada. 


\section{$\underline{\text { Anexos }}$}

Tabela 1A - Deflator implícito do PIB fixo (1919=100)

\begin{tabular}{cccccccccccc}
1928 & 1929 & 1930 & 1931 & 1932 & 1933 & 1934 & 1935 & 1936 & 1937 & 1938 & 1939 \\
\hline 148,1 & 156,2 & 127,7 & 116,6 & 113,6 & 111,1 & 112,6 & 114,9 & 138,2 & 162,1 & 161,2 & 157,6 \\
& & & & & & & & & & & \\
1940 & 1941 & 1942 & 1943 & 1944 & 1945 & 1946 & 1947 & 1948 & 1949 & 1950 & \\
\hline 165,8 & 186,3 & 206,8 & 253,9 & 288,7 & 360,9 & 413,6 & 413,6 & 413,6 & 413,6 & 413,6 &
\end{tabular}

Fonte: C. Haddad. Crescimento do produto real brasileiro (1900-1947),p. 147-148. In: Flávio Rebelo Versiani e José Mendonça de Barros (org.). Formação econômica do Brasil. A experiência da industrialização. Ed.

Saraiva. São Paulo, 1977; e M. P. ABREU. A Ordem do Progresso, p. 388-412.

Tabela 1 - Indústria geral paulista (1928-1937)

\begin{tabular}{cccccccccc} 
& 1928 & 1929 & 1930 & 1931 & 1932 & 1933 & 1934 & 1935 \\
\hline Número de Fábricas & 6.923 & 8.842 & 5.388 & 5.748 & 6.070 & 6.555 & 8.575 & 7.840 & 8 \\
K - Total (1) & 1.101 .823 & 1.355 .153 & 1.477 .490 & 1.486 .454 & 1.589 .749 & 1.906 .482 & 2.911 .700 & 3.188 .533 & 2.2 \\
K - Total (2) & 743.972 & 867.576 & 1.157 .001 & 1.274 .832 & 1.399 .427 & 1.716 .005 & 2.585 .879 & 2.775 .050 & 1.6 \\
Operários & 148.376 & 138.002 & 119.296 & 147.370 & 150.808 & 171.667 & 202.900 & 213.668 & 22 \\
Força Motriz (H.P.) & 181.076 & 190.074 & 189.499 & 211.731 & 192.159 & 212.108 & 231.871 & 237.509 & 25 \\
Produção (1) & 2.441 .436 & 2.368 .774 & 1.864 .294 & 1.954 .142 & 1.944 .987 & 2.060 .363 & 2.346 .699 & 2.918 .657 & 3.1 \\
Produção (2) & 1.648 .505 & 1.516 .501 & 1.459 .901 & 1.675 .937 & 1.712 .136 & 1.854 .512 & 2.084 .102 & 2.540 .171 & 2.3
\end{tabular}

Fonte: Estatística Industrial do Estado de São Paulo, 1928-1937.; (1) contos; (2) contos deflacionados (contos - D).

Tabela 2 - Indústria têxtil paulista (1928-1939)

\begin{tabular}{|c|c|c|c|c|c|c|c|c|c|c|}
\hline & 1928 & 1929 & 1930 & 1931 & 1932 & 1933 & 1934 & 1935 & 1936 & 1937 \\
\hline Número de Fábricas & 264 & 356 & 450 & 468 & 470 & 510 & 561 & 552 & 589 & 608 \\
\hline K Total (1) & 468.955 & 576.709 & 492.617 & 476.771 & 469.037 & 557.411 & 862.461 & 954.469 & 922.601 & 962.087 \\
\hline K Total (2) & 316.648 & 369.212 & 385.761 & 408.895 & 412.885 & 501.720 & 765.951 & 830.695 & 667.584 & 593.514 \\
\hline Operários & 67.810 & 48.351 & 49.015 & 60.320 & 61.762 & 71.511 & 76.617 & 82.169 & 86.192 & 89.358 \\
\hline Força Motriz (H.P.) & 62.259 & 71.906 & 71.960 & 78.357 & 77.140 & 82.151 & 86.766 & 89.453 & 91.235 & 100.605 \\
\hline Produção (1) & 829.105 & 687.209 & 591.041 & 543.849 & 603.249 & 691.979 & 803.895 & 914.885 & 959.435 & 1.102 .882 \\
\hline
\end{tabular}

Fonte: Estatística Industrial do Estado de São Paulo, 1928-1939.; (1) contos; (2) contos deflacionados (contos - D);

* dado não-disponível (símbolo válido para as demais tabelas).

Tabela 3 - Indústria têxtil algodoeira paulista (1928-1939)

\begin{tabular}{ccccccccccc} 
& 1928 & 1929 & 1930 & 1931 & 1932 & 1933 & 1934 & 1935 & 1936 & 1937 \\
\hline Número de Fábricas & 82 & 112 & 119 & 113 & 112 & 114 & 124 & 118 & 118 & 129 \\
K Total (1) & 310.538 & 372.084 & 279.701 & 264.293 & 248.580 & 276.537 & 473.801 & 583.807 & 545.685 & 516.281 \\
K Total (2) & 209.681 & 238.210 & 219.030 & 226.666 & 218.820 & 248.908 & 420.782 & 508.100 & 394.852 & 318.495 \\
Operários & 46.359 & 29.284 & 25.863 & 35.452 & 37.386 & 42.939 & 47.285 & 52.052 & 52.319 & 52.105 \\
Força Motriz (H.P.) & 46.882 & 53.842 & 50.163 & 53.087 & 51.194 & 53.248 & 56.503 & 63.478 & 63.018 & 66.198 \\
Produção (1) & 413.327 & 298.068 & 277.625 & 205.012 & 245.021 & 301.413 & 394.341 & 418.118 & 441.762 & 464.675 \\
Produção (2) & 279.086 & 190.825 & 217.404 & 175.825 & 215.688 & 271.299 & 350.214 & 363.897 & 319.654 & 286.659 \\
Produção (3) & 191.139 & 149.034 & 135.314 & 181.514 & 200.592 & 232.012 & 278.490 & 273.112 & 296.249 & 287.220 \\
Teares & 22.823 & 24.900 & 26.100 & 24.900 & 24.900 & 25.683 & $*$ & $*$ & $*$ & $*$ \\
Fusos & 730.844 & 825.500 & 816.800 & 822.900 & 803.500 & 814.450 & $*$ & $*$ & $*$ & $*$ \\
\hline
\end{tabular}

Fonte: Estatística Industrial do Estado de São Paulo, 1928-1939.; (1) contos; (2) contos deflacionados (contos - D); e (3) 1.000 metros 
Tabela 4 - Indústria têxtil da juta paulista (1928-1939)

\begin{tabular}{cccccccccccc} 
& 1928 & 1929 & 1930 & 1931 & 1932 & 1933 & 1934 & 1935 & 1936 & 1937 & 1938 \\
\hline Número de Fábricas & 5 & 7 & 9 & 10 & 11 & 11 & 13 & 10 & 11 & 11 & $*$ \\
K Total (1) & 60.700 & 72.747 & 54.315 & 52.510 & 51.702 & 100.220 & 142.617 & 36.604 & 41.294 & 45.574 & $*$ \\
K Total (2) & 40.986 & 46.573 & 42.533 & 45.034 & 45.512 & 90.207 & 126.658 & 31.857 & 29.880 & 28.115 & $*$ \\
Operários & 6.390 & 6.268 & 6.617 & 6.630 & 5.223 & 5.491 & 5.618 & 4.351 & 4.150 & 4.822 & 6.241 \\
Força Motriz (H.P.) & 7.085 & 7.786 & 7.984 & 8.498 & 8.382 & 8.453 & 8.819 & 4.603 & 4.579 & 4.936 & $*$ \\
Produção (1) & 126.919 & 76.527 & 59.276 & 45.214 & 51.573 & 43.842 & 46.398 & 56.783 & 44.834 & 69.083 & $*$ \\
Produção (2) & 85.698 & 48.993 & 46.418 & 38.777 & 45.399 & 39.462 & 41.206 & 49.419 & 32.441 & 42.618 & $*$ \\
Produção (3) & 62.808 & & 39.517 & 37.645 & 42.933 & 43.171 & 50.675 & 45.395 & 34.498 & 44.042 & $*$ \\
\hline
\end{tabular}

Fonte: Idem Tabela 3.

Tabela 5 - Indústria têxtil de malhas paulista (1928-1939)

\begin{tabular}{lrrrrrrrrrrr} 
& 1928 & 1929 & 1930 & 1931 & 1932 & 1933 & 1934 & 1935 & 1936 & 1937 & 1938 \\
\hline Número de Fábricas & 114 & 151 & 138 & 149 & 133 & 130 & 131 & 114 & 111 & 115 & 139 \\
K Total (1) & 35.188 & 38.744 & 33.447 & 24.687 & 23.409 & 33.266 & 40.768 & 43.659 & 42.568 & 52.895 & $*$ \\
K Total (2) & 23.760 & 24804 & 26192 & 21172 & 20607 & 29942 & 36206 & 37997 & 30802 & 32631 & $*$ \\
Operários & 7.167 & 5.292 & 4.660 & 4.961 & 4.762 & 5.314 & 5.527 & 5.447 & 5.478 & 5.924 & 4.350 \\
Força Motriz (H.P.) & 2.864 & 2.771 & 2.068 & 2.557 & 1.516 & 1.652 & 1.932 & 1.978 & 1.599 & 1.608 & $*$ \\
Produção (1) & 84.703 & 83.197 & 53.641 & 49.190 & 48.510 & 59.509 & 61.975 & 64.618 & 66.349 & 78.295 & $*$ \\
Produção (2) & 57.193 & 53263 & 42005 & 42187 & 42702 & 53563 & 55040 & 56238 & 48009 & 48300 & $*$ \\
Produção (3) & $*$ & $*$ & 15.184 & 22.114 & 18.796 & 26.441 & 26.519 & 24.079 & 28.137 & 22.574 & $*$ \\
\hline
\end{tabular}

Fonte: Idem Tabela 3.

Tabela 6 - Indústria têxtil lanífera (1928-1939)

\begin{tabular}{lrrrrrrrrrrr} 
& 1928 & 1929 & 1930 & 1931 & 1932 & 1933 & 1934 & 1935 & 1936 & 1937 & 1938 \\
\hline Número de Fábricas & 21 & 20 & 21 & 21 & 20 & 18 & 21 & 19 & 18 & 21 & $*$ \\
K Total (1) & 15.935 & 23.225 & 20.757 & 23.757 & 20.177 & 20.963 & 28.480 & 36.990 & 33.203 & 35.504 & $*$ \\
K Total (2) & 10.760 & 14.869 & 16.255 & 20.375 & 17.761 & 18.869 & 25.293 & 32.193 & 24.025 & 21.903 & $*$ \\
Operários & 2.302 & 2.219 & 2.586 & 2.650 & 3.247 & 4.367 & 4.625 & 4.093 & 5.644 & 4.684 & 6.677 \\
Força Motriz (H.P.) & 2.611 & 3.774 & 3.191 & 3.413 & 3.423 & 3.957 & 4.717 & 3.573 & 4.421 & 3.999 & $*$ \\
Produção (1) & 108.240 & 70.145 & 52.594 & 111.727 & 114.708 & 61.530 & 64.403 & 69.032 & 75.147 & 84.154 & $*$ \\
Produção (2) & 73.086 & 44.907 & 41.186 & 95.821 & 100.975 & 55.383 & 57.196 & 60.080 & 54.376 & 51.915 & $*$ \\
Produção (3) & 4.330 & $*$ & 2.889 & 4.271 & 4.318 & 4.230 & 5.048 & 4.192 & 4.427 & 4.358 & $*$ \\
\hline
\end{tabular}

Fonte: Idem Tabela 3.

Tabela 7 - Indústria têxtil de seda (natural e artificial) - 1928-1939

\begin{tabular}{lrrrrrrrrr} 
& 1928 & 1929 & 1930 & 1931 & 1932 & 1933 & 1934 & 1935 & 1936 \\
\hline Número de Fábricas & 42 & 66 & 63 & 63 & 74 & 105 & 129 & 141 & 176 \\
K Total (1) & 46.594 & 69.909 & 63.619 & 65.696 & 71.677 & 71.888 & 100.175 & 157.040 & 164.821 \\
K Total (2) & 31.461 & 44.756 & 49.819 & 56.343 & 63.096 & 64.706 & 88.965 & 136.675 & 119.263 \\
Operários & 5.592 & 5.288 & 5.700 & 6.662 & 6.592 & 7.714 & 8.037 & 10.142 & 12.074 \\
Força Motriz (H.P.) & 2.817 & 3.961 & 3.639 & 4.395 & 4.456 & 5.857 & 7.240 & 8.399 & 10.439 \\
Produção (1) & 95.916 & 159.272 & 115.669 & 67.686 & 79.071 & 139.745 & 148.339 & 202.777 & 214.683 \\
Produção (2) & 64.764 & 101.967 & 90.579 & 58.050 & 69.605 & 125.783 & 131.740 & 176.481 & 155.342 \\
Produção (3) & $173.157(5)$ & $291.560(5)$ & 317.358 & 354.256 & 443.367 & 966.891 & 1.247 .444 & 1.650 .570 & \\
Produção (4) & $*$ & $*$ & $*$ & $*$ & $*$ & 22.017 & 19.781 & 25.541 & 24.036 \\
\hline
\end{tabular}

Fonte: Estatística Industrial do Estado de São Paulo, 1928-1939 - (1) contos; (2) contos deflacionados (contos - D); e (3) quilos; (4) 1.000 metros; (5) calculado estatisticamente mediante uso da variável força motriz (0,94 índice de correlação)

Tabela 8 - Indústria têxtil paulista geral e discriminada por ramo (1943) 


\begin{tabular}{c|cccccc|} 
& \multicolumn{7}{|c|}{1943} \\
& Geral (4) & Algodão & Juta & Lã & Malha & Seda Art. /Nat. \\
\hline Número de Fábricas & 1.025 & 183 & 21 & 47 & 161 & 315 \\
K Total (1) & 1.104 .200 & 512.108 & 46.835 & 87.254 & 66.056 & 271.366 \\
K Total (2) & 700.635 & 324.942 & 29.718 & 55.364 & 41.914 & 172.187 \\
Operários & 117.542 & 58.921 & 5.602 & 10.659 & 6.697 & 23.530 \\
Energia (3) & 232.552 & 130.528 & 7.441 & 17.642 .639 & 2.466 & 56.314 .185 \\
Produção (1) & 1.994 .605 & 1.618 .098 & 135.711 & 539.614 & 214.680 & 1.088 .911 \\
Produção (2) & 1.265 .612 & 1.026 .712 & 86.111 & 342.395 & 136.218 & 690.933 \\
\hline
\end{tabular}

Tabela 8 (cont.) - Indústria têxtil paulista geral e discriminada por ramo (1944)

\begin{tabular}{c|cccccc|} 
& \multicolumn{7}{|c|}{1944} & & \\
& Geral & Algodão & Juta & Lã & Malha & Seda Art. /Nat. \\
\hline Número de Fábricas & 1.154 & 189 & 23 & 61 & 168 & 354 \\
K Total (1) & 1.874 .268 & 673.882 & 130.996 & 154.276 & 87.415 & 442.452 \\
K Total (2) & 1.130 .439 & 406.443 & 79.008 & 93.049 & 52.723 & 266.859 \\
Operários & 125.624 & 54.686 & 6.770 & 12.249 & 7.511 & 26.680 \\
Energia (3) & 306.726 & 147.257 & 5.225 & 19.435 .331 & 3.809 & 84.287 .459 \\
Produção (1) & 7.763 .109 & 1.775 .262 & 271.645 & 778.842 & 308.765 & 1.479 .194 \\
Produção (2) & 4.682 .213 & 1.070 .725 & 163.839 & 469.748 & 186.227 & 892.156 \\
\hline
\end{tabular}

Fonte: Estatística Industrial do Estado de São Paulo, 1943-1944 - (1) Cr\$1.000; (2) Cr\$1.000 deflacionado; (3) 1.000 Kwh; (4) As Estatísticas de 1943 e 1944 agregaram os dados da indústria paulista de maneira distinta das demais. Assim, para que uma comparação com os dados da Estatística de 1938-1939 fosse minimamente possível, não foram somados, nestes dados gerais, os seguintes ramos da subdivisão indústria têxtil: i) beneficiamento de algodão; ii) beneficiamento de outras fibras (exclusive algodão); iii) botões, fivelas, fechos e semelhantes; iv) curtientes; v) curtimento de couros e peles; vi) fôrmas para chapéus, solas para tamancos e semelhantes; vii) solas e saltos de borracha para calçados; viii) acessórios para sapataria. Por outro lado, foram somados da subdivisão indústria de embalagens: i) sacaria de algodão; ii) fiação, tecelagem e sacaria de juta; iii) barbantes, cordas e semelhantes. Também foram somados da subdivisão indústria de artigos de limpeza e toucador: i) vassouras, espanadores e semelhantes; ii) escovas e pincéis para toucador; e, por último, da subdivisão indústria do vestuário:i) meias e roupas de malha. 
Tabela $8 b$ - Indústria têxtil paulista geral e discriminada por ramo (1950)

\begin{tabular}{|c|c|c|c|c|c|c|}
\hline & Estabelecimentos & Capital (1) & Operários & Salários (1) & Força Motriz (2) & Valor produç: \\
\hline \multicolumn{7}{|l|}{ Algodão } \\
\hline Fiação & 46 & 738.620 & 11.642 & 122.350 & 25.255 & \\
\hline Tecelagem & 181 & 193.150 & 6.489 & 61.549 & 9.443 & \\
\hline Fiação e tecelagem & 66 & 1.481 .722 & 50.919 & 554.816 & 92.110 & 2.8 \\
\hline Sacaria & 13 & 113.222 & 3.782 & 44.681 & 5.504 & 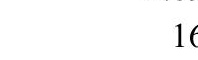 \\
\hline Total & 306 & 2.526 .714 & 72.832 & 783.396 & 132.312 & 4.32 \\
\hline Participação relativa (\%) & 28,1 & 53,5 & 56,4 & 53,2 & 60,6 & \\
\hline \multicolumn{7}{|l|}{ Seda natural e artificial } \\
\hline Fiação seda natural & 12 & 8.266 & 647 & 3.976 & 544 & \\
\hline Tecelagem seda natural & 15 & 25.333 & 637 & 8.516 & 958 & \\
\hline Fiação seda artificial & 5 & 672.329 & 9.020 & 123.377 & 29.827 & \\
\hline Tecelagem seda artificial & 446 & 762.977 & 22.418 & 262.815 & 26.364 & 1.91 \\
\hline Total & 478 & 1.468 .905 & 32.722 & 397.066 & 57.693 & \\
\hline Participação relativa (\%) & 43,9 & 31,1 & 25,4 & 27,0 & 26,4 & \\
\hline \multicolumn{7}{|l|}{ Lã } \\
\hline Fiação & 21 & 296.392 & 6.995 & 97.653 & 10.354 & \\
\hline Tecelagem & 52 & 133.941 & 4.141 & 62.481 & 5.449 & \\
\hline Total & 73 & 430.333 & 11.136 & 160.134 & 15.803 & \\
\hline Participação relativa (\%) & 6,7 & 9,1 & 8,6 & 10,9 & 7,2 & \\
\hline Malha & 223 & 191.745 & 8.388 & 88.398 & 5.201 & \\
\hline Participação relativa (\%) & 20,5 & 4,1 & 6,5 & 6,0 & 2,4 & \\
\hline Juta & 8 & 101.473 & 3.996 & 42.592 & 7.495 & 28 \\
\hline Participação relativa (\%) & 0,7 & 2,2 & 3,1 & 2,9 & 3,4 & \\
\hline Outros & 455 & 292.345 & 12.973 & 126.402 & 30.324 & 2.71 \\
\hline Total Geral & 1.088 & 4.719 .170 & 129.074 & 1.471 .586 & 218.504 & 9.0 \\
\hline \% Total geral do subsetor têxtil & 70,5 & 94,2 & 90,9 & 92,1 & 87,8 & \\
\hline
\end{tabular}


Tabela 9 - Indústria têxtil paulista discriminada por tamanho e ramo (1928)

\begin{tabular}{|c|c|c|c|c|c|c|c|}
\hline & Pequeno & Peq $(\%)$ & Médio & Med (\%) & Grande & Gde. (\%) & Total \\
\hline \multicolumn{8}{|l|}{ Geral } \\
\hline Fábricas & 157 & 59,7 & 73 & 27,8 & 33 & 12,5 & 263 \\
\hline Capital & 35.047 & 7,5 & 106.080 & 22,6 & 327.831 & 69,9 & 468.958 \\
\hline Operários & 4.903 & 7,6 & 13.877 & 21,6 & 45.543 & 70,8 & 64.323 \\
\hline \multicolumn{8}{|l|}{ Algodão } \\
\hline Fábricas & 22 & 26,8 & 34 & 41,5 & 26 & 31,7 & 82 \\
\hline Capital & 9.624 & 3,1 & 57.738 & 18,6 & 243.179 & 78,3 & 310.541 \\
\hline Operários & 883 & 2,1 & 6.578 & 15,3 & 35.598 & 82,7 & 43.059 \\
\hline \multicolumn{8}{|l|}{ Juta } \\
\hline Fábricas & 0 & 0,0 & 2 & 40,0 & 3 & 60,0 & 5 \\
\hline Capital & 0 & 0,0 & 2.100 & 3,5 & 58.600 & 96,5 & 60.700 \\
\hline Operários & 0 & 0,0 & 303 & 4,7 & 6.087 & 95,3 & 6.390 \\
\hline \multicolumn{8}{|l|}{ Malha } \\
\hline Fábricas & 97 & 85,1 & 16 & 14,0 & 1 & 0,9 & 114 \\
\hline Capital & 13.198 & 37,5 & 20.990 & 59,7 & 1.000 & 2,8 & 35.188 \\
\hline Operários & 2.498 & 34,9 & 3.362 & 46,9 & 1.307 & 18,2 & 7.167 \\
\hline \multicolumn{8}{|l|}{ Lã } \\
\hline Fábricas & 11 & 52,4 & 10 & 47,6 & 0 & 0,0 & 21 \\
\hline Capital & 3.235 & 20,3 & 12.700 & 79,7 & 0 & 0,0 & 15.935 \\
\hline Operários & 323 & 14,0 & 1.979 & 86,0 & 0 & 0,0 & 2.302 \\
\hline \multicolumn{8}{|c|}{ Seda Natural e Art. } \\
\hline Fábricas & 27 & 65,9 & 11 & 26,8 & 3 & 7,3 & 41 \\
\hline Capital & 8.990 & 19,3 & 12.552 & 26,9 & 25.052 & 53,8 & 46.594 \\
\hline Operários & 1.199 & 21,4 & 1.655 & 29,6 & 2.738 & 49,0 & 5.592 \\
\hline
\end{tabular}

Fonte: Estatística Industrial do Estado de São Paulo, 1928. Pequeno estabelecimento - Até 99 operários; médio estabelecimento - de 100 até 499 operários; grande estabelecimento - de 500 a mais operários (mesmos critérios foram utilizados para as Tabelas $9 \mathrm{~b}, 9 \mathrm{c}$ e $9 \mathrm{~d}$ ). 
Tabela 9b - Indústria têxtil paulista discriminada por tamanho e ramo (1932)

\begin{tabular}{cccccccc} 
& Pequeno & Peq (\%) & Médio & Med (\%) & Grande & Gde. (\%) & Total \\
\cline { 2 - 8 } Geral & & & & & & & \\
Fábricas & 234 & 69,85 & 72 & 21,49 & 29 & 8,66 & 335 \\
Capital & 52.725 & 12,98 & 129.693 & 31,94 & 223.694 & 55,08 & 406.112 \\
Operários & 6.358 & 11,51 & 18.091 & 32,76 & 30.777 & 55,73 & 55.226 \\
Algodão & & & & & & & \\
Fábricas & 45 & 41,28 & 44 & 40,37 & 20 & 18,35 & 109 \\
$\quad$ Capital & 12.079 & 4,89 & 97.361 & 39,42 & 137.522 & 55,69 & 246.962 \\
Operários & 1.534 & 4,19 & 12.119 & 33,13 & 22.923 & 62,67 & 36.576 \\
Juta & & & & & & & \\
$\quad$ Fábricas & 3 & 27,27 & 4 & 36,36 & 4 & 36,36 & 11 \\
$\quad$ Capital & 480 & 0,93 & 4.622 & 8,94 & 46.600 & 90,13 & 51.702 \\
Operários & 175 & 3,35 & 972 & 18,61 & 4.076 & 78,04 & 5.223 \\
Malha & & & & & & & \\
$\quad$ Fábricas & 119 & 92,97 & 9 & 7,03 & 0 & 0,00 & 128 \\
$\quad$ Capital & 18.581 & 69,90 & 8.000 & 30,10 & 0 & 0,00 & 26.581 \\
Operários & 2.471 & 54,20 & 2.088 & 45,80 & 0 & 0,00 & 4.559 \\
Lã & & & & & & & \\
$\quad$ Fábricas & 9 & 50,00 & 7 & 38,89 & 2 & 11,11 & 18 \\
$\quad$ Capital & 6.357 & 32,47 & 5.420 & 27,69 & 7.800 & 39,84 & 19.577 \\
Operários & 376 & 11,58 & 1.809 & 55,71 & 1.062 & 32,71 & 3.247 \\
Seda Natural e Art. & & & & & & & \\
Fábricas & 58 & 84,06 & 8 & 11,59 & 3 & 4,35 & 69 \\
Capital & 15.228 & 24,85 & 14.290 & 23,32 & 31.772 & 51,84 & 61.290 \\
Operários & 1.802 & 32,06 & 1.103 & 19,62 & 2.716 & 48,32 & 5.621 \\
\hline Fonte: Estatistica Industrial do Estado de São Paulo, 1932. & & & &
\end{tabular}

Fonte: Estatística Industrial do Estado de São Paulo, 1932. 
Tabela 9c - Indústria têxtil paulista discriminada por tamanho e ramo (1935)

Geral

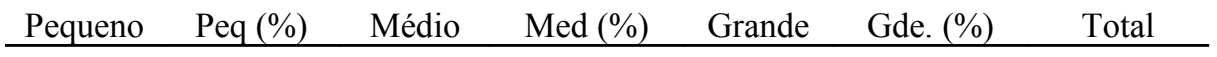

Fábricas

Capital

$\begin{array}{ccccccc}274 & 66,34 & 93 & 22,52 & 46 & 11,14 & 413 \\ 62.747 & 7,87 & 209.956 & 26,34 & 524.348 & 65,79 & 797.051 \\ 7.924 & 10,85 & 20.998 & 28,74 & 44.143 & 60,42 & 73.065\end{array}$

Algodão

Operários

Fábricas

$39 \quad 30,47$

55

8.939

1,71

42,97

$34 \quad 26,56$

128

Operários

1.759

3,59

$13.647 \quad 27,83$

364.981

69,82

522.773

Juta

Fábricas

Capital

Operários

Malha

Fábricas

Capital

Operários

$\begin{array}{cc}2 & 20,00 \\ 410 & 1,12 \\ 15 & 0,34\end{array}$

$\begin{array}{cc}4 \\ 4.902 & 40 \\ 599 & 13\end{array}$

40,00

33.639

68,59

49.045

Lã

$\begin{array}{cccccccc}\text { Fábricas } & 9 & 47,37 & 7 & 36,84 & 3 & 15,79 & 19 \\ \text { Capital } & 5.958 & 15,99 & 16.002 & 42,95 & 15.300 & 41,06 & 37.260 \\ \text { Operários } & 504 & 12,31 & 1.794 & 43,83 & 1.795 & 43,86 & 4.093\end{array}$

\begin{tabular}{cccccccc} 
Seda Natural e Art. & 0 & & & & & & \\
Fábricas & 122 & 85,92 & 15 & 10,56 & 5 & 3,52 & 142 \\
Capital & 26.455 & 16,82 & 18.012 & 11,45 & 112.778 & 71,72 & 157.245 \\
Operários & 2.946 & 29,05 & 2.224 & 21,93 & 4.972 & 49,02 & 10.142 \\
\hline Fonte: Estatística Industrial do Estado de São Paulo, 1935
\end{tabular}

Fonte: Estatística Industrial do Estado de São Paulo, 1935. 
Tabela 9d - Indústria têxtil paulista discriminada por tamanho e ramo (1937)

\begin{tabular}{|c|c|c|c|c|c|c|c|}
\hline & Pequeno & Peq $(\%)$ & Médio & Med $(\%)$ & Grande & Gde. $(\%)$ & Total \\
\hline \multicolumn{8}{|l|}{ Geral } \\
\hline Fábricas & 309 & 69,91 & 84 & 19,00 & 49 & 11,09 & 442 \\
\hline Capital & 84.002 & 9,86 & 211.904 & 24,87 & 556.248 & 65,28 & 852.154 \\
\hline Operários & 9.485 & 3,58 & 200.389 & 75,54 & 55.404 & 20,89 & 265.278 \\
\hline \multicolumn{8}{|l|}{ Algodão } \\
\hline Fábricas & 49 & 38,58 & 41 & 32,28 & 37 & 29,13 & 127 \\
\hline Capital & 14.417 & 2,78 & 122.844 & 23,67 & 381.630 & 73,55 & 518.891 \\
\hline Operários & 2.061 & 3,77 & 10.395 & 19,03 & 42.172 & 77,20 & 54.628 \\
\hline \multicolumn{8}{|l|}{ Juta } \\
\hline Fábricas & 4 & 36,36 & 4 & 36,36 & 3 & 27,27 & 11 \\
\hline Capital & 2.630 & 5,77 & 12.731 & 27,94 & 30.211 & 66,29 & 45.572 \\
\hline Operários & 226 & 4,69 & 1.038 & 21,53 & 3.558 & 73,79 & 4.822 \\
\hline \multicolumn{8}{|l|}{ Malha } \\
\hline Fábricas & 101 & 89,38 & 12 & 10,62 & 0 & 0,00 & 113 \\
\hline Capital & 23.406 & 44,31 & 29.418 & 55,69 & 0 & 0,00 & 52.824 \\
\hline Operários & 2.857 & 1,54 & 182.892 & 98,46 & 0 & 0,00 & 185.749 \\
\hline \multicolumn{8}{|l|}{ Lã } \\
\hline Fábricas & 7 & 35,00 & 10 & 50,00 & 3 & 15,00 & 20 \\
\hline Capital & 3.750 & 10,56 & 20.377 & 57,39 & 11.377 & 32,04 & 35.504 \\
\hline Operários & 317 & 6,79 & 2.674 & 57,23 & 1.681 & 35,98 & 4.672 \\
\hline \multicolumn{8}{|c|}{ Seda Natural e Art. } \\
\hline Fábricas & 148 & 86,55 & 17 & 9,94 & 6 & 3,51 & 171 \\
\hline Capital & 39.799 & 19,96 & 26.534 & 13,31 & 133.030 & 66,73 & 199.363 \\
\hline Operários & 4.024 & 26,12 & 3.390 & 22,00 & 7.993 & 51,88 & 15.407 \\
\hline
\end{tabular}


Tabela 10 - Indústria têxtil paulista discriminada por localização (capital e interior) e por ramo (1928)

\begin{tabular}{|c|c|c|c|c|c|}
\hline & Cidade SP & Interior & Total & $\%$ Cid. SP & $\%$ Interior \\
\hline \multicolumn{6}{|l|}{ Gerais } \\
\hline Fábricas & 196 & 67 & 263 & 74,5 & 25,5 \\
\hline Capital & 298.996 & 169.962 & 468.958 & 63,8 & 36,2 \\
\hline Operários & 38.353 & 25.970 & 64.323 & 59,6 & 40,4 \\
\hline \multicolumn{6}{|l|}{ Algodão } \\
\hline Fábricas & 41 & 41 & 82 & 50,0 & 50,0 \\
\hline Capital & 162.586 & 147.955 & 310.541 & 52,4 & 47,6 \\
\hline Operários & 20.121 & 22.938 & 43.059 & 46,7 & 53,3 \\
\hline \multicolumn{6}{|l|}{ Juta } \\
\hline Fábricas & 4 & 1 & 5 & 80,0 & 20,0 \\
\hline Capital & 59.900 & 800 & 60.700 & 98,7 & 1,3 \\
\hline Operários & 6.023 & 180 & 6.203 & 97,1 & 2,9 \\
\hline \multicolumn{6}{|l|}{ Malha } \\
\hline Fábricas & 99 & 15 & 114 & 86,8 & 13,2 \\
\hline Capital & 31.143 & 4.045 & 35.188 & 88,5 & 11,5 \\
\hline Operários & 6.047 & 1.120 & 7.167 & 84,4 & 15,6 \\
\hline \multicolumn{6}{|l|}{ Lã } \\
\hline Fábricas & 18 & 3 & 21 & 85,7 & 14,3 \\
\hline Capital & 9.735 & 6.200 & 15.935 & 61,1 & 38,9 \\
\hline Operários & 1.536 & 766 & 2.302 & 66,7 & 33,3 \\
\hline \multicolumn{6}{|c|}{ Seda Natural e Art. } \\
\hline Fábricas & 34 & 7 & 41 & 82,9 & 17,1 \\
\hline Capital & 35.632 & 10.962 & 46.594 & 76,5 & 23,5 \\
\hline Operários & 4.626 & 966 & 5.592 & 82,7 & 17,3 \\
\hline
\end{tabular}

Fonte: Estatística Industrial do Estado de São Paulo, 1928. 
Tabela 10b - Indústria têxtil paulista discriminada por localização (capital e interior) e por ramo (1932)

\begin{tabular}{|c|c|c|c|c|c|}
\hline & Cidade SP & Interior & Total & $\%$ Cid. SP & $\%$ Interior \\
\hline \multicolumn{6}{|l|}{ Gerais } \\
\hline Fábricas & 249 & 86 & 335 & 74,3 & 25,7 \\
\hline Capital & 254.232 & 151.880 & 406.112 & 62,6 & 37,4 \\
\hline Operários & 30.709 & 24.517 & 55.226 & 55,6 & 44,4 \\
\hline \multicolumn{6}{|l|}{ Algodão } \\
\hline Fábricas & 55 & 54 & 109 & 50,5 & 49,5 \\
\hline Capital & 132.115 & 114.847 & 246.962 & 53,5 & 46,5 \\
\hline Operários & 17.373 & 19.203 & 36.576 & 47,5 & 52,5 \\
\hline \multicolumn{6}{|l|}{ Juta } \\
\hline Fábricas & 7 & 4 & 11 & 63,6 & 36,4 \\
\hline Capital & 48.180 & 3.522 & 51.702 & 93,2 & 6,8 \\
\hline Operários & 4.235 & 988 & 5.223 & 81,1 & 18,9 \\
\hline \multicolumn{6}{|l|}{ Malha } \\
\hline Fábricas & 117 & 11 & 128 & 91,4 & 8,6 \\
\hline Capital & 21.560 & 5.021 & 26.581 & 81,1 & 18,9 \\
\hline Operários & 3.681 & 878 & 4.559 & 80,7 & 19,3 \\
\hline \multicolumn{6}{|l|}{ Lã } \\
\hline Fábricas & 13 & 5 & 18 & 72,2 & 27,8 \\
\hline Capital & 10.177 & 9.400 & 19.577 & 52,0 & 48,0 \\
\hline Operários & 2.030 & 1.217 & 3.247 & 62,5 & 37,5 \\
\hline \multicolumn{6}{|c|}{ Seda Nat. e Artificial } \\
\hline Fábricas & 57 & 12 & 69 & 82,6 & 17,4 \\
\hline Capital & 42.200 & 19.090 & 61.290 & 68,9 & 31,1 \\
\hline Operários & 3.390 & 2.231 & 5.621 & 60,3 & 39,7 \\
\hline
\end{tabular}


Tabela 10c - Indústria têxtil paulista discriminada por localização (capital e interior) e por ramo (1935)

\begin{tabular}{|c|c|c|c|c|c|}
\hline & Cidade SP & Interior & Total & $\%$ Cid. SP & $\%$ Interior \\
\hline \multicolumn{6}{|l|}{ Gerais } \\
\hline Fábricas & 313 & 100 & 413 & 75,8 & 24,2 \\
\hline Capital & 470.538 & 326.513 & 797.051 & 59,0 & 41,0 \\
\hline Operários & 41.089 & 31.976 & 73.065 & 56,2 & 43,8 \\
\hline \multicolumn{6}{|l|}{ Algodão } \\
\hline Fábricas & 73 & 55 & 128 & 57,0 & 43,0 \\
\hline Capital & 298.863 & 223.910 & 522.773 & 57,2 & 42,8 \\
\hline Operários & 25.334 & 23.711 & 49.045 & 51,7 & 48,3 \\
\hline \multicolumn{6}{|l|}{ Juta } \\
\hline Fábricas & 6 & 4 & 10 & 60,0 & 40,0 \\
\hline Capital & 26.252 & 10.349 & 36.601 & 71,7 & 28,3 \\
\hline Operários & 2.845 & 1.506 & 4.351 & 65,4 & 34,6 \\
\hline \multicolumn{6}{|l|}{ Malha } \\
\hline Fábricas & 102 & 12 & 114 & 89,5 & 10,5 \\
\hline Capital & 33.065 & 10.107 & 43.172 & 76,6 & 23,4 \\
\hline Operários & 4.250 & 1.184 & 5.434 & 78,2 & 21,8 \\
\hline \multicolumn{6}{|l|}{ Lã } \\
\hline Fábricas & 13 & 6 & 19 & 68,4 & 31,6 \\
\hline Capital & 23.550 & 13.710 & 37.260 & 63,2 & 36,8 \\
\hline Operários & 2.289 & 1.804 & 4.093 & 55,9 & 44,1 \\
\hline \multicolumn{6}{|c|}{ Seda Nat. e Artificial } \\
\hline Fábricas & 119 & 23 & 142 & 83,8 & 16,2 \\
\hline Capital & 88.808 & 68.437 & 157.245 & 56,5 & 43,5 \\
\hline Operários & 6.371 & 3.771 & 10.142 & 62,8 & 37,2 \\
\hline
\end{tabular}

Fonte: Estatística Industrial do Estado de São Paulo, 1935. 
Tabela 10d - Indústria têxtil paulista discriminada por localização (capital e interior) e por ramo (1937)

\begin{tabular}{|c|c|c|c|c|c|}
\hline & Cidade SP & Interior & Total & $\%$ Cid. SP & $\%$ Interior \\
\hline \multicolumn{6}{|l|}{ Gerais } \\
\hline Fábricas & 317 & 125 & 442 & 71,7 & 28,3 \\
\hline Capital & 432.022 & 420.132 & 852.154 & 50,7 & 49,3 \\
\hline Operários & 224.229 & 41.049 & 265.278 & 84,5 & 15,5 \\
\hline \multicolumn{6}{|l|}{ Algodão } \\
\hline Fábricas & 60 & 67 & 127 & 47,2 & 52,8 \\
\hline Capital & 237.329 & 281.562 & 518.891 & 45,7 & 54,3 \\
\hline Operários & 24.594 & 30.034 & 54.628 & 45,0 & 55,0 \\
\hline \multicolumn{6}{|l|}{ Juta } \\
\hline Fábricas & 6 & 5 & 11 & 54,5 & 45,5 \\
\hline Capital & 27.517 & 18.055 & 45.572 & 60,4 & 39,6 \\
\hline Operários & 2.904 & 1.918 & 4.822 & 60,2 & 39,8 \\
\hline \multicolumn{6}{|l|}{ Malha } \\
\hline Fábricas & 101 & 12 & 113 & 89,4 & 10,6 \\
\hline Capital & 41.386 & 11.438 & 52.824 & 78,3 & 21,7 \\
\hline Operários & 184.656 & 1.093 & 185.749 & 99,4 & 0,6 \\
\hline \multicolumn{6}{|l|}{ Lã } \\
\hline Fábricas & 13 & 7 & 20 & 65,0 & 35,0 \\
\hline Capital & 17.917 & 17.587 & 35.504 & 50,5 & 49,5 \\
\hline Operários & 2.671 & 2.001 & 4.672 & 57,2 & 42,8 \\
\hline \multicolumn{6}{|c|}{ Seda Nat. e Artificial } \\
\hline Fábricas & 137 & 34 & 171 & 80,1 & 19,9 \\
\hline Capital & 107.873 & 91.490 & 199.363 & 54,1 & 45,9 \\
\hline Operários & 9.404 & 6.003 & 15.407 & 61,0 & 39,0 \\
\hline
\end{tabular}

Fonte: Estatística Industrial do Estado de São Paulo, 1937. 
Tabela 11 - Comércio de cabotagem - Brasil e São Paulo, toneladas e Cr\$1.000 (1929-1947)

\begin{tabular}{|c|c|c|c|c|c|c|c|c|c|c|c|}
\hline & \multicolumn{3}{|c|}{ Brasil } & \multicolumn{3}{|c|}{ São Paulo - Exportação } & \multicolumn{3}{|c|}{ São Paulo - Importação } & \multicolumn{2}{|c|}{ Saldo } \\
\hline & $(1)$ & $(2)$ & $(3)$ & (1) & $(2)$ & (3) & (1) & $(2)$ & (3) & (1) & \\
\hline 1928 & 1.898 .752 & 3.026 .398 & 2.043 .483 & 101.679 & 403.176 & 272.232 & 454.449 & 528.671 & 356.969 & -352.770 & \\
\hline 1929 & 1.921 .352 & 2.787 .880 & 1.784 .814 & 101.223 & 385.349 & 246.702 & 525.448 & 473.870 & 303.374 & -424.225 & \\
\hline 1930 & 1.560 .032 & 2.058 .446 & 1.611 .939 & 96.169 & 308.816 & 241.829 & 338.307 & 287.712 & 225.303 & -242.138 & \\
\hline 1931 & 1.632 .840 & 2.234 .409 & 1.916 .303 & 114.348 & 359.715 & 308.503 & 331.149 & 309.584 & 265.509 & -216.801 & \\
\hline 1932 & 1.727 .541 & 2.346 .731 & 2.065 .784 & 127.199 & 340.198 & 299.470 & 273.772 & 277.650 & 244.410 & -146.573 & \\
\hline 1933 & 1.865 .641 & 2.551 .114 & 2.296 .232 & 135.246 & 442.616 & 398.394 & 326.676 & 300.796 & 270.743 & -191.430 & \\
\hline 1934 & 2.087 .376 & 2.782 .035 & 2.470 .724 & 139.609 & 474.328 & 421.250 & 337.924 & 328.352 & 291.609 & -198.315 & \\
\hline 1935 & 2.179 .652 & 3.297 .531 & 2.869 .914 & 140.448 & 590.199 & 513.663 & 358.699 & 387.815 & 337.524 & -218.251 & \\
\hline 1936 & 2.365 .322 & 3.794 .450 & 2.745 .622 & 157.117 & 633.284 & 458.237 & 472.168 & 488.061 & 353.156 & -315.051 & \\
\hline 1937 & 2.523 .284 & 4.255 .161 & 2.625 .022 & 171.952 & 664.636 & 410.016 & 478.003 & 547.016 & 337.456 & -306.051 & \\
\hline 1938 & 2.606 .695 & 4.100 .427 & 2.543 .689 & 197.668 & 698.996 & 433.620 & 513.606 & 505.193 & 313.395 & -315.938 & \\
\hline 1939 & 2.892 .550 & 4.528 .417 & 2.873 .361 & 229.375 & 818.795 & 519.540 & 557.752 & 571.421 & 362.577 & -328.377 & \\
\hline 1940 & 2.968 .557 & 4.876 .645 & 2.941 .282 & 264.286 & 1.008 .199 & 608.081 & 590.269 & 633.926 & 382.344 & -325.983 & \\
\hline 1941 & 3.215 .044 & 6.256 .424 & 3.358 .252 & 300.371 & 1.304 .330 & 700.123 & 595.098 & 835.997 & 448.737 & -294.727 & \\
\hline 1942 & 3.049 .161 & 6.641 .336 & 3.211 .478 & 340.340 & 1.367 .948 & 661.484 & 523.654 & 879.841 & 425.455 & -183.314 & \\
\hline 1943 & 2.857 .530 & 7.340 .303 & 2.891 .021 & $*$ & $*$ & $*$ & $*$ & $*$ & & $*$ & $*$ \\
\hline 1944 & 3.323 .526 & 11.056 .136 & 3.829 .628 & $*$ & $*$ & $*$ & $*$ & $*$ & $*$ & $*$ & $*$ \\
\hline 1945 & 3.331 .874 & 12.472 .025 & 3.455 .812 & $*$ & $*$ & $*$ & $*$ & $*$ & $*$ & $*$ & $*$ \\
\hline 1946 & 3.523 .215 & 15.354 .019 & 3.712 .377 & $*$ & $*$ & $*$ & $*$ & $*$ & $*$ & $*$ & $*$ \\
\hline 1947 & 3.353 .738 & 15.419 .673 & 3.420 .513 & $*$ & $*$ & $*$ & $*$ & $*$ & $*$ & $*$ & \\
\hline
\end{tabular}

Fonte: Comércio de cabotagem pelo porto de Santos, 1928-1944; e Comércio de cabotagem pelo porto de Santos, 1928-1944; (1) toneladas; (2) Cr\$ 1.000; (3) Cr\$ 1.000 deflacionado.

Tabela 11b - Crescimentos percentuais do comércio de cabotagem - Brasil e São Paulo (1929-1947)

\begin{tabular}{ccccccc} 
& \multicolumn{2}{c}{ Brasil } & \multicolumn{2}{c}{ São Paulo - Exp. } & \multicolumn{2}{c}{ São Paulo - Imp. } \\
& Toneladas & 1.000 Cr\$ (D) & Toneladas & 1.000 Cr\$ (D) & Toneladas & 1.000 Cr\$ (D) \\
\hline 1929 & 1,2 & $-12,7$ & $-0,4$ & $-9,4$ & 15,6 & $-15,0$ \\
1930 & $-18,8$ & $-9,7$ & $-5,0$ & $-2,0$ & $-35,6$ & $-25,7$ \\
1931 & 4,7 & 18,9 & 18,9 & 27,6 & $-2,1$ & 17,8 \\
1932 & 5,8 & 7,8 & 11,2 & $-2,9$ & $-17,3$ & $-7,9$ \\
1933 & 8,0 & 11,2 & 6,3 & 33,0 & 19,3 & 10,8 \\
1934 & 11,9 & 7,6 & 3,2 & 5,7 & 3,4 & 7,7 \\
1935 & 4,4 & 16,2 & 0,6 & 21,9 & 6,1 & 15,7 \\
1936 & 8,5 & $-4,3$ & 11,9 & $-10,8$ & 31,6 & 4,6 \\
1937 & 6,7 & $-4,4$ & 9,4 & $-10,5$ & 1,2 & $-4,4$ \\
1938 & 3,3 & $-3,1$ & 15,0 & 5,8 & 7,4 & $-7,1$ \\
1939 & 11,0 & 13,0 & 16,0 & 19,8 & 8,6 & 15,7 \\
1940 & 2,6 & 2,4 & 15,2 & 17,0 & 5,8 & 5,5 \\
1941 & 8,3 & 14,2 & 13,7 & 15,1 & 0,8 & 17,4 \\
1942 & $-5,2$ & $-4,4$ & 13,3 & $-5,5$ & $-12,0$ & $-5,2$ \\
\hline
\end{tabular}

Fonte: Idem Tabela 10. 
Tabela 11c - Participação relativa comércio de cabotagem São Paulo - Brasil (1929-1947)

\begin{tabular}{ccccc} 
& \multicolumn{2}{c}{ Exportações SP $(\%)$} & \multicolumn{2}{c}{ Importações SP (\%) } \\
& Toneladas & 1.000 Cr\$ (D) & Toneladas & 1.000 Cr\$ (D) \\
\hline 1929 & 5,4 & 13,3 & 23,9 & 17,5 \\
1930 & 5,3 & 13,8 & 27,3 & 17,0 \\
1931 & 6,2 & 15,0 & 21,7 & 14,0 \\
1932 & 7,0 & 16,1 & 20,3 & 13,9 \\
1933 & 7,4 & 14,5 & 15,8 & 11,8 \\
1934 & 7,2 & 17,3 & 17,5 & 11,8 \\
1935 & 6,7 & 17,0 & 16,2 & 11,8 \\
1936 & 6,4 & 17,9 & 16,5 & 11,8 \\
1937 & 6,6 & 16,7 & 20,0 & 12,9 \\
1938 & 6,8 & 15,6 & 18,9 & 12,9 \\
1939 & 7,6 & 17,0 & 19,7 & 12,3 \\
1940 & 7,9 & 18,1 & 19,3 & 12,6 \\
1941 & 8,9 & 20,7 & 19,9 & 13,0 \\
1942 & 9,3 & 20,8 & 18,5 & 13,4 \\
\hline
\end{tabular}

Fonte: Idem Tabela 11.

Tabela 12 - Indústria têxtil discriminada por unidade da Federação (1920 e 1940)

(1)

(2)

(3)

(4)

(5)

\begin{tabular}{ccccccccccc} 
& 1920 & 1940 & 1920 & 1940 & 1920 & 1940 & 1920 & 1940 & 1920 & 1940 \\
\hline Alagoas & 96 & 53 & 26.988 & 79.232 & 5.790 & 6.294 & 7.715 & 8.797 & 31.079 & 64.663 \\
Amazonas & 0 & 0 & 0 & 0 & 0 & 0 & 0 & 0 & 0 & 0 \\
Bahia & 14 & 75 & 28.097 & 44.659 & 5.707 & 5.574 & 5.239 & 10.349 & 27.651 & 39.935 \\
Ceará & 126 & 125 & 7.752 & 40.817 & 2.820 & 2.633 & 2.117 & 4.735 & 17.021 & 55.247 \\
Distrito Federal & 73 & 88 & 191.692 & 479.288 & 20.054 & 21.298 & 30.106 & 39.376 & 138.983 & 299.426 \\
Espírito Santo & 2 & 1 & 1.400 & $*$ & 522 & $*$ & 18 & 466 & 2.643 & $*$ \\
Goiás & 0 & 3 & 0 & $*$ & 0 & $*$ & 0 & $*$ & 0 & $*$ \\
Maranhão & 51 & 59 & 13.666 & 25.762 & 3.354 & 3.119 & 3.553 & 5.777 & 17.587 & 24.698 \\
Mato Grosso & 0 & 1 & 0 & $*$ & 0 & $*$ & 0 & $*$ & 0 & $*$ \\
Minas Gerais & 77 & 123 & 39.002 & 187.715 & 9.956 & 16.588 & 11.433 & 24.507 & 51.150 & 169.660 \\
Pará & 3 & 16 & 1.137 & 12.920 & 322 & 838 & 178 & 1.209 & 2.387 & 13.268 \\
Paraíba & 169 & 212 & 6.485 & 93.518 & 2.098 & 8.984 & 1.495 & 8.520 & 20.380 & 120.963 \\
Paraná & 14 & 18 & 853 & 10.904 & 310 & 569 & 302 & 811 & 1.791 & 13.718 \\
Pernambuco & 95 & 84 & 41.590 & 258.234 & 8.037 & 21.784 & 10.001 & 24.292 & 48.620 & 218.317 \\
Piaú́ & 5 & 24 & 1.347 & 4.310 & 389 & 427 & 443 & 905 & 2.666 & 2.503 \\
Rio de Janeiro & 31 & 62 & 74.290 & 216.104 & 10.752 & 17.336 & 15.753 & 25.052 & 80.863 & 167.138 \\
Rio Grande do & & & & & & & & & & \\
Norte & 115 & 144 & 5.242 & 31.557 & 1.428 & 1.300 & 659 & 3.434 & 17.082 & 55.461 \\
Rio Grande do Sul & 20 & 44 & 24.759 & 99.371 & 3.859 & 4.063 & 4.284 & 9.831 & 30.630 & 66.694 \\
Santa Catarina & 18 & 40 & 5.368 & 62.980 & 1.447 & 4.972 & 919 & 5.260 & 8.593 & 62.229 \\
São Paulo & $\mathbf{2 4 7}$ & $\mathbf{9 9 8}$ & $\mathbf{2 2 3 . 6 4 5}$ & $\mathbf{1 . 4 1 1 . 9 6 8}$ & $\mathbf{3 6 . 4 4 7}$ & $\mathbf{9 4 . 1 6 1}$ & $\mathbf{4 3 . 4 3 4}$ & $\mathbf{1 4 2 . 9 4 4}$ & $\mathbf{3 0 2 . 5 0 4}$ & $\mathbf{2 . 1 9 2 . 4 9 2}$ \\
Sergipe & 55 & 40 & 13.094 & 51.526 & 4.443 & 6.149 & 2.468 & 7.640 & 23.760 & 48.792
\end{tabular}

$\begin{array}{cccccccccccc}\text { Território do Acre } & 0 & 0 & 0 & 0 & 0 & 0 & 0 & 0 & 0 & 0 \\ \text { Brasil } & 1.211 & 2.210 & 706.415 & 3.110 .865 & 117.765 & 216.089 & 140.117 & 323.905 & 825.400 & 3.615 .204\end{array}$

Fonte: Recenseamento Geral do Brasil, 1920 e 1940

Legenda: (1) Estabelecimentos; (2) capital - 1920 em contos e 1940 em Cr\$ 1.000; (3) operários; (4) força motriz - 1920 em H.P. e 1940 em c.v.; (5) valor de produção - 1920 em contos e 1940 em Cr\$1.000. Válida para tabela 12b. 
Tabela 12b - Indústria têxtil discriminada por unidade da Federação (1920 e 1940) - \%

\begin{tabular}{|c|c|c|c|c|c|c|c|c|c|c|}
\hline & \multicolumn{2}{|c|}{ (1) } & \multicolumn{2}{|c|}{ (2) } & \multicolumn{2}{|c|}{ (3) } & \multicolumn{2}{|c|}{ (4) } & \multicolumn{2}{|c|}{ (5) } \\
\hline & 1920 & 1940 & 1920 & 1940 & 1920 & 1940 & 1920 & 1940 & 1920 & 1940 \\
\hline Alagoas & 7,9 & 2,4 & 3,8 & 2,5 & 4,9 & 2,9 & 5,5 & 2,7 & 3,8 & 1,8 \\
\hline Amazonas & 0,0 & 0,0 & 0,0 & 0,0 & 0,0 & 0,0 & 0,0 & 0,0 & 0,0 & 0,0 \\
\hline Bahia & 1,2 & 3,4 & 4,0 & 1,4 & 4,8 & 2,6 & 3,7 & 3,2 & 3,4 & 1,1 \\
\hline Ceará & 10,4 & 5,7 & 1,1 & 1,3 & 2,4 & 1,2 & 1,5 & 1,5 & 2,1 & 1,5 \\
\hline Distrito Federal & 6,0 & 4,0 & 27,1 & 15,4 & 17,0 & 9,9 & 21,5 & 12,2 & 16,8 & 8,3 \\
\hline Espírito Santo & 0,2 & 0,0 & 0,2 & $*$ & 0,4 & $*$ & 0,0 & 0,1 & 0,3 & $*$ \\
\hline Goiás & 0,0 & 0,1 & 0,0 & $*$ & 0,0 & $*$ & 0,0 & $*$ & 0,0 & $*$ \\
\hline Maranhão & 4,2 & 2,7 & 1,9 & 0,8 & 2,8 & 1,4 & 2,5 & 1,8 & 2,1 & 0,7 \\
\hline Mato Grosso & 0,0 & 0,0 & 0,0 & $*$ & 0,0 & $*$ & 0,0 & * & 0,0 & $*$ \\
\hline Minas Gerais & 6,4 & 5,6 & 5,5 & 6,0 & 8,5 & 7,7 & 8,2 & 7,6 & 6,2 & 4,7 \\
\hline Pará & 0,2 & 0,7 & 0,2 & 0,4 & 0,3 & 0,4 & 0,1 & 0,4 & 0,3 & 0,4 \\
\hline Paraíba & 14,0 & 9,6 & 0,9 & 3,0 & 1,8 & 4,2 & 1,1 & 2,6 & 2,5 & 3,3 \\
\hline Paraná & 1,2 & 0,8 & 0,1 & 0,4 & 0,3 & 0,3 & 0,2 & 0,3 & 0,2 & 0,4 \\
\hline Pernambuco & 7,8 & 3,8 & 5,9 & 8,3 & 6,8 & 10,1 & 7,1 & 7,5 & 5,9 & 6,0 \\
\hline Piauí & 0,4 & 1,1 & 0,2 & 0,1 & 0,3 & 0,2 & 0,3 & 0,3 & 0,3 & 0,1 \\
\hline Rio de Janeiro & 2,6 & 2,8 & 10,5 & 6,9 & 9,1 & 8,0 & 11,2 & 7,7 & 9,8 & 4,6 \\
\hline Rio Grande do Norte & 9,5 & 6,5 & 0,7 & 1,0 & 1,2 & 0,6 & 0,5 & 1,1 & 2,1 & 1,5 \\
\hline Rio Grande do Sul & 1,7 & 2,0 & 3,5 & 3,2 & 3,3 & 1,9 & 3,1 & 3,0 & 3,7 & 1,8 \\
\hline Santa Catarina & 1,5 & 1,8 & 0,8 & 2,0 & 1,2 & 2,3 & 0,7 & 1,6 & 1,0 & 1,7 \\
\hline São Paulo & 20,4 & 45,2 & 31,7 & 45,4 & 30,9 & 43,6 & 31,0 & 44,1 & 36,6 & 60,6 \\
\hline Sergipe & 4,5 & 1,8 & 1,9 & 1,7 & 3,8 & 2,8 & 1,8 & 2,4 & 2,9 & 1,3 \\
\hline Território do Acre & 0,0 & 0,0 & 0,0 & 0,0 & 0,0 & 0,0 & 0,0 & 0,0 & 0,0 & 0,0 \\
\hline Brasil & 100,0 & 100,0 & 100,0 & 100,0 & 100,0 & 100,0 & 100,0 & 100,0 & 100,0 & 100,0 \\
\hline
\end{tabular}


Tabela 13 - Indústria têxtil discriminada por unidade da Federação (1920 e 1950) - \%

(1) (2) (3)

(3) (4)

(5)

\begin{tabular}{ccccccccccc} 
& 1920 & 1950 & 1920 & 1950 & 1920 & 1950 & 1920 & 1950 & 1920 & 1950 \\
\hline Alagoas & 96 & 108 & 26.988 & 156.534 & 5.790 & 10.582 & 7.715 & 13.093 & 31.079 & 353.773 \\
Amazonas & 0 & 0 & 0 & 0 & 0 & 0 & 0 & 0 & 0 & 0 \\
Bahia & 14 & 44 & 28.097 & 63.688 & 5.707 & 5.632 & 5.239 & 8.384 & 27.651 & 162.859 \\
Ceará & 126 & 189 & 7.752 & 155.611 & 2.820 & 4.763 & 2.117 & 13.883 & 17.021 & 350.433 \\
Distrito Federal & 73 & 94 & 191.692 & 832.913 & 20.054 & 27.401 & 30.106 & 52.352 & 138.983 & 1.613 .272 \\
Espírito Santo & 2 & 4 & 1.400 & 4.017 & 522 & 681 & 18 & 1.012 & 2.643 & 27.208 \\
Goiás & 0 & $*$ & 0 & $*$ & 0 & $*$ & 0 & $*$ & 0 & $*$ \\
Maranhão & 51 & 58 & 13.666 & 42.386 & 3.354 & 3.968 & 3.553 & 6.718 & 17.587 & 115.689 \\
Mato Grosso & 0 & $*$ & 0 & $*$ & 0 & $*$ & 0 & $*$ & 0 & $*$ \\
Minas Gerais & 77 & 134 & 39.002 & 522.671 & 9.956 & 28.352 & 11.433 & 36.868 & 51.150 & 1.218 .814 \\
Pará & 3 & $*$ & 1.137 & $*$ & 322 & $*$ & 178 & $*$ & 2.387 & $*$ \\
Paraíba & 169 & 240 & 6.485 & 158.190 & 2.098 & 10.308 & 1.495 & 11.962 & 20.380 & 582.475 \\
Paraná & 14 & 17 & 853 & 49.220 & 310 & 1.270 & 302 & 1.813 & 1.791 & 85.396 \\
Pernambuco & 95 & 99 & 41.590 & 429.943 & 8.037 & 27.074 & 10.001 & 31.025 & 48.620 & 1.307 .747 \\
Piaú́ & 5 & 14 & 1.347 & 5.338 & 389 & 269 & 443 & 392 & 2.666 & 6.630 \\
Rio de Janeiro & 31 & 81 & 74.290 & 706.891 & 10.752 & 19.936 & 15.753 & 36.608 & 80.863 & 1.016 .898 \\
Rio Grande do Norte & 115 & 161 & 5.242 & 61.535 & 1.428 & 1.248 & 659 & 4.177 & 17.082 & 267.560 \\
Rio Grande do Sul & 20 & 59 & 24.759 & 308.682 & 3.859 & 7.684 & 4.284 & 14.061 & 30.630 & 413.293 \\
Santa Catarina & 18 & 78 & 5.368 & 237.777 & 1.447 & 10.220 & 919 & 11.434 & 8.593 & 421.448 \\
São Paulo & 247 & 1.522 & 223.645 & 5.079 .800 & 36.447 & 141.730 & 43.434 & 247.155 & 302.504 & 11.706 .089 \\
Sergipe & 55 & 61 & 13.094 & 94.755 & 4.443 & 7.734 & 2.468 & 13.345 & 23.760 & 225.302 \\
Território do Acre & 0 & 0 & 0 & 0 & 0 & 0 & 0 & 0 & 0 & 0
\end{tabular}

\begin{tabular}{ccccccccccc} 
Território do Acre & 0 & 0 & 0 & 0 & 0 & 0 & 0 & 0 & 0 & 0 \\
\hline Brasil & 1.211 & 2.969 & 706.415 & 8.927 .225 & 117.765 & 309.676 & 140.117 & 506.195 & 825.400 & 19.928 .834
\end{tabular}

Fonte: Recenseamento Geral do Brasil, 1920 e 1950

Legenda: (1) Estabelecimentos; (2) capital - 1920 em contos e 1950 em Cr\$ 1.000; (3) operários; (4) força motriz - 1920 em H.P. e 1950 em c.v.; (5) valor de produção - 1920 em contos e 1950 em Cr\$ 1.000. Válida para tabela 13b. 
Tabela 13b - Indústria têxtil discriminada por unidade da Federação (1920 e 1950) - \%

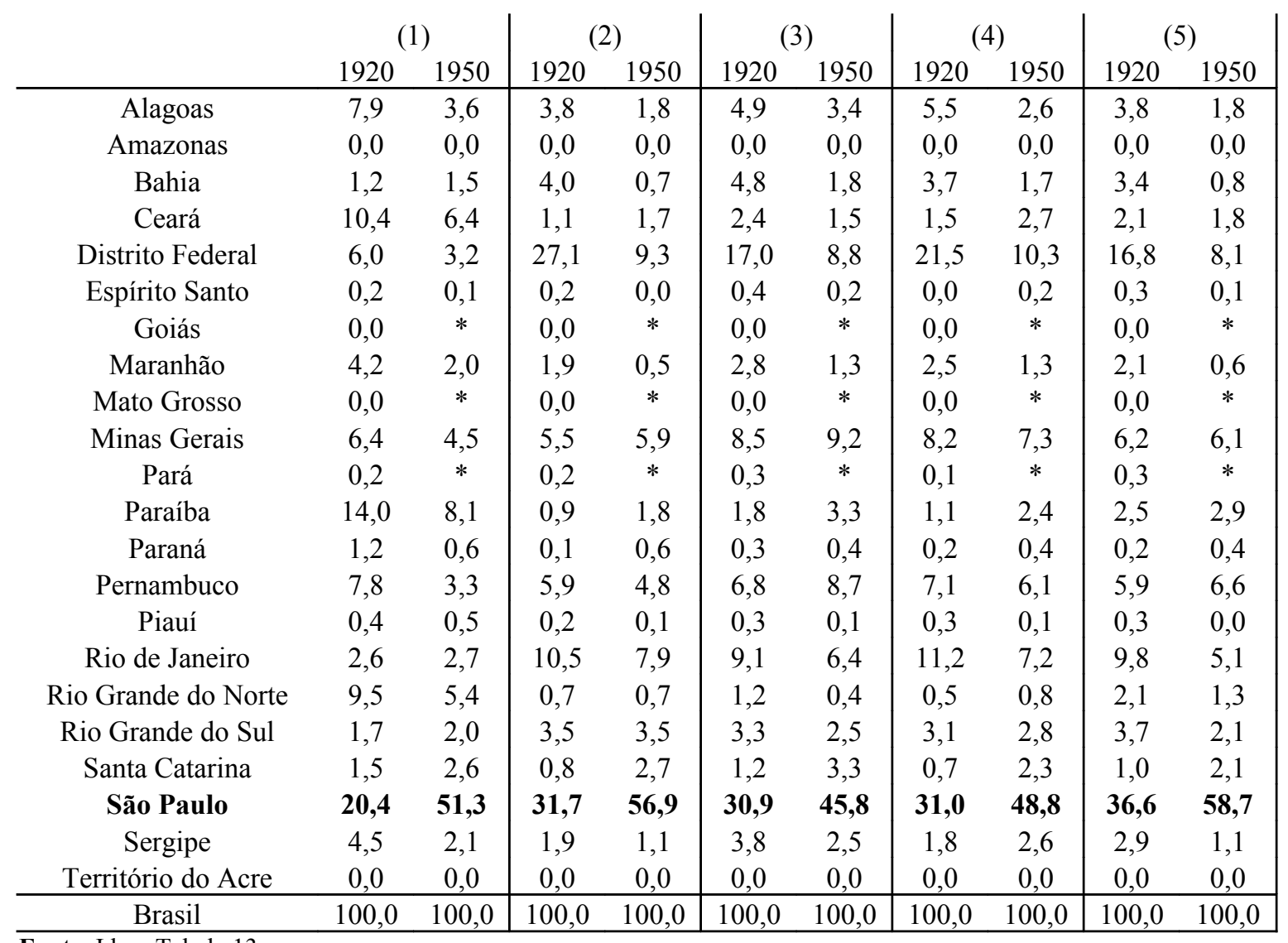

Fonte: Idem Tabela 13. 
Tabela 14 - Empresas têxteis paulistas sob estatuto jurídico de sociedade anônima (S.A.) fundadas durante a Segunda Guerra (1939-1945)

\begin{tabular}{|c|c|c|c|c|}
\hline Nome & $(1)$ & $(2)$ & $(3)$ & $(4)$ \\
\hline S.A. Emílio Vanini & 1939 & Geral & n.d. & 6.00 \\
\hline Fiação e Tecelagem Odete S.A. & 1940 & Geral & n.d.* & 3.000 \\
\hline Fiação Brasileira de Lã & 1940 & Lã & n.d.* & 1.500 \\
\hline Lanifício Lapa S.A. & 1940 & Lã & n.d.* & 500 \\
\hline Tecelagem Moderna S.A. & 1940 & Geral & n.d.* & 600 \\
\hline Têxtil Paulo Abreu S.A. & 1941 & Geral & Itatiba & 3.000 \\
\hline Têxtil Nacional S.A. - TENASA & 1942 & Geral & n.d.* & 3.000 \\
\hline Cia. Fiação de Tecidos N. S. do Carmo & 1942 & Algodão & Sorocaba & 1.000 \\
\hline Cia. Nacional de Tecidos & 1942 & Geral & São Paulo & 5.000 \\
\hline Estabelecimento Nacional Ind. De Tecidos (ENIT) & 1942 & Geral & $*$ & 1.000 \\
\hline Fiotêxteis S.A. & 1942 & Fiação Algodão & $*$ & 1.000 \\
\hline Fiação e Tecelagem Eliana S.A. & 1943 & Algodão & $*$ & 3.000 \\
\hline Lanifício Inglês S.A. & 1943 & Lã & $*$ & 4.000 \\
\hline Setifício Glória & 1943 & Fiação S. Natural & $*$ & 500 \\
\hline Tecelagem Satúrnia S.A. & 1943 & Seda Natural & $*$ & 900 \\
\hline Indústria de Tecidos Pindorama S.A. & 1943 & Algodão & Catanduva & 400 \\
\hline Tecidos Guapéva S.A. & 1943 & Geral & Jundiaí & 600 \\
\hline Lanifícios Helios S.A. & 1944 & Lã & * & 1.000 \\
\hline Fiação Camandocaia S.A. & 1944 & Fiação Algodão & Amparo & 18.000 \\
\hline Cia. Têxtil Indianópolis S.A. & 1944 & Geral & * & 1.500 \\
\hline Fiação de Seda São Paulo S.A. & 1944 & Fiação Seda Natural & Birigui & 300 \\
\hline Indústria de Tecidos de Malha Tricot S.A. & 1944 & Malhas & $*$ & 2.000 \\
\hline Indústria de Seda Fidasil S.A. & 1944 & Fiação Seda Natural & Limeira & 500 \\
\hline Cia. Têxtil Fornasaro & 1944 & Algodão & Vila Sta. Terezinha & 2.000 \\
\hline Industil S.A. & 1944 & Geral & $*$ & 500 \\
\hline Lanifício Argos S.A. & 1944 & Lã & Jundiaí & 3.000 \\
\hline Sementagem e Fiação de Seda de Cafelândia S.A. & 1944 & Fiação Seda Natural & Cafelândia & 700 \\
\hline Cia. Industrial N. S. da Conceição & 1944 & Algodão / Rayon & $*$ & 8.000 \\
\hline Lanifício Maria José S.A. & 1944 & Lã & $*$ & 1.000 \\
\hline Cia. Têxtil Sta. Helena & 1944 & Geral & $*$ & 600 \\
\hline Fiação de Seda Guararapes S.A. & 1944 & Fiação Seda Natural & Guararapes & 1.000 \\
\hline Fiação de Seda Meirelles S.A. & 1944 & Fiação Seda Natural & Campinas & 640 \\
\hline Tecelagem Aida S.A. & 1944 & Seda Natural & Sto. André & 1.000 \\
\hline S.A. Fiação de Seda Sta. Cecília & 1944 & Geral & $*$ & 5.000 \\
\hline Tecelagem São José de Cerquilho S.A. & 1944 & Geral & Tietê & 700 \\
\hline Fibrayon - Fábricas Brasileiras de Rayon S.A. & 1944 & Fiação - Tec. Rayon & São Paulo & 20.000 \\
\hline Empresa Industrial Sacaria S.A. & 1944 & Juta & Jundiaí & 500 \\
\hline Tecelagem União Cosmopolense S.A. & 1944 & Rayon / Algodão & Campinas & 600 \\
\hline Cia. Ind. de Tecidos Rayon Americana S.A. & 1944 & Rayon / Algodão & Americana & 3.000 \\
\hline Tecidos Lotaif S.A. & 1944 & Geral & $*$ & 2.000 \\
\hline Tecelagem Brasil & 1944 & Geral & $*$ & 4.000 \\
\hline Cia. Industrial de Sericultura - CIS & 1945 & Seda Natural & Sorocaba & 2.000 \\
\hline Fiação de Seda Biriguiense S.A. & 1945 & Seda Natural & Biriguí & 300 \\
\hline S.A. Setifício Gauimbé & 1945 & Seda Natural & Lins & 726 \\
\hline Tecelagem Sto. Alberto S.A. & 1945 & Geral & $*$ & 200 \\
\hline Tecelagem Colúmbia S.A. & 1945 & Rayon / S. Natural & $*$ & 2.000 \\
\hline Fiação de Seda Centenário S.A. & 1945 & Seda Natural & Brotas & 400 \\
\hline Incatêxtil S.A. & 1945 & Rayon / S.N./ AL & * & 1.000 \\
\hline
\end{tabular}




\begin{tabular}{ccccc} 
S.A. Cia. de Tecidos Schahin & 1945 & Geral & $*$ & 3.500 \\
Têxtil Utinga S.A. & 1945 & Geral & Sto. André & 500 \\
Fiação de Seda Bandeirante S.A. & 1945 & Seda Natural & $*$ & 500 \\
Sedacampineira S.A. & 1945 & Seda Natural & Campinas & 450 \\
Lanifício Bradford S.A. & 1945 & Lã & $*$ & 2.000 \\
Malharia Cambucy S.A. & 1945 & Malhas & São Paulo & 1.200 \\
Cotonifício Beltramo S.A. & 1945 & Algodão & Osasco & 2.000 \\
Fiatex S.A. - Ind. Têxtil Brasileira & 1945 & Fiação Algodão & $*$ & 20.000 \\
Tec. Sta. Terezinha de Cerqueira César S.A. & 1945 & Geral & Avaré & 1.000 \\
Cia. Têxtil São Martinho & 1945 & Geral & $*$ & 8.000 \\
de Tec. Elásticos Godoy - Valbert S.A. & 1945 & Tecidos elásticos & Campinas & 1.200 \\
\hline
\end{tabular}

Fonte: Diário Oficial do Estado de São Paulo, 1940-1946.

Legenda: (1) Ano de fundação; (2) Ramo; (3) Cidade; (4) Capital (Cr\$ 1.000; * - dado não-disponível (n.d.)

Tabela 14b - Empresas têxteis paulistas sob estatuto jurídico de sociedade anônima (S.A.) fundadas no pós-guerra (1939-1945)

\begin{tabular}{|c|c|c|c|c|}
\hline Nome & (1) & (2) & (3) & (4) \\
\hline Fiação e Tecelagem Najla S.A. & 1946 & Algodão & $*$ & 4.000 \\
\hline Tecelagem Calux & 1946 & Seda (rayon) & $*$ & 6.000 \\
\hline Chicopee do Brasil - S.A. Fiação e Tecelagem & 1946 & Geral & $*$ & 1.000 \\
\hline Indústria Têxtil T. Gabriel & 1946 & Geral & $*$ & 7.000 \\
\hline Cotonifício Indaiatuba & 1946 & Algodão - Lã & Indaiatuba & 1.450 \\
\hline Indústria e Comércio de Tecidos Daud Cury S.A. & 1946 & Rayon e Lã & $*$ & 3.000 \\
\hline Têxtil Maggioni S.A. & 1946 & Geral & $*$ & 1.000 \\
\hline Soc. Têxtil Fongaro S.A. & 1946 & Geral & $*$ & 2.500 \\
\hline Indústrias Brasileiras de Fios S.A. & 1946 & Fios em geral & $*$ & 4.000 \\
\hline Tecelagem Sylvia S.A. & 1946 & Geral & * & 1.000 \\
\hline Comércio e Indústria de Tecidos Fornasaro S.A. & 1946 & Geral & $*$ & 1.000 \\
\hline Fábrica de Tecidos Regina S.A. & 1946 & Algodão & * & 1.000 \\
\hline Indústria de Tecidos Elvira S.A. & 1946 & Geral & * & 1.000 \\
\hline Fiação e Tecelagem Tuiuty S.A. & 1946 & Geral & São Paulo & 7.000 \\
\hline Fiação Araguaia & 1946 & Algodão & São Paulo & 15.000 \\
\hline Cia. Brasileira de Fiação & 1946 & Fios em geral & * & 20.000 \\
\hline Têxtil Sto. Antônio S.A. & 1946 & Geral & $*$ & 500 \\
\hline Tecelagem de Seda Parisiense S.A. & 1946 & Seda em geral & $*$ & 1.200 \\
\hline Têxtil Neide S.A. & 1946 & Algodão & $*$ & 1.200 \\
\hline Fiação e Tecelagem Paulicéia S.A. & 1946 & Algodão & * & 10.000 \\
\hline Cia. Rhodiosa de Rayon S.A. & 1946 & Rayon e Lã & S. José dos Campos & 40.000 \\
\hline Têxtil Scheidler S.A. & 1946 & Geral & * & 1.000 \\
\hline Fiação Sta. Izabel & 1946 & Algodão & Tatuí & 1.800 \\
\hline CONREX - Malhas e Confecções S.A. & 1946 & Malhas & $*$ & 2.000 \\
\hline Tecelagem Paraíso S.A. & 1946 & Geral & * & 2.000 \\
\hline Tecelagem Taquara S.A. & 1947 & Geral & $*$ & 2.000 \\
\hline Torção São Jorge S.A. & 1947 & Fios em geral & $*$ & 10.000 \\
\hline LINHARTE S.A. & 1947 & Linhas & Franco da Rocha & 4.000 \\
\hline Tecelagem Raymo S.A. & 1947 & Algodão & $*$ & 650 \\
\hline Tinturaria e Beneficiamento Têxtil S.A. - TIBET & 1947 & Geral & $*$ & 1.000 \\
\hline Cotonifício Rio Preto S.A. & 1947 & Algodão & S. José do Rio Preto & 15.000 \\
\hline Têxtil José A. Kair S.A. & 1947 & Seda em geral & $*$ & 1.500 \\
\hline CIT - Cooperação Industrial Têxtil S.A. & 1947 & Geral & $*$ & 1.500 \\
\hline Lanifício Cariema S.A. & 1948 & Lã & $*$ & 25.000 \\
\hline Têxtil Arb S.A. & 1948 & Seda em geral & * & 1.000 \\
\hline Têxtil Nazaré S.A. & 1948 & Geral & $*$ & 800 \\
\hline
\end{tabular}


Argovia S.A. - Fábrica de Malhas Finas

Indústria e Comércio de Tecidos Sta. Rosa S.A.

União Têxtil Abib S.A.

Tinturaria e Estamparia Finetex S.A. Anchieta Têxtil S.A.

Indústrias Têxteis Aurélio Bianchi S.A.

Tecidos Finos Bocater S.A.

Fios Prado S.A.

S.A. Têxtil Nova Odessa

Têxtil Nova Inglaterra S.A.

Têxtil Gabriel Calfat S.A.

Cotonifício Amparo S.A.

Indústria de Tecidos Firme S.A.
1948

1949

1949

1949

1949

1949

1949

1949

1949

1949

1949

1950

1950

1950

$$
\begin{gathered}
\text { Malhas } \\
\text { Geral } \\
\text { Geral } \\
\text { Geral }
\end{gathered}
$$

Fios em geral

Lã

Seda em geral

Fios em geral

Algodão

Geral

Geral

Algodão

Lã

Geral
1.000

1.500

1.500

800

S. Bernardo do Campo

10.000

500

2.000

6.000

1.000

8.000

7.000

300

1.500

Fonte: Diário Oficial do Estado de São Paulo, 1947-1951.

Legenda: (1) Ano de fundação; (2) Ramo; (3) Cidade; (4) Capital (Cr\$ 1.000; * - dado não-disponível (n.d.)

\section{Grupos - Dados Diário Oficial do Estado de São Paulo}

Grupo I - Argos Industrial S.A.; Cia. Fiação e Tecelagem Tatuí; Cia. Fiação e Tecidos São Bento; Cia. Nacional de Estamparia; Cia. Têxtil Brasileira; Cotonifício Guilherme Giorgi; Cotonifício Rodolfo Crespi; Fábrica de Tecidos Labor; Fábrica de Tecidos Tatuapé; Fiação e Tecelagem Santana; Fiação e Tecelagem São Paulo; S.A. Boyes; S.A. Cotonifício Paulista; S.A. Fábrica de Tecidos e Bordados Lapa; S.A. Fábrica Votorantim.

Grupo II - Cia. Fiação e Tecelagem Azem; Cia. Fiação e Tecelagem Sta. Bárbara; Cia. Fiação e Tecidos São Bento; Cia. Nacional de Estamparia; Cia. Têxtil Brasileira; Cotonifício Guilherme Giorgi; Cotonifício Rodolfo Crespi; Fábrica de Tecidos Labor; Fábrica de Tecidos Tatuapé; Fiação e Tecelagem São Paulo; Fiação Extra-Fina de Extra-Fina de Algodão, S.A. Boyes, S.A. Calfat, S.A. Fábrica de Tecidos e Bordados Lapa, S.A. Votorantim, S.A. Fiação e Malharia Ypiranga Assad e S.A. Fiação, Tecelagem e Estamparia Ypirranga Jafet.

Grupo III - Cia. Fiação e Tecelagem Azem; Cia. Fiação e Tecelagem Sta. Bárbara; Cia. Fiação e Tecelagem Tatuí; Cia. Fiação e Tecidos São Bento; Cia. Fiação e Tecidos Sta. Maria; Cia. Nacional de Estamparia; Cia. Têxtil Brasileira; Cotonifício Guilherme Giorgi; Cotonifício Rodolfo Crespi; Fábrica de Tecidos Labor; Fábrica de Tecidos Tatuapé; Fiação e Tecelagem Pirassununga; Fiação e Tecelagem Santana; Fiação e Tecelagem São Paulo; Fiação Extra-Fina de Extra-Fina de Algodão;S.A. Boyes; S.A. Calfat; Cotonifício Adelina; S.A. Fábrica Paulista de Roupas Brancas; S.A. Fábrica de Tecidos e Bordados Lapa; S.A. Fábrica Japy; S.A. Votorantim; S.A. Fiação e Malharia Ypiranga Assad e S.A. Fiação, Tecelagem e Estamparia Ypirranga Jafet.

Grupo IV - Argos Industrial S.A.; Brasital S.A; Cia. Fiação e Tecelagem Sta. Bárbara; Cia. Fiação e Tecelagem Tatuí; Cia. Fiação e Tecidos São Bento; Cia. Fiação e Tecidos Sta. Maria; Cia. Nacional de Estamparia; Cia. Têxtil Brasileira; Cotonifício Guilherme Giorgi; Cotonifício Rodolfo Crespi; Fábrica de Tecidos Labor; Fábrica de Tecidos Tatuapé; Fiação e Tecelagem Pirassununga; Fiação e Tecelagem Santana; Fiação e Tecelagem São Paulo; Fiação Extra-Fina de Extra-Fina de Algodão;S.A. Boyes; S.A. Calfat; Cotonifício Adelina; S.A. Fábrica Paulista de Roupas Brancas; S.A. Fábrica de Tecidos e Bordados Lapa; S.A. Fábrica Japy; S.A. Votorantim; S.A. Fiação e Malharia Ypiranga Assad e S.A. Fiação, Tecelagem e Estamparia Ypirranga Jafet.

Grupo V - Cia. Anglo-Brasileira de Juta, Cia. Industrial de Juta e Cia. Paulista de Aniagens.

Grupo VI - Cia. Paulista Artigos de Seda; S.A. Tecelagem de Seda Ítalo-Brasileira; S.A. Tecelagem de Seda Lavínia; Textila S.A.; Tinturaria e Estamparia Arnaldo Pessina; S.A. Indústria de Seda Nacional e Tinturaria Brasileira de Sedas. 
Grupo VII - Lanifício Minerva, Lanifício Lapa, Fiação Brasileira de Lã e Lanifício Fileppo.

Grupo VIII - Argos Industrial S.A.; Brasital S.A; Cia. Fiação e Tecelagem Azem; Cia. Fiação e Tecelagem Sta. Bárbara; Cia. Fiação e Tecelagem Tatuí; Cia. Fiação e Tecidos São Bento; Cia. Fiação e Tecidos Sta. Maria; Cia. Nacional de Estamparia; Cia. Têxtil Brasileira; Cotonifício Guilherme Giorgi; Cotonifício Rodolfo Crespi; Fábrica de Tecidos Labor; Fábrica de Tecidos Tatuapé; Fiação e Tecelagem Pirassununga; Fiação e Tecelagem Santana; Fiação e Tecelagem São Paulo; Fiação Extra-Fina de Extra-Fina de Algodão; S.A. Boyes; S.A. Calfat; Cotonifício Adelina; S.A. Fábrica Paulista de Roupas Brancas; S.A. Fábrica de Tecidos e Bordados Lapa; S.A. Fábrica Japy; S.A. Votorantim; S.A. Fiação e Malharia Ypiranga Assad e S.A. Fiação, Tecelagem e Estamparia Ypirranga Jafet; B. Stororani; Beneficiamento de Fios São José S.A.; Cia. Têxtil Sta. Basilissa; Fábrica N. S. Mãe dos Homens; Fiação e Tecelagem Eliana; Fiação e Tecelagem Germano Fehr; Fiação Sul-Americana; Fiotêxtil; S.A. Sto. André Têxtil e Tecelagem Paraíba S.A.

Grupo IX - BrasitalS.A.; Cia. Têxtil Brasileira Cotonifício Guilherme Giorgi; Cotonifício Rodolfo Crespi; Fábrica de Tecidos Labor; Fábrica de Tecidos Tatuapé; Fiação e Tecelagem Pirassununga; S.A. Boyes; S.A. Fábrica de Tecidos e Bordados Lapa; Fiação, Tecelagem e Estamparia Ypiranga Jafet; Beneficiamento de Fios S. José; Cia. Fiação e Tecidos N. S. Carmo; Cia. Têxtil Sta. Basilissa; Fiação e Tecelagem Eliana; Fiação e Tecelagem Germano Fehr e S.A. Sto. André Têxtil.

Grupo X - Cia. Anglo-Brasileira de Juta; Cia. Industrial de Juta; Cia. Paulista de Aniagens; Cia. Fabril de Juta; Fiação e Tecelagem de Juta e Jutifício Maria Luiza.

Grupo XI - Lanifício Anglo-Brasileiro; Lanifício S. Paulo; Fambra S.A.; Fiação, Brasileira de Lã; Lanifícios Argos; Lanifício Asta; F. Kowarick; Lanifício Inglês; Lanifício Ítalo-Adami; Lanifício Jafet; Lanifício Masber; Lanifício Sta. Branca; Lanifício Varam; S.A. Fabril Scavone; S.A. Lanifício Lapa e S.A. Lanifício Minerva.

Grupo XII - Cia. Brasileira Rhodiaseta de Seda; Cia. Paulista Artigos de Seda; S.A. Indústria Seda Naciona; S.A. Tecelagem de Seda Lavínia; S.A. Tinturaria Brasileira de Sedas; Textila S.A.; Tinturaria e Estamparia Arnaldo Pessina; Cia. Fabril Fuad Kairalla; Cia. Fiação e Tecidos S. Miguel; Cia. Industrial de Tecidos Rayon de Americana; Cia. Tecelagem de Seda Vila de S. Bernando; Fábrica Brasileira de Rayon; Indústria Têxtil de Rayon; Indústria de Seda de Marília; Indústria de Seda e Rayon Yazigi; Indústria e Comércio de Tecidos Daud Cury S.A.; Indústria e Comércio de Tecidos Nigri; Indústria Têxtil Irmãos Romano; Indústria Têxtil Nicolau Jeha; Indústrias Têxteis de Seda Maluf; Indústrias Têxteis Aziz Nader; Indústrias Têxteis Najar; S.A. Fiação e Tecelagem Luftalla; Setifício Glória; Tecelagem Ainda; Tecelagem As Américas;; Tecelagem Calux; Tecelagem Colúmbia; Tecelagem de Seda Âmbar; Tecelagem de Seda N. S. da Penha, Tecelagem de Seda Sta. Sophia;Tecelagem de Seda Sta. Terezinha; Tecelagem de Seda Sul América; Tecelagem Marajó; Tecelagem Satúrnia; Tecelagem Sto. Alberto; Tecelagem Urca; Tecelagem Beyruti, Têxtil Checri e Racy, Têxtil Sedamital, Torção de Seda Fiased. 


\section{Bibliografia}

\section{Publicacões oficiais}

Brasil. Coleção das Leis da República dos Estados Unidos do Brasil. Imprensa Nacional, Rio de Janeiro, vários anos.

Brasil. Conselho Nacional de Estatística. Instituto Brasileiro de Geografia e Estatística. Anuário Estatístico do Brasil (1929-1942; 1944-1950, vol. III).

Brasil. Conselho Nacional de Estatística. Instituto Brasileiro de Geografia e Estatística. Sinopse do censo industrial e do censo de serviços, Rio de Janeiro, 1948.

Brasil. Instituto Brasileiro de Geografia e Estatística. Estatísticas do século XX (www.ibge.gov.br)

Brasil. Ministério da Agricultura. Serviço de Estatística de Produção. Juta, Rio de Janeiro, 1950 (mimeo).

Brasil. Ministério da Agricultura, da Indústria e do Comércio. Diretoria Geral de Estatística. Recenseamento do Brasil realizado em 1 de setembro de 1920. Volume V - Indústria.

Brasil. Ministério da Agricultura, da Indústria e do Comércio. Diretoria Geral de Estatística. Recenseamento do Brasil realizado em 1 de setembro de 1940. Volume III - Agrícola, Industrial, Comercial e dos Serviços.

Brasil. Ministério da Agricultura, da Indústria e do Comércio. Diretoria Geral de Estatística. Recenseamento do Brasil realizado em 1 de setembro de 1950. Volume III - Agrícola, Industrial, Comercial e dos Serviços.

Brasil. Ministério da Fazenda. Serviço de Estatísticas Econômicas e Financeiras (anteriormente Diretoria...). Quadros estatísticos, 1928-1935 (1930-1937, 1932-1939, 1936-1945).

Brasil. Ministério da Fazenda. Serviço de Estatística Econômica e Financeira. Comércio de cabotagem do Brasil. 1927-1928; 1933-1942; 1946-1947.

Brasil. Ministério da Fazenda. Serviço de Estatística Econômica e Financeira. Comércio Exterior do Brasil por mercadorias, segundo os portos. 1945-1946, 1948-1949 e 1949-1950, Rio de Janeiro.

Brasil. Ministério das Relações Exteriores. O Brasil e a Segunda Guerra Mundial. 2 vols.

Brasil. Ministério das Relações Exteriores. Brasil: 1943-1944, recursos, possibilidades. Mendes Júnior, Rio de Janeiro, 1944. (muito importante - estatísticas de tecidos, olhar)

Brasil. Ministério do Trabalho, da Indústria e do Comércio. Departamento de Estatística e Publicidade. Boletim do Ministério do Trabalho, da Indústria e do Comércio, (mensal), 1935-1950.

Brasil. Ministério do Trabalho, Indústria e Comércio. Comissão Executiva Têxtil (CETex). Indústria têxtil algodoeira. Rio de Janeiro, 1946.

Brasil. Ministério do Trabalho, Indústria e Comércio. Comissão Executiva Têxtil (CETex). A juta brasileira. Rio de Janeiro, 1948.

Brasil. Ministério do Trabalho, Indústria e Comércio. Comissão Executiva Têxtil (CETex). A juta no Brasil e no mercado mundial. Imprensa Nacional, Rio de Janeiro, 1940.

Brasil. Ministério do Trabalho, Indústria e Comércio. Comissão Executiva Têxtil (CETex). A indústria têxtil do algodão e da lã. Rio de Janeiro, 1949. 
São Paulo. Coleção de Leis e Decretos do Estado de São Paulo. Tipografia do Diário Oficial, São Paulo, vários anos.

São Paulo. Departamento Estadual de Estatística. Alguns aspectos da indústria paulista - 1941. Separata do Boletim n. 1 - Primeiro Trimestre de 1945, São Paulo.

São Paulo. Departamento Estadual de Estatística. Boletim do Departamento Estadual de Estatística, (mensal), $1939-1950$.

São Paulo. Departamento Estadual de Estatística. Catálogo das Indústrias do Município da Capital, 1945.

São Paulo. Departamento Estadual de Estatística. Catálogo das Indústrias do Estado de São Paulo (exclusive a capital), 1945.

São Paulo. Secretaria da Agricultura, Indústria e Comércio (SAIC). Diretoria de Estatística, Indústria e Comércio (DEIC). Estatística Industrial do Estado de São Paulo, 1928-1937, 1938-1939, 1943 e 1944.

São Paulo. Secretaria da Agricultura, Indústria e Comércio (SAIC). Diretoria de Estatística, Indústria e Comércio (DEIC). Comércio de cabotagem pelo porto de Santos, 1928-1944

São Paulo. Secretaria da Agricultura, Indústria e Comércio (SAIC). Diretoria de Estatística, Indústria e Comércio (DEIC). Estatística do comércio do porto de Santos, 1927-1947.

São Paulo. Secretaria da Agricultura, Comércio e Obras Públicas do Estado de São Paulo. Boletim do Departamento Estadual do Trabalho. São Paulo, 1919-1933.

São Paulo. Secretaria da Indústria, Comércio, Ciência e Tecnologia. Conselho Estadual de Política Industrial, Comercial e Agroindustrial (COINCO). A indústria têxtil brasileira: diagnóstico setorial. Campinas, 1985.

São Paulo. Secretaria de Estado dos Negócios da Agricultura. Nivaldo Alves Bonilha. A amoreira na alimentação do bicho-da-seda, São Paulo, 1961.

United Nations. Economic Commission for Latin America. Productividad de la mano de obra en la industria textil algodonera de cinco países latinoamericanos., Naciones Unidas, Dept. de Asuntos Económicos, Nova York, 1951.

\section{Publicações das associações}

Centro Industrial do Brasil. O Brasil, suas riquezas naturais, suas indústrias. Volume III: Indústria de transporte e indústria fabril. M. Orosco, Rio de Janeiro, 1909.

Centro das Indústrias do Estado de São Paulo. Circulares, São Paulo, 1929-1931.

Centro Industrial de Fiação e Tecelagem de Algodão (Rio de Janeiro) e Centro Industrial de Fiação e Tecelagem de Algodão (São Paulo). Memorial apresentado ao congresso nacional sobre o projeto de revisão das tarifas alfandegárias, Rio de Janeiro, 1927.

Centro dos Industriais de Fiação e Tecelagem de São Paulo. Circulares. São Paulo, 1921-1931.

Centro dos Industriais de Fiação e Tecelagem de São Paulo. Atas das Assembléias Gerais Extraordinárias. São Paulo, 1931.

Paulo, 1931. Atas das Assembléias Gerais Ordinárias, São

Centro dos Industriais de Fiação e Tecelagem de São Paulo. A crise têxtil. São Paulo, 1928. 
Um ensaio de socialismo de Estado no Brasil e as Indústrias Nacionais. São Paulo, Liceu Coração de Jesus, 1927.

Centro Industrial de Fiação e Tecelagem de Algodão. Relatórios de Diretoria, 1925-1950, Rio de Janeiro. Atas das Reuniões de Diretoria, 1928-1950, Rio de Janeiro. Circulares, 1928-1950, Rio de Janeiro.

Extraordinárias, 1928-1950, Rio de Janeiro.

Atas das Assembléias Ordinárias e

Sindicato Patronal das Indústrias Têxteis do Estado de São Paulo. Atas das Assembléias Ordinárias e Extraordinárias. São Paulo, 1931-1940. Atas das Reuniões de Diretoria, São

Paulo, 1940. O problema da sacaria, São Paulo, 1935.

Sindicato da Indústria de Fiação e Tecelagem em Geral. Atas das Assembléias Ordinárias e Extraordinárias, São Paulo, 1941-1950.

Paulo, 1942-1943. Atas das Reuniões de Diretoria, São

Sindicato da Indústria de Fiação e Tecelagem do Rio de Janeiro e Sindicato da Indústria de Fiação e Tecelagem de São Paulo. Em defesa das nossas fibras e da sua indústria, Jornal do Comércio, Rio de Janeiro, 1948.

\section{Jornais}

- A Plebe-SP

- A Terra Livre - SP

- Correio Paulistano - SP

- Diário Popular - SP

- Folha da Manhã - SP

- Folha da Noite - SP

- Jornal do Comércio - RJ

- Jornal do Comércio - SP

- O Estado de São Paulo - SP

\section{Publicação das empresas}

Balanços, atas de assembléias ordinárias e extraordinárias e relatórios de diretoria (1929-1950) das seguintes empresas $^{798}$ :

- A. J. Renner S.A. (1944)

- Anchieta Têxtil S.A. (1949)

- Argovia S.A. - Fábrica de Malhas Finas

\footnotetext{
798 Salvo falências no período citado. As datas entre parêntesis assinalam o ano de fundação da sociedade anônima. Empresas que não possuem parêntesis já existiam como S.A. antes de 1929. Lembrar que muitas companhias transformadas em S.A. ao longo do período de estudo já existiam antes, porém sob a forma de sociedade limitada. Não precisavam, assim, publicar seus documentos no Diário Oficial.
} 
- Automatic Sprinkelers do Brasil

- Beneficiamento de Fios São José S.A. (1942)

- Beneficiadora Nacional de Tecidos S.A.

- B. Storani S.A. - Fiação e Tecelagem Sant'Anna (1944)

- Cia. Anglo-Brasileira de Juta

- Cia. Brasileira de Fiação (1946)

- Cia. Brasileira de Linhas para Coser

- Cia. Brasileira de Sedas Rhodiaseta

- Cia. de Indústrias Têxteis

- Cia. de Tecidos de Malha Filinha S.A.

- Cia. de Tecidos Progredior

- Cia. Fabril de Juta

- Cia. Fabril de Tapetes e Veludos 'TABACOW' (1943)

- Cia. Fiação Guaratinguetá

- Cia. Fiação Pedreira

- Cia. Fabril Santa Basilissa

- Cia. Fabril União das Américas Têxtil (1943)

- Cia. Fiação e Tecelagem Assunção (1946)

- Cia. Fiação e Tecelagem Azem S.A.

- Cia. Fiação e Tecidos N. Senhora do Carmo (1942)

- Cia. Fiação e Tecidos Pedreira

- Cia. Fiação e Tecidos São Bento

- Cia. Fiação e Tecidos Santa Maria

- Cia. Fiação e Tecidos São Carlos

- Cia. Fiação e Tecidos São Miguel (1943)

- Cia. Fiação e Tecelagem Fides

- Cia. Fiação e Tecelagem Sta. Bárbara (1936)

- Cia. Fiação e Tecelagem São Pedro (1936)

- Cia. Fabril Fuad Kairalla (1946)

- Cia. Industrial de Juta

- Cia. Industrial de Tecidos Alfo (1943)

- Cia. Indústria Mogiana de Tecidos

- Cia. Industrial de Sericultura - CIS (1945)

- Cia. Industrial de Tecidos Rayon de Americana - CITRA (1944)

- Cia. Industrial Nami Haddad (1944)

- Cia. Industrial N. S. da Conceição (1944)

- Cia. Lanifício São Paulo (1944)

- Cia. Leyen Tecelagem de Seda

- Cia. Nacional de Estamparia

- Cia. Nacional de Sericultura (1945)

- Cia. Nacional de Tecidos (1942)

- Cia. Nacional de Tecidos de Juta

- Cia. Nacional de Veludos (1941)

- Cia. Nitro-Química Brasileira

- Cia. Paulista de Aniagens

- Cia. Paulista de Artigos de Seda S.A.

- Cia. Paulista de Fibras

- Cia. Prada S.A.

- Cia. Rhodosa de Rayon S.A. (1946)

- Cia. Salto Fabril

- Cia. São Manoel S.A. (1940)

- Cia. São Patrício (1942)

- Cia. Sto. André de Fiação e Tecelagem - COSAF (1944)

- Cia. Tecelagem de Seda Vila de S. Bernardo

- Cia. Tecidos de Seda Santa Branca

- Cia. Têxtil Agro-Industrial (1942) 
- $\quad$ Cia. Têxtil Fornasaro (1944)

- Cia. Têxtil Indianópolis (1944)

- Cia. Têxtil São Martinho (1945)

- Cia. Têxtil Sta. Catarina S.A.

- Cia. Têxtil Sta. Helena (1944)

- $\quad$ CIT - Cooperação Industrial Têxtil S.A. (1947)

- Cheinile do Brasil - Tecelagem e Confecções S.A. (1950)

- Chicoppe do Brasil - S.A. Fiação e Tecelagem (1946)

- Comércio e Indústria de Tecidos Fornasaro S.A. (1946)

- CONREX - Malhas e Confecções S.A. (1946)

- Cotonifício Amparo (1950)

- Cotonifício Beltramo S.A. (1945)

- Cotonifício Guilherme Giorgi

- Cotonifício Indaiatuba S.A. (1946)

- Cotonifício Rio Preto S.A. (1947)

- Cotonifício Rodolfo Crespi

- $\quad$ Crepe Rayon S.A. (1944)

- Empresa Industrial Sacaria S.A. (1944)

- Estabalecimento Fabril Pinotti Gamba

- Estabelecimento Nacional Indústria Tecidos S.A. - ENIT (1941)

- Fábrica de Casemiras 'Adamastor' S.A. (1944)

- Fábrica de Linhas SETTA S.A. (1945)

- Fábrica de Lonas S.A. (1943)

- Fábrica de Tecidos 'Carioba` S.A. (1945)

- Fábrica de Tecidos Elásticos Godoy - Valbert S.A. (1945)

- Fábrica de Tecidos Labor

- Fábrica de Tecidos Regina (1946)

- Fábrica de Tecidos Sta. Teresinha de Cerqueira César S.A. (1945)

- Fábrica Nacional de Máquinas Têxteis - FANAMATEX S.A. (1946)

- Fábrica Trussardi S.A. (1943)

- Fambra S.A. - Fiação e Malharia de Lã

- Fiação Amparo S.A.

- $\quad$ Fiação Araguaia S.A. (1946)

- Fiação Brasileira de Lã (1940)

- Fiação Camandocaia (1944)

- Fiação Campinas S.A. (1944)

- $\quad$ Fiação de Arte Bandeirante S.A. (1945)

- Fiação de Seda Biriguiense S.A. (1945)

- Fiação de Seda Centenário S.A. (1945)

- $\quad$ Fiação de Seda Meirelles S.A. (1944)

- Fiação de Seda São Carlos S.A.

- Fiação de Seda São Paulo S.A. (1944)

- Fiação Extra-Fina de Algodão S.A. (1936)

- Fiação e Tecelagem de Juta S.A. (1943)

- Fiação e Tecelagem de Juta Sta. Izabel S.A. (1947)

- Fiação e Tecelagem Eliana (1943)

- Fiação e Tecelagem Najla S.A. (1946)

- $\quad$ Fiação e Tecelagem Nice S.A. (1947)

- Fiação e Tecelagem Odete S.A. (1940)

- Fiação e Tecelagem Paulicéia S.A. (1946)

- Fiação e Tecelagem Pirassununga

- Fiação e Tecelagem São Joanense S.A.

- Fiação e Tecelagem São João S.A. - FIATECE (1945)

- Fiação e Tecelagem São Paulo S.A.

- Fiação e Tecelagem Sto. André (1944)

- Fiação e Tecelagem Tognato S.A.

- Fiação e Tecelagem Tuiuty S.A. (1946) 
- Fiação e Tinturaria Sant'Anna

- Fiação Progresso S.A. (1942)

- Fiação São Leopoldo S.A.

- $\quad$ Fiação Sta. Izabel S.A. (1946)

- Fiação Sul-Americana S.A (1939)

- $\quad$ Fiatex S.A. - Indústria Têxtil Brasileira (1945)

- $\quad$ FIBRAYON - Fábricas Brasileiras de Rayon S.A. (1944)

- Fios Prado S.A. (1949)

- Fiotêxteis S.A. (1941)

- Gália Industrial de Seda S.A.

- Incatêxtil S.A. - Indústria e Comércio de Tecidos (1945)

- Industil S.A. - Indústria Têxtil (1944)

- Indutex S.A. - Indústria Têxtil de Rayon (1945)

- Indústria Brasileira de Meias S.A. (1943)

- Indústria Brasileira Químico - Têxtil S.A. (1945)

- Indústria e Comércio de Tecidos Daud Cury S.A. (1946)

- Indústria e Comércio de Tecidos Gasparian S.A. (1943)

- Indústria e Comércio de Tecidos Nigri (1946)

- Indústria e Comércio de Tecidos Sta. Rosa S.A. (1948)

- Indústria de Seda de Marília (1944)

- Indústria de Máquinas Têxteis Ribeiro S.A. (1943)

- Indústria de Seda 'Fidasil' S.A. (1944)

- Indústria de Tecidos Angar S.A. (1946)

- Indústria de Tecidos Elvira S.A. (1946)

- Indústria de Tecidos Firme S.A. (1950)

- Indústria de Tecidos de Malha Tricot S.A. (1944)

- Indústria de Tecidos Paramount S.A. (1942)

- Indústria de Tecidos São Sebastião S.A. (1943)

- Indústria Fongaro de Meias 'Marte' S.A. (1942)

- Indústria Nacional de Meias S.A.

- Indústria Nacional de Tecidos e Artefatos de Elástico S.A. (1943)

- Indústria Rayon - Seda S.A. (1945)

- Indústrias Reunidas Francisco Matarazzo

- Indústria Têxtil Americana S.A. (1945)

- Indústria Têxtil Nicolau Jeha (1943)

- Indústria Têxtil Irmãos Romano S.A. (1946)

- Indústria Têxtil T. Gabriel S.A. (1946)

- Indústrias Brasileiras de Fios S.A. (1946)

- Indústrias de Seda e Rayon Yazigi S.A. (1945)

- Indústrias de Seda Maluf S.A. (1944)

- Indústrias Fibrasil de São Paulo S.A. (1946)

- Indústrias Têxteis Aurélio Bianchi S.A. (1949)

- Indústrias Têxteis Aziz Nader S.A. (1942)

- Indústrias Têxteis Carone S.A. (1944)

- Indústrias Têxteis Najar S.A. (1945)

- Indústrias Têxteis Sto. André S.A. (1946)

- Irmãos Bruderer S.A. - Fábrica de Tecidos Simper Idem (1945)

- Irmãos Petrella S.A. - Beneficiadora de Fios S.A.

- Jutifício Maria Luíza S.A. (1942)

- Lanifício Anglo-Brasileiro

- Lanifício Argos S.A. (1944)

- Lanifício Asta (1944)

- Lanifício Bradford S.A. (1945)

- Lanifício Cariema S.A. (1948)

- Lanifício Cianflone S.A. (1943)

- Lanifício F. Kowarick S.A. (1943)

- Lanifício Fileppo S.A. 
- Lanifício Jafet S.A. (1944)

- Lanifício Inglês S.A. (1943)

- Lanifício Ítalo-Adami (1943)

- Lanifício Maria José S.A. (1944)

- Lanifício Masber S.A. (1944)

- Lanifício Myrtes S.A. (1946)

- Lanifício Pirituba S.A. (1947)

- Lanifício Record S.A. (1945)

- Lanifício Sapucaia S.A. (1946)

- Lanifício Sta. Branca S.A. (1943)

- Lanifício Sta. Izabel S.A. (1944)

- Lanifício Sta. Lúcia S.A.

- Lanifício Urânia S.A.

- Lanifício Varam S.A. (1943)

- Lanifícios Hélios S.A. (1944)

- LINHARTE S.A. - Indústria de Linhas e Artefatos Têxteis (1947)

- LUCA S.A. - Beneficiamento de Fios de Algodão e Lã (1944)

- Malharia Albion S.A. (1949)

- Malharia Cambucy S.A. (1945)

- Malharia N. Senhora da Conceição

- Oetterer, Speers e Cia.

- Organizações Têxteis Irmãos Chamma S.A. (1946)

- Produtex S.A. - Indústria e Comércio de Tecidos (1946)

- Rappa Milani S.A. - Fiação e Tecelagem (1944)

- S.A. Boyes

- S.A. Calfat (1939)

- S.A. Cia. de Tecidos Schahin (1945)

- S.A. Cotonifício Adelina

- S.A. Cotonifício Paulista

- S.A. de Tecidos Votex

- S.A. Emílio Vanini Tinturaria e Estamparia (1939)

- S.A. Fábrica de Linhas Arlete Marconcini (1937)

- S.A. Fábrica de Tecidos e Bordados Lapa

- S.A. Fábrica de Tecidos N. Senhora Mãe dos Homens

- S.A. Fábrica Japy

- S.A. Fábrica Votorantim

- S.A. Fabril Scavone

- S.A. Fiação e Malharia Assad

- S.A. Fiação e Tecelagem Lutfalla (1939)

- S.A. Fiação para Malharia Indiana

- S.A. Fiação Sta. Cecília (1944)

- S.A. Industria de Meias Eterna (1938)

- S.A. Jacareí Industrial

- S.A. Lanifício Lapa (1941)

- S.A. Lanifícios Minerva

- S.A. Lingerie Brasileira (1940)

- S.A. Moinho Santista

- S.A. Setifício Guaimbé (1945)

- SATA - Sociedade Anônima Têxtil Algodoeira (1946)

- S.A. Sto. André Têxtil (1945)

- S.A. Tecidos e Confecções 'SATECO'

- S.A. Tecelagem Brasileira de Seda (1942)

- S.A. Tecelagem de Seda Ítalo-Brasileira

- S.A. Tecelagem de Seda Lavínia

- S.A. Têxtil Nova Odessa (1949)

- S.A. Tinturaria Brasileira de Tecidos

- São Paulo Alpargatas Company S.A. 
- Seda Fiação Guararapes S.A. (1944)

- Sedas Guttermann S.A. (1941)

- Sementagem e Fiação de Seda de Cafelândia S.A. (1944)

- Sericampineira S.A. (1945)

- Setifício Glória S.A. (1943)

- Setificío Guaimbé S.A.

- Sociedade Têxtil Fongaro S.A. (1946)

- Tecelagem Alba S.A. (1945)

- Tecelagem Anda S.A. (1944)

- Tecelagem 'As Américas' (1944)

- Tecelagem Artis S.A.

- Tecelagem Brasil S.A. (1944)

- Tecelagem Calux S.A. (1946)

- Tecelagem Colúmbia S.A. (1945)

- Tecelagem de Seda Âmbar (1937)

- Tecelagem de Seda N. Senhora da Penha

- Tecelagem de Seda Paulicéia S.A. (1947)

- Tecelagem de Seda Sta. Sofia S.A. (1943)

- Tecelagem de Seda Sta. Terezinha S.A. (1943)

- Tecelagem de Seda Sul América S.A. (1943)

- Tecelagem de Sedas Parisiense S.A. (1946)

- Tecelagem Francesa S.A.

- Tecelagem Marajó S.A. (1946)

- Tecelagem Maria Ângela S.A.

- Tecelagem Mascote S.A. (1944)

- Tecelagem Moderna S.A. (1940)

- Tecelagem Paraíba S.A.

- Tecelagem Paraíso S.A. (1947)

- Tecelagem Raymo S.A. (1947)

- Tecelagem Satúrnia S.A. (1943)

- Tecelagem Salomão S.A. (1945)

- Tecelagem São Carlos S.A. - Germano Fehr (1944)

- Tecelagem Sto. Alberto S.A. (1945)

- Tecelagem São José de Cerquilho S.A. (1944)

- Tecelagem Sirius S.A. (1947)

- Tecelagem Sylvia S.A. (1946)

- Tecelagem Taquara S.A. (1947)

- Tecelagem União Cosmopolense S.A. (1944)

- Tecelagem Urca S.A. (1943)

- Tecidos Finos Bocater S.A. (1949)

- Tecidos Guapeva (1944)

- Tecidos Lotaif S.A. (1944)

- Têxtil Assid Nassif S.A. (1945)

- Têxtil Assunção S.A. (1945)

- Têxtil Arb S.A. (1948)

- Têxtil Arte S.A. (1944)

- Têxtil Assad Abdala S.A. (1941)

- Têxtil Beyruti S.A. (1944)

- Têxtil Checri A. Racy S.A. (1944)

- Têxtil Gabriel Calfat S.A. (1949)

- Têxtil Industrial Pierri e Belli S.A. (1942)

- Têxtil José A. Kair S.A. (1947)

- Têxtil Maggioni S.A. (1946)

- Têxtil Mobadda Haddad S.A. (1944)

- Têxtil Nacional S.A. - TENASA (1941)

- Têxtil Nazaré S.A. (1948)

- Têxtil Neide S.A. (1946) 
- Têxtil Nova Inglaterra S.A. (1949)

- Têxtil Paulo Abreu (1941)

- Têxtil Piratininga S.A. (1946)

- Têxtil Sedamital S.A. (1946)

- Têxtil Scheidler S.A. (1946)

- Têxtil Sto. Antônio S.A. (1946)

- Têxtil Utinga S.A. - TUSA (1945)

- Texnovo S.A.

- Textila S.A. (1936)

- Tinturaria Brasileira de Sedas

- Tinturaria e Beneficiamento Têxtil S.A. - TIBET (1947)

- Tinturaria e Estamparia Cruzeiro do Sul S.A. (1946)

- Tinturaria e Estamparia Finetex S.A. (1949)

- Tinturaria e Estamparia de Tecidos Fernandes S.A. (1944)

- Torção Cordeiro S.A. (1946)

- Torção de Seda Fiased S.A. (1943)

- Torção Indaiá S.A. (1944)

- Torção São Jorge S.A. (1947)

- União Têxtil Abib S.A. (1949)

- Vagnotti - Cia. Industrial de Acessórios Têxteis (1944)

- VARIETEX S.A. - Variedades Têxteis (1944)

- VELBRA’s S.A. - Indústria Brasileira de Veludos (1944)

\section{Artigos contemporâneos}

Sem autor. Superprodução industrial? In: Observador econômico e financeiro, março de 1937.

. A indústria de fiação de algodão. In: Observador econômico e financeiro, fevereiro de 1937. . As indústrias de tecelagem, seda, juta e lã. In: Observador econômico e financeiro, fevereiro de 1937. . A indústria têxtil no Brasil. In: Observador econômico e financeiro, março de 1946.

ALMEIDA, Luis Castanho. A primeira fábrica de tecidos. In: Revista Têxtil, julho de 1944.

AZEVEDO, Aldo Mário de. A Superprodução industrial. In: Observador econômico e financeiro, abril de 1937.

D'AGOSTINHO, C. Nova crise de tecidos? In: Observador econômico e financeiro, fevereiro de 1937.

HOLANDA, Sérgio Buarque de. A mais antiga fábrica de tecidos de São Paulo. Digesto Econômico, IV (41), 1948.

MONTEIRO, B. Curso breve de técnica de lanifícios. In: Lanificios - Boletim Mensal, n. 117-118, Lisboa, s/ d, pp. 563- 579 .

NOGUEIRA, Octávio Pupo. A superprodução têxtil. In: Observador econômico e financeiro, s/ mês, 1937.

OLIVEIRA NETTO, José Ribeiro de. Profilaxia das causas diretas de insalubridade das fábricas paulistas de fiar, tecer e tingir algodão. In: Boletim da Sociedade de Medicina e Cirurgia de São Paulo, n. 05, 1922.

SODRÉ, Nelson Werneck. História da Indústria em São Paulo. In: Observador Econômico e Financeiro, janeiro de 1948.

VIEIRA, Dorival Teixeira. A evolução industrial brasileira. Digesto Econômico, n. 51, ano V, fevereiro de 1949. 


\section{Artigos não-contemporâneos}

BARAT, Josef. $\underline{O}$ investimento em transportes como fator de desenvolvimento regional - Uma análise da expansão rodoviária no Brasil. In: Revista Brasileira de Economia, setembro de 1969.

BARROS, J. R. Mendonça de e GRAHAM, D. H. A recuperação econômica e a desconcentração de mercado da indústria têxtil paulista durante a Grande Depressão: 1928-1937. Pesquisa e Planejamento Econômico, Rio de Janeiro, 11(1), abril de 1981.

COHN, Gabriel. Problemas da industrialização no século XX. In: MOTA, Carlos Guilherme. Brasil em perspectiva. $12^{\circ}$ Edição. Ed. Difel, São Paulo, 1981.

CORSI, Francisco Luiz Corsi. Política econômica e nacionalismo no Estado Novo. In: SMRECSÁNYI, Tamás e SUZIGAN, Wilson Suzigan (org.). História Econômica do Brasil Contemporâneo. Imprensa Oficial, São Paulo, 2002, p. 03-16.

FONSECA, Pedro César Dutra. Estado e industrialização consicente: 1930-1950. In: Questões de Economia Política, 3 (4).

HIRSCHMAN, Albert. The Political Economy of Import-substituting Industrialization in Latin América. The Quartely Journal of Economics, LXXXII, 1968.

HUDDLE, Donald L. Balanço de pagamentos e controle de câmbio no Brasil: diretrizes políticas e história. (1946-1954). In: Revista Brasileira de Economia, XVIII, n. 01, março de 1964.

Balanço de pagamentos e controle de câmbio no Brasil: eficácia, bem-estar e desenvolvimento econômico. In: Revista Brasileira de Economia, n. 02, junho de 1964.

LEWIS, Colin M. States and markets in Latin America: government, business and the political economy of economic intervencionism. (mimeo), Araraquara, 2003.

LOEB, G.F. Números e índices de desenvolvimento físico da produção industrial (1931-1949). Revista Brasileira de Economia, março de 1953.

MARTINS, Luciano. Formação do empresariado industrial. Revista Civilização Brasileira, n 13, 1967.

PELÁEZ, C. A Balança Comercial, a Grande Depressão e a Industrialização Brasileira. Revista Brasileira de Economia, ano 22, n. 01, março de 1968.

PREBISCH, Raul. $\mathrm{O}$ desenvolvimento econômico da América Latina e seus principais problemas. In: Revista Brasileira de Economia, set-dez de 1949.

SINGER, Paul. Interpretação do Brasil: uma experiência histórica de desenvolvimento. In: FAUSTO, Boris (org). História Geral da Civilização Brasileira. Tomo III. Volume 4. Ed. Difel, São Paulo, 1994.

SUZIGAN, Wilson. Notas sobre o desenvolvimento industrial e política econômica no Brasil na década de 30. Revista de Economia Política, 4 (1), 1984.

Industrialização e política econômica: uma interpretação em perspectiva histórica. Pesquisa e planejamento econômico, dezembro de 1975.

SZMRESCÁNYI, Tamás. Retomando a questão do início da historiografia econômica no Brasil. In: Nova Economia, Belo Horizonte, janeiro-abril de 2004. 
VERSIANI, Flávio Rabelo. Industrialização e emprego: o problema da reposição de equipamentos. In: Pesquisa e Planejamento Econômico. Vol. 2, n. 01, junho de 1972, pp. 03-53.

\section{Bibliografia}

ABREU, Marcelo de Paiva. O Brasil e a economia mundial (1930-1945). Ed. Civilização Brasileira, Rio de Janeiro, 1999.

(1889-1999). Ed. Campus, Rio de Janeiro, 1990.

ALBUQUERQUE, Rui H. P. L. Capital comercial, indústria têxtil e produção agrícola. As relações de produção na cotonicultura paulista (1920-1950). Ed. Huitec, São Paulo, 1982.

ALBUIXECH, Joaquim Muns. Industrialización y crescimento de los países em desarollo. Ediciones Ariel, Barcelona, 1972.

AURELIANO, Liana Maria. No limiar da industrialização. Editora Brasiliense, São Paulo, 1981.

BAER, Werner. A economia brasileira. $2^{\circ}$ Edição. Nobel, São Paulo, 2002.

$\overline{\text { de Janeiro, } 1966 .}$

A industrialização e o desenvolvimento econômico no Brasil. Fundação Getúlio Vargas, Rio

BANDEIRA Jr., Antônio Francisco. A indústria no estado de São Paulo em 1901. Tipografia do Diário Oficial, São Paulo, 1901.

BARBOSA, Wilson do Nascimento. Balanço da economia brasileira (1940-1980). LCTE Editora, São Paulo, 2006.

BASTOS, Humberto. Posição econômica do Brasil. Martins, São Paulo, 1951.

Desenvolvimento ou escravidão. Aspectos de influências externas na formação

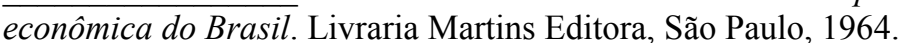

BELLUZO, Luis Gonzaga de Mello. Valor e capitalismo. Ed. Brasilense, São Paulo, 1980.

BRANCO, Catullo. Energia elétrica e capital estrangeiro no Brasil. Ed. Alfa-Ômega, São Paulo, 1975.

BRESSER PEREIRA, L. C. Estado e subdesenvolvimento industrializado. $2^{\circ}$ Edição. Ed. Brasiliense, São Paulo, 1981.

Janeiro, 1968.

Desenvolvimento e crise no Brasil entre 1930 e 1967. Ed. Zahar, Rio de

CANABRAVA, Alice P. O desenvolvimento da cultura do algodão na Província de São Paulo (1861-1875). S/e, São Paulo, 1951.

CANO, Wilson. Desequilíbrios regionais e concentração industrial no Brasil (1930-1970 / 1970-1995). Ed. da Unicamp, Campinas, 1998.

1998.

Raízes da concentração industrial em São Paulo. $4^{\circ}$ Edição. Ed. da Unicamp, Campinas,

CARONE, Edgard. O Centro Industrial do Rio de Janeiro e a sua importante participação na economia nacional (1827 - 1977). Ed. Cátedra, Rio de Janeiro, 1978. 
. A Segunda República (1930-1937). Ed. Difel, São Paulo, 1978.

. A República Nova (1930-1937). $3^{\circ}$ Edição. Ed. Difel, São Paulo, 1982.

São Paulo, 1985. . A República Liberal. Instituições e Classes Sociais (1945-1964). Volume 1. Ed. Difel, . A Quarta República (1945-1964). Ed. Difel, São Paulo, 1980.

. O Estado Novo (1937-1945). Difusão Européia do Livro, São Paulo, 1968.

. A evolução industrial de São Paulo (1889-1930). Ed. Senac, São Paulo, 2000.

CASTRO, Antônio Barros de. Sete ensaios sobre a economia brasileira. Volume II. Forense Universitária, Rio de Janeiro, 1975.

COLISTETE, Renato Perim. Labour relations and industrial performance in Brazil: Greater São Paulo, 1945-1960. Tese de doutoramento, Oxford, 1998.

DEAN, Warren. A industrialização de São Paulo (1880-1945). 4Edição. Ed. Bertrand Brasil, Rio de Janeiro, 1991.

DOVE, Emil. Economia industrial têxtil. Elementos para su estudio. Volume 1. Gráficas Marina S.A., Barcelona, 1946.

D'OLIVEIRA, C. O trabalhador brasileiro: esboço antropo-sociológico seguido de inquérito sobre salários e sobre o trabalho feminino no Brasil. A Balança, Rio de Janeiro, 1933.

DRAIBE, Sônia. Rumos e metamorfoses. Estado e industrialização no Brasil: 1930-1960. Paz e Terra, Rio de Janeiro, 1985.

EICHENGREEN, Barry. A globalização do capital. Uma história do sistema monetário internacional. Editora 34, São Paulo, 2002.

FURTADO, Celso. Formação econômica do Brasil. 27 Edição. Cia. Editora Nacional, São Paulo, 2000. A economia latino-americana. Formação histórica e problemas contemporâneos. $2^{\circ}$ Edição. Cia. Editora Nacional, São Paulo, 1978. O mito do desenvolvimento econômico. $4^{\circ}$ Edição. Ed. Paz e Terra, Rio de Janeiro, 1974. . Desenvolvimento e subdesenvolvimento. Ed. Fundo de Cultura, Rio de Janeiro, 1961.

HARDMAN, Francisco Foot e LEONARDI, Victor. História da indústria e do trabalho no Brasil. Global Editora, São Paulo, 1982.

HILTON, Stanley. O Brasil e a crise internacional (1930-1945). Civilização Brasileira, Rio de Janeiro, 1977.

HOLLOWAY, Thomas H. Imigrantes para o café. Ed. Paz e Terra, Rio de Janeiro, 1984.

IANNI, Octávio. Estado e planejamento econômico no Brasil (1930-1970). Ed. Civilização Brasileira, Rio de Janeiro, 1971. Janeiro, 1963. . Industrialização e desenvolvimento social no Brasil. Ed. Civilização Brasileira, Rio de Estado e capitalismo. Estrutura social e industrialização no Brasil. Ed. Civilização Brasileira S.A., Rio de Janeiro, 1965. 
IGLÉSIAS, Francisco. A industrialização brasileira. Ed. Brasiliense, São Paulo, 1985.

JENKINS, D.T. The Textile Industries: General Survey. In: Williams, T.I. (ed.). A History of Tecnhology. Vol. 6: The Twentirth Century, c.1900 to c.1950. Calrendon Press, Oxford, 1978.

LABINI, P. Sylos. Oligopólio y progresso técnico. Oikos-Tau, Barcelona, 1966.

LEFF, N. H. Underdevelopment and development in Brazil. Volume 1: Economic Structure and change, 1822-1947. George Allen e Unwin, Londres, 1982.

LEME, Marisa Saenz. A ideologia dos industriais brasileiros (1919-1945). Ed. Vozes. Petrópolis, 1978.

LESSA, Carlos. Quinze anos de política econômica. Ed. Brasiliense, São Paulo, 1981.

LIMA, Heitor Ferreira. Evolução industrial de São Paulo. Esboço histórico. Editora Livraria Martins, São Paulo, 1954.

Paulo, 1976. História Político-Econômica e Industrial do Brasil. Cia. Editora Nacional, São

LOVE, J. L. A locomotiva: São Paulo na federação brasileira (1889-1937). Paz e Terra, Rio de Janeiro, 1982.

LUZ, Nícia Vilela. A luta pela industrialização do Brasil. $3^{\circ}$ Edição. Ed. Alfa-Ômega, São Paulo, 2004.

As tentativas de industrialização no Brasil. In: HOLANDA, Sérgio Buarque de e CAMPOS, Pedro Moacyr. História Geral da Civilização Brasileira. Tomo II. $4^{\circ}$ Volume. $5^{\circ}$ Edição. Ed. Bertrand Brasil, Rio de Janeiro, 1955, pp. 28-41.

MALAN, Pedro. Relações econômicas internacionais do Brasil (1945-1964). In: Boris Fausto. História Geral da Civilização Brasileira. Tomo III. Volume 4. Difel, São Paulo, 1984.

Janeiro, 1977.

Política econômica e industrialização no Brasil (1939-1952). IPEA / INPES, Rio de

MANTOUX, Paul. A Revolução Industrial no Século XVIII. Editora Unesp / Huitec, São Paulo, s/d.

MARTINS, José de Souza. Empresário e empresa na biografia do Conde Matarazzo. Ed. do Instituto de Ciências Sociais da Universidade Federal do Rio de Janeiro, Rio de Janeiro, 1967.

MARTINS, Luciano. Industrialização, burguesia nacional e desenvolvimento. Introdução à crise brasileira. Ed. Saga, Rio de Janeiro, 1968.

MARX, Karl. O Capital. Crítica da Economia Política. $5^{\circ}$ Edição. Ed. Civilização Brasileira, Rio de Janeiro, 1980.

MASSUDA, Ely Mitie. Inovação na Indústria Têxtil Brasileira (1983-1989) - o caso das fiações na região de Maringá. Tese de Doutorado, FFLCH, USP, 2002.

MATOS, Maria Izilda de. Trama e poder. Um estudo sobre as indústrias de sacaria para o café (São Paulo / 1889-1934). SESI-DN, Brasília, 1994.

MELO, Afonso de Toledo Bandeira de. Política Comercial do Brasil. Departamento Nacional de Estatística, Rio de Janeiro, 1933.

MELlo, João Manuel Cardoso de. O capitalismo tardio. Contribuição à revisão crítica da formação $e$ desenvolvimento da economia brasileira. Ed. Brasiliense, São Paulo, 1994.

MELLO, Maria Regina de M. Ciparrone. A industrialização do algodão na cidade de São Paulo no alvorecer do século XIX (1813-1830). Ed. Perspectiva, São Paulo, 1983. 
NEGRI, Barjas. Concentração e desconcentração industrial em São Paulo (1889-1990). Editora da Unicamp, Campinas, 1996.

NETTO, Antônio Delfim. O problema do café no Brasil. IPEA / FIPE, São Paulo, 1981.

NICOL, Robert Cajado (1974).

NORMANO, J. F. Evolução econômica do Brasil. S/ Editora. São Paulo, 1939.

OLIVEIRA, Carlos Alonso Barbosa de. Processo de industrialização. Do capitalismo originário ao atrasado. Ed. Unesp / Ed. Unicamp, Campinas, 2003.

PELÁEZ, Carlos Manuel. História da industrialização brasileira. Crítica à Teoria Estruturalista no Brasil. APEC Editora, Rio de Janeiro, 1972.

Brasília, 1981. e Wilson Suzigan. História monetária do Brasil. Ed. Universidade de Brasília,

PEREIRA, José Carlos. Estrutura e expansão da indústria em São Paulo. Cia. Editora Nacional, São Paulo, 1967.

PEREIRA, Wlademir. Evolução industrial do Estado de São Paulo. Empresa Gráfica da Revista dos Tribunais S.A., São Paulo, 1969.

PRADO Jr., Caio. História econômica do Brasil. 15 Edição. Ed. Brasiliense, São Paulo, 1972.

PREBISCH, Raúl. Keynes. Uma introdução. Ed. Brasiliense, São Paulo, 1998

RIBEIRO, Maria Alice Rosa. Condições de Trabalho na Indústria Têxtil Paulista (1870-1930). Editora da Unicamp/Huitec, São Paulo, 1998.

RICCI, Fábio. Origens e aspectos do desenvolvimento das indústrias têxteis no Vale do Paraíba Paulista na República Velha. Tese de doutoramento, FFLCH / USP, 2002.

ROSE, R. S. Uma das coisas esquecidas: Getúlio Vargas e o controle social no Brasil (1930-1954). Ed. Companhia das Letras, São Paulo, 2001.

SANDRONI, Paulo. Dicionário de economia. Abril Cultural, São Paulo, 1985.

SILVA, Sérgio. Expansão cafeeira e origens da indústria no Brasil. $3^{\circ}$ Edição. Alfa-Ômega, São Paulo, 1980.

SILVA, Zélia Lopes da. A domesticação dos trabalhadores nos anos 1930. Ed. Marco Zero, São Paulo, 1990.

SIMONSEN, Roberto C. Evolução industrial do Brasil e outros estudos. Cia. Editora Nacional, São Paulo, 1973.

SINGER, Paul. Interpretação do Brasil: Uma experiência histórica de desenvolvimento. In: FAUSTO, Boris. História Geral da Civilização Brasileira. Tomo III. Volume 4. Difel, São Paulo, 1984.

O Brasil no contexto do capitalismo internacional (1889-1930). In: FAUSTO, Boris. História Geral da Civilização Brasileira. Tomo III. Volume 1. $5^{\circ}$ Edição. Ed. Bertrand Brasil, Rio de Janeiro, 1989, pp. 345-390.

Desenvolvimento econômico e evolução urbana. Análise da evolução econômica de São Paulo, Blumenau, Porto Alegre, Belo Horizonte e Recife. Companhia Editora Nacional, São Paulo, 1968.

. Curso de introdução à economia política. $5^{\circ}$ Edição. Ed. Forense, Rio de Janeiro, 1979. 
SODRÉ, Nelson Werneck. Formação histórica do Brasil. $2^{\circ}$ Edição. Ed. Brasiliense, São Paulo, 1963. . Brasil. Radiografia de um modelo. $2^{\circ}$ Edição. Ed. Vozes, Petrópolis, 1974.

1964. História da burguesia brasileira. Ed. Civilização Brasileira, Rio de Janeiro,

SOUZA, Luiz Eduardo Simões de. Formação econômica do Brasil. Tópicos especiais. LCTE Editora, São Paulo, 2005.

SPREAFICO, Luigi. A transferência da tecnologia na indústria têxtil e do vestuário (mimeo), São Paulo, 1970.

STEIN, Stanley J. Origens e evolução da indústria têxtil no Brasil (1850-1950). Ed. Campus, Rio de Janeiro, 1979.

SUZIGAN, Wilson. Indústria brasileira. Origens e desenvolvimento. Ed. Huitec / Ed. da Unicamp, São Paulo, 2000.

TAVARES, Maria da Conceição. Da substituição de importações ao capitalismo financeiro. Ensaios sobre economia brasileira. $2^{\circ}$ Edição. Ed. Zahar, Rio de Janeiro, 1973.

Unicamp, Campinas, 1998.

. Acumulação de capital e industrialização no Brasil. $3^{\circ}$ Edição. Ed. da

TOLIPAN, Ricardo e TINELLI, Arthur Carlos (org.). A controvérsia sobre distribuição de renda e desenvolvimento. Zahar Editores, Rio de Janeiro, 1975.

UTTON, M. A. Industrial concentration. Penguim Books, Middlesex, 1991.

VASCONCELOS, Marco Antônio Sandoval de. Economia. Micro e macro. Ed. Atlas, São Paulo, 2001

VERSIANI, Flávio Rebelo e BARROS, José Mendonça de (org.). Formação econômica do Brasil. A experiência da industrialização. Ed. Saraiva. São Paulo, 1977.

VILlELA, Aníbal e SUZIGAN, Wilson. Política de governo e crescimento da economia brasileira (1889-1945). IPEA/INPES, Rio de Janeiro, 1973.

YAMEY, Brail S. (Ed.). Economics of industrial structure. Penguim Books, Middle, 1973.

WEID, Elisabeth Von der e BASTOS, Ana Maria Rodrigues. O fio da meada. Estratégia de expansão de uma indústria têxtil. Companhia América Fabril (1878-1930). Fundação Casa Rui Barbosa / Confederação Nacional da Indústria, Rio de Janeiro, 1986.

WIRTH, John D. A política de desenvolvimento na Era de Vargas. FGV, Rio de Janeiro, 1973.

WOOD, Ellen Meiksins. A origem do capitalismo. Ed. Zahar, Rio de Janeiro, 2001. 
